UNIVERSIDAdE DE SÃo PAULO

FACUldade de Filosofia, Letras E CiênCIAS Humanas DEPARTAMENTO DE HISTÓRIA

PROGRaMa de Pós-GRadUAÇÃo EM HISTÓRIA SOCIAL

Marília Dalva Klaumann Cánovas

\title{
IMIGRANTES ESPANHÓIS NA PAULICÉIA: Trabalho e sociabilidade urbana, 1890-1922
}

Tese apresentada ao Programa de Pós-Graduação em História Social, do Departamento de História da Faculdade de Filosofia, Letras e Ciências Humanas da Universidade de São Paulo, para a obtenção do título de doutora em História Social, sob a orientação da Prof $^{a}$ Dr $^{a}$ Maria Luiza Marcílio 
IMIGRANTES ESPANHÓIS NA PAULICÉIA:

Trabalho e sociabilidade urbana, 1890-1922

Marilia Dalva Klaumann Cánovas 
"De esa mirada arranca esta historia, aunque para llegar a ella todavía tenga que contar otras cosas, como casi todas las cosas especiales de la vida, en las simetrías que nos hacen volver a lo que fuimos, en esas reproduciones del pasado que tantas veces acumula el presente, ya que el pasado es un presente sin tiempo y el presente, un pasado sin distancia"

Luis Mateo Díez, La mirada del alma

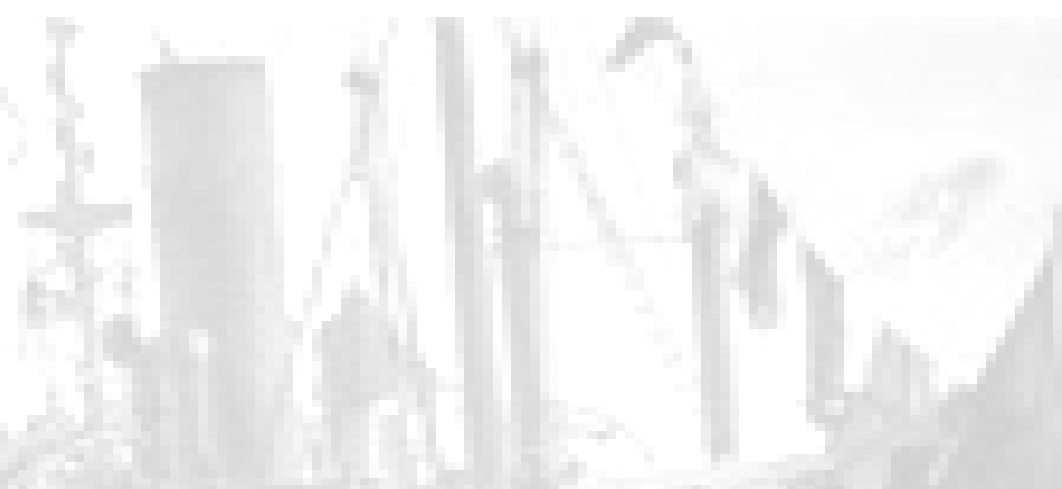

Ao José Pedro, com amor, dedico 


\section{Agradecimentos}

A trajetória da elaboração de uma tese é sempre partilhada de dúvidas, incertezas, angústias e dificuldades. É o capítulo não-escrito que fica inscrito em cada linha do trabalho, com imagens de situações e pessoas a quem, finalmente, encontro a oportunidade para reiterar a minha mais profunda gratidão.

Inicio essa vasta lista de gratidão pela minha orientadora, a prof ${ }^{\underline{a}}$ Dra. Maria Luiza Marcílio, de cuja orientação segura e competente tive o privilégio de usufruir. Desfrutar do convívio da mestra, como afetuosamente a trato, nessa dupla jornada, só me fez renovar a admiração por seu rigor e por sua capacidade intelectual. Minha dívida com ela que, além de extraordinária e reconhecida profissional, é um exemplo de ser humano, é substancial, em todos os sentidos.

Minhas dívidas não param aí. Gostaria de manifestar meu agradecimento à Prof ${ }^{\underline{-}}$ Esmeralda B. Bolsonaro de Moura, da banca de qualificação que, ponderada e firme, descortinou-me outras possibilidades, com sugestões enriquecedoras, que tentei incorporar ao trabalho final. Também da Prof ${ }^{a}$ Maria Inez Machado Pinto, de quem recebi e acatei valiosas sugestões, agradeço os iluminados comentários, produto da atenta leitura que realizou.

Sou especialmente grata à amiga e historiadora Mirian Silva Rossi, arguta e entusiasta interlocutora que, com generosidade, soube responder aos meus inúmeros anseios $e$ inseguranças, dispensando-me atenção mais do que a merecida. Sua crítica rigorosa e seu espírito instigante foram essenciais em diversas fases do trabalho, com o qual também contribuiu com elementos de sua brilhante dissertação.

Extremamente fecundo foi o contato com alguns pesquisadores de temas correlatos e colegas de ofício. Gostaria de expressar o meu sincero agradecimento a José Leonardo do Nascimento e a Zeila de Brito Demartini pela atenção na remessa e cessão de (primorosos) textos de sua lavra. A Esther Gambi, de Salamanca e a Dolores Martin Rodriguez Corner, historiadora e filha de espanhóis, sou grata pela disponibilidade em atender, com solicitude, aos mais inusitados pedidos e questionamentos de uma pesquisadora extraña. À amiga Maria Eta Vieira, ilustre hispanista, apoio certeiro em horas de inquietude, agradeço. Também em Adriana Arantes, encontrei a palavra certa, na hora exata. A Sonia Maria de Freitas, pelo carinho, estímulo e trocas de experiências, sou grata. A Luis Filipe Silvério Lima, pela generosidade no intercâmbio de descobertas que pudessem aliviar as dificuldades do percurso, a Elena Pájaro Peres, pelo auxílio pontual e a Daniela Kiessling, pela leitura atenta e comentários dispensados a partes do trabalho, meu reconhecimento. Também a Beth Salum, sou reconhecida pela 
generosidade em franquear-me informações nas horas cruciais dos apertos do vernáculo e das normas técnicas.

Na impossibilidade de nomear os inúmeros funcionários lotados nas muitas instituições por onde peregrinei, gostaria de lembrar aqui, particularmente, a solicitude desses anônimos essenciais, nas figuras de Denis Rossi, do IEB; de Mario Garcia-Guillén, Maria Luiza Moreno Carmona, a "Marisa", e Laura de Madariaga Charro, do Consulado Geral da Espanha. Ali, especialmente na pessoa do cônsul-geral, D. Fernando Martinez Westerhausen, por haver finalmente acedido às (im)pertinentes e reiteradas moções para que o acervo, então com vários livros já em decomposição, fosse restaurado. Sou muita grata à equipe da Secretaria de PósGraduação do Departamento de História da USP, nas pessoas de Andréia Piva, Aparecida dos Santos, Elizabete Viana, Osvaldo Medeiros e Priscila Cardoso.

De alguns amigos, a doce e acalentadora lembrança da presença constante, mesmo em tempos de confinamento compulsório de redação de tese. A Helga Reidler, pela inesgotável sabedoria; a Neide Prado, pelo precioso afeto; a Wagner Mar, pela confiança; a Serginho Moreira, pela longínqua amizade; a Luis Boiadeiro Soliano, pela acolhida certa e pelo amparo, em momentos dificeis; a Leila Rochert, pela troca constante de experiências; a William Astolfi, pelo carinho; a todos eles, sou profundamente reconhecida.

Finalmente, gostaria de agradecer à minha família, de quem tive o necessário apoio, imprescindível a uma empresa que por vezes pareceu acima das minhas forças. Minhas filhas, Heloisa, Maria Fernanda e Isabella são as grandes musas inspiradoras da minha vida. Junto a elas, minha mãe, Rosa, com quem aprendi, em longos serões, ao lado de sua máquina de costura, as primeiras letras, e a quem devo muito do que sou. Aos meus genros, Paul e Rafael, e agora também o Ingo, quero externar minha gratidão, por se disporem a atender aos inúmeros chamados e pedidos de socorro. Ao meu marido, José Pedro, presença definitiva, sou especialmente grata. Como ninguém, ele soube ficar do meu lado, encorajando-me continuamente. Como ninguém, abriu mão de seus projetos para, generosamente, permanecer comigo nessa empreita que, sem ele, seria impossível. Devo a ele ainda, colaborador constante, os gráficos e quadros, as imagens, o arranjo do banco de dados, as planilhas, e também a leitura de partes do trabalho mas, sobretudo, fico-lhe devedora do imenso afeto e da infinita paciência, na compreensão do meu esforço.

Encerrando, deixo consignados meus agradecimentos a essa Universidade, que sempre me acolheu, e onde, a par da formação intelectual, tem contribuído no processo de minha autodescoberta.

Esse trabalho contou com o apoio do CNPq. 


\section{Resumo}

Esta investigação pretendeu recuperar, amparada por substantivo corpus documental, a multiplicidade de papéis vivenciados pelo imigrante espanhol na Paulicéia: redes de afazeres e práticas associativas, modos efetivos de incorporação e experiências precárias de acomodação à atividade produtiva da cidade, formas de sociabilidade, enfim, os diversos meios de inserção, as estratégias e as experiências concretas relacionadas à sua trajetória na urbe paulistana, entre os anos de 1890 e 1922.

Conhecido como o da emigração em massa, esse período será o responsável pelo deslocamento de imensas ondas humanas que cruzavam o Atlântico em direção à América. Para o Brasil, vinham atraídas pela eficiente e agressiva política oficial de arregimentação de braços em larga escala que se alicerçava no subsídio à passagem das famílias emigrantes, modalidade de captação com a qual se pretendia irrigar com mão-de-obra farta e, portanto, barata, a lavoura cafeeira do Estado de São Paulo, em constante expansão.

Grande parte desse caudal emigratório espanhol movia-se fugindo das distorções do sistema agrário, da miséria, das convocações militares para as guerras coloniais e da falta de perspectiva no futuro, trazendo, em sua bagagem imaginária, o desejo de melhoria em sua condição de vida e o sonho do retorno ao seu país de origem.

Desses milhares de desterrados, muitos, por razões que a pesquisa buscou explorar, acabaram se dirigindo - refluindo ou não do colonato - para a cidade de São Paulo que, promovendo para si a atração de capitais e população, ostentava com eloquiência os frutos colhidos pelo café, metamorfoseando-se radicalmente de maneira acelerada e se transformando, na passagem do século $\mathrm{XX}$, de pequeno núcleo urbano, na metrópole do café.

Face à especificidade da constituição da urbe, o adensamento de uma população diversificada verdadeiro caleidoscópio étnico no qual o imigrante espanhol, em que pese a sua quase total obscuridade historiográfica, figurou entre as três correntes majoritárias -, constituída por universos socioculturais heterogêneos e assimétricos, amálgama de múltiplas expectativas e experiências de vida, representou campo fecundo para a investigação, descortinando perspectivas e abordagens privilegiadas na problematização do objeto e no tratamento teórico-metodológico das fontes e da bibliografia utilizadas.

Palavras-chave: emigração em massa, emigração espanhola, imigração, imigrantes espanhóis em São Paulo, população, cidade de São Paulo, Paulicéia, vida urbana. 
Abstract

This investigation tries to recover concrete practices, strategies and experiences related to the urban trajectory made by the Spanish immigrants in the city of São Paulo between 1890 and 1922. This period, which has been denominated mass emigration, was responsible for the displacement of immense human waves that crossed the Atlantic, towards America. Originally from Spain, great population contingents made their way to the coffee nucleus in the State of São Paulo, attracted by the efficient and aggressive official policy of recruiting of hands, based on the granting of passage to the emigrating families. They ran away from hunger, misery, the military calls to the colonial wars and the lack of future perspectives. One great share of this population however, settled in the rising Paulicéia, which at that time was going through deep transformations and attracting capital and population. It thus quickly transformed itself from a small urban nucleus, in the passage to the 20th century, into the coffee metropolis. In the ethnic kaleidoscope of the Paulicéia, the Spanish arise in three main immigrating chains. The specificity of the city's constitution, the increase in the diversified population, and the mixture of multiple life expectations and experiences, will result in a conflicting cosmopolitanism, an inseparable aspect of the city's urbanization process.

In this investigation we try to examine, with the support of substantial and unpublished documentation, the multiple roles of the population originally from Spain and the research shows the reasons why it ended up settling in the metropolis that was being built, and becoming, together with the other inhabitants of the city, the main characters of one of the most expressive chapters of its History.

Key words: mass emigration, Spanish emigration, immigration, Spanish immigrants in São Paulo, population, city of São Paulo, Paulicéia, urban life. 


\section{CAPÍTULO I - A CIDADE EM TRANSIÇÃO E A PRESENÇA DO} IMIGRANTE ESPANHOL $\quad \mathbf{4 7}$

1. A metamorfose da Paulicéia e a presença maciça dos imigrantes 48

2. As primeiras imagens do espanhol na Paulicéia 66

2.1. O incessante deslocamento em busca de trabalho 95

2.2. Locais de concentração e moradia $\quad 105$

CAPÍTULO II - TERRITÓRIOS DO TRABALHO

1. Protagonistas de uma economia invisível 124

1.1. O homem anônimo $\quad 129$

2. O espanhol na construção civil 145

3. Pequenos ofícios autônomos 152

3.1. Trabalho domiciliar e feminino 163

4. O espanhol na indústria 183

5. O espanhol nos serviços públicos urbanos 195

6. O espanhol profissional liberal 203

CAPÍTULO III - DE GRÃO EM GRÃO: O ESPANHOL EMPRESÁRIO 224

1. Segmentos da pequena indústria e comércio 224

2. Os atacadistas de cereais $\quad 248$

3. Importadores, exportadores e casas comissárias 264

4. Comércio varejista: vendas, empórios e armazéns - um estudo de caso 271

5. Setor hoteleiro, de entretenimento e lazer 276

CAPÍTULO IV - CENÁRIOS DA VIDA PÚBLICA: PRÁTICAS

ASSOCIATIVAS E DE LAZER $\quad 290$

1. As sociedades beneficentes, culturais, artísticas e recreativas 301

1.1. A Sociedade Espanhola de Socorros Mútuos e Instrução (SESM) 302

1.2. A Federação Espanhola (FE) $\quad 324$

1.3. O Centro Espanhol (CE) 335

1.4. As associações culturais, artísticas e recreativas, e os grupos
amadores de dramaturgia

2. O lazer e a vida cotidiana 344

CAPÍTULO V - EXPRESSÕES DA MILITÂNCIA E PROPAGANDA

LIBERTÁRIA 383

$\begin{array}{ll}\text { NOTAS CONCLUSIVAS } & 427\end{array}$

ÍNDICE DE TABELAS E QUADROS 
CRÉDITO DAS IMAGENS

$\begin{array}{ll}\text { ABREVIATURAS E SIGLAS } & 445\end{array}$

$\begin{array}{ll}\text { ACERVOS CONSULTADOS } & 446\end{array}$

$\begin{array}{ll}\text { FONTES } & 447\end{array}$

BIBLIOGRAFIA $\quad 456$

ANEXO

CGE - Índice de sobrenomes (apellidos). São Paulo (Capital), 1893-1922 478 


\section{INTRODUÇÃo}

No livro Nem tudo era italiano, seu autor, Carlos José Ferreira dos Santos ${ }^{1}$ buscou recuperar a participação, na virada do século XIX, da parcela pobre da população nativa no processo de constituição da Paulicéia nascente, personagem cuja presença raramente é mencionada, ofuscada pelo peso que é atribuído ao estrangeiro nesse processo.

As questões discutidas pelo autor, para quem "os elementos indiscutíveis do nosso progresso" foram indagados à luz da ideologia que marcou com o silêncio ou com o menosprezo a participação da parcela nacional pobre, além de conterem boa dose de questionamento a paradigmas historiográficos, na distinção e reforço da importância do imigrante nesse cenário, remetem a oportunas reflexões no tocante ao nosso objeto de investigação, o imigrante espanhol, também ele componente excluído do corpo-a-corpo conflituoso do despertar da Metrópole.

Ao perceber, em suma, que na formação da urbe paulistana figuraram outros sujeitos históricos, via de regra relegados pela historiografia ${ }^{2}$, o autor sugere - como o próprio título da obra indica -, a associação imediata do "italiano" como elemento sintetizador da imagem que se construiu do imigrante desse período, concepção que parece haver se cristalizado, e não apenas na opinião pública.

Esta identificação não é aleatória, indicando, particularmente na análise dos imigrantes que compuseram a miscelânea étnica da cidade, outros e complexos ângulos que fornecem pistas capazes de ilustrar o caso específico do espanhol, de reconhecida e reiterada obscuridade historiográfica.

Uma dessas questões poderia estar associada ao predomínio esmagador dos italianos, não apenas frente aos nacionais, mas também diante das demais correntes imigratórias envolvidas no processo de metropolitização da cidade. A esse fator considere-se um segundo, agravante, que merece ser levado em conta no tocante aos espanhóis: estes, como os nacionais

\footnotetext{
${ }^{1}$ SANTOS, Carlos J. F. dos. Nem tudo era italiano. São Paulo e pobreza, 1890-1915. São Paulo: Annablume, 1998.

${ }^{2}$ Cf. PINTO, Maria Ignez Machado Borges. Cotidiano e sobrevivência: a vida do trabalhador pobre na cidade de São Paulo, 1890-1914. São Paulo: Tese de doutoramento, FFLCH-USP, 1984; São Paulo: Edusp, 1994 (Coleção Campi, 18); HAHNER, June E. Pobreza e política. Os pobres urbanos no Brasil - 1870/1920. Brasília: Edunb, 1993 e KOWARICK, Lúcio. Trabalho e vadiagem. A origem do trabalho livre no Brasil. São Paulo: Brasiliense, 1987.
} 
reclamados pelo autor, constituirão, em sua maioria, como veremos, uma massa desfavorecida economicamente, um grupo social marginalizado e oprimido.

Tais premissas poderiam, assim, ser as responsáveis pelo silenciamento historiográfico do espanhol que, como os nacionais, teria permanecido à sombra dos italianos, e à margem de inumeráveis realizações no período? Importante, a questão não prescinde no entanto de um exame mais aprofundado levando-se em conta outras variáveis que não emergem exclusivamente dessa tensão fundamental com o elemento majoritário, o italiano, e cujos desdobramentos merecerão acurado exame delineando outras possibilidades de análise para a sua singularização.

Em grande parte camuflados ou pouco explicitados, tais aspectos, em seu corolário, parecem contudo indicar, tal como pretendemos demonstrar, uma convergência com as questões antes apontadas, ou seja, que a reiterada obscuridade atribuída a esse elemento envolve igualmente questões de ordem "interna", tanto do ponto de vista da dinâmica que se estabelecerá entre os membros da colônia espanhola, quanto na relação destes com os demais habitantes, questões estas que se reproduzem tendo como pano de fundo circunstâncias de ordem conjuntural. Tais circunstâncias, configurando a dimensão coletiva do fenômeno migratório de massa que tipificou o período, envolvem quase sempre elementos intangíveis ao imigrante comum, como assim poderia ser designada a evolução tardia do movimento imigratório espanhol, cujos índices máximos em direção ao Brasil foram registrados somente nas duas primeiras décadas do Novecentos ${ }^{3}$.

É inegável o fato de que nossa historiografia, ao reconhecer a relevância do papel desempenhado pelo imigrante na sociedade brasileira, tenha privilegiado alguns contingentes em detrimento de outros. No tocante ao Estado de São Paulo em especial, uma leitura mais atenta mostrará o quanto um exame mais acurado do processo migratório desse período, com seus desdobramentos e implicações recíprocas, segue os indicadores oferecidos pelo modelo conformado pelo italiano.

Se por um lado os estudos historiográficos evidenciam as características desse grupo migratório, de indiscutível superioridade numérica, por outro, tendem a relegar, desconsiderar e mesmo ignorar outros contingentes populacionais imigrados, dentre os quais o espanhol, cujo

\footnotetext{
${ }^{3} \mathrm{O}$ caráter tardio da emigração ultramarina espanhola evidencia-se quando relacionamos seu ritmo ao dos demais países europeus, especialmente os da Europa Ocidental, interessando-nos particularmente compará-lo aos índices protagonizados pelos italianos e portugueses, grupos que, com o espanhol, constituirão as três correntes majoritárias na Cidade de São Paulo, no período. Para o entendimento do fenômeno emigratório espanhol de massa e seus antecedentes, $c f$. BAHAMONDE, Angel. "Los dos lados de la migración transoceánica”. In: Historia General de la emigración española a Iberoamérica. Madrid: v. 1, Fundación Cedeal, 1992, p. 93-134.
} 
volume aponta para cifras que o posicionam entre os três principais contingentes europeus a demandarem o Brasil até 1929, precedido somente pelo italiano, grupo majoritário, e pelo português. Além disso, quando consideramos especificamente o Estado de São Paulo, a análise dos percentuais de direcionamento do total ingressado no período revela que o espanhol figurou na segunda posição, suplantando largamente o imigrante português ${ }^{4}$.

Ainda se poderia argumentar em favor da corrente imigratória espanhola que, comparativamente às demais correntes consideradas, entre os anos de 1905-1909, ela corresponderá a 35,5\% das entradas de emigrantes no Estado, montante que apresenta pequena queda entre 1910-1914, mantendo-se contudo significativo (29,8\%), quando então já se contabilizavam os primeiros ingressos de japoneses, esboçando nova curva ascendente entre 1915-1919 (32,5\%). Ou seja, o espanhol será responsável, entre os anos de 1905 a 1919, por aproximadamente $32 \%$ do total de imigrantes ingressados no Estado ${ }^{5}$.

Essa constatação, a da existência numérica e oficial do espanhol como praticamente o único atributo da sua existência concreta, levou-nos a proceder não apenas a um necessário rastreamento documental, mas, sobretudo, encorajou-nos a buscar fontes de outra natureza para viabilizar a sua investigação que culminou, após longa gestação, com a Dissertação de Mestrado mencionada ${ }^{6}$, por meio da qual buscamos reconstituir aspectos de sua trajetória no colonato.

$\mathrm{Na}$ ocasião, apoiando-nos na pluralidade de influências oferecidas pela interdisciplinaridade no âmbito dos estudos migratórios, buscamos levar a efeito, tal como aspiramos nesse momento, uma investigação que, conjugada aos aspectos históricodemográficos do processo, trouxesse à tona as experiências dos sujeitos históricos envolvidos, contemplando, assim, as múltiplas faces do fenômeno migratório, "em sua dupla dimensão, de fato coletivo e de itinerário individual" 7 .

\footnotetext{
${ }^{4} \mathrm{O}$ espanhol, apresentando, do total ingressado no Brasil, um percentual de encaminhamento da ordem de $79 \%$ para São Paulo, suplantaria com grande vantagem ao português que aparece com apenas $29 \%$. Ver nota 5.

${ }^{5}$ Os cálculos reais e percentuais da evolução comparativa do movimento imigratório registrado no Estado de São Paulo entre 1880 e 1930, baseados no exame dos dados extraídos dos Relatórios da Secretária da Agricultura constam dos Quadros elaborados em: CÁNOVAS, M. A emigração espanhola e a trajetória do imigrante na cafeicultura paulista: o caso de Villa Novaes, 1880-1930. São Paulo: Dissertação de Mestrado, FFLCH-USP, 2001, pp. 123 e ss. (disponível para consulta na URL: http://www.teses.usp.br/teses/disponiveis/8/8138/tde-11112001134010/publico/01tde.pdf); para os dados estatísticos relativos à imigração no Brasil, consultamos: LEVY, Maria Stella Ferreira. "O papel da imigração internacional na evolução da população brasileira (1872 a 1972)". In: Revista de Saúde Pública, 8 (supl.). São Paulo: 1974, p. 54. A esse respeito $c f$. a Tabela 14. Imigrantes espanhóis entrados em São Paulo, 1885-1929. Porcentagem em relação às outras correntes, por qüinqüiênio, no Capítulo I.

${ }^{6}$ CÁNOVAS, M. Op. cit., 2001. Ver também em: Hambre de Tierra. Imigrantes espanhóis na cafeicultura paulista. São Paulo: Lazuli, 2005.

${ }^{7}$ Cf. SAYAD, Abdelmalek. A imigração ou os paradoxos da alteridade. São Paulo: Edusp, 1998, p.13.
} 
Emergindo da crise dos paradigmas tradicionais na escrita da História, uma dessas possibilidades centrou-se na discussão em torno do "cotidiano", campo multidisciplinar, aberto portanto a influências plurais, e perspectiva importante para a problematização do objeto. De fundamental importância, nessa opção, foram as inumeráveis contribuições teóricas notadamente de Henri Lefebvre ${ }^{8}$, Karel Kosik ${ }^{9}$ e Agnes Heller ${ }^{10}$-, responsáveis pela produção de significativa massa crítica na configuração dos componentes essenciais de uma teoria da vida cotidiana, redescoberta que trouxe em seu bojo, como uma das influências mais marcantes, a redefinição do político frente ao deslocamento da esfera de poder das instituições públicas do Estado para a esfera do privado, com a politização do dia-a-dia, no âmbito do cotidiano, no qual se desenvolvem múltiplas relações de poder.

Nessa perspectiva, destacam-se elementos valiosos nos discursos de Foucault para a compreensão dos micro-poderes ${ }^{11}$, bem como nos de E.P.Thompson ${ }^{12}$, que trata do que poderíamos chamar de uma "cultura de resistência", pela qual a sobrevivência e a improvisação adquirem comportamento de feição política e conscientização. Nesse particular, igualmente relevante tem sido a obra de Michel de Certeau ${ }^{13}$, na apreensão do sentido implícito às diversas estratégias, atitudes e modos de vida, observados na atuação desses agentes históricos em sua passagem pela cidade.

${ }^{8}$ Com destaque para: LEFEBVRE, Henri. La vida cotidiana en el mundo moderno Madrid: Alianza Editorial, S.A., 1972.

${ }^{9}$ Especialmente em KOSIK, Karel. Dialética do concreto. Rio de Janeiro: Paz e Terra, 1969.

${ }^{10}$ Particularmente em HELLER, Agnes.O cotidiano e a História. Rio de Janeiro, Paz e Terra, 1972; Sociologia de la vida cotidiana. Barcelona: Ediciones Península, 1994 (edição original publicada em 1970) e La revolución de la vida cotidiana. Barcelona: Ediciones Península, 1982. Não poderíamos deixar de citar, a título de ilustração, a decisiva contribuição de Georg Lukács, sobre a qual, aliás, repousa o essencial dos trabalhos de Heller, destacadamente a riqueza categorial, elaborada na investigação sobre a cotidianidade. Para ele não há sociedade sem cotidianidade, não há homem sem vida cotidiana que é, portanto, ineliminável ou insuprimível, enquanto espaçotempo de constituição, produção e reprodução do ser social. Desta forma, se em toda a sociedade a cotidianidade existe, em cada uma delas a estrutura da vida cotidiana é distinta quanto o seu âmbito, ritmos e regularidades e quanto aos comportamentos diferenciados dos sujeitos sociais (grupos, classes, etc.). Posta assim, em sua insuprimibilidade ontológica, a vida cotidiana não se desloca do histórico - antes, é um dos seus níveis constitutivos, aquele em que a reprodução social se realiza na reprodução dos indivíduos enquanto tais. Embasada nessa determinação, Heller proporá o tema do cotidiano enquanto competência de reprodução direta do indivíduo, no mesmo processo em que este reproduz indiretamente a sociedade. A esse respeito, ver: Ontologia do ser social. São Paulo: Ciências Humanas, 1979. Graal, 1979.

${ }^{11}$ FOUCAULT, Michel. "Por uma genealogia do poder". In: Microfísica do poder. Rio de Janeiro: Ed.

${ }^{12}$ THOMPSON, E.P. "La sociedad inglesa del siglo XVIII: lucha de clases sin clases?" In: Tradición, revuelta y conciencia de clase. Barcelona: Crítica, 1979.

${ }^{13}$ CERTEAU, Michel de. A invenção do cotidiano. Artes de fazer. Petrópolis, RJ: Vozes, 1994 e "Teoria e método no estudo das práticas cotidianas". In: SZMRECSANYI. Maria Irene. Cotidiano, cultura popular e planejamento urbano. São Paulo: Anais do encontro, FAU-USP, 1985. 
De outras disciplinas, cujas fronteiras são intermitentemente cruzadas nos estudos migratórios, novas perspectivas ${ }^{14}$, têm descortinado um campo inédito para a ampliação das áreas de investigação, ressaltando-se dentre elas a Psicologia Intercultural; especialmente os trabalhos de John W. Berry ${ }^{15}$ e Jean S. Phinney ${ }^{16}$ que trazem importantes subsídios para o tratamento da questão identitária ${ }^{17}$.

Tais níveis analíticos implicam incorporar à História tensões do dia-a-dia e a reconstrução da organização da sobrevivência de grupos marginalizados do poder - caso dos imigrantes - e, às vezes, até do próprio processo produtivo, ao qual se imiscuíam de forma "invisível”, particularidade que, como veremos, tipifica o espanhol da conjuntura de urbanização da cidade de São Paulo, o que implica especialmente o estudo de formas sociais provisórias, instáveis e intermediárias.

Partindo desse pressuposto, a não linearidade impõe um tratamento de constante problematização ao objeto, encerrando um corpo de indagações "aberto" às mais diversas possibilidades de abordagem, que transita pelo limite imposto pelas fontes e pela documentação, mas que não se esgota aí, orientando-se para o não explícito, para o silenciado, para as lacunas e vazios, espaços densos de significação. No processo social vivenciado por esses agentes históricos, numa esfera intermediária entre a norma e a ação, surge a possibilidade da emergência de elementos que politizaram o seu cotidiano, seja por meio da apreensão de papéis informais que fugiram ao controle e domínio dos papéis prescritos, seja pelo estudo da multiplicidade de mediações e da percepção da margem de resistência possível ou, ainda, pela análise da improvisação, da espontaneidade e do exame da capacidade de mudança e de transformação.

É no cotidiano, parafraseando Lefebvre, que se encontram a reação, a oposição, o não conformismo e a resistência, elementos enfim que não foram capturados pelos poderes institucionais - e pelas fontes oficiais, poderíamos completar. É também ali, no conjunto de atitudes que compõe o seu modus vivendi, e que constituiriam ancestralidades do homem total, provido de vontade e potência, de espírito criador e capaz ao mesmo tempo da busca da liberdade e do sentido da obra, é ali, conforme nos diz o autor, que ocorre o ensejo para a análise

\footnotetext{
${ }^{14}$ Ver, a respeito: POVOA NETO, Helion e FERREIRA, Ademir P. Cruzando fronteiras: um panorama dos estudos migratórios. Rio de Janeiro: Ed. Revan, 2005.

${ }^{15}$ BERRY, J. “Migração, aculturação e adaptação". In: DeBIAGGI, Sylvia Dantas e PAIVA, Geraldo José (org.) Psicologia, e/imigração e cultura. São Paulo: Casa do Psicólogo, Livraria e Editora, 2004, pp. 29-45.

${ }^{16}$ PHINNEY, J. "Formação da identidade de grupo e mudança entre migrantes e seus filhos". In: DeBIAGGI, S. e PAIVA, G. (org.). Op. cit., 2004, pp. 47-62.

17 A esse respeito, ver também: DeBIAGGI, Sylvia Dantas. "Migração e implicações psicológicas. Vivências reais para o indivíduo e o grupo". In: Travessia. Revista do Migrante. São Paulo: ano XVIII, n.53, set./dez. 2005, pp. 16-20.
} 
do cotidiano, em que as estratégias e atitudes permitem entrever as possibilidades de improvisação e de resistência, forjadas na inevitabilidade da sua reinvenção ${ }^{18}$.

Porém, não é só. A temática imigratória característica do período denominado "imigração em massa"19 é das mais complexas. Desenrola-se no plano visível e concreto dos deslocamentos humanos coletivos, resultado de ajustes macrossociais na esfera internacional, que envolvem circunstâncias históricas e determinações sócio-econômicas, culturais e demográficas. Considerada porém no âmbito da experiência individual e, portanto, subjetiva, abre-se para outros saberes, que, para sua aproximação, obrigam o próprio pesquisador a "migrar" para outras áreas do conhecimento, no reconhecimento da complexa dimensão do fenômeno - migrar e, no caso específico do espanhol, ser inventivo, diversificar, criar e eleger novas perspectivas de abordagem e de análise.

Nesse sentido, consagramos como fundamental nossa experiência anterior de utilização - em articulação a um conjunto de fontes convencionais então também empregadas, destacadamente os registros cartoriais -, das narrativas de imigrantes espanhóis remanescentes, pertencentes ainda às primeiras correntes massivas que se dirigiram ao núcleo cafeeiro do Oeste Paulista, que permitiu a apropriação de outros ângulos e a recuperação de experiências cujos contornos dificilmente lograriam ser apreendidos pela História formal e documental.

Naquela oportunidade, em suma, em que buscávamos delinear a trajetória do espanhol no colonato, não foram poucos os indícios e referências que, reforçados pelos próprios protagonistas daquela história, sinalizavam para outro espaço, insinuando a sua presença para além das fronteiras dos cafezais, apontando enfim para as cidades, São Paulo especialmente que, pela importância assumida dentro da economia do café, tomava forma como futura metrópole.

Essa nova proposta de investigação abria-se, no entanto, como a anterior, sem grandes perspectivas do ponto de vista documental: as menções a esse contingente em sua trajetória

${ }^{18}$ A esse respeito, ver também: DIAS, Maria Odila Silva. "Hermenêutica do quotidiano na historiografia contemporânea". In: Projeto História. Revista do Programa de Estudos Pós-Graduados em História e do Departamento de História da PUC-SP. Trabalhos de Memória. São Paulo: n. 17, EDUC, nov. 1998, pp. 223-258.

${ }^{19}$ Período compreendido entre o final das guerras napoleônicas e a depressão mundial de 1930 em que 60 milhões de europeus e 10 milhões de asiáticos cruzaram o Atlântico em direção a outros continentes. Desse contingente, $21 \%$ (11 milhões) teriam se dirigido a América Latina e, desses, 36\% teriam vindo para o Brasil. Focalizando-se especificamente o caso espanhol tem-se aproximadamente uma cifra de 3 milhões de pessoas no período. Cf. MÖRNER, Magnus. Aventureros y proletarios. Los emigrantes en Hispanoamerica. Madrid: Ed. Mapfre, 1992, p. 76. 
urbana, escassas, esparsas e episódicas, traduziam aspectos já fartamente sinalizados por outros estudiosos, dificuldade, aliás, atestada pela incipiente produção preexistente sobre a temática. A rigor, localizamos uma certa produção bibliográfica, porém fragmentária e desordenadamente distribuída, muitas vezes extrapolando o período considerado, cujo mapeamento então levado a efeito evidenciou a existência de trabalhos de natureza multidisciplinar, a maioria dos quais enfatizando aspectos sócio-demográficos do processo e/imigratório espanhol, referidos à América Latina e ao Brasil em geral, em diversos momentos ${ }^{20}$.

Particularizando o momento enfocado, pudemos também registrar contribuições de caráter local, segundo as quais se buscou revelar a trajetória desse elemento em outros Estados brasileiros; destacam-se aqui os trabalhos produzidos na Bahia e no Rio de Janeiro, locais onde sua presença também se evidenciou ${ }^{21}$. A esse quadro, um tanto disperso, associamos os trabalhos intradisciplinares consultados no transcorrer do mestrado. Vale dizer que esta produção encontra-se ainda grandemente monopolizada por estudos sobre o italiano, tanto na cidade quanto no colonato, no âmbito do qual verificamos, comparativamente, exígua produção

${ }^{20}$ É o caso de "La evolución cuantitativa del proceso migratorio español a Iberoamérica (1890-1950), con especial referencia a Brasil”, de Ricardo Evaristo dos Santos, publicado na Revista de Economía y Sociologia del Trabajo (Madrid, 19-20, março/junho de 1993, pp. 138-153); de "Brasil y lo español', de Gilberto de Melo Kujawski, publicado na Revista Cuenta y Razón (Madrid, 8, 1982, pp. 69-81); de Os espanhóis no Brasil. Contribuição ao estudo da imigração espanhola, de Cláudio Aguiar. Rio de Janeiro: Tempo Brasileiro, 1991; de "A integração social e econômica dos imigrantes espanhóis no Brasil”, de Herbert Klein. In: Estudos Econômicos (19), no 03, 1989; Paisagem da Alma: a experiência de emigrar, de Maria de la Asunción Carollo Blanco. Dissertação de mestrado em Psicologia Social, PUC-SP,1996; "Permanente presencia española en Brasil: la gran emigración a Brasil, 1824-1914", de Mario García-Guillén. In: MARCONDES, Neide e BELLOTTO, Manoel (orgs.). Turbulência cultural em cenários de transição. O século XIX ibero-americano. São Paulo: Edusp, 2005, pp. 149163; do mesmo autor, Máquinas para o progresso. São Paulo: Editora do Escritor, 1975 e Viemos por nuestras águas: espanhóis no Brasil. São Paulo: Editora Senac São Paulo, 2005; Produção escrita em língua portuguesa e castelhana: realização de imigrantes estabelecidos em São Paulo, 1960-1970, de Maria Del Pilar S. Martin. São Paulo: FFLCH-USP, 1985; A hispanidade em São Paulo: da casa rural à Capela de Santo Antônio, de Araci Abreu Amaral. São Paulo: Nobel/Edusp, 1981; "República Espanhola: um modelo a ser evitado", de Ismara Izepe de Souza. In: Inventário Deops: módulo IV - Espanhóis. São Paulo: Arquivo do Estado, Imprensa Oficial, 2001; “A imigração espanhola no Brasil. Estado do fluxo migratório para o Estado de São Paulo (1931-1936)", de Manoel Lelo Bellotto. In: Estudios interdisciplinarios de América Latina y el Caribe, vol. III, nº 2, Julho-dezembro/1992 e especialmente dos trabalhos da historiadora argentina radicada na Espanha Elda González Martinez: "Españoles en Brasil: características generales de un fenómeno emigratorio", publicado na Revista Ciência e Cultura, da SBPC, volume 42, nos 5/6, maio/junho de 1990b, pp. 341-346; "Identidad y representación coletiva de un grupo inmigrante: los españoles em São Paulo, 1850-1970”. In: Reflexiones en torno a 500 años de historia de Brasil. Madrid: Ed. Catriel, 2001; "Los inmigrantes invisibles: condiciones de vida e identidad de los españoles en São Paulo, en la segunda mitad del siglo XX”. In: Estudios Interdisciplinarios de América Latina y el Caribe, vol. 11, $\mathrm{n}^{\circ}$ 1, enero-junio/2000, p. 1-17 e "O Brasil como país de destino para os imigrantes espanhóis". In: FAUSTO, B. (comp). Fazer a América. A emigração em massa para a América Latina. São Paulo: Edusp, 1999, pp. 239-271.

21 A esse respeito, consultar: Os espanhóis em Salvador. Análise sociológica das possibilidades de assimilação de um grupo de imigrantes. Tese para concurso de professor assistente - UFBA, de Célia Maria Leal Braga, de 1972; Os espanhóis no Rio de Janeiro (1880-1914) - Contribuição à historiografia da imigração. Tese de livre-docência de Lucia Maria Paschoal Guimarães, apresentada ao IFCH da UERJ em 1988; Galegos no paraíso racial (Salvador: Ianamá/CEAO/CED, 1994) e Negros e espanhóis. Identidade e ideologia étnica em Salvador (Salvador: UFBA, 1983), de Jefferson Afonso Bacelar e A imigração galega na Bahia, de Maria del Rosario Alban. Salvador: UFBA, 1983 
relativa ao espanhol no colonato ${ }^{22}$ recentemente acrescida por duas publicações: um livro em que seu autor, um jornalista, utilizando-se de expressiva documentação oficial, fontes iconográficas e depoimentos orais, narra sua convivência com a colônia espanhola de Sorocaba, constituída a partir de $1885^{23}$ e uma Dissertação de Mestrado (publicada) ${ }^{24}$, em que sua autora busca recompor a trajetória desse imigrante na cidade de Bauru.

Focalizando especificamente nosso objeto, ou seja, buscando recuperar aspectos da passagem do espanhol pela Paulicéia, foi possível contabilizar significativa, porém como era esperado, exígua produção ${ }^{25}$, destacando-se, entre ela, a valiosa contribuição de Maria Antonieta Antonacci e Laura Antunes Maciel ${ }^{26}$, na sistematização de um objeto, cuja "diluição" - para usar a terminologia das autoras - vem instigando há muito os pesquisadores: "Desde el comienzo de esta investigación, teniendo en cuenta que las informaciones y justificaciones de la ausencia de estudios en relación a la inmigración española en São Paulo fueron pautadas por la inexistencia de registros y materiales en proporciones lo suficientemente significativas (...), assim reiterava Antonacci, pronunciando-se a respeito ${ }^{27}$. Nessa mesma trilha, em Trabalho e prestígio social: os espanhóis em São Paulo, José Leonardo do Nascimento ${ }^{28}$, o autor, tecendo as considerações de praxe acerca da invisibilidade dos espanhóis em São Paulo - "a presença espanhola em São Paulo, embora tangível, se esconde" - esboça primorosa e original investigação baseada em narrativas de descendentes, focalizando uma das atividades tradicionalmente atribuídas a esse elemento, a do comércio de sucata ou ferro-velho. "Espreita

${ }^{22}$ Especialmente relevantes são: de Elda González Martinez, Café e inmigración: los españoles en San Pablo, 1880-1930. Madrid: Cedeal - Centro Español de Estudios de América Latina, 1990a (no qual a autora demonstra que a política de subsidios foi a responsável pela atração exercida sobre a mão-de-obra espanhola) e "Los pequeños propietarios en los Núcleos Coloniales del Estado de São Paulo - un intento frustrado de participación española”. In: Ciencia, pensamiento y cultura. Madrid: n. 536-537, Arbor, 1990c, pp. 127-142 e de José de Souza Martins “A imigração espanhola para o Brasil e a formação da força-de-trabalho na economia cafeeira: 1880-1930". In: Revista de História, no 121, ago/dez. 1989, pp. 5-26 (aqui, o autor desenvolve uma análise comparada entre a imigração italiana e a espanhola na economia cafeeira).

${ }^{23}$ Cf. OLIVEIRA, Sérgio Coelho de. Os Espanhóis. Sorocaba: TCM, 2002.

${ }^{24}$ Cf. D’ÁVILA, Rosemeire Pereira. Lembranças da imigração: cenas e cenários dos imigrantes espanhóis em Bauru, 1892-1930. Bauru: Editora da Universidade do Sagrado Coração, 2004.

${ }^{25}$ Cf NETO, Antonio e SANTA HELENA, Bosco. O imigrante espanhol em São Paulo. São Paulo: Departamento de Imigração e Colonização, 1963; GALLEGO, Avelina. Espanhóis em São Paulo: presença e invisibilidade. Dissertação de Mestrado, apresentada à Faculdade de Ciências Sociais da PUC-SP, 1993 e "Espanhóis". In: Cadernos de migração: 5. São Paulo: CEM- Centro Estudos Migratórios, 1995; GONZÁLEZ MARTINEZ, Elda. "La estructura ocupacional de los gallegos en la ciudad de San Pablo (Brasil), 1893-1903". In: Revista da Comisión Galega do Quinto Centenario, nº 05, 1992, pp. 57-68.

${ }^{26}$ ANTONACCI, M. Antonieta e MACIEL, Laura Antunes. "Espanhóis em São Paulo: modos de vida e experiências de associação". In: Revista Projeto História, PUC-SP. São Paulo: n. 12, 1995, pp. 173-192 e "Revisitando a imigração: cultura, cotidiano e experiências de espanhóis em São Paulo, 1890-1930". In: Margem, n' 6, 1997, pp. 62-63.

27 ANTONACCI, Maria Antonieta. “Atravesando el Atlántico: españolas en São Paulo”. In: Historia, Antropologia y Fuentes Orales. Barcelona: n. 28, Universitat de Barcelona, 2002, p. 3.

28 NASCIMENTO, J. L. "Trabalho e prestígio social: os espanhóis em São Paulo". In: SILVA, S. e SZMRECSÁNYI, T. (org.). História Econômica da Primeira República. São Paulo: Hucitec/Associação Brasileira de Pesquisadores em História Econômica. Universidade de São Paulo/Imprensa Oficial, 2002, pp. 369-393. 
os lugares sombrios dos objetos relegados, e escoa suas mercadorias nos bastidores da economia fabril" 29 , afirma, apontando como essa atividade articulava-se com a vida da cidade de modo parcial e seletivo.

Acreditamos, em suma, que a inexistência, a fragmentação e a dispersão das fontes e da documentação, de há muito comentadas, e, em sua decorrência, a lacuna ou a ausência de trabalhos sobre o espanhol e, daí, a sua "invisibilidade" especialmente no período considerado, podem estar associadas a facetas e aspectos distintivos e singulares vinculados à sua trajetória específica e à maneira como, diferentemente dos demais grupos, se colocaram entre si e perante a nova sociedade, e a também nova condição que o estatuto de emigrante lhe conferia. Essa é uma das questões sobre as quais o presente trabalho pretende refletir mais detidamente quando da análise particularizada a determinados aspectos que, se não a podem elucidar por completo, ao menos a pretendem iluminar.

Pistas foram esquadrinhadas nessa direção, algumas resultando em descobertas reveladoras, exemplo dos renhidos quistos ideológicos e/ou regionalistas que sem disfarce dividiram, desde a primeira hora, a suscetível camada ilustrada e abastada da colônia. Essas indisfarçáveis rinhas ocorriam particularmente entre os dirigentes das associações beneficentes - muitos dos quais, coincidentemente, também eram diretores e/ou redatores de órgãos da imprensa (periódica ou militante) que circulava na cidade - dificultando em particular a organização comunitária. Ipso facto, a convivência entre os diversos dirigentes dessas entidades e agremiações, como teremos oportunidade de examinar, apresentou-se longe de ser pacífica.

Ainda que muitas agremiações tenham sido criadas, em número excessivo até, se comparado ao contingente a elas referido, cumpre ressaltar que algumas já nasciam de dissidências ou fraturas incontornáveis nas preexistentes, aspecto cujo ônus se refletia, da mesma maneira, na condição financeira dessas agremiações, de complexa manutenção no período. Em outras palavras, se por um lado pululavam iniciativas na criação de entidades e associações por parte de indivíduos ou grupos - em geral expoentes de camada sócio-cultural bastante diferenciada da massa miserável emigrada -, por outro, a raiz do isolamento dos diferentes grupos, aspecto relevante que deve ser ponderado na problemática da manutenção de elementos relacionados à sua identidade cultural e étnica, poderia estar localizada na dificuldade e/ou na impossibilidade da organização comunitária.

Cumpre salientar no entanto que, em que pese a sua relevância, esse dado isolado não se mostra suficiente para explicar o "ocultamento" do espanhol. A título de comparação,

\footnotetext{
${ }^{29}$ Idem, p. 390.
} 
poderíamos exemplificar, citando a experiência da colônia italiana, no seio da qual "por muitos anos prevaleceram sentimentos regionais e às vezes, mero bairrismo". "Em 1896 ainda não existia na cidade de São Paulo um único círculo italiano", mas já funcionavam e "eram numerosas, ao mesmo tempo, as associações regionais (...), perpetuando barreiras culturais e lingüísticas muitas vezes às raias do fanatismo" ${ }^{\circledR 0}$. Pouco sabemos das demais colônias que se formaram na cidade, mas parece-nos que este exemplo envolvendo o imigrante italiano, por sua expressividade numérica, é lapidar na comparação com os espanhóis, relativizando aquele argumento. No caso dos espanhóis, a propósito, essa questão realmente recrudesceu mais tarde, na década de 1930, na tomada de posição política frente à guerra civil espanhola ${ }^{31}$. Fica patente, em princípio, que foram muitos os aspectos implicados e que a asserção do "ocultamento" e da "invisibilidade" do espanhol passa necessariamente por essas questões, transitando e derivando, contudo, em outra via de variáveis, contradições, anacronismos e conciliações, elementos cuja complexidade se apresentam, na ubiqüidade do quadro, manifestos, latentes ou apenas implícitos.

Outra particularidade evidenciada do que foi exposto refere-se à existência de uma camada sócio-econômica e culturalmente diferenciada da grande massa marginalizada e subalterna de emigrados então domiciliada na cidade de São Paulo do período. Ocupando progressivamente posição destacada dentre a grande maioria de despossuídos, porém exibindo em suas relações interpessoais indisfarçáveis divergências, compunha-se esse grupo minoritário de comerciantes, pequenos industriais e profissionais liberais e partia dele, quase sempre, as iniciativas que culminavam com as experiências de associação e atividades coletivas do grupo imigrante.

Se as relações entre si já eram pontuadas de indisfarçáveis conflitos, da mesma maneira se produziam as relações desse grupo para com a autoridade consular, marcadas por tensões, protestos e acusações mútuas, muitas vezes resvalando para enfrentamentos públicos. Residia como foco central dessas controvérsias a censura, muitas vezes pública, circulando nos periódicos, que se fazia a tais funcionários que aqui deveriam representar o Estado espanhol,

${ }^{30}$ Opinião expressa por Ângelo Trento, historiador da emigração italiana, autor de Do Outro lado do Atlântico. Um século de imigração italiana no Brasil. São Paulo: Nobel/Instituto Italiano di Cultura di San Paolo/Instituto Cultural Ítalo-Brasileiro, 1988. Ver também, do mesmo autor: "Miséria e esperanças: a emigração italiana para o Brasil: 1887-1902". In: DEL ROIO, José Luis (org.). Trabalhadores no Brasil: imigração e industrialização. São Paulo: Ícone/Edusp, 1990, p. 41.

${ }^{31}$ Cf. GALLEGO, A. Op. cit., 1995, p.6 e ss., argumento que dissocia a desunião da colônia (que a autora aceita), decorrente de sentimentos regionalistas (que discute), como explicação para a dispersão. Sobre a questão da mobilização dos espanhóis aqui residentes diante da proclamação da República e da Guerra Civil na Espanha, consultar: GAMBI, Esther. "Republicanos y franquistas en Brasil: la guerra civil al otro lado del Atlántico". Versão inédita, a ser publicada na Revista Studia Historica Contemporánea, da Universidade de Salamanca, em cujo Centro de Estudios Brasileños a autora é pesquisadora. 
acusando-os de se esquivarem e atuar com desmazelo, quando não apenas para tirar proveito, nas questões que diretamente interessavam ao imigrado comum, a gente simples que constituía a maioria absoluta dos espanhóis na cidade.

Esse contingente constituía-se, na passagem do século XX, basicamente de elementos oriundos do campo em seu país, com reduzido cabedal informativo e, provavelmente, em boa parte, analfabetos ${ }^{32}$, muitos dos quais acorriam à cidade refluindo do colonato, em situação de penúria.

O que pareceu evidenciar-se, desde os primeiros resultados do cruzamento do banco de dados e da documentação examinada, foi a existência maciça na cidade de São Paulo de elementos "deslocados" de lugar e de contexto, largados à própria sorte, em crônica itinerância, à procura de qualquer trabalho. Esse elemento buscava na cidade o que não encontrara no núcleo cafeeiro, ou, quando não, em sua terra natal. Era um peregrino que se sentia fracassado em pelo menos algum desses estágios prévios e para quem o infortúnio alimentava novas e desafiadoras tentativas de realização. A miragem redentora das pequenas cidades que nasciam no rastro dos trilhos - e especialmente da cidade de São Paulo, pela qual já haviam transitado surgia como única alternativa. Nela, na babel em conturbado processo de urbanização, esse anônimo a mais vinha engrossar as fileiras de miseráveis e mendigos, desempregados e subempregados, segmentos dificilmente "documentados".

A maioria, contudo, ansiava pelo retorno à sua pátria e se encontrava declaradamente de passagem pelo Brasil, país que jamais representou destino preferencial para esse imigrante ${ }^{33}$ - antes, se pudesse, preferiria ter ido à Argentina ${ }^{34}$, para onde muitos julgavam estar embarcando. Prova inconteste dessa intenção transitória reside no fato de que muitos haviam deixado casa e/ou pertences com parentes ou conhecidos no pueblo ${ }^{35}$, conforme relato que

${ }^{32}$ Dos três principais contingentes, o espanhol é o que teria a maior porcentagem de analfabetos, 72,03\%, considerando-se o período de 1908 a 1936. Neste mesmo período, o imigrante italiano apareceria com 40,91\% e o português, com 57,48\% de analfabetos. Cf. Boletim da Diretoria de Terras, Colonização e Imigração, D.C.T.I. São Paulo: Secretaria da Agricultura, Indústria e Comércio, ano I, nº 01, outubro de 1937, pp. 54, 61, 64, 67 e 74.

${ }^{33}$ Há consenso entre os historiadores espanhóis contemporâneos de que a emigração espanhola desse período, de caráter quase peninsular, era determinada, mais que por opção pessoal do emigrante, por uma série de fatores ou facilidades, muitas vezes independentes de sua vontade, como: conexões portuárias, subsídios concedidos pelos países receptores, propagandas levadas a efeito pelos agentes de recrutamento (os ganchos) e cartas de chamada de parentes e conhecidos previamente estabelecidos.

34 A esse respeito, $c f$. SILBERSTEIN, Carina Frid de. "A imigração espanhola na Argentina (1880-1930)". In: FAUSTO, B. (org.) Op. cit., 1999, pp.93-126.

35 Pueblo: Termo de origem latina, com várias acepções, dentre as mais correntes, massa, multidão, público, população ou habitantes de um território, país ou nação. Em espanhol, conservou algumas delas, representando em primeiro lugar, um conjunto de pessoas que vivem em um conglomerado urbano de tamanho reduzido; pode também equivaler a lugar, aldeia ou vila, ou, ainda, à classe mais humilde de uma sociedade urbana ou rural. Aqui, a palavra terá quase sempre o sentido de lugar e aldeia. Cf. Diccionario de Historia de España. Tomo II, I-Z y Apendices. Madrid: Revista de Occidente, 1952, p. 941. 
colhemos junto aos imigrantes, em Villa Novaes ${ }^{36}$. Esse aspecto é revelador do desajuste constante e da permanente sensação experimentada por eles de que "no se pertenece ya al mundo que se deja, y no se pertenece aún al mundo que se llega ${ }^{37}$. O sentimento de "pertencimento", ou a possibilidade de desenvolvê-lo parece ser requisito indispensável para a integração em um novo espaço, bem como para a manutenção da própria identidade ${ }^{38}$.

Nessas condições, nada impede imaginar, não havia qualquer interesse por parte desse indivíduo em aprofundar vínculo de qualquer natureza com o Brasil, dado o caráter intencionalmente temporário de sua passagem por ele. Esse fato, de certo modo, também contribuiu para torná-lo imperceptível do ponto de vista formal e oficial, aspecto este reforçado pela intensa movimentação que, aliada à sua constante itinerância, se dava para os países do cone sul, especialmente a Argentina, para onde se dirigia sem deixar rastros documentais. Desse modo, conforme procuramos delinear, são inúmeros os aspectos que se somam, reforçando largamente os efeitos operados para a "invisibilidade" desse contingente.

\section{O mundo do trabalho}

A era moderna trouxe a glorificação teórica do trabalho e resultou na transformação efetiva de toda a sociedade em uma sociedade do trabalho ${ }^{39}$.

Um imigrante é essencialmente uma força de trabalho (...); foi o trabalho que fez nascer o imigrante, que o fez existir, que condiciona toda a existência do imigrante; ser trabalhador e imigrante [é] quase um pleonasmo ${ }^{40}$.

... dissociados de toda ordem nacional (...) e porque essa dupla dissociação fez dele uma espécie de homem abstrato - um homem "integral", dir-se-ia, pois escapa a todas as determinações concretas, empíricas, histórica e territorialmente, socialmente, politicamente e culturalmente (i.é., nacionalmente) especificadas, pois está liberto de todos os laços (sociais, nacionais, etc.) que o identificam.

O homem "ideal", em suma, aquele paradoxalmente postulado na expressão "Direitos do Homem" -, o imigrante poderia acabar, como por exemplo acaba o deportado, não sendo mais nada: nada além de uma individualidade corporal, um corpo biológico e técnico (um "corpo-trabalho") 41 .

\footnotetext{
${ }^{36}$ Constituída basicamente por emigrantes espanhóis que em seus arredores haviam se fixado no início do século XX, como pequenos proprietários, após a obrigatória passagem pelo colonato, Villa Novaes - hoje município de Novais - localizava-se no Oeste Cafeicultor, próximo à Catanduva, Estado de São Paulo. Outros depoimentos podem ser vistos em: CÁNOVAS, M. “Os espanhóis de Villa Novaes e suas narrativas”. In: Travessia. Revista do Migrante. São Paulo: CEM - Centro de Estudos Migratórios, ano XVII, nº 49, maio-agosto/2004, pp. 31-39.

${ }^{37}$ GRINBERG, León y GRINBERG, Rebeca. Psicoanálisis de la migración y del exílio. Madrid: Alianza Editorial, 1984, p.37.

${ }^{38}$ Passim.

${ }^{39}$ ARENDT, Hanna. A condição humana. Rio de Janeiro: Forense/Universitária, 1989, p. 12.

${ }^{40}$ SAYAD, A. Op. cit., pp. 54-55.

${ }^{41}$ Idem, p. 273.
} 
"Nós viemos da Espanha, porque lá não tinha trabalho". Mais do que uma reiterada afirmação, essa constatação do Sr. Ildefonso Blasquez Sánchez ${ }^{42}$, colocou em evidência a questão central, a mola propulsora que os mobilizou e motivou à emigração e, como instrumento manifesto da busca pela sobrevivência ${ }^{43}$, traduz a qualidade intrínseca ao emigrado, enquanto definidora do movimento ao qual se submetera. No entanto, o trabalho é também "de

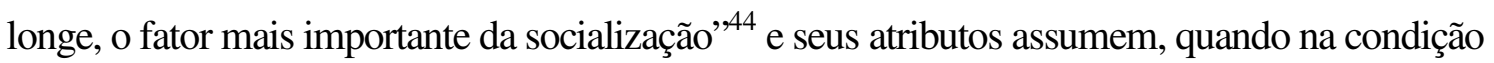
de emigrado, outras prerrogativas, até mesmo como ajustamento à nova situação e às novas circunstâncias.

Assim entendido como questão essencial - evocada e reiterada na fala dos imigrantes espanhóis, para quem o trabalho implacavelmente perpassara a própria existência e fora, antes de tudo, uma experiência visceral e estratégica - cremos ter definido o eixo em torno do qual convergiram as demais instâncias da vida e demarcaram a sua trajetória enquanto tal.

Partindo do enfoque das distintas experiências laborais e dos espaços econômicos produzidos pelo grupo na cidade, iniciando pelos múltiplos setores incluídos na chamada "economia invisível” (porquanto imperceptível, submersa, oculta, não oficial), de difícil mensuração, na qual se alojava boa parcela desse contingente, e prosseguindo a análise pelas demais categorias no reconhecimento de outras formas de absorção, buscamos, nesse rastreamento, perceber e recobrar os diversos modos de inserção e redes de afazeres do espanhol na Paulicéia - opção que implicou avaliar em que medida o seu equipamento cultural permitiu operar os códigos previamente estabelecidos na cidade pelos demais contingentes migratórios (especialmente o italiano) e pelos nacionais previamente instalados, como reagiu/resistiu a eles e, enfim, como equacionou o seu cotidiano concreto na dinâmica da cidade.

"Ser imigrante e desempregado é um paradoxo", porquanto constituem "objetos inconciliáveis: o não-trabalho com o que só se concebe e só existe pelo trabalho" ${ }^{\text {,45 }}$, abordagem que remete à reflexão sobre o trabalho enquanto categoria analítica e histórica ${ }^{46}$. Trata-se de uma perspectiva instigante que, à luz do objeto aqui considerado, o imigrante espanhol

\footnotetext{
${ }^{42}$ Fragmento de depoimento. Sr. Ildefonso Blasquez Sánchez. Villa Novaes, 1981. In: CÁNOVAS, M. Op. cit., 2004, p. 32.

${ }^{43}$ A esse respeito, ver: FORACCHI, Marialice. "A valorização do trabalho na ascensão social dos imigrantes". In: Revista do Museu Paulista. São Paulo: vol. XV, 310:319, 1963.

${ }^{44}$ GORZ, André. Metamorfoses do trabalho. Crítica da razão econômica. Tradução de Ana Montoia. São Paulo: Annablume, 2003, p. 21.

${ }^{45}$ SAYAD, A. Op. cit., p. 55.

${ }^{46}$ SILVA, Maria Aparecida de Moraes. "Contribuições metodológicas para a análise das migrações". In: DEMARTINI, Z. e TRUZZI, O. (orgs.). Estudos Migratórios. Perspectivas Metodológicas. São Carlos: EdUFSCar, 2005, pp. 59 e 81.
} 
franqueou-se, tornando-se manifesta pela emergência de uma multiplicidade de possibilidades avistadas pelo exame do banco de dados de que se compôs a pesquisa, evidenciando uma imensa massa cuja "qualificação" declarada não a "qualificava" para o exercício das diversas ocupações ensejadas pela cidade em seu salto de crescimento. Envoltos no turbilhão crescente que marcará o espaço, tal constatação fez-nos explorar um outro repertório de atividades, palmilhar um outro trajeto possível, vislumbrar artifícios viáveis, ingerências exequíiveis e práticas factíveis, na recuperação dos expedientes de que lançaram mão como estratégia para sobreviver. Essa "opção" obrigou-nos a transitar por uma face oculta da Paulicéia, em nada "oficial", uma face ofuscada e encoberta da metrópole "nova rica" em transição, na recuperação das formas de inserção e dos modos empregados por esses sujeitos históricos de, hábil e improvisadamente, se infiltrarem nas frestas e se imiscuírem nas brechas abertas pela cidade, espaços forjados que ocupavam de esguelha, como única saída, e de perceber, na reunião dos cacos dessa história, os conflitos, as discriminações e os preconceitos que encontraram ao trilhar formas peculiares e inusitadas de integrar o concorrido mercado de trabalho da cidade. Além desse percurso, no encalço da memória de um "espaço do trabalho", ao qual agregaremos alguns caminhos para a recuperação de elementos do cotidiano do grupo, pretendemos alcançar um outro, um "espaço coletivo", representado pelas associações, agremiações e instituições então criadas, produto da mesma dinâmica instaurada.

Sob essa ótica, era imperativo privilegiar o mundo do trabalho desses sujeitos históricos, domínio cuja centralidade, neste contexto histórico (e individual) readquiriu dimensão e função superlativas, verdadeira caixa de ressonância, tanto na organização da existência pessoal, quanto na esfera de integração social - "a cidade é trabalho social materializado: produto, condição e meio do processo de reprodução da sociedade em determinado momento histórico" ${ }^{47}$-, pela multiplicidade de vivências sociais e articulações que engendra. Foi relevante nessa opção, o exame de alguns autores, destacadamente Edward P. Thompson $^{48}$ na configuração da complexidade e das singularidades do mundo do trabalho urbano nas sociedades contemporâneas, apontando para as especificidades de um processo de industrialização incipiente e suas decorrências. Nesse sentido, à luta pela sobrevivência

${ }^{47}$ CARLOS, Ana Fani Alessandri. Espaço e Indústria. São Paulo: Editora Contexto, 1989, pp. 44. Ver também, da autora: Os caminhos da reflexão sobre a cidade e o urbano. São Paulo: Edusp, 1994 e A (re) produção do espaço urbano. São Paulo: Edusp, 1994.

48 THOMPSON, E.P. A formação da classe Operária Inglesa. Vol. I: A Árvore da liberdade. Rio de Janeiro: Paz e Terra, 1997; Vol.II: A maldição de Adão. Rio de Janeiro: Paz e Terra, 1988 e Vol. III: A força dos trabalhadores. Rio de Janeiro: Paz e Terra, 1989. 
cotidiana atribuiu-se - especialmente em Eric Hobsbawm - um timbre "político", cuja dimensão e impasses, neste caso específico, procuramos delinear ${ }^{49}$.

A consulta à outra série de trabalhos, que serão sistematicamente citados, preocupados com o surto de crescimento da cidade e com as formas alternativas, improvisadas e casuais de sobrevivência da camada pobre (imigrante ou não) da população excedente que a ela afluía no período, viabilizou possibilidades e ângulos de análise, antes inimagináveis, do objeto aqui examinado.

Foi nossa preocupação buscar, dentro desses elementos, a reconstituição das experiências vividas pelos imigrantes espanhóis na cidade nas décadas finais do século XIX e primórdios do XX, levando-se em conta o descompasso brutal entre o ritmo acelerado de seu crescimento demográfico e seu febril desenvolvimento, as condições de vida e as tensões urbanas geradas desse quadro, caracterizado pela formação de um mercado de mão-de-obra assediado e concorrido, onde o fator trabalho representava a atração maior exercida pela cidade em transição.

De relevância, vale lembrar, foram também as leituras de autores (poucos), cuja abordagem sobre a emergência das chamadas camadas médias urbanas - "aglomerado heterogêneo" e "numericamente inexpressivo na Primeira República",50 -, nos estimulou a refletir sobre o papel assumido por determinados segmentos assim identificados que compunham pequena mas ativa fração da colônia espanhola, não apenas em termos de organização e coesão interna e em sua relação com a grande maioria dos conterrâneos economicamente oprimida, mas tentando decompor seu padrão de vida e aferir como se situavam diante dos grupos oligárquicos e das elites então reinantes, apurando seu nível de integração ${ }^{51}$.

E, apenas para ilustrar, de fundamental importância representou o minucioso exame realizado, quando da pesquisa historiográfica do período, especialmente dos blocos temáticos fundamentais envolvidos - e/imigração, industrialização e urbanização - e das demais fontes de apoio de caráter estatístico-demográficas, às quais nos reportaremos no decorrer da tese.

${ }^{49}$ HOBSBAWM, E. Os trabalhadores. Estudos sobre a história do operariado. Rio de Janeiro: Paz e Terra, 1982; Rebeldes Primitivos. Estudos sobre as formas arcaicas de movimentos sociais nos séculos XIX e XX. Rio de Janeiro: Zahar, 1970.

${ }^{50}$ SAES, Décio. "O civilismo das camadas médias urbanas na Primeira República Brasileira (1889-1930)". In: Cadernos do Instituto de Filosofia e Ciências Humanas, $n^{\circ}$ 01. Campinas: Universidade Estadual de Campinas, 1973 , p. 35.

${ }^{51}$ SAES, D. Op. cit., 1973 e Classe média e sistema político no Brasil. São Paulo: T.A. Queiróz, Editor, 1984; PINHEIRO, Paulo Sérgio. Classes médias urbanas: formação, natureza, intervenção na vida política. In: FAUSTO, Bóris (org.) O Brasil Republicano. Tomo III, $2^{\circ}$ volume (Sociedade e Instituições). Rio de Janeiro/São Paulo: Difel, 1978, pp. 7-37 e CARONE, Edgard. A Primeira República, 1889-1930. Texto e Contexto. São Paulo: Difel, 1973. 


\section{As fontes primárias}

O documento não é qualquer coisa que fica por conta do passado, é um produto da sociedade que o fabricou segundo as relações de forças que aí detinham o poder. Só a análise do documento enquanto documento permite à memória coletiva recuperá-la e ao historiador usá-lo cientificamente, isto é, com pleno conhecimento de causa ${ }^{52}$.

Definida como o próximo passo após a dissertação de mestrado, a recuperação de aspectos da trajetória promovida pelo imigrante espanhol na cidade de São Paulo no período em pauta revelou-se, num primeiro momento, missão quase impossível. Árdua e pacienciosa peregrinação a distintos locais, e o exame minucioso de diferentes acervos antecedeu a descoberta das principais fontes que, sistematizadas, viriam a compor o banco de dados que utilizamos. À espinha dorsal do trabalho, constituída pelas principais fontes abaixo elencadas mediante as quais a viabilidade dessa pesquisa se mostrou exequível -, somaram-se outros caminhos que nos conduziram a acervos com menor potencial, dos quais destacamos os arquivos públicos espanhóis que, para o período em foco, conservam reduzido material de consulta e pesquisa.

\section{a) Livros de Registro de Imigrantes}

Localizada no Consulado Geral da Espanha (CGE), na cidade de São Paulo, uma dessas fontes refere-se aos dados coligidos dos livros (inéditos) denominados Inscripción de súbditos españoles residentes en el Distrito Consular (ou livro de registro consular, LRC), cuja série iniciou-se em 1893, ano da abertura do CGE.

Ao iniciar o levantamento dos dados manuscritos referidos aos registros individuais efetuados em tais livros, lamentavelmente ainda não informatizados, pensávamos estender essa pesquisa até 1930. Atribulações de toda natureza, a restrição ao espaço e ao horário de consulta no local e difíceis, quando não por vezes impraticáveis, condições materiais para a captação dos dados, foram fatores que, comprimindo o período de tempo inicialmente programado para os procedimentos de coleta dos registros - atividade que se prolongou por quatro anos, pela impossibilidade de efetuar-se a captação digitalizada - impuseram uma nova cronologia ao objeto. Não obstante, dentro das condições operadas, foi possível viabilizar a transcrição manual de aproximadamente 22 mil registros (exatamente 21.971) referentes a um período de 30 anos, ou seja, de 1893 a 1922. Tais dados, inicialmente transcritos manualmente em planilha

${ }^{52}$ LE GOFF, J. “Documento/monumento”. In: Memória-história. Trad. Suzana Ferreira Borges. Lisboa: Imprensa Nacional/Casa da Moeda, 1984. p.102 (Enciclopédia Einaudi, 1). 
especialmente elaborada, foram na sequiência digitalizados em linguagem Access constituindo um banco de dados informatizado. Algumas intervenções se fizeram necessárias para a manipulação desse banco de dados. Assim ocorreu com a supressão e posterior transferência dos registros em duplicidade, i.é., aqueles realizados em datas distintas, porém pertencentes a um mesmo indivíduo; tal operação resultou em um segundo banco de dados, composto de 5.113 registros individuais, de cujo exame buscaremos apreender, na escolha de algumas amostras selecionadas, ocorrências que ilustrem, por comparação, confirmando ou infirmando, hipóteses vinculadas a aspectos de mobilidade social, espacialização e deslocamento.

Após a supressão dos registros em duplicidade, o novo banco de dados resultante passou a conter um total de 16.858 registros. Desse montante, em somente 13.742 registros foi declarado o domicílio do declarante: 7.163 para a Capital e subúrbios e 6.579 registros pertencentes a informantes residentes no Interior e outras localidades também pertencentes à circunscrição do CGE. A diferença observada nesses números representa o total de registros sem a declaração de domicílio (3.116 registros).

Destacando-se, contudo, a variável “ocupaciones", observamos que somente em 15.856 registros constava essa indicação. A diferença (992 registros) equivale, portanto, ao número dos declarantes sem "ocupación”, dos quais 434 pertenciam a declarantes domiciliados na Capital e 288 a residentes no Interior. Os 270 casos faltantes equivalem a registros dos quais não consta nenhuma das duas rubricas mencionadas (domicílio e ocupación).

O Consulado General de España da cidade de São Paulo foi criado em 1893, evidenciando o crescente aumento desse contingente na cidade. Informações extra-oficiais indicam que, antes dele, já existia o Consulado de Santos, porém, nenhum documento pertencente àquela cidade foi encontrado com data anterior. Localizou-se, no período em foco, em diferentes sedes alugadas ${ }^{53}$. Em 1908, memorando do então cônsul, Ricardo Gomes Navarro, ao Ministro de Estado participava-lhe a péssima situação financeira do Consulado e comentando sobre a "insuficiência do valor dos salários dos que lhe servem na América que, no caso do Brasil, é uma verdadeira mesquinharia", comparava o seu salário ao de um sapateiro, um alfaiate ou um carpinteiro. Argumentava ainda que, até aquela data nenhum "cônsul de carreira" havia ali sido empossado e que, enfim, os demais que por ali passaram não haviam se pronunciado sobre o assunto da calamitosa situação que ora o obrigava a, além de realizar cortes de pessoal (caso do canciller, ou chanceler, cargo hierarquicamente abaixo do de vice-cônsul),

${ }^{53}$ A maioria delas pôde ser identificada pela consulta ao El Diário Español (EDE), no qual as alterações de endereço eram comunicadas. Desse modo, só pudemos acompanhá-las a partir de 1912: Rua Barão de Itapetininga, 13-A (EDE 27.06.1912); Rua Augusta, 164 (EDE 12.02.1913); Rua Augusta, 205, em um Hotel (EDE 06.08.1913); Rua Direita, 2-2º sala 6 (EDE 27.07.1914) e Rua Adolfo Gordo, 39 (EDE 21.10.1921). 
aventar a possibilidade de ter de entregar o prédio e passar a despachar no hotel onde residia, para a redução dos gastos ${ }^{54}$.

Essa pequena evidência demonstra que, após quinze anos de sua criação, o CGE ainda não havia sido distinguido, pelo Estado espanhol, com uma autoridade consular "de carreira" e que os recursos enviados para sua manutenção eram parcos, denotando claramente a falta de interesse com relação aos súditos aqui residentes. Entende-se por isso uma vasta região que a ele foi sendo agregada e cuja jurisdição abrangia, em 1913, cinco anos depois, os Estados do Paraná, Goiás e Mato Grosso onde viviam quatrocentos mil espanhóis 55 .

Tentando contornar essa (assim declarada) precária situação financeira, é provável que a autoridade consular tenha preferido agir apenas quando pressionada - e em todo o período considerado, não foram poucas as ocasiões em que o EDE exibia "cobrança” aberta, disparando contra o cônsul ou contra os vice-cônsules do interior, denúncias e reclamações que chegavam a seu conhecimento, algumas delas diretamente a Eiras Garcia, que as encampava. Nestes casos, a autoridade consular assumia algumas causas mais "públicas", caso do assassinato, na Rua Condessa de S. Joaquim, do espanhol Manuel Garcia Gonzalez, com 7 filhos, crime que "comoveu a todos, inclusive brasileiros e italianos" e cuja subscrição, em favor da viúva, foi iniciativa do Consulado, sendo as doações discriminadas e publicadas no $\mathrm{EDE}^{56}$; posicionavase mais timidamente em outras questões, inescapáveis contudo, quando então soltava alguma nota pelo EDE, posicionando-se como mediador entre os colonos e o Patronato ${ }^{57}$. O EDE e seu diretor-proprietário, Eiras Garcia, em suma, iam paulatinamente assumindo a posição de portavozes da colônia, que a eles encaminhavam todas as suas reivindicações, ao invés de se dirigirem à autoridade legalmente constituída para tal. Em 1912, por exemplo, a propósito dos abusos e da exploração a que se viam submetidos os emigrantes que, do interior passavam pela cidade aí se hospedando para depois seguirem para Santos, onde embarcariam como repatriados, o EDE - e não o CGE - insurge-se contra os corretores e agenciadores de hotéis de "vigésima ordem", quase todos "italianos e espanhóis", que os esperavam nas estradas de ferro, a certa distância da Estação da Luz, oferecendo-lhes bilhetes de passagem ou propondo-lhes a troca de moeda brasileira por libras ou moeda italiana, ambas falsificadas.

${ }^{54}$ AMAE. Série Brasil. Correspondencia Embajadas y Legaciones, H-2048. Correspondência datada de 03.12.1908.

${ }^{55}$ EDE 07.11.1913.

${ }^{56} \mathrm{EDE} 11.02 .1913$. Essa subscrição teria alcançado a quantia de $1.567 \$ 700$.

${ }^{57} \mathrm{EDE}$ 14.05.1913. 
Por certo que à autoridade consular restavam outras ocupações mais "produtivas". Aproveitando-se das notícias depreciativas que reiteradamente circulavam sobre o Brasil na imprensa espanhola e, no intuito de "desfazer tais calúnias", o cônsul Juan Solórzano - o mesmo que, por "negociar" com as passagens para os repatriados será alvo de denúncia do EDE - toma a iniciativa de publicar o livro El Estado de São Paulo, contendo informações e dados econômicos sobre o mesmo, e pelo qual, mal disfarçando a verdadeira finalidade, buscava "demonstrar a sua pujança e o potencial mercado que se constituía" 58 , perseguindo claramente o objetivo de incrementar as vendas de produtos espanhóis no Estado. Tal preocupação não era novidade: já então se mantinha no CGE uma seção especial de Catálogos e Mostras de Produtos Espanhóis para apreciação dos comerciantes locais ${ }^{59}$.

Outras questões mais pujantes também os absorviam, como o controle do contingente para o alistamento militar, desta feita orientado para a guerra do Marrocos ${ }^{60}$. O mais curioso a destacar-se nesse particular é o fato de muitas famílias terem justamente emigrado tentando evitar que seus filhos fossem convocados. Essas convocações - também para a guerra de Cuba iniciada em 1897 e para a das Filipinas - verdadeiros sorvedouros de vida humana, repercutiam como uma sentença nos lugarejos, diante da visão devastadora produzida pelos poucos sobreviventes que logravam retornar, inutilizados para a vida.

Os emigrados jovens eram monitorados pela autoridade consular da cidade, controle este que se evidenciou na análise da correspondência oficial. Por intermédio dela, os cônsules informavam ao Ministro de Estado espanhol do contingente disponível para alistamento. Anualmente os jovens entre 20 e 21 anos eram passados em revista. Cadastrando-se "voluntariamente" evitavam ser declarados desertores ${ }^{61}$. Em caso de solicitação de baixa pelo interessado, cabia a ele exibir credenciais e provas que comprovassem a necessidade de sua permanência no Brasil, e a dispensa do alistamento ${ }^{62}$.

De qualquer modo, conjugado aos diversos interesses paralelos e aos procedimentos burocráticos que detinham maior ou menor interesse das autoridades do CGE, foi instituído

${ }^{58}$ EDE 12.01.1914.

${ }^{59}$ EDE 06.03.1913.

${ }^{60}$ Desde 1909, a Espanha havia implementando a ocupação militar de Marrocos, disputado por aguerridas tribos berberes locais, conforme acordo realizado com a França, fixando as respectivas zonas de protetorado. $\mathrm{O}$ principal objetivo era garantir a exploração das minas de ferro próximas a Melilla. No entanto, choques com os marroquíes eram freqüentes, exigindo constante suplemento de pessoal; daí o interesse do Estado Espanhol em impedir a saída dos jovens em idade militar. A guerra do Marrocos, como ficou conhecida, se prolongará até 1927.

${ }^{61}$ EDE 08.01.1914.

${ }^{62}$ AMAE. Série Brasil. Correspondencia Embajadas y Legaciones, H-2048. Correspondências datadas de 20.09 e 25.10 .1909 
formalmente, a partir da sua criação, em 1893, o livro Inscripción de súbditos españoles residentes en el distrito consular, o livro de registro dos imigrantes, com cuja série trabalhamos.

Tal registro, em tese, constituía prática legal obrigatória a todos os imigrantes, ainda que não houvesse como obrigá-los a realizá-lo. Desconhecimento, desinteresse, puro descaso à autoridade ou especialmente falta de recursos, dada a condição da maioria que acorria à cidade, faz supor uma considerável parcela de "transgressores".

Há evidências indicando que se cobrava uma taxa para a sua realização ou pela emissão da "cédula" dele decorrente, o que também deve ter representado fator impeditivo adicional. "Nuestros emigrados no pueden figurar inscriptos en el Consulado porque se les cobran cantidades que dificilmente pueden pagar. Un obrero del campo paga 5\$200 reis y, si ha dejado un año sin inscribirse, $5 \$ 000$ reis más; si dos años, $10 \$ 000$ y en adelante 20\$000”, informava em relatório um inspetor às autoridades espanholas ${ }^{63}$. Consta, em muitos registros, a eloqüente observação "se expide gr. por indigente" (expede-se gratuitamente por ser indigente) demonstrando que, apenas nesta condição, o imigrante estava a salvo do pagamento da taxa de serviço correspondente.

Informes extra-oficiais de atuais funcionários do Consulado dão conta de que era obrigatório o recadastramento a cada dois anos, e de que, nessa ocasião, era expedida uma cédula, da qual se originava a Carteira de Estrangeiro. Essa prática, por nós denominada "registros duplicados", e que gerou um segundo banco de dados, iniciou-se somente a partir de 1915.

No início do período analisado, a maioria dos registros pertencia exclusivamente a elementos do sexo masculino que, ainda que se declarassem casados, faziam apenas o seu registro, individualmente. A partir de 1911, no entanto, percebemos uma progressiva incidência de registros familiares (o casal e filhos), ou seja, de registros que, em tese, compunham o perfil familiar do imigrante com passagem prévia pelo colonato. Nesses casos, uma única cédula gerava várias cédulas individuais, uma para cada membro da família, com o detalhe de que a grafia dos sobrenomes dos filhos levava, ao estilo espanhol, o sobrenome materno por último. De qualquer modo, observamos que a prática inicialmente restrita aos homens estendeu-se progressivamente às mulheres, conforme demonstraremos.

63 "El 'Formose', el Cap Norte y la Emigración al Brasil. Memoria de un viaje de Inspección", 01.04.1925, p. 77-78. Apud: Ministerio de Trabajo y Asuntos Sociales (MTAS). Documento avulso. 
Uma das colunas do livro traz o tipo de documento apresentado pelo interessado ou seu representante (consular ou não) no ato do registro ${ }^{64}$. O elenco de tais documentos, muitos dos quais representavam o único que possuíam, é lapidar na identificação do grau de exigência e burocracia, crescente e restritiva, conforme o perfil ${ }^{65}$, imposto pelas autoridades espanholas ao interessado em emigrar, o que certamente representava um estímulo à clandestinidade, movimento que crescia valendo-se do porto de Gilbraltar ${ }^{66}$. Muitos, no entanto, compareciam ao CGE sem portar qualquer documento de identificação, apresentando-se, nestes casos, com testemunhas ("Presentado por" ou "Información del patrón, Sr. Tal”). Podia ocorrer ainda a apresentação de um “Certificado de no haber sido procesado”, em outras palavras, um atestado de antecedentes criminais, salvo conduto expedido por autoridade brasileira.

Entretanto, esses registros não eram exclusivos dos residentes na cidade de São Paulo, e, ainda que tenhamos optado por transcrever a todos, indiscriminadamente, foram inúmeros os registros de emigrantes residentes no interior do Estado, e outros, em menor número, de residentes nos outros Estados que compunham a jurisdição consular. Neste caso, eram apresentados geralmente em bloco, pelo agente consular da localidade, que comparecia ao CGE e procedia ao registro individual, munido ou não dos documentos pessoais do interessado.

Dependendo do escrevente, compilava-se um número maior ou menor de informações sobre o declarante, ocasionando falhas e lacunas nos registros, em determinados períodos. Dados referentes à filiação do declarante, à data de saída da Espanha, ao local de embarque, e informes acerca dos seus possíveis defeitos físicos, foram os que mais acusaram lacunas. Ainda assim, de modo geral, e esse foi um dos critérios para sua eleição, esse conjunto de livros, que tem suas séries bem conservadas ${ }^{67}$, apresentou com regularidade variável um somatório de informações importantes sobre o imigrante. Assim se compunham suas colunas, cujos dados, sistematicamente informatizados, foram depois cruzados e operacionalizados, gerando uma série de relatórios em seqüência numérica, aos quais denominamos Relatórios Access:

\footnotetext{
${ }^{64}$ Licencia militar; Permiso paterno (para os menores de 18 anos); Fé de bautismo; Acta de Matrimonio; Documento de embarque; Permiso de embarque; Certificado de buena conducta (expedido pela Polícia Civil); Certificado de quintas; Certificado del Juzgado; Declaración Testifical (feita de próprio punho pelo declarante); Pasaporte e Cédula personal foram alguns dos documentos apresentados no período. Aos maiores de 65 anos expedia-se uma "licencia absoluta".

${ }^{65}$ Aos jovens do sexo masculino em idade militar, por exemplo, expedia-se, em alguns casos, uma "licencia limitada", categoria que designava os que, por excedente de contingente, não haviam sido incorporados; estes, no entanto, deveriam permanecer como reserva ativa, ou seja, disponíveis. É revelador que esse tipo de documento tenha sido apresentado no CGE já que, nesses casos, não era permitida a mudança de domicílio, menos ainda a saída do país.

${ }^{66}$ Gibraltar, (ainda hoje) colônia inglesa, localizada na costa andaluz, era o porto preferido pelas Companhias de Navegação que ali embarcavam clandestinamente os candidatos à emigração sem o aval legal.

${ }^{67}$ Para o período de 30 anos analisado, foram transcritos os dados de 11 livros, cada qual com 100 páginas duplas, exibindo, em cada página, um total de 24 registros individuais, em 16 colunas.
} 
* Número de ordem

* Data

* Nome e sobrenome

* Naturalidade (cidade, província)

* Idade

* Se sabe (ler, escrever)

* Ocupação

* Pais do emigrado (nomes e sobrenomes/naturalidade/se são falecidos)

* Data em que saiu da Espanha

* Local de embarque

* Se o fez em companhia de seus pais ou sozinho

* Locais onde residiu desde sua saída da Espanha

* Residência atual (localidade ou domicílio)

* Tempo de residência na localidade

* Se apresenta alguma deficiência física

* Observações

$\mathrm{Na}$ planilha elaborada foram criadas colunas visando comportar outras informações de interesse, caso da classe de embarque e as possíveis evidências de o declarante estar apenas transitando pela cidade. A coluna residência atual também foi desmembrada, separando-se os domiciliados na capital dos residentes no interior.

b) O El Diário Español (EDE)

Demarcando a progressiva presença do espanhol na cidade, dá-se, quase simultaneamente à criação do CGE, o aparecimento de um periódico em língua espanhola, o $E l$ Diario Español (EDE), iniciado em 1898, e cuja série, localizada para exame, com algumas lacunas, engloba os anos de 1912 a 1922, coincidindo, portanto, com os anos finais examinados nos livros consulares.

A passagem do século XIX representa o marco de transição da pequena para a grande imprensa, e seu crescimento traduz e ilustra um momento decisivo da existência da nascente metrópole do café, sublinhando a realidade inerente aos novos espaços da vida urbana, e aos novos personagens e grupos sociais que passam a coexistir. Esse novo momento vivenciado pela cidade em seu acelerado processo de urbanização foi marcado por profundas alterações em todos os níveis da vida social e pela incorporação de novos hábitos, que surgiam no bojo dessas transformações.

A escrita ganha status privilegiado e se populariza: cartazes, letreiros, fachadas, anúncios, transformam-se em elementos essenciais desse novo cenário, agora impressos nas oficinas gráficas que apresentam grande surto de desenvolvimento na cidade, em decorrência das recentes demandas. 
A atividade jornalística também se beneficiou pela introdução de uma série de inovações tecnológicas, como a ligação das províncias por uma rede de telégrafos, e a implantação de cabos submarinos ligando o Brasil a Lisboa, em 1874, permitindo a recepção de notícias internacionais. Em São Paulo, foi inegável a importância da rede de estradas de ferro, implementada para dar vazão à produção do café, como estímulo à circulação.

É dentro desse quadro, portanto, e ilustrando esse momento, que vemos nascer a imprensa periódica, e é a cidade de São Paulo, com seus personagens e linguagens, sua principal referência $^{68}$. Em fins do século XIX, a cidade estrangeira que nela coabitava passa a editar folhas em sua língua natal, desenvolvendo uma vigorosa imprensa, sobre a qual há referências esparsas $^{69}$, poucos exemplares e escassa investigação ${ }^{70}$.

Há certa unanimidade, entre os autores que buscam referência à imprensa periódica em língua espanhola editada na cidade de São Paulo no período em questão, quanto à dificuldade de localização de séries, e mesmo de exemplares avulsos para sua avaliação. A carência nesse campo já era sinalizada por José de Souza Martins em 1989 que, em seu estudo sobre a presença espanhola na formação da força de trabalho na economia cafeeira observa que, dos quinze periódicos em língua espanhola publicados na cidade, no período em pauta, nada mais teria restado $^{71}$. A mesma deficiência é apontada por Elda González Martinez em 1990 que, ao relacionar todos os acervos e fundos por ela pesquisados, no Brasil e no exterior, verificou restarem apenas "escassos números",72, e por Maria Antonieta Antonacci que no decorrer de seu estudo lamenta o pouco que se conservou da "rica e efervescente produção de periódicos" e que as coleções, fragmentadas e incompletas, não raro, exibem apenas um número por ano ${ }^{73}$. As análises e constatações efetuadas por esses autores reforçam e corroboram, ainda mais, a inusitada importância da série aqui examinada.

${ }^{68}$ A esse propósito, ver SCHMIDT, Afonso. “A imprensa paulistana em 1888”. In: São Paulo dos meus amores. São Paulo: Paz e Terra, 2003 (1ª edição em 1954), pp. 168 e ss.

${ }^{69}$ Nesse particular, ressalte-se o exaustivo levantamento do Catálogo dos Periódicos (Alfabético, Geográfico e Cronológico), realizado por CAMARGO, Ana Maria de Almeida. A imprensa periódica como objeto de instrumento de trabalho: Catálogo da Hemeroteca Júlio de Mesquita do Instituto Histórico e Geográfico de São Paulo. São Paulo: Tese de Doutoramento, FFLCH-USP, 1975.

70 Especificamente sobre a imprensa periódica "étnica" conhecemos: CONSOLMAGNO, Marina. Fanfulla: perfil de um jornal de colônia (1893-1915). Dissertação de mestrado, FFLCH-USP, 1993 e SILVA, Maria Manuela Ramos de Souza. Horror à farda ou A saga dos imigrantes portugueses no "Gazeta Luzitana” (18831889). São Paulo: Tese de doutoramento, FFLCH-USP, 1991. No primeiro caso, o Fanfulla, jornal da colônia italiana, teria circulado na cidade de São Paulo. Já o Gazeta Luzitana circulou na cidade do Rio de Janeiro.

${ }^{71}$ MARTINS, J.S. "A imigração espanhola para o Brasil e a formação da força de trabalho na economia cafeeira: 1880-1930”. In: Revista de História. São Paulo: n.121, 1989, p.12.

72 GONZÁLEZ MARTINEZ, E. Op. cit.,1990a, pp. 218-219.

73 ANTONACCI, M. A. Op. cit., 1997, p. 65; "Atravessando o Atlântico: Memórias de imigrantes espanholas no fazer-se de São Paulo”. In: Trajetos, vol. 1, n 2, 2002, p. 4. 
Embora fossem muitas as publicações em língua espanhola no período, pouquíssimas eram citadas por estudos coevos. Alfredo Moreira Pinto, por exemplo, enumerando os periódicos que circulavam na cidade de São Paulo em $1900^{74}$, citava, dentre outros, os jornais Fanfulla, La Tribuna Italiana, Il Tribuno e La Cronaca Italiana, publicados em língua italiana, e o Germânia e o Deutsche Zeitung, em língua alemã. Dos periódicos em língua espanhola faz referência apenas ao La Ibéria, e, curiosamente, não menciona outros como o EDE, que já circulava (diariamente) na cidade, desde outubro de 1898, com redação, administração e tipografia à Rua São João, 83.

Ao EDE e ao La Ibéria, àquela altura, já se somavam outros títulos em língua espanhola, como o El Correo Español (1891), El Heraldo (semanário, 1892), La Gaceta Española (três vezes por semana, 1897) e $O$ grito do povo (em português/italiano/ espanhol - semanário, 1900) ${ }^{75}$.

O La Voz de España (LVE) ${ }^{76}$, cujo primeiro número circulou em 01.07.1900 ${ }^{77}$, também fundado e dirigido por Eiras Garcia, suspendeu sua circulação em 31 de março do ano seguinte, reaparecendo em outubro de 1905, reiniciando com o número 1. Há evidências de que este semanário tenha circulado simultaneamente ao EDE (diário) e que, mais tarde, tenha ocorrido a fusão das duas publicações.

O EDE, por sua vez, será editado na cidade até 1922, data limite da série localizada. Ele não sobreviveria à morte de seu fundador, Eiras Garcia, em finais de 1921, que sempre soubera enfrentar e driblar as habituais crises financeiras pelas quais passara. É dele, aliás, o editorial que inaugurava o primeiro número, em outubro de 1898, e pelo qual fixava, de modo didático, o seu propósito:

A parte de todo aquello que afecte directamente a nuestra patria, dentro o fuera de ella; asuntos que serán expuestos y comentados, con sencillez y absoluta veracidad; nos proponemos informar a nuestros lectores de todo cuanto se refiera al país en que hoy residimos, en forma tal que se haga innecesario acudir a la lectura de los otros periódicos para enterarse de los acontecimientos del día.

\footnotetext{
${ }^{74}$ Ano da publicação de seu livro A cidade de São Paulo em 1900. $2^{\mathrm{a}}$ ed., fac-símile. São Paulo: Governo do Estado, 1979 (Coleção Paulística, 14); (1ª ed. 1900), p. 137.

${ }_{75}$ Entre os anos de 1890 a 1900 identificamos por volta de 40 novos títulos de periódicos publicados em língua estrangeira na cidade de São Paulo. A esse respeito, ver: Catálogo dos periódicos publicados no Estado de São Paulo. Organizado pelo Dr. Pedro Augusto Carneiro Lessa, para as comemorações e exposição da Imprensa no Brasil. Primeiro Centenário da Imprensa no Brasil, 1808-1908 (2164 títulos); FREITAS, Affonso de. A imprensa periódica de São Paulo desde os seus primórdios em 1823 até 1914. São Paulo: Typografia do Diário Oficial, 1915.

${ }^{76}$ Da Hemeroteca do Arquivo do Estado de São Paulo constam dois números do La voz de España, um de 1904 e o outro de 1908.

${ }^{77} C f$. informação contida em exemplar localizado no AMAE, datado de 16.10.1902.
} 
O LTE surgiria somente em $1902^{78}$. Desconhecemos o período de sua circulação. Consta que teria sido fundado por Valentin Diego, irmão de Isidoro Diego, ambos ativistas e também gráficos como Eiras Garcia, atividade que contribuiu em número considerável na criação (e também na colaboração) de periódicos no período, muitos deles de coloração militante operária ${ }^{79}$.

Diferindo de muitas dessas, o EDE era uma empresa jornalística e isso talvez explique a sua relativa longevidade, num ambiente em que folhas se criavam e se extinguiam, provavelmente por falta de recursos, ainda que, como vimos, sua trajetória tenha sido pontuada de dificuldades financeiras. Foram muitas as estratégias orquestradas para a sua manutenção no período, uma das quais diz respeito aos anúncios publicitários veiculados: em determinados períodos pôde ser observada a circulação de anúncios em língua portuguesa, uma "abertura" do jornal a outros anunciantes não pertencentes exclusivamente à colônia. Por outro lado, tal longevidade, levando-se em conta as características do seu público-alvo é, no mínimo, instigante. O imigrante espanhol desse período está "entre os mais pobres e os de menor mobilidade social" $" 80$, e, somado a isto, devemos contabilizar o seu elevado índice de analfabetismo, como aspectos a desafiarem a nossa compreensão.

Cabe aqui também interrogar o modo pelo qual conseguiu, ao longo do período, conciliar tantos e tão díspares interesses da população imigrada espanhola tornando-se, como se observou, porta-voz de uma camada específica dela, sem que, pelas evidências, tenha abdicado dos pressupostos inerentes ao "empresário" e imigrante bem-sucedido.

No caso específico dos jornais paulistanos, não devemos esquecer, a sua prosperidade e duração podem estar associadas ao fato de terem sido fundados por poderosos fazendeiros ${ }^{81}$, condição que os colocava como porta-vozes da aristocracia cafeeira, o que por vezes redundará em conflito com os jornais ditos étnicos.

A primeira edição da série que examinamos, no $15^{\circ}$ ano de sua publicação, foi a de número 984. Seu exemplar custava então 100 réis. A sua composição gráfica, bastante variada, não seguiu um padrão rígido. Durante todo o período avaliado, via de regra circulou com quatro páginas (ocasionalmente com seis e raramente com oito), e seis colunas. Nestas,

\footnotetext{
${ }^{78}$ Era dirigido por Higino Bisbal. Sua redação localizava-se à Rua XV de Novembro e Rua São Bento, 4 altos, e circulava às quintas-feiras, em São Paulo e em Santos.

${ }^{79}$ Sobre a imprensa operária, $c f$. FERREIRA, Maria Nazareth. Imprensa Operária no Brasil (1880-1920). Petrópolis: Vozes, 1978.

${ }^{80}$ MARTINS, J. Op. cit., 1989, p. 10.

${ }^{81}$ CAPELATO, Maria Helena Rolim. Os intérpretes das luzes. Liberalismo e Imprensa Paulista, 19201945. Tese de doutoramento, FFLCH-USP, 1986, p. 11.
} 
notamos uma certa divisão temática por matérias, nada rígida, que, de certo modo, respeitava uma hierarquia aplicada diferentemente a cada período analisado, atribuindo ou não posição de destaque a determinados assuntos, em dado momento. De modo geral, no entanto, os textos, anúncios, reclames, matérias e seções ali contidos testemunharam o quadro histórico em que foi produzido; em outras palavras, fica clara a sua produção historicamente determinada, enquanto registro comprometido com um dado contexto específico.

Nos exemplares iniciais avaliados, notícias alimentadas pelas freqüentes viagens que fazia Eiras Garcia ou enviados seus para as localidades onde fosse expressiva a colônia (Jaú, São Carlos, Araraquara, Jaboticabal, Bebedouro), exaltavam o "progresso e a abundância dos espanhóis" enumerando nominalmente, para cada localidade visitada, os que "passaram da categoria de assalariados para a de homens livres", ou seja, os novos pequenos proprietários ${ }^{82}$. Este podia ser um bom assunto para a primeira página, onde geralmente figurava. Também ali, as questões e/imigratórias estavam sempre na pauta do dia: a reforma da lei de emigração, a reorganização das inspeções e a simplificação da documentação exigida para o embarque, a regulamentação da emigração golondrina ${ }^{83}$. Com relação à questão emigratória e ao aluvião de pessoas que então deixava o país e as tentativas do Governo espanhol de impedi-la por meio de legislação restritiva, o jornal expunha claramente a sua opinião, para quem "a iniciativa de proibir era inútil’"84.

Eiras Garcia nesta época, década de 1910, viajava regularmente para a Europa, de onde retornava trazendo uma série de livros, muitos deles escolares, que eram anunciados no $\mathrm{EDE}^{85}$. Notícias domésticas, de preferência sensacionalistas, bem ao gosto popular, na tentativa de atrair o público leitor, também aí, na primeira página, eram estampadas. A notícia do suposto suicídio de uma mulher espanhola no Alto da Serra circularia por quase uma semana. Mantinham-se também, como assunto de primeira página, as notícias recebidas por telégrafo dos correspondentes internacionais (Inglaterra, França, Alemanha, Itália, Estados Unidos, Argentina, Chile, Paraguai, Japão e Rússia, além, evidentemente, do de Madrid). por exemplo.

${ }^{82}$ Essas viagens serviam também para a divulgação e venda de assinaturas do periódico. EDE 10.06.1912,

${ }^{83}$ Golondrina, ou andorinha: assim se denominava a emigração sazonal, com saídas e retornos determinados pelo calendário agrícola, para a Argélia, então colônia francesa. Em finais do século XIX do total emigrado $21,5 \%$ para lá se destinavam. O declínio do fluxo pode ser atribuído à insurreição dos nativos ocorrida em 1881, a partir do qual cresce o interesse por novos destinos, como a América; já em 1912, essa cifra havia baixado para $11,6 \%$.

${ }^{84}$ EDE 17.02 e 24.07 .1912$.

${ }^{85}$ En el Vapor Cadiz (...) ven una remesa libros que nos remetió el director de esa publicación (...) Silabario, Según libro, Tercer libro, Juanito, Guia del artesanato, Geografia, Historia de España, Gramática, Catecismo, Tabua de contas, Aritmética, Cuadernos de papel para aprender a escribir. EDE 24.07.1912. 
As pautas internacionais eram bastante diversificadas e mesmo inusitadas, tratando de política a questões climáticas locais (explosões, tremores de terra, tempestades, chuvas torrenciais, inundações); catástrofes e naufrágios (Titanic); agitações populares (desordens, saques, greves, seqüestros, prisões de agitadores), e até prognósticos astrológicos. Os acontecimentos de 1917 na Rússia, do correspondente em São Petersburgo, deslocaram para outras páginas os assuntos geralmente reproduzidos na primeira.

$\mathrm{Na}$ segunda página também podiam ser encontrados assuntos internacionais, dependendo do volume de informações, mas, inevitavelmente, destinava-se a atender os interesses mais imediatos de um público-alvo, estampando ocorrências civis envolvendo colonos (nascimentos; falecimentos; casamentos na colônia; abertura de estabelecimentos industriais ou comerciais) e informações de seu interesse, como questões relativas à colheita e às linhas férreas.

Podia, além disso, conter publicidade, veiculando produtos fabricados também no interior do Estado, exclusivamente de espanhóis, num primeiro momento momento. Regularmente, a segunda página trazia, em suas colunas da esquerda, um romance em capítulos (folhetim) e, eventualmente, poesia, indicando, em ambos os casos, a existência de um público leitor feminino, e uma tendência que se afirmara na imprensa brasileira, por inspiração francesa. A sua localização sugere que muito provavelmente este romance seriado seria recortado, e talvez encadernado para sua conservação integral ${ }^{86}$.

A terceira página ainda podia mostrar uma ou outra notícia internacional, mas era nitidamente publicitária. Publicavam-se nela periodicamente anúncios de empresas de navegação, as saídas e os destinos dos navios e dos vapores de viagem ${ }^{87}$. O preço de uma passagem de terceira classe para Almeria, na Andaluzia, por exemplo, custava 180 francos, acrescido de 5\% de imposto federal. Outras empresas de transporte, de bandeira não espanhola, também anunciavam suas saídas, caso do Lloyd Real Holandez, com passagens de $3^{\text {a }}$ classe para Portugal e Espanha, a 105\$000 (mais o imposto de 5\%), e a Chargeurs Reunis - Amiral Exelmans, que, curiosamente cobrava, pela mesma passagem de $3^{\text {a }}$ classe, para Lisboa ou Vigo, apenas 40\$000. Estabelecimentos bancários faziam-se igualmente presentes nestas páginas, tal

${ }^{86}$ Gênero bastante popular na época, os folhetins, como eram chamados, passaram a ser publicados com regularidade na imprensa paulistana, nas primeiras décadas de 1900. $C f$. FIORENTINO, Teresina Aparecida del. $A$ produção e o consumo da prosa de ficção em São Paulo (1900-1922). Dissertação de mestrado, FFLCH-USP, 1976, p. 94. Ver, a respeito, o Capítulo IV.

${ }^{87}$ Pela Vapores Correos Españoles, de Pinillos, Izquierdo \& Co., empresa de Cádiz, por exemplo, o paquete Barcelona ia para Las Palmas, Cádiz, Málaga, ALMERIA (grafada com letra maiúscula), Barcelona, Leixões, Vigo, Coruña, Santander e Bilbao, enquanto o paquete Valbanera seguia para Montevideo e Buenos Aires, numa clara evidência, tanto num caso como noutro, dos destinos preferenciais da colônia aqui instalada. 
como o Banco Español del Río de la Plata, com matriz em Buenos Aires, funcionando com sede também em São Paulo, na Rua Álvares Penteado, 17.

Esta terceira página acolhia eventuais anúncios publicitários ligados às Casas Importadoras, neste momento sobretudo as de gêneros alimentícios: o vinho produzido em Málaga era bastante divulgado, evidenciando a existência de um mercado consumidor mais refinado e/ou com maior poder aquisitivo. Aqui também se situavam os anúncios dos estabelecimentos hoteleiros pertencentes a espanhóis na Capital de São Paulo ${ }^{88}$, e na cidade de Santos, no Estado de São Paulo. Era ainda neste espaço que observamos os reclames de alguns estabelecimentos comerciais da colônia ${ }^{89}$; programações sócio-esportivas da cidade ${ }^{90}$, e convocações para as festas de suas associações. Apareciam, e eram freqüentes no período analisado, as convocações para ingresso nas sociedades e agremiações e notas sobre eleições de dirigentes (Federação Espanhola, Centro Galego, etc.). A exclusividade inicial a anunciantes da colônia foi sendo progressivamente alterada para abrigar outras peças publicitárias, e, das empresas notadamente estrangeiras que passaram a divulgar em suas folhas, destacam-se especialmente as alemãs, pelo volume e variedade de produtos.

A quarta página podia acomodar, como às vezes também a terceira, dependendo da frequiência dos anúncios, a seção Biblioteca del Diário Español, trazendo contos seriados, apresentados em capítulos. Pensamentos, provérbios, notas cômicas e humorísticas, eram seções sem maior regularidade. Vez por outra aparecia uma cotação de preços dos gêneros alimentícios (tal qual uma bolsa de mercadorias), ou anúncio de atacadistas de cereais, como a Casa Española, de Aparício Marti, na rua Paula Souza, 51. Neste caso, o prestigiado comerciante alertava que "algunos nombres de los productos estaban en el idioma del país, para mayor inteligencia de los lectores”, e, assim, frijoles transformava-se em feijão, maíz em milho, e ajo em alho, por exemplo. Assim agindo, estaria ele tentando atrair o consumidor nacional?

Tais anúncios publicitários, com o tempo, foram adquirindo maior expressividade, passando em alguns casos, a grandes anúncios, especialmente no segmento dos depósitos de

${ }^{88}$ Caso do Gran Hotel Eiras, na Rua Brigadeiro Tobias, 83 "a dos pasos de las estaciones de la Inglesa e Sorocabana"; do Hotel Continental, de Agapito Alvarez, na rua da Conceição, 101 (hoje Avenida Cásper Líbero); do Hotel dos Viajantes, de Mariano Fernandez, Rafael de Souza e Manuel Ferreira, também na Rua da Conceição, 86.

${ }^{89}$ Caso do Taller de modista Hermanas Garcia, situado à Rua Conselheiro Ramalho, 102 e do Café Ibérico - Gran Cervezaria, de Manuel Vaz, na rua São Caetano, 135 ou dos importadores de vinhos.

${ }^{90}$ Destacando-se o "sport de la pelota", praticado no Frontón Boa Vista. Pelota era um esporte onde atuavam os pelotarios ou pelotaris, originários da região basca. Provavelmente, teria sido introduzida por esses imigrantes, como veremos adiante. 
venda por atacado de cereais e sementes de cebola das Ruas Santa Rosa, Paula Souza e da Cantareira. A regularidade dos mais antigos e a crescente incorporação de novos anunciantes neste segmento parecem indicar uma área em que os espanhóis iam obtendo certa hegemonia.

Nas páginas finais eram divulgadas notas oficiais como as da Diretoria de Terras, Colonização e Imigração, informando sobre leilões de terras ou as da Diretoria de Obras Públicas, notificando a construção de escolas e cárceres. No início do período analisado, eram nessas últimas páginas que se veiculavam notícias sobre colonos espanhóis do interior, envolvidos em querelas com capangas de fazendas e assassinatos.

Nos inícios da década de 1920, provavelmente em função do crescente volume de espanhóis já instalado no núcleo cafeeiro e do acirramento das relações entre fazendeiros e colonos, é nítida a abordagem mais agressiva com que o EDE (leia-se Eiras Garcia) passou a encaminhar as questões de violência contra os paisanos por parte dos fazendeiros, que lhe eram relatadas. O discurso agora vigente, e que ganhava as primeiras páginas, denunciava: "es sabido que aquí las garantias son letra muerta cuando las invoca el humilde, el flaco, el explotado (...) contra la brutalidad de hacendados" ${ }^{, 1}$, e acusava a falta de respeito dos fazendeiros, que não cumpriam os contratos e que maltratavam os colonos, condenando-os à miséria. A esse discurso seguia-se, quase sempre, a íntegra de uma carta enviada à redação por um colono, relatando infortúnios e passagens degradantes geralmente ocorridas nas contendas com os administradores das fazendas.

Paulatinamente promovidos à primeira página foram os anúncios imobiliários, aspecto sintomático numa cidade que alcançava os 600 mil habitantes. Neste particular, oferecia-se com insistência terrenos no Alto da Lapa, descrevendo as vantagens de residir em "local tão aprazível". Também aí, na primeira página, e no ano de 1922, o derradeiro do período analisado, observamos que a colônia espanhola se movimentava no sentido de homenagear o país de acolhimento em seu centenário da independência. Era intenção construir um monumento para as festas e uma comissão foi organizada para arrecadar as subscrições junto aos membros da colônia.

Ocasionalmente, veiculavam-se notas relacionadas a eventos culturais ou de entretenimento, como a Romería Española ${ }^{92}$, exposições de artistas plásticos espanhóis na cidade e espetáculos teatrais.

\footnotetext{
${ }^{91}$ EDE 17.02.1922.

${ }^{92}$ Festa comemorativa à Virgem do Rocio, de Sevilha. Representou um dos principais eventos da colônia e será objeto de análise específica no Capítulo IV.
} 
Entrementes, já aqui se delineava o grande balcão de mão-de-obra representativo dessa cidade em construção: solicitava-se, em qualquer espaço do jornal, marceneiros, carpinteiros, torneiros, serralheiros, guarda-livros, e até cigarreras, para fazer cigarros de palha, num primeiro momento, seguido depois por crescentes ofertas para empregos domésticos. Por outro lado, também se pedia colocação, enunciando a qualificação ou a habilidade do interessado. Um exemplo: "Espanhol de boa idade, educado, instruído e com boas cartas de recomendação, deseja colocar-se em casa de família espanhola que queira utilizar seus serviços como escrevente ou educador de crianças" $" 93$.

Observa-se, no decorrer do período analisado, crescente oferta de serviços na área médica, dentária, farmacêutica e farmacológica ${ }^{94}$. Notável a alteração observada, no decorrer do período examinado, da natureza dos produtos anunciados, denotando maior exigência e poder aquisitivo por parte dos consumidores, e claramente orientados para um público leitor também feminino: oferecia-se voiles de todos os tipos, estampados, bordados; mousselines; chitas; cinta chamelotte; pañuelos y guantes de pellica blanca y seda ${ }^{95}$, disponíveis em um local que era considerado um dos mais chics da cidade, a Rua Direita, nº.16-18-20.

Outra seção bastante concorrida foi a de personas buscadas. Nela, publicava-se o nome, a origem, a data de chegada e o suposto último domicílio do elemento procurado, num claro indicativo de como as famílias se desintegravam e perdiam o contato com seus membros também emigrados.

Apenas como dado complementar, em algumas das edições do ano de 1918 pudemos observar a palavra Censura estampada no centro de um espaço em branco. Faltam-nos, a respeito, dados concretos, embora seja patente que o jornal de Eiras de há muito incomodava os interesses dos fazendeiros, a quem desafiava, denunciando ou procurando-os pessoalmente para negociar os contratos dos imigrantes que se sentissem lesados. Por essa razão, passou a sofrer ameaças, tendo sido processado e preso, em 1907. Essas questões, somadas às dificuldades que provavelmente enfrentasse em conseqüência, refletiam na situação financeira de seu periódico. Sujeito à censura, essa é a única evidência que transpareceu. Somente mais tarde alguns desses fatos foram declarados, como a sua inclusão em uma "lista negra", que subtraía dos integrantes "as garantias de que gozava a imprensa brasileira", cuja pena imediata era a alta no preço do papel importado dos Estados Unidos. Durante os anos finais da Primeira Guerra Mundial, em que ele saiu em defesa da Alemanha "por acreditar ser aquele povo vítima de uma infame

\footnotetext{
${ }^{93}$ EDE 27.06.1912.

${ }^{94}$ Dentre os anúncios de medicamentos, destaque especial para algumas vedetes, como a Emulsão Scott e o Elixir de Nogueira, ao lado de um outro que prometia a cura do reumatismo.

95 Pañuelo: lenço; guantes: luvas.
} 
confabulação de interesses bastardos",96, o jornal mal se sustentava, passando a exibir crescentes anúncios de firmas germânicas. Neste ano, em pelo menos uma ocasião, a circulação do jornal teria sido suspensa ${ }^{97}$. Nessas condições, Eiras admitia que sua sobrevivência se devia a doações particulares e subscrições da colônia de várias partes do país, para quem emitia "ações de empréstimo que eram oferecidas à comunidade" ${ }^{98}$. Apresentou-se durante certo tempo com apenas três, das quatro, seis ou até oito páginas habituais, muitas vezes reeditando o EDE que era publicado na cidade do Rio de Janeiro - do qual não obtivemos qualquer informação ${ }^{99}$. Mantinha-se, contudo, provocador, incitando especialmente órgãos da imprensa nacional. Por ocasião do aniversário do Rei Alfonso XIII publicou nota com o título "odio sarraceno", comentando que o jornal $O$ Estado de São Paulo não dedicara uma linha sequer em sua homenagem $^{100}$.

$\mathrm{Na}$ verdade, Eiras conhecia perfeitamente o ambiente da imprensa nacional, onde já trabalhara logo após a sua chegada à cidade, há quase três décadas. É de seu necrológio alguns dados coletados: galego de Pontevedra, nascido em 1868, era então proprietário de um grande "estabelecimento tipográfico e de uma livraria", e em seu diário local "combatia o caciquismo político", até que, sendo ameaçado de prisão e de intervenção em seus negócios pelo governador da província, e para "evitar ser assassinado", vê-se premido, em 1894, a fugir no primeiro barco que saía de Vigo para a América; partiu, assim, sem destino certo, deixando mulher e um filho. Tendo desembarcado em Santos, viria a São Paulo, onde ocuparia diversos cargos em empresas jornalísticas, inclusive no Correio Paulistano, até fundar um primeiro diário, do qual nada conhecemos, "mas por desconocer los trámites de la prensa en Brasil y por la inferioridad numérica de los españoles, no logró sustentarlo". Fundou, então, o La Voz de España, em 1900, ao qual mais tarde, entre interrupções e recomeços, se fundiria o EDE.

Embora conste que sua chegada ocorreu em 1894, na consulta aos LRC do CGE, seu primeiro registro é de 1903 , ocasião em que se declarou tipógrafo ${ }^{101}$. Em 1907, no próximo registro localizado, aparecia como negociante e periodista ${ }^{102}$ e nos dois últimos encontrados, em 1918 e 1920, indicou ser industrial ${ }^{103}$.

\footnotetext{
${ }^{96}$ EDE 23.12.1921, $c f$. dados obtidos em seu necrológio.

${ }^{97}$ EDE 25.10.1918, dentre outros.

${ }^{98}$ EDE 11.09.1918.

${ }^{99}$ EDE 18.05.1918.

${ }^{100}$ EDE 19.05.1919.

${ }^{101}$ LRC 10.06.1903.

${ }^{102}$ LRC 21.03.1907

${ }^{103}$ LRC 28.08.1918 e 29.07.1920.
} 
Dos dez anos examinados, um tema dificilmente ficou de fora da pauta editorial do EDE, quer seja como uma pequena nota ou artigo, quer seja em grandes manchetes de primeira página. "As últimas notícias de Espanha e Marrocos" ${ }^{104}$ : em geral sob essa epígrafe, reproduziam-se matérias enviadas pelo correspondente de Madri, pelas quais se informava desde a série de desacertos contínuos e os abusos da oficialidade, em geral muito jovens, "que transformaram Mellila em um centro de recreio"105, até os assaltos de "bandoleros marroquíes". Inúmeras foram as listas de subscrição iniciadas tanto na capital quanto em localidades do interior destinadas "à obra patriótica de prestar auxílio a todos os irmãos de nacionalidade que, vítimas do seu heroísmo, caem nos campos de batalha de Marrocos...”"106, cujo valor era enviado ao EDE para, depois de publicado, ser entregue ao cônsul. O assunto de tal modo sensibilizava a colônia, afinal muitos deles haviam fugido por receio das convocações militares, que "uma grande fotografia do bravo general Manuel Fernandez Silvestre que morreu frente às tropas espanholas que lutaram em Marrocos" foi distribuída como brinde aos novos assinantes de $1922^{107}$, o que, de certo modo, poderia indicar que seus assinantes eram simpatizantes da causa imperialista que seu país vinha desenvolvendo no norte da África.

A comunhão entre as representações do jornal e aquelas presentes no imaginário social da época, ou o seu papel na conformação de imaginários, ou seja, na representação de uma autocoletividade, constituem matéria privilegiada para o historiador, cujos indicadores, aqui apenas sugeridos, apontam para a multiplicidade de enfoques divisados e que buscaremos examinar.

A publicidade consiste noutra fonte de importância na apreensão das práticas cotidianas, traduzindo o aparecimento de uma camada média emergente, que se distanciava da grande maioria do contingente de espanhóis que habitava a cidade, constituída por comerciantes, pequenos industriais e profissionais liberais, uma nova elite, cujos hábitos e preferências iam se "refinando" muito ao gosto de um padrão "civilizado". Para sua abordagem e delineamento foi essencial o exame de trabalhos específicos ${ }^{108}$, levando-se em conta, porém, a dificuldade em se

${ }^{104}$ EDE 24.03.1922.
${ }^{105}$ EDE 04.11.1921.
${ }^{106}$ EDE 17.09.1921.
${ }^{108}$ EDE 21.10.1921. anos 20. Dissertação de mestrado, FFLCH-USP, 1977; SANT'ANNA, Denise Bernuzzi de. "Propaganda e História: antigos problemas, novas questões". In: Revista Projeto História. PUC-SP. São Paulo: n. 14, EDUC, fev./97, pp. 89112; RAMOS, Ricardo. Do reclame à comunicação. Pequena história da propaganda no Brasil. São Paulo: Atual Editora, 1985; SEVCENKO, N. "Introdução: o prelúdio republicano, astúcias da ordem e ilusões do progresso". In: História da vida privada no Brasil, 3. São Paulo: Companhia das Letras, 1998, pp. 7-48 e BAUDRILLARD, Jean. "Significação da publicidade". In: Teoria da Cultura de massa.Rio de Janeiro, Paz e Terra, 1978. 
captar, para essas duas primeiras décadas do século, a real dimensão do caos, do nervosismo e da aceleração vivenciados pelo universo paulistano em sua conturbada e contraditória experiência de urbanização - "São Paulo vivia numa impressionante impossibilidade e, a maior delas, era a impossibilidade do seu próprio retrato", pontua muito sabiamente Maria Inez Machado Borges Pinto ${ }^{109}$.

\section{c) As fontes literárias}

A Paulicéia exibe para o período que nos toca um notável desfile de narrativas literárias e memorialísticas conduzidas quase sempre pela preocupação em registrar as múltiplas transformações que se iam impondo àquela, até então, inexpressiva cidade que, cada vez mais, vinha sendo absorvida pela vertigem da modernidade. Relatos que, no período do despertar da metrópole, pontuam as diversas faces que a Capital paulista assumia, caracterizando, no seu cosmopolitismo conflituoso, as diversas temporalidades e as múltiplas tensões que experimentava.

Acentuando características urbanas específicas, priorizando determinados locais da cidade, falando da gente que nela habitava e de seus costumes, particularizando singularidades das colônias de estrangeiros que nela se fixavam, enfim, demarcando sua fisionomia, as narrativas buscam resguardar uma Paulicéia que incessantemente se esvaía para dar lugar a uma outra, que contínua e inapelavelmente se impunha, deixando-nos registros de reconhecido potencial histórico. A minuciosa consulta que realizamos a esta fonte visava, portanto, transitar por lugares de outro modo dificilmente acessíveis, e, se como era esperado, a quantidade de citações ao elemento espanhol na cidade não foi a desejável, constituindo-se, na grande maioria dos casos, de referências esparsas nas quais aparecia quase sempre secundando a personagem principal (o imigrante italiano), ainda assim, os pequenos fragmentos em que aparece revelam sua presença em circunstâncias das mais surpreendentes e inauditas nesse novo espaço social da metrópole em formação ${ }^{110}$.

109 PINTO, M.I.B.P. "Flashes do cotidiano: modernidade postiça e provincianismo na urbe da belle époque. São Paulo nos anos 20”. In: História: Fronteiras. XX Simpósio Nacional da ANPUH. São Paulo: Humanitas/FFLCH-USP, 1999, p. 893.

${ }^{110}$ Há diversas alusões, nessas obras, a imigrantes espanhóis habitando também em outras cidades. É o caso de Quincas Borba, de Machado de Assis (Rio de Janeiro: Civilização Brasileira, 1975) e O Ateneu, de Raul Pompéia (In: Obras, vol. II. Rio de Janeiro: Civilização Brasileira, Oficina Literária Afrânio Coutinho, Fename, 1981), nas quais há clara referência à criadagem espanhola da cidade do Rio de Janeiro. No primeiro caso, a pajem de Murilo Rubião era espanhola; no segundo, o jardineiro andaluz e a camareira canarina eram, ambos, funcionários do diretor do Ateneu, Aristarco. 
Nessa rica, fascinante e deliciosa incursão, grandes descobertas, no seleto elenco de escritores que, por sua produção e estreita ligação com a cidade, merecem destaque especial. É o caso, por exemplo, do jornalista e escritor António de Alcântara Machado. Como ninguém, ele conseguiu exprimir a síntese da efervescência da cidade, seus contrastes, sua modernidade postiça e suas gentes - sua galeria de tipos italianos e ítalo-paulistanos e sua exaltação a eles integra o que lhes é mais característico, a linguagem -, numa visão irônica e crítica à urbanização excludente. Com extrema sensibilidade, ele retratou este momento da história da cidade (décadas de 1910 a 30), em que nela fervilhavam diversos ritmos, contrapondo à tradição a modernidade, fixando-se particularmente em observações da vida cotidiana de seus habitantes $^{111}$. Mas é, sobretudo quando suas obras abrigam a temática do trabalho e dos trabalhadores na cidade, que ela se revela essencial para compor o cenário que mais nos interessa e que integra nossos protagonistas. Com efeito, Alcântara Machado, como também Mário de Andrade, de uma outra maneira, explorou em seus escritos a cidade operária, valendose da descrição das fábricas ou dos personagens que elegia para sua trama, geralmente compostos na esfera das camadas médias e populares.

Declara abertamente o seu objetivo no "artigo de fundo" de uma delas: "Brás, Bexiga e Barra Funda. Como membro da livre imprensa que é tenta fixar tão somente alguns aspectos da vida trabalhadeira, íntima e cotidiana desses novos mestiços nacionais e nacionalistas (...). Acontecimentos de crônica urbana. Episódios de rua"112.

Dos seus inumeráveis escritos, por meio dos quais pretendemos compor imagens da vida cotidiana da cidade, há passagens, lamentavelmente poucas, em que aparece o imigrante espanhol $^{113}$.

${ }^{111}$ Sua obra, ademais, é objeto de análise em: CARELLI, Mario. "A especificidade de António de Alcântara Machado". In: Carcamanos e comendadores - Os italianos de São Paulo: da realidade à ficção (19191930). São Paulo: Ática, 1985, pp. 153-170; 182-187; PINTO, M. Op. cit., 1999, pp. 883-897 e PACHECO, Renato José Costa. "O imigrante na literatura brasileira de ficção". In: Sociologia, 18, nº 3, agosto 1956, pp. 201-232.

${ }^{112}$ MACHADO, Antonio de Alcântara. Brás, Bexiga e Barra Funda. Notícias de São Paulo. São Paulo: Imprensa Oficial do Estado/Arquivo do Estado, 1982, pp. 18-19 (edição fac-similar).

113 "Caramba, come dicono gli spagnuoli!" (Caramba, como dizem os espanhóis), aparece em Brás, Bexiga e Barra Funda, op. cit., p. 134; em "Laranja da China" há referências sobre o condutor galego que trabalhava no bonde do Largo de Santa Cecília e sobre o fotógrafo espanhol que trabalhava no Jardim da Luz (In: Novelas Paulistanas. Belo Horizonte: Itatiaia: São Paulo: Edusp, 1988), pp. 129 e 169 respectivamente. Em Lira Paulistana, na coleção de modinhas populares por ele recolhida, aparecem as canções "El huérfano", que conta a tragédia de uma migrante fugida do campo, depois que o marido fora assassinado pelo feitor, p. 211; "Milonguita", fala de Leonor, brasileira, filha de espanhóis que é assassinada pelo marido, p. 212 e "Adiós, mis farras", da moça do Brás, abandonada pelo noivo que se suicidou no Viaduto do Chá, p. 206 (In: Revista do Arquivo Municipal de São Paulo, vol. XVII, out. 1935, pp.189-220). Em Jacó Penteado (In: Belenzinho, 1910. Retrato de uma época. São Paulo: Martins, 1962, pp. 206 e 222), aparece a tentativa de ascensão do aeróstato do Capitão Martinez (espanhol) e referências ao time de futebol "Flor do Belém", da colônia espanhola. Em Henrique Raffard (In: Alguns dias na paulicéia. São Paulo: Biblioteca Academia Paulista de Letras, vol. 4, 1977) (Coleção Academia Paulista de Letras), ( $1^{a}$ ed.1890), p. 19, menção à “hermosa hija de Castilla”, caixeira do Café do Terraço Paulista. 
Como Alcântara Machado, também Mário de Andrade soube destacar na cidade "da garoa", a cidade "do trabalho", embora diferentemente daquele, deixasse entrever em muitos escritos certo mal-estar diante da invasão da cidade pelos italianos (sempre os italianos!). Não que não se sensibilizasse pela miséria da massa de emigrados, recorrente em sua obra, porém, opondo-lhes imagens daqueles melhor situados, emigrantes ou não, não poupava em sua sátira social sequer a tradicional família brasileira, acomodada em seus privilégios.

O conto Primeiro de maio é lapidar: nele, o autor, vai buscar um representante, no caso, um carregador, numa das mais humildes categorias laborais, dotando-lhe apenas de um número de registro ou matrícula (o “35”), deixando claro aqui, a sua crítica da sociedade coisificada. O carregador, sem nome, porta apenas um número que o identifica. Ele sai caminhando pela cidade - deserta e com o comércio fechado, mas com forte presença policial -, e vê frustradas as suas expectativas de comemorar o seu dia. A cidade, que lhe era tão familiar, ambiguamente causava-lhe sensação de estranheza, de não-pertencimento. Em outro momento, ilustra os conflitos entre brasileiros e estrangeiros, como no caso de Terezinha, italiana, acusada da prisão do marido, a quem traía com Fernandez, carroceiro espanhol, insultada pela sogra, que "não estava pra sustentar cachorrice de italiana acueirada com espanhol", retrucava "gritando que espanhol era muito milhor que brasileiro, sabe! Sua filha de negro! Não careço da senhora, sabe! Mulata! Mulatona! Mãe de assassino!"114.

Em outro momento, Mário, que conhecia bem o meio musical paulista e a marca da influência italiana nele, fala do maestro Marchese - "maestro uma ova (...) me contaram que na Itália ele esfregava rabecão num barzinho de Gênova, não sei” -, que havia instalado uma escola de música (uma "espécie de escola de música”), numa casinha da avenida Rangel Pestana, e acabara se transformando "numa espécie [de] rei da música do Brás". O personagem central e revelador, aqui, no entanto, era Dolores Bermudes, filha de imigrantes (espanhóis, por certo, embora ele não cite), cuja fala, ao discordar da forma de tratamento que lhe era dedicada pelo tal maestro, remeteu a uma nossa análise anterior, pela qual buscávamos ilustrar a questão entre gerações, isto é, entre pais espanhóis com seus filhos, a primeira geração de brasileiros: Fale `Dores` [dizia ela] 'Dores` como fiz me chamarem lá em casa (...). 'Dolores`é espanhol, não gosto. Sou tão brasileira como o senhor, fique sabendo! Já não basta esse Bermudes tão feio que não posso mudar..."

${ }^{114}$ ANDRADE, Mário de. "Piá não sofre? Sofre". In: Os contos de Belazarte. Belo Horizonte-Rio de Janeiro: Vila Rica, Editoras Reunidas Limitada, 1992, p. 90. 
Entrementes, até mesmo em Mário de Andrade pode-se perceber o equívoco, também observado em outros memorialistas, de confundir galego com português ${ }^{115}$, talvez pela semelhança entre os dois idiomas falados, engano também encontrado em Jacob Penteado ${ }^{116}$, Aluísio de Azevedo ${ }^{117}$, Aldo Nay ${ }^{118}$ e até mesmo em Chico Buarque de Holanda, no Prólogo da Ópera do Malandro - “... dá uma baixa, no português; o galego, acha estranho ...”119.

Não era, contudo, apenas o galego que aqui passava por português. Em Parque Industrial, obra de acentuada coloração política, Patrícia Galvão, a Pagú, comenta que "Paco" (apelido de "Francisco" tipicamente espanhol), garçom de restaurante em "chácara festiva da Penha", não passava de um "italiano dio cane!" 120.

Passagens como esta e tantas outras, registradas pela ótica de cronistas da metrópole em construção, surpreendidos e às vezes confundidos pela perplexidade de seu ritmo, revelam um universo de dimensões e percepções da cidade, fragmentado e circunstancial, porém amplo de significados, cujas entrelinhas evocando no seu cotidiano o cosmopolitismo conflituoso, sugerem múltiplas pistas e direções e são fundamentais na recuperação de aspectos que, de outro modo, seriam irrecuperáveis. Vislumbres de situações, breves cenas e pequenos retalhos transmitidos por esses olhares informados e nutridos pela realidade puderam, desse modo, ser costurados aos dados empíricos apresentados pela documentação consultada, na recuperação de importantes aspectos da trajetória do espanhol na cidade em um momento de profunda reformulação urbana e econômica, com ênfase especial nos expedientes, estratagemas e improvisos de que lançou mão como modo efetivo de subsistência. Grande parte desse contingente, de quem se reclama visibilidade, fez, pela cidade, um percurso marcadamente subterrâneo, furtivo, velado, invisível. Como figuras anônimas e incidentais esgueiravam-se nas franjas de seu espaço desordenado, na prática de atividades identificadas não apenas com a “invisibilidade", beirando, muitas vezes, as fímbrias da marginalidade. Nesse exame, interessa reconhecer os pontos de contato, as aproximações e as múltiplas realidades que se entrelaçam na reconstituição de experiências singulares e cotidianas por eles vividas. Importa também

\footnotetext{
${ }^{115}$ Idem, ibidem, o "padeiro portuga" de "bigode principiando, não vê que galego larga bigode...", p. 32.

116 PENTEADO, J. Op. cit., 1962, p. 100. Também aqui, a confusão entre "portugueses, morrugas ou galegos".

117 Em AZEVEDO, A. O cortiço (São Paulo: Editora Ática, 1995), aparecem diversas figuras de portugueses, e aspectos do contato entre lusitanos e brasileiros. Na p. 224, uns chamam os outros de "galegos".

${ }^{118}$ NAY, Aldo. Os três sargentos (São Paulo: Typografia Garraux, 1931) p. 22, traz um dono de botequim português, a quem os clientes chamam de "galego".

${ }^{119}$ HOLANDA, Chico B. Ópera do malandro. São Paulo: Círculo do Livro,1978, pp. 21 e 23.

${ }^{120}$ GALVÃO, P. Parque Industrial. Porto Alegre: Mercado Aberto; São Paulo: EDUFSCar, 1994, pp. 100-102.
} 
observar que as alusões veladas, esparsas e casuais a este elemento impõem uma reflexão que, de certo modo, aponta para a problemática natureza de sua inclusão.

\section{A estrutura da Tese}

Estabelecidas, assim, as possibilidades e limitações do nosso material empírico, e explicitadas algumas questões de ordem quanto ao objeto em questão, convém esclarecer como se encontra estruturado o trabalho. No primeiro capítulo buscamos apresentar aspectos do processo de metropolitização da cidade em seu cosmopolitismo conflituoso, salientando a presença maciça dos imigrantes e procuramos delinear a natureza dos primeiros contatos do espanhol com a metrópole em construção. O segundo capítulo busca examinar a complexa inserção do espanhol nesse momento da cidade em transição focalizando elementos que compuseram os seus modos de vida e sobrevivência. No terceiro capítulo elencamos para análise alguns setores econômicos em que despontou uma camada média composta de imigrantes espanhóis (pequenos empresários, comerciantes e importadores e uma camada constituída por profissionais liberais). O quarto capítulo foi dedicado ao exame dos diversos cenários de sua vida pública, como aqueles constituídos por meio das associações, e no quinto pinçamos expressões da militância e da propaganda libertária protagonizadas por alguns de seus expoentes.

Tais blocos, aparentemente dissociados entre si na forma de exposição, estão entretanto intrinsecamente relacionados e articulados na trama histórica da "cidade em transição". Seu exame, é nossa expectativa, deve contribuir com novos elementos no desvendamento de aspectos que, em seu conjunto, possam atribuir uma feição ao espanhol que nela viveu, dotando-lhe de maior visibilidade.

A invisibilidade é efeito, o silêncio é eloqüente. As matrizes, responsáveis pelo “ocultamento" e, em decorrência, pela obscuridade historiográfica do espanhol, se inscrevem, não exclusiva, mas largamente, nas circunstâncias ditadas pela trajetória singular desse contingente enquanto tal, segundo aspectos já sinalizados que no decorrer da exposição serão aprofundados.

O caminho de sua superação, parece-nos óbvio nesse momento, transita pela utilização de fontes alternativas que possam contribuir com novos elementos para ampliar a sua reflexão, e implica um olhar que esmiúce o silêncio, e que o faça falar. 
CAPítulO I

A Cidade EM TRAnSiÇão E A PRESEnÇA do

IMIGRANTE ESPANHOL

A cidade se escoa como uma esponja dessa onda que reflui das recordações e se dilata...

A cidade não conta o seu passado, ela o contém como as linhas da mão, escrita no ângulo das ruas, nas grades das janelas... nas antenas do pára-raio, nos mastros das bandeiras.

Ítalo Calvino, Cidades Invisíveis 


\section{A metamorfose da paulicéia e a presença maciça dos imigrantes}

Século XIX, últimas décadas. No Brasil, a república, recém instaurada, revelaria o despontar vertiginoso de uma até então pacata e provinciana cidade, descrita como modorrenta e monótona e habitada por gente taciturna, no registro das impressões dos viajantes que por ela transitaram ${ }^{1}$.

Sua fisionomia colonial, de burgo acanhado, começaria a adquirir aspectos de cidade européia, ainda que sua infra-estrutura urbana permanecesse modesta. Os velhos edifícios coloniais, as tortuosas e escassas ruas calçadas, os bondes de burros, as pequenas pontes de madeira e a iluminação a gás ainda aguardariam as primeiras grandes reformas, que viriam mais tarde quando a cidade "nova rica" buscava assemelhar-se ao padrão europeu.

Do eixo central, o chamado "Triângulo", começava a espraiar-se, serpenteando em diversos sentidos, seguindo a trilha dos velhos caminhos de tropas, das estreitas estradas entrecortadas por várias chácaras e ao longo das linhas férreas. Jorge Americano ${ }^{3}$, em sua passagem pela cidade, em 1898, deixou registradas suas impressões no mapeamento urbano que traçou da cidade:

São Paulo teria entre 150 e 200 mil habitantes. Além do Triângulo Central estendia-se para o lado da Liberdade, até o largo desse nome, prosseguindo, meio rua, meio estrada, para Vila Mariana, com algumas chácaras. Da esquina da rua São Joaquim partia a estrada de ferro para Santo Amaro. A avenida Brigadeiro Luis Antonio seguia, recémaberta, em prolongamento da rua de Santo Amaro, mas o seu começo ainda estava interceptado pela chácara de Dona Paulina, na rua do Riachuelo, onde houve depois o Fórum Criminal.

A cidade exibia outros eixos: o Largo da Memória, de onde, seguindo pela rua da Consolação alcançava-se a Avenida Paulista recém-inaugurada e limite sul da cidade - local conhecido até há pouco como "Alto do Caaguaçu”, denominação a que se seguiu a de Rua Real Grandeza, então uma simples trilha - em cujos arredores ficava o Hospital de Isolamento.

${ }^{1}$ Cf. MARQUES, Gabriel. Ruas e tradições de São Paulo. Uma história em cada rua. São Paulo: Cons. Estadual de Cultura, s/d (1ª edição 1957), pp. 124-125; MARTIN, Jules. São Paulo Antigo e São Paulo Moderno. São Paulo: Eds. Vanorden Cia., 1905, p. 90 e ZALUAR, Emílio, viajante português que teria circulado pela cidade em 1860, em sua Peregrinação à Província de São Paulo. Apud: TAUNAY, Afonso d'Escragnole. Velho São Paulo. Vol. II. São Paulo: Ed. Melhoramentos, 1954, p.25.

2 O "Triângulo", alusão recorrente na literatura de época, era constituído pelas ruas XV de Novembro, Direita e São Bento.

${ }^{3}$ AMERICANO, J. São Paulo naquele tempo (1895/1915). São Paulo: Saraiva, 1957, p. 99. 
Essa trilha começava, mais ou menos, na Rua da Consolação, até encontrar a Rua Augusta e continuava serpenteando pelo alto do espigão do Caaguaçu, descia pela ribanceira do vale que vinha do Riacho do Anhangabaú [...] ia para a baixada do Rio Pinheiros, subia novamente pelo espigão [...] e continuava pelo referido espigão até a Rua Vergueiro ${ }^{4}$.

Diversas chácaras retalhadas ${ }^{5}$ dariam nome a ruas e início a bairros, caso da Chácara Nothmann, origem do bairro de Campos Elíseos alcançado seguindo-se pelo Viaduto do Chá, construído em 1892 - que para Paulo Cursino de Moura deveria chamar-se "viaduto do café"6 _ , e pelo qual quem atravessasse as guaritas de madeira colocadas em cada extremidade pagava um pedágio de três vinténs, procedimento que durou até o ano de $1896^{7}$.

Prosseguindo, passava-se pela Chácara do Rodovalho (onde hoje se localiza o Teatro Municipal), pela rua Baronesa de Itapetininga, atingindo-se a Praça da República “descampada e lamacenta ou cheia de pó, conforme a estação”. Reto, dava-se na Lagoa do Arouche. À esquerda, Vila Buarque e Higienópolis, e à direita, no fim, a Barra Funda, onde se situava a Chácara do Conselheiro Antonio Prado.

Havia os bairros operários, que surgiam sem qualquer planejamento, próximos às estações das estradas de ferro, onde se erguiam as chaminés da zona industrial nascente: Brás, Bom Retiro e Luz configurariam, por isso mesmo, as áreas de maior densidade que depois se expandiriam em direção à Moóca e ao Belenzinho. Núcleos isolados, no rastro dos trilhos, começavam a aparecer nas estações mais distantes: Ipiranga, Vila Prudente, Vila Mariana, Água Branca e Lapa ${ }^{8}$.

Paulatinamente, suas funções iam se alterando, a tal ponto que se chega a falar em uma "segunda fundação de São Paulo", , referindo-se ao período de 1872-1875, quando era então

${ }^{4}$ MARQUES, G. Op. cit., pp. 39, 41 e 44.

${ }^{5}$ Ernani da Silva BRUNO, em História e tradições da cidade de São Paulo (Vol. III - Metrópole do Café, 1872-1918; São Paulo de Agora, 1918-1954). São Paulo: Hucitec, 1991), p. 1027, apresenta detalhada exposição da arruação e loteamento das chácaras pelos seus proprietários, os quais, após a proclamação da República "mandaram abrir ruas, avenidas, alamedas e largos em suas terras".

${ }^{6}$ MOURA, Paulo Cursino. São Paulo de outróora (evocações da metrópole - Pysicologia das ruas). $3^{\mathrm{a}}$ ed., São Paulo: Livraria Martins S/A, 1954 (ou) São Paulo: Itatiaia/Edusp, 1980; (1ª ed. 1932), p. 171.

${ }^{7}$ SANT'ANNA, Nuto. São Paulo Histórico (Aspectos, Lendas e Costumes). São Paulo: Departamento de Cultura, 1934-1944, 4 v. Apud: MARQUES, G. Op. cit., p. 107.

${ }^{8}$ Idem, ibidem, p. 100. Sobre a evolução das diversas faces da cidade, (Norte, Leste, Sul e Oeste), outros aspectos e curiosidades que a caracterizavam nas últimas décadas do oitocentos, $c f$. também MONBEIG, Pierre. " $L a$ croissance de la Ville de São Paulo". In: Revue de Geographic Alpine. Grenoble: s.n., v. XLI, 1953, pp.59-97; AMERICANO, J. Op. cit., 1957, p. 99 e ss; SOUZA, Everardo Vallim P. “A Paulicéia há 60 anos - São Paulo em 1886”. In: Revista do Arquivo Municipal. São Paulo: CXI, 1946, pp. 53-65. Sobre a evolução das vilas, bairros e paróquias periféricas da Cidade de São Paulo, cf. MARCÍLIO, Maria Luiza. A cidade de São Paulo, Povoamento e população, 1750-1850. São Paulo: Pioneira, Editora da Universidade de São Paulo, 1973, pp. 40 e ss e 103 e $A$ Reconstituição da Memória Estatística da Grande São Paulo. São Paulo: Governo do Estado de São Paulo, Secretaria dos Negócios Metropolitanos. Emplasa - Empresa Metropolitana de Planejamento da Grande São Paulo S.A.,vol. I, 1983, p. 135.

${ }^{9}$ BRUNO, E. Op. cit., p. 106, aludindo a Eurípides Simões de Paula. 
presidente da Província João Teodoro, que gastou quase metade do orçamento embelezando a cidade.

À função cultural que a notabilizara representada pela Faculdade de Direito, incorporou novos papéis, cada vez mais estimulada pela riqueza gerada pelo café e da sua ligação ferroviária com o porto de Santos. Sua vida comercial sofre grande impulso, com a abertura de inúmeras casas de comércio varejista de grande variedade, casas atacadistas e depósitos, e sua vitalidade também pode ser medida pelo aumento no número de casas comissárias. Sua função bancária também deve ser lembrada, reflexo do incremento nas transações e do aumento na circulação da moeda. E, finalmente, sua função industrial começava a despontar: se em 1889 a cidade não contava com mais de 32 estabelecimentos fabris, com predomínio das pequenas fábricas e de uma indústria artesanal, a virada do século contabilizaria uma centena delas, com predomínio da pequena indústria ${ }^{10}$.

Profissionais liberais também avultavam pela cidade, capitaneados pelos advogados, seguidos pelos guarda-livros (contadores), evidência da intensificação nas atividades empresariais, e pelos empreiteiros de obras, função essencial numa cidade em pulsante ritmo de transformação.

A ainda modesta função industrial, bem como a pequena indústria artesanal, foi sendo desenvolvida inicialmente no Triângulo, na periferia do centro e nas saídas da cidade. Quanto aos profissionais liberais (professores, dentistas, médicos, advogados, etc.) também instalados na área central, eram acostumados, no exercício de sua função, a utilizarem-se de um ou mais cômodos de sua própria residência, hábito típico de cidade provinciana, ainda não superado ${ }^{11}$. Já nesta época, ano de 1900, a cidade contava com 77 quiosques espalhados pelo centro e pelos bairros, destinados à venda de comidas frias, bebidas e bilhetes de loteria para a população, que também funcionavam como pontos de referência para trabalhadores autônomo-ambulantes, vendedores de jornais e baleiros, os quais, paulatinamente foram sendo removidos pela ação da polícia, sob a alegação de que formavam aglomerações ou "antros" de "desocupados" ".

A metamorfose radical da cidade, de pacata capital da Província em centro urbano envergando sua armadura de cimento e ostentando com eloqüência os frutos colhidos pelo café,

\footnotetext{
${ }^{10}$ Ver a esse respeito, a divisão das fábricas e oficinas elencadas por MATOS, Odilon Nogueira de. "A cidade de São Paulo no século XIX”. In: Revista de História. São Paulo: 21/22, 1955, pp. 112 e ss., com base no Almanaque da Província de São Paulo, de Assis Moura, de 1883.

${ }^{11}$ Cf. AZEVEDO, Aroldo de (org). A cidade de São Paulo. Estudos de geografia urbana (4 vol). Vol. III “Aspectos da metrópole paulista". São Paulo: Cia. Editora Nacional,/AGB, 1954, pp. 135-136.

${ }^{12}$ Cf. BARBOSA, Maria do Carmo Bicudo. "Tudo como dantes na casa de Abrantes". As práticas da produção de espaço na cidade de São Paulo. São Paulo: Tese de Doutoramento, FAU-USP, 1987, pp. 130-131.
} 
vinha, assim, a ritmo de locomotiva - máquina revolucionária, percebida como símbolo do progresso pelo ideário liberal - e impulsionada pela imigração européia ${ }^{13}$.

Para Samuel Kruchin, a nova condição (industrial) da cidade a obrigava a um novo comportamento espacial e a um redimensionamento interno. Redimensionamento também social provocado pelo impacto da entrada maciça de imigrantes, responsáveis pela introdução de referências novas quanto aos padrões de relacionamento interétnicos e especialmente quanto à noção de trabalho. Em "faixas estreitas de tempo (...) amplas e profundas transformações no espaço urbano" indicavam que começava a terminar uma longa história de hegemonia agrária, apontando para

uma subjetividade outra que deriva das novas relações de trabalho, dos termos da hierarquia social, dos princípios massificadores da vida cultural, enfim [que] exige a internalização de termos diferenciados para as trocas econômicas como para as efetivas. De alguma forma e de modo ainda incipiente, tímido, apesar da pretensa agressividade que contém, é essa subjetividade que emerge da Paulicéia, é o caos da cidade em múltipla expansão $(\ldots)^{14}$.

No Estado de São Paulo, a virada do século contabilizava índices expressivos: 3.375 km de ferrovias, mais de meio bilhão de cafeeiros e uma população de aproximadamente 2.300 .000 habitantes ${ }^{15}$.

Na cidade, a década crucial, a de 1890-1900, exibiria uma população que pulou de 64.934 para 239.820 habitantes, elevação de $268 \%$ em 10 anos, revelando taxa de crescimento anual de 13,9\%; apenas como comparativo, no período de 18 anos entre 1872-1890 essa taxa havia sido de apenas $5,2 \%{ }^{16}$.

Não era, portanto, tarefa fácil a esses viajantes descrevê-la agora, diferentemente do que fora para Saint-Hilaire em $1819^{17}$, em cujos relatos vislumbram-se os indícios primeiros de sua transformação. Tudo nela agora era acelerado, pulsante, transitório, desordenadamente intenso, espaço em construção, em cujo território, reconhecível pelos antigos traços, agora se

${ }^{13}$ A metáfora se justifica: somente a partir de 1920 o concreto armado passará a ser usado para prédios com mais de quatro andares, substituindo o cimento.

${ }^{14}$ KRUCHIN, Samuel. "Modernismo e cidade: o sentido do urbano nas três primeiras décadas". In: Espaço e debate. Revista de Estudos Regionais e Urbanos. São Paulo: ano VI, vol. 3, nº 19, 1986, p. 43 e 51.

${ }^{15}$ MATOS, O. Op. cit., p. 105.

${ }^{16}$ Os dados são dos Censos Nacionais de 1872, 1890, 1900 e 1920 e do Censo da Cidade de São Paulo de 1893; as taxas anuais de crescimento foram estimadas por Gerald Michael Greenfield, in The Challenge of Growth: The growth of urban public services in São Paulo, 1885-1913. Ph.D.Dissertation, Indiana University, Bloomington, 1975. Apud: FAUSTO, B. "Controle e criminalidade em São Paulo: um apanhado geral (1890-1924)". In: PINHEIRO, Paulo Sérgio (org.) Crime, violência e poder. São Paulo: Brasiliense, 1983, p. 195. Com respeito ao crescimento da população imigrante na cidade: em 1872 representava $6,4 \%$ da população total; já em 1886, menos de 15 anos depois, este percentual cresce para 25,8\%, decrescendo levemente em 1890 para 22,1\% (ou 14.303 pessoas).

${ }^{17}$ SAINT-HILAIRE, Auguste de. Viagem à Província de São Paulo e Resumo das viagens ao Brasil, Província Cisplatina e Missões do Paraguai. Trad. de Rubens Borba de Morais. São Paulo: $2^{\mathrm{a}}$ ed., Livraria Martins Editora, 1945. 
sobrepunham as grandes novidades do progresso. Espanto, deslumbramento, nostalgia: a cidade inspirava diferentes e controversas impressões, impedindo, muitas vezes, uma descrição objetiva.

Június (Antônio de Paula Ramos Júnior), que voltara a ela trinta anos mais tarde, em 1882, já então se surpreendera com os sinais visuais de sua tumultuária transformação: seu trepidante ritmo de vida, a alteração dos hábitos, o estabelecimento de famílias ricas do interior, os cafés e restaurantes, os hotéis, as linhas de bonde, a profusão de lojas de comércio, os edifícios públicos, a iluminação das ruas, as estradas de ferro, os novos subúrbios e ... a colônia estrangeira $^{18}$.

A esse propósito, interrogava em 1898 o memorialista Jorge Americano: "Onde é que nós vamos parar com estes estrangeiros todos? Onde é que estão os paulistas?"19, reconhecimento ocular do ingresso, nessa década, da maior leva de imigrantes, totalizando 734.985 pessoas $^{20}$, das quais $80 \%$ através da imigração subvencionada.

Também Alfredo Moreira Pinto que a ela voltaria depois de 30 anos, quando então deixara a Faculdade de Direito (sem se formar) regressando ao Rio de Janeiro, sua cidade natal, exclamava, surpreso, em seu A cidade de São Paulo em 1900 (impressões de viagem) ${ }^{21}$ :

São Paulo, quem te viu e quem te vê!

Não passavas naqueles tempos de uma pobre aldeia, completamente segregada do Rio de Janeiro. Fazia-se a viagem por mar até Santos e daí pela estrada de ferro até o Alto da Serra do Cubatão. Tinhas então as tuas ruas sem calçamento, iluminadas pela luz baça e amortecida de uns lampiões de azeite, suspensos a postes de madeira; tuas casas, quase todas térreas, tinham nas janelas umas rótulas através das quais conversavam os estudantes com as namoradas; os carros de bois guinchavam pelas ruas, sopesando enormes cargas e guiados por míseros cativos, que empunhavam compridas varas com um ferrão na ponta; as donzelas, formosas como são as paulistas, com a cabeça e o rosto envoltos em uma mantilha, caminhavam em direção às igrejas...

E lá pelas tantas complementava, antes de dedicar quase 300 páginas em minuciosa e rica descrição dos diversos aspectos da cidade que deixara: "Era então São Paulo uma cidade puramente paulista, hoje é uma cidade italiana!".

Evidentemente, o que saltava aos olhos nesta cidade, era a presença estrangeira: Ernst Von Hesse-Wartegg, no decênio de 1910, afirmava:

\footnotetext{
${ }^{18}$ JÚNIUS. "Notas de viagem”. In: Em São Paulo, 1882. Apud: TAUNAY, A. Op. cit., p. 28

${ }^{19}$ AMERICANO, J. Op. cit., 1957, p. 369.

${ }^{20}$ LEVY, M. Op. cit., p. 83, Tabela 9.

${ }^{21}$ PINTO, Alfredo Moreira. A cidade de São Paulo em 1900 (impressões de viagem). $2^{\text {a }}$ ed., fac-símile.
} São Paulo: Governo do Estado, 1979 (Coleção Paulística, 14); (1ª ed. 1900).Ver especialmente o Capítulo I. 
São Paulo não é uma cidade brasileira de 450.000 habitantes, mas uma cidade italiana de aproximadamente 100.000, uma portuguesa de talvez 40.000, uma espanhola de igual tamanho e uma pequena cidade alemã de mais ou menos 10.000 habitantes, com poucas de suas vantagens, mas muitas de suas desvantagens. Ainda há uns 5.000 sírios [...] alguns mil franceses, russos, japoneses, poloneses, turcos, ainda ingleses, escandinavos, americanos em número desconhecido. O resto, provavelmente um terço do total, devia ser de brasileiros ${ }^{22}$.

Se em 1872 era a décima cidade brasileira em população - superada inclusive por Cuiabá, São Luis, Fortaleza e Niterói -, nos finais do Novecentos a cidade de São Paulo emergia como a segunda, perdendo apenas para a Capital da República, a cidade do Rio de Janeiro. Em 1890, relatório da Comissão de Saneamento das Várzeas já diagnosticava sobre São Paulo: “... seguramente duas terças partes da cidade atual é de data recente" ${ }^{\text {"23 }}$.

Capitais afluíam da lavoura cafeeira, diversificando-se em aplicações em diferentes setores, dentre os quais a indústria e o comércio e, assim, adentrando pelas primeiras décadas do século XX, a Paulicéia nascente, em constante movimento e processo de transformação, vai assumindo seu novo estilo, transformando-se no mais expressivo centro administrativo, industrial e comercial paulista e concentrando em si diferentes funções, dentre as quais a de centro distribuidor de mão-de-obra para todo o Estado.

Chega-se mesmo a falar em uma "terceira fundação da cidade" 24 , que corresponderia à primeira década do século XX, sob a administração dos prefeitos Antonio Prado e Raimundo Duprat, período em que a cidade sofre inúmeras intervenções de remodelação urbanística: obras de saneamento (várzea do Tamanduateí); canalização de rios e ribeirões; melhor distribuição de água potável para a população; abertura de novas ruas e avenidas, iniciativas que resultaram em profunda alteração da fisionomia da antiga cidade que, apesar disso, ainda guardava aspectos pré-urbanos, com chácaras e moradias precárias de ranchos, cômodos alugados e cortiços se alternando na cartografia de um processo urbanizador mais espontâneo do que organizado. As ruas tranqüilas da antiga vila jesuítica estavam profundamente alteradas e suas primeiras avenidas passaram a ser mais movimentadas e continuamente agitadas por pregões, circulação de carroças, carros de praça, gente transitando a pé, vendedores mal vestidos, cabras leiteiras, compradores de sucatas, ambulantes, artistas.

De conformidade com as estatísticas oficiais, no período da grande emigração em massa, de cada 10 imigrantes desembarcados no Porto de Santos, 8 deles destinavam-se às

\footnotetext{
${ }^{22}$ Apud: PETRONE, Pasquale. "A cidade de São Paulo no século XX”. In: Revista de História. São Paulo: no 21/22, janeiro-junho 1955, p.135.

${ }^{23}$ KLINTOWITZ, Jacob. A arte do comércio. São Paulo 1900-1930. São Paulo: Senac, 1988, p. 18.

${ }^{24}$ Atribuição de PETRONE, P. Op. cit., 1955, p. 139, em comparação à anterior, de Eurípides Simões de Paula.
} 
zonas cafeeiras ${ }^{25}$. Especula-se que, do restante, parte tenha permanecido na própria cidade de Santos, burlando a fiscalização de desembarque. Os demais, embarcados para a cidade de São Paulo, eram instalados na Hospedaria dos Imigrantes ${ }^{26}$ por força de contratos previamente pactuados, pelos quais, na categoria de "imigrante", fazia-se a concessão da passagem pelo governo estadual. Ali, e apesar da extrema vigilância, muitos deles eram resgatados clandestinamente por amigos ou familiares, permanecendo na cidade ${ }^{27}$.

A grande maioria, no entanto, dirigia-se para as fazendas do Oeste Paulista ${ }^{28}$, então em franca expansão. Em sua bagagem traziam a motivação maior consubstanciada na expectativa de se tornarem proprietários, condição esta aliás que, no caso espanhol - e certamente nos demais -, já era aventada em seu país de origem pelos agentes recrutadores ou ganchos, cuja atuação agressiva atrelava esta possibilidade ao benefício da passagem subsidiada.

Ganchos de emigrantes [título]

Policia de Coruña há incoado alí algunos procesos por estafa a varios agentes de emigración, por engañar a famílias ${ }^{29}$.

Tal subvenção, por outro lado, consistia numa eficiente modalidade de captação de braços, com a qual se procurava irrigar de mão-de-obra farta e, portanto, barata, a lavoura cafeeira em constante expansão.

Estatísticas dão conta da adequada performance do Poder Público no programa de imigração subvencionada, em sua tarefa de abastecer as lavouras cafeeiras paulistas de um contingente de força de trabalho sempre superior à demanda, durante vários anos. Estimativas feitas por Holloway apontam que, no período de 1894-1914, o volume de imigrantes que afluíram para as áreas do café era praticamente o dobro do que seria necessário para o trabalho naquelas, equivalendo esse excedente a cerca de 300.000 pessoas $^{30}$.

O alcance desta política de arregimentação em larga escala, baseada em uma complexa e bem articulada estrutura, já repercutia na Espanha nas décadas finais do século XIX, conforme

${ }^{25}$ Ministério da Agricultura, Indústria e Comércio. Directoria Geral de Estatística, Recenseamento do Brasil realizado em $1^{\circ}$ de setembro de 1920 . Rio de Janeiro: Imprensa Oficial, 1962.

${ }^{26}$ Cabia à Hospedaria dos Imigrantes de São Paulo, para onde os imigrantes eram transportados pelos trens da São Paulo Railway Company, depois de desembarcados no porto de Santos, recepcionar, dar alojamento e encaminhá-los às fazendas de café. A passagem pela Hospedaria era uma exigência contratual, certamente atrelada à tentativa de mantê-los à disposição dos agentes oficiais que intermediavam os acordos e contratos entre eles e os fazendeiros.

${ }^{27}$ De 1901 a 1910 houve o ingresso de mais 10.891 imigrantes (e trabalhadores nacionais) na cidade e de 1911 a 1920, ingressaram mais 41.691. Cf. A Reconstituição da Memória Estatística da Grande São Paulo, op. cit., vol. I, p.138.

${ }^{28}$ Costuma-se usar o designativo para identificar aquelas áreas situadas a oeste da Capital, tendo em Campinas e adjacências, cidades desbravadas pela onda verde do café, seu marco inicial e irradiador.

${ }^{29}$ LTE 16.03.1908.

${ }^{30}$ SPINDEL, Cheywa R. Homens e máquinas na transição de uma economia cafeeira. Rio de Janeiro: Paz e Terra, 1979, p. 94 (citando HOLLOWAY, T.,1974, pp. 249-258). 
pronunciamento do seu Ministério dos Assuntos Exteriores, segundo o qual "la propaganda fue dirigida por la Legación en Madrid y por los Consulados de carrera. Desde el sacerdote pueblerino en el púlpito hasta las casas de billetes para ultramar, no se ha escatimado médio" ${ }^{31}$, é diagnóstico que dá a medida da dimensão da rede de agentes locais envolvida e sustentada pelas próprias companhias de navegação contratadas pelo governo brasileiro para o transporte dos mesmos.

A questão foi assunto para reiterada troca de correspondência entre Pedro Canavilles, um dos cônsules lotado na cidade e o Ministro de Estado espanhol, pela qual aquele denunciava a atuação do escritório recrutador de Lucas Imossi e Hijos, de Gibraltar. Utilizando funcionários comissionados, espécie de viajantes e propagandistas, que percorriam as aldeias em ativa campanha de recrutamento valia-se também o tal escritório, de prospectos e circulares habilmente redigidos, pelos quais se exaltava as "excelências e vantagens que no Brasil se oferece ao imigrante" 32 .

Do cônsul anterior, a denúncia partia do Brasil, indicando agentes de emigração espanhóis aqui infiltrados que, sob encomenda dos fazendeiros, traziam as famílias diretamente da Espanha ${ }^{33}$. Acusações dessa natureza, envolvendo o tráfico de imigrantes incriminavam até mesmo autoridades federais. Entre 1913-1914, intensa correspondência denuncia a existência de "agentes secretos" mantidos por autoridades brasileiras, acusação que teria partido do comissário do Estado de São Paulo na Espanha, fato em decorrência do qual o governo paulista teria eliminado o Comissariado daquele país ${ }^{34}$.

Anteriormente o Governo do Estado de São Paulo já havia enviado solicitação formal ao Ministério das Relações Exteriores, no sentido de que intercedesse junto às autoridades espanholas para que um inspetor de embarque de passageiros pudesse residir no porto de Gibraltar. Tal solicitação, datada de 1918, visava evidentemente recrudescer, à saída, o controle da "seleção" dos elementos ali embarcados, sabidamente clandestinos. O curioso é que, assim agindo, a autoridade local praticamente reconhecia e aceitava com naturalidade essa espécie de operação ${ }^{35}$.

Inicialmente alimentada em grande escala pela imigração italiana, a oferta crescente de mão-de-obra, alicerce da política imigratória, necessitou nutrir-se de imigrantes de outras

\footnotetext{
${ }^{31}$ AMAE, Leg. 721, exp. 29. Apud: GONZÁLEZ MARTINEZ, E. Op. cit., 1992, p. 14. A autora referia-se aos primórdios da implantação do sistema de subsídios.

32 AGA. Caja 1691. Memorando de 24.01.1922. Trad. da autora.

33 AGA. Caja 1691. Memorando de 26.04.1921.Os envolvidos denunciados eram Cipriano Sola Rubio e José Arias Maldonado, que teria trazido 40 famílias para a Fazenda Martinho Prado.

${ }^{34}$ AHI. AMAE. Imigração. Correspondência trocada entre novembro de 1913 e fevereiro de 1914.

${ }^{35}$ AHI. AMAE. Emigração. Maço nº 11. Correspondência trocada entre janeiro e novembro de 1918.
} 
procedências, voltando sua atenção para a importação de portugueses e espanhóis, especialmente frente à proibição imposta pelo governo italiano, em $1902^{36}$, fato que deve ter determinado o acirramento de expedientes, cada vez mais agressivos e menos criteriosos, na sua captação.

Em 1910 foi a vez do governo espanhol baixar uma proibição à emigração para o Brasil. Incidia apenas sobre a de natureza gratuita e resultara de relatório do inspetor enviado pelo Conselho Superior de Emigração de Madri acerca das condições dos imigrantes aqui instalados. As negociações para sua revogação por parte do governo brasileiro, que protestava contra a "inexatidão na exposição que acompanha o Decreto de Proibição" geraram abundante correspondência oficial "confidencial" até o ano de $1913^{37}$.

Anteriormente, nos inícios da década dos anos 1900, os jornais espanhóis já vinham a público com denúncias acerca do tratamento oferecido aos espanhóis, razão de outra intensa troca de correspondência diplomática, e desmentidos por parte das autoridades brasileiras ${ }^{38}$. Tanto neste, como no caso da proibição, seus efeitos devem ter sido inócuos, especialmente sobre o derrame clandestino que se dava por Gibraltar, a considerar que o ano de 1912 representou um dos maiores picos de entrada de espanhóis no Brasil.

Para aqueles que, afinal de contas, se punham a caminho, a crueza da realidade local, não muito diversa daquela que haviam deixado para trás em seu país de origem, de pronto se desenharia, por vezes antes mesmo do desembarque. O impacto provocado pelas precárias condições de vida e trabalho na lavoura e a baixa remuneração decorrente de contratos quase inteiramente comprometidos com as suas despesas de subsistência, levavam esse imigrante a peregrinar com sua família de fazenda em fazenda, numa constante itinerância, em busca de condições mais favoráveis que garantissem a possibilidade da acumulação de algum pecúlio, o qual se destinava prioritariamente ao retorno a seu país - sonho acalentado, porém de difícil concretização -, ou à aquisição de alguma (pequena) propriedade.

[...] o imigrante que foi trabalhar como colono não era um conformado com os ganhos monetários reduzidos. Estava de passagem pela fazenda. Ela era apenas uma etapa no movimento pela autonomia que o próprio capital lhe havia tirado no país de origem [...]. Essa inquietação conformista, essa mobilidade, teve contrapartida na economia do café: a contínua oferta de mão-de-obra subvencionada pelo governo, condição da também contínua ocupação de terras novas ${ }^{39}$.

\footnotetext{
${ }^{36}$ KOWARICK, L. Op. cit., 1987, p. 96.

37 AHI. AMAE. Emigração. Maços no 03, 09, 16 e s/no. Decreto de 26 de agosto de 1910. Correspondência trocada entre 18.08.1910 e 06.01.1913.

38 AHI. AMAE. Imigração. Maço 75, miscelânea. Correspondência trocada entre dezembro de 1904 e janeiro de 1905.

${ }^{39}$ MARTINS, José de Souza. O cativeiro da terra. São Paulo: Livraria Ed. Ciências Humanas, 1979, p. 91.
} 
Esse raciocínio pode conduzir à constatação inequívoca de que, uma vez esgotados os recursos e expedientes na concretização de sua aspiração, e uma vez livre de suas obrigações contratuais no colonato, tivesse esse imigrante a inclinação de buscar uma melhoria em sua condição de vida nas oportunidades que despontavam na capital, para onde eram atraídos pelo seu desenvolvimento e pela oferta de empregos na indústria nascente. A rigor, esse representaria o roteiro inapelável dessa horda de desenraizados, que se apresentou com inúmeras variações mais ou menos pungentes dependendo do caso.

Nesse quadro, estabelecido pela expansão internacional da economia cafeicultora, a cidade de São Paulo, subproduto imprevisto e até inoportuno dessa evolução, aparece aos agentes desgarrados e itinerantes enredados nela, como a possível bóia salva-vidas no descomunal naufrágio que os flagelara. Desenganados das falácias do "ouro verde" [...], esses homens e mulheres das mais variadas culturas e extrações sociais, buscariam em São Paulo uma válvula de escape, um abrigo temporário ou, no melhor dos casos, uma segunda chance, na indústria ou nos serviços ${ }^{40}$.

A afluência desses indivíduos à cidade é crescente: em 1886 a cidade exibia, para uma população de 47.697 indivíduos, um total de 11.939 imigrantes, dos quais os italianos sozinhos representavam 47,9\%, seguidos dos portugueses $(29,3 \%)$, dos alemães $(9,9 \%)$ e dos espanhóis $(3,2 \%)^{41}$. As cifras dos espanhóis, neste momento, eram ainda pálidas quando comparadas às dos italianos, inclusive considerando-os em relação ao Estado de São Paulo, onde representariam de conformidade com o Recenseamento de 1886 apenas 1.003 indivíduos para um total de 36.921 estrangeiros $^{42}$, acusando um percentual ligeiramente inferior àquele apresentado para a capital, ou seja, $2,7 \%$.

No entanto, a partir de 1887, data inicial da política de concessão de subsídios pelo então ministro da agricultura o conselheiro Antonio Prado, foram investidas grandes somas para garantir a vinda das famílias imigrantes ${ }^{43}$. Essa política, responsável pelo ingresso de um largo contingente de imigrantes, será a responsável, no período de 1887 a 1900, pelo ingresso, para o conjunto do Estado de São Paulo, de 564.800 italianos, que representaram 62\% do total de

${ }^{40}$ SEVCENKO, N. Orfeu extático na metrópole. São Paulo, sociedade e cultura nos frementes anos 20. São Paulo: Companhia das Letras , 1992, p. 21/2.

${ }^{41}$ Cf. A Reconstituição da Memória Estatística da Grande São Paulo, op. cit., vol. 2, p. 170, Tabela I-19.

42 AZEVEDO, Sálvio de Almeida. "Imigração e colonização no Estado de São Paulo". In: Revista do Arquivo Municipal. São Paulo: 75, 1941, p. 113.

${ }^{43}$ No período de 1881 a 1917 , a política oficial imigratória teria absorvido valores globais da ordem de 140.000 contos, despendidos pelo Tesouro Nacional e de 70.000 contos despendidos pela Província/Estado de São Paulo. Cf. GRAHAM, Douglas. "Migração estrangeira e a questão da oferta de mão-de-obra no crescimento econômico brasileiro, 1880-1930"' In: Estudos Econômicos, 3 (1), 1973, p. 37; quanto ao montante empregado, no ano de 1895, por exemplo, $15 \%$ do orçamento do Estado foi despendido em compra de passagens, um pouco menos em 1901, ano em que se destinou $11 \%$ do total de receitas para o pagamento das mesmas. Cf. VASCONCELOS, Henrique Doria de. "Alguns aspectos da imigração no Brasil". In: Boletim da Diretoria de Terras, Colonização e Imigração. São Paulo: 1:13, 1937, pp.6-7 e 27-28. 
ingressantes. Observa-se, em decorrência, um movimento crescente no ingresso também dos espanhóis, que apresentarão então, neste período inicial da concessão, até 1900, a cifra de $10,3 \%$ (93.777 pessoas) da soma emigrada, então totalizando 909.417 indivíduos ${ }^{44}$.

Com efeito, se no período de 1888 a 1890 (em plena crise do café) dos 158.000 imigrantes entrados em São Paulo apenas 63\% vieram com o subsídio da passagem, no decênio seguinte, $1890-1900,80 \%$ de um total de 720.000 ingressantes foram subvencionados ${ }^{45}$.

Esse brusco aumento pode ser em parte também atribuído ao efeito "desvio", consequiência da menor atração exercida pela Argentina para o imigrante: em 1890, a economia Argentina sofria acentuado retrocesso, refletindo num marcado declínio da emigração para aquele país ${ }^{46}$.

Não devemos nos esquecer, de qualquer modo que, entre o contingente majoritário, o de italianos (com aproximadamente 564 mil ingressos até 1900) e o segundo, o de espanhóis (com pouco menos de 94 mil) há uma diferença de mais de 470 mil pessoas, aspecto que põe em relevo a absoluta supremacia do italiano!

Entre 1886 e 1890, a população da cidade de São Paulo cresceu cerca de 36\%, concentrando, então, aproximadamente $5 \%$ do total da população do Estado ${ }^{47}$, alcançando a cifra de 64.934 habitantes, média de 4.309 pessoas a mais por ano ${ }^{48}$. Destes, $77,9 \%$ constituíase de nacionais e $22,1 \%$ de estrangeiros ${ }^{49}$.

O salto espetacular, porém, se daria nos primeiros anos da década seguinte, alterando drasticamente a composição étnica da cidade: entre 1890-1893, a população emigrante na cidade alcançaria o percentual de 54,7\% ou 71.568 pessoas (algumas estatísticas falam em 67.060 pessoas), para um total de 130.775 habitantes, portanto representando mais da metade da sua população ${ }^{50}$. Note-se que, até há pouco, em 1890, os estrangeiros na cidade constituíam apenas $22,1 \%$ do total de sua população. Agora, menos de três anos depois, os italianos, em

${ }^{44}$ A Reconstituição da Memória Estatística da Grande São Paulo, op. cit., vol. 1, p. 128, Tabela III.1.8.

${ }^{45}$ VILLELA, Aníbal e SUZIGAN, Wilson. Política do governo e crescimento da economia brasileira, 1889-1945. Rio de Janeiro: IPEA-ANDES, 1975, p. 249. Já na década de 1901-1910 apenas 40\% dos 420.000 ingressos o fizeram através do subsídio; essa porcentagem tende a baixar para $36 \%$ nos cinco primeiros anos da década de 1910, ocasião em que se contabilizou o ingresso de 356.000 imigrantes. Cf. GRAHAM, D. Op. cit., p. 40. Os dados quanto à imigração não subsidiada para o Brasil, ainda segundo o autor, são precários. Para São Paulo, no entanto, há algumas porcentagens: de 1889 a 1892 foi de 6,4\% (ou 13.770 pessoas) o número dos ingressos espontâneos, isto é, sem subsídio. Já de 1893-1898, essa porcentagem aumentou para 22,5\% (115.758 pessoas) do total de ingressos.

${ }^{46}$ GRAHAM, D. Op. cit., 1973, p. 37. A respeito da alternância de ciclos migratórios entre a Argentina e o Brasil, consultar: SILBERSTEIN, C. Op. cit., 1999, p. 106 e ss.

${ }^{47}$ A população do Estado de São Paulo em 1890 era de 1.384 .753 habitantes. Cf. Recenseamento do Brasil de 1920, citado.

${ }^{48}$ Cf. HAHNER, J. Op. cit., 1993, p. 21.

${ }^{49}$ Reconstituição da Memória Estatística, op. cit., p. 134, Tabela III.1.14.

50 "Estudos demográficos - a população de São Paulo no último decênio, 1907-1916, por Alberto de Souza”. In: Reconstituição da Memória Estatística, op. cit., pp. 130 e 134. 
número de 45.457 representavam quase $35 \%$ do total de habitantes da cidade, cifra esta que subia para $63,5 \%$ considerando-se o conjunto de estrangeiros nela instalado. O português, em segundo lugar, detinha apenas $11 \%$ da população total (14.437 pessoas), enquanto o espanhol timidamente se insinuava, em terceiro, com 4.818 pessoas ou $3,7 \%$ da população total da cidade $^{51}$. Esse seria, então, o número oficial de espanhóis na cidade em 1893, ano da criação do CGE e data inicial dos registros, objeto de nosso exame.

Nesta década que encerrava o século, a cidade continuaria crescendo extraordinariamente. Se em 1890 concentrava aproximadamente $5 \%$ do total da população do Estado, em 1900 este percentual subira para 10,5\% $\%^{52}$. Em outros termos, um salto de $269 \%$, passando de 64.934 (em 1890) para 239.820 habitantes em $1900^{53}$. Os italianos sozinhos perfaziam um total de 75.000 pessoas, representando, então, $31 \%$ do total de população estimado para a cidade pelo Recenseamento Geral de 1900.

Atribui-se em grande parte à imigração estrangeira (e aos italianos, em particular) as altas taxas de crescimento urbano por volta da virada do século XIX, crescimento este fundamental no aparecimento de um mercado urbano, com hábitos de consumo europeus e para alguns autores como Graham ${ }^{54}$, também como estímulo à abertura de indústrias de substituição de importação, como as de alimentos, bebidas e têxteis.

De qualquer modo, os números acima não deixam margem à dúvida e são indicadores da presença maciça dos italianos na cidade na virada do século XIX, representando, então, sozinhos, $31 \%$ do total da população que nela habitava.

Para Pierre Monbeig, a pequena colônia européia que a partir de 1870 passou a buscar a cidade "não era ainda a massa dos imigrantes proletários à procura de qualquer trabalho por qualquer salário" ${ }^{, 55}$, constituindo-se em sua maioria de artesãos, comerciantes ou engenheiros, dentre os quais citava italianos, ingleses, franceses ou alemães. A propósito, já em 1890, na visão de Van de Putte

[...] os gêneros alimentícios eram em geral vendidos por portugueses e brasileiros, e os tecidos por brasileiros, alemães, franceses e italianos. Eram ainda os italianos os principais vendedores a varejo de sapatos, funilaria e ferragens. Os padeiros, confeiteiros e curtidores eram franceses ou alemães. As metalúrgicas pertenciam na sua maioria a ingleses e americanos, seguindo-se em importância brasileiros e alemães.

${ }^{51}$ Cf. HAHNER, J. Op. cit., p. 62; VANGELISTA, Chiara. Os braços da lavoura. Imigrantes $e$ "caipiras" na formação do mercado de trabalho paulista (1850-1930). São Paulo: Editora Hucitec-Istituto Italiano di Cultura-Instituto Cultural Ítalo-Brasileiro, 1991, p. 244.

${ }^{52}$ ARAÚJO FILHO, J.R. de. “A população paulistana”. In: AZEVEDO, A. Op. cit., p.178.

${ }^{53}$ Cf. MATOS, O. Op. cit., p. 114.

${ }^{54}$ GRAHAM, D. Op. cit., 1973, p. 46.

${ }^{55}$ MONBEIG, P. Op. cit., pp. 44 e ss. 
Portugueses e brasileiros faziam os serviços mais grosseiros de carpintaria, sendo os marceneiros mais capacitados também brasileiros, ou então franceses e alemães ${ }^{56}$.

Esse quadro parece ter sido progressivamente alterado, provocado, muito provavelmente, pelo refluxo das primeiras levas de colonos das lavouras cafeeiras. Assim é que, na afirmação de Paula Beiguelman, "o principal contingente [desta] população urbana estrangeira se constituía [nos primórdios do século XX], dos egressos da lavoura que buscavam a Capital e as cidades das áreas cafeeiras"

A cidade em transição ia sucessiva e aceleradamente exibindo novas feições, e nessa incessante (re) composição vislumbramos os primeiros indícios documentais do espanhol que nela passou a fixar-se ou que por ela passou a transitar, em deslocamento para outros lugares. Sua presença, neste momento, última década do dezenove, apenas se insinuava frente à avalanche italiana já então instalada.

Resultante do comportamento atípico desse contingente, determinado pela natureza tardia de seu movimento ultramarino no conjunto das imigrações de massa ${ }^{58}$, nessa asfixia inicial, enfim, podem residir alguns dos componentes essenciais para o questionamento da sua problemática inserção na cidade, respeito ao estreitamento e à compressão das oportunidades nela apresentadas.

Com base nos Censos demográficos de 1872, 1900 e 1920 e buscando examinar a importância da mão-de-obra estrangeira na evolução da força de trabalho nacional no período, Merrick e Graham $^{59}$ realizaram o exame dos padrões de crescimento então observados. Detiveram-se, contudo - em razão da constatação da grande variação ocorrida nas atividades ocupacionais e setoriais ocorridas no período, de grandes transformações na economia brasileira, e em que várias atividades não constam em todos os anos -, à análise do crescimento da força de trabalho masculina, a única tabulada consensualmente nos três censos.

Reportando-se a esses dados, enfim, os autores apontaram para o fato de a força de trabalho masculina estrangeira ter mantido, no período avaliado, uma tendência crescente, acusando em média um aumento de 3,5\% ao ano entre 1872 e 1920, mas realçaram o fato de que esse crescimento teria se processado em escala maior nas décadas iniciais do período

${ }^{56}$ VAN DE PUTTE, Huber. La Province de São Paulo du Brésil (Bruxelas, 1890), pp. 34-5. Apud: MORSE, Richard. Formação Histórica de São Paulo (de comunidade à metrópole). São Paulo: Difusão Européia do Livro, 1970, p. 238. 11.

${ }^{57}$ BEIGUELMAN, P. A crise do escravismo e a grande imigração. São Paulo: Brasiliense, 1982, pp. 10-

${ }^{58}$ A esse respeito, ver: "Rumo ao Estado de São Paulo: características de uma corrente tardia". In: CÁNOVAS, M. Op. cit., 2005, pp. 71-76.

${ }^{59}$ MERRICK, Thomas W. e GRAHAM, Douglas. População e desenvolvimento econômico no Brasil. Rio de Janeiro: Zahar Editores, 1981, especialmente Capítulo 3. 
analisado, até 1900, quando então apresentou um aumento de 5 a 11\%, cujo declínio, verificado para o período posterior, quiseram atribuir à Primeira Guerra Mundial e provavelmente ao aumento da taxa de retorno.

Os autores detalharam a sua análise para regiões escolhidas, assinalando que o impacto, entre os dois primeiros Censos (1872-1900), particularmente forte para São Paulo, sobretudo em seu efeito direto ou de primeira geração, teria representado no período $46 \%$ nos acréscimos da força de trabalho total da Província - 48\% de aumento da força de trabalho agrícola e $45 \%$ da força de trabalho não-agrícola; neste caso, ressalvaram os autores, há grande probabilidade das atividades "não-agrícolas" estarem intimamente relacionadas com a agricultura e servirem de escoadouro para a mão-de-obra imigrante nesse período. Em escala nacional, completam, esse segmento "não-agrícola" responderia pelas demandas nos setores industriais especialmente em dois Estados, Rio de Janeiro e São Paulo, os mercados de trabalho industriais mais importantes e de mais rápido crescimento no país, naquele período considerado.

Na cidade de São Paulo, apenas para reforçar o impacto provocado por tais números, a taxa de crescimento do emprego industrial masculino era maior do que a taxa de crescimento da própria cidade, que já não era desprezível $(8,7 \text { contra } 6,3 \%)^{60}$. No conjunto do período analisado (1872-1920), para ilustrar, o crescimento da oferta de mão-de-obra estrangeira em São Paulo superou a local (a nacional) em todos os setores, de duas a quatro vezes, dependendo do setor em questão. É provável, comentam os autores, que se houvesse dados sobre os filhos dos imigrantes aqui nascidos, para 1900 e 1920, o impacto sobre a população e a força de trabalho fosse ainda maior no segundo Recenseamento, o de 1920, que poderia conter índices continuados da imigração e outros relativos aos filhos dos imigrantes da primeira geração.

É na análise objetiva de algumas categorias, contudo (já que foram tabulados índices globais para todo o Estado de São Paulo), que reside a possibilidade da inferência da importância relativa do imigrante na Capital. Trabalhando com as categorias "atividades nãoagrícolas", "indústria" e "comércio", claramente identificadas com a cidade de São Paulo, então o centro de maior crescimento desses setores, os autores afirmam que, para o período de 18721900, o de maior afluxo da imigração italiana - lembremos que o italiano detinha sozinho, na virada do Novecentos, $35 \%$ do total da população da cidade -, a porcentagem dos estrangeiros nas "atividades não agrícolas" cresceu de 8 para 47\%; na "indústria", de 11 para 57\% e no "comércio", de 21 para 50\%. Para o período seguinte, o das primeiras décadas dos anos 1900, prosseguindo no raciocínio dos autores, ou esses números permanecem os mesmos ou registrase um declínio, marcadamente acentuado no setor da "indústria". Este momento, claramente

${ }^{60}$ Idem, ibidem, p. 143. 
coincidente com a retração registrada nos ingressos da corrente italiana, vai assistir, por outro lado, ao crescente afluxo de espanhóis, cujos maiores picos, quando considerado o Estado de São Paulo, foram observados nos anos de 1905 e 1912.

Esses dados podem orientar algumas hipóteses. Em primeiro lugar, é impossível não associar o primeiro período analisado (1872-1900), ao qual se atribuem altas taxas de crescimento da força de trabalho estrangeira (no caso, masculina), àquele identificado como o de maiores regalias. A cidade em transição como era a São Paulo de então, neste período inicial, oferecia-se à exploração, com a multiplicidade de oportunidades que despontavam, e assim, é lícito supor que tenham sido usufruídas pelo elemento estrangeiro que majoritariamente a ela acorria, o italiano, de presença maciça no período.

Em segundo, e nessa perspectiva, é fácil deduzir que os indicativos de retração apontados para o período imediatamente posterior - o qual, simultaneamente, passa a exibir índices crescentes de ingresso de espanhóis ao passo que registra um recuo dos italianos exprimem diminuição ou mesmo escassez no leque de oportunidades e perspectivas potenciais, vislumbrado no período anterior.

Outros fatores também devem ser considerados: esse momento específico coincidiu com as freqüentes crises conjunturais da economia cafeeira como a ocorrida em 1903, em decorrência do que se restringiu, inclusive por lei, a criação de novos cafezais; tais crises trouxeram como consequiência imediata o rebaixamento nos salários e a restrição da possibilidade de plantação nas culturas intercalares de subsistência para o colono, razão da aceleração da rotatividade de mão-de-obra e, até certo ponto, do abandono das fazendas. A proclamada falta de braços reclamada pelos fazendeiros, injustificada em certa medida, referiase assim mais propriamente à alta rotatividade e à dificuldade de fixação desses colonos nas fazendas, sempre em busca de melhores contratos e condições ${ }^{61}$. Para Roberto Simonsen ${ }^{62}$ por exemplo, o primeiro desses momentos havia ocorrido já em 1898, provocado pela queda nos preços do café, resultante da superprodução, que implicou em substancial baixa nos salários dos trabalhadores agrícolas, e, como é de se prever, em quebra ou descumprimento de contratos, situação inevitavelmente aliada à marcha itinerante e ao êxodo contínuo de colonos estrangeiros que deixavam as fazendas em direção às cidades.

Nem todos os colonos que abandonaram a sua fazenda após a colheita se engajam nas fazendas vizinhas; cada ano, a colheita assinala um novo movimento de concentração da população rural para os centros urbanos. Esse movimento é ininterrupto (...). Todas

\footnotetext{
${ }^{61}$ A esse respeito, ver: SPINDEL, C. Op. cit., especialmente Capítulo 2.

${ }^{62}$ SIMONSEN, R. Evolução Industrial do Brasil e outros estudos. São Paulo: Brasiliana/Nacional/Edusp, 1973, p. 25
} 
as cidades do Estado, inclusive a capital, são povoadas por velhos imigrados que romperam com o trabalho agrícola ${ }^{63}$.

Repentina, essa migração tendia a inchar a cidade com imensas vagas de trabalhadores rurais pobres, sobrecarregando a força de trabalho da Capital, particularmente o setor terciário. A abundante presença desses trabalhadores na cidade excedia largamente as necessidades do mercado, constituindo-se um grande mercado de mão-de-obra disponível; tal disponibilidade de mão-de-obra resultaria, como é de se esperar, em alta taxa de desemprego permanente e rebaixamento nos salários, obrigando-os a viverem precariamente de trabalho informal e temporário; do subemprego e do emprego flutuante e rotativo e em trânsito permanente; enfim, a esquadrinhar a cidade atrás de biscates, fatores que se conjugavam para acirrar a instabilidade e o apego a práticas de subsistência pouco usuais, pequenos expedientes, tarefas ocasionais. "Existem nessa cidade mais de 30 mil pessoas de todas as idades que vivem de pequenos expedientes, à procura de um emprego, de um trabalho, muitas vezes sem ter o necessário para comprar o pão cotidiano", afirmava um periódico em $1902^{64}$.

Tal improvisação encontrava passe livre frente ao trabalhador nacional, marcado pelo forte preconceito herdado da sociedade escravista quanto ao trabalho manual, fator que deve ter concorrido para a atenuação e facilitação de acesso às brechas de ocupações e ofícios aos imigrantes, que, com desenvoltura, senso de oportunidade e despidos de prejulgamentos em relação ao trabalho manual iam penetrando os espaços abertos pela cidade em movimento.

Apesar de tudo, a cidade fascinava. Sinais do deslumbramento que provocava podem ser captados na série de impressões que sobre ela foram registradas para o período: Affonso de Freitas, que escreveu nos primeiros anos do século XX referia-se a ela como "uma bela cidade, muito comerciante e industriosa" ${ }^{\text {65 }}$. Pouco mais tarde, Paul Walle - no dizer de Pasquale Petrone, uma fonte "menos suspeita" - considerava-a "uma das mais belas da União, reconstruída e aumentada com apuro artístico a partir de 1890"; era "a capital econômica do Brasil”, para Manuel Bernardes; "uma moderna metrópole", para Marie Wright ${ }^{66}$ e, finalmente, na consideração de Pierre Denis, a urbe "estendendo-se desmesuradamente sobre o Planalto, traz na desordem de sua estrutura, o traço do seu precoce crescimento, embora ali reinem a animação e o movimento de uma grande cidade" ${ }^{\circ 7}$.

\footnotetext{
${ }^{63}$ DENIS, Pierre. O Brasil no século XX. Lisboa: Antiga Casa Bertrand, José Bastos \& Cia.Ed., s/d, p. 152.

${ }^{64}$ O Commercio de São Paulo, 23 de março de 1902. Apud: VANGELISTA, C. Op. cit., p. 263.

${ }^{65}$ FREITAS, Affonso de. Geografia do Estado de São Paulo. São Paulo: Escolas Profissionais Salesianas,

${ }^{66}$ Apud: PETRONE, P. Op. cit., 1955, pp.133 e ss.

${ }^{67}$ DENIS, P. Op. cit., pp. 111-113.
} 1906. 
É provável, portanto, que se existisse um índice de "absorção" da força de trabalho levando em conta o mercado de trabalho da cidade considerado esse período imediatamente anterior à virada do século XIX, este certamente registraria porcentagens bastante elevadas, diferentemente do período posterior, sobretudo se considerada a primeira década do século, momento em que as condições para o imigrante recém-chegado diferiam fundamentalmente das apresentadas no período imediatamente anterior. Não que a economia da cidade sofresse estagnação, e nem porque faltassem oportunidades a serem exploradas, porém é inegável a concorrência que então passa a existir, provocada pelo crescente afluxo de colonos que nela desembarcavam vindos do interior a disputar um mercado de trabalho ${ }^{68}$, razão do seu rápido crescimento populacional. Por conseguinte, nessas circunstâncias, é irrefutável que se deva atribuir ao italiano que, em maioria, precedeu aos demais contingentes, certa primazia que redundou em condições mais vantajosas a serem auferidas.

Deste modo, e considerando o retardo observado nos fluxos migratórios de origem espanhola no Estado, e, em consequiência, também na cidade, resta-nos, portanto, conjeturar acerca das condições que a cidade reservou àqueles, de certa forma retardatários, que a ela demandaram num período posterior, e refletir sobre a ambigüidade de expectativas que a nascente metrópole criava nessa população, atentando para os mecanismos de atração e repulsão intrínsecos ao seu processo de metropolitização.

Outro aspecto importante sobre o qual buscaremos refletir com base nas evidências oferecidas pelas fontes consultadas é em que medida o espanhol recém-chegado reagia às condições e códigos previamente estabelecidos pelas outras colônias de imigrantes ali instaladas, provenientes de horizontes culturais diversos, e também diante do elemento nacional, buscando avaliar como se produziu, no âmbito pessoal e coletivo, o conjunto de estratégias interativas, acomodativas ou de resistência manifestadas nessa dinâmica, importando, enfim, examinar o modo como reelaborou o repertório difuso da própria identidade da cidade, estranha em sua essência, posto que, em maioria, eram elementos de perfil predominantemente rural, oriundos em sua quase totalidade do campo e, portanto, quase sempre despreparados para as nascentes atividades relacionadas à buliçosa cidade que emergia. Interessa perceber, nesse itinerário, se o seu equipamento cultural mostrou-se adequado no aproveitamento das

${ }^{68}$ A respeito da inserção dos imigrantes (e também dos nacionais, negros e mulatos) no mercado de trabalho de São Paulo ver, entre outros: SIMÃO, Aziz. Sindicato e Estado - suas relações na formação do proletariado em São Paulo. São Paulo: Dominus, 1966; DEAN, Warren. A industrialização em São Paulo. São Paulo: Difel, 1971; KOWARICK, L. Op. cit., 1987; FERNANDES, Florestan. A integração do negro na sociedade de classes. São Paulo: Dominus, 1965. FAUSTO, B. Trabalho urbano e conflito social, 1880-1920. São Paulo: Difel, 1977 e PINTO, M. Op. cit., 1984. 
oportunidades que dela emergiam, nas condições dadas e buscar apreender as diversas manifestações de sua identidade individual e grupal projetando alguma luz à obscura trajetória urbana desse contingente.

Face à especificidade da constituição da urbe, o adensamento de uma população diversificada, mescla de múltiplas expectativas e experiências de vida, e as indisfarçáveis tensões provocadas pela sobreposição de diferentes ritmos sociais, marcarão o cosmopolitismo conflituoso, aspecto indissociável do processo de urbanização da cidade.

$\mathrm{Na}$ ordem liberal republicana (ou na ordem republicana supostamente liberal) a exclusão passava a se revestir de múltiplas caras. Misturados no tecido urbano, mas profundamente separados, circulavam por esta cidade uma parcela pobre da população nacional “os chamados negros, índios, mestiços, pretos, pardos, caboclos, caipiras, mulatos, nativos, brasileiros, os da terra" ${ }^{\prime 69}$ e uma grande massa de estrangeiros que para ela afluíam ofertando a sua força de trabalho, compondo um leque que, de acordo com o Recenseamento Geral de $1920^{70}$, chegaria a 33 nacionalidades distintas.

... a Babel era de verdade. Ela agregava centenas de milhares de seres desenraizados, arrancados pela força ou pela aflição dos seus lares e regiões de origem, transportados como gados através dos mares, negociados por "agentes de imigração" com preço fixo por cabeça, conforme a idade, sexo, origem e condições físicas [...] sem instrução, sem conhecimento da língua, sem recursos, sem condições de retorno, reduzidos a mais drástica privação, para que a penúria mesma lhes servisse de acicate ao trabalho e motivo de submissão [...] postos a competir com os párias negros, recém egressos da escravidão e os "caipiras", mestiços $[\ldots]^{71}$.

${ }^{69}$ SANTOS, C. Op. cit., p.15.

${ }^{70}$ Recenseamento Geral de 1920 (tomo IV, Rio de Janeiro, Imprensa Oficial, 1962) do Ministério da Agricultura, Indústria e Comércio. De acordo com ele, a cidade de São Paulo possuía 577.621 habitantes. Deste total, $35,5 \%$ ou 205.245 pessoas eram estrangeiros, compondo 33 nacionalidades distintas. Os espanhóis representavam, então, aproximadamente $13 \%$ desse total de estrangeiros, com uma colônia de 24.902 pessoas, isso sem computar os descendentes já nascidos no Brasil.

${ }^{71}$ SEVCENKO, N. Op. cit.,1992, p. 21. 


\section{As primeiras imagens do espanhol na Paulicéia}

Não se têm muitas informações sobre o tipo de trabalho em que se engajou o espanhol que ficou nas cidades. Penso, aliás, que esse tema deveria ser objeto de um estudo à parte ${ }^{72}$.

A questão do trabalho, eixo central em torno do qual gravitou o fenômeno migratório, concentrou em suas determinantes fundamentais, como vimos, os mecanismos responsáveis pelo processo que acabamos de desenhar, referido à urbanização da Paulicéia. Nessa esfera essencial e determinante enquanto motora do processo aqui evocado, como nas demais subjacentes ou dela decorrentes, o imigrante espanhol dormita, conforme apropriadamente enunciado pela epígrafe, embalado por uma história de reticências.

O ano de 1893, não obstante, contempla dois marcos importantes para um primeiro contato com a questão. Inicialmente, neste ano, como vimos, ocorria a criação do Consulado Geral da Espanha (CGE) que, dentre outros procedimentos protocolares, instaurou o registro dos imigrados, em livros especialmente elaborados para tal e cujos dados, praticamente uma radiografia da trajetória de vida de cada indivíduo ali inscrito, constituem importantes indicadores e ensejo para a exploração de uma multiplicidade de aspectos a ele referidos. Dentre as possibilidades ofertadas pelo exame dos dados ali indicados, interessa-nos nesse momento delinear em especial a face viabilizada por meio da apreciação da coluna "ocupaciones", uma das muitas de que se compôs aquele inventário, referida particularmente à inserção laboral do contingente então fixado na cidade. Sua apreciação, contudo, revelaria um traço que the foi peculiar no período: sob a mesma rubrica desfilarão categorias laborais de natureza por vezes distintas, associadas não apenas a profissões, mas também a diferentes atividades, funções, ofícios e tarefas, razão pela qual preferimos manter a sua nomenclatura como no documento original.

O segundo marco importante seria ensejado pela elaboração, para o mesmo ano de 1893, pela primeira vez e especificamente para a Cidade de São Paulo, de um Censo da sua estrutura ocupacional (vide Tabela 1), inventário que, contendo dados de toda a população, nacional e estrangeira então estabelecida na cidade, deixa entrever, pela distribuição setorial elencada, a participação ocupacional relativa desses elementos nas suas diversas esferas econômicas.

\footnotetext{
${ }^{72}$ MARTINS, J. Op. cit., 1989, p.14.
} 
Tabela 1. São Paulo (Capital) - Estrutura Ocupacional, 1893

\begin{tabular}{|c|c|c|c|c|c|c|c|}
\hline \multirow{2}{*}{$\frac{\text { Setores ou Ramos }}{\text { Indústria Manufatureira }}$} & \multicolumn{3}{|c|}{$\underset{\%}{\text { Estrangeiros }}$} & \multicolumn{3}{|c|}{$\begin{array}{c}\text { Nacionais } \\
\%\end{array}$} & \multirow{2}{*}{$\frac{\text { Total }}{3.667}$} \\
\hline & 2.893 & 79 & $\%$ & 774 & 21 & $\%$ & \\
\hline Indústria Artística & 8.760 & 85,5 & $\%$ & 1.481 & 14,4 & $\%$ & 10.241 \\
\hline Transportes e conexos & 8.527 & 81 & $\%$ & 1.998 & 19 & $\%$ & 10.525 \\
\hline Comércio & 6.776 & 71,6 & $\%$ & 2.680 & 28,3 & $\%$ & $\underline{9.546}$ \\
\hline \multicolumn{8}{|l|}{ Administração pública, sacerdócio e } \\
\hline profissões liberais $(*)$ & 330 & 14 & $\%(*)$ & 2.110 & 87 & $\%$ & 2.551 \\
\hline Banqueiros, capitalistas e proprietários & 267 & 29 & $\%$ & 651 & 71 & $\%$ & $\overline{918}$ \\
\hline Serviços domésticos & 8.226 & 58,3 & $\%$ & 5.879 & 41,6 & $\%$ & $\underline{14.104}$ \\
\hline Atividade agro-pasto & 783 & 32 & $\%(*$ & 1.673 & 68 & $\%$ & 2.483 \\
\hline Sem profissão d & 360 & 71 & $\%$ & 149 & 29 & $\%$ & 509 \\
\hline Diversos & & & & - & & & 86 \\
\hline Total & $\underline{36.992}$ & 68 & $\%$ & $\underline{17.394}$ & 32 & $\%$ & 54.540 \\
\hline
\end{tabular}

Fonte: Relatório apresentado ao cidadão Dr. Cesário Motta Jr., Secretário dos Negócios do Interior do Estado de São Paulo, pelo Diretor da Repartição da Estatística e Arquivo, Dr. Antonio de Toledo Pizza em 31de julho de 1894, Rio de Janeiro, 1894. (*) As cifras totais não coincidem com a discriminação entre nacionais e estrangeiros por terem sido excluídos os farmacêuticos (96) e enfermeiros (15) sobre os quais não há discriminação. (**) Idem, por exclusão de atividades pecuárias (27). Apud FAUSTO, B. Trabalho urbano e conflito social, 1880-1920. São Paulo: DIFEL, 1977, p. 30. Optamos por manter os números da Tabela original, alguns dos quais, aqui sublinhados, continham prováveis erros gráficos.

Dessa maneira, de posse dos informes extraídos dos livros de registros consulares no ano de sua implantação, deles destacando-se os indicadores da coluna ocupación e em cotejamento aos dados oferecidos pelo Censo Ocupacional de 1893, vislumbramos concretamente o ensejo para uma aproximação aos elementos que demarcaram esse primeiro contato "oficial" do espanhol com a cidade, ainda que obrigados a realizar, sem que isso inviabilizasse a sua utilização, algumas "adaptações” às rubricas então adotadas.

Para começar, é imperioso constatar pelos dados ali apontados como, a essa altura, já se evidenciava na cidade um relativo processo de industrialização e, simultaneamente, destacar que se tratavam de setores onde reinavam quase absolutos os estrangeiros - na indústria manufatureira aparecendo com $79 \%$ e na artística com 85,5\% deles em sua composição. No entanto, e mesmo que essa hegemonia não possa ser questionada, as rubricas adotadas não deixam claras algumas distinções que seriam desejáveis; no caso da "indústria manufatureira", por exemplo, de qual seria a porcentagem de empresários e a de operários aí envolvidos? O mesmo para a categoria "indústria artística" que comportaria ainda equívoco maior: poderia estar referida apenas aos artesãos em geral? Ou também aos empresários e operários da construção civil? Ou ainda aos gráficos e músicos? Outra distinção problemática: a categoria "comércio", composta também ela por maioria de estrangeiros $(71,6 \%)$, a quem poderia estar aludindo? Aos comerciantes ou aos empregados do setor? Enfim, são questões incontornáveis 
que, de todo modo, não invalidam a evidência inequívoca da supremacia dos estrangeiros, já àquela altura, ano de 1893, preponderantes em dois setores-chave, a indústria e o comércio. Isso sem levar em conta os outros segmentos também contabilizados: o de "transportes e conexos", onde dominavam com $81 \%$ e o de "serviços domésticos", com 58,3\%. Enfim, no cômputo geral, excluindo-se setores claramente monopolizados pelos nacionais - caso da "administração pública, sacerdócio e profissionais liberais" - o que salta aos olhos é que eram os estrangeiros que constituíam a proporção maior da população "ocupada": 36.992 indivíduos ou $68 \%$ contra 17.394 ou $32 \%$ dos nacionais. Não só, eles também constituíam a maioria da população da cidade: considerado o censo do mesmo ano, na Capital de São Paulo eles representariam $55 \%$ do total de habitantes, montante do qual o imigrante italiano perfazia, sozinho, a elevada porcentagem de 63,5\% (45.457 pessoas).

Diante desse quadro, portanto, parece razoável questionar, à luz dos dados do recenseamento de 1893 - segundo o qual eram os estrangeiros que compunham a parcela maior da população ocupada, ou seja, $68 \%$ - se, considerada a imensa superioridade numérica dos italianos perante os estrangeiros não estariam eles, também em maioria, sendo representados pelas cifras acima. Nessa esteira, parece procedente a afirmação de Trento, indicando que

... por volta do início do século, cerca de um terço do contingente de imigrantes italianos no Brasil estava empregado nos centros urbanos [...]. Essa massa de gente dedicou-se às mais variadas profissões: alfaiates, sapateiros, pedreiros, barbeiros, carpinteiros, garçons, eram com frequiência italianos [e] praticamente detinham o monopólio do pequeno comércio. Ao mesmo tempo, desembarcavam médicos, engenheiros, técnicos, advogados e profissionais que encontravam boas oportunidades de emprego ${ }^{73}$.

Esse raciocínio, bastante razoável, orientou o passo seguinte e evidenciou, na analogia entre o percentual de estrangeiros ocupados (68\%) e o percentual representado pelo imigrante italiano, comparado às demais etnias na cidade $(63,5 \%)$ que ele, o italiano, seria o detentor de 43\% do total dos postos de trabalho em mãos de estrangeiros, na Capital. Este cálculo foi obtido aplicando-se sobre a população estrangeira ocupada (36.992 indivíduos) o percentual de 63,5\% representado pelo montante de italianos perante os demais estrangeiros, cálculo que resulta, como vimos, em $43 \%$ (ou 23.489 pessoas).

O desdobramento seguinte, também por analogia, buscou configurar o espanhol nesse contexto. Nesse caso, se considerarmos que seu percentual, em 1893, era de apenas 6,7\% do total de imigrantes na cidade $\mathrm{f}^{74}$, pode-se inferir, aplicando-o sobre o total de estrangeiros

\footnotetext{
${ }^{73}$ TRENTO, A. Op. cit., 1990, p. 39.

${ }^{74}$ Esse cálculo resultou da operação de divisão do número de espanhóis na cidade (4.818 pessoas) pelo total de estrangeiros (71.468 pessoas).
} 
ocupados (36.992 indivíduos), que eram 2.478 os espanhóis então ocupados na cidade, concluindo-se, por conseguinte que, do conjunto de espanhóis residentes na Capital em 1893 (4.818 pessoas), aproximadamente a metade deles, i.é, 2.340 pessoas ou $49 \%$, não se fez representar pelos números apresentados na Tabela 1.

Esse aspecto já seria surpreendente, não fosse por uma particularidade adicional, a inclusão de categorias, no Censo Ocupacional de 1893, claramente identificadas com o mercado de trabalho informal - caso de "serviços domésticos", segmento também constituído em maioria por estrangeiros $(58,3 \%)$.

Diante dessa evidência, restou-nos indagar por essa porção da população espanhola residente na cidade que não se viu representada no Censo Ocupacional de 1893. Excetuando-se nesse momento os casos não passíveis de serem computados (mulheres e crianças, ainda que ambos trabalhassem), os indicadores disponíveis parecem sinalizar casos de indivíduos claramente à margem do trabalho regular, formal ou informalmente constituído, (sobre)vivendo provavelmente à custa de qualquer atividade ocasional, ou de pequenas tarefas ou, ainda, de bicos eventuais.

Não obstante essa evidência flagrante, restava ainda a outra parcela, a que por suposto se viu representada nas estatísticas do Censo Ocupacional e, assim, partindo dessa premissa, buscamos delinear a medida da participação do espanhol no mercado de trabalho, com base naquele inventário. Então, partindo de um indicativo apenas quantitativo (o do Censo Ocupacional) procuramos, valendo-nos do inventário das ocupaciones declaradas no ano da abertura do CGE - 1893, coincidentemente o mesmo do Censo - agrupá-las qualitativamente diante das categorias ali formuladas de modo a estabelecer alguns parâmetros de análise comparativa.

Evidentemente que essa operação encerrou problemas; em alguns casos, tal como na análise dos dados recenseados, a dificuldade, quase a impossibilidade do reconhecimento da natureza de algumas rubricas declaradas, constituiu-se no principal deles.

De todo modo, e na observância de tais limitações, o procedimento evidenciou, conforme pretendemos demonstrar, que parcela desse contingente que se declarou vivendo neste momento na Paulicéia insinuava-se, com maior ou menor representatividade, em diversos dos segmentos mencionados no Censo Ocupacional, surpreendendo até, nesse contato preliminar, pela variedade de ocupaciones que foram declaradas no CGE (vide Quadro 1$)^{75}$.

\footnotetext{
${ }^{75}$ Preferimos manter, nesse momento, a grafia original dessas ocupaciones em espanhol; a versão das mesmas para o português encontra-se nos Quadros 2, 3 e 4 .
} 
Quadro 1. São Paulo (Capital)

Ocupaciones declaradas, 1893

\begin{tabular}{ll}
\hline \hline abaniquero & dulcero \\
abogado & empleado \\
ajustador & encuadernador \\
ajustador mecánico & ingeniero \\
albañil & jornalero \\
artista & labrador \\
ayudante de ingeniero & mecánico \\
barbero & músico \\
barrilero & pedrero \\
bracero & pintor \\
cantero & sirviente \\
capataz & sombrerero \\
cigarrero & sus labores \\
cochero & tabaquero \\
cocinero & tabulero \\
comerciante & taponero \\
comercio & tipógrafo \\
constructor de obras & tornero \\
delineante & zapatero \\
\hline \hline
\end{tabular}

Por conseguinte e observando uma classificação setorial equivalente àquela da Tabela 1, assim se poderia "enquadrar", de modo aproximativo, as diversas ocupaciones a que se dedicava o espanhol encontrado na cidade: em primeiro lugar, perfazendo um percentual de $37,2 \%$ do universo considerado, surpreendemos a maioria envolvida com atividades identificadas com o setor da "indústria artística", segmento passível de ser redistribuído, resultando desse total $22,7 \%$ sujeitos de serem incluídos numa categoria genérica de "artesãos em geral" (abaniquero; barrilero; sombrerero; tabulero; zapatero; barbero; encuadernador e tipógrafo); 10,9\% que se poderia inserir na categoria "construção civil" (ayudante de ingeniero; constructor de obras; delineante; albañil; pintor; cantero e sirviente) e 3,6\% de artistas e músicos $^{76}$.

A seguir, em segundo lugar, despontava o "comércio", com $24,5 \%$ do total de ocupados, setor onde agregamos indistintamente, para estabelecer uma correspondência com o Censo Ocupacional, as ocupaciones de comerciante; comercio; empleado, cocinero e dulcero. Por último, percentuais menores para a "indústria manufatureira", correspondendo a 7,2\% dos declarantes (ajustador mecánico; mecánico; capataz; cigarrero; tabaquero; taponero; tornero) e, para finalizar, o setor de "transportes e conexos", com 1,8\%, representados pelos cocheros, e o das "profissões liberais", também com 1,8\% (abogado e ingeniero).

\footnotetext{
${ }^{76}$ As versões para o português das ocupaciones declaradas encontram-se nos Quadros 2, 3 e 4.
} 
Este constituiu, a princípio, o modo como em tese vislumbramos uma primeira possibilidade de reconstituição do modo efetivo de inclusão ocupacional do espanhol na cidade, neste momento específico. Esta amostragem delineia, como vimos, não apenas a multiplicidade de oportunidades oferecidas por esta cidade em transição, mas o fato de o espanhol, numericamente ainda inexpressivo, já apresentar uma relativa participação em todas as instâncias arroladas, fato este que merece atenção especial, pela pulverização de ocupaciones que salta aos olhos numa rápida observação. Discreta, em alguns setores, caso dos "profissionais liberais", "transportes e conexos" e "artistas e músicos", porém salientando-se mais em outros segmentos, esse contingente já revelava certa tendência ao "comércio" - setor no qual despontará uma camada média de que a pesquisa se ocupará - e aos ofícios associados à pequena "indústria artística".

Não obstante, seguindo nosso raciocínio, tais declarantes representariam tão-somente uma parcela desse contingente, aquele que pôde ser "percebido" e mensurado pelos números oficiais. O outro montante, por sua especificidade não passível de ser diagnosticado oficialmente, conforme constatamos, despontava ainda timidamente em vista dos expressivos índices que progressivamente passaria a exibir: estamos nos referindo à categoria dos jornaleros $^{77}$, rubrica que, apenas neste ano de 1893, já seria a responsável, isoladamente, por $10,9 \%$ do total de ocupaciones declaradas no $\mathrm{CGE}^{78}$. Partindo desse indicativo, buscamos ampliar o período de análise e, realmente, a evidência de sua expressividade não tardaria a se fazer notar: na análise dos dados referentes ao primeiro decênio (1893-1902), os jornaleros despontarão com um percentual de $25 \%$ do universo total dos declarantes que afirmavam então residir na cidade ${ }^{79}$. E aqui cabe um esclarecimento que, nada impede imaginar, poderia evidenciar um percentual ainda mais expressivo dessa categoria nesse decênio. É que, no conjunto do período total abrangido pelo levantamento documental (30 anos) percebemos a gradual extinção de determinadas categorias (correlatas, a considerar o contexto então analisado) as quais, queremos crer, poderiam estar migrando para outras, no caso, para a de jornalero.

Nesse particular parece exemplar o observado quanto à categoria labrador. Nesse primeiro decênio, ela será a responsável por $8 \%$ das ocupaciones declaradas; contudo, quando

77 Nossa hipótese para essa asserção fundamenta-se no fato de a categoria não ser passível de enquadramento em qualquer dos segmentos arrolados pelo Censo, exceto se compondo a rubrica "Diversos" para a qual não há distinção entre estrangeiros e nacionais.

${ }^{78}$ As categorias que completariam o universo de ocupaciones mencionado no CGE no ano de 1893, seriam: labrador, 7,2\%; bracero, $1,8 \%$; sus labores $5,5 \%$ e outras com inexpressivo percentual.

${ }^{79}$ Relatório Access 38. Neste caso, estabelecemos como critério o "domicílio" na Capital, i.é., o conjunto dos inscritos domiciliados na cidade, independentemente de outras variáveis como sexo e estado civil. 
computados os registros dos decênios subseqüentes, ela praticamente desaparecerá dos registros dos domiciliados na Capital - no interior, ao contrário, considerado o mesmo período, ela revelará o alto percentual de $31 \%$. Essa evidência levou-nos a conjecturar da probabilidade de uma progressiva "reabsorção" dessa categoria pela dos jornaleros, operada no contexto da cidade. Em menor incidência, mas revelando possibilidade similar, o mesmo raciocínio pode ser estendido para outra categoria que também foi gradualmente eliminada dos registros referidos aos domiciliados na Capital de São Paulo, a de bracero.

Excetuando-se, assim, o percentual de $25 \%$, referido aos jornaleros neste decênio, e mesmo sem levar em conta o mencionado percentual de $8 \%$ de labradores - que, segundo nossa hipótese foi categoria que migrou, como outras, para a de jornaleros, passando com ela a compor elevados índices, cuja expressividade impõe análise particularizada - o número de outras ocupaciones declaradas para a Capital, foi da ordem de 99 categorias distintas ${ }^{80}$, conforme apresentamos no Quadro 2 (no qual apresentamos destaque especial para a categoria jornalero).

Por outro lado, conforme podemos observar, em que pese a evidência da participação crescente do espanhol em diversos segmentos ocupacionais - alguns dos quais de perfil marcadamente feminino, como sirvienta e partera - foi espantoso o salto manifestado pelos números, expondo índices ainda mais expressivos nos percentuais apresentados pelos jornaleros quando evoluímos para o segundo decênio (1903-1912), quando passam a deter sozinhos o expressivo percentual de $61 \%$ do universo considerado para a Capital de São Paulo.

Esse brutal aumento, evidentemente, não pode ser tomado de maneira aleatória, não dissimulando, conforme dissemos, a probabilidade da migração de outras categorias para a de jornaleros, face às crescentes restrições do mercado de trabalho da cidade.

Nesta segunda década examinada, entre os anos de 1903-1912, a propósito, inúmeras rubricas foram suprimidas, i.é., desapareceram gradualmente dos registros, ainda que, simultaneamente, tenhamos identificado o ingresso de outras (novas) mencionadas pela primeira vez. O saldo do confronto, contudo, foi negativo: foram 54 categorias subtraídas para 31 novas apresentadas, resultando, portanto, num deficit de 23 categorias eliminadas (vide Quadro 3, adiante).

E note-se que, no conjunto das "novas", se deu o aparecimento de categorias como campo, colono e vendedor ambulante as quais, por sua natureza, se apresentarão com forte potencial para uma aproximação à de jornalero, na conjuntura específica da cidade de São Paulo naquele momento, conforme a pesquisa buscará demonstrar.

\footnotetext{
${ }^{80}$ Relatório Access 39.
} 


\section{Quadro 2. São Paulo (Capital) - Composição da estrutura ocupacional dos imigrantes espanhóis, 1893-1902 (destaque especial para a categoria jornalero )}

\begin{tabular}{|c|c|}
\hline abaniquero (leque)* & gasista (acendedor de lampiões) \\
\hline abogado (advogado) & guarnicionero (sela para montaria)* \\
\hline agricultor & herrero (ferreiro) \\
\hline ajustador & hojalatero (trabalha c/ folhas metálicas) \\
\hline ajustador mecánico & industrial \\
\hline albañil (pedreiro) & ingeniero (engenheiro) \\
\hline alpargatero (alpargatas)* & jornalero (25\%) \\
\hline ambulante & labrador (lavrador) \\
\hline aprendiz & machinista** (maquinista) \\
\hline artista & marinero (marinheiro) \\
\hline ayudante de ingeniero (ajud.engenheiro) & marmolista (mármore)* \\
\hline barbero (barbeiro) & mecánico \\
\hline barnizador (envernizador) & minero (mineiro) \\
\hline barrilero (barris)* & molinero (trabalha em moinho) \\
\hline bracero (braçal) & músico \\
\hline calista & negociante \\
\hline camarero (balconista) & notario (escrivão) \\
\hline cantero (cortador de pedra) & obrero (operário) \\
\hline capataz & panadero (padeiro) \\
\hline carpintero (carpinteiro) & partera (parteira) \\
\hline cerrajero (serralheiro) & pedrero** \\
\hline cestero (cestas)* & pelotari (jogador de pelota basca) \\
\hline cigarrero (cigarreiro)* & pescador \\
\hline cirujano dentista (cirurgião dentista) & pintor \\
\hline cochero (cocheiro) & pomarero** \\
\hline cocinero (cozinheiro) & profesor de equitación \\
\hline comerciante & propietario \\
\hline comercio (trabalhador no comércio) & religioso \\
\hline confitero (confeiteiro) & sastre (alfaiate) \\
\hline constructor de obras (construtor de obras) & sastre y negociante \\
\hline cristalero (vidreiro) & secretario del X.C. \\
\hline cuntador (contador) ${ }^{* *}$ & serrador \\
\hline curtidor & sirvienta \\
\hline deficiente & sirviente \\
\hline delineante (projetista/desenhista industrial) & sillero (cadeiras)* \\
\hline dulcero (doceiro) & sombrerero (chapéu)* \\
\hline ebanista (marceneiro) & sus labores (do lar) \\
\hline empleado & tabaquero (tabaco)* \\
\hline empleado de hotel & tabulero** \\
\hline empleado fábr.gás & taponero (tampas/rolhas)* \\
\hline encanador*** & tejedor (tecelão) \\
\hline encuadernador (encadernador) & tenedor de libros (guarda-livros) \\
\hline escribiente & tipógrafo \\
\hline fabricante & tornero (torneiro) \\
\hline fabricante de vinagre & tornero mecánico \\
\hline fogonero (foguista) & trabajador (trabalhador) \\
\hline foguista*** & tratador de caballos (tratador de cavalos) \\
\hline fotógrafo & vidriero (vidreiro) \\
\hline fundidor & yesero (gesseiro) \\
\hline ganadero (boiadeiro) & zapatero (sapateiro) \\
\hline
\end{tabular}

(*) Fabrica e/ou vende; (**) Palavra aportuguesada; (***) Grafado em português 
Quadro 3. Ocupaciones suprimidas (1893-1902)

e novas ocupaciones declaradas (1903-1912)

\begin{tabular}{|c|c|c|}
\hline \multicolumn{2}{|c|}{ Suprimidas (54) - 1893-1902 } & \multirow{2}{*}{$\begin{array}{l}\text { Novas (31) - 1903-1912 } \\
\text { campo }\end{array}$} \\
\hline abaniquero & ganadero & \\
\hline ajustador & gasista & colono \\
\hline ajustador mecánico & guarnicionero & corredor \\
\hline aprendiz & ingeniero & costurera \\
\hline ayudante de ingeniero & marmolista & electricista \\
\hline barbero & mecánico & empleada \\
\hline barnizador & minero & encrustrador $* *$ \\
\hline barrilero & molinero & estudiante \\
\hline calista & músico & fabricante de alpargatas \\
\hline capataz & notario & farmacéutico \\
\hline cerrajero & partera & fazedor de libros \\
\hline cestero & pescador & grabador (estampador de tecido) \\
\hline cirujano dentista & pomarero & impresor \\
\hline constructor de obras & profesor de equitación & industrial pintor \\
\hline cristalero & sastre y negociante & ingeniero de obras \\
\hline cuntador & secretario del X.C. & jardinero \\
\hline curtidor & serrador & jornalero inválido \\
\hline deficiente & sillero & lavandera \\
\hline delineante & sombrerero & operario \\
\hline dulcero & tabaquero & pensionista \\
\hline empleado fábr.gás & tabulero & picapedero (cortador de pedra) \\
\hline encanador & taponero & pintor decorador \\
\hline fabricante & tenedor de libros & planchador (passador) \\
\hline fabricante de vinagre & tornero & profesor \\
\hline foguista & tornero mecánico & profesor de latim \\
\hline fotógrafo & tratador de caballos & profesor normal \\
\hline fundidor & yesero & sirviente \\
\hline & & tintorero (tintureiro) \\
\hline & & tonelero $(\text { tonel })^{*}$ \\
\hline & & vendedor ambulante \\
\hline
\end{tabular}

(*) Fabrica e/ou vende; (**) Palavra aportuguesada

Esse quadro, demonstrando grande volatilidade no mercado de trabalho da cidade nesse momento, é questão já sinalizada por diversos autores, apontando para as condições progressivamente restritivas encontradas pelo imigrante recém-chegado que, agora, diferiam fundamentalmente das apresentadas no período anteriormente analisado.

O espanhol, como vimos, demarcará um movimento ultramarino em descompasso cronológico quando comparado ao italiano, que o antecedeu. Os autores examinados apontam para o período de 1872-1900 como o de maior afluxo da imigração italiana, fato que se comprova pela hegemonia desse elemento na cidade, na virada do Novecentos - 35\% do total de população da cidade e maioria isolada com relação ao montante de imigrantes nela instalados - período apontando como aquele das oportunidades, no qual puderam ser usufruídas as melhores condições de realização. 
O decênio (1903-1912) aqui analisado, portanto, coincidindo com a retração nos ingressos do italiano (lembremo-nos do Decreto Prinetti, de 1902) contemplando, por outro lado, o crescente afluxo de espanhóis, elemento que apresentará dois picos no período, nos anos de 1905 e 1912, apresentava-se, assim, como o responsável por um quadro de diminuição e escassez de oportunidades, bastante diferente do observado no período anterior.

Nessas circunstâncias, o espanhol que desembarcava na Cidade de São Paulo nesta década, seja procedente do Interior do Estado ou não, se defrontava com uma realidade em parte responsável pelos números que acabamos de apontar, consubstanciada no vertiginoso aumento do jornalero.

Fundada na tradição de seu país, classicamente associada ao campo, declarar-se "jornalero" - categoria dinâmica e volátil que, conforme se evidenciou, progressivamente passou a acomodar, em espaços e tempos variados, a complexa realidade dessas populações que por vezes tangenciava a miséria mais absoluta - sublinhava, agora, não apenas a trajetória prévia de flutuação e instabilidade estrutural associada ao país de origem (e cumulativamente também ao latifúndio cafeeiro, em alguns casos), mas expressava a transposição histórica de suas determinantes essenciais para o país de destino e, nele, também para os núcleos urbanos.

El valor semántico que los censos dan al término "jornalero" no se refiere únicamente a las formas de percepción del salario, sino que refleja a la perfección el problema de la inestabilidad del empleo. De ahí que los censos incluyan en la categoría de jornaleros en las ciudades a todos aquellos trabajadores sin conocimiento expreso de un oficio, cuyo quehacer cotidiano se mueve a lo largo de un año en ámbitos mиy diferentes: peón de albañil, mozo de cuerda, recadero, mendigo involuntario..., una situación que afecta sobre todo a los campesinos que llegan a la ciudad y que encuentran difícil acomodo en los mercados de trabajo urbanos ${ }^{81}$.

A disseminação do uso da expressão não pode ser tomada de forma aleatória. Tudo indica que esses elementos, marginalizados pelos desajustes da conjuntura agrária, e oriundos em larga escala do campo, especialmente da região andaluza, ao sul da Península, a tivessem "transplantado", como significado de valor evocativo, na percepção da analogia de condições vivenciadas no colonato e, por extensão, também nas cidades. A menção não se restringiu, conforme ressaltamos, a elementos fixados apenas nas localidades do núcleo cafeeiro: extrapolando esses limites, passou a ser encontrada de maneira gradual nos domiciliados na Capital de São Paulo.

${ }^{81} C f$. BAHAMONDE, A. e MARTÍNEZ, J. Historia de España, siglo XIX. Madrid: Ediciones Cátedra, 1994, pp. 476-477. 
De qualquer modo, sua aplicação, sugerindo acentuado peso simbólico implicou, por parte do imigrante evocar, frente à nova realidade, uma sensação de experiência já vivenciada, com toda a carga a ela indissociável, de instabilidade e desajuste, traduzindo-se concretamente, em face do concorrido mercado de trabalho da cidade, na aceitação de qualquer trabalho, tarefa ou incumbência esporádica e/ou temporária ou no subemprego, sem garantia e de baixa remuneração.

Em outros termos, essa condição auto-atribuída que se caracterizava, na luta cotidiana, pela aceitação de qualquer oferta de trabalho ou pela busca de soluções improvisadas e fórmulas provisórias que lhe garantissem ao menos a sobrevivência - origem de uma experiência cumulativa de improvisação - também designava, pelo seu emprego, a consciência da condição que exprimia.

A terminologia acabou, por razão que desconhecemos, sendo oficializada: nossa legislação estadual sancionada para regulamentar a imigração e a colonização, diante da crescente presença dos imigrantes na cidade e dispondo sobre ocupações até então não identificadas e para as quais não havia jurisprudência, cita, dentre outras, a dos "jornaleiros" e "artistas", tentativa de acompanhar as modificações impostas pelo crescimento da cidade e pelos novos elementos com os quais progressivamente se deparava ${ }^{82}$.

Não obstante os elevados e progressivos índices percentuais exibidos pela categoria nas duas décadas anteriormente mencionadas, quando examinamos os indicadores do terceiro e último decênio (1913-1922), verificamos uma tendência à estabilização nos seus patamares indicando um discreto acréscimo que, por outro lado, demonstrava que o quadro de dificuldades apresentado no período anterior não se alterara. No Interior do Estado, as proporções seguiriam a mesma tendência da Capital, evidenciando uma analogia de situações ${ }^{83}$. O decênio revelará ainda outras categorias, algumas facilmente associadas ao crescente parque industrial da cidade e outras claramente vinculadas ao setor de serviços e às profissões liberais. Através delas também se pôde vislumbrar uma maior participação relativa da mulher emigrante em diversas ocupações - bordadera e modista, por ex. - e outras refletindo a ebulição da vida artística e cultural da cidade - guitarrero, violinista, pirotécnico, profesor (vide Quadro 4).

\footnotetext{
${ }^{82}$ Veja-se em: Coleção de Leis e Decretos do Estado de São Paulo. Lei 1.045-C, de 27/12/1906 e decreto 1.458, de 10/04/1907, artigo 1. Typografia do Diário Oficial. Tomo XVI, 1906, pp.77 a 90; Tomo XVII, 1907, p. 87.

${ }^{83}$ No Interior do Estado de São Paulo os percentuais de jornalero apresentaram para os três decênios aqui mencionados, respectivamente, as cifras de $25 \%, 72 \%$ e $75 \%$ do total declarado.
} 
Quadro 4. Novas ocupaciones, 1913-1922

\begin{tabular}{ll}
\hline \hline artista cinema & motorista \\
bordadera & negocios \\
capitalista & ordenanza del consulado \\
carabinero retirado (soldado aposentado) & pequeño comerciante \\
cerámico (ceramista) & pequeño industrial \\
charutero (charuteiro)* & pequeño negociante \\
chauffeur (chofer) & pequeño propietario \\
comerciante y propietario & pastor protestante \\
comprador & pensionista del Estado \\
cónsul general España em São Paulo & periodista (jornalista) \\
corrector (revisor de texto) & pirotécnico \\
dibujante (desenhista) & pollero (galinhas)* \\
doctor en ciencias & practicante \\
dorador (trabalha c/ douração metálica) & practicante de farmacia \\
empleado público & presbítero \\
empresario & propietaria \\
escribiente del consulado & religiosa \\
guitarrero (guitarista) & representante comercial \\
hacendado (fazendeiro) & saquero (sacos)* \\
indigente & tapecero (tapeceiro) \\
laminador & técnico en tejidos \\
latero (trabalha cl folhas metálicas) & tejedora (tecelã) \\
litógrafo & vendedor \\
maestra jubiliada (professora aposentada) & viajante \\
maestro casetero (professor domiciliar) & vice cónsul general \\
mecánico y electricista & violinista \\
modista & \\
\hline \hline Fabica e/ou cia e/ou vende & \\
\hline
\end{tabular}

(*) Fabrica e/ou cria e/ou vende

No entanto, este período culminou com o aparecimento de algumas categorias novas coroando uma realidade subjacente à colônia espanhola da cidade, qual seja, a emergência de uma camada média que gradualmente se insinuava e cujo padrão de vida, conforme pudemos observar, inspirava-se mais e mais no comportamento das nobres famílias paulistanas. Podemos destacar, a título de ilustração, uma vez que a pesquisa adentrará a seus palacetes, algumas dessas novas ocupaciones, aqui já um tanto distanciadas do sentido original que tomou a palavra. Assim, capitalista, empresario e hacendado (fazendeiro), atributos que passaram a perfilar lado a lado com outros como indigente, surgidos também pela primeira vez na década, representam eloqüente atestado dos paradoxos que permeavam a vida da cidade em seu conflituoso cosmopolitismo.

O espanhol que se manifestou como domiciliado na Capital do Estado de São Paulo no primeiro decênio (1893-1902) representava aproximadamente 56,8\% do total dos declarantes; os demais indicavam viver no Interior (29,5\%), e de parcela deles não constava o domicílio $(13,7 \%)$. 
No segundo decênio, esse percentual sofreu considerável baixa para os domiciliados na Capital, apresentando-se com a cifra de apenas 25,9\%. Para o Interior do Estado, o percentual no mesmo período foi de 37,8\%. Como se observa, os dois percentuais somados totalizam $63,7 \%$, e a diferença de $36,3 \%$ refere-se à parcela, nesta década bastante expressiva, daqueles que não declararam o domicílio, dado que não pode ser tomado aleatoriamente.

Os dados referentes ao terceiro decênio apresentaram-se de forma mais equilibrada, configurando um percentual de 46,3\% para a Capital, 48,3\% para o Interior, com apenas 5,4\% de domicílios não informados.

Dos inscritos domiciliados na Capital de São Paulo no período total abrangido pela pesquisa, quanto a gênero e estado civil, verificamos que, no primeiro decênio 96,7\% dos registros pertenciam a elementos do sexo masculino - 55\% dos quais casados. No segundo decênio, houve um relativo acréscimo percentual dos registros femininos, de 3,3\% para 12,5\%; nesse período, o masculino apresentou-se, assim, com 87,5\%. Do total considerado, 60,2\% eram de elementos que se diziam casados.

É no terceiro decênio, todavia, que observamos significativa tendência à alta nos registros femininos, que compuseram o percentual de 22,7\%. Essa mulher imigrante constituíase quanto ao estado civil, de $63,8 \%$ de casadas, $23,2 \%$ de solteiras e $12,9 \%$ de viúvas. Os homens, neste decênio, compondo 77,3\% do total de registros, apresentavam-se com um percentual de $66,9 \%$ de casados, $29,9 \%$ de solteiros e $3,2 \%$ de viúvos.

Nos 30 anos analisados, o conjunto dos dados evidenciou que o imigrante do sexo masculino que se fixou na Capital de São Paulo, independentemente de sua origem e estado civil apresentava-se com uma idade média de aproximadamente $35 \operatorname{anos}^{84}$, sendo casado em sua maioria $(59,7 \%)$ e exibindo um tempo médio de residência na cidade de 4,6 anos.

Já a mulher imigrante, também casada em sua maioria (61,4\%), residia na cidade em média há 5,2 anos e sua idade média era de aproximadamente $36 \operatorname{anos}^{85}$.

Quanto à origem, o espanhol que se destinou ao Estado de São Paulo no período total abrangido pelo levantamento documental, procedia prioritariamente de três Regiões na Espanha.

Destacando-se das demais Regiões, a Andaluzia apresentou-se como a região originária do fluxo mais expressivo, independentemente do decênio examinado.

\footnotetext{
${ }^{84}$ A menor idade encontrada nos LRC foi de 9 anos, e a máxima de 82 anos, no período.

${ }^{85}$ Para a mulher, a menor idade foi de 7 anos e a máxima de 88 anos.
} 
No primeiro deles, sua cifra já se revelaria pouco modesta: detinha, então, 43,6\% do fluxo total para o Estado, curva que tendeu ao crescimento, alcançando, no segundo decênio, o patamar de 53\% do total de espanhóis ingressados, índice que tendeu à estabilização para o período imediatamente posterior.

Seguindo-se à Andaluzia, duas outras Regiões apresentaram-se como as de maior demanda para o Estado de São Paulo no período. Na segunda posição, apresentando, contudo, percentuais bastante inferiores ao do andaluz, destacou-se o contingente originário da Galícia. Sua performance também se distinguiria da andaluza, que se apresentou, conforme pontuamos, com uma inclinação à alta, notadamente do primeiro para o segundo decênio.

Analisando os dados para o período, pudemos observar que a corrente galega revelouse mais expressiva na primeira década, ocasião em que se apresentou com um percentual de 22,6\% do total emigrado daquele país. A partir daí, no entanto, essa corrente passou a apresentar um contínuo movimento de queda para as décadas seguintes, apresentando índices de 14,5\% no segundo e de $10,3 \%$ no terceiro decênio.

E em terceiro posto, com índices menores, porém ainda assim superiores ao da maioria das Regiões examinadas, surgia a Região de Castilla-León, cujo desempenho, no período, revelou certo equilíbrio, manifestando-se com índices sem alternâncias bruscas - 10,4; 12,0 e 10,6\% respectivamente nos três decênios examinados - aproximando-se já no segundo decênio dos índices que a região galega passaria a exibir em seu movimento declinante ${ }^{86}$.

Desse modo, em resumo, contabilizados os índices percentuais globais, evidenciou-se a preponderância do caudal constituído pelas correntes originárias das três regiões consideradas, responsáveis pelo expressivo percentual de aproximadamente $3 / 4$ do total ingressado no Estado de São Paulo no período, conforme dados exibidos na Tabela 2, na qual também incluímos os percentuais correspondentes a cada uma das demais regiões espanholas de que se compôs o fluxo que se estabeleceu no Estado de São Paulo.

\footnotetext{
${ }^{86}$ Os fatores determinantes dos distintos movimentos populacionais que tipificaram e singularizaram as diversas Regiões de origem, notadamente a Andaluzia e a Galícia, foram analisados em: CÁNOVAS, M. $O p$. cit.,2001, pp. 58 e ss.
} 
Tabela 2. Estado de São Paulo - Distribuição percentual dos imigrantes espanhóis por Regiões, 1893-1922, por decênios (destaque para as três principais regiões)

\begin{tabular}{|c|c|c|c|}
\hline Regiões de Origem & $\begin{array}{c}1^{\circ} \text { Decênio } \\
1893-1902 \\
\%\end{array}$ & $\begin{array}{c}2^{\circ} \text { Decênio } \\
1903-1912 \\
\%\end{array}$ & $\begin{array}{c}3^{\circ} \text { Decênio } \\
1913-1922 \\
\%\end{array}$ \\
\hline Andaluzia & 43,6 & 53,0 & 50,0 \\
\hline Galícia & 22,6 & 14,5 & 10,3 \\
\hline Castilla - Léon & 10,4 & 12,0 & 10,6 \\
\hline $\begin{array}{l}\text { Subtotal } \\
\text { Demais Regiões }\end{array}$ & 76,6 & 79,5 & 70,9 \\
\hline Aragon & 0,8 & 2,0 & 1,4 \\
\hline Astúrias & 1,1 & 0,4 & 0,7 \\
\hline Baleares & 0,2 & 0,4 & 0,3 \\
\hline Canárias & 2,0 & 0,7 & 0,3 \\
\hline Cantabria & 0,3 & 0,1 & 0,2 \\
\hline Castilla La Mancha & 1,1 & 1,2 & 3,0 \\
\hline Catalunha & 6,9 & 2,3 & 1,8 \\
\hline Extremadura & 0,7 & 1,2 & 6,2 \\
\hline Madrid & 1,9 & 0,7 & 0,7 \\
\hline Murcia & 0,7 & 5,2 & 8,5 \\
\hline Navarra & 1,3 & 2,0 & 0,9 \\
\hline País Basco & 2,9 & 1,0 & 1,0 \\
\hline Rioja & 0,7 & 0,6 & 0,9 \\
\hline Valencia & 2,1 & 1,9 & 1.8 \\
\hline Outras/não declarados & 0,7 & 0,8 & 1,4 \\
\hline Total & 100,0 & 100,0 & 100,0 \\
\hline
\end{tabular}

Não obstante, a análise da Tabela em pauta pode revelar outros indicadores importantes em seu conjunto. Fica patente, por exemplo, uma particularidade do fenômeno emigratório espanhol de massa que, em seus desdobramentos, determinaria perfis distintos para um mesmo destino, ou seja, evidenciou-se, embora em diferentes escalas, que o espanhol que se encaminhou para o Estado de São Paulo procedia, sem exceção, de todas as Regiões daquele país.

Prosseguindo na análise, no passo seguinte buscamos destacar, desse conjunto analisado sob a ótica da origem proporcional das correntes que demandaram o Estado de São Paulo, o seu direcionamento, em outras palavras, o seu domicílio, para, em suma, identificar as características do contingente que se estabeleceu na Capital de São Paulo. Essa consulta se mostraria reveladora, indicando uma outra face da questão. Com efeito, tendo compilado os dados percentuais para cada região de origem, um aspecto se destacou na distribuição por domicílio, qual seja, um elevado índice de registros com ausência dessa informação, os quais, para essa finalidade, tiveram de ser descartados. Contudo, o seu montante, expressivo, 
manifestaria um índice surpreendente sobretudo na segunda década, e de modo uniforme, i.é., para a maioria das correntes, ainda que com oscilações percentuais entre si.

Esse fato chamou-nos a atenção, instigando-nos a refletir sobre as prováveis causas desse fenômeno. Em que circunstância - incessantemente nos indagávamos - alguém, melhor dizendo, milhares de indivíduos, à frente de um escrivão de consulado, admitiria "desconhecer" seu domicílio, ocasionando uma lacuna considerável nessa informação?

Acreditamos que esses índices abriguem, em seu bojo, um conjunto de indicadores, cuja ocorrência espelharia fatores relacionados à contínua mobilidade que se observou no período em diversas direções, refletindo, por outro lado, o grau de instabilidade e o modo precário de acomodação que marcou a trajetória de boa parcela desses indivíduos.

No primeiro decênio, os lapsos da informação revelaram-se específicos de contingentes oriundos de determinadas Regiões: os contingentes de Aragón, Castilla La Mancha e Múrcia, por exemplo, não apresentaram qualquer omissão. Para as demais Regiões, índices que oscilaram entre 7,7\%, o apresentado pelos asturianos e 66,7\%, pelos baleares, caso excepcional que pode conter outras determinantes.

Contudo, como dizíamos, foi no segundo decênio que a tendência se acentuou, período em que cresceram as omissões de domicílio, aspecto que abrangeu, de modo quase uniforme, a todas as regiões, excetuando-se a Cantábria, decrescendo nitidamente para o terceiro decênio, revelando-se, da mesma maneira, de forma uniforme para todas as regiões. Os lapsos apresentados em cada decênio para cada região espanhola individualmente, e os correspondentes percentuais de distribuição para a Capital e Interior, apresentados pelas mesmas, no período, estão na Tabela 3.

Embora portando um claro indicativo do fator relacionado à itinerância e aos sucessivos deslocamentos - uma das marcas do período -, ainda assim, alguns desses índices merecem comentário particular. É o caso daqueles revelados pela corrente andaluza, que se constituiu na de maior expressividade no período.

Se atentarmos para o percentual de direcionamento, na distribuição Capital/Interior, observaremos uma ligeira paridade entre os números correspondentes ao primeiro e ao terceiro decênio, i.é, uma distribuição menos desproporcional do que aquela apontada para a segunda década. Com efeito, os índices apontam para um percentual de fixação desse elemento na cidade, no primeiro decênio, da ordem de 55,1\% (com $11 \%$ de domicílios não declarados) e de 43,4\% para o terceiro decênio, que apresentou um índice de 5,3\% de não declarados. Isso poderia revelar algo, levando-se em conta os índices atípicos do segundo decênio, que apontavam para apenas $22,8 \%$ o índice equivalente para a Capital? Nesse caso particular, é 
possível que sim, que também possam significar ocorrências de indivíduos que, já domiciliados na cidade, provavelmente há pouco tempo, dela tivessem ainda reduzido conhecimento, o que se traduziria na não identificação dos logradouros (ruas e bairros, particularmente). Ou daqueles que, recém-chegados, do Interior ou mesmo da Espanha, pudessem estar habitando temporária e improvisadamente em algum cômodo ou quintal, ou mesmo que estivessem "de favor" dividindo espaço na casa de algum familiar ou conhecido, sem contudo, ter o menor domínio do entorno em que se achavam. Essa é uma hipótese, e apenas aplicada ao caso específico dos andaluzes que, sem pretender minimizar a ocorrência da itinerância, busca acentuar as precárias condições em que se dava primeiro contato com a cidade, por parte do elemento que representou o grosso dessa imigração. De todo modo, convém destacar, se constituíssem casos de indivíduos domiciliados no Interior, é bastante provável que não lhes fosse desconhecido o nome da localidade ou da fazenda de onde saíram, em último caso, o da estação de trem em que embarcaram, indicações, aliás, comuns, oferecidas nos registros de residentes no Interior.

Tabela 3. São Paulo (Capital e Interior). Distribuição percentual por Regiões de origem dos imigrantes espanhóis, 1893-1922, por decênios (destaque para os domicílios não declarados)

\begin{tabular}{|c|c|c|c|c|c|c|c|c|c|c|c|c|}
\hline \multirow[b]{2}{*}{ Regiões de origem } & \multicolumn{4}{|c|}{$\begin{array}{c}1^{\circ} \text { Decênio } \\
1893-1902 \\
\% \\
\end{array}$} & \multicolumn{4}{|c|}{$\begin{array}{c}2^{\circ} \text { Decênio } \\
1903-1912 \\
\% \\
\end{array}$} & \multicolumn{4}{|c|}{$\begin{array}{c}3^{\circ} \text { Decênio } \\
1913-1922 \\
\% \\
\end{array}$} \\
\hline & 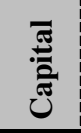 & 产 & 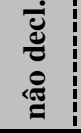 & है & שٓ & 冚 & 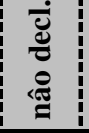 & हूँّ & 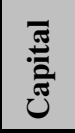 & 离 & 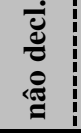 & हैँ \\
\hline Andaluz & 5,1 & 33,8 & 11,1 & 100,0 & 22,8 & 43,4 & 33,8 & 100,0 & 43,4 & 51,3 & 5,3 & 100,0 \\
\hline Galícia & 55,8 & 30,4 & 13,8 & 100,0 & 23,6 & 28,5 & 47,9 & 100,0 & 52,8 & 40,3 & 6,9 & 100,0 \\
\hline $\begin{array}{l}\text { Castilla - Léon } \\
\text { Demais Regiões }\end{array}$ & 51,2 & 37,8 & 11,0 & 100,0 & 25,6 & 37,1 & 37,3 & 100,0 & 46,5 & 48,7 & 4,8 & 100,0 \\
\hline Aragon & 90,0 & 10,0 & & 100,0 & 47,9 & 22,5 & 29,6 & 100,0 & 60,0 & 34,5 & 5,5 & 100,0 \\
\hline Astúrias & 69,2 & 23,1 & 7,7 & 100,0 & 40,0 & 26,7 & 33,3 & 100,0 & 68,3 & 24,4 & 7,3 & 100,0 \\
\hline Baleares & 33,3 & & 66,7 & 100,0 & 38,5 & 23,1 & 38,4 & 100,0 & 71,0 & 12,9 & 16,1 & 100,0 \\
\hline Caná & 66,7 & 20,8 & 12,5 & 100,0 & 3,8 & 50,0 & 46,2 & 100,0 & 46,2 & 53,8 & & 100,0 \\
\hline Cantábria & 50,0 & 25,0 & 25,0 & 100,0 & 60,0 & 40,0 & & 100,0 & 73,7 & 15,8 & 10,5 & 100,0 \\
\hline Castil & 53,8 & 46,2 & & 100,0 & 21,4 & 38,1 & 40,5 & 100,0 & 32,7 & 60,2 & 7,1 & 100,0 \\
\hline Catalunha & 64,3 & 15,5 & 20,2 & 100,0 & 54,2 & 10,8 & 35,0 & 100,0 & 76,4 & 19,3 & 4,3 & 100,0 \\
\hline Extrer & 33,4 & 33,3 & 33,3 & 100,0 & 39,0 & 39,0 & 22,0 & $\begin{array}{l}100,0 \\
\end{array}$ & 39,6 & 54,7 & 5,7 & 100,0 \\
\hline Madrid & 65,2 & 4,4 & 30,4 & 100,0 & 50,0 & 16,7 & 33,3 & 100,0 & 77,1 & 16,9 & 6,0 & 100,0 \\
\hline Murcia & 75,0 & 25,0 & & 100,0 & 23,5 & 36,7 & 39,8 & 100,0 & 39,7 & 57,0 & 3,3 & 100,0 \\
\hline Navarra & 68,8 & 18,7 & 12,5 & 100,0 & 38,6 & 35,7 & 25,7 & 100,0 & 62,3 & 33,0 & 4,7 & 100,0 \\
\hline País Basco & 68,6 & 5,7 & 25,7 & 100,0 & 58,3 & 27,8 & 13,9 & 100,0 & 85,0 & 9,2 & 5,8 & 100,0 \\
\hline Rioja & 33,4 & 33,3 & 33,3 & 100,0 & 22,7 & 40,9 & 36,4 & 100,0 & 54,3 & 43,8 & 1,9 & 100,0 \\
\hline Valenc & 64,0 & 16,0 & 20,0 & 100,0 & 29,0 & 24,6 & 46,4 & 100,0 & 57,0 & 35,7 & 7,3 & 100,0 \\
\hline Outras/não declaradas & 62,5 & 12,5 & 25,0 & 100,0 & 43,3 & 26,7 & 30,0 & 100,0 & 54,2 & 38,5 & 7,3 & 100,0 \\
\hline
\end{tabular}


Contudo, e retornemos agora para a questão envolvendo a distribuição desse contingente, era imperativo o estabelecimento de um percentual comportando a cidade de São Paulo, melhor dizendo, um índice através do qual, comparativamente àqueles globais apresentados para o Estado no período, se pudesse destacar os pertencentes à Capital. Desse modo, computando-se os registros nos quais a informação de domicílio foi informada, pudemos constatar que era, ainda assim, a mesma corrente, representativa das três regiões (Andaluzia, Galícia e Castilla-León), a que se apresentaria, para a Capital como hegemônica diante das demais. Mais que isso: observamos que, com pequenas oscilações, essa corrente apresentaria, em sua distribuição percentual, índices muito próximos aos desempenhados para o Estado de São Paulo, performance que resultou, desse modo, na liderança exercida pela corrente procedente da Andaluzia, que se fez representar com larga vantagem sobre as demais, em todo o período examinado, ainda que levemos em conta tão-somente as outras duas correntes com as quais compôs o grosso do contingente estabelecido.

$\mathrm{Na}$ Tabela 4, abaixo, procuramos destacar a participação percentual desse grupo predominante, distribuindo-o por decênios, para a Capital de São Paulo, em comparação aos índices apresentados pelas correntes das demais Regiões de origem.

Tabela 4. São Paulo (Capital) - Distribuição percentual dos imigrantes espanhóis por Regiões, 1893-1922, por decênios (destaque para as três principais regiões)

\begin{tabular}{lccc}
\hline \hline \multicolumn{1}{|c}{ Principais Regiões de Origem } & $\begin{array}{c}\mathbf{1}^{\mathbf{0}} \text { Decênio } \\
\mathbf{1 8 9 3 - 1 9 0 2} \\
\mathbf{\%}\end{array}$ & $\begin{array}{c}\mathbf{2}^{\mathbf{0}} \text { Decênio } \\
\mathbf{1 9 0 3 - 1 9 1 2} \\
\mathbf{\%}\end{array}$ & $\begin{array}{c}\mathbf{3}^{\mathbf{0}} \text { Decênio } \\
\mathbf{1 9 1 3 - 1 9 2 2} \\
\mathbf{\%}\end{array}$ \\
\hline \hline & & & \\
Andaluzia & 42,0 & 46,4 & 46,9 \\
Galícia & 22,1 & 13,2 & 11,9 \\
Castilla - Léon & 9,4 & 12,0 & 10,6 \\
$\quad$ Subtotal & $\mathbf{7 3 , 5}$ & $\mathbf{7 1 , 6}$ & $\mathbf{6 9 , 4}$ \\
$\quad$ Demais Regiões & 26,5 & 28,4 & 30,6 \\
\hline \multicolumn{1}{l}{ Total } & $\mathbf{1 0 0 , 0}$ & $\mathbf{1 0 0 , 0}$ & $\mathbf{1 0 0 , 0}$ \\
\hline \hline
\end{tabular}

Por outro lado, quando confrontamos a distribuição percentual do contingente oriundo de algumas Regiões espanholas pelo Interior e pela Capital de São Paulo - levando-se em conta especialmente o primeiro e o terceiro decênio, pela questão antes apontada - é notório o desequilíbrio apresentado por alguns deles, cuja variação percentual pode indicar perfis distintos daquele expresso pelas três correntes majoritárias, os quais, na divisão, apresentaram-se mais equiitativamente. 
Notamos, em suma, fluxos emigratórios atraídos fortemente para as cidades, revelando índices de fixação bastante elevados na Capital de São Paulo, tendência que pôde ser identificada nos casos de Astúrias, no das Canárias, no de Cantábria, mas especialmente no caso de Madrid, conforme evidenciado pela Tabela 3.

Contudo, e em que pese esse diagnóstico que mereceria um estudo particularizado que excederia os propósitos desse trabalho, é indiscutível a predominância do elemento andaluz na Capital de São Paulo e, considerada a hegemonia desse elemento no conjunto do período examinado, a proveniência desse caudal pôde ser mapeada como originária principalmente de três Províncias.

Em primeiro lugar, aparecendo como a principal Província de origem dos fluxos aqui localizados e somando $14 \%$ do total dos habitantes da cidade no período total examinado, destacou-se a Província de Granada, a que se seguiram duas outras, as Províncias de Almeria e Málaga, com $11 \%$ e 10\%, respectivamente. Em outras palavras, essas três Províncias foram as responsáveis por $34 \%$ do total de andaluzes fixado na Capital, no conjunto do período analisado. Se, contudo, acrescentarmos a elas as demais Províncias que compõem a Região andaluza, alcançaremos o expressivo montante de aproximadamente $45 \%$ do total de espanhóis que se declarou domiciliado na Capital de São Paulo no período.

Em Málaga, cidade portuária da Andaluzia e porto de saída da maioria do contingente que se destinou a São Paulo, o governo brasileiro instalou, em 1896, um Escritório Oficial de Inspeção, cujos comissários, se encarregando da triagem dos candidatos, cuidavam para que não fossem (ainda mais) ludibriados pelos agentes contratadores ou ganchos $^{87}$, desembolsando uma quantia a maior do que a diferença entre o custo da passagem cobrada pelas Companhias de Navegação, então de 50 francos, e o subsídio recebido pelo imigrante.

No período considerado, portanto, quer em números percentuais ou absolutos, pode-se atribuir à Região da Andaluzia o caudal que, com supremacia, passa a habitar na Paulicéia, região que, também em maioria, exercerá uma segunda hegemonia, como a de origem do maior percentual que se declarou jornalero na totalidade do período examinado ${ }^{88}$.

${ }^{87}$ Eram assim denominados os agentes de emigração, contratados pelas companhias de navegação ou pelos próprios governos dos países receptores que, percorrendo os pueblos, tentavam persuadir as pessoas do campo das vantagens da emigração, além de facilitar-lhes os trâmites para a obtenção da documentação e até mesmo a sua falsificação. Muitos encareciam os preços das passagens e outros ainda ofereciam empréstimos com juros elevados, pelos quais sugeriam a hipoteca de alguns bens a seu favor. Atuavam como ganchos secretários das prefeituras e juizes locais, farmacêuticos, comerciantes e até párocos, ou qualquer indivíduo que fosse bem relacionado. Muitos eram proprietários das pensões próximas aos portos de embarque. Cf. CÁNOVAS, M. Op. cit., 2001, pp. 141 e ss.

${ }^{88}$ Procedendo, em seu conjunto, de outras tantas Regiões espanholas, observamos alguns casos de jornaleros que se declaravam procedentes até mesmo da Argélia. Praticava-se para a Argélia, então colônia francesa, 
Este aspecto pode ser observado por meio dos dados da Tabela 5, abaixo, pela qual traçamos a evolução percentual desse contingente para a Capital, destacando as três principais Regiões de origem, mas também, como informação adicional, apontando a sua representatividade percentual no Interior do Estado.

Tabela 5. São Paulo (Capital e Interior)

Jornaleros: principais Regiões de origem, por decênios - \%

\begin{tabular}{lcccccc}
\hline \hline \multirow{2}{*}{ Regiões } & \multicolumn{2}{c}{$\mathbf{1 8 9 3 - 1 9 0 2}$} & \multicolumn{2}{c}{$\mathbf{1 9 0 3 - 1 9 1 2}$} & \multicolumn{2}{c}{$\mathbf{1 9 1 3 - 1 9 2 2}$} \\
& Capital & Interior & Capital & Interior & Capital & Interior \\
\hline Andaluzia & 41,5 & 56,7 & 57,7 & 64,8 & 51,9 & 54,1 \\
Galícia & 26,9 & 22,2 & 10,4 & 9,9 & 11,8 & 8,7 \\
Castilla-Léon & 11,1 & 15,6 & 9,6 & 11,6 & 9,5 & 10,3 \\
$\quad$ Subtotal & $\mathbf{7 9 , 5}$ & $\mathbf{9 4 , 5}$ & $\mathbf{7 7 , 7}$ & $\mathbf{8 6 , 3}$ & $\mathbf{7 3 , 2}$ & $\mathbf{7 3 , 1}$ \\
Demais Regiões & 20,5 & 5,5 & 22,3 & 13,7 & 26,8 & 26,9 \\
\hline Total & $\mathbf{1 0 0 , 0}$ & $\mathbf{1 0 0 , 0}$ & $\mathbf{1 0 0 , 0}$ & $\mathbf{1 0 0 , 0}$ & $\mathbf{1 0 0 , 0}$ & $\mathbf{1 0 0 , 0}$ \\
\hline \hline
\end{tabular}

Historicamente, a Andaluzia é considerada como a responsável pelo maior contingente de famílias enviadas para o colonato, conforme demonstramos em nossa Dissertação de Mestrado $^{89}$. Desta forma, não deixa de ser instigante que essa Região apareça, desde a primeira década aqui considerada, cujos anos, iniciando-se em 1893 antecederam a chegada das grandes levas originárias daquele país, como também a de proveniência da maioria dos emigrantes então vivendo na cidade e, detalhe adicional, já se fazendo representar por importante contingente de jornaleros. Com efeito, na primeira década, do contingente total emigrado daquela região, 1/4 apresentou-se como jornalero e, destes, a metade provinha de Málaga. Contudo, já para a segunda década, essa cifra sofre um aumento extraordinário passando a representar aproximadamente $3 / 4$ do contingente total, número este que tendeu a se estabilizar, com pequeno declínio para a terceira década.

Esse dado, demonstrando um brutal acréscimo da categoria jornalero na Capital, do primeiro para o segundo decênio, poderia indicar que essa corrente tenha sido, em grande parte, beneficiária da política imigratória de subsídios e que, portanto, parcela desse contingente realizara uma passagem prévia pelo colonato. Observaremos, contudo, que outras variáveis vêem ao encontro dessa premissa, reforçando-a.

a denominada emigração golondrina, ou andorinha, emigração sazonal com saídas e retornos determinados pelo calendário agrícola. Em finais do século XIX, do total emigrado, em média 20\% se dirigiam à Argélia. O declínio do fluxo pode ser atribuído às insurreições dos nativos, a partir das quais cresce o interesse por novos destinos, como a América; já em 1912, essa cifra havia baixado para $11,6 \%$.

${ }^{89}$ Ver a esse respeito: CÁNOVAS, M. Op. cit.,2001, especialmente Cap. II, pp. 77 e ss. 
Depois dos andaluzes, se bem que em parâmetros bastante inferiores, localizamos a Galícia, Região ao norte da Península, como a responsável pela segunda maior corrente que desembarcou no Estado de São Paulo (vide Tabela 2). Porém, em processo distinto ao andaluz - que se manteve praticamente com o mesmo patamar no período, apresentando variação irrelevante nas três décadas examinadas - o galego protagonizará um percurso de declínio com relação ao montante global ingressado na Capital (e também no Interior) conforme ficou explicitado na Tabela 4, pela qual demonstramos que a representatividade dos fluxos da Galícia se apresentará em declínio a partir da segunda década, passando de 22,1\% para 13,2\%.

Na Região galega, duas localidades de pronto se destacaram como a origem prioritária do contingente que passou a fixar-se na Paulicéia: Orense em primeiro lugar, seguida de Pontevedra $^{90}$, províncias que, juntas, perfizeram $11 \%$ do total de imigrantes ingressados na Capital, considerado o período total analisado. Com relação ao contingente de jornaleros originários da Galícia, verificamos que da cifra inicialmente alta apresentada para o primeiro decênio (26,9\%), constante da Tabela 5, houve um acentuado declínio já para o segundo decênio analisado (10,4\%), com pequena oscilação a maior para o terceiro $(11,8 \%)$. As cidades prioritárias de origem desses jornaleros provenientes da Galícia, coincidentemente, também foram Pontevedra e Orense, porém nesse caso Pontevedra destacou-se, apresentando o dobro da cifra pertencente a Orense (28 e $56 \%$ respectivamente $)^{91}$.

Quanto à terceira maior corrente estabelecida na Capital de São Paulo, originária de Castilla-León, pudemos observar que seus índices mantiveram um patamar mais estável quando comparados ao dos galegos no período e, diferentemente daqueles, apresentaram um acréscimo do primeiro para o segundo decênio (de 9,4\% para 12\%). Nesta Região, três províncias sairão na dianteira das demais, encabeçadas por Salamanca, à qual se seguiram León e Zamora, totalizando um percentual de 9,6\% do conjunto de espanhóis ingressados na Capital, no período. Na análise de seus percentuais para jornalero verificamos que houve pequena tendência à queda, quando analisados os três decênios (11,1; 9,6 e 9,5\% respectivamente).

Apenas como dado informativo, convém destacar a representatividade da corrente andaluza, não apenas na Capital, conforme já evidenciamos, mas também no Interior. Os dados da Tabela 5 são eloqüentes, demonstrando que do total de jornaleros estabelecidos nas localidades do Interior do Estado de São Paulo, importante parcela compunha-se de andaluzes.

${ }^{90}$ A respeito do perfil regional do galego no Brasil, $c f$. EIRAS ROEL, Antonio y REY CASTELAO, Ofelia. Los gallegos y América. Madrid: Editorial Mapfre, 1992, especialmente pp. 258 e ss.

${ }^{91}$ As demais Províncias galegas apresentaram o seguinte índice: Coruña, com 13\% e Lugo com 3\%. 
Na segunda década, por exemplo, a região alcançaria sozinha o expressivo percentual de $64,8 \%$ do total da categoria.

Partindo, assim, desses parâmetros iniciais com respeito à origem dessa população, procuramos avançar no exame das características desse contingente. Seu leque de ocupaciones diversificara-se e se ampliara, é fato, acompanhando o ritmo da Paulicéia, conforme demonstramos no Quadro 4. Porém, esse aspecto, o da multiplicidade de atividades em segmentos diversificados não dissimulava uma realidade que tenderia a se impor: o progressivo e vertiginoso acréscimo nos índices de jornaleros na cidade, categoria de caráter emblemático que, especialmente na segunda década viu dobrarem seus índices até finalmente atingir $62 \%$ do universo considerado.

Esses jornaleros, categoria formada por $98 \%$ de indivíduos do sexo masculino, apresentaram-se no período, do ponto de vista do estado civil, com uma maioria de $61,7 \%$ de casados, para 34,4\% de solteiros e 3,3\% de viúvos, com pequeno percentual não informado.

Este dado demonstrando que neste momento a cidade acolhia um percentual expressivo e crescente de população emigrada declarando-se jornalera, composta de alto percentual de casados - indício de sua provável constituição em famílias, requisito este, aliás, essencial para a obtenção da passagem subsidiada dentro da política oficial de captação de braços para a lavoura -, reforça a suposição de sua passagem inicial pelo núcleo cafeeiro, de onde teriam marchado em direção à cidade.

Há ainda outros elementos que podem corroborar essa premissa, e um deles diz respeito ao exame da classe de embarque declarada nos registros, cuja análise revelou que, no período, a maior parte dos inscritos que informou esse dado, foi usuário de categorias inferiores, destinadas ao transporte de imigrantes, ou seja, 27,7\% haviam embarcado de $3^{a}$ classe, $57 \%$ de $4^{a}$ classe e $14,5 \%$ disseram ter embarcado grátis, restando, em outras palavras, menos de $1 \%$ para as demais categorias ${ }^{92}$.

Outro forte indício é revelado pela documentação, melhor dizendo, pela ausência de qualquer documento que identificasse o declarante perante o escrevente no CGE. Na primeira década, por exemplo, do total registrado, $66,5 \%$ não portavam qualquer documento, fato que se evidenciou por meio de anotações adicionais feitas aos registros, nas quais o escrevente os complementava denegando a sua apresentação: s/conocimiento; s/cédula; s/documentos; s/pasaporte, eram as rubricas empregadas para formalizar o lapso. Nesses casos, utilizava-se o

\footnotetext{
${ }^{92}$ Os passageiros de 3 a classe eram considerados "imigrantes" pelas disposições do Decreto 2400, de 9 de julho de 1913. São Paulo: Typografia do Diário Oficial, 1913. Quanto à $4^{\mathrm{a}}$ classe, não conseguimos obter qualquer informação; porém imaginamos que se tratasse de uma categoria inferior à $3^{\mathrm{a}}$.
} 
expediente da apresentação, que pressupunha uma testemunha, indivíduo que acompanhava o declarante, "apresentando-o", ou seja, responsabilizando-se por ele perante o CGE. Com uma maior familiaridade adquirida pelo manuseio dos dados, gradualmente passamos a reconhecer nominalmente alguns desses indivíduos, os quais, em alguns casos, eram representantes de camadas mais prósperas ou eram indivíduos com certa posição social na colônia. É provável que alguns deles fossem os próprios empregadores desses elementos, contudo, essa condição a de não-portador de qualquer documento - mais do que evidenciar a sua vinculação à política imigratória de subsídios, é altamente sugestiva da probabilidade de esses indivíduos terem embarcado clandestinamente por Gibraltar, e, muito provavelmente, com documentação falsificada.

O fenômeno do refluxo dos imigrantes que do interior marchavam para as cidades, de tão eloqüiente e trivial, não passou desapercebido nem mesmo do discurso literário. No registro de passagens como a que abaixo transcrevemos, da descrição de um episódio da vida cotidiana de um desses egressos da "roça", enseja-se a oportunidade para se pensar, por um lado, como esse sujeito era percebido na cidade e, por outro, como reagia e se municiava de astuciosos subterfúgios no contato com ela, com os espanhóis de outras regiões (no caso, galegos) e com a maioria "carcamana" hegemônica:

O bonde parou [...]. Ramirez distraiu-se, para, logo depois, constatar que já polemizavam sobre futebol. Chegou ao cortiço onde morava. Criou alento quando os moradores lhe informaram que havia vaga para trabalho em muitas fábricas [...] "não diga que veio da roça porque lhe pagarão muito mal, se é que o colocam... E outra! Você é espanhol. Não se meta em briga de galego com carcamano por causa de Santo Antonio ou de São Roque" ${ }^{, 93}$.

Desse modo e mesmo desconsiderando uma possível vinculação da política oficial imigratória que tinha na constituição em famílias nucleares um requisito para a subvenção da passagem era, ainda assim e também, a Andaluzia que se apresentava como a região de procedência do grosso dessa massa emigrante e, se os registros analisados sinalizam uma provável passagem prévia pelo núcleo cafeicultor de parcela considerável desse contingente, outros indicadores oferecem-se na identificação de outros perfis que, aparentemente, não estiveram submetidos à trajetória que marcou o grosso desse contingente. Estamos, por certo, nos referindo ao percentual que escapou a essa determinação, representado pelos diversos segmentos inventariados no CGE aos quais atribuímos a denominação genérica de "outras ocupações", cuja evolução procuramos traçar por meio dos dados apresentados nos Quadros de

\footnotetext{
${ }^{93}$ MAFFEI, Eduardo. A greve. São Paulo: Paz e Terra, 1978, p. 36, discorrendo sobre Ramirez, espanhol de Barcelona, viúvo e com uma filha de dias, recém-chegado do interior.
} 
$\mathrm{n}^{\circ} \mathrm{s} 2$ a 4. Trata-se de categorias claramente vinculadas ao florescente parque industrial, ao emergente setor de serviços e às profissões liberais, e, concretamente, a indivíduos que, na Paulicéia protagonizariam uma trajetória diferenciada da imensa massa de jornaleros.

Desenhando um percentual inicial de 39,2\% do total ingressado de homens e mulheres, para os 30 anos examinados, observamos que, na composição desta rubrica (não-jornaleros), 16,4\% referiam-se à ocupação sus labores (dona de casa), que se constituiu em $84 \%$ do universo feminino examinado; destas, $64 \%$ eram casadas, $22 \%$ solteiras e $14 \%$ viúvas. Integrando o restante das ocupações femininas, temos $6 \%$ para jornaleras, $5 \%$ para outras ocupações e 5\% sem ocupação declarada. Dessa forma, o percentual restante, $22,8 \%$, se compôs quase que exclusivamente por elementos do sexo masculino, disseminados, como vimos, em ocupações diversas (vide Quadro 2). Destes, 51\% eram casados e $45 \%$ eram solteiros.

Considerada, entretanto, em seu conjunto, a categoria aqui designada como outras ocupações - cujo percurso, indicando a ocorrência de uma retração quando cotejada com a categoria jornalero -, repetiu a tendência antes observada com relação à proveniência dos maiores contingentes fixados na Capital de São Paulo, e na mesma escala. Desse modo, observamos que Andaluzia, Galícia e Castilla-León se farão representar novamente como as três principais regiões, conforme indicamos na Tabela 6, pela qual apresentamos a sua distribuição percentual, por decênio, para a Capital e Interior, esta última apenas para informação.

Nessa Tabela preferimos manter a composição integral da categoria, contemplando inclusive o universo feminino, uma vez que, conforme procuraremos demonstrar, a categoria sus labores, incluiria casos de trabalho domiciliar. Como dado complementar, esta categoria compareceu, na Capital de São Paulo, no período de 30 anos, com um percentual médio de $42 \%$ do total de outras ocupaciones. Em outras palavras, destacando-se, por exemplo, o percentual de 71,5\% referido às três principais proveniências dos elementos que compuseram essa rubrica, no primeiro decênio, para a Capital, verificamos que 30\% constituíam-se de sus labores. Se, contudo, desdobrarmos a participação percentual da categoria sus labores por Regiões de origem, observaremos que, das três regiões principais, a Andaluzia se apresentará com o maior percentual (52\%), seguida por Castilla-León (35\%) e Galícia (26\%), revelando, também aqui, a hegemonia da Andaluzia. Em outras palavras, caberia também a ela a responsabilidade pela manutenção do elevado índice médio observado (42\%), para a categoria, no período total. 
Tabela 6. São Paulo (Capital e Interior)

Outras Ocupaciones: principais Regiões de origem, por decênios - \%

\begin{tabular}{lcccccc}
\hline \hline \multirow{2}{*}{ Regiões } & \multicolumn{2}{c}{$\mathbf{1 8 9 3 - 1 9 0 2}$} & \multicolumn{2}{c}{$\mathbf{1 9 0 3 - 1 9 1 2}$} & \multicolumn{2}{c}{$\mathbf{1 9 1 3 - 1 9 2 2}$} \\
& Capital & Interior & Capital & Interior & Capital & Interior \\
\hline Andaluzia & 42,0 & 48,9 & 29,1 & 43,6 & 38,1 & 44,5 \\
Galícia & 20,8 & 22,7 & 17,1 & 13,9 & 12,5 & 9,8 \\
Castilla-León & 8,7 & 12,1 & 16,5 & 16,4 & 12,4 & 12,2 \\
$\quad$ Subtotal & $\mathbf{7 1 , 5}$ & $\mathbf{8 3 , 7}$ & $\mathbf{6 2 , 7}$ & $\mathbf{7 3 , 9}$ & $\mathbf{6 3 , 0}$ & $\mathbf{6 6 , 5}$ \\
Outras Regiões & 28,5 & 16,3 & 37,3 & 26,1 & 37,0 & 33,5 \\
\hline Total & $\mathbf{1 0 0 , 0}$ & $\mathbf{1 0 0 , 0}$ & $\mathbf{1 0 0 , 0}$ & $\mathbf{1 0 0 , 0}$ & $\mathbf{1 0 0 , 0}$ & $\mathbf{1 0 0 , 0}$ \\
\hline \hline
\end{tabular}

Analisando os dados da Tabela acima, notadamente para a Capital, fica nítido o desempenho diferenciado de cada uma das três principais Regiões. No caso da Andaluzia, verificamos que, do seu alto percentual inicial (42\%, no primeiro decênio), após um decréscimo também acentuado no segundo decênio $(29,1 \%)$, há uma quase retomada da posição inicial (38\%) para o terceiro decênio. Já a Galícia, como se pode observar, apresentou uma performance decrescente no período: seu índice inicial de $21 \%$, após a queda manifestada no segundo decênio (17\%) se apresentará, no terceiro, com apenas 13\%. Quanto a Castilla-León, seu pequeno percentual inicial (8\%) sofreu forte impulsão no segundo decênio (16\%), apresentando queda no terceiro, estabilizando-se em $12 \%$.

Em síntese, para configurar a atuação das três principais Regiões de origem, procuramos exibir, por meio de Tabelas, os índices individuais representados por cada uma de suas Províncias. Essas Tabelas (de nº 7, 8 e 9) pretendem demonstrar, para a Capital de São Paulo, a representatividade de cada uma delas, em cada decênio, consideradas as categorias jornalero e outras ocupações. Duas análises estão implicitadas nestas Tabelas. A primeira busca recompor a participação percentual de cada Província no tocante à sua Região específica no que concerne às categorias jornalero e outras ocupações. A segunda análise nos permite observar a distribuição percentual de cada Província para cada uma das categorias analisadas. Esses dados, apresentados entre parêntesis, devem ser analisados de forma horizontal.

Iniciando-se pela região andaluza, a análise da distribuição percentual interna, ou seja, das suas oito Províncias, indica, para o primeiro decênio, quando comparadas as duas categorias, uma participação irrelevante para o jornalero. Essa década apresentou, conforme se evidencia, elevados índices de indivíduos compondo outras categorias laborais, tendo apresentando inclusive duas Províncias - Córdoba e Huelva - nas quais não foram computados casos de jornaleros. No entanto, quando evoluímos para as décadas seguintes, o quadro se reverte, indicando crescentes percentuais de jornaleros, em sua maioria provenientes de Almeria, Granada e Málaga. Esta Província, a propósito, destacou-se das demais, quando, no 
primeiro decênio, exerceu a liderança da categoria jornaleros, apresentando mais da metade do contingente emigrado daquela Região, conforme pode ser observado na Tabela 7, abaixo.

Tabela 7. São Paulo (Capital ) - Região da Andaluzia: jornaleros e outras ocupaciones. Percentual por Províncias e por decênios

\begin{tabular}{|c|c|c|c|c|c|c|c|c|c|c|c|c|}
\hline \multirow{3}{*}{ Províncias } & \multicolumn{4}{|c|}{ 1893-1902 } & \multicolumn{4}{|c|}{ 1903-1912 } & \multicolumn{4}{|c|}{ 1913-1922 } \\
\hline & \multicolumn{2}{|c|}{ Jornalero } & \multicolumn{2}{|c|}{ Outras } & \multicolumn{2}{|c|}{ Jornalero } & \multicolumn{2}{|c|}{ Outras } & \multicolumn{2}{|c|}{ Jornalero } & \multicolumn{2}{|c|}{ Outras } \\
\hline & $\%$ & $\%$ & $\%$ & $\%$ & $\%$ & $\%$ & $\%$ & $\%$ & $\%$ & $\%$ & $\%$ & $\%$ \\
\hline Almeria & 1,4 & $(11,1)$ & 3,7 & $(88,9)$ & 29,4 & $(84,6)$ & 16,5 & $(15,4)$ & 23,7 & $(70,9)$ & 21,9 & $(29,1)$ \\
\hline Cádiz & 9,9 & $(26,9)$ & 8,7 & $(73,1)$ & 5,0 & $(88,2)$ & 2,1 & $(11,8)$ & 6,0 & $(63,9)$ & 7,7 & $(36,1)$ \\
\hline Córdoba & & & 2,7 & $(100,0)$ & 1,3 & $(50,0)$ & 4,1 & $(50,0)$ & 1,6 & $(55,3)$ & 2,8 & $(44,7)$ \\
\hline Granada & 26,8 & $(31,1)$ & 19,2 & $(68,9)$ & 26,0 & $(77,2)$ & 23,7 & $(22,8)$ & 32,5 & $(70,5)$ & 30,7 & $(29,5)$ \\
\hline Huelva & & & 2,7 & $(100,0)$ & 2,0 & $(54,5)$ & 5,2 & $(45,5)$ & 2,6 & $(65,7)$ & 3,1 & $(34,3)$ \\
\hline Jaén & 7,0 & $(33,3)$ & 4,6 & $(66,7)$ & 6,3 & $(86,4)$ & $\mathbf{3 , 0}$ & $(13,6)$ & 12,1 & $(71,5)$ & 10,8 & $(28,5)$ \\
\hline Málą & 52,1 & $(24,8)$ & 51,1 & $(75,2)$ & 20,7 & $(62,0)$ & 39,2 & $(38,0)$ & 17,6 & $(68,9)$ & 17,9 & $(31,1)$ \\
\hline Sevilla & 2,8 & $(11,1)$ & 7,3 & $(88,9)$ & 9,3 & $(82,4)$ & 6,2 & $(17,6)$ & 3,9 & $(63,5)$ & 5,1 & $(36,5)$ \\
\hline & 100,0 & & 100,0 & & 100,0 & & 100,0 & & 100,0 & & 100,0 & \\
\hline
\end{tabular}

A Galícia, origem do segundo maior percentual que se instalará na Paulicéia, apresentou-se, nesse período, com uma movimentação mais linear, sem saltos bruscos como os que pudemos observar na Andaluzia, especialmente do primeiro para o segundo decênio.

Observamos, por outro lado, que algumas das quatro Províncias galegas, especialmente Pontevedra e Orense, mais particularmente esta, se fizeram representar por elevados índices de jornalero, já a partir do primeiro decênio, cuja evolução mostrou tendência crescente e linear. A Província de Coruña, por outro lado, revelará para o período o maior percentual (interno) de elementos compondo outras ocupações, apresentando índices de 80,6\% e $61 \%$ respectivamente para o primeiro e o terceiro decênios. Na Tabela 8, abaixo, apresentamos os índices correspondentes a essa Região e suas Províncias.

Tabela 8. São Paulo (Capital) - Região da Galícia: jornaleros e outras ocupaciones. Percentual por Províncias e por decênios

\begin{tabular}{|c|c|c|c|c|c|c|c|c|c|c|c|c|}
\hline \multirow{3}{*}{ Províncias } & \multicolumn{4}{|c|}{ 1893-1902 } & \multicolumn{4}{|c|}{ 1903-1912 } & \multicolumn{4}{|c|}{$1913-1922$} \\
\hline & \multicolumn{2}{|c|}{ Jornalero } & \multicolumn{2}{|c|}{ Outras } & \multicolumn{2}{|c|}{ Jornalero } & \multicolumn{2}{|c|}{ Outras } & \multicolumn{2}{|c|}{ Jornalero } & \multicolumn{2}{|c|}{ Outras } \\
\hline & $\%$ & $\%$ & $\%$ & $\%$ & $\%$ & $\%$ & $\%$ & $\%$ & $\%$ & $\%$ & $\%$ & $\%$ \\
\hline Coruña & 13,0 & $(19,4)$ & 23,1 & $(80,6)$ & 18,5 & $(52,6)$ & 15,8 & $(47,4)$ & 6,0 & $(39,0)$ & 14,8 & $(61,0)$ \\
\hline Lugo & 2,2 & $(50,0)$ & 1,0 & $(50,0)$ & 3,7 & $(28,6)$ & 8,8 & $(71,4)$ & 6,5 & $(64,1)$ & 5,7 & $(35,9)$ \\
\hline Orense & 56,5 & $(37,1)$ & 40,7 & $(62,9)$ & 37,1 & $(46,5)$ & 40,4 & $(53,5)$ & 44,2 & $(61,7)$ & 43,0 & $(38,3)$ \\
\hline Pontevedra & 28,3 & $(25,5)$ & 35,2 & $(74,5)$ & 40,7 & $(52,4)$ & 35,0 & $(47,6)$ & 43,3 & $(65,0)$ & 36,5 & $(35,0)$ \\
\hline & 100,0 & & 100,0 & & 100,0 & & 100,0 & & 100,0 & & 100,0 & \\
\hline
\end{tabular}


A terceira Região majoritária da população espanhola na Capital de São Paulo, CastillaLeón, composta de nove Províncias, a rigor foi a única em que os percentuais da categoria jornalero não ultrapassaram, em nenhum dos decênios, ao das demais ocupações. Não que não se fizesse representar por ela. Expressando índices crescentes e graduais, do primeiro ao terceiro decênio, a categoria atingirá, entretanto, a média de $48 \%$ somente neste último. As Províncias de León, Salamanca e Zamora foram as responsáveis pelos maiores índices da categoria na Capital de São Paulo. As Províncias de Burgos e Segóvia não apresentaram índices para jornaleros nos dois primeiros decênios; Soria não apresentou apenas no primeiro. Atípicos são os casos de Ávila e Palencia. Esta apresentará movimentação apenas a partir do segundo decênio, para outras ocupações, com pequena taxa (3,6\%). Já Ávila, registrará índices somente no terceiro decênio, revelando alta taxa de jornaleros (69,8\%). Na Tabela 9, abaixo, essa composição regional fica evidenciada.

Tabela 9. São Paulo (Capital) - Região de Castilla-León: jornaleros e outras ocupaciones . Percentual por Províncias e por decênios

\begin{tabular}{|c|c|c|c|c|c|c|c|c|c|c|c|c|}
\hline \multirow{3}{*}{ Províncias } & \multicolumn{4}{|c|}{ 1893-1902 } & \multicolumn{4}{|c|}{ 1903-1912 } & \multicolumn{4}{|c|}{ 1913-1922 } \\
\hline & \multirow{2}{*}{\multicolumn{2}{|c|}{$\begin{array}{l}\text { Jornalero } \\
\%\end{array}$}} & \multicolumn{2}{|c|}{ Outras } & \multicolumn{2}{|c|}{ Jornalero } & \multicolumn{2}{|c|}{ Outras } & \multicolumn{2}{|c|}{ Jornalero } & \multicolumn{2}{|c|}{ Outras } \\
\hline & & & $\%$ & $\%$ & $\%$ & & $\%$ & $\%$ & $\%$ & & $\%$ & $\%$ \\
\hline Ávila & & & & & & & & & 9,8 & $(69,8)$ & 5,4 & $(30,2)$ \\
\hline Burgos & & & 6,6 & $(100,0)$ & & & 12,7 & $(100,0)$ & 6,5 & $(39,2)$ & 12,8 & $(60,8)$ \\
\hline León & 47,4 & $(37,5)$ & 33,3 & $(62,5)$ & 24,0 & $(54,5)$ & 18,2 & $(45,5)$ & 30,9 & $(62,5)$ & 23,6 & $(37,5)$ \\
\hline Palencia & & & & & & & 3,6 & $(100,0)$ & 0,7 & $(16,7)$ & 4,1 & $(83,3)$ \\
\hline Salamanca & 21,0 & $(20,0)$ & 35,6 & $(80,0)$ & 50,0 & $(62,5)$ & 27,3 & $(37,5)$ & 30,9 & $(62,5)$ & 23,6 & $(37,5)$ \\
\hline Segovia & & & 2,3 & $(100,0)$ & & & 5,5 & $(100,0)$ & 0,3 & $(33,3)$ & 0,8 & $(66,7)$ \\
\hline Soria & & & 2,3 & $(100,0)$ & 4,0 & $(22,2)$ & 12,7 & $(77,8)$ & 2,9 & $(56,2)$ & 2,9 & $(43,8)$ \\
\hline Valladolid & 5,3 & $(25,0)$ & 6,6 & $(75,0)$ & 14,0 & $(70,0)$ & 5,5 & $(30,0)$ & 8,2 & $(49,0)$ & 10,7 & $(51,0)$ \\
\hline Zamora & 26,3 & $(45,5)$ & 13,3 & $(54,5)$ & 8,0 & $(33,4)$ & 14,5 & $(66,6)$ & 9,8 & $(43,5)$ & 16,1 & $(56,5)$ \\
\hline & 100,0 & & 100,0 & & 100,0 & & 100,0 & & 100,0 & & 100,0 & \\
\hline
\end{tabular}

É imperioso reiterar a importância do aluvião representado pela corrente andaluza na Capital de São Paulo que, conforme demonstramos, se fará representar, proporcionalmente às demais - e até mesmo diante das correntes provenientes da Galícia e de Castilla-León que a secundaram no período -, em todos os âmbitos laborais considerados, como hegemônica.

Em algumas dessas categorias, sua presença pôde ser notada de imediato, i.é, a partir da primeira década examinada. É o caso da atividade de negociante. Essa categoria, conforme comprovamos depois, pela análise evolutiva de algumas trajetórias pessoais que pudemos acompanhar por meio dos registros duplicados, foi declarada indiscriminadamente, por vezes sendo substituída pela de "comerciante". Na prática, queremos crer que essas rubricas se confundissem, podendo designar, sem distinção, o dono de um “negócio", de varejo ou atacado. 
Porém, não descartamos a hipótese de que nela pudessem estar representados elementos que "negociavam", sem ter, necessariamente, seu negócio de porta aberta ${ }^{94}$. Encabeçada por andaluzes que mantiveram o domínio da categoria no período total abrangido pela pesquisa com $34 \%$ do total, no decorrer do período a ela foram se agregando os galegos que atingiriam um percentual de $25 \%$, seguidos de perto pelos castilha-leoneses, representando $22 \%$ do total. Uma pequeno percentual pôde ser verificado para os catalães, que se apresentaram, então, com $7 \%$.

Categoria análoga, se levarmos em conta as ocorrências de registros com ambigüidade de sentidos, também as categorias comercio/comerciante/p.comerciante passariam à hegemonia dos andaluzes. Inicialmente dominadas por um percentual comparativamente maior de galegos - na primeira década, com 55\% -, pudemos constatar eficiente reação andaluza no levantamento realizado para o período total analisado: com efeito, quando observados os 30 anos de que se compõe a pesquisa, a Andaluzia despontará em primeiro lugar, detendo $28 \%$ dos registros correspondentes, deixando atrás de si Castilla-León, então na segunda colocação (25\%) e os galegos, já agora em terceiro lugar, com 23\%. Novamente aqui a Catalunha aparecia em quarta posição, como a procedência de $9 \%$ dos inscritos declarados.

Em outras palavras, era também da Andaluzia que procedia a maioria dos indivíduos que se declararam com algum negócio ou comércio na cidade, embora esse diagnóstico não estime a natureza e o porte desses empreendimentos. Essa impossibilidade, contudo, não impediu o acompanhamento que operamos a algumas "carreiras" pessoais no ramo dos negócios, especialmente naquelas vinculadas ao comércio, que revelarão, no período, o despontar de três personagens cujas origens, por sincronia, apresentaram-se representativas das três procedências majoritárias do espanhol que viveu na cidade nessas três décadas.

Estamos falando de Aparício Martí, andaluz de Córdoba, prestigiado cerealista da Rua Paula Souza e fundador do Centro Espanol (CE); do galego de Orense, destacado cerealista estabelecido na Rua Santa Rosa, dono de Casa Importadora e fundador do Centro Galego (CG), Perfecto Ares, e do zamorense (Castilla-León) Raimundo Díez, conceituado comerciante e dono de Casa Importadora, sócio-fundador da Sociedade Espanhola de Socorros Mútuos e Instrução (SESM) com Eiras Garcia.

Contudo, se nos negócios e no comércio é que se revelaram as três figuras de maior destaque no período, uma outra parcela da população (não jornalera) já se fazia notar em outras

${ }^{94}$ A esse respeito, consultar: BORGES, Maria Urquiza. Negociantes da cidade de São Paulo, 1875-1880. São Paulo: Dissertação de mestrado. FFLCH-USP, 1979, p.40. 
ocupaciones, no caso, em pequenos ofícios. Estamos nos referindo, por exemplo, ao ofício de zapatero, também praticado sob a hegemonia andaluza (81\%) e que, por sua expressão no período, merecerá um destaque especial neste trabalho.

Em mais dois importantes ofícios os andaluzes se sobressairão: no de carpintero e albañil (pedreiro), nos quais ocuparão percentuais da ordem de 40 e $43 \%$ respectivamente, seguidos pelos galegos com 31 e $27 \%$, e cuja análise também buscamos recuperar, por sua representatividade no cômputo geral.

No período, divisamos apenas uma categoria, se é que assim a podemos chamar, que escaparia à hegemonia andaluza - e, porque não, também da galega que, em muitos casos a ameaçou seriamente. Trata-se do jogo da pelota, esporte típico do País Basco e que seria praticado pelos pelotaris, categoria que figurou no período também com grandes índices.

Esse esporte se difundiria na cidade, não apenas entre os imigrantes, e era praticada no Frontão Boa Vista. Os pelotaris eram rapazes jovens e solteiros, na faixa dos 22 anos, quase exclusivamente vindos de Guipuzcoa e Vizcaya.

Em suma, de qualquer ângulo que se divise, salta aos olhos a presença na Paulicéia do elemento originário da Andaluzia, secundado pelo oriundo da Galícia. A passagem prévia de parte considerável desse contingente, especialmente do elemento andaluz, pelo colonato parece inequívoca, instigando-nos a pensar em como esse contingente majoritário, composto gradualmente por jornaleros e sem qualquer familiarização com a vida urbana, que deixou seu país para tentar a sorte no outro lado do oceano, na lavoura de café, e que dali foi impelido a trasladar-se para a cidade de São Paulo, como uma segunda alternativa, reagia ao se defrontar com o seu gigantismo e com a infinidade de papéis que lhe eram requeridos. 


\subsection{O incessante deslocamento em busca de trabalho}

Em rápida apreciação na Introdução desse trabalho comentamos a respeito de um aspecto que foi indissociável ao itinerário de boa parte desses indivíduos, a contínua mobilidade e a constante itinerância a que obstinadamente se submetiam, em busca de trabalho e melhores condições de sobrevivência. Ora se deslocando de fazenda em fazenda, ora se movendo em direção às cidades que surgiam no rastro do café, ou buscando a Paulicéia que, tentadora, os seduzia acenando com inúmeras oportunidades, ou mesmo se dirigindo para outros países como a Argentina e o Uruguai, o certo é que esse aspecto crônico foi inseparável da trajetória desses sujeitos, nesse dado período.

A questão que se coloca ao historiador é como percebê-lo, já que, em sua maioria, esse transitar incessante não deixava rastro - dado este denso de significados, conforme quisemos demonstrar nos elevados índices dos sem domicílio - tornando o fenômeno praticamente imperceptível do ponto de vista documental. Informes da Secretaria da Agricultura baseados na Inspetoria de Imigração do Porto de Santos indicam, apenas em alguns anos, o destino para onde embarcavam ${ }^{95}$, porém, do ponto de vista da sua circulação interna, considerando as entradas e saídas, a ocorrência é de difícil aferição.

No caso do espanhol, porém, há algumas outras evidências dessa mobilidade, reveladas por informações constantes nos LRC. A primeira delas, insuspeita, apareceria logo nos primeiros anos compulsados, quando observamos a existência de reiterados casos de inscritos, cujos registros continham pequena anotação no canto da página indicando "Vá a Rio" ou "Vá a Buenos Aires" e, ainda mais acintosamente "Vá a Rio a buscar trabajo" . Nessa trilha, outras pistas. O simples trânsito em direção a outro destino patenteava-se, na indicação de hotéis da cidade como domicílio. O Hotel Español então situado na Estação do Norte (hoje Estação Roosevelt) encabeçava uma lista de tantos outros ${ }^{97}$, numa evidência suplementar da falta de apoio oficial de qualquer natureza e da escassez de uma rede de solidariedade. Esse é um dos ângulos da questão, que evidenciaria desdobramentos dos mais inusitados, que tenderam ao acirramento na proporção em que avultava a demanda dessa população itinerante à cidade.

\footnotetext{
${ }^{95}$ Esses informes indicam as saídas pelo porto de Santos para outros países ("Europa; Ásia; África; NorteAmérica; Argentina; Uruguai e diversos").

${ }^{96}$ Em registros posteriores, na década de 1910, a esses locais acrescentou-se "Vá a España".

97 Apenas para exemplificar, entre os anos de 1893-1902, foram os seguintes os hotéis mencionados: Español, Paulista, Português, Alberto, Bela Jardineira, Nápole, Cantagalo, Estação da Luz e Internacional.
} 
Revelador nesse sentido, e indicador do vulto que a questão tomaria, traduz-se o fato de a Federación Española (FE) prever, por meio de seus estatutos, a criação de um "albergue noturno onde possam pernoitar os espanhóis sem recursos [...] por no máximo 15 dias"98. É provável que esse projeto não tenha se concretizado, acentuando mais o problema dos muitos recém-chegados, famílias inteiras por vezes, que passavam a viver na indigência, perambulando sem destino.

Esta questão, como tantas outras, demorou a merecer a atenção da autoridade consular, ainda que casos de declarados indigentes já frequientassem as dependências do CGE e as páginas de seus registros. Somente em 1915 é que o Cônsul Ignácio de Arana, em memorando ao Ministro de Estado espanhol, assim se pronunciaria a esse respeito:

Los asilos y casas de beneficência de San Pablo segun me participan las autoridades locales no podrán en lo sucesivo acoger a mas niños y ancianos por estar desde hace varios meses llenos y atendiendo a muchas mas personas de las que en ellos caben ${ }^{99}$.

Regularmente, durante o período analisado, o EDE publicaria subscrições que se abriam em favor desses desamparados, como no caso ocorrido nos finais da segunda década, quando o problema parecia ter-se acirrado ainda mais, em que solicitava adesão para ajuda "ao compatriota Manuel Díaz, esposa e três filhos, recém-chegados do interior e que carecem de albergue" ${ }^{, 100}$.

O êxodo em direção às áreas urbanizadas de um contingente de miseráveis expulsos do campo em situação de penúria, e o inchaço das cidades, em suas consequiências, desde há muito vinha alarmando as autoridades e se transformara numa das preocupações centrais da Sociedade Promotora de Imigração. Dentre outras questões apontadas, note-se o que dizia o Secretário da Agricultura, já em 1895:

Apesar de todas as seguranças introduzidas nos contratos, verifica-se que uma parte considerável dos imigrantes tendo embarcado com declaração de serem agricultores, recusam-se, depois de chegados às hospedarias, a aceitar colocação na lavoura. A consequiência é o crescimento extraordinário de população proletária das cidades, principalmente da capital ${ }^{101}$.

A questão central, para as autoridades, era a retenção dessa mão-de-obra no campo e, até certo ponto é incompreensível a rotatividade que passa a existir, levando-se em conta a

\footnotetext{
${ }^{98} \mathrm{EDE}$ 18.03.1914.

${ }^{99}$ AGA. Caja 1692. Memorando de 16.01.1915.

${ }^{100}$ EDE 25.08.1920. Ver também, a esse respeito: FLOREAL, Sylvio. "Os párias. Uma noite no albergue noturno". In: Ronda da meia noite. Vícios, misérias e esplendores da cidade de São Paulo. São Paulo: Paz e Terra, 2003 (escrito originalmente em 1925), pp. 49-55.

${ }^{101}$ Relatório Anual apresentado ao cidadão Dr. Presidente pelo Dr. Theodoro Dias de Carvalho Junior. São Paulo, 1896, p. 41. Apud: TRENTO, A. Op. cit.,1988, p. 121.
} 
constatação de que a primeira crise provocada pela queda dos preços internacionais do café ocorreria apenas em $1896^{102}$.

Para Aziz Simão, contudo, as evidências indicam que "o mercado de trabalho rural foi apenas sua larga via de acesso a outras oportunidades de ação econômica, principalmente nos núcleos urbanos que se criavam ou cresciam, com sua expressiva participação"103.

Outros fatores, por suposto, estariam envolvidos. Os relatórios oficiais vinham apontando para o fato de as saídas de emigrantes superarem as entradas, no movimento global, denunciando o fato de que muitos emigrantes embarcados com passagem subvencionada até Santos, uma vez na cidade, dali prosseguiam viagem por conta própria para os países platinos, especialmente para a Argentina, ao mesmo tempo em que registravam o aumento no número de repatriamentos, a partir de 1887. A Argentina sempre significou a pedra no sapato de nossa política imigratória e era fato corriqueiro a preferência dos imigrantes por aquele país, ao qual se atribuíam distintas justificativas: "[Na Argentina] no ocurre como en el Brasil, donde, a mas de ofrecer graves inconvenientes para la salud, los naturales tienen odio letal a los extraños”, afirmaria uma autoridade diplomática espanhola, em $1911^{104}$.

Fica evidente assim que, mesmo no período anterior à virada do século XIX, houve a conjunção de inúmeras variáveis na intensificação da mobilidade do imigrante, sendo contudo interessante reter que, em suma, alguns desses fatores acabariam por dilatar a cidade de São Paulo com o crescente aumento do contingente de miseráveis em situação de extrema penúria, fatores a respeito dos quais se pronunciaria, em memorando ao Ministro de Estado espanhol, o cônsul Juan Solórzano alertando da

necesidad de vigilar y fiscalizar los embarques por el puerto de Gibraltar de gente indocumentada, desconocedora de las faenas del campo, de gente agrupada constituyendo familias falsas que llegan, se separan, no pueden ir a las fazendas y aumentan el número de los que diariamente llegan a la puerta de este Consulado en demanda de socorro y repatriación ${ }^{105}$.

Para Maria Alice Rosa Ribeiro ${ }^{106}$ dentre outras razões, esse fato decorreu também das dificuldades de permanência no interior, atacado constantemente por epidemias de febre

102 O preço do café em moeda nacional começou a declinar a partir de 1894, ocasião em que passou de 15 mil réis por $10 \mathrm{~kg}$, para 13 mil réis em 1896; em 1900, caiu para 9 mil réis e em 1902 para 5 mil réis. Cf. MALUF, Marina. Ruídos da memória. São Paulo: Siciliano, 1995, p. 131.

${ }^{103}$ SIMÃO, A. Op. cit., 1966, p. 28.

${ }^{104}$ El Mundo, 28.07.1911. AHI. AMAE. Ofícios da Legação Brasileira em Madrid.

105 AGA. Caja 1692. Memorando de 01.01.1913.

${ }^{106}$ RIBEIRO, M. A. História sem fim ... Inventário da saúde pública-São Paulo, 1880-1930. São Paulo: Editora Unesp, 1993, p. 105. 
amarela, que, na última década do Novecentos, atingira especialmente as imensas regiões do Oeste por onde se alastrava o cafezal, poupando, no entanto, a Capital. A esse propósito,

Meus bisavós estiveram na Fazenda Monte Alto, por volta de 1893, 1895. Comeram o pão que o diabo amassou ali. A mãe da minha bisa perdeu dois filhos de febre amarela e foi banida para o mato com eles queimando de febre. Os dois morreram e ela os enterrou, cavando com as próprias mãos as suas sepulturas. Fugiram dali a pé (....) ${ }^{107}$.

A necessidade de se repatriar, de retornar a seu país em situação mais deplorável do que quando o deixou, afigurava-se para o imigrante como o mais degradante e humilhante dos desfechos. Em seu imaginário, e no daqueles que permaneceram, o retorno só se justificaria após uma bem sucedida trajetória no país de acolhida. Retornar, portanto, era atestar o próprio fracasso, dupla e publicamente, com a agravante de ter de apelar às autoridades para sua concretização.

No livro de repatriamentos do CGE, é possível listar algumas das alegações aventadas pelos solicitantes: "velhice"; "abandono do chefe de família"; "abandono do filho e do marido"; "abandonada pelo marido"; "enfermidade"; "viuvez e sem recursos" e "tuberculose" para o caso de um tipógrafo, foram razões enumeradas em duas páginas consultadas, apenas no ano de 1909.

Analisemos de perto um desses casos, o "abandono do chefe de família". A requerente era uma mulher de 48 anos, com cinco filhos (idades entre 2 e 19 anos), há apenas um ano em Ribeirão Preto que, todavia, embarcara por Gibraltar, ou seja, realizara um embarque clandestino. Casos similares pipocavam, desenhando inumeráveis variações dentro do mesmo enredo, como este, filtrado pela lente de um escritor:

Esta mulher franzina, pálida, com 4 filhos, veio há 6 meses da Espanha para uma fazenda; é viúva e diz que já veio assim da sua terra. Dorme aqui [no albergue] há 2 semanas. Quer voltar à Espanha, mas, como o seu estado de miserabilidade o não permite, espera que o cônsul lhe conceda uma passagem gratuitamente ${ }^{108}$.

No decênio 1903-1912, analisando as inscrições femininas nos LRC flagramos 80\% dos casos como pertencentes a viúvas com idade média de 30 anos, nas quais constava, em mais da metade, a observação indicando que eram candidatas à repatriação.

107 DIEGUEZ, Márcia. Fragmento de depoimento. Comunicação pessoal. Correio eletrônico de 17.03.2003. A depoente reside em Santos e é funcionária da Biblioteca do Centro Español daquela cidade.

${ }^{108}$ FLOREAL, S. 2003, Op. cit., p. 51. 
Oficialmente, no período compreendido entre 1887 e 1914, a repatriação foi a responsável pelo grosso das saídas, 65\%. Do restante, $30 \%$ foram para a Argentina e o Uruguai, $4 \%$ para outras regiões brasileiras e $1 \%$ para os Estados Unidos ${ }^{109}$.

Esses homens e mulheres em constante deslocamento moviam-se aparentemente em grupos, alguns de natureza familiar (fato evidenciado pelos sobrenomes comuns) ou provenientes de um mesmo local no interior onde provavelmente trabalhassem como colonos (fazenda, localidade, cidade ou agência consular), dado evidenciado pela realização de registros no CGE em sequiência, numa mesma ocasião. Esta mesma evidência pôde ser observada para os casos em que a coincidência, nos registros seqüenciais, dizia respeito aos locais de origem comum (pueblos ou províncias), indicando ser esta uma outra maneira de que se valiam nessa mobilização, indício que sugere ter sido esta uma decisão compartilhada. Jornaleros em sua maioria, conforme salientamos, declaravam haver viajado de terceira ou quarta classe e apresentavam-se ao CGE geralmente s/documentos, e talvez aí residisse a única motivação de sua inscrição, a necessidade de um documento individual (lembremos que o passaporte era um documento familiar) que pudesse viabilizar a locomoção para outros Estados ou mesmo países.

Neste caso, pode-se aventar a hipótese, bastante plausível, de que muitos talvez fossem obrigados a partir sozinhos, deixando para trás a família, nuclear ou não, abandonando as fazendas, onde deixavam mulher e filhos. Em outros casos, era a própria viúva que se punha a caminho, com seus filhos pequenos.

Nessa constante peregrinação, muitos acabavam se desencontrando, perdendo-se de seus familiares e conhecidos. Se assim não fosse, por que razão o EDE manteria com regularidade, durante toda a série examinada, a coluna personas buscadas? Eram irmãos desaparecidos e/ou que se perderam, tios que reclamavam por seus sobrinhos, e conhecidos que, embarcados juntos acabavam se dispersando, indicando que a incidência de indivíduos que não retornavam ou não davam notícias era grande. Crescente, a demanda para esse tipo de nota, inicialmente gratuita, passou a custar $2 \$ 000$ por cada três publicações ${ }^{110}$.

Referindo-se muito apropriadamente sobre essa questão, o problema dos desaparecimentos, Afonso Schmidt ${ }^{111}$ assim se pronunciava:

Quase todos os dias os jornais são solicitados a publicar fotografias de homens, mulheres e crianças de quem os parentes ignoram o paradeiro [...]. E mesmo alguns

${ }^{109}$ Boletim do Departamento Estadual do Trabalho, nº 59-61, 1927. In: TRENTO, A. Op. cit.,1988, p. 121.

${ }^{110}$ EDE 16.05.1913, dentre muitas outras edições.

${ }^{111}$ SCHMIDT, A. “Desaparecidos”. In: Op. cit., 2003, pp. 141-144. 
consulados [...]. Há também os que nunca mais dão sinal de si. São os que morrem por essas estradas e não se consegue identificar.

Conjugados todos os fatores - crises conjunturais, epidemias, conflitos com fazendeiros e capangas, falta de perspectiva, inadaptabilidade às condições locais adversas -, surgia, enfim, do ponto de vista do colono, a força de atração da cidade de São Paulo, de onde emanava a maior demanda de mão-de-obra de todo o Estado, o "mercado de homens", no entender de Pierre Denis, a acenar com múltiplas e diversificadas possibilidades de inserção laboral, formal ou informalmente. Além do mais, em alguns casos, até mesmo o colono cuja intenção fosse apenas a de trocar de fazenda, tenderia a vir para São Paulo, cidade de onde partiu e que conhecia, e onde estavam as oportunidades de emprego na lavoura. Nesses casos, dificilmente esse imigrante retornaria para o interior, fascinado com a cidade, com seus atrativos e as possibilidades potenciais que à primeira vista se apresentavam; outro fator relevante nessa decisão foram representadas pelas redes de parentesco, amizade ou vizinhança, fundamentais na decisão de permanecer ${ }^{112}$.

Essas evidências sugerem de imediato que havia uma enorme massa flutuante de pessoas desocupadas vagando ou em trânsito pela cidade, composta em sua maioria por estrangeiros, que representavam a maioria da sua população. Essa abundante oferta de mão-deobra, resultante dos ingressos massivos de imigrantes com passagem subvencionada pelo poder público, pode, do mesmo modo, ser considerada como a responsável pelos baixos salários no colonato - que, no entanto, produzia alguns artifícios para amenizar a compressão, como a permissão para a produção de gêneros de subsistência para venda, nas fileiras dos cafezais jovens.

Na cidade, receptora dessa mão-de-obra, os salários ou a remuneração, pautando-se pelo padrão cafeeiro, também flutuavam de acordo com seu movimento cíclico. Daí as altas taxas de desemprego e a crescente quantidade de desempregados pela cidade, homens e mulheres, adultos e menores, vivendo de atividades esporádicas, alguns na indigência e que passariam a ser identificados como "vagabundos", em cujo enquadramento, para o caso de reincidência, previa-se a expulsão.

Quanto aos imigrantes já estabelecidos na cidade, a situação também deixava a desejar. Logo no ano seguinte ao da abertura do CGE, 1894, os registros indicam uma avalanche de inscritos aqui domiciliados indicando sua intenção de se dirigirem para a cidade do Rio de Janeiro, e, nesse particular, uma rápida apreciação às suas ocupaciones é lapidar:

112 TRENTO, A. Op. cit., 1988, p. 122. 
eram barbeiros, sapateiros, alfaiates, carpinteiros, pedreiros, ferreiros, vidreiros, foguistas, cocheiros, marinheiros, cigarreiros, caldeireiros, empregados do comércio, escreventes e também jornaleros, homens com idade variando entre 14 e 54 anos.

Andaluzes em sua maioria, a sua influência, infiltrando-se no cotidiano da cidade, já podia ser percebida, por meio dos chistes jocosos que se espalhavam pelas ruas:

Ouve-se aqui freqüentemente um ditado anedótico, de forma variável:

"está como o outro, que foi persignar-se e quebrou o nariz".

É o andaluz: "púsose a santiguar y se sacó un ojo".

Outra frase nossa: "é um pão e um pedaço".

Não a encontramos nos catálogos, mas é vulgaríssima em São Paulo.

Prende-se evidentemente ao espanhol - "Bueno es un pan con un pedazo" ${ }^{\prime 113}$.

Esse indicador apontando indivíduos de vários segmentos profissionais e ocupacionais domiciliados na cidade, muitos casados e provavelmente com família, que necessitavam buscar trabalho fora dela, é sinal do quanto o mercado de trabalho da cidade estava saturado já a esta altura, até mesmo para aqueles com alguma especialidade ou ofício. Pode-se, a partir daí, imaginar como seria para o indivíduo desqualificado - o jornalero, por exemplo - sem o domínio de qualquer ofício, que a ela demandava ou nela permanecia à cata de qualquer trabalho, na sua faina diária de improvisação pela sobrevivência.

Ainda mais calamitosa demonstrava ser a condição daqueles que, por infortúnio, adoeciam. Percorrendo-se as notas do EDE, através das quais se buscava ajudar a esses infelizes, iniciando-se alguma subscrição ou simplesmente pedindo auxílio, alguns casos são exemplares. Numa delas, pedia-se mantimentos e roupas para 5 crianças, a maior com 11 anos que, órfãs, aguardavam a repatriação. Estariam "recolhidas" na Rua São Caetano, $179^{114}$. Em outra, uma mulher com 6 filhos, vivendo na Rua Rocha, 45, cujo marido encontrava-se "gravemente enfermo" e com a sogra de idade avançada (88 anos) "de cama", pedia auxílio às pessoas caridosas ${ }^{115}$. Em outro momento, o próprio articulista do EDE se manifestaria, lastimando o estado em que encontrou a família de Federico Martín, “ele, adoentado, cadavérico, no fundo da cama, vivendo num quintal da Rua Caetano Pinto, 70, de aluguel"116 e, novamente invocando a caridade da comunidade, informava da condição do "compatriota José

113 AMARAL, Amadeu. Tradições populares. São Paulo: Editora Hucitec, 1976, p. 240. Santiguar: fazer vários sinais da cruz, estranhando ou se escandalizando com algo.

${ }^{114}$ EDE 14.02.1914.

${ }^{115}$ EDE 30.09.1918.

${ }^{116}$ EDE 19.12.1919. 


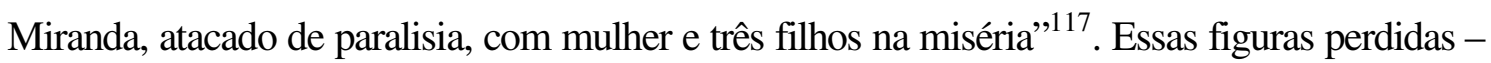
contingentes de homens e mulheres oriundos em sua maioria da Andaluzia, cujo destino inicial era o núcleo cafeicultor e que, por razões as mais diversas acabaram cruzando ou fixando-se na cidade -, se não fizeram parte do Censo Ocupacional da Cidade, atrás examinado, com certeza logo passariam a engrossar páginas de relatórios oficiais, que informavam do desconforto que a sua presença vinha causando na população da Paulicéia. Com efeito, os poderes públicos vinham demonstrando preocupação com a crescente leva de desempregados na cidade: homens, mulheres e crianças pobres que viviam de ocupações esporádicas, como ameaça à manutenção da ordem, identificados como "vagabundos" $" 118$ e que, como tal, traziam perigo à sociedade ${ }^{119}$.

Anteriormente esse fato já vinha frequientando os relatórios policiais. Guido Fonseca ${ }^{120}$, com base nos Relatórios apresentados pelos Chefes de Polícia aos Presidentes da Província, fez uma incursão no mundo policial da cidade, ressaltando que já em 1875 era grande a preocupação das autoridades para com o "grande número de estrangeiros refratários ao trabalho". Os imigrantes seriam novamente citados em outro Relatório, anos depois, 1878, como quem não respeitava a propriedade e a integridade física dos cidadãos, nomeando locais, na cidade, em que atuavam. Chamados de alienígenas e vagabundos, completava o Relatório que "sua ousadia era tanta que atacavam os transeuntes à mão armada e nas ruas mais freqüentadas" e que "os espanhóis e os italianos deviam estar sempre sob as vistas da Polícia,

117 EDE 16.12.1920. A esses chamamentos manifestavam-se com contribuições alguns membros da colônia, geralmente esposas de comerciantes ou pequenos empresários, estes geralmente membros de alguma sociedade beneficente.

${ }^{118}$ No artigo 300 do Regulamento no 120, de 31.01.1842, são definidos como "vagabundos" os indivíduos que não têm domicílio certo, nem profissão ou ofício, nem renda ou meio conhecido de subsistência. Ver: SALLES, Iraci. República: a civilização dos excluídos (representações do "trabalhador nacional", 1870-1919). São Paulo: Tese de doutoramento, FFLCH-USP, 1995, p. 63.

${ }^{119}$ Dentro dessa premissa e demonstrando que a "criminalidade transformara-se numa dimensão da vida de São Paulo (...) seja pela sua interiorização sob a forma de insegurança que passou a integrar a vida das pessoas, em grau maior ou menor", e utilizando-se de estatísticas policiais, Boris Fausto concentrou sua análise em duas modalidades de infrações, ocorridas no período: os crimes e as contravenções penais, ou "crimes sem vítima", utilizando-se para tanto das prisões efetuadas na cidade e dos inquéritos abertos pela polícia, com cuja comparação demonstra a enorme defasagem entre o número de pessoas presas na cidade e as processadas, número que expressaria, provavelmente, "a significação das prisões como instrumento de controle social". Para exemplificar, o autor indica, por exemplo, que em 1893, foram detidas 3.466 pessoas na capital, com a abertura de apenas 329 inquéritos. In: "Controle social e criminalidade em São Paulo: um apanhado geral (1890-1924)". Cf. PINHEIRO, Paulo Sérgio (org.) Op. cit., 1983, p. 196 e ss. Para Guido da Fonseca (In: Crimes, criminosos e a criminalidade em São Paulo (1870-1950). São Paulo: Ed. Resenha Tributária, 1988, p. 64), no entanto, a questão era de outra natureza, envolvendo a noticiada falta de uma "colônia penal", local onde pudessem ser presos os detidos. Como ela inexistia, a ação policial resumia-se ao prende e solta sem, obviamente, ter havido a abertura do processo. E exemplifica: em 1893, dos 509 vadios presos, somente nove foram submetidos a processo (cinco brasileiros, três italianos e um português). $\mathrm{O}$ autor aponta, nas pp.48/9, para o mesmo ano a existência de 368 inquéritos sendo que destes 268 referiam-se a delitos praticados por estrangeiros (italianos 149; portugueses, 70; espanhóis, 21; alemães, 9; franceses, 7; ingleses, 4; húngaros, 3; turcos, 2; austríacos, 2 e 1 de norte-americano). Em 1894 o número de presos era de 4.487 indivíduos, e aqui os espanhóis, em número de 357, aparecem depois dos italianos, dos brasileiros e dos portugueses (1903, 1346 e 550 respectivamente).

${ }^{120}$ FONSECA, G. Op. cit., 1988. Ver especialmente a segunda parte. 


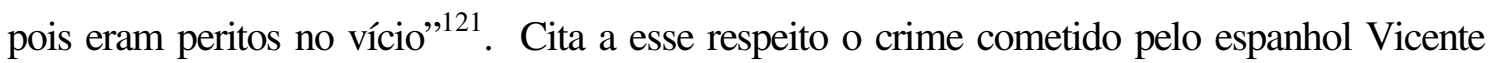
Curto, o qual, armado de um punhal investiu contra um professor que saía de um hotel, tentando arrancar-lhe o dinheiro e outros valores que trazia ${ }^{122}$.

Boris Fausto, a propósito da grande preocupação policial com a ordem pública sugere uma evidência, na comparação que faz para o período de 1892-1896: neste período, afirma o autor, a categoria "contravenção" responsável por 16.397 prisões, incluiria a "desordem", a "embriaguez" e a "vadiagem" como as maiores responsáveis ou de maior incidência, representando, juntas, $89 \%$ do montante. A categoria "vadiagem" pontua, certamente incluiria os detidos por mendicância, considerada por muitos juristas como simples modalidade de vadiagem $^{123}$.

Ao imigrante acusado de "vagabundo" a legislação previa, nos casos de reincidência, a sua expulsão, como vimos, e já em 1895 a autoridade legislativa manifestava o temor com relação à sua presença crescente. “A população corria grande risco, porque esses milhares de indivíduos que ficam por longo tempo nesta capital, pouco afeitos ao nosso meio social, espalhados pelas ruas, em plena vadiagem (...) constituem uma ameaça à ordem pública"124.

Essa associação do mendigo ao vagabundo é algo que deve ter-se cristalizado no imaginário coletivo. Analisando um "Atestado de Antecedentes Criminais" expedido pela polícia estadual a uma espanhola, Amélia Fontenha, de profissão "serviços domésticos" e residente na Rua Joaquim Nabuco, 32, em 1913, constatamos esta observação escrita na lateral: "reside no país há mais de 5 anos e não exerceu a mendicidade","

A imprensa engrossava as fileiras dos descontentes e já em 1892 o Diário Popular ${ }^{126}$ assim se referia aos mendigos existentes na cidade: "São todos estrangeiros, e estrangeiros que não empobreceram aqui, estrangeiros que vieram dos seus países chamados pela fama da nossa generosidade e que vieram dar uma nota escura à nossa vida ativa com o triste quadro das suas deformidades". Outro periódico também se manifestava a esse respeito, um ano depois (1893):

${ }^{121}$ Idem, ibidem, p. 46.

${ }^{122}$ Idem, ibidem, p. 97. Nas pp. 146-147, o autor examina o que denominou de "a profissionalização do crime", isto é, a substituição do delinqüente ocasional e esporádico pelo profissional. Dentro desta categoria, havia os que se muniam de habeas-corpus, como era o caso de João Peres, o "galegão", um dos mais conhecidos larápios do final do século conforme o autor que, ao ser preso em 14 de agosto de 1895 portava uma alavanca própria para arrombamentos e um habeas-corpus preventivo. Na p. 148, o autor comenta sobre outro espanhol, o Bejarano ou Antonio Benito Arias, um dos mais conhecidos delinqüientes da época, ligado aos jogos fraudulentos.

${ }^{123}$ FAUSTO, B. Op. cit., 1983, pp. 198 e ss.

124 Idem, ibidem, citando Anais da Câmara dos Deputados, sessão de 14 de agosto de 1895, pronunciamento do Sr. Carlos Villalva, p. 108.

${ }^{125}$ CGE. Documento avulso, de 16.11.1913.

${ }^{126}$ Diário Popular de 30.04.1892. Apud: MORSE, R. Op. cit., 1970, p. 242. 
De todos os ângulos surgem mendigos de ambos os sexos, cobertos de farrapos e sujos, de aspecto mais ou menos repelente, mulheres com crianças famélicas no colo, velhas em estado quase senil, negros com os pés deformados e com verminose (...) descontentes de todos os povos: aventureiros, conquistadores e nômades vieram aqui apodrecer - purulência da emigração em massa ${ }^{127}$.

Contudo, parece ficar evidenciado que, embora em menor escala, uma certa circularidade nesse circuito, um caminho de volta, também era praticado. Iraci Salles ${ }^{128}$ comentando do deslocamento dos desempregados, a leva de homens pobres que transitava pelo Estado, esclarece que tal movimento também ocorria da capital para o interior, por ocasião da colheita das safras de café que exigia mão-de-obra extra. Também nós, nos anúncios do EDE, observamos as inúmeras solicitações nesse sentido, evidenciando que esse caminho de mão dupla, realmente existia ${ }^{129}$, e, mais que isso, era estimulado pelos órgãos oficiais ${ }^{130}$, por razões que nos parecem óbvias.

Como vimos, a cidade em transformação que tanto encantava, escondia dos forasteiros e desavisados algumas armadilhas. Nos setores formais de sua economia - a indústria, o comércio e o terciário - reinavam absolutos entre os estrangeiros, os italianos, alguns deles já envergando comendas e residindo em palacetes na Avenida Paulista.

Nessa conjuntura, em descompasso com as oportunidades que a cidade em transição criava e oferecia àqueles que a ela se apresentavam com maior condição de aproveitamento, isto é, dos que se valiam de alguns benefícios ou vantagens como redes de conhecimento, apoio de seus representantes oficiais, o domínio de algum ofício ou certa reserva monetária para aplicação em algum pequeno negócio inicial, condições que melhor os capacitavam na sua exploração, a situação do imigrante espanhol pobre e desqualificado, representado pela crescente massa de jornaleros que a ela demandava, era crítica, acrescendo-se aqui o fato adicional do seu tardio contato com ela, quando comparado aos italianos. Essa condição subalterna, supomos, responde em parte pela inclusão problemática desse contingente na cidade, que se acostumou a vê-los como destemperados e grosseiros, atribuindo-lhes, dentre outras características, a "inclinação" por atividades "por conta".

${ }^{127}$ O Commercio de São Paulo, 22.07.1893. Apud: VANGELISTA, C. Op. cit., p. 240.

${ }^{128}$ SALLES, I. Op. cit., 1995, p. 62.

${ }^{129}$ EDE 18.01.1913. Anúncio da Fazenda "Villa Biella" (S. J. Rio Pardo), na Mogiana, propriedade do Dr. Jordano da Costa Machado, por exemplo, solicitava colonos, informando os valores pagos para as diversas atividades. Oferecia: casa e pasto para criar gado e terra para plantar cereais.

${ }^{130}$ EDE 25.04.1913. Com o título "Colheita de café", a Agência Oficial de Colocação, da Hospedaria dos Imigrantes, autorizada pelo secretário da agricultura do Estado convocava os trabalhadores "sueltos" da capital, que "em qualquer número" desejassem trabalhar na colheita de café do interior do Estado. 


\subsection{Locais de concentração e moradia}

Cerca de 1910 [...], mais uma carroça de mudança entrou, desequilibrando-se toda, na barrenta Rua Xingu. O carroceiro, negro de beiços volumosos, desceu da boléia, agarrou a rédea junto ao freio, e dando valentes puxões, gritava ao animal:

- Vamos, Princesa!

A Princesa refugou, arregalou os olhos, levantou as orelhas, encolheu as pernas traseiras e empinou. O carroceiro, com ar sonolento, judiou do queixo da besta, deu-the com o cabo do relho, e a carroça não andou sequer um centímetro.

"Seu" João Martinez, que se conservava pacientemente na boléia, gritou ao carroceiro: Ei, homem, não judie da coitada. Eu desço e ajudo a empurrar o carro.

O carroceiro consentiu prontamente e o imigrante juntou o ombro à grade traseira. (...) O carro balançou, os varais chacoalharam a coatheira, fazendo a gamarilha afrouxar, enquanto a retranca, comprimindo a traseira do animal, fez com que ele se acocorasse no barro.

- Pára, pára! Se empurras mais um pouco, fazes o varal quebrar.

Com efeito, o solavanco dado pelo cachaço musculoso de João Martinez fizera a carroça inclinar e o varal enterrado no barro arcava com todo o peso que a Princesa repudiara.

- Vem cá!...

O imigrante meio barreado não estranhou o ar autoritário do carroceiro e foi executando as ordens.

- Vamos ver se levantamos os varais sem quebrá-los.

Pegaram, cada qual numa das pontas e, ao som de outro ô ô ô baixo-profundo, já realizavam o intento quando a correia do dorso conteve o impulso. A Princesa havia deitado $e$ para erguer os varais era necessário que ela se levantasse primeiro. Foi o que Martinez tentou, dando-the forte ponta-pé na itharga. A mula bufou e abaixou completamente a cabeça junto às patas dianteiras.

O carroceiro olhou desanimado, enquanto João Martinez aplicava outro pontapé, agora no peito da besta. Estranho esse espanhol, a princípio com tanto dó e agora nesse frenesi incontido de bater!

- Velho assanhado, pensou o carroceiro, e gritou:

- Pára com isso que não adianta.

- Não adianta como? Inquiriu o imigrante.

- A Princesa é assim mesmo. Quando abaixa a cabeça, não há quem a faça levantar. O melhor é tratar de levar a carga até sua casa, porque a roda não desatola mais. Veja como afundou...

Com efeito, o eixo de ferro já estava quase tocando o chão.

Martinez não quis esperar e afundando os pés nas poças barrosas foi pondo nas costas os badulaques mais acessiveis.

Seriam quatro horas da tarde. A rua estava quase deserta de gente grande. Apenas alguns moleques brincavam na enxurrada. A carroça atolara uns cento e cinqüenta metros 
aquém da casa que João alugara. SNinguém poderia ajudá-lo. "Melhor!" pensou o espanhol decidido, "ninguém também para atrapalhar".

Como o carroceiro estava vendo se dava jeito na besta, João foi continuando o transporte, na expectativa de um breve auxílio. Sua surpresa foi bem grande quando, voltando pela terceira vez de sua casa para o local do desastre, viu a Princesa em pé e o carroceiro sentado na sarjeta, suarento, encostando a um poste, a descansar indiferente.

- Quem sabe poderemos chegar agora até mais adiante?

- “Num dianta”, resmungou o negro. A carroça só sai para trás.

João que, durante o trajeto na boléia, notara o cinismo e a moleza do carroceiro, desistiu de pedir-lhe qualquer auxílio e continuou seu trabalho.

$\mathcal{N a}$ oitava viagem, conseguiu levar todo o resto da carga. O negro olhava-o com despeito. Que camarada forte! E ele afi sem fazer nada. Era vergonhoso. Mas também não tinha culpa do espanhol arranjar aquela rua para morar!... Ora!

João entrou com dois enormes caixotes sobre o ombro e não apareceu mais à porta. Foi então que o preto se lembrou de que ainda não recebera os dez tostões do serviço. Só agora teve forças para se levantar, correr cento e cinqüenta metros e berrar à janela do freguês.

-Ei! Espanho!! Meus "deis tustão"?

Lá de dentro, ninguém responde. O carroceiro entreabre a porta e vê o homem armando e colocando os móveis.

-Ei! Espanho!! Meus "deis tustão"?

João virou-se lentamente com o rosto carrancudo.

- "Que quiere usted"?

- O meu dinheiro.

Fique sabendo que não sou nenhum idiota! Não dou dinheiro nenhum! Você não me trouxe até aqui, por isso não tem direito. Vá saindo antes que eu...

João pronunciou um "Yo" tão cheio, numa voz tão trovejante, que o negro achou methor escapulir mesmo sem o dinheiro...

Instalava-se assim naquele grupo vetusto de casas mais um imigrante de Castela... Seus próprios patrícios não se importaram muito com o fato.

Apenas uma Dona Concepción (havia tantas delas)! Veio saber se não necessitava de nada. João soube mais tarde que era a mulher do vendeiro e que se ele tivesse querido alguma coisa teria ou de correr os cobres ou então de abrir uma cademeta no armazém do seu marido. E só Deus sabe o que isso representaria para o estreito orçamento do modesto lar.

João Martinez esperou até as vinte horas e a família nada de chegar! Ele viera adiante para tomar conta da mudança e deixara D. Encarnação e o filho Pedro, para virem com o mano Augusto. Este, há dois anos, insistia com ele para deixar Buenos Aires. Porque, é 6om que se diga, João Martinez não vinha diretamente da Espanha e sim da Argentina. 
O levantamento dos primeiros dados referentes ao local de moradia dessa população espanhola domiciliada na cidade de São Paulo no período compreendido no primeiro decênio analisado (1893-1902), revela que, do cômputo geral, 56\% dos imigrantes inscritos declarava-se domiciliado no bairro do Brás. Do total de inscritos no período, apenas $67 \%$ dos registros puderam ser aproveitados; os demais pertencentes à Capital, ou não traziam a informação completa ou estavam ilegíveis ou ainda pertenciam a informantes com residência em hotéis (provavelmente em trânsito pela cidade). De todo modo, dos $56 \%$ de domiciliados em logradouros do bairro do Brás, um percentual de $44 \%$ referia-se a domicílios coincidentes, em alguns casos com até 6 citações para um mesmo endereço, realizadas num único dia, evidência provável de que esses indivíduos coabitavam em habitações coletivas ${ }^{131}$.

A considerar-se o total de domicílios declarados, sem as lacunas, esse percentual ainda poderia ser considerado elevado, $38 \%$, indicando forte concentração no local, ainda que não se possa estimar em números relativos o total de habitantes envolvidos.

De qualquer modo, esse dado parece incontestável, levando-se em conta os registros dos "nascimentos" ocorridos na cidade durante o ano de 1901, por exemplo. Assim, de conformidade com o Annuário Estatístico de São Paulo ${ }^{132}$ neste ano houve a ocorrência de 8.710 nascimentos na Capital $^{133}$, de cujo total apenas 1.727 ocorrências pertenciam a pais brasileiros. As demais 6.983 ocorrências eram pertencentes a filhos de pais estrangeiros, distribuídas por dez nacionalidades diferentes. Destas, 415 eram pertencentes a pais de nacionalidade espanhola, porcentagem próxima a $5 \%$ do total geral e $6 \%$ do total de estrangeiros.

Uma análise aos Distritos de Paz de origem desses registros indicou o do Brás com quase a metade deles (188 registros ou $45 \%$ ), referidos a pais de nacionalidade espanhola ${ }^{134}$, ratificando, assim, a nossa hipótese anterior, baseada nos LRC de que quase a metade da colônia espanhola da Capital, na virada do século, se concentrava nas imediações do bairro do Brás.

Observando os dados desse mesmo Annuário referidos ao "Mapa do movimento de imigrantes no alojamento da Capital" ${ }^{\text {135 }}$, em outras palavras, o balanço do volume de imigrantes que passou pela Hospedaria neste ano específico (1901), nas categorias de subsidiados (por

${ }^{131}$ É o caso, por exemplo do domicílio situado na "Rua do Braz, 47", citado num único dia (17.04.1893) por 6 indivíduos distintos (um barrilero; um taponero; dois tipógrafos; um delineante; um jornalero), todos andaluzes, dos quais quatro casados e dois solteiros. In: Relatório Access 32.

${ }^{132}$ Annuário Estatístico de São Paulo (Brazil), 1901. Repartição de Estatística e do Archivo do Estado de São Paulo. São Paulo: Typografia do "Diário Official”, 1904, pp. 412 e ss.

${ }^{133}$ Destes, 8.573 nasceram vivos.

${ }^{134}$ Para o caso dos pais de nacionalidade brasileira, portuguesa ou italiana, essa porcentagem é de $14 \%$, $29 \%$ e $27 \%$ respectivamente.

${ }^{135}$ Annuário Estatístico de São Paulo (Brazil), 1901, op. cit., p. 100. 
conta do Estado) e espontâneos, constatamos que dos 49.599 imigrantes de diversas procedências ingressados, 5.538 eram originários da Espanha, configurando um percentual de $11 \%$ frente às demais etnias.

Esse percentual, por outro lado, ratifica informes da Secretaria da Agricultura, indicando uma estabilidade nos ingressos até 1904, cuja tendência crescente, sobretudo no decênio seguinte, pode ser observada na Tabela 10, abaixo.

Tabela 10. Imigrantes espanhóis entrados em São Paulo, 1885-1929 Porcentagem em relação às outras correntes, por quiinquiênio

\begin{tabular}{ccc}
\hline \hline Período & Quantidade & \% \\
\hline & & \\
$1885-1889$ & 4.834 & 2,9 \\
$1890-1894$ & 42.316 & 13,2 \\
$1895-1899$ & 44.678 & 10,8 \\
$1900-1904$ & 18.842 & 11,0 \\
$1905-1909$ & 69.682 & 35,5 \\
$1910-1914$ & 108.154 & 29,8 \\
$1915-1919$ & 27.172 & 32,5 \\
$1920-1924$ & 36.502 & 18,5 \\
$1925-1929$ & 27.312 & 9,4 \\
\hline Total & \\
\hline \hline Fonte: Relatórios da Secretaria da Agricultura. In:CÁNOVAS, M. Op.cit., 2005, p.121
\end{tabular}

Do total de espanhóis ingressados na Hospedaria neste ano de 1901 (5.538 indivíduos), 96,7\% o fizeram através da subvenção da passagem (5.360 indivíduos), restando, portanto, uma pequena porcentagem para designar os que embarcaram às suas próprias expensas. Teoricamente todos os ingressantes nas condições acima, que tiveram sua passagem paga pelo Estado, deveriam dirigir-se para o interior, porém não era exatamente como se dava. Neste ano específico, por exemplo, dos 96,7\% subvencionados, apenas 80,5\% (ou 4.455 indivíduos) dirigiram-se para as lavouras, permanecendo na capital o restante (1.083 indivíduos ou 19,5\%), dado este que pode revelar que o imigrante recém-chegado já tinha conhecimento (ou os adquiria no contato com os demais) de subterfúgios e estratagemas com os quais burlava a acirrada fiscalização da Hospedaria, permanecendo na cidade.

Nessa primeira década considerada, portanto, eles concentravam-se em maioria no Brás, especificamente em algumas ruas, com predominância para a "Rua do Bráz" (57 domicílios), a principal artéria de acesso às estações ferroviárias. Os registros referidos a este domicílio, frequientes até o ano de 1901, contudo, a partir desta data desapareceram, provavelmente em função da alteração da nomenclatura dessa via, inicialmente para "rua" e 
depois para "avenida" Rangel Pestana. A propósito, "a avenida Rangel Pestana - eixo fixo do grande e operoso bairro da cidade - chamou-se n'outros tempos Rua do Bráz" ${ }^{\text {"136 }}$. O segundo domicílio mais citado neste decênio, no Brás, foi a Rua Carneiro Leão ${ }^{137}$ (47 menções), suplantado, no decênio seguinte, pela Rua Caetano Pinto.

O bairro do Brás passou a existir como tal na planta cadastral da cidade somente em 1874 com o início das atividades da estrada de ferro do Norte ${ }^{138}$ e, de acordo com a Planta da Cidade de São Paulo, elaborada pela Cia. Cantareira em 1881, possuía duas ruas principais - “a Rua do Brás, antigo caminho da Penha e a Rua do Gasômetro, ambas ligadas ao núcleo principal da cidade por meio de aterros construídos através da várzea inundável do Tamanduatế,"139.

Em 1893, ano inicial dos registros consulares, já são muitos os domicílios situados no Brás $^{140}$, tendência crescente nos anos subseqüentes dos registros examinados, fato que pode estar aliado ao vertiginoso aumento da população imigrante na cidade no período e à "eleição" do Brás como domicílio. Com efeito, se o Censo Provincial de 1886 dava ao Brás 6000 habitantes, este número quase foi triplicado em quatro anos - 16.807 habitantes em 1890 -, e duplicado três anos depois, passando a 32.387 habitantes em $1893^{141}$.

O Brás representava o primeiro contato do imigrante com a cidade, porquanto lá se localizava a Hospedaria dos Imigrantes, cuja presença desencadeou um movimento paralelo de hotéis, pensões, pequeno comércio, escritórios de locação de serviços e "agentes de trabalho que

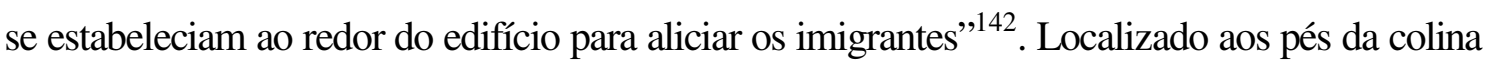
histórica, porém nas várzeas da cidade, era uma região basicamente alagadiça, insalubre e foco permanente de endemias. Talvez seja por essa sua característica física que o Brás concentrou tudo que o núcleo central de certa forma rejeitou: as fábricas do incipiente parque industrial, as hospedarias baratas, os mercados populares, as pensões e os cortiços e até o Gasômetro da

${ }^{136}$ MOURA, Paulo Cursino de. São Paulo de outr'ora (evocações da metrópole - Pysicologia das ruas). $3^{\text {a }}$ ed., São Paulo: Livraria Martins S/A, 1954 (ou) São Paulo: Itatiaia/Edusp, 1980; (1 ${ }^{\text {a }}$ ed. 1932), p. 346.

${ }^{137}$ Relatório Access 31.

${ }^{138}$ CENNI, Franco. Italianos no Brasil. São Paulo: $2^{\text {a }}$ edição fac-similar comemorativa do centenário da imigração italiana no Brasil, 1875-1975, Martins, Edusp, 1975, p. 231.

139 AZEVEDO, A. (org). Op. cit., p. 232.

140 As ruas do Hipódromo, Carlos Garcia, Souza Mursa, Cel. Seabra e Visconde de Parnaíba já foram citadas em 1893.

${ }^{141}$ TORRES, Maria Celeste Teixeira Mendes. O Bairro do Brás. São Paulo: Prefeitura Municipal de S.Paulo, s.d., pp. 91 e 112.

${ }^{142}$ LEME, Marisa Saenz. Aspectos da evolução urbana de São Paulo na Primeira República. São Paulo: Tese de doutoramento, FFLCH-USP, 1984, p. 152. 
cidade, com seu mau cheiro, cujo aterrado foi construído por Bernardino de Campos em $1893^{143}$.

A presença espanhola no bairro, ainda que maciça, parecia subordinar-se, também nesse microcosmo, à presença ostensiva dos italianos:

Perscrutado esse bairro medularmente, ele oferece um aspecto deveras curioso: é um verdadeiro tabuleiro de xadrez de raças e povos, os mais estranhos pelos sentimentos e os mais diferentes pelas procedências onde [...] disputam entre si, agressivos e astutos, maneirosos e calculistas, a partida fatal para vencer o rei dinheiro e a torre milhões [...]

Em cada esquina desse bairro, fala-se uma língua estranha e ostenta-se um hábito disparatado. Em cada rua, exibe a sua tradição um povo diferente [...]

Ao lado desse espetáculo de enorme agitação, surpreendemos, a miúdo, os que vieram para aqui e encasquetaram a idéia inamovível de fazer a América, seja lá como for. [...] vemos então a plebe mourejando nas fábricas (...) e os ofícios mais contraditórios e os misteres mais desiguais e chocantes aí se confundem e se entrelaçam, formando uma rede extremada e resistente de múltiplas atividades que buscam invadir e dominar todas as esferas da luta pela vida [...]

Não se pode, contudo, negar que no seio dessa vasta aglomeração, os italianos, donos do bairro, em franca camaradagem, formam a regra; os outros, a exceção; e, apesar de bem vistos, não passam de inquilinos ${ }^{144}$.

Monbeig também se refere a essa região que, conforme ele, até 1886 não passava de "simples subúrbio de artesãos e de chácaras, albergue para os tropeiros vindos pela estrada do Rio" e que atraía pela "possibilidade de escapar dos impostos urbanos"145.

Os investidores logo perceberiam nesta "vasta aglomeração" e na "possibilidade de escapar dos impostos urbanos", uma possibilidade de lucro fácil. A subdivisão das antigas chácaras em lotes que eram vendidos, antecedeu a etapa imediatamente seguinte, a da corrida imobiliária, que se tornara investimento rentável não apenas para as pequenas poupanças, mas para todos os setores vinculados direta ou indiretamente à economia do café, que viam na construção de moradias populares para locação uma forma eficaz e segura de rentabilizar o seu capital $^{146}$. Conforme a Recebedoria de Rendas estimou para 1912, existiriam na Capital 39.697 casas. O Brás saia na frente dos demais bairros, com quase 23\% do total desses imóveis (9047),

${ }^{143}$ Sobre a evolução urbana do Bairro do Brás, ver, entre outros, MARTIN, André Roberto. O bairro do Brás e a deterioração urbana. Dissertação de mestrado em Geografia Urbana. São Paulo: FFLCH-USP, 1984.

${ }^{144}$ FLOREAL, S. Op. cit., 2003, p. 20-21.

${ }^{145}$ MONBEIG, P. Op. cit., 1953, p. 57

${ }^{146} \mathrm{O}$ aluguel se configuraria um excelente investimento: em 1920 mais de $80 \%$ dos prédios existentes em São Paulo eram alugados e apenas $19 \%$ eram ocupados por seus proprietários. $C f$. BONDUKI, N.G. "Origem do problema da habitação popular em São Paulo - primeiros estudos”. In: Espaço e Debates. São Paulo: Cortez Editora, ano $2, n^{\circ} 05,1982$, p. 101. 
seguido por "Santa Efigênia, 6478; Consolação, 6304; Santa Cecília, 6143; Liberdade, 4497; Belenzinho, 2320; Vila Mariana, 1759; Sé 1267; Cambuci, 775; Santana, 737; Penha 361”,147.

A locação revelou-se excelente negócio: "A prática de ter casas para aluguel era cada vez mais difundida", afirma Maria Luiza de Oliveira, para quem "morar não tinha necessariamente relação com o fato da propriedade da casa", dada à mobilidade que se impunha também àqueles que tentavam acompanhar os progressos da cidade, com seus comércios de porta aberta. Esse fenômeno, conforme a autora, teria dessacralizado a idéia da casa como um lar, e queremos crer que isso talvez acontecesse pela violação do lar entendido não apenas como o domicílio da família ${ }^{148}$.

Era comum às famílias mais abastadas alugarem cômodos em suas residências "aluga-se em casa de família alemã uma bonita sala de frente e dormitório, bem ventilados, com entrada independente, com ou sem móveis. Alameda Santos, 134-A, entrada pela Rua Pamplona" "149. Uma "casa de dois cômodos, $17 \mathrm{~m}$ de comprimento e 4,5m de frente, com cozinha grande e quintal" vendida no Brás, Rua Ipanema, 72, por 6.500\$000, era anunciada como "excelente negócio para aluguel", sugerindo-se para tal o valor de $80 \$ 000$, valor proporcionalmente mais elevado quando comparado aos valores praticados hoje em dia para locação, por exemplo, em média $1 \%$ do valor venal do imóvel ${ }^{150}$. Talvez pelo alto custo do aluguel proliferassem anúncios para locação com ofertas do tipo "serve para duas famílias pequenas" 151 , ou "aluga-se os fundos de uma casa de negócio"152 ou até mesmo oferecendo "porão habitável"153. Valia-se de referências pessoais como garantia nas propostas para locação: "família espanhola, honrada, composta de casal e um filho de 15 anos, deseja alugar dois quartos em casa de outra família, também pequena. Tratar na Rua Piratininga, 99, Brás"154. Com a carestia e a elevação nos valores das locações, os senhorios preferiam rescindir os contratos (verbais ou não) com os antigos inquilinos, pois assim agindo poderiam, através de um novo contrato, aumentar o valor anteriormente pactuado. Juan Aranda que residia com a família - mulher e cinco filhos - na Rua Caetano Pinto, 89, teria sido despejado pela proprietária do imóvel sem que houvesse deixado de pagar os aluguéis, "tendo passado a noite

${ }^{147}$ EDE 15.06.1912.

148 OLIVEIRA, Maria Luiza Ferreira de. Relações sociais e experiências de urbanização. São Paulo, 1870-1900. São Paulo: Tese de doutorado, FFLCH-USP, 2003, pp. 258-259.

${ }^{149}$ EDE 01.10.1919. Tradução da autora.

${ }^{150}$ EDE 01.09.1921. Tradução da autora.

${ }^{151}$ EDE 08.08.1920. Tradução da autora.

${ }^{152}$ EDE 11.09.1921. Tradução da autora.

${ }^{153}$ EDE 01.09.1921. Tradução da autora.

${ }^{154}$ EDE 19.07.1920. Tradução da autora. 
ao relento". A proprietária, Pascualina Gacciapoluto, conforme notícia publicada no EDE ${ }^{155}$ teria se negado a receber o aluguel do último mês, em seguida apresentando-se à delegacia, formalizando uma queixa contra seu devedor que se veria despejado poucos dias depois pelo oficial de justiça e 5 soldados.

Já em 1886 os jornais publicavam anúncios de casinhas para alugar, caso do Diário Popular que as oferecia na Rua do Gazômetro, por apenas $7 \$$ ou $8 \$ \frac{156}{}$. Ali proliferaram as “construções em série das casas térreas e geminadas e, no interior dos quarteirões, vieram aparecer os cortiços"157. Assim, a pequena moradia de aluguel, o cortiço, a vila e os quintalões ${ }^{158}$ erguidos por esse tipo de investidor, responderiam pela grande maioria das habitações do Brás, representando variações de um mesmo padrão de construção coletiva.

Nos cortiços moravam até 30 famílias misturadas de espanhóis e italianos; nós cozinhávamos no mesmo quintal e usávamos o mesmo banheiro. As portas das casas ficavam sempre abertas e uns ajudavam os outros. Além disso, eu podia brigar com uma espanhola por causa de futebol, mas se alguém de fora me ofendesse, ela vinha correndo me defender ${ }^{159}$.

As brigas "por causa de futebol" certamente existiam e se manifestavam sobretudo em dias de jogo "entre o Palestra Itália e o Juventus, time da colônia espanhola". Moradores da Rua Caetano Pinto, ao observarem fotos antigas, lembravam da reação dos espanhóis durante os jogos, a cada gol do time adversário ou quando este era vitorioso: "Colocavam um boneco vestido com o uniforme do Palestra Itália dentro de um caixão e percorriam, diversas vezes, a Caetano Pinto de uma ponta a outra" " 160 . Jacob Penteado refere-se ao "Flor do Belém" como um dos times constituídos por elementos da colônia ${ }^{161}$ e Geraldina Marx indica o "Girassol Futebol Clube", do qual também participavam ${ }^{162}$. Porém, o clube exclusivo dos espanhóis no período parece ter sido o Madri constituído basicamente pelos espanhóis da Rua Santa Rosa ${ }^{163}$.

${ }^{155}$ EDE 23.06.1922.

${ }^{156}$ Diário Popular, 27.04.1886. Apud: REALE, Ebe. Brás, Pinheiros, Jardins, três bairros, três mundos. São Paulo: Pioneira/Edusp, 1982, p. 24.

${ }^{157}$ AZEVEDO, A. Op. cit., p. 233.

${ }^{158}$ O maior cortiço do Brás localizava-se na Rua Caetano Pinto e denominava-se "Quintalão"; havia também o famoso "Quintal dos espanhóis".

${ }^{159}$ Depoimento de Joana Teodósio. In: A Reconstituição da Memória Estatística da Grande São Paulo, op. cit., vol. II, p. 47.

160 RIBEIRO, Suzana Barretto. Italianos do Brás. Imagens e memórias, 1920-1930. São Paulo: Brasiliense, 1994, pp. 110-111.

${ }^{161}$ PENTEADO, J. Op. cit., 1962, p. 222.

${ }^{162}$ MARX, G. Os Humildes. São Paulo: Publisher Brasil, 1996, pp. 87 e 173.

${ }^{163}$ Ver, a esse respeito, o Capítulo II. 
Ao delimitar espaços geográficos, a expansão urbana da cidade obedecia a critérios sociais. Nos jornais, os anúncios informavam da venda dos terrenos baratos, especiais para os pobres: "Grande atenção - terrenos para os pobres" ou "pela primeira vez em São Paulo vendem-se lotes de terrenos por 200\$000, para os pobres"164. Dispostos na várzea da cidade, portanto mais baratos por serem pantanosos e sujeitos à inundação, esses terrenos formaram os primeiros bairros populares, dentre os quais o Brás. Essa segregação espacial tendeu a se acentuar, como explicita o (grande) anúncio publicitário estampado nas páginas do EDE: “Terreno para operários (alto, seco, situado em zona industrial, excelentemente calçado e todo cercado, vende-se cada lote de 10X5 ao preço total de Rs.400\$ a 500\$). Inf. Rua José Bonifácio, $30-1^{\mathbf{0}}, 165$.

Os terrenos de várzea interessavam igualmente aos industriais que os adquiriam a preços vantajosos para instalarem suas indústrias, no que eram beneficiados também pela localização das estradas de ferro para o transporte das mercadorias, além da presença maciça da população pobre que neles se fixavam atraídas pelo custo (relativamente) mais baixo das moradias ${ }^{166}$. Para Martin, tratava-se de um padrão habitacional horizontal compacto e concentrado, firmado na escassez de espaço, material de construção e tecnologia, que produziria uma paisagem urbana característica, de "casario baixo e compacto, com ruas estreitas e chaminés de fábricas pontilhando aqui e ali’167.

A transição para o século XX configuraria uma mudança estrutural no bairro do Brás, uma mudança de escala, com acentuado crescimento demográfico e variação de funções, conjunto ao qual se associaram os melhoramentos nos equipamentos e serviços urbanos, os quais tiveram uma evolução menos acelerada quando comparados à rapidez das transformações desencadeadas. Nesse ritmo frenético também caminhava a cidade em transição. Em 1886 nela existia um prédio para cada 6,8 habitantes, porém 14 anos mais tarde essa proporção já se elevara para 11,07 habitantes, isso sem contar as pessoas em trânsito pela cidade, então o mais importante entroncamento ferroviário do Estado ${ }^{168}$.

A febre das construções e loteamentos ${ }^{169}$ impulsionada pelo aumento demográfico também pode ser atribuída ao Encilhamento, fase de especulação desenfreada que caracterizou

${ }^{164}$ DECCA, Maria Auxiliadora Guzzo de. Cotidiano de trabalhadores na República. São Paulo, 18891940. São Paulo: Brasiliense, 1990 (Coleção Tudo é História), 1990, p.17.

${ }^{165}$ EDE 11.05.1914.

${ }^{166}$ DECCA, M. Op. cit., 1990, p. 22.

${ }^{167}$ MARTIN, A. Op. cit., p. 69.

${ }^{168}$ BONDUKI, N. Op. cit., p. 85.

${ }^{169}$ Sobre os loteamentos implantados no início do século XX, suas respectivas plantas e arruamentos, ver: BARBOSA, M. Op. cit., pp. 236 e ss. 
o biênio de $1890-1891^{170}$. Construía-se de 50 a 60 casas por mês em 1890, e, ainda assim, persistia a falta de moradia ${ }^{171}$. Muitos espertalhões se aproveitavam para a prática de ilicitudes, como bem descreve Afonso Schmitd: "E as assustadoras tabuletas - "Este terreno é propriedade do Dr. Garnacha" -, espalhavam-se pelos bairros, tirando o sono dos hortelãos açorianos do Marco de Meia Légua e dos leiteiros de Santiago de Compostela, que mantinham estábulos com três vacas nas ruas projetadas às margens do Tietê, ${ }^{, 172}$, narrando como se dava a apropriação indébita do terreno alheio, especialmente de pessoas falecidas sem herdeiros. Primeiro uma pequena tabuleta, depois uma maior, no ano seguinte, um muro de tijolos e a construção de um telheiro provisório onde iam morar o caseiro com a mulher e os filhos: era a posse!

Em 1886, preocupado com o agravamento da questão da moradia e das questões sanitárias daí decorrentes o poder público passa a definir, através do Código de Posturas do Município de São Paulo, uma série de "padrões municipais" quanto aos loteamentos, às ruas e às construções em geral, dedicando, a propósito, um capítulo específico aos "cortiços, casas de operários e cubículos", tipo de moradia que proliferava na cidade ${ }^{173}$.

A Câmara Municipal de São Paulo, compenetrada da grande responsabilidade que lhe pesa sobre os ombros, no quadro aflitivo de iminência da invasão pestosa, não podia proceder com maior acerto e com medida de maior alcance higiênico do que atender com particular cuidado para esses incontáveis antros de infecção a que chamamos geralmente "casas de habitação coletiva" ou mais precisamente cortiços ${ }^{174}$.

Surtos epidêmicos eram freqüentes na cidade, e os cortiços eram tidos como focos irradiadores fazendo muitas vítimas (a que estavam sujeitos também outras camadas da população), como o grande surto ocorrido em 1893, o que deve ter motivado a criação de uma Comissão de Exame e Inspeção das Habitações Operárias e Cortiços, que produziu Relatório homônimo que assim descrevia as então péssimas condições de habitação:

Há ainda a casinha, como prédio independente, com frente para a rua pública e apenas considerada cortiço pelo seu destino e espécie de construção. Pequena e insuficiente para a população que abriga, não oferece garantia alguma pelo que respeita a higiene. $\mathrm{O}$

${ }^{170} \mathrm{O}$ termo foi aplicado por analogia. Designava-se encilhamento "o momento, nas corridas de cavalo, em que estes estavam encilhados antes da largada, e o jogo dos apostadores chegava ao frenesi”. Queria designar nesse momento "os lances dos investidores na compra e venda de ações de companhias diariamente constituídas, em escala desmedida". Cf. GORENDER, Jacob. A burguesia brasileira. São Paulo: Brasiliense, 1981, p. 27. Crédito fácil e proteção alfandegária representaram a condição com que se beneficiaram inúmeras sociedades e bancos criados em 1890.

${ }^{171}$ HOMEM, Maria Cecília Naclério. O palacete paulistano e outras formas urbanas de morar da elite cafeeira. São Paulo: Martins Fontes, 1996, p. 125.

${ }^{172}$ SCHMIDT, Afonso. Mirita e o ladrão. São Paulo: Clube do Livro, 1960, p. 51.

${ }^{173}$ BONDUKI, N. Op. cit., p. 85.

${ }^{174}$ Folha do Braz, ano III, no $89,12.11 .1889$. Apud: BONDUKI, N. Idem, ibidem. 
soalho sem ventilação e assentado sobre o solo, o forro sem ventilador, os cômodos pequenos e ainda subdivididos por biombos que os fazem ainda mais escuros, as paredes sujas e ferido o reboco que deixa perceber a má qualidade da alvenaria. No fundo, uma área exígua, mal ladrilhada ou cimentada com um ralo para esgoto e uma latrina ordinária sem abrigo. A cozinha, quando não é ao lado da latrina, está assentada junto do aposento de dormir e então as condições de asseio são as mais precárias possíveis $^{175}$.

Esta Comissão, no rastreamento das habitações dos pobres da cidade, identificava basicamente cinco tipos de "cortiços", o mais comum, o cortiço-pátio, ocupando uma área perpendicular no interior do quarteirão, com o máximo aproveitamento do terreno e das paredes comuns, que eram construídos por investidores para aluguel:

Um portão lateral dá entrada por estreito e comprido corredor para um pátio de 3 a 4 metros de largo nos casos mais favorecidos. Para esse pátio ou área livre se abrem as portas e janelas de pequenas casas enfileiradas, com o mesmo aspecto, a mesma construção, as mesmas divisões internas e a mesma capacidade. Raramente cada casinha tem mais de 3 metros de largura, 5 a 6 de fundo e altura de 3 a 3,50 m., com uma capacidade para 4 pessoas quando muito ${ }^{176}$.

Outras construções improvisadas de moradia tornavam-se comuns neste período e também aqui eram identificadas pela Comissão: é o caso das "casas de cômodos", sobrados convertidos em cortiços para famílias numerosas, transformados em "casas de dormida", com alguns cômodos de uso comum "uma sala com vários fogões (...) umas latrinas pessimamente instaladas e compridos corredores com iluminação insuficiente"; o cortiço-casinha, casa com frente para a rua pública e assim considerada tão somente por sua função; o hotel-cortiço, espécie de restaurante onde a população, geralmente homens solteiros, se aglomera à noite, para dormir, em aposentos reservados ou comuns; e aquilo que já poderia ser identificado como o protótipo das primeiras favelas, "os telheiros de zinco", barracos de tábua em geral instalados nos fundos dos depósitos de materiais de construção ${ }^{177}$.

Essa era, de modo geral, e apesar do fervilhante ritmo da construção civil na cidade ${ }^{178}$, a precária condição da habitação das camadas populares, a crítica situação da moradia dos pobres

${ }^{175}$ DECCA, M. Op. cit., p. 18. Referia-se especialmente ao Distrito de Santa Efigênia.

${ }^{176}$ Passim, p. 19. "Relatório da Comissão de Exame e Inspeção das Habitações Operárias e Cortiços no Distrito de Santa Efigênia, 1893”. In: Relatório do Intendente Municipal. São Paulo: Tip. A.Vap. de Espíndola, Siqueira e Companhia, 1894, pp. 46-47.

${ }^{177}$ DECCA, M.A. Op. cit., p. 20 e BONDUKI, N.G. Op. cit., p. 87.

${ }^{178}$ Conforme CARNEIRO LEÃO, A. (São Paulo em 1920. Rio de Janeiro: Annuário Americano, 1920, p. 12), de 1900 a 1918 o número de construções cresceu em 300\%. Eram 22 mil prédios em 1900 e 60 mil, 18 anos depois, e, ainda assim, o problema perdurava "e se calcula haver uma necessidade urgente de cerca de 15 mil prédios para acomodar a população da Capital". 
na Paulicéia, acentuada pela avalanche de novos habitantes que a ela acorria continuamente, exacerbando o problema nos locais mais populosos, caso do bairro do Brás.

Os bairros em que mais se concentram, por ser os que contêm o maior número de fábricas, são os do Brás e do Bom Retiro. As casas são infectas, as ruas, na sua quase totalidade, não são calçadas, há falta de água para os mais necessários misteres, escassez de luz e de esgotos. O mesmo se dá em Água Branca, Lapa, Ipiranga, São Caetano e outros pontos um pouco afastados ${ }^{179}$.

Com o editorial "problema de vivienda", o $\mathrm{EDE}^{180}$ comenta a crise de habitação na cidade, avançando para a terceira década do Novecentos, provocada, segundo ele, pela escassez e mesmo pela absoluta falta de material de construção, o que provocaria o encarecimento e impediria a edificação de casas, aumentando sobremaneira os preços dos aluguéis.

Os anúncios publicitários para venda de lotes, estampados no EDE, utilizavam farta argumentação, ressaltando em um dos casos que "o custo das casas em V. Moreira é mais barato porque existe no local uma grande fábrica de telhas e pisos, areia grossa, tudo vendido

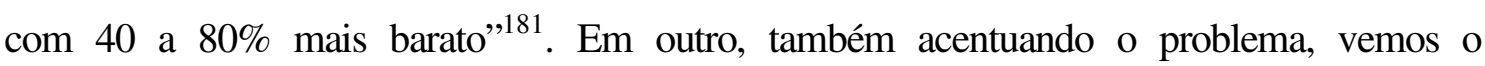
aperfeiçoamento dos argumentos na conquista e convencimento do público-alvo: "em vista do aperto que há nesta capital, alta constante do material e da mão-de-obra e a aproximação dos grandes festejos de 1922, valerá mais de 60 contos caso o comprador queira vendê-la [a casa anunciada]"182. Em mais outro, no lançamento do Parque Imperial, loteamento na continuação da Rua Domingos de Moraes, havia um “automóvel à disposição dos interessados” em conhecê-lo e os nomes de quem já o adquirira, à disposição ${ }^{183}$.

A construção das vilas operárias, de 1911 em diante, alcança essa conjuntura em andamento. Por ocasião da inauguração da fábrica Maria Zélia, em 1911, “os tecelões fizeram fila para conseguir vaga no recém-instalado estabelecimento fabril" que, entre outras vantagens, oferecia moradia a preços razoáveis aos seus empregados ${ }^{184}$.

Sua ocorrência revelou-se iniciativa irregular e irrisória frente às necessidades de moradia da capital, onde, apesar do número de indústrias, seu número era insignificante: um levantamento feito pelo Departamento Estadual do Trabalho em 1919 revelaria que, das 227 indústrias pesquisadas no Estado de São Paulo, somente 37 dispunham de casas para seus

${ }^{179}$ BANDEIRA JR., Antonio Francisco. A indústria no Estado de São Paulo em 1901. São Paulo: Typ. do Diário Oficial, 1901, p. XIV.

${ }^{180}$ EDE 31.10.1919.

${ }^{181}$ A Vila Moreira mencionada situava-se na altura do $n^{\circ} 872$ da Celso Garcia, nas franjas do bairro do Brás. EDE 07.10.1922. Tradução da autora.

${ }^{182}$ EDE 26.07.1920. Tradução da autora.

${ }^{183}$ EDE 15.12.1922. Tradução da autora.

${ }^{184}$ PENTEADO, J. Op. cit., 1962, p. 111. 
operários, e que, destas 37 , apenas 11 estavam localizadas na capital ${ }^{185}$. E lembremos que a massa do operariado constituía apenas uma parcela da população, restando um outro enorme contingente que, cada qual à sua maneira e possibilidade, tentava contornar a questão.

No caso dos espanhóis, excetuando-se a maioria instalada no Brás que progressivamente aumentaria espraiando-se por outros logradouros próximos, pertencentes ao vizinho bairro da Moóca, vemos pipocar domicílios informados nos LRC que se pulverizariam por outros locais mais distantes deste núcleo. O bairro do Bom Retiro, especialmente a Rua dos Imigrantes (hoje Rua José Paulino), foi um desses locais, onde, desde os primeiros registros, os encontraríamos. Contudo, outro contingente menor foi localizado vivendo em alguns pontos mais extremos da cidade ${ }^{186}$ - Lageado (hoje Guaianases), Penha, Água Branca, Alto da Serra, por exemplo -, já na última década do Dezenove, espraiando-se depois para outros "subúrbios", caso de São Caetano que, especificamente a partir de 1911, passa a concentrar um crescente contingente de espanhóis.

Nabil Georges Bonduki ${ }^{187}$ na análise que faz do período de 1886 a 1918, indica, dentre as práticas então utilizadas para a solução da questão da casa própria, a aquisição de lotes longínquos e desprovidos de equipamentos urbanos.

O Lajeado (hoje, Guaianases) formava com Itaquera uma antiga fazenda dos padres carmelitas, região atravessada pelos trens da antiga Companhia São Paulo e Rio de Janeiro, hoje Central do Brasil ${ }^{188}$. Este local parece ter-se progressivamente constituído em um núcleo de espanhóis que, em 1897, já foram localizados ali domiciliados e, ainda que não possamos assegurar, parece provável que exercessem atividades relacionadas à estrada de ferro. Em 1922, a propósito, o EDE publica nota informando da "morte de Antonio Gómez, espanhol, na Santa Casa, motivada pelas queimaduras que sofrera quando trabalhando em Lajeado, na linha da Central"189. Ofertas de lotes ou "terrenos à prestação" naquela região afastada também

${ }^{185}$ BONDUKI, N.G. Op. cit., p. 96. O autor examina essa questão ponderando as reais motivações que levaram à sua construção, dentre elas, a necessidade operacional das indústrias mais afastadas. Considera, no entanto, mais importantes as iniciativas de empresários, construtores e investidores particulares, empresas imobiliárias e sociedades mutuarias na construção dos conjuntos de casas unifamiliares, como a Vila Economizadora (a primeira delas construída entre 1908 e 1910, situada na Rua São Caetano entre a Rua da Cantareira e a Avenida do Estado), por exemplo, que, no entanto, se destinava, por sua própria natureza, aos setores mais bem remunerados do operariado e às camadas médias da população.

${ }^{186}$ A respeito das paróquias periféricas da cidade e sua evolução, consultar: MARCÍLIO, M. L. Op. cit., 1973, especialmente p. 40 (São Bernardo; Juqueri); p. 47 (Juqueri, S. Amaro, N. S. do Ó, Cotia, Nazaré, Atibaia, Jaguari, S. Bernardo e Santana); p. 54 (a "separação" eclesiástica e "civil” das 15 localidades da Sé) e p. 103.

${ }^{187}$ BONDUKI, N. Op. cit., 1982.

${ }^{188}$ AZEVEDO, A. Op. cit., pp. 55 e ss.

${ }^{189}$ EDE 28.07.1922. Tradução da autora. 
passariam a frequientar as páginas do $\mathrm{EDE}$, antes mesmo que fosse servida por transporte de passageiros:

Oferta de lotes de terrenos à prestação - Empresa Paulista de Terrenos, de Bellandi, Pinto \& Comp. - Vila Cosmopolita, [situada no] bairro denominado Passagem Funda, distante da estação de Lageado 1.500 metros, e já servida por um ramal da Central do Brasil, que atualmente conduz os produtos de muitas olarias e de diversas pedreiras da região, estando previsto para breve também o transporte de passageiros. A estação de Lajeado é servida por 10 trens diários de subúrbio. Inf. Rua Quintino Bocaiúva, 4 - $1^{\circ}$ andar, Palacete Lara ${ }^{190}$.

A Penha, e especialmente a Vila Matilde e a Vila Esperança são tradicionalmente tidas como bairros de concentração de espanhóis ${ }^{191}$. Jacó Penteado também se referiu aos "galegos da Vila Carrão"192. Ali já residiam dois irmãos, procedentes de Navarra (Lucas e Damaso Berrois), que se registraram no CGE como "industriais", em 1896. Não temos como identificar a natureza da citada indústria, porém imaginamos que devesse se vincular a alguma atividade relacionada ao fabrico de tijolos nas olarias localizadas às margens do Rio Tietê que se constituíram elemento característico daquela paisagem ${ }^{193}$.

A Penha protagonizará uma das festas mais importantes da colônia ${ }^{194}$, a Romería Espanhola, que se realizava no Parque São Jorge. Aí também residia um próspero emigrante, Antonio Nieto Cortés Ruano, que possuía uma finca (chácara) com uma gruta e "esplêndida capela", construída em homenagem a N. Sa de Lourdes, na qual realizou uma festa em comemoração ao retorno da viagem que fizera à Espanha, com missa, procissão, fogos de artifício e bandas de música a que compareceram "pessoas da elite da capital". A nota do EDE, complementa: "apesar de sua riqueza, D. Antonio não abandona a vida de trabalho que se impôs, e continuará administrando os estabelecimentos comerciais e as fincas que possui na capital e na Penha"

Com a inauguração da Companhia Inglesa, em 1867, a Água Branca, por sua posição estratégica, numa bifurcação de caminhos, foi escolhida para sediar uma estação entre São Paulo e Perus. A partir daí, o diminuto núcleo, que até então servira como pouso aos viajantes, teve um impulso considerável, aumentado com a descoberta de um tipo de areia de excepcional qualidade, em 1895, o que motivou a abertura da empresa Prado \& Jordão, de Antonio da Silva

${ }^{190}$ EDE 19.11.1921. Tradução da autora.

${ }^{191}$ DIEGUES JR., Manuel. Imigração, urbanização e industrialização. Estudos sobre alguns aspectos da contribuição cultural do imigrante no Brasil. Rio de Janeiro: Centro Brasileiro Pesquisas Educacionais, 1964, p. 174 (Vila Matilde) e AZEVEDO, Aroldo. Subúrbios orientais de São Paulo. Tese de concurso à cadeira de Geografia do Brasil $\left(X X X V^{a}\right)$ da FFLCH-USP, 1945, pp. 53 e 78 (Vila Esperança e Vila Matilde).

192 PENTEADO, J. Op. cit., 1962, p. 97.

193 AZEVEDO, A. Op. cit., 1945, p. 79.

${ }^{194}$ Ver, a respeito, o Capítulo IV.

${ }^{195}$ EDE 12.05.1920 e 21.06.1921. Tradução da autora. 
Prado e Elias Fausto Pacheco Jordão, embrião da Vidraria Santa Marina, que, apenas 10 anos depois já empregava 400 operários. Essa vidraria, que na primeira década protagonizará uma greve de proporções, dispunha de casas de aluguel para seus empregados, provavelmente por estar situada em bairro mais distante, e em seu regulamento constava que a casa deveria ser desocupada em 8 dias após a dispensa do empregado. Na greve de 1909 ocorreu que os grevistas e suas famílias foram desalojados, sendo que a empresa aceitou reabilitar apenas os que não fossem considerados os cabeças do movimento ${ }^{196}$, evidenciando, assim, o verdadeiro intuito dessas concessões.

O ofício de vidreiro era extremamente sacrificado, conforme comenta Jacob Penteado que, menino como muitos, passou a trabalhar em uma vidraria, a Cristaleria Itália de onde relata a rotina desses menores, de até 7 anos de idade, alguns como o "espanholzinho, o Fantomas", que se submetiam, por vezes, a até 15 horas diárias de exaustivo trabalho, submetidos aos maus tratos dos vidreiros mais velhos ${ }^{197}$. Dos inscritos no CGE domiciliados na Água Branca, encontramos poucos "vidrieros" e muitos "jornaleros" assim declarados, então trabalhando na Cristaleria Santa Marina, alguns indicando como domicílio a "Vila Santa Marina”. Constatamos também no bairro a existência de espanhóis lá residentes desde 1893 que declaravam ter outra ocupación ${ }^{198}$. Dos vidrieros inscritos, no entanto, sintomaticamente nenhum da Andaluzia - "um oficial de vidreiro não se improvisa. São necessários vários anos de aprendizado, percorrer todas as escalas"199. Vinham de Barcelona, Navarra, Santander, Orense e Leon ${ }^{200}$.

O bairro da Água Branca deve ter sido gradualmente habitado por um número crescente de espanhóis, a considerar a convocação, em 1913, para uma assembléia a ser realizada na "Rua Sertão, 2, Água Branca”, com a colônia ali residente, para a criação no local, de uma seção da $\mathrm{FE}^{201}$. Eiras Garcia também ali investira: em 1919, anunciava-se no EDE a venda de um lote de 3 mil metros na Rua Guaicurus, Estação da Água Branca, "próprio para uma fábrica”, a ele pertencente $^{202}$.

${ }^{196}$ DECCA, M. Op. cit., p. 27.

${ }^{197}$ PENTEADO, J. Op. cit., 1962, p. 117 e ss.

${ }^{198}$ A primeira inscrição indicando o local como domicílio, de 1893, foi de Manuel Maldonado Rallego, um zapatero, solteiro, de trinta anos, natural de Badajóz (Extremadura).

${ }^{199}$ PENTEADO, J. Op. cit., 1962, p. 120.

${ }^{200}$ Relatório Access 28.

${ }^{201}$ EDE 28.11.1913.

${ }^{202}$ EDE 18.10.1919. Em edição anterior, no mesmo mês, o mesmo proprietário vendia 500 alqueires em cidade do interior (ilegível). Anteriormente, em outra edição (ilegível) e novamente no EDE 01.12.1919, a oferta da venda de 500 alqueires de terras situadas a pouco mais de três léguas da Estação Lusanvira, na Noroeste, próprias para o café. Provavelmente tais vendas se destinassem a levantar fundos para a manutenção do periódico EDE. 
A Lapa, como extensão da Água Branca, também passará a concentrar um gradativo contingente de espanhóis, com flagrante vinculação ao Frigorífico "Armour", instalado no "km. 10", ambas as citações constantes nos LRC a partir de 1918 com clara alusão à vinculação desse elemento com a empresa ${ }^{203}$.

Ao examinar os primeiros indícios dos locais de moradia da população espanhola então residente na cidade, para além desses parâmetros avaliados e outras indicações que serão incorporadas no decorrer do trabalho, percebemos o hábito (ou a necessidade) de se residir no próprio local de trabalho, aspecto flagrantemente comum para os inscritos que se declararam empleados. Neste caso, observamos alguns hotéis indicados como domicílio, mas igualmente uma série de logradouros reconhecidos como tipicamente comerciais, tais como a Rua Boa Vista e a Duque de Caxias, onde despontava um comércio promissor, para citar os mais convencionais. Porém, ao lado desses, um local incomum, eufemismo para bizarro, a "cocheira" existente na Rua do Brás, que aparece como a residência de um jovem de 15 anos, na mesma categoria, a dos empleados. No final da Rua do Brás, a propósito, ficavam as cocheiras dos burros que puxavam os bondes movidos por tração animal que até 1918 circularam no Brás ${ }^{204}$.

Para São Caetano, antigo núcleo colonial que se estabeleceu, na década de 1870, nas antigas terras da Fazenda São Caetano, seu volume foi inexpressivo até 1917, quando considerado o crescente afluxo observado nos anos posteriores, revelando expressiva acorrida ao CGE especialmente no ano de 1919.

As primeiras referências a esse local como domicílio começaram a surgir a partir de 1911, ao lado da indicação "estação de trem" ou "linha inglesa". A estação da estrada de ferro "inglesa" seria inaugurada somente em 1883, ainda que, como bem pontuou Pasquale Petrone, o crescimento do local não tenha se dado ao longo da via férrea, mas paralelamente, em terrenos mais elevados ${ }^{205}$.

Tratava-se de indivíduos em sua maioria casados e jornaleros com grande incidência de naturais da cidade de Cáceres (Extremadura). A partir de 1918, outras ocupaciones, embora em menor proporção, começarão a ser citadas para essa localidade, como a de fundidor e a de laminador, esta última em maior percentual que a anterior. Nesse caso, em quase maioria absoluta, os indivíduos eram provenientes de Oviedo (Astúrias). Cabe ao fundidor, que trabalha

203 A análise do espanhol enquanto operário está no Capítulo II. Neste, as referências são apenas circunstanciais, envolvendo o domicílio então mencionado nos LRC.

${ }^{204}$ RIBEIRO, S. Op. cit., p. 107.

${ }^{205}$ PETRONE, P. Op. cit., 1955, p. 132. 
com o ferro, a moldagem de peças de metal, e ao laminador, como o próprio nome indica, comprimindo massas de metais maleáveis, convertê-las em lâminas. Tais ocupaciones provavelmente se vinculassem ao estabelecimento, naquela localidade, da The Anglo Brasilian Forging Steel Structural and Importing Co. Ld., empresa de capital inglês que passou a operar na década de 1910 com a fundição de ferro e aço, com isenção de impostos. Tal empresa daria origem à Companhia Mecânica Importadora ${ }^{206}$.

A cidade contudo ficou famosa por suas olarias - de onde teriam sido produzidos os tijolos para a construção do Museu do Ipiranga -, fato aliás que motivou um livro que falaria de suas “torbas”207. Teria tido, apenas em 1914, 23 unidades, aí incluída a Cerâmica São Caetano, e tem no atual bairro de Monte Alegre, as reminiscências da presença espanhola na cidade ${ }^{208}$. A "Villa Monte Alegre", fundada em 1912 era local muito procurado para compra de terrenos pelos espanhóis, conforme se pode atestar pelos anúncios que encontramos no EDE, publicados pelo alemão Samuel Heinsfurter e pelo italiano Francisco Canger, pelos quais enalteciam o local pela existência de "terrenos arruados" e de fábricas já ali instaladas ${ }^{209}$. Braço direito e amigo dos dois criadores do bairro, o espanhol Joaquin Gutierrez, carvoeiro que com sua carroça entregava carvão no Brás e no Canindé, aproveitava, entre suas andanças, para divulgar entre seus compatriotas, a "gran oportunidad" ${ }^{210}$, fator que deve ter sido preponderante na atração de muitas famílias espanholas para aquele lugarejo distante. Ele, chegado ao Brasil em 1911, havia sido, aliás, o primeiro comprador de um dos lotes à venda, no qual construiu um cômodo. Seu filho Afrodisio, conforme relato de seu neto Geraldo ${ }^{211}$ teria estudado em um seminário na Espanha e, uma vez em São Caetano, teria ensinado muitas pessoas a ler e a escrever. Mais tarde, Afrodisio, do qual localizamos uma inscrição no $\mathrm{CGE}^{212}$ se tornaria o presidente e o diretor cênico da Sociedade Recreativa Monte Alegre.

${ }^{206}$ MEDICI, Ademir. Migração e urbanização. A presença de São Caetano na região do ABC. São Paulo/São Caetano: Editora Hucitec-Prefeitura de São Caetano do Sul, 1993, pp. 49 e ss.

${ }^{207}$ PERRELLA, Nicola. Entre as tórbas de São Caetano. São Paulo: Ed. Alarico, 1961. Torba: terra negra, turfosa, característica das várzeas e usada na fabricação de tijolos. $C f$. Dicionário Eletrônico Houaiss da língua portuguesa 1.0.

${ }^{208}$ MEDICI, A. Op. cit., pp. 31 e 55.

${ }^{209}$ EDE 04.03.1920.

${ }^{210}$ MEDICI, A. Op. cit., p. 346.

${ }^{211}$ XAVIER, Sônia Maria Franco e PATRÃO, Jayme. "A presença espanhola em São Caetano do Sul”. In: Revista Raízes. São Caetano: ano IV, n. 8, dez 1992, p. 18.

212 Afrodisio Januário Gutierrez Fernandez, natural de Ávila (Castilla-León) esteve no CGE em 1917, tinha, então, 20 anos e se declarou jornalero. 


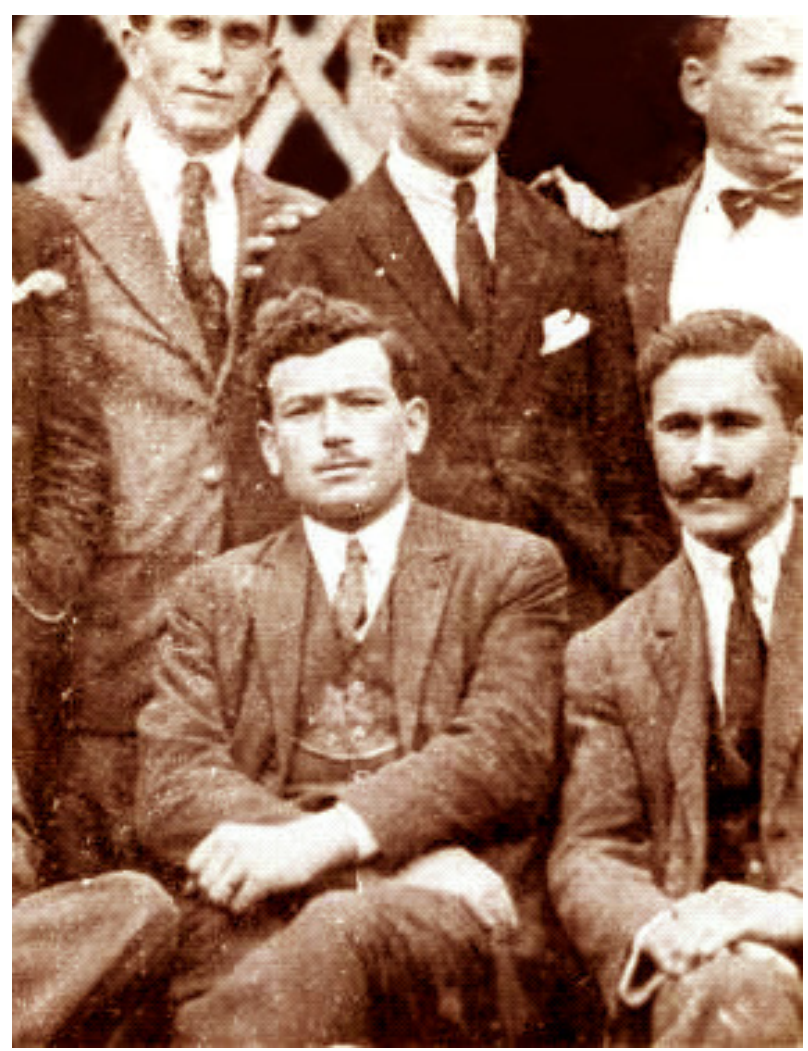

Fig. 1. Afrodisio Gutierrez, diretor cênico da Sociedade Monte Alegre (sentado, ao centro), c.1918.

O fato é que, já em 1918, ali encontramos instalado um Restaurante Español, de Suarez \& Infiesta, locais onde se podia comer "fabes con llacon (sic) e marciella",213. Laureano Suarez Vazquez e Fernando Suarez Enterria, ambos casados, naturais de Oviedo e seguramente aparentados, eram os prováveis sócios, no restaurante, de Francisco Infiesta Fernandez, também casado e natural de Vizcaya (País Basco) ${ }^{214}$. Com respeito ao estado civil dos espanhóis ali radicados, notamos nos registros femininos um expressivo número deles cuja naturalidade da mulher (esposa) era italiana, evidenciando a forte presença desse contingente também naquela localidade $^{215}$.

${ }^{213}$ EDE 04.01.1918.

${ }^{214}$ Relatório Access 56. Os citados registros foram realizados no CGE no ano de 1919.

${ }^{215}$ A respeito da evolução de São Caetano do Sul e da presença de espanhóis na cidade, ver também: MARTINS, J. Op. cit., 1979, p. 163 e ASCENCIO, Yolanda. "Imigrantes espanhóis que lutaram e venceram em São Caetano: Família Pereira Otero". In: Revista Raízes. São Caetano do Sul: ano IX, n. 17, jul. 1998, pp. 44-45. 
Era um dinâmico espanhol que nesse tempo vendia sua mercadoria para nossa "italianada" ... Era ele que ali estava com sua valise bastante "gorda" para vender sua mercadoria...

-É ... í te volêvo mesmu incutrá ... U sinhore mi vendeu uma belíssima róba... Uma róba qui era mesmu "uma bela róba"...

- Mas que queria ustê com tan pocu dineru?... Vm ternu di cacimira... Um sombreru i um par de Gurzeguim, todo essu porvinte mil réis.

O italiano havia comprado um terno de casemira, um chapéu e um par de botinas por apenas vinte cruzeiros, ou melhor, vinte mil réis desse tempo, mas, parecia sentir que o espanhol o havia embrulhado... Porisso, retrucara novamente:

- Ma guarda.. Guarda, espanhuôlo ... Óia come ío devu levá u capelu im gopa da cabeça... Num entra mais... Ficô tutu apertatu... $U$ capelu si a inculhito (o chapéu havia encolfiido).

O espanhol olhando para seu interfocutor com um sorriso talvez de malícia, enrolando a pontinha do seu bigode, fôra logo respondendo:

- Essu num és nadie, mi amigo... El sombrero si puede alargá... És um chapéu di buena qualidá...

- Ma, porca miséria.. Côme vamu alargá u capelu si giá istá tuto inculfitu? I issu num é nata, spanhuôlo... V ternu qui mi a venduto, tive qui dá pru meu filhu...

- Bueno... Bueno, ustê ês um bom pai... La madre de seu filho si quedô contente com nissu...

- Bela canzione... Bela canzione u sinhore está falando agora... As butina tive que pinxá fora... Era molto grande pru meu filfu... Pórco-ladro, u sinhore me a embrulhato, má fregátu, mais num mi aciapi quiú (o senhor me (udibriou, mas não me pega mais).

- Êstu num ês nad́a para ustê... Tiengu aqui otrus sombreru de melhor qualidá... Tiengu cacimira muxu buena... Tiengu um "ternito" qui fuê encomendado para seu corpo... Sôlo... Sôlo es um pouquito mas caro.

- Ma vá via... Vá via spagnuôlo... ío giá disse... Giá disse que aqui...

- Calma... Calma hombre... Garanto a ustê que puede chover molhado $i$ esta mercadoria num se vá incolher... Aqui agora ês tudo de buena qualidá..

- Giô garantu... Giô garantu que ustê vai fazê um alto negócio...

- Vá béne... vá bene, vamu a vê u qui tem di buono... Má óia lá bem spanhôlo... Si num é coisa buona di verdate... Unaltra veiz é melhore tocá diréto... Ti pinxu us caxorru pur cima...

- Entonces voi a trazer bistécas para los animales....

Nicola Perrella, Entre as tórbas de São Caetano 


\section{Protagonistas de uma economia invisível}

No Capítulo anterior procuramos discutir, a partir das fontes pesquisadas, alguns modos efetivos de incorporação do espanhol na atividade produtiva da cidade e apontamos para a relativa participação, não obstante sua ainda pequena representação numérica, em alguns setores ou atividades econômicas então evidenciados. No entanto, a par disso, salientamos o progressivo percentual observado no decorrer do período integrando a rubrica de jornaleros, transportada na bagagem imaginária dos imigrantes e que, apesar de sua ancestralidade, apenas muito recentemente passou a merecer a atenção da historiografia daquele país: "no existe documentación que haga referencia a ellos, al margen de las disposiciones oficiales y de los documentos censales", diria Peiró Arroyo, e, desse modo, "lo que de ellos conocemos procede de fuentes indirectas",

Nesse particular, especialmente a literatura e, mais particularmente, a de época, revelouse recurso inestimável, através do qual pudemos desvendar alguns aspectos mais característicos dessa categoria, classicamente associada ao campo e indissociavelmente vinculada a uma trajetória prévia em seu país, de trabalho "a jornal" (por dia, por mês ou por temporada) e que, nos finais do Oitocentos, ocupava 3/4 partes da população, mantendo-a "en paro" por mais de 6 meses ao ano $^{2}$.

Essa modalidade, historicamente transposta para as cidades - estudos atuais revelam sua presença em um "marco urbano" -, provavelmente por apresentar as mesmas condições de descontinuidade, traduzia-se, concretamente, por uma mão-de-obra transitória e casual que, deslocada para o país hospedeiro, passou a ser utilizada, conforme percebemos, indistintamente também nas cidades.

Na cidade de São Paulo, parece ter denotado, de imediato, a vinculação a atividades e ocupações eventuais e de pouco ganho, a pequenas incumbências ocasionais, ao subemprego e a serviços autônomos, enfim, a inumeráveis atividades improvisadas e marginais ao processo produtivo da nova conjuntura urbana que, por suas características, se apresentam de difícil aferição documental. Essa constatação, a da existência de uma vasta rede de atividades à margem dos registros oficiais, prosperando ao mesmo tempo em que tomava forma a futura

\footnotetext{
1 PEIRÓ ARROYO, Antonio. Jornaleros y mancebos. Identidad, organizazión y conflicto en los trabajadores del Antiguo Régimen. Barcelona: Crítica, 2002, p. 61.

${ }^{2}$ Para um quadro mais amplo do contexto espanhol do período, $c f$. BRENAN, Gerald. El laberinto español: antecedentes sociales y politicos de la guerra civil. Madrid: Ed. Ruedo Ibérico, 1962, p. 97. Sobre as condições de vida jornalera, $c f$. BLASCO IBAÑEZ, V. La bodega (novela). Valencia: Prometeo, 1919.

${ }^{3}$ PEIRÓ ARROYO, A. Op. cit., p. 64, referindo-se especificamente a Zaragoza.
} 
metrópole, nutrida por diversos indicadores, destacadamente os literários de época, ganha sentido e corpo e se reforça, no caso específico do espanhol, pela evidência inequívoca do progressivo aparecimento de uma maioria jornalera então habitando na cidade. Nessa perspectiva, e considerando as limitações documentais, procuraremos delinear algumas probabilidades de incorporação desse elemento à atividade produtiva, ao mundo do trabalho, enfim, iniciando por focalizar aquelas que, por sua própria natureza e características estariam incluídas na chamada "economia invisível" - porquanto "oculta, subterrânea, submersa, informal, paralela, não-oficial, negra"4 - buscando, nessa trilha, reconstituir formas e dimensões peculiares dos modos efetivos encontrados para sua sobrevivência.

Fundamental nessa recuperação, a análise de Maria Inez M. B. Pinto que investigou detidamente a estrutura do mercado de trabalho da metrópole paulistana do período, alertando para a "predominância acentuada e a proliferação das pequenas ocupações autônomas e do trabalho informal" os quais, em decorrência da sua característica basicamente "paralela" ou "oculta" escaparam às classificações formais, às estatísticas, aos recenseamentos e aos registros oficiais $^{5}$, circunstância que dificulta a sua aferição e, logo, o seu exame.

Operando com o conceito - o de setor informal - e mencionando pesquisas recentes, Maria Izilda de Matos $^{6}$ procura alertar para o conveniente de se evitar a imediata polaridade entre informal/arcaico e formal/moderno, sem levar em conta a sua vinculação a um determinado momento histórico, percebendo, deste modo, o "informal" apenas como o residual e ultrapassado. A autora, frente ao processo de formação do mercado de trabalho livre em São Paulo e das múltiplas formas passíveis de vinculação à categoria informal, insiste na necessidade da análise de sua emergência, construção e inserção que, afirma, está inscrita em "processos históricos datados". O que no fundo a autora defende é a impossibilidade em se rotular imediatamente de informal com toda a carga subjacente, inclusive de ilegalidade em alguns casos, a determinados espaços econômicos que puderam ser explorados de forma apenas "diferenciada" através das brechas que se abriram e se modificavam ao sabor das necessidades apresentadas pelo mercado da metrópole em expansão.

No caso específico do jornalero na cidade de São Paulo, categoria imediatamente associada à informalidade, não seria despropositado sugerir a hipótese, frente às cifras astronômicas que passou a apresentar a categoria no decorrer dos anos analisados, de que pode

\footnotetext{
4 “A Economia Invisível”. In: Revista Exame, 02.05.1984, p. 26.

${ }^{5}$ PINTO, M. I. "Pequenas ocupações autônomas e trabalho informal: a economia invisível". In: Op. cit., 1984, pp. 101 e ss.

${ }^{6}$ MATOS, Maria Izilda. Cotidiano e Cultura. História, cidade e trabalho. Bauru: EDUSC, 2002, pp. 50 e SS.
} 
ter ocorrido, por parte do imigrante, no ato da sua inscrição no CGE, qualquer que fosse a sua qualificação, ofício ou mesmo profissão, uma propensão a declarar-se jornalero, em caso de encontrar-se circunstancialmente desempregado ou subempregado. Lembremos que a sua ida ao Consulado, a rigor obrigatória, geralmente se movia por questões práticas, como necessidade de um documento de identificação, por exemplo, muitas vezes exigido no ato da contratação formal. É provável assim que, quando diante do escrevente e inquirido sobre sua ocupación, muitos deles, sem qualquer vínculo empregatício no momento, tivessem a inclinação de declarar-se jornalero.

Essa hipótese não é aleatória. Em extenso editorial em que comentava a respeito dos candidatos à emigração, das expectativas que nutriam e do desapontamento quando em contato com a realidade local, especialmente pela crônica falta de emprego, o EDE apontava o caso de um padre que "desistiu e foi trabalhar como vendedor ambulante de legumes e frutas", alertando que muitos aqui chegavam, iam para o campo "sem saber o manejo de uma enxada", citando como exemplo "telegrafistas, tipógrafos, eletricistas, guarda-livros, desenhistas, periodistas e professores"7.

Conduzindo essa hipótese, realizamos a análise individual, caso a caso, do banco de dados das inscrições nominais "duplicadas", i.é., daquelas em que um mesmo declarante apareceu com mais de um registro no CGE, dentre as quais destacamos aqueles em que pelo menos uma das ocupaciones mencionadas fosse a de jornalero, variável à qual cruzamos outros indicadores documentais disponíveis, consulta que, se em alguns casos pareceu vir ao encontro da suposição acima posta, reforçou, pela alternância contínua de ofícios, o quadro de extrema volatilidade ocupacional revelador desse tumultuado momento da Paulicéia.

$\mathrm{Na}$ afirmação do pressuposto, casos como o do malaguenho Sisto Moreno Rodriguez que, em seu primeiro registro em 1894 e nos subseqüentes (1896/7) declarou-se carpinteiro, mas que, no registro efetuado em 1906, dizia-se jornalero, indicativo de que, provavelmente, naquele momento estivesse desempregado. O caso de Patrício Ribas Rodriguez, de Granada, é ainda mais revelador de como a apropriação da rubrica de jornalero muitas vezes decorreu de circunstâncias aleatórias ou até certo ponto injustificadas. Nos registros efetuados em 1918 e 1919 declarava-se com comércio e estabelecido na Rua Silva Bueno, 81. Porém, no registro de 1920, ainda mantendo o mesmo domicílio (com ou sem o comércio, não sabemos), declarou-se jornalero, retornando à rubrica anterior em 1921 (comércio), sem haver, no entanto, alterado o domicílio onde, aliás, possuía duas casas e mantinha um comércio de tecidos, os quais, através

\footnotetext{
${ }^{7}$ EDE 14.05.1913. Trad. da autora.
} 
de oferta pelo EDE punha à venda em 1920, com outros 100 alqueires de terra na Sorocabana, a três léguas da estação, ao preço de $60 \$ 000$ o alqueire. O motivo alegado para a venda, também anunciado, era de "viagem à Europa"8 fato que, para um jornalero, seria inimaginável.

Também de Granada, Antonio Sanchez Rodriguez pareceu indicar eventual falta de emprego quando se declarou jornalero. Mecânico nos dois primeiros registros (1915/6), no seguinte já se declarava jornalero (1917), retomando à categoria anterior nos subseqüentes, em 1920/1. Malaguenho, José Quesada Rodriguez declarou-se pintor no registro de 1906, passando a jornalero em 1919. Já Juan Sanchez Trujillo, de Jaén (andaluz, como os demais) fez um tortuoso caminho para chegar ao seu ponto de partida. Era um alfaiate em 1915, com domicílio na Rua Sayão Lobato, 7, transformando-se em jornalero um ano depois, em empregado no seguinte, e novamente em alfaiate quatro anos depois, 1921. O artista Juan Bautista Soalleiro Estevez, de Pontevedra, conservou essa atividade por dois anos, entre 1916/17, porém em 1918 declarou-se jornalero para, no ano seguinte, 1919, assumir-se empregado. Domingo Fernandez Macia, de Orense, impressor em todos os seis registros efetuados, de 1907 a 1920, declarou-se jornalero em apenas um deles, o que efetuou em 1919.

Foram inúmeros os casos elencados pelos quais a utilização da rubrica deixa transparecer a circunstância do desemprego (eventual?) do declarante e o quadro de ofícios itinerantes que tipificou o período. O mais curioso a observar é que na maioria desses casos não se tratava de trabalhadores ocasionais, como um carregador, por exemplo. Em muitos deles, ao contrário, o titular possuía um ofício ou profissão - sapateiro, carpinteiro, torneiro, ferreiro, mecânico, vidreiro, laminador, eletricista, maquinista, padeiro, garçom, confeiteiro, professor, impressor, barbeiro, charuteiro, chauffeur, escrevente, etc., o que estampa, além do mais o cenário de volatilidade e descontinuidade característico do mercado de trabalho da metrópole em construção, cujo modelo mais bem acabado encontramos em Juan Ventura Tranquera: no intervalo entre 1893 e 1922 esse espanhol de Barcelona compareceu ao CGE por treze vezes, apresentando-se nas diversas ocasiões como jornalero; mecânico; novamente jornalero; pequeno proprietário; proprietário; novamente jornalero; comerciante; proprietário e, finalmente pequeno proprietário.

Assim, se por um lado temos de admitir a inclusão por vezes sem critério, refletindo casos circunstanciais de desemprego eventual, por outro, é inegável o vulto de homens cuja participação no mercado de trabalho da cidade pode-se claramente associar ao perfil que a categoria traduzia.

\footnotetext{
${ }^{8} \mathrm{EDE}$ 12.11.1920.
} 
De todo modo, a análise individual comparativa foi importante para, por outro lado, demonstrar algumas possibilidades de mobilidade social associada à categoria, especialmente acentuada no caso dos comerciantes, cujo exame dos registros precedentes de seus titulares revelou alta incidência de menção à ocupación de jornalero. Essa menção, por sua vez referiuse quase inteiramente a registros de domiciliados no interior, do que se depreende ter seu titular protagonizado uma passagem prévia pelo colonato. Exemplificando: Manuel Adamis Carrillo, de Granada, antes de abrir seu comércio, em 1919, à Rua Paula Souza, 42 (provavelmente de cereais), trabalhou em São José do Rio Preto e Inácio Uchoa, como jornalero. Em 1908, José Rodriguez Fernandez, de Granada, era jornalero vivendo em Sorocaba, de onde partiu, nos inícios da década de 1920, para a Rua Santa Rosa, 94, outro local que, como a Rua Paula Souza, passará a concentrar muitos espanhóis. Também instalado na Rua Santa Rosa, no ${ }^{\circ} 88$, encontramos, em 1922, o estabelecimento comercial de Manuel Garcia Molina, de Jaén, que se declarava jornalero, desde 1916 no CGE. E os membros da família Funcia, de Zamora, composta dos irmãos Angel, Francisco e Sebastian, antes de se estabelecerem, em 1922 com A Cearense, uma loja de passamanarias e afins no Largo do Arouche, 24, declararam-se, ambos, jornaleros, desde seu primeiro registro, em 1912.

Essa se mostraria uma das possibilidades. Um outro artifício, intermediário, seria empregar-se com os conterrâneos até chegar ao seu próprio negócio. Foi o caso de Antonio Reina Lopes, de Málaga, que, antes de se estabelecer com seu comércio à Rua da Cantareira, 48, em 1921, empregou-se na Rua Santa Rosa, 46, como jornalero, 9 anos antes, em 1912. Essa foi também a trajetória de alguns proprietários de hotéis. Juan Garcia Lopez, de Orense, solteiro, trabalhou para Celestino Costa, dono do Hotel dos Viajantes desde 1913, antes de uma rápida passagem pelo Hotel Eiras, até instalar seu próprio estabelecimento à Rua da Conceição, 103, em 1922, quando tinha então 36 anos ${ }^{9}$.

\footnotetext{
${ }^{9} \mathrm{EDE} 15.02 .1912$ e 29.01.1920.
} 


\subsection{O homem anônimo}

O tom castanho.

Carroceiros castanhos, de camisa de malha castanha, afundados entre sacas castanhas e domando burros castanhos.

O tom castanho do silêncio.

Siêncio também castanho. Silêncio de estopa de saco suja de terra.

Silêncio.

Apenas o ranger dos dentes das engrenagens no corpanzil pardo dos autocaminhões; apenas o raspar de ferro e pedra das patas dos burros nos paralelepípedos bruscos.

Nem uma voz humana.

$\mathcal{E}$, dentro desse silêncio comercial, vão chegando e vão passando uns homens do trabalho, lerdos, abobalhados, inexpressivos, como motores parados. Não dizem nada. Que homens são esses, que vão chegando e vão passando? De que pátria fugiram? Que música estrangeira terá a sua fala?

- Telojuro!

Antes dos meus olhos, os meus ouvidos já haviam "visto" o primeiro espanhol. O gutural mourisco do "j" descreveu logo a calça cor de pinhão, de saragoça grossa, 6ambeando as pernas fracas; o tronco atarracado, sem paletó, dentro do colete desabotoado como um bolero e enfeitado com uma corrente de prata e um dinheiro de prata; a camisa de algodão listado; o boné de burel puxado para a nuca; a cara magra, grisalha, raspada, de padre e torero; os othinhos sem vergonha nem pestanas, contando coisas de Quevedo; e a boca estreita jurando.

Guilherme de Almeida, Um carvão de Goya 
Dos setores "ocultos" de que se constituiu a nascente metrópole que, em sua expansão urbana produziu, reproduziu e improvisou diversificadas experiências de trabalho eventual e formas precárias de acomodação às atividades produtivas, algumas delas permaneceram no imaginário coletivo como imediatamente associadas ao espanhol. Esculpidas nesse universo, alguns fragmentos puderam ser capturados nos textos literários nos quais as alusões, embora esparsas, são recorrentes. É o caso do “carroceiro” espanhol.

Na virada do século, em 1900, o número de veículos de tração animal circulando pela cidade era de 9.589 unidades, dos quais aproximadamente $90 \%$ constituíam-se de carroças (8.468 unidades). Havia também as carroças de mão, em número de $870^{10}$. Novas fábricas foram criadas, o número de carroças tendeu a crescer na proporção que a expansão do espaço urbano, na incorporação de áreas semi-rurais (chácaras), fazia aumentar as distâncias. Em 1920, $51 \%$ dos veículos que trafegavam pela cidade eram ainda de tração animal ${ }^{11}$.

Nesse contexto, cresciam também os carroceiros autônomos, os nacionais e os imigrantes pobres sem recursos, para quem bastava possuir uma carroça que poderia ser por eles mesmos construída, com restos de tábuas. Muitos puxavam suas carroças sem a ajuda de um animal de tração. Além do mais, a função não requeria qualquer especialização ou habilidade.

"Você vai me sair carroceiro?"12. A indagação contrariada e provocativa de uma mãe endereçada a seu filho revela o fardo de preconceito que carregavam tais indivíduos, cuja remuneração, eventual e descontínua, ficava abaixo do nível mínimo para a subsistência, porém que, apesar de sua condição, vivendo no limiar da miséria, ainda assim eram admirados.

Em Contos de Belazarte, Mário de Andrade - em cuja obra a questão dos imigrados é recorrente e que, em muitas delas deixa entrever seu mal-estar diante da invasão da cidade, sobretudo pelos italianos - ilustra uma passagem protagonizada por Fernandez, carroceiro espanhol e Terezinha, italiana, que com ele traía o marido, um brasileiro, de cuja prisão por assassinato do espanhol fora acusada. Insultada pela sogra que "não estava pra sustentar cachorrice de italiana acueirada com espanhol", respondia gritando que "espanhol era muito milhor que brasileiro, sabe! Sua filha de negro! Não careço da senhora, sabe! Mulata! Mulatona! Mãe de assassino!" E o troco, rápido: "Carcamana porca”! ${ }^{3}$.

\footnotetext{
${ }^{10}$ A Reconstituição da Memória Estatística da Grande São Paulo, op. cit., vol.1, p. 194.

${ }^{11}$ RIBEIRO, M. A. Rosa. "O mercado de trabalho na cidade de São Paulo nos anos vinte". In: SILVA, Sérgio e SZMRECSÁNYI, Tamás (org). História Econômica da Primeira República. $2^{\mathrm{a}}$ edição revista, São Paulo: Hucitec/Ass. Brasileira de Pesquisadores em História Econômica/Edusp/Imprensa Oficial, 1996, p. 349.

${ }^{12}$ BATINI, Tito. “E agora, que fazer?” (São Paulo, 1941, s. ed.). Apud: PACHECO, R. Op. cit., 1956, p. 213.

${ }^{13}$ ANDRADE, M. "Piá não sofre? Sofre”. In: Os contos de Belazarte, op. cit., 1992, p. 90.
} 
Faziam parte integrante e importante da paisagem do período, agentes que foram do transporte e do abastecimento da Paulicéia, na circulação de mercadorias e produtos indispensáveis ao funcionamento da cidade em transformação e na coleta e compra, para comercialização e revenda, de artefatos e objetos para reutilização. Executavam, enfim, tarefas menores, esporádicas e de pequena remuneração, e que, por essa razão, não foram assimiladas pelos setores formais regularmente estabelecidos, porém, compondo com esses setores e segmentos formais um conjunto que, embora oculto, funcionava à sua sombra, complementando-o. Para a construção civil, em expansão, seu papel era fundamental no transporte dos materiais - areia dos rios, pedras, madeiras, tijolos e telhas das olarias que circundavam a cidade.

Acidentavam-se com freqüência. Levantamento realizado no mês de dezembro de 1911, pelo Departamento Estadual do Trabalho indicava a construção civil como a campeã de acidentes, seguida pela categoria dos carroceiros que, dentre as ocorrências arroladas conjuntamente para chauffeurs e cocheiros, referentes ao setor de transportes, 15 ao todo, concentraram para si 11 delas, 5 das quais consideradas de danos graves ${ }^{14}$.

Eram vistos por toda parte, mas era na região central, onde a cidade definia a sua função comercial e de abastecimento que sua presença mais pôde ser notada, pelas ofertas de trabalhos e entregas eventuais a domicílio. Muitos faziam ponto próximos à zona de mercado da cidade à espera de que os pequenos chacareiros e fruteiros os contratassem para "descarregar caixas de frutas, legumes, verduras, cestas com lingüiças e frangos, sacos de cereais, pilhas de cestinhas e peneiras tecidas em taquara, potes e moringas de barro e até bacalhau seco"15.

Garcia encostou a carroça na frente de um botequim. Procurou uma mesinha vaga de onde pudessem vigiar a carroça. Na mesa, abriu o embrulho que continha o almoço preparado pela mulher e que consistia num grande pão redondo, um pedaço de queijo fresco de Minas e uma enorme tortilla espanhola, mas que nada mais era do que um vasto omelete de ovos e batatas ${ }^{16}$.

Na região central também sua presença era maciça junto aos depósitos atacadistas de cereais. Ali, os "carroceiros castanhos" tratavam de comercializar a sacaria para a embalagem

${ }^{14}$ MOURA, Esmeralda Blanco Bolsonaro de. O acidente de trabalho em São Paulo (1890-1919). São Paulo: Tese de Doutoramento. FFLCH-USP, 1984, p. 28. Aos cocheiros exigia-se uma prova de "perícia e idoneidade", requisito para a sua matrícula na Repartição de Polícia, para a concessão da permissão, após o que os candidatos eram treinados, em locais específicos, na aprendizagem da condução de "seges, carros e tílburis". In: PENTEADO, J. Op. cit., 1962, p. 300.

15 Mercado Pequeno ou "mercadinho" (na Rua São João); Mercado de Peixes (próximo ao Parque D.Pedro) e Mercado Grande, na Ladeira João Alfredo (hoje General Carneiro) esquina com 25 de março. In: PINTO, M. Op. cit., 1984, pp. 141-142.

${ }^{16}$ MARX, G. Op. cit., 1996, p. 39. 
dos cereais cujo comércio, gradualmente nas mãos dos conterrâneos, dominava determinadas vias, caso das Ruas Paula Souza e Santa Rosa ${ }^{17}$ e algumas adjacentes em menor escala. Há indícios de que neste local de concentração e comércio hegemonicamente espanhóis, exercessem atividades autônomas correlatas, dentre as quais aquelas relacionadas à venda de carvão para a população.

Meu tempo de juventude foi muito empregado no esporte; (...) Dirigi o Clube São Cristóvão aí do Brás, composto de vendedores de jornal. Depois fui convidado para dirigir o Madri dos espanhóis da Rua Santa Rosa; eram todos carroceiros ${ }^{18}$.

Entre os principais times de várzea, temos o "Club São Cristóvão" formado por vendedores de jornais e o "Madri”, pelos carvoeiros da Rua Santa Rosa (...) ${ }^{19}$.

O carvão era o combustível das casas paulistanas na virada para o Novecentos, utilizado nos fogareiros e nos ferros de passar, e vendido a domicilio pelo carvoeiro "que adquiria oftalmia ao esfregar o antebraço nos olhos para acalmar coceiras". Numa carrocinha puxada por um burro, o lenheiro representava outra das figuras que compunham esse universo ${ }^{20}$.

A atividade de carvoeiro, importante numa cidade que lentamente conheceu as benesses da energia elétrica e mesmo assim muito seletivamente, insere-se nesse grupo de funções informais de baixa remuneração, porém, o setor alavancou no período outros segmentos, como o da importação e representação de "máquinas de quebrar e moer carvão", ao qual vimos dedicados elementos da colônia ${ }^{21}$.

Insuspeitadamente, a atividade contou com larga participação do elemento espanhol, quer na distribuição do carvão com a carrocinha, ou na sua fabricação, ainda que poucos assim tenham se declarado nos LRC. Empreitava-se mão-de-obra com frequiência pelo EDE, requisitada para subúrbios próximos da capital: "Carvoeiros. Tratar em Caieiras, com Lázaro Bogajo, $^{, 22}$.

Eventualmente convocavam-se famílias inteiras a quem se oferecia local para morar, porém, como de praxe, pagava-se por trabalho realizado, quer dizer, por quantidade de carvão produzida: "Precisa-se de 30 a 40 famílias de carvoeiros para trabalhar em Campo Largo ou em outro sítio próximo a São Bernardo, pagando-se 900 réis o saco de 100 litros. Oferece-se a cada

\footnotetext{
${ }^{17}$ Esse aspecto será objeto de análise específica no Capítulo III.

${ }^{18}$ BOSI, E. "Lembranças do Sr. Amadeu”. In: Memória e sociedade: lembranças de velhos. São Paulo: T.A. Queiróz, 1979, p. 88.

${ }^{19}$ REALE, E. Op. cit., 1982, p. 41.

${ }^{20}$ AMERICANO, J. Op. cit., 1957, pp.106 e 115.

21 EDE 21.11.1919. Anúncio da Importadora pertencente ao filho de Eiras Garcia, Heitor, então representando empresa de Nova York, a The Williams Patent Cru-scher and Pulverizer Co.

${ }^{22}$ EDE 29.12.1919.
} 
família terreno para plantio e criação de animais. Tratar com Manuel Alú, Rua Oriente, $60^{23}$. O contratante certamente possuía no local, à Rua Oriente, um depósito de carvão, que abastecia as carrocinhas. Lentamente, porém, vimos que o negócio evoluía, incorporando outros segmentos, como material de construção, cujos anúncios passaram a ser estampados no EDE: "Fernandez \& Caballero. Grande depósito de materiais de construção, lenha e carvão. Rua São Caetano, 213. Vendas a varejo e atacado, 24 .

O setor computava, como vimos, "empregadores" ou empreiteiros contratantes espanhóis, observando-se impreterivelmente entre as parte acordos verbais, seja individuais ou coletivos. Não raro, mesmo dentro da colônia, havia desentendimentos por interpretação desse acordo verbal, para o que se convocava a mediação do diretor-proprietário do EDE (e não da autoridade consular ou policial) e fazia-se publicar a "Reclamación" pertinente. Numa dessas ocasiões, vinha-se a público para denunciar os "abusos cometidos pelo espanhol Antonio Barriga a 8 famílias, por ele contratadas para fabricar carvão em Atibaia, na Estação Belém”. Residentes no bairro do Carandiru, os espanhóis José Montero e Juan Espinel, o acusavam de falta de pagamento, motivo que os levou a abandonar o trabalho. Sem perder oportunidade, o jornal prontamente se posiciona: "Cuando nos quejemos de que existen hacendados que faltan a sus contratos, nos contestarán que hay españoles que le dan el ejemplo”,25.

Neste período, a paisagem paulistana é composta e se familiariza com outros indivíduos, também integrantes da economia dita invisível, que nela desfilavam, caso dos ambulantes que tomavam conta das ruas.

Conservemos em nossos ouvidos os pregões matinais quebrando o silêncio da rua pacata: o vassoureiro espanhol, o fruteiro italiano, o peixeiro, a buzina do tintureiro, o retinir do "triângulo" do vendedor de taboca, o tilintar compassado, tristonho, do cincerro da vaca leiteira, o galhofeiro pregão do moço português: "Olhaá o paaaadeiro! $!^{26}$.

Nesse flagrante de um contemporâneo, tem-se bem a medida do volume de pessoas que transitava pela cidade oferecendo seus produtos ou mercadorias, alternativa de trabalho para os muitos desempregados. Nessas andanças pela cidade, na disputa pela clientela, podiam ocorrer

${ }^{23}$ EDE 17.02.1912 e sucessivamente em outras edições de diversos anos. No EDE 29.12.1919, por exemplo, a solicitação era para Caieiras e foi repetida reiteradas vezes. Trad. da autora.

${ }^{24}$ EDE 02.05.1922. Trad. da autora.

${ }^{25}$ EDE 07.04.1913.

${ }^{26}$ MARQUES, Cícero. De Pastora a rainha (Memórias). São Paulo: Editora da Rádio Pan-Americana, 1944, p. 225. Caracterizando as diversas camadas sonoras que se sobrepunham na cidade, no período, ver: APROBATO $\mathrm{F}^{\mathrm{o}}$, Nelson. Sons da metrópole: entre ritmos, ruídos, harmonias e dissonâncias. As novas camadas sonoras da cidade de São Paulo (final século XIX, início do XX). Dissertação de mestrado. FFLCH-USP, 2001. 
entreveros e agressões. Juan Martinez, 53 anos, comerciante de galinhas residente no Ipiranga, na Rua Aristides Lobo, 20 foi agredido com um objeto que lhe feriu o rosto, pelo turco João Ginada no Mercado Central, o qual foi preso, enquanto o espanhol era socorrido pela assistência pública $^{27}$.

Alguns utilizavam pequenas carroças, facilitando-lhes a locomoção e ampliando seu raio de ação, porém a maioria se locomovia a pé, praticando uma atividade extremamente irregular e instável em termos de rendimentos, porque dependente das oscilações de consumo, e com pequena margem de lucro ${ }^{28}$. Há 6 meses na cidade e morando no mesmo domicílio, à Rua Caetano Pinto, 89, no Brás, Carlos Amador Bautista, de 40 anos e Juan Maya Aporra, de 30, ambos naturais de Lérida, o primeiro deles casado, exerciam a atividade de vendedor ambulante, que declararam no $\mathrm{CGE}^{29}$, da mesma forma que outro vizinho do Brás, Andrés Rodriguez Gervilla, de Granada, solteiro, de $34 \operatorname{anos}^{30}$. Também era a atividade da "idosa espanhola, vendedora de bananas [que] passeava a sua cesta ouvindo e retrucando liberdades", nas portas das fábricas do Brás ${ }^{31}$. Essa capacidade de criar novos meios de ganho e atividades ocasionais não deixa de constituir a cultura de resistência do homem marginalizado ${ }^{32}$, na qual também se inscreve a ocupación de pescador declarada por Isaías Oropesa, sevilhano solteiro de 32 anos que, residente em Baureri às margens do Tietê em 1894 compunha a camada pobre da população ribeirinha vivendo nas proximidades dos rios, que pescava para o sustento, comercializando o excedente.

Exercendo a ocupación de pomarero, Francisco Rodriguez Galvez, andaluz de Granada, 32 anos e casado, por certo plantava no terreiro ou nos arredores de sua casa as frutas que comercializava na cidade no ano de $1901^{33}$. O mesmo devia acontecer ao chacarero José Callado Gonzalez, de Salamanca, que, em 1906 realizou sua inscrição no CGE.

A imposição de explorar minúsculas brechas de ganho para poder sobreviver, fez com que muitos trabalhadores com alguma habilidade, desempregados ou impossibilitados de montar uma pequena oficina, acabassem por exercê-la autonomamente, de porta em porta, especialmente nos setores ligados à manutenção e conserto de objetos, função do hojalatero ou

\footnotetext{
${ }^{27}$ EDE 11.07.1918.

${ }^{28}$ PINTO, M. I. Op. cit., 1984, pp. 141 e ss.

${ }^{29}$ LRC 1911.

${ }^{30}$ Rua Claudino Pinto, 22. LRC 1921.

${ }^{31}$ MAFFEI, E. Op. cit., 1978, p. 38.

${ }^{32}$ PINTO, M. Op. cit., 1984, p. 155.

${ }^{33}$ Era domiciliado à Rua da Consolação, 89. LRC 1901.
} 
latero, o folheiro, indivíduo que, de porta em porta, consertava utensílios domésticos e panelas de folha de Flandres, já circulando na cidade pelo menos desde $1894^{34}$.

Enquanto isso, melhor aquinhoado, o cestero Vicente Callado Vaillanueva, de Castellón (Valencia), com endereço à Avenida São João, 66, portanto próximo ao "Mercadinho"35 - local freqüentado pelos hortigranjeiros que aí comercializavam seus produtos -, já em 1897 instalara-se vantajosamente com pequeno negócio de cestaria, explorando uma necessidade no fornecimento de um utensílio indispensável para o transporte da produção, e que também atendia aos ambulantes. E não apenas a esses setores, daí a proliferação de vendedores ambulantes de balaios e cestos de vime "para colocar farnel para piqueniques" - hexagonais, com divisões internas; "para acomodar a roupa suja"; no feitio de bandejas, "para transportar a roupa lavada"; "para os padeiros entregarem o pão" e, menores, para "guardar o pão". Outros, menores ainda, para "guardar os alimentos que deveriam ficar arejados" e abertos, para guardar ovos ou frutas. Ainda havia os que imitavam brinquedos para crianças, como carrinhos para transportar bonecas. E uma infinidade de objetos, fabricados para o uso doméstico, como o espantador de moscas e o abanador de fogão à lenha ${ }^{36}$, carregados por Maximino Fernandez, "o espanhol dos balaios" que aparecia com "quatro taquaras entreveradas, formando qualquer coisa de que só ele entendia", e vinha "com barba de muitas semanas, meio branca e meio preta, bem dura, o cabelo despenteado, saindo por baixo do chapéu". Maximino era também o trançador dos balaios que vendia, e morava numa "tenda coberta de zinco" em um beco, tendo por companhia a dois vira-latas ${ }^{37}$.

Essa contingência, pois, envolvia o brutal crescimento, no período, do trabalho casual, expondo a incapacidade da cidade em conciliar seu pujante desenvolvimento econômico com os crescentes ingressos de imigrantes.

Vivendo à margem dos padrões do mercado de trabalho formal, tomados muitas vezes por "vadios", eram esses sujeitos objeto de perseguição da polícia, que aprenderam a subornar.

No EDE pudemos acompanhar, em alguns editoriais, a batalha que se travava nas ruas com esses indivíduos que praticavam o comércio ambulante "para ganhar o pão de cada dia”38 e

\footnotetext{
${ }^{34}$ Apenas neste ano, foram três os hojalateros inscritos: Manuel Leon Monforte, de Navarra, 36 anos, casado e domiciliado na Rua da Consolação, 257; José Haro Mora, de Málaga, 27 anos, casado e residente na Rua Carneiro Leão, 28 e Manuel Perez Sans, de Madrid, solteiro, com 28 anos e residente na Rua do Gasômetro, 128. LRC 1894

${ }^{35}$ PINTO, M.I. Op. cit., p. 125.

${ }^{36}$ AMERICANO, J. Op. cit., 1957, p. 122.

${ }^{37}$ BATINI, Tito. Entre o chão e as estrelas. Rio de Janeiro/São Paulo: Editora Civilização Brasileira S/A, 1943, pp. 91 e ss.

${ }^{38}$ EDE 30.04.1919.
} 
as denúncias de que, se não pagassem propina aos inspetores municipais, eram perseguidos e levados à delegacia como delinqüientes.

No período entre 1890 e 1914/5, no afã de normatizar e disciplinar o comércio, e aumentar a receita do Município para dar encaminhamento a todos os projetos em andamento na cidade, sobretudo as obras públicas (iluminação, pavimentação, alinhamento) e as desapropriações $^{39}$, criaram-se novas taxas e impostos que incidiam sobre quase todas as atividades produtivas, inclusive sobre os vendedores ambulantes. Procurava-se legalizar a atividade, exigindo a licença da Prefeitura para o seu exercício. Para os inscritos e, portanto, legalizados fornecia-se uma placa para que se diferenciassem dos demais ${ }^{40}$. A medida ainda previa a uniformização, com traje específico, dos demais prestadores de serviços e trabalhadores de rua que freqüentavam o centro (cocheiros, engraxates, carregadores, vendedores de bilhetes).

Em torno desses vendedores ambulantes, foi se constituindo uma rede de fornecedores para o abastecimento e o suprimento de mercadorias, ao passo que proliferavam no EDE as ofertas de produtos dos mais variados para serem vendidos - "grandes sortimentos de jóias, relógios e metais diversos e incomparável estoque para mercadores ambulantes a preços irrisórios. Matriz: Av. São João, 2 e duas sucursais, Rua Mauá, 95 e General Carneiro, 85 ”41 ou "os famosos sonhos com creme, comissão de 35\%. Tratar com Ramón"42.

Eram alvo de perseguição também dos comerciantes estabelecidos, que apelavam às autoridades pelas providências contra os ambulantes que progressivamente invadiam o seu espaço, alegando que não pagavam impostos e faziam concorrência desleal. Muitos desses ambulantes, estrangeiros, reclamavam da discriminação e da perseguição a que eram submetidos. A propósito, já em 1899 era encaminhada uma petição à Associação Comercial solicitando providências com relação a eles, os ambulantes estrangeiros ${ }^{43}$.

Muitos não sobreviveriam às transformações e ao comércio que impôs novos costumes à cidade, sucumbindo com o passar do tempo: "jornaleiros; leiteiros; o carroceiro de verduras; a carroça do padeiro; o carro de gelo; o amolador; o folhador; o tintureiro; o lenheiro; o

${ }^{39}$ Sobre as desapropriações realizadas no período entre 1909 e 1912, cf. BARBOSA, M. Op. cit., pp. 209 e ss.

${ }^{40}$ Ato $\mathrm{n}^{\circ} 442$ de 04 de janeiro de 1912, em Leis e Atos do Município de São Paulo, 1912, p. 189. Apud: DEAECTO, Marisa Midori. Comércio e vida urbana na cidade de São Paulo (1889-1930). São Paulo: Editora SENAC São Paulo, 2002, p. 167.

${ }^{41}$ EDE 26.09.1919. Trad. da autora.

${ }^{42}$ EDE 13.01.1922. Trad. da autora.

${ }^{43}$ MUNHOZ, Sidney J. Cidade ao avesso - desordem e progresso em São Paulo no limiar do século XX. São Paulo: Tese de doutoramento, FFLCH-USP, 1997, p.121. 
empalhador; o baleiro; o sorveteiro; o mascate dos aviamentos de costura; o pipoqueiro e o castanheiro; 0 vendedor de cestos" ${ }^{, 44}$.

“Ambulantes", em certo sentido foram, em seus primórdios, outros dois segmentos, embora de natureza distinta, em que o espanhol se destacou: o cinema e o teatro. Muito apreciado pelas classes populares, o teatro ambulante aproximava-se do povo pelas encenações de temas da vida cotidiana, próximos da realidade, retratando "os dramas, os conflitos e a tensão social vivida por estes grupos na sua rotina diária de sobrevivência"45. Eram grupos de artistas que se deslocavam de uma cidade à outra, carregando seus parcos aparatos cênicos e que, nessas andanças, acabavam por perder-se de suas famílias. Em 1913 a família de Miguel Rodriguez Ruiz, de Granada, residente na Rua Caetano Pinto, 83, publicaria uma nota no EDE na qual informava do seu sumiço, identificando-o como "artista eqüestre, proprietário de um teatrito ambulante" 46 .

Francisco Serrador, aqui desembarcado em 1900, exibia desde 1905 filmes como ambulante com seu projetor de fitas. Em seguida, teria organizado uma trupe ambulante, a Empresa Richabony, com que excursionava pelo interior, sendo responsável pela montagem da primeira sala de cinema da cidade, a El Dorado, e, a partir de 1909, pela Companhia Serrador $^{47}$. Seu negócio era promissor. Em 1912, o EDE publicaria uma matéria ilustrada destacando o "palácio residência do capitalista espanhol D. Francisco Serrador. Pagou-lhe meio milhão de pesetas. Está no Brasil há 18 anos. Rua Brigadeiro Tobias, esquina com Washington Luis" ${ }^{\text {"48 }}$, numa evidência de que seu negócio prosperara, e rapidamente.

Foi, contudo, envergando a atividade de negociante de materiais e artefatos descartados notadamente os de metal, vulgo "sucata", que o espanhol mais se destacou, tanto assim que, no período ela, a sucata, lhe é imediatamente associada. As indicações literárias são mais generosas nessa direção, em que dados oficiais são praticamente inexistentes.

Os espanhóis constituíam uma fauna à parte. Quando não vendiam bilhete, apareciam comprando ferro-velho, garrafas, sacos vazios, chumbo, metal e cobre. Apesar da humildade de sua profissão, faziam praça do orgulho peculiar à sua estirpe. Paravam, sobranceiros, no meio da rua, e gritavam:

- Tchumbo, metal i cobre!

Davam uma volta sobre si mesmos com o donaire semelhante a um famoso toureiro em sua arena, e concluíam:

\section{- Ifierro viejo también!}

\footnotetext{
${ }^{44}$ AMERICANO, J. Op. cit., 1957, pp. 111-112.

${ }^{45}$ PINTO, M. I. Op. cit., 1984, p. 170.

${ }^{46}$ EDE 29.08.1913. Trad. da autora.

${ }^{47}$ GALVÃ̃, M. Rita Eliezer. Crônica do cinema paulistano. São Paulo: Ática, 1975, pp. 21 e 36.

${ }^{48}$ EDE 10.06.1912. Trad. da autora.
} 
Não conversavam com ninguém (...) seguiam pelas ruas, imperturbáveis, de cabeça alta $^{49}$.

Como tantos outros apregoadores que imprimiram uma sonoridade característica à cidade, os espanhóis também seguiam o ritual cotidiano de percorrer as suas ruas aprumando-se com maestria em trejeitos na formulação de seu personagem típico, anunciando alto e bom som, para atrair a clientela, os produtos que arrematavam para revenda. Quando a estratégia não se mostrava suficientemente eficaz, sacavam de um "ponteiro [que] ia ferindo as costas de uma frigideira de ferro, causando um som estridente e metálico" ${ }^{50}$ que repetiam infinitamente para chamar a atenção.

Nessas sortidas a bairros opostos, iam longe e só voltavam à tardinha carregados de quinquilharias que separavam para depois vender. Saíram na manhã seguinte para os lados do Cambuci. Logo que passaram a ponte sobre o Rio Tamanduateí, tomaram a Luís Gama. Garcia empurrava o carrinho e Ramón ia apregoando:

- Compra-se ferro-velho. Panelas, fogões, ferros, canos de chumbo (...).

Nesse dia não quiseram comprar garrafas vazias, pois, quando iam longe, preferiam adquirir ferro-velho que, depois de vendido a peso, rendia mais ${ }^{51}$.

Os espanhóis ficavam nos armazéns de cereais, mas principalmente no ferro-velho. $\mathrm{Na}$ fábrica, poucos. A maioria preferia se estabelecer por conta própria. Abriam uma portinha de cebolas na Santa Rosa.

Hoje, os espanhóis ficam principalmente na Rua Piratininga. Comercializavam ferrovelho, depois ficaram com a venda de peças de automóvel. Conheci muitos espanhóis: o Rafael Morales, pai do jogador de pingue-pongue; Macotera, Sevillano, que já tem oitenta anos, Francisco Herrerias.... O filho de Sevillano mora no Jardim Paulista. O velho, já com oitenta e dois anos, mora ainda no Brás ${ }^{52}$.

Passaram pelo ferro-velho e ali um espanhol discutia o carreto dum chevrolé em pandarecos, todo amassado num descontrole contra um muro:

- No te voy a pagar más que veinte mil réis... sabes? ${ }^{53}$.

Há, como vimos, diversas menções literárias ao espanhol que rotineiramente palmilhava as ruas da cidade, de porta em porta, à cata de materiais ou mercadorias remanescentes e refugadas, de sobras, resíduos, restolhos, rebotalhos e sucatas que recolhia ou arrematava, promovendo o lance inicial de uma cadeia de atividades subseqüentes do reaproveitamento ${ }^{54}$.

\footnotetext{
${ }^{49}$ PENTEADO, J. Op. cit., 1962, pp. 228-229.

${ }^{50}$ MARX, G. Op. cit., p. 38.

${ }_{51}^{51}$ Idem, ibidem, pp. 38 e 138.

52 “Lembranças do Seu Amadeu". In: BOSI, E. Op. cit., pp. 94-95.

${ }^{53}$ BATINI, T. Op. cit., 1943, p. 106.

${ }^{54}$ A esse respeito, ver: NASCIMENTO, J. L. Op. cit., 2002, 1996.
} 
O comércio do reuso, da reciclagem para reutilização era praticado nas próprias casas: "os diversos vidros e potes de farmácia, dos remédios consumidos durante o mês, já foram entregues ao farmacêutico, que descontou 1.200 réis na conta”, menciona Jorge Americano, sinalizando um hábito arraigado. Havia, no entanto, vasilhames como "garrafas de vinagre, de espírito de vinho, de cerveja e de água mineral, à espera do garrafeiro", as quais se atribuía um preço de acordo com a demanda do mercado. E aí eclodia o espanhol, em contínuo deslocamento, figura popular responsável por cenas de rua que permaneceram na memória coletiva, repisando o seu refrão cadenciado "garrafiero! garrafiero!"55. Não adquiria garrafas de vinho, por exemplo, porque não havia mercado, não se produzia vinho na cidade. $\mathrm{O}$ mesmo acontecia com as garrafas de champagne $e^{56}$.

É contudo pelo trabalho de Geraldina Marx - Os Humildes - no qual a autora franqueia ao leitor generosas passagens, recolhidas inicialmente em um caderno de anotações, que se apresenta a possibilidade da reconstituição de facetas do "universo sem heroísmo dos humildes", dos quais o de Juan Garcia, o "ferro-velho", carroceiro espanhol residente em um cortiço à Rua Maria Domitila, apresentado pela autora:

Ali habitavam as sete pessoas da família de Juan Garcia. No minúsculo chão de terra batida, um rapaz de cara encardida e roupa suja [um dos filhos de Garcia e quem trabalhava com o pai] guardava a carrocinha de madeira (...).

Junto ao barranco, havia uma pilha de ferro-velho compreendendo objetos como panelas, torneiras, latas, tubos, ferramentas, pontas de trilhos, grades, pedaços de chumbo, folhas de zinco e uma profusão de pregos e parafusos, formando alta montanha ferruginosa e que constituía o comércio de Garcia, o espanhol. Por isso, o chamavam de "ferro-velho".

Agora revolvia os fragmentos, as correntes e as novas peças adquiridas durante o dia, remexendo-os, pesando-os e comparando os seus valores para revendê-los no depósito de ferro-velho. Num meio de sotaques de malaguenhos, Lola [a filha do carroceiro] falou em castelhano, que era o idioma usual e empregado em casa, embora os filhos falassem português: "Hola padre...",57

De qualquer maneira e em que pese a permanência da figura do "ferro-velho" encarnada pelo espanhol no imaginário coletivo da época, resultou frustrado o escopo, mediante a análise das ocupaciones dos LRC, de reunir mais indicadores na tentativa de reconstituir elementos com os quais se pudesse atribuir uma forma, uma fisionomia a esse indivíduo, pois em todo o período de 30 anos compulsado, não ocorreu sequer um único inscrito se declarando chatarrero.

\footnotetext{
${ }^{55}$ SALGADO, Plínio. O estrangeiro. Rio de Janeiro: $8^{\text {a }}$ ed., J.Olympio, 1972, p. 124.

${ }^{56}$ AMERICANO, J. Op. cit., 1957, pp. 114-115.

${ }^{57}$ MARX, G. Op. cit., pp. 17-18. O sotaque malaguenho, ao qual se refere a autora, atribuído à família de Garcia, denota claramente a ascendência andaluza do negociante de sucata.
} 
As razões para esse fato não são difíceis de presumir, dizem claramente respeito à natureza da atividade, por sua essência identificada em larga medida com as formas marginais de atividades produtivas que pontuaram o universo da urbe paulistana e que, como tais, foram decodificadas inicialmente como formas jornaleras de incorporação. Isso não impediu todavia que, com o passar do tempo, indivíduos envolvidos previamente com o penoso negócio da chatarra, prosperassem e se firmassem e que, a partir de então, buscassem alterar a ocupación com que se declaravam no CGE. Com o prestígio alcançado, é lícito supor, muitos buscariam alterar a sua ocupación utilizando-se de categoria menos estigmatizada que a de jornalero, passando a engrossar outra natureza de categorias mais afinadas com a atividade, a saber, a de negociante e a de comerciante, por exemplo.

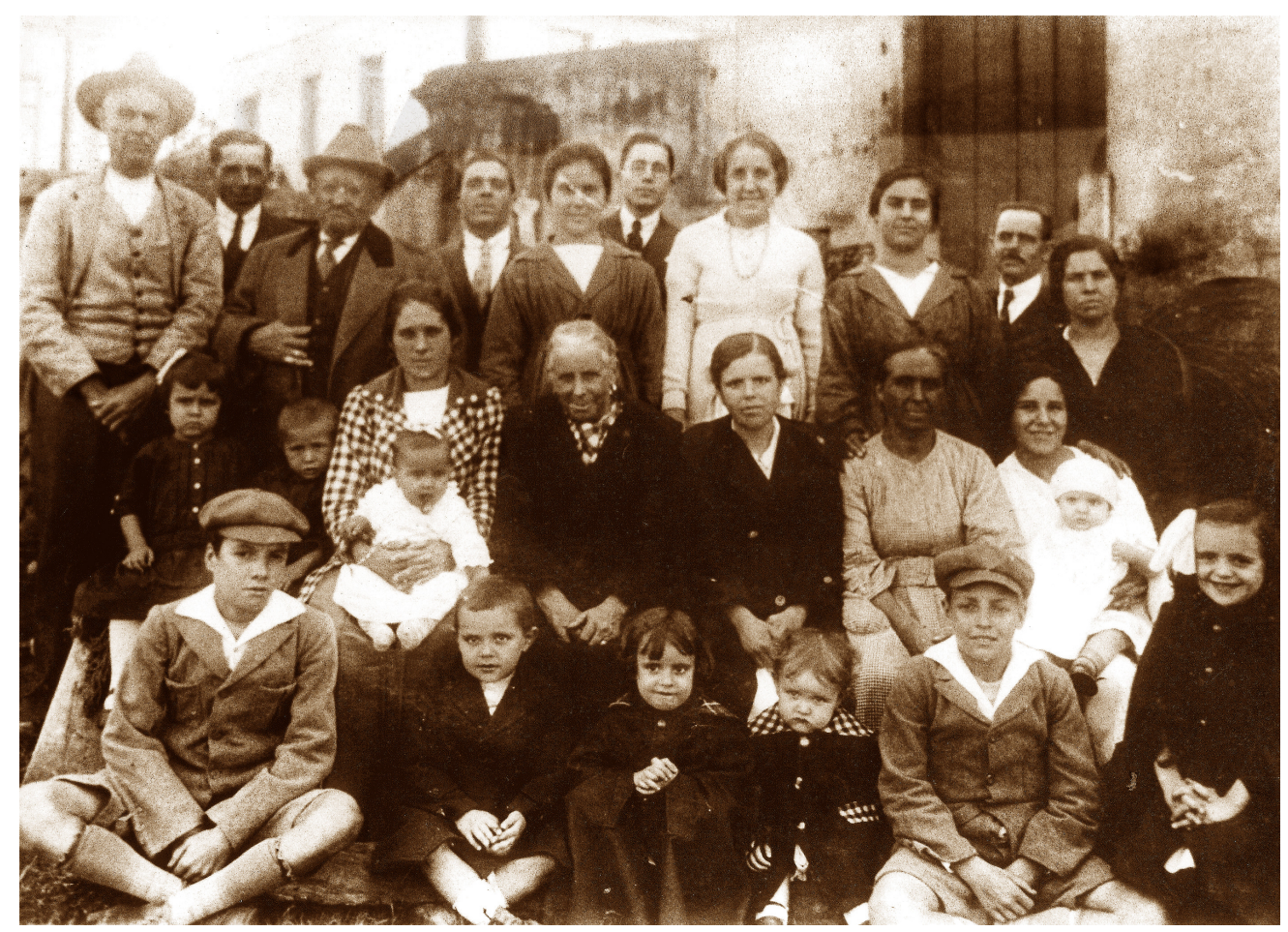

Fig. 2. Funcionários e família de imigrante espanhol, proprietário de depósito de ferro-velho. São Paulo (SP), década de 1920.

Não há dúvida de que o negócio da chatarra era atraente e de que, com ele, muitos conseguiram melhorar de vida. Há evidências de que comerciantes previamente estabelecidos com outros negócios a ele acorriam, como forma de investimento. Este foi o caso de Antonio 
Lopez Campillo, murciano, que chegou ao Brasil em 1906 e em 1910 estabeleceu-se no bairro do Ipiranga, inicialmente "com um comércio de bebidas, louças e diversos artigos",58.

Empório Español (el rey de los barateros) de A. Lopez Campillo. Rua Bom Pastor, 23. Aceites e aceitunas de Sevilla, vinos de Rioja y Málaga, y sardinas de las rias gallegas; lozas nacionales y extrangeiras, gran surtido de ropa hecha para hombres, mujeres y niños ${ }^{59}$.

Campillo permaneceria com seu empório até 1916, quando então passaria a se dedicar exclusivamente à compra e venda de ferro, novo e velho, estabelecendo-se com grande depósito, à Rua Uruguaiana, 33, que passou a anunciar regularmente no EDE: "Compra-se ferro batido, fundido, canos, arcos de "cartola" e barricas, arame galvanizado, metais de todas as qualidades, trilhos, etc. etc., aos melhores preços da praça. Depósito junto à Estação do Norte Brás, tel. 474 (Brás) ${ }^{960}$. Utilizando-se da matéria-prima disponível em seu depósito, pouco depois, em 1918, Campillo passa a produzir utensílios de ferro e aço, instalando uma pequena indústria "registrada na Associação Comercial com o capital de 20 contos de réis", de que se orgulhava de vender toda a produção, antes mesmo da fabricação. Continuava assíduo anunciante do EDE: "Fabricação de foices e enxadas, marca São Paulo, de A. Lopez Campillo. Rua Uruguaiana, 33,"61.

Não se pode descartar também a possibilidade de muitos emigrantes terem tido, em sua terra de origem, um prévio contato ou algum conhecimento sobre minerais, e que tivessem a inclinação de seguir, do outro lado do oceano, uma atividade que, de algum modo, já lhes fosse familiar. Múrcia, a terra de Campillo, a propósito, é reconhecida zona de minério, fator que deve ter pesado na sua opção.

Parece corroborar a hipótese o depoimento de D. Encarnación Jerez Rodriguez, também natural de Múrcia e então com 90 de idade, a Maria Antonieta Antonacci: "La idea de mi padre era abrir un depósito de hierro, en Espana trabajaban con minas, siempre fueron mineros, mi abuelo Diego en una mina de plomo y mi abuelo Valeriano en una de hierro". Negócio, afinal, conseguido. Iniciando a sua faina de apropriação de materiais rejeitados, inicialmente com uma sacola na cabeça, depois com um cavalo, seu pai aproveitava-se de seu conhecimento prévio com os metais, galgando as escalas do ofício, passando de mero coletor que vendia a sucata para os depósitos, a dono de um deles, chegando a fundar a Casa La Unión Brasil:

${ }^{58}$ EDE 30.06.1920. Desta edição constam as informações mencionadas a seu respeito. Neste momento, ele já era um dos grandes anunciantes do jornal.

${ }^{59}$ EDE 15.02 e 15.06.1912.

${ }^{60}$ EDE 12.04.1918. Trad. da autora.

${ }^{61}$ EDE 30.06.1920. Trad. da autora. 
Después fuimos para la calle Lavapés y comenzamos a progresar, porque allá era más grande, se compraba chatarra, metal, cobre, plomo, papel hueso, vidrio (...). Entonces, ganaban bién, ¿no? Ellos compraron um terreno (...) uma cuadra entera (...) fue el primer depósito de chatarra que hubo em São Paulo, era de mi padre ${ }^{62}$.

Nesta mesma trilha, na recuperação da história do comércio de artefatos de metal usados, José Leonardo do Nascimento ${ }^{63}$ utilizou-se apropriadamente de depoimentos orais de forma retrospectiva, revelando inúmeras facetas desse negócio realizado na "surdina". Descobriu, por exemplo, que os maiores comerciantes de máquinas usadas ainda na ativa na cidade são descendentes de antigos sucateiros, muitos até agora instalados na Rua Piratininga, permanência geracional na atividade a indicar que o "início foi sólido e seguro". Em seu trabalho de garimpeiro, exumou, da memória dos mais antigos, muitos personagens que compuseram a fama de um "rei do ferro-velho" - Tomás Marúbia, um dos mais importantes deles -, nomes que hoje não constam sequer das listas telefônicas ${ }^{64}$. "Como os mitos, sobrevivem apenas nas narrativas", assinala. Seu texto também indica como as atividades envolviam o grupo familiar e foram continuadas pelos descendentes, muitos dos quais ainda hoje podem ser localizados, incorporando, em seus negócios, as mudanças na economia do país (desmanche de automóveis, comércio de peças, máquinas usadas, leilões das indústrias automobilísticas e ...sucata, que permanece como ofício de longa duração).

O relato de D. Maria del Rosário Rodriguez Perez, hoje com 94 anos de idade, complementa os demais, indicando que o ofício de sucateiro transpôs, no decorrer do tempo, os limites do Brás, bairro onde nos acostumamos a vê-los em seus depósitos, alastrando-se para outros bairros, acompanhando o crescimento da cidade. Recorda-se de seu primo, Cristobal Martin Rodriguez, de Granada, que teria iniciado a coleta com uma carrocinha, tendo depois adquirido um cavalo até finalmente comprar um caminhão com o qual percorria toda a cidade.

Cristobal tinha 13 anos quando desembarcou com sua família, pais e irmãos, indo rumo a Catanduva, onde permaneceriam por 2 anos no trato do cafezal sem haver conseguido, neste período, "quitar a dívida da viagem". Desolada, a família abandonou a fazenda, fugindo a pé, em direção a São Paulo. E foi aí, na Rua Carneiro Leão, que se iniciou a saga do menino Cristobal que, bom negociante, passou a recolher ferro-velho nas ruas para ajudar no sustento da casa, agora já sem o pai, que havia falecido.

${ }^{62}$ ANTONACCI, M. Op. cit., 2002, pp. 9; 17-24. Na Revolução de 1924, conforme sua narrativa, a família, depois de alcançar certo status social, perde tudo, com a intervenção sofrida em seus negócios.

${ }^{63}$ NASCIMENTO, J. Op. cit., 2002, pp. 381-387.

${ }^{64}$ Pesquisando nos LRC, localizamos apenas 2 inscrições, em todo o período analisado, que continham o sobrenome "Marúbia": a primeira, de Maria Marúbia Ruiz, coincidentemente também de Múrcia, residente na Rua Tamandaré, 28 (LRC 29.05.1917) e a segunda, de José Marúbia Ruiz, de Linares, Jaén, profissão jornalero, residindo à Rua Wandenkolk, 38 (LRC 25.04.1918). 
Como o negócio progredira, e muito provavelmente para fugir à concorrência, assim que se casou pela primeira vez, Cristobal foi estabelecer-se com seu depósito em Pinheiros, na rua Padre Carvalho. Viúvo com um filho, logo se casaria pela segunda vez, desta feita com uma brasileira - sua primeira mulher era de Almeria - que se transformaria em seu braço direito na administração do depósito. Cristobal viajava muito, e a expansão do seu negócio obrigou-o a manter uma rede de fornecedores no interior do Estado de São Paulo, onde familiares também envolvidos com a atividade "juntavam" os produtos descartáveis que arrematava em constantes visitas que realizava, despachando-os por trem. Sua filha Dolores, nascida e criada no bairro de Pinheiros, "no ferro-velho", lembra que o pai passou a comprar também papelão.

Ele, apesar do sucesso, não se fixaria no negócio que passaria adiante para adquirir um hotel em Sorocaba, o Hotel Familiar, defronte à estação, onde permaneceu por pouco tempo. Retornando a São Paulo, era novamente o bairro de Pinheiros que atrairia o seu investimento, dessa feita voltado para o aluguel. Queria "viver de renda" conforme atesta sua filha Dolores e, nesse intuito, compraria um terreno em Vila Beatriz, no qual construiria uma boa casa para a família e 12 casas para aluguel. Sua vida estabilizara-se financeiramente e Cristobal, mais tranqüilo, aderiria a formas de lazer mais alinhadas com as camadas abastadas, como andar de avião (teco-teco), por exemplo. Numa dessas viagens que realizava com um primo piloto que tinha brevê, de volta a um passeio a Santos, o avião em que viajavam apresentou pane, caindo. Ele morreria desse acidente aéreo, aos 46 anos de idade, em $1954^{65}$.

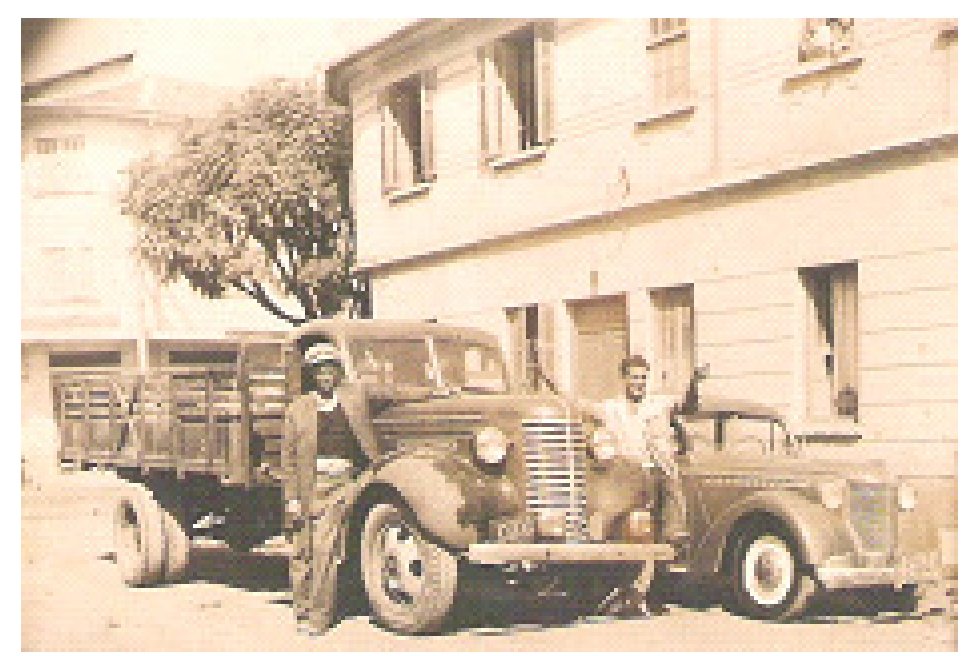

Fig. 3. Cristobal M. Rodriguez, na rua Padre Carvalho, em Pinheiros, onde se situava seu ferro-velho. São Paulo (SP), anos 50.

${ }^{65}$ Fragmento de depoimento de D. Maria del Rosário Rodriguez Perez, prima de Cristobal Martin Rodriguez, a 26.11.2006. D. Maria é madrinha de Dolores, filha de Cristobal que, em comunicação pessoal datada de 03.12.2006, complementou os dados por ela mencionados. É de sua autoria: CORNER, Dolores Martin Rodriguez. A gastronomia como fator identitário. Lembranças e silêncios dos imigrantes espanhóis na cidade de São Paulo (1946-1965). São Paulo: Dissertação de Mestrado, PUC-SP, 2005. 
Não apenas Múrcia, mas também Granada, a terra de Cristobal, era zona de mineração. Precisamente Orgiva, localidade da origem de sua família foi zona de minério de chumbo (plomo), dado que torna razoável a hipótese antes mencionada, a da probabilidade de muitos deles se sentirem familiarizados com a atividade pelo contato anterior, ou ao menos por terem, em suas histórias de família, casos de elementos que tenham trabalhado nas minas de seu país, o que os inclinou para uma atividade correlata.

Reminiscências desse passado afluíam repentinamente à memória como imagem construída de um conjunto de representações cuja evocação exumava experiências dolorosas vivenciadas no país de destino:

- Mãe, não quero mais ir à escola...

- E por quê? Para continuar burro como o Manuel, que carrega mais sacos que um asno o ano todo e mal se agüenta de fome? Para sofrer como sofreu meu pai trabalhando nas minas de chumbo, arrastando pernas doloridas, contorcendo-se de cólicas e sangrando nas gengivas, enquanto o puxa-saco do Eulógio lhe dava ordens e colocava os filhos no seminário, só porque sabia ler? ${ }^{66}$.

Capitais gerados no negócio da sucata foram aplicados em arte, e pendores artísticos foram revelados: Francisco Garcia, negociante de ferro-velho e ator de teatro com seu conterrâneo João Cypriano, encanador e também ator, acabariam por produzir e protagonizar o filme Segredo do Corcunda, de 1924, que pretendia mostrar o cotidiano de uma fazenda de café. Com recursos próprios, a ajuda de amigos e da Rossi Films, esse será o primeiro filme brasileiro mostrado no exterior, tendo sido exibido em Lisboa, em $1926^{67}$.

Retomando o início desse capítulo vimos como, dentre outras fórmulas encontradas, o espanhol aderiu também à de mercador ambulante, à da venda a domicílio, atividade então praticada nos arredores da cidade (no caso, em São Caetano), forma tradicional de comércio que passa a coexistir com as modernas, porém à sua margem, relegada espacialmente aos bairros mais afastados. Agentes intermediários entre os atacadistas do centro e os moradores dessas áreas distantes, todas as referências a esse tipo de comércio, feito de porta em porta são, contudo, tradicionalmente associadas ao "turco da prestação".

\footnotetext{
${ }^{66}$ MAFFEI, E. Op. cit., p. 15, relatando lembrança evocada por Ramirez, imigrante espanhol solteiro, recém-chegado à cidade, proveniente do interior e residente em um cortiço da Carneiro Leão.

${ }^{67}$ GALVÃO, M. Op. cit., 1975, pp. 186-193.
} 


\section{O espanhol na construção civil}

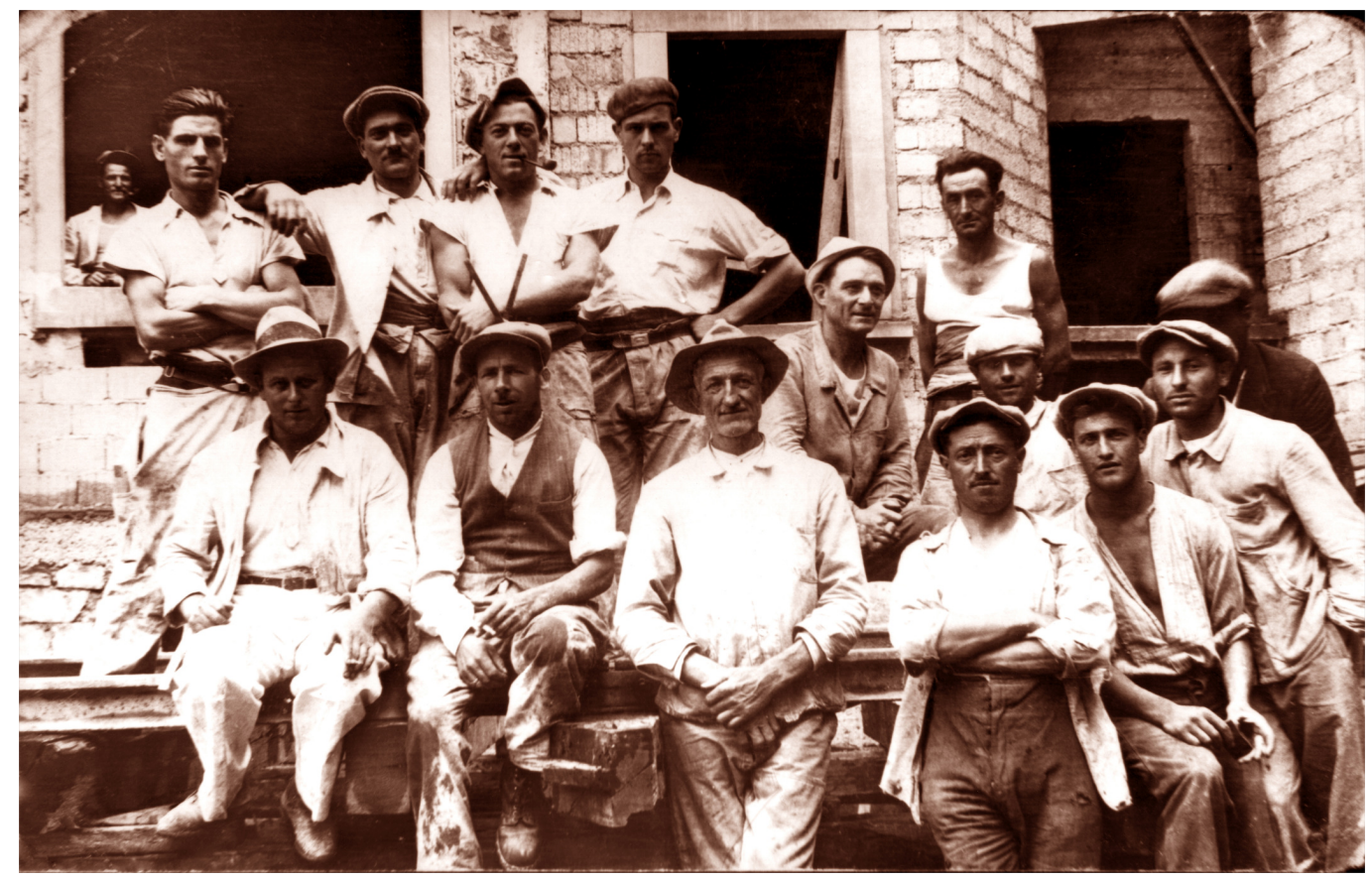

Fig. 4. Imigrantes espanhóis na construção civil. São Paulo (SP), s.d.

Em 17 de setembro de 1913, pequena nota publicada no EDE informava da morte do menor espanhol Danuro Diego, de 12 anos, ajudante de pedreiro então trabalhando nas obras da nova Igreja da Consolação, provocada pela queda de uma altura de 22 metros. Na mesma edição, notícia do acidente sofrido por Joaquim Galvez, espanhol de 25 anos, carretero que recolhia terra em um barranco na Rua Bonita e que havia se ferido gravemente, soterrado pelo desbarrancamento do mesmo ${ }^{68}$. Outra edição e mais um acidente, desta feita uma queda de andaime, sofrida pelo espanhol Vicente Luis de 18 anos, na rua Teixeira Leite ${ }^{69}$.

Os acidentes na construção civil, e as mortes decorrentes, viraram matéria corriqueira nas primeiras edições do periódico examinadas e delas não escapavam nem mesmo os operários que trabalhavam na construção da Catedral da cidade de São Paulo, cuja escavação, para a colocação "dos pilares medindo 5 metros de profundidade e 3 de largura", provocaria um deslizamento de terra em que morreriam mais 2 espanhóis, Florentino Barba, de Cáceres, 38 anos, casado, 2 filhos, residente na travessa Tibiriçá, 38 e Francisco Justo Lopez, de Huelva, 22

\footnotetext{
${ }^{68}$ EDE 17.09.1913. Trad. da autora.

${ }^{69}$ EDE 18.04.1913. Trad. da autora.
} 
anos, solteiro, "deixando ao desamparo sua mãe, viúva e 4 irmãos". No acidente também se feriram os espanhóis Juan Muñoz, Manuel Perez da Silva, Manuel Martins e Miguel Abrahán ${ }^{70}$.

A fatalidade da morte por acidente em construção civil também batera cedo à porta da família de Juan Garcia, o "ferro-velho", e qualquer situação de perigo com a família fazia D. Pepa lembrar-se com angústia do corpo caído e da "brecha no crânio" do filho que despencara do andaime de um prédio na Rua Líbero Badaró $^{71}$.

Entre 1900 e 1910, o número de prédios anualmente construídos na cidade atingia a marca de mil. Em 1910 já eram 32.914 prédios e em 1928, 60 mil $^{72}$, quase o dobro em menos de 20 anos. Esse surto de novas construções, configurando o quadro de diversificação vivenciado pela metrópole, passou a demandar uma constelação de novos ofícios, materiais e serviços, alguns mais especializados que outros.

Em ambos podia-se notar com frequiência variável a presença de espanhóis. No conjunto dos declarantes do CGE apareceram de maneira crescente albañiles, canteros, cerrajeiros, delineantes, ebanistas, encanadores, herreros, hojalateros, lateros, marmolistas, pintores, torneros e yeseros, disputando um espaço na cidade que se agigantava, enquanto as páginas do EDE exibiam anúncios publicitários requisitando e ofertando mão-de-obra para o setor.

À cidade em construção acediam inumeráveis segmentos profissionais e milhares de homens sem qualificação, grupos de trabalhadores pobres, muitos vivendo miseravelmente, provocando o aumento da massa de imigrantes semi-empregados e desempregados, gerando maior excedente de mão-de-obra e, portanto, rebaixamento da remuneração. Alimentavam-se de tarefas eventuais e funções improvisadas e marginais, sem qualquer garantia ou segurança, para as quais também eram atraídos jovens de pouca idade.

Dentre os setores que despontarão, a indústria extrativa - extração de pedra, de areia e de caulim - conservou seu predomínio por muito tempo, ligada que estava à construção física da cidade (prédios, calçamento das ruas) e era previsível que a demanda por produtos empregados nesse setor aumentasse, na proporção do aceleramento das obras.

Era comum, nesse período, observar anúncios solicitando, por exemplo, indivíduos para trabalharem em pedreiras, na extração de pedras, trabalho pelo qual se pagava por metro cúbico, ou seja, por produção. Esses agenciadores tinham seus escritórios no centro da cidade. Juan

\footnotetext{
${ }^{70}$ EDE 27.07.1914, matéria com imagem do local. Trad. da autora

${ }^{71}$ MARX, G. Op. cit., p. 54.

${ }^{72}$ PETRONE, P. Op. cit., 1955, p. 145.
} 
Cardoso, espanhol com agência de contratação à Rua XV de Novembro, 27, $3^{\circ}$ andar, admitia canteros (arrancadores de pedra) e tejeros (oleiros) ${ }^{73}$, basicamente para abastecer outro setor em alta com a febre das construções, o da indústria de minerais não metálicos, fabricante de telhas e tijolos.

Essas olarias ou cerâmicas funcionando no período compunham pequenas e médias unidades, algumas artesanais, em bairros periféricos da cidade, e preferentemente junto às margens dos rios, em geral às do Rio Tietê, na Penha ${ }^{74}$. Usualmente, pedia-se "camaradas tejeros", ou, quando não, apenas tejeros e ladrilleros ${ }^{75}$, cuja preferência, explicitada nos anúncios, recaía sobre os orensanos ou alicantinos ${ }^{76}$.

Há indícios de que essa atividade era praticada preferentemente por galegos, e também no Interior do Estado. Na seção "Notas de viaje", em matéria sobre a excursão promovida pela região de Monte Azul, o EDE faz menção à "Fazenda S. Juan", de Juan Saborido - o qual aparece em foto com o uniforme de Capitão da Guarda Nacional ${ }^{77}$ - localizada na Estação Monte Verde. No inventário da propriedade, descrito pelo anúncio, há uma fábrica de telhas e ladrilhos, de nome "La Gallega" pertencente ao genro de Saborido, Sr. José Cemos ${ }^{78}$.

$\mathrm{Na}$ Capital, no período, já pontuavam grandes indústrias de cerâmica: a dos Irmãos Falchi, a Sacoman Frères, na Vila Prudente e a antiga Rodovalho, depois Melhoramentos, além da Companhia Mecânica Importadora, na Água Branca, embora a maior produção ainda estivesse a cargo das menores ${ }^{79}$.

Nestas pequenas unidades, o material recolhido, mistura de terra negra, turfosa, barro branco e areia, transportado pelos carroceiros em carroças, seguia para a amassadeira, movida à força animal ou a motor, antes de ir para as formas de tijolos, trabalho geralmente de mulheres e crianças. A secagem, processo posterior, podia durar de 10 a 15 dias, quando então entravam no forno, operação que demandava de 90 a 100 horas $^{80}$.

${ }^{73} \mathrm{EDE}$ 13.02.1920.

${ }^{74}$ EDE 07.04.1913.

${ }^{75}$ Tejero é quem faz telhas e também tijolos (oleiro); ladrillero, quem faz ladrilhos.

${ }^{76}$ EDE 22.05.1913.

${ }^{77}$ Esse dado evidencia o poder político que detinha esse indivíduo na localidade. Dentre suas prerrogativas enquanto "capitão", o sujeito poderia recomendar ao governo a nomeação dos majores, capitães, tenentes e alferes que, organizados em batalhões ou regimentos, constituíam "grupo de políticos e chefes eleitorais devotados". $C f$. AMERICANO, J. Op. cit., 1957, pp. 141 e ss. Trad. da autora.

78 "A fazenda possui 380 mil pés de café, com produção de 14 mil arrobas que, vendidas, alcançam a cifra de um milhar de libras esterlinas; já lhe ofereceram um milhão de pesetas pela fazenda; possui 45 casas de colonos; casas para depósitos; prédio para maquinário de limpeza e preparação do grão de café e de arroz; moinhos para farinha de milho". EDE 22.05.1913. Trad. da autora.

${ }^{79}$ LEME, M. Op. cit., 1984, p. 240.

${ }^{80}$ AZEVEDO, A. Op. cit., 1945 , p. 83. 
Aproveitando-se da arrancada da cidade em seu salto de crescimento, profissionais autônomos estabeleciam-se por conta própria e tornavam-se importadores de segmentos afins: "José Gimenez, mecânico fabricante de modelos divisores para fábricas de mosaicos e ladrilhos. Importador de F. Guilhon \& Fils, de Avignon, especialistas em máquinas e acessórios para industrias de cimento comprimido. Rua Paula Souza, $75^{\prime \prime 81}$.

Os arrancadores de pedra ou canteros (ou picapederos, conforme alguns registros) provinham majoritariamente da Região da Galícia e, especialmente, da cidade de Pontevedra. Dos 26 inscritos no CGE apenas na primeira década, 24 eram dessa Província ${ }^{82}$. Muitos outros canteros, também ingressados neste período encontravam-se domiciliados em Jundiaí, possivelmente atraídos pela ferrovia, para cuja manutenção eram requisitados. Notamos que havia uma intensa movimentação dessa categoria, especialmente para o norte do país, sobretudo para a cidade de Belém (PA), e queremos crer que, também neste caso, estivessem sendo atraídos pela ferrovia, no caso a Madeira-Mamoré. No ano de 1911 especificamente e em menor escala, observamos uma movimentação atípica em direção à cidade de Guaxupé (MG), de jovens canteros também naturais de Pontevedra, com idade média de 21 anos, declarando-se “canteros carabineros do $2^{\circ}$ Destacamento".

Seu número tendeu a crescer a cada década examinada, mantendo-se regular para todo o período considerado (1893-1922) revelando, no entanto, que os naturais de Pontevedra continuavam mantendo a hegemonia ${ }^{83}$.

Alguns canteros mais prestigiados chegaram a trabalhar com Ramos de Azevedo, caso de Antonio Rotea, casado e residente na Rua 25 de março, 10, que, tendo se dirigido ao Rio de Janeiro "por incumbência de seu patrão, lá teria desaparecido misteriosamente". Essa matéria, com o título de "Desaparecido" circulou no EDE e, além de pontuar a preocupação da família que solicitava providências às autoridades espanholas daquela cidade, sugeria a hipótese de que "a polícia poderia tê-lo detido por equívoco" 84 .

Os albañiles ou pedreiros também compõem esse mesmo perfil de mão-de-obra rotativa e ocasional. Acorreram à cidade prontamente em proporção superior a muitas outras categorias no período, revelando, por sua concentração nos dois primeiros anos de existência do CGE, que talvez já estivessem nela domiciliados há mais tempo. Após esse boom inicial, a

${ }^{81}$ EDE 23.07.1913. O cimento é substituído pelo concreto armado para prédios com mais de quatro andares, a partir de 1920.

${ }_{82}^{82}$ Relatório Access 10.

${ }^{83}$ A respeito dos canteros, procedência, fluxos e destino no Brasil, ver: EIRAS ROEL, A. y REY CASTELAO, O. Op. cit., 1992, especialmente pp. 258 e ss.

${ }^{84}$ EDE 24.04.1919. Ramos de Azevedo comandava um dos maiores escritórios de engenharia e arquitetura na cidade. Trad. da autora. 
categoria oscilou com números menores, reaparecendo novamente com força depois da Primeira Guerra. Vinham indistintamente de diversas regiões da Espanha, porém, em maioria da Região Andaluza (43\%); da Galícia (27\%) e da Catalunha (7\%), apresentando idade mínima de 17 e máxima de $62 \operatorname{anos}^{85}$. A análise da planilha de dados cumulativos evidenciou grande incidência de pedreiros com registro anterior de jornaleros, sobretudo a partir do início da década de 1920, rubrica que alguns exibiram em diversos registros seqüenciais anteriores. Curiosamente, no entanto, quase a mesma proporção de pedreiros tornava, com periodicidade variável, a declarar-se jornalero, indício da natureza rotativa, descontínua e instável da atividade para a qual havia um exército de homens disponíveis.

E não era apenas a mão-de-obra desqualificada que se via atraída para a atividade. Foi observada a ocorrência de indivíduos com ofício, temporariamente exercendo a atividade de pedreiro, e, nesse particular, o caso de José Solé Valles, de Tarragona, é exemplar. Localizamos seu primeiro registro em 1903, informando ser pedreiro. No registro seguinte, realizado em 1906, contudo, já se declarava encuadernador, profissão de seu irmão, Martín, também inscrito e que, em 1913, inauguraria um Taller Gráfico - aliás, em concorrido banquete oferecido à comunidade espanhola ${ }^{86}$-, no qual José Solé passaria a trabalhar.

Artigo publicado no Fanfulla, jornal da colônia italiana, informava em 1911 que, levando-se em conta a estação das chuvas e das festas, o pedreiro trabalhava em média 20 dias por mês, perfazendo 220 dias por ano, recebendo um salário de 1.320\$000 (hum conto, trezentos e vinte mil réis), valor que lhe facultava gastar consigo e com sua família, geralmente numerosa, a irrisória quantia de $3 \$ 616$ ao dia ${ }^{87}$. Esse aspecto, o da escassa remuneração, provocava notável mobilidade entre esses homens.

O ramo da construção civil revolucionou o mercado de trabalho da cidade, com o leque de novas ocupações e atividades que passaram a orbitar à sua volta, abrindo novas perspectivas e oportunidades para o estabelecimento de pequenas oficinas de artesãos, ao lado das indústrias que progressivamente se estabeleciam.

É o caso da enorme expansão da indústria metalúrgica para a fabricação de materiais e componentes, como pregos, materiais de encanamento, artigos de serralheria, etc. e esta foi a oportunidade encontrada para pequenos serralheiros, geralmente residentes no bairro do Brás

\footnotetext{
${ }^{85}$ Relatório Access 19.

${ }^{86}$ O Taller Gráfico realizava: "serviços de encadernação, papéis pautados, fábrica de livros em branco, material escolar, importação de papéis para imprensa e escritório" e estava situado na Avenida Rangel Pestana, 244. EDE 10.11.1913.

${ }^{87}$ VANGELISTA, Chiara. Op. cit., 1991, p. 261.
} 
instalarem suas pequenas oficinas de serralheria para a "fabricação de ferramentas", as quais progressivamente iam se ampliando e necessitavam de "camaradas aprendizes"

Oficinas de pintura também se estabeleciam: "executa-se qualquer trabalho relativo ao ramo de pintor decorador; contratos para pintura total ou parcial de edifícios e estabelecimentos comerciais ou industriais, anúncios, letreiros de lojas, etc ${ }^{" 89}$. Outras funções ou atividades paralelas também foram impulsionadas, caso do construtor-empreiteiro. Negócio próspero, a empreita, uma espécie de "terceirização" atual, envolvia a contratação de pessoal e a execução do contrato da obra:

Antonio Moral, Construtor - Encarrega-se da construção de edifícios e de fachadas; reforma de edifícios, seja por contrato ou por administração; dispõe de um elevado número de operários para levar a cabo as obras que se encomendem; também executa toda classe de reformas. Tratar em seu escritório: Rua Piratininga, 26-A ou em sua residência, Rua da Moóca, 77. Também informam no Café América ${ }^{90}$.

Apenas 6 meses depois, a empresa expandia-se. Em sociedade com um conterrâneo, a oportunidade para ampliar o raio de ação, instalado em local prestigiado e investindo-se de novas atribuições: “Antonio Moral e Rafael Dominguez. Construtores, Aprovação de Plantas na Inspetoria de Higiene e na Câmara Municipal. Travessa do Comércio, $2-2^{\circ}$ piso - Palacete União Mútua"91.

Empreiteiros ou constructores de obras, como se declaravam no CGE, esses indivíduos já estavam estabelecidos na cidade desde 1893 e foi exatamente nos dois primeiros anos de sua existência que observamos a maioria dos seus registros ${ }^{92}$.

Circulavam pelos países do cone sul, e na primeira década do Novecentos, podiam ser percebidos refluindo da Argentina, buscando melhores oportunidades: "Carpinteiro recémchegado da Argentina, com muita prática de planos (projetos) [onde] trabalhou como contratista (empreiteiro), possuindo certificados. Dirigir-se a Manuel Porto, Hotel dos Viajantes, Rua da Conceição, 86,"93.

Filhos de espanhóis, pertencentes às famílias mais abastadas e que tiveram oportunidade de cursar a Escola Politécnica ${ }^{94}$, à época estabeleciam-se em ramo correlato:

\footnotetext{
${ }^{88}$ EDE 18.06.1912. Esta mencionada localizava-se na Rua Martin Buchard, 31.

${ }^{89}$ EDE 03.11.1920. De Antonio Garcia. Rua Maestro Cardim, 25. Trad. da autora.

${ }^{90}$ EDE 14.08.1913. Trad. da autora.

${ }^{91}$ EDE 11.02.1914. Trad. da autora.

${ }^{92}$ LRC 1893 e 1894.

${ }^{93}$ EDE 28.11.1913. Trad. da autora.

${ }^{94}$ Existia desde 1893, especialmente com os cursos de Engenharia Civil. In: LEME, M. Op. cit., 1984, p.
} 251. 
"Escritório Técnico de Engenharia. Sociedade constituída por engenheiros e arquitetos. Diretorchefe: Héctor Eiras Garcia, engenheiro civil. Rua Brigadeiro Tobias,194"95.

Segmento afim, a representação comercial de firmas e casas comerciais estrangeiras, fabricantes de diversos materiais e produtos, apresentava-se como garantia de excelente negócio, ao qual aderiram os dois filhos de Eiras Garcia com um sócio, Luis Mestres, constituindo a Hermanos Eiras Garcia \& Mestres, Rua Brigadeiro Tobias, 93, tendo como representadas, em maioria empresas americanas, as seguintes ${ }^{96}$ : de Indianápolis, a The Reilly Co., fábrica das pinturas Weatherwax, para madeira, ferro, cimento e ladrilho; de New York, a The Williams Patent Cruscher and Pulverizer Co., fábrica de máquinas de quebrar e moer carvão, material de cimento, argila, materiais fibrosos, pedras, etc. e a The Specialty Device Company, fabricantes das brocas (perfuratriz) marca Standar (sic) para abrir poços e para instalação de postes. De Cincinati, Ohio, The Edwards Manufacturing Co., fábrica de materiais de aço estampado para tetos e paredes exteriores, ornamentos, material galvanizado, estampado e pintado e da Filadélfia, fábricas de anilinas e corantes e produtos químicos.

Ao crescimento vinculado à expansão física da cidade, percebia-se paralelamente um florescimento do comércio de materiais de construção, elétrico e de ferragens: "Fernandez \& Caballero. Grande depósito de materiais de construção, lenha e carvão. Rua São Caetano, 213. Vendas a varejo e atacado".

Tais depósitos e lojas tiveram um crescimento enorme. Eram apenas 20, até 1914, sendo que, apenas 15 anos depois, somavam 178. Ao lado desses, surge um novo tipo de negócio na cidade, o depósito para a venda de materiais usados "assoalhos, portas, janelas, venezianas, vigas, caibros, ripas, banheiras, fogões, pias, latrinas, etc. Al. Glete, $2^{\text {"997. }}$

\footnotetext{
${ }^{95}$ EDE 07.10.1919. Trad. da autora.

${ }^{96}$ EDE 21.01.1919 e 08.11.1919. Trad. da autora.

${ }^{97}$ EDE 26.06.1919. Trad. da autora.
} 


\section{Pequenos ofícios autônomos}

No atendimento às novas demandas, vemos surgir na cidade uma profusão de modestas oficinas artesanais, pequenos negócios instalados em fundo de quintal ou em algum cômodo da casa que, para início, requeriam reduzidas aplicações de capital. De manutenção barata, geralmente utilizando-se apenas da mão-de-obra de seu titular, ou, em alguns casos, conforme a demanda, incorporando elementos do grupo familiar, parentes ou eventualmente conterrâneos, tal fórmula trazia vantagens adicionais como a possibilidade de uma melhor adaptação a períodos de maior demanda, reduzindo as despesas fixas nos momentos de recessão.

$\mathrm{Na}$ análise que fizemos nos LRC, conforme mencionamos, tais ofícios autônomos e domiciliares, pressupondo certa qualificação ou habilidade específica, vinham sendo praticados na última década do Dezenove pelos espanhóis, numa diversificação crescente. É o caso de sapateiro, carpinteiro, chapeleiro, marceneiro, barbeiro, alfaiate, alpargateiro, tintureiro, cesteiro, tapeceiro e muitos outros ofícios que, declarados, não permitem, contudo, pressupor por sua natureza exclusivamente domiciliar e autônoma ${ }^{98}$.

Trata-se de atividade de difícil aferição, dada a sua natureza. Em alguns casos, dispomos de poucos indícios a respeito de algumas delas, geralmente quantitativos. O caso dos carpinteiros e dos sapateiros é exemplar: em um único ano, 1894, constatamos nos LRC 29 carpinteiros e 18 sapateiros domiciliados na cidade, número que tendeu ao crescimento ${ }^{99}$. Apesar disso, intriga que todas as referências a esses ofícios convergissem para o italiano, a quem sempre foram atribuídas tais atividades. Antonio Bandeira Jr. por exemplo, em seu estudo de 1901 sobre a indústria no Estado de São Paulo, enaltecia "o espírito empreendedor do paulista e a imigração italiana" surpreendendo-se pelo "incalculável número de tendas de sapatarias, marcenarias (...) tinturarias, fábricas de calçados, manufaturas de roupas e chapéus, que funcionam em estalagens, em fundos de armazéns, em resumo: em lugares que o público não vê" ${ }^{, 100}$.

Autores vários associaram a existência dessas pequenas oficinas, nas cidades, aos imigrantes italianos. Ângelo Trento, estudioso da emigração italiana, afirma: "Essa massa de gente dedicou-se às mais variadas profissões: alfaiates, sapateiros, pedreiros, barbeiros,

98 É o caso das ocupaciones de funileiro, tapeceiro, ferreiro, funileiro, chaveiro, barrilero (barris), cigarreiro, curtidor, doceiro, abaniquero (leques), calista, taponero (rolhas), fotógrafo, tabulero (tábua), sillero (cadeiras), gesseiro, etc.

${ }^{99}$ No conjunto dos 30 anos, esses números foram de 69 e 65 declarantes com as respectivas ocupações.

${ }^{100}$ BANDEIRA Jr., A. Op. cit., p.X. 
carpinteiros, garçons, eram com freqüência italianos" ${ }^{, 101}$. E finalmente Mário Carelli para quem os italianos constituíram "verdadeiros monopólios" sendo "logo apreciados como talentosos artesãos", contando-se entre eles "os alfaiates mais reputados da cidade" (...) o mesmo ocorrendo com os "sapateiros e boteiros"102.

A análise do ofício de carpinteiro revelou algumas singularidades. No primeiro decênio, era atividade exercida com preponderância pelos andaluzes (52\%, em maioria da cidade de Málaga), seguidos por galegos (29\%), porém, considerado todo o período, a fração de andaluzes tendeu a retrair-se para $40 \%$, ao mesmo tempo em que a atividade pareceu pulverizar-se com indivíduos oriundos de diversas outras regiões. Espraiavam-se por toda a cidade, do Brás à Moóca, do Bom Retiro à Luz, do Centro à Liberdade e da Barra Funda à Lapa, bairro onde foram encontrados especialmente os galegos (de La Coruña, Orense e Pontevedra), que revelaram uma estabilidade percentual no período de 30 anos $^{103}$.

Os registros iniciais, especialmente os de 1894 sugerem uma possível vinculação à política oficial de subsídio da passagem, quando não de embarque clandestino. Nessa primeira leva que se registrou em 1894, parcela considerável apresentou-se ao CGE "sem documentos", sendo em maioria oriundos de Málaga, o que sugere uma provável saída ilegal por Gibraltar.

Natural de Málaga, Francisco Gallado "encontrado muerto en su casa, un quarto de la Calle Carneiro Leão, ebanista, 60 años, onde deja mujer y hijos" ${ }^{\prime 104}$, era notícia que expunha a crua realidade desses sujeitos que, sem opção, largavam tudo, deixando para trás muitas vezes até a família, alimentados pelo projeto do retorno em melhores condições ou de vencer em seu negócio para trazer a família. O início era difícil, improvisado, no próprio local de moradia, e as dificuldades enormes: "se vende pequeno negócio de ebanisteria. Rua Claudino Pinto, 21"105. Os mais afortunados por conjunturas favoráveis conseguiam progredir lentamente, associandose a algum conhecido ou familiar, quando então instalavam seu pequeno negócio em local mais apropriado: "Oficina de carpintería mecánica de Júlio Paz y Hermano. Rua Tocantins, 7 (B.Retiro). Com trabalho de molduras e todo o necessário para edificações" ${ }^{\prime 106}$.

A divulgação publicitária que alguns passaram a fazer de suas oficinas pelo EDE é evidência desses casos: a sociedade de Costillas \& Flores freqüentava regularmente as páginas

\footnotetext{
${ }^{101}$ TRENTO, A. Op. cit., 1990, p. 39.

${ }^{102}$ CARELLI, M. Op. cit., 1985, p. 40.

${ }^{103}$ Relatório Access 20.

${ }^{104}$ EDE 11.09.1914.

${ }^{105}$ EDE 03.02.1914. Trad. da autora.

${ }^{106}$ EDE 01.04.1913. Trad. da autora.
} 
publicitárias do EDE. Sua empresa tinha um sugestivo nome fantasia: "Al Progreso - Gran Depósito y Fábrica de Muebles a Electricidad', e apresentava-se com dois endereços: o depósito, na Rua do Rosário, 50 e as oficinas e o escritório na mesma rua, no ${ }^{\circ} 144^{107}$.

A Rua dos Gusmões parece haver se tornado um "ponto" no qual, em determinado trecho, muitos profissionais do ramo acabariam se instalando. No $\mathrm{n}^{\mathrm{o}} 62$, declarou-se domiciliado Manuel Vidal Pousado, galego de Pontevedra, em 1894; no n 67, José Lorca Cervero, malaguenho, em $1897^{108}$ e no no 49 admitia-se "ebanistas, carpinteros, torneros, lustradores de torno" "109 , do embrião que seria a empresa Estepa, Blois \& Cia. "fabricantes de mesas de bilhar, tacos, bolas de marfim e demais acessórios", que se vangloriava de ter sido "premiada na Exposição Nacional do Rio de Janeiro Grand Prix e medalha de ouro", e que, apesar do sucesso de vendas que passara a ter, continuaria "com suas atividades de torno e de móveis finos" $" 110$.

Uma das grandes do ramo, a Estepa, Blois \& Cia., altera sua razão social, 5 anos depois para Estepa \& Frascati, Torneria e Ebanisteria, efeito provável de algum remanejamento societário. Continuava a fabricar os mesmos produtos, móveis "em qualquer estilo e desenho", passando contudo a acrescentar em seus anúncios o adjetivo "de luxo""111, indicando a progressiva incorporação de uma fatia de mercado mais abastada.

A análise da planilha de dados cumulativos sugeriu pequena incidência de carpinteiros com registro anterior de jornaleros e, ainda assim, casos circunstanciais, revelando desemprego temporário. Observamos entretanto que, no decorrer do período, ainda que houvesse a distinção, nos LRC, do carpintero para o ebanista (marceneiro), tornava-se cada vez mais comum firmas de carpintaria solicitarem marceneiros, provavelmente porque, apesar das distinções quanto ao produto fabricado, a habilidade requerida para o trato com a matéria-prima utilizada, a madeira, fosse a mesma para as duas atividades, em certa medida complementares.

Ocorreu-nos que a esse fato pudesse estar relacionado o porte da empresa, menos artesanal para o caso dos carpinteiros. Algumas traziam essa fusão estampada em sua razão social: Colin \& Co., Carpintería y Ebanistería, instalada na Rua Santa Cruz da Figueira, 20, então admitindo ebanistas e torneros ${ }^{112}$. Também o Taller de Muebles de Carpintaria, denominação da empresa pertencente a Ramón Monconill, de certo modo expressava as características acima apontadas, quanto à convergência dos ofícios. Responsável pelo mobiliário

\footnotetext{
${ }^{107}$ EDE 04.08.1913.

${ }^{108}$ Relatório Access 20.

${ }^{109}$ EDE 30.07.1912. Trad. da autora.

${ }^{110}$ EDE 28.06.1913. Nesta data, a empresa já dispunha de telefone, de número 1894. Trad. da autora.

${ }^{111}$ EDE 17.01.1918. A empresa mudara-se então para a Rua General Osório, 29.

${ }^{112}$ EDE 22.09.1913.
} 
do luxuoso Grand Hotel Ausonia (dos espanhóis Sebastião Prat e Juan Guerrero) inaugurado na cidade em 1914, a marcenaria/carpintaria situada na Rua Paula Souza, 75 foi objeto da visita prévia do articulista do EDE às suas instalações o qual, impressionado, descreveria o mobiliário então em fase final de fabricação e em maioria feito de imbuia nacional, "como parecendo móveis importados da Inglaterra" $" 113$.

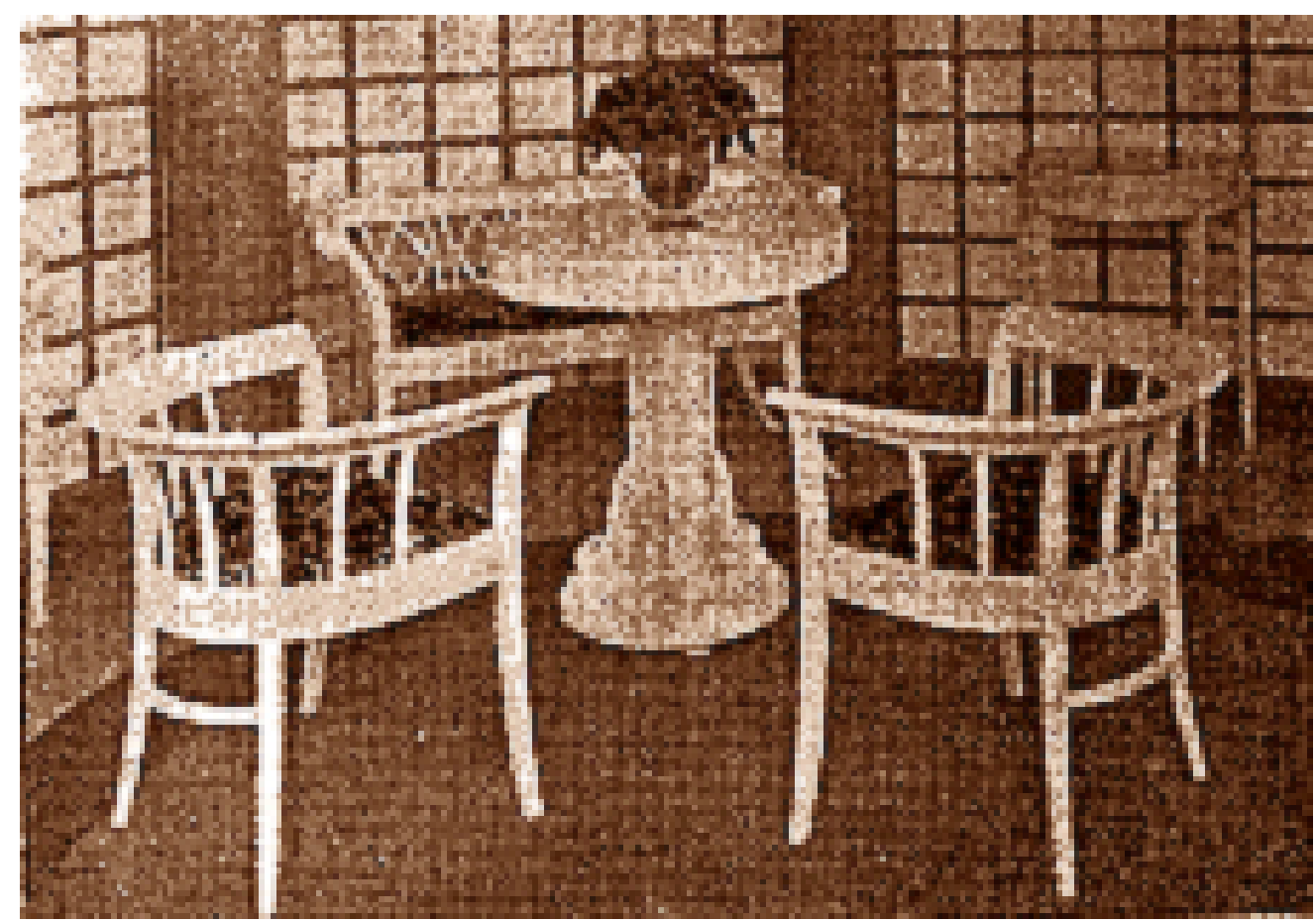

Fig. 5. Móveis executados pela marcenaria e carpintaria de Thomaz Alliegro, participante da primeira exposição municipal industrial de São Paulo. Rua da Consolação, 21 [1916].

Uma cadeia de atividades afins foi despontando, operando em complemento à produção de móveis e objetos de madeira, no atendimento às exigências do mercado consumidor, como a casa "especializada em douração sobre móveis e madeiras", de J. Castro, instalada na rua Sebastião Pereira, $n^{\circ}$ s 15 e 17"114. Até mesmo anunciantes de cidades próximas passaram a ofertar seus produtos, caso de Victoria \& Giles, de Bragança, com seu estabelecimento de "serrar madeira"115.

Curiosamente, no entanto, os marceneiros (ebanistas), diferentemente dos carpinteros no período eram, em grande parte, catalães de Barcelona ${ }^{116}$, região para a qual não consta um único registro para carpintero que, como vimos, foi representado por maioria andaluza.

\footnotetext{
${ }^{113}$ EDE 13.04.1914. Trad. da autora.

${ }^{114}$ EDE 02.05.1922. Trad. da autora.

115 EDE 01.04.1913. Trad. da autora.

${ }^{116}$ Relatório Access 17.
} 
O crescimento vertiginoso da cidade demandava um setor diversificado de serviços que fizesse face às crescentes necessidades derivadas do "comportamento urbano" de sua população. Nessa medida, há um enorme incremento nos segmentos prestadores de serviços pessoais - as barbearias, por exemplo, cresceram, em 15 anos, de 1914 a 1929, 6.100\%, passando de 19 para 1.196 estabelecimentos ${ }^{117}$. É também desse período o aumento das sapatarias que, junto com as alfaiatarias, os ateliês de costura e as relojoarias quadruplicaram.

Sapateiro era ofício relativamente novo na cidade - quando, em 1893, constatamos os primeiros registros do CGE para essa ocupación - tendo em conta que, uma década antes, era muito dificultoso conseguir quem efetuasse consertos em calçados: "A reforma dos calçados é aqui desconhecida; usam-nos até se tornarem imprestáveis e depois são substituídos por outros novos", comentava Ina Von Binzer, professora domiciliar dos filhos da família Prado, em carta à sua irmã na Alemanha. "Não há bons sapateiros, mas somente lojas de calçados prontos, em sua maioria importados da França; assim, para os estrangeiros é muito difícil mandar consertar qualquer coisa" ${ }^{\prime 18}$, concluía.

Tratava-se, portanto de atividade promissora, rapidamente "percebida" pelos imigrantes, desprovidos de qualquer preconceito com relação ao trabalho manual, herança da senzala. Somente entre os anos de 1893 e 1894, foram 23 os declarantes zapateros mencionados nos LRC e 31 no primeiro decênio computado (até 1902), período que corresponde, em parte, àquele mencionado por Ina Von Binzer.

Nesse período, a maioria $(80,6 \%)$ que assim se declarou no CGE era natural da região andaluza, destacando-se Málaga como a Província de maior número de citações. Não havia nenhum galego entre eles. Domiciliados predominantemente no Brás, metade declarou-se casada e concentravam-se basicamente numa única rua deste bairro, a Carneiro Leão ${ }^{119}$.

Seu número tendeu a estabilizar-se no segundo decênio considerado (1903/12), porém o último decênio revelou uma curva ascendente que culminou em 1922, ano em que, a propósito, Juan Gutierrez, sapateiro espanhol declarava o prejuízo de um conto de réis em mercadoria furtada (peles, tecidos e calçados), em decorrência do assalto de que fora vítima sua sapataria,

${ }^{117}$ RIBEIRO, M. Op. cit., 1996, p. 352.

${ }^{118}$ BINZER, Inna Von. Os meus romanos - alegrias e tristezas de uma educadora alemã no Brasil. $3^{\mathrm{a}}$ ed., Rio de Janeiro: Paz e Terra, 1982, p. 88.

${ }^{119}$ Relatório Access 4. 
instalada na rua Barão de Iguape, 57. Comentava ainda, em nota ao $\mathrm{EDE}^{120}$, que nada ouvira mesmo residindo nos altos do estabelecimento com a família.

O exame da planilha de dados cumulativos sugeriu a incidência de sapateiros com registro anterior de jornaleros, ainda que não se possa garantir por sua passagem prévia pelo colonato. Pedro Larrubia Penas, de Málaga, representa um desses casos, estabelecendo-se com sua oficina de sapateiro em 1922, na Rua Carneiro Leão, 237, onde provavelmente residisse, depois de diversas citações anteriores como jornalero. O mesmo ocorreu com Luiz Sanchez Bruna, jornalero desde 1915 que, em 1920, estabelece-se como sapateiro, na Av. Rangel Pestana, 48.

Não é improvável que algumas dessas incipientes oficinas, funcionando inicialmente no próprio domicílio, tenham prosperado, transformando-se em fábricas de calçados de porte variável, conforme demonstraremos, em que pese o ofício de sapateiro ter representado um dos segmentos mais resistentes à crescente industrialização.

Considerados os 30 anos examinados, o número de zapateros inscritos no CGE foi de 65, número restrito a indivíduos do sexo masculino, apesar de haver indícios de que a profissão era exercida também por mulheres no período: "Pede-se boa oficial feminina, uma meio oficial e um aprendiz, para calçado fino de senhora. Rua 24 de maio, 18, casa particular","121.

Dentre os investimentos de capitais estrangeiros no ramo calçadista, a Clark \& Co., empresa inglesa que já operava no país no comércio de calçados importados, instala sua primeira fábrica no Alto da Moóca em São Paulo no ano de 1904, visando evitar os impostos de importação. A partir de sua instalação, marco modernizador do setor, introduzindo no segmento a venda a varejo, passa a operar com empresas nacionais e com muitas outras fabriquetas menores $^{122}$. Para essas, a maquinaria requerida era de pequeno porte, como complemento ao trabalho do homem (máquinas de costura, artefatos para aplainar solas, cilindrar e abrir biqueiras, palmilhar, cortar, ajustar e pregar saltos) ${ }^{123}$.

É bastante provável que o estabelecimento das indústrias maiores tenha ocasionado a absorção de porção dessas pequenas oficinas, as quais, devido a concorrência, passariam a adotar a estratégia do trabalho domiciliar: "A Alpargatas [instalada na cidade em 1907] que também tinha muitos trabalhadores espanhóis, cedia cordas e cola para que se fizessem as solas

${ }^{120} \mathrm{EDE} 30.05 .1922$.

121 EDE 16.12.1920. A propósito da mão-de-obra feminina em setores considerados tipicamente masculinos, ver: MOURA, Esmeralda Blanco Bolsonaro de. "Além da indústria têxtil: o trabalho feminino em atividades masculinas”. In: Revista Brasileira de História. São Paulo: v. 9, n.18, ago./set.1989, pp. 83-98.

122 SUZIGAN, Wilson e SZMRECSÁNYI, Tamás. "Os investimentos estrangeiros no início da industrialização do Brasil”. In: SILVA, S. e SZMRECSÁNYI, T. (org). Op. cit., 1996, pp. 264-265.

${ }^{123}$ LEME, M. Op. cit., 1984, pp. 228-229. 
dos calçados" relembra o Sr. Rômulo Carraro, italiano chegado na cidade em 1911. "Então", complementa, "eles [os espanhóis] ficavam nas portas das casas, faziam um fogãozinho onde esquentavam a cola e em uma tábua com dois pregos eles enrolavam a corda em formato de pé. Depois era só levar as solas de volta" ${ }^{24}$.

Em 1907, eram 9 as fábricas de calçados na cidade, muitas com 400 operários ou mais. O calçado aqui produzido era enviado para o Rio de Janeiro e para os Estados do Norte ${ }^{125}$. Até 1913 podiam ser consideradas as empresas mais mecanizadas do ramo.

Através das páginas publicitárias do EDE ficou demonstrada, a partir de 1912, ano inicial da consulta, a existência de fábricas de calçados de porte variado pertencendo a espanhóis, provavelmente gestadas nas inúmeras sapatarias encontradas desde a última década do Novecentos.

Foi, aliás, protagonizada por um sapateiro espanhol, José Ineguez Martinez, de 21 anos, no momento em que eclodiam as greves operárias, o marcante episódio de julho de 1917, que redundaria com a sua morte, depois de ferido, no piquete que se chocou com a polícia quando se dirigia à rua Flórida, para fechar a Fábrica Mariângela ${ }^{126}$. Seu óbito, no dia seguinte, provocaria protesto e comoção geral e o cortejo de seu sepultamento foi acompanhado por uma multidão de 10 mil pessoas, sob a vigilância da força policial. Residia com sua família à Rua Caetano Pinto, 91, e seu pai Antonio Iñeguez Vera, de Albacete, registrou-se no CGE logo após o acontecido, sendo bastante provável que buscasse a repatriação ${ }^{127}$. A Greve de $1917^{128}$ vitimaria outro sapateiro, Virgílio Hidalgo que, por sua vez, foi deportado, acusado de $\operatorname{anarquista~}^{129}$.

${ }^{124}$ Depoimento do Sr. Rômulo Carraro. In: A reconstituição da memória estatística, op. cit., vol. 2, p.134. A Alpargatas Co. teria se instalado em São Paulo em 1907 e, segundo consta, sua principal atividade era a da importação de algodão e lã mercerizada. $C f$. DEAECTO, M. Op. cit., 2002, p. 76.

${ }^{125}$ LEME, M. Op. cit., 1984, p. 254.

${ }^{126}$ LOPREATO, Christina Roquette. O espirito da revolta. A greve geral anarquista de 1917. São Paulo: Annablume, 2000, p. 31.

${ }^{127}$ LRC 09.10.1917.

${ }^{128}$ Para uma melhor compreensão da conjuntura paulista de 1917, ver o Capítulo V.

${ }^{129}$ Junto com ele, outros espanhóis: José Sarmento Marques, chapeleiro, naturalizado brasileiro, Primitivo Raymundo Soares (que utilizava o pseudônimo de Florentino de Carvalho), comerciário, Antonio Lopes, tecelão e José Fernandes, pintor. In: LOPREATO, C. Op. cit., p. 163. 
Sastres (alfaiates)

Inferior ao número de sapateiros, o número de alfaiates que se registrou no CGE no período teve evolução semelhante àqueles, apresentando dois focos de incidência, no primeiro e no último decênio. No primeiro decênio (1893/1902) o número de declarantes era de apenas 5 , sem, no entanto, possibilitar a distinção entre oficiais ou donos de alfaiataria. Esse número tendeu a triplicar no período considerado. Diferentemente dos sapateiros, contudo, os alfaiates dividiam-se entre andaluzes e galegos em proporção bastante equilibrada (30\% cada), porém a categoria ainda se compunha de elementos de outras Regiões (Rioja, Aragon, País Basco, Navarra).

É provável que muitos atendessem à clientela em alguma dependência do próprio domicílio; há claras indicações nesse sentido com a menção de endereços nitidamente residenciais, como a Rua Maria Domitila, por exemplo.

Porém, há indícios de que outros já atendessem em endereço comercial, alguns dos quais aliando ao ofício outras atividades, caso de Andrés Sanchez Mosquera, galego de La Coruña, que se declarou "sastre y negociante", com domicílio no Largo da Sé, $15^{130}$.

Longe da região central, o Bairro Alto da Serra, concentração de muitos espanhóis como vimos, era atendido por Antonio Bonzada Silva, de Pontevedra, registrado no CGE em 1916.

Nas folhas diárias do EDE consultadas, notamos anúncios contratando com regularidade "ajudante e aprendiz de sastre"131, alguns explicitando a "preferência por espanhóis"132, em clara demonstração de que o ofício era aprendido na prática diária, com o oficial ou mestre alfaiate e que, para tanto, dava-se preferência por compatriotas.

Dentre as alfaiatarias, destaque especial para a Sastrería La Vida de Madrid, de Fermín Barnó e Eduardo Burgos, estabelecida à Rua São Caetano, 156. Seus proprietários, neste período, ano de 1913, eram respectivamente presidente e secretário da Liga Defensora de los Españoles (LDE), agremiação que deveria estar passando por dificuldade financeira, já que seus titulares, comunicando a mudança temporária para Rua do Gazômetro, 49-A, informavam ser o local onde também residiam ${ }^{133}$. Eduardo Burgos Dias, um dos sócios, era natural de Sevilha, na região andaluza, tendo-se inscrito no CGE apenas em 1921, quando então declarou estar domiciliado na Rua Visconde de Abaeté, 32.

\footnotetext{
${ }^{130}$ LRC 1897. Relatório Access 16

${ }^{131}$ EDE 30.07.1912.

${ }^{132}$ EDE 31.07.1912.

${ }^{133}$ EDE 29.07.1913.
} 
Aparentemente, tais sastrerías não fabricavam exclusivamente roupas masculinas. Os anúncios sugerem a "confecção de toda classe de prendas para senhoras e cavalheiros, com elegância e perfeição" ${ }^{\prime 34}$. Imaginamos que peças mais estruturadas e de modelagem mais complexa, como os manteauxs ou os casacões femininos, por exemplo, pudessem ser aí confeccionados, posto que a calça comprida feminina ainda não era moda disseminada.

Muitos deles, sensíveis aos novos hábitos impostos por uma cultura urbana que se instituía ganhando ares europeus e "sob os vícios da ostentação"135, apelavam em suas peças publicitárias para o "gosto chic e moderno" do cliente: "casa montada a la moderna, confecciones elegantes", caso da Sastrería Internacional, de Modesto Nunes Martins, situada à Rua do Rosário, 136 de cuja especialidade "roupas sob medida" como "camisas, colarinhos e gravatas" vemos derivar "um permanente, completo e variado sortimento de roupas feitas para homem e crianças", destacando-se os artigos importados provavelmente destinados a uma clientela exigente e de maior poder aquisitivo: "variadíssimo estoque de casimiras francesas e inglesas, alpacas, brins brancos e de fantasia"136.

O termo sastrería, bastante distinto do significado equivalente em português - e provavelmente porque dificultasse o reconhecimento para alguns leitores - foi paulatinamente substituído, nos anúncios publicitários, pelo termo "alfaiataria" conservando-se, no entanto, o restante do anúncio em espanhol. Tornando-se mais inteligíveis, tentavam a comunicação com a seleta camada de novos consumidores, atingindo outras fatias de mercado, especialmente fora da colônia. Nesse particular, o primeiro dos casos observados, foi o da "Alfaiataria" Oriente, de Cipriano Barata, localizada no Brás, à rua Maria Marcolina, 89- $\mathrm{A}^{137}$.

Novos segmentos dentro do setor passaram a ser explorados, em sintonia fina com as crescentes novas necessidades da cidade. Assim, a Ao Grande Amazonas - Sastrería, de Maia \& Branco, localizada numa das mais prestigiadas vias de comércio da época, a Rua São Bento, passou a fabricar uniformes para militares, colegiais, chauffeurs, etc., e era fornecedora da Associação Brasileira de Escoteiros ${ }^{138}$.

O setor foi se aprimorando com o tempo, diversificando e especializando-se. Em complemento ao traje masculino, passava-se a produzir também as camisas. A Camisaría y Sastrería Barros também situada na imponente Rua São Bento ${ }^{139}$ instalou-se próximo à mais antiga delas, a Casa Hermanos Carnicelli, fundada em 1892, que ofertava "casimiras inglesas

\footnotetext{
${ }^{134}$ EDE 10.06.1913. Trad. da autora.

135 DEAECTO, M. Op. cit., 2002, p. 79.

${ }^{136}$ EDE 11.02.1914. Trad. da autora.

${ }^{137}$ EDE 18.04.1914.

${ }^{138}$ Rua São Bento, 95. EDE 18.04.1914.

${ }^{139}$ Rua São Bento, 62-A. EDE 02.05.1922.
} 
de $1^{\text {a }}$ qualidade, e trajes de paletot, a 150\$000", além de incorporar, oportunamente, um "curso de cortador para trajes masculinos e femininos" $" 140$.

Na Rua São Bento, ocupando dois imóveis, nº 84 e 86, também estava estabelecida a firma Valentin Guerra \& Hermano, fundada pouco depois, em 1895. A Casa Guerra, como era conhecida, habilmente se aproveitava de outro segmento promissor, produzindo "fantasias para carnaval". Neste item, assegurava: "executa-se qualquer figurino, por mais original que seja, com a maior presteza e elegância. Aceitam-se encomendas para o interior" ${ }^{, 141}$. Aliava a isto, o pequeno comércio de "tecidos, modas, armarinhos, confecções, viés de linho"142.

Nessa mesma direção, e no atendimento às novas demandas resultantes da alteração no comportamento e atitudes "urbanizadas" da população, a cidade passa a exibir, por meio do crescimento de um número de estabelecimentos afins, um diversificado segmento de novos serviços, dentre os quais sobressaíam, como já destacamos anteriormente, os prestadores de serviços pessoais. Nos LRC vislumbramos com alguns desses segmentos despontando na miríade de ocupaciones apresentadas que espelhavam o "momento" vivenciado pela cidade: tintureiros, chauffeurs, fotógrafos, calistas, relojoeiros, ateliês de costura, cabeleireiros, barbeiros, foram setores profissionais que tiveram grande impulso nas primeiras décadas do Novecentos.

Anteriormente a este período, mais exatamente no primeiro ano de registros examinados, 1893, já haviam 2 barberos espanhóis radicados na cidade, número que tendeu a crescer até os anos finais daquele século ${ }^{143}$. À sua existência, constatada nos registros e ao seu talento inegável, exaltado na literatura, contudo, não corresponderam os anúncios publicitários no EDE, bastantes escassos.

- Acabo de sair do Gastón. Dedos maravilhosos!

- O maior coiffeur do mundo! Nem em Paris! ${ }^{144}$.

Um desses escassos anúncios, o da Peluquería Salón Madrid, de Fernandez Requena ${ }^{145}$, trazia uma curiosa "cobrança” endereçada a um barbeiro, Manolo Marín, estabelecido à Rua Caetano Pinto, 69, para que comparecesse à mesma rua, no $\mathrm{n}^{\circ} 115$, "para fazer o respectivo pagamento de roupas que, por luxo, deve"146, indicando provavelmente que o credor,

${ }^{140}$ Rua São Bento, 47. EDE 01.04.1913.

${ }^{141}$ EDE 15.02.1922. Trad. da autora.

${ }^{142}$ EDE 02.05.1922. Trad. da autora.

${ }^{143}$ Ainda na última década constatamos um registro para calista e um para fotógrafo (1894). Os tintureiros começaram a aparecer apenas em 1911 e os chauffeurs, somente em 1913.

${ }^{144}$ GALVÃO, P. Op. cit. 1994; (1 ${ }^{\mathrm{a}}$ ed. 1933), p. 68.

${ }^{145}$ EDE 14.08.1914. Peluquería: salão de beleza e barbearia.

${ }^{146}$ EDE 15.10.1913. Trad. da autora. 
proprietário do estabelecimento, o utilizasse para comercializar outros produtos, como roupas. Em outro desses (poucos) anúncios, com o título "barba de senhoras", oferecia-se para a "extração radical de cabelos por eletricidade", à Rua Benjamin Constant, $21{ }^{147}$.

${ }^{147}$ EDE 14.12.1914. Trad. da autora. 


\subsection{Trabalho domiciliar e feminino}

O trabalho domiciliar deste período, apropriadamente estudado por Esmeralda B.B. de Moura $^{148}$ revelou nuanças como expressão de um momento de adensamento populacional continuado na cidade que, se por um lado se via incapacitada de absorver à crescente demanda de mão-de-obra, também apresentava "soluções", melhor dizendo, brechas que foram percebidas por uma parcela dessa população pobre. Conforme sustenta a autora, o "trabalho a domicílio não era exclusividade das mulheres", demonstrando entretanto que, mais do que ninguém, elas souberam integrá-lo ao seu cotidiano driblando a conjuntura da cidade, na execução de tarefas "no lar", adaptadas e complementares à cidade que se industrializava. Nessa direção, a autora destacou, dentre outros, o ofício de costureira "muitas vezes por conta própria [que] surge como uma das principais atividades desempenhadas no lar por mulheres que tinham filhos e precisavam trabalhar" e que esse trabalho mostrou-se essencial para a "história da mulher de condição social inferior"149.

As costureras que acorreram ao CGE, assim autodenominadas, concentraram sua inscrição apenas entre os anos de 1910 e 1915. No período total de 30 anos abrangido pela pesquisa, entretanto, no caso dos registros femininos, dentre as modalidades ocupacionais declaradas para as residentes na Capital, subtraindo-se a categoria majoritária de sus labores, identificada com as donas de casa e aparecendo no período compondo 16,4\% do total geral, a categoria das costureras destacou-se, permanecendo numericamente atrás apenas das “jornaleras", das "artistas" e das "sirvientas" (domésticas).

Queremos crer no entanto, que a alta cifra de inscritas sob a rubrica sus labores ocultava uma realidade inerente ao seu cotidiano: a necessidade de ajudar na manutenção da casa, de buscar algum meio de ganho para somar aos reduzidos, e muitas vezes, descontínuos ordenados do homem. À instabilidade e insuficiência do salário de seus parceiros e no intuito de aumentar a renda doméstica, essas mulheres respondiam com "trabalhos para fora" realizados no lar, onde se multiplicavam para conciliá-los com as obrigações domésticas e familiares.

Quanto às costureras, as indicações constantes nestes registros mostraram-se, de imediato, insuficientes para o diagnóstico da natureza de seu trabalho, não permitindo identificar se estavam referidas a operárias de alguma fábrica ou oficina de costura, ou se esse labor era praticado no lar.

${ }^{148}$ MOURA, E. B. "Trabalhadoras no lar: reflexões sobre o trabalho domiciliar em São Paulo nos primeiros anos da República”. In: Diálogos. U.E.M., Maringá, PR: v.4, 2000, pp. 161-181.

${ }^{149}$ Idem, ibidem, pp. 173 e 178. 
Alguns indicativos, contudo, podem ser sugestivos nessa elucidação: primeiro, muitas delas apresentaram-se ao CGE sem documentos, acompanhadas por uma testemunha, cujo nome se fazia constar do registro, que as "apresentava"; supomos que se tratasse de pessoa conhecida na colônia e, eventualmente, de seu empregador; segundo, o estado civil declarado, apresentando pequena vantagem para as solteiras e terceiro, o local do domicílio declarado, revelando vias pouco habituais de moradia, como as Ruas Florêncio de Abreu, General Carneiro, Ipiranga e Marquês de Itu que seriam, muito provavelmente, o local do exercício da profissão ${ }^{150}$. Em que pese tais evidências, por outro lado também não se pode esquecer o fato de as indústrias têxteis terem se instalado geralmente no Brás ou no Belenzinho, portanto, longe da área central em que declaravam trabalhar.

O fato é que, contornando todos esses senões, parece razoável aceitar a hipótese de que, pelo menos nesses casos ocorridos, não se tratasse de trabalho domiciliar, mas possivelmente de trabalho exercido em alguma oficina ou atelier de costura dos muitos que surgiram na cidade $^{151}$, ou até mesmo em alfaiatarias, conforme evidenciamos.

Para o mercado da moda, em alta numa cidade que buscava aderir às metáforas da modernidade, convergiam distintos profissionais, em especial as modistas, algumas das quais se apresentaram no CGE. É o caso de Asunción Gabaldo Navarro, casada e com 20 anos que, em $1913^{152}$, indicou residir à Rua do Carmo, 17, local onde possivelmente atendesse sua clientela. Outras, mais articuladas, divulgavam seu estabelecimento publicando anúncios no EDE e se especializavam em segmentos afins: "Hermanas Garcia, modistas, especialidad en vestidos para novias. Rua Conselheiro Ramalho,102"153.

Enredos policialescos também envolviam essas profissionais da moda. A esposa do espanhol Enrique Castro, uma modista, o traía "com um rico comerciante", com quem passaria a viver, abandonando-o. Sem mais, o insuspeito cidadão passa a ser perseguido pela Polícia, e é ameaçado de expulsão. Indefeso, procura ajuda com Eiras Garcia e este imediatamente se insurge ${ }^{154}$, convocando o cônsul para que o acompanhasse à Polícia Central, com a intenção de protestar contra esse procedimento ${ }^{155}$. Meses mais tarde o assunto vem novamente à baila, ocasião em que uma carta anônima é enviada ao diretor do EDE para que se prevenisse contra possíveis agressões que a polícia secreta estaria preparando contra ele e o motivo alegado seria o

\footnotetext{
${ }^{150}$ Relatório Access 15.

${ }^{151}$ De 1914 a 1929, o número de oficinas de costura para senhoras teria passado de 21 para 170 unidades. Cf. RIBEIRO, M. Op. cit., 1996, p. 352.

${ }^{152}$ LRC 10.04.1913.

${ }^{153}$ EDE 08.01.1912.

${ }^{154} \mathrm{EDE} 13.09 .1913$

${ }^{155} \mathrm{EDE}$ 14.09.1913.
} 
seu posicionamento de denúncia quanto à questão da expulsão de Castro que, por fim, acabou não acontecendo. Houve intensa movimentação da colônia da cidade de São Paulo e também de Santos, em solidariedade a Eiras Garcia para, por fim, descobrir-se que o "rico comerciante" com quem a modista se amasiara, não passava de um "alto escalão da Polícia Central" "

O setor da moda movimentava outros segmentos correlatos, especialmente o comércio. A Casa Guerra, de Valentin Guerra \& Hermano, funcionando desde 1885 na Rua São Bento, 86, comercializava, além de tecidos (ou fazendas), "modas, armarinhos, confecções, viés de linho"157. A revista espanhola semanal ilustrada El Hogar y la Moda, contendo "dezesseis páginas de modas, trabalhos de todos os tipos, figurinos e padrões" promovia um concurso em que um dos prêmios seria uma máquina de costura e o outro, cortes de tecido. Tinha seu representante exclusivo em Augusto Fernandez \& Co., estabelecido à Rua Maria Matarazzo, $18^{158}$. Seu concorrente, Pablo Cornadó, com centro de assinaturas de revistas espanholas na Av. Rangel Pestana, 119-A, apressou-se em divulgar suas representadas, três dias após haver circulado o anúncio anterior ${ }^{159}$.

As referências literárias acerca da permanência de algum hábito costumeiro no vestuário dos imigrantes ou do uso de algum traje típico espanhol na cidade existem, porém são esparsas e ambíguas. Everardo Vallim P. de Souza, por exemplo, refere-se de passagem àqueles "idos tempos em que a capa espanhola constituía granfinada moda" " Sobre as mantilhas, tradicional xale utilizado na Espanha, destacamos duas cenas breves em Geraldina Marx, acerca das mulheres idosas que "seguiam para a igreja" [Matriz do Brás], "de mantilha na cabeça" e, em outro momento, atentando especialmente para Dona Pepa, a autora informava que esta, nas mesmas circunstâncias, "usava uma mantilha de renda negra que trouxera da Espanha"161.

Sobre os leques, componente essencial da indumentária andaluza, encontramos duas alusões, nos mesmos autores. Marx comentando do alvoroço que ocorria no cortiço quando lá chegava o "turco da prestação" que, dentre outros objetos, trazia "leques espanhóis" para vender e em Marques, ao narrar uma fatídica tourada no Campo dos Curros - em que os toureiros eram "todos uns míseros amadores" e na qual "o Tam-Tam, um pobre diabo manco de uma perna",

${ }^{156}$ EDE 06.02.1914. Trad. da autora.

${ }^{157}$ EDE 02.05.1922. Trad. da autora.

${ }^{158}$ EDE 26.01.1914. Trad. da autora.

${ }^{159}$ EDE 29.01.1914. As publicações oferecidas eram: Por esos mundos; Blanco y Negro; Nuevo Mundo; Mundo Gráfico; Unión Ilustrada; Los Sucesos; Sol y Sombra; El Motim; Alrededor del mundo.

${ }^{160}$ SOUZA, E. V. “A Paulicéia há 60 anos". In: Revista do Arquivo Municipal. São Paulo: CXI, 1946, p. 65.

${ }^{161}$ MARX, G. Op. cit., pp. 110 e 152. 
morreria - salientando que, no momento do impacto com o animal, as damas teriam coberto os olhos "com os leques"162.

\section{As cigarreras}

Mas os meus olhos daquela hora traiçoeira, enviesada, sinuosa como os caminhos pérfidos, escorrem atrás de uma operária moça: muito penteada, accroche-coeurs violentos, oleosos, na testa e nas faces, e uma écharpe verde no pescoço. Uma cigarrera, como Carmen? ... ${ }^{163}$.

A Souza Cruz, cuja maior parte dos trabalhadores era de nacionalidade espanhola, também trabalhava assim [dando serviço a domicílio]. De manhã, as mocinhas saíam de casa com um baú de lata, iam até a Souza Cruz, pegavam o fumo e o papel, voltavam para casa e ficavam nas janelas enrolando os cigarros. No dia seguinte devolviam os cigarros prontos" $" 164$.

Essa prática, a do trabalho domiciliar de embalar cigarros, é outra daquelas atividades pertencentes à economia invisível, de difícil mensuração. Dela participavam as mesmas figuras anônimas que exerceram inúmeras atividades "inexistentes" do ponto de vista formal. As cigarreras espanholas, apesar disso, representavam mão-de-obra muito requisitada, senão preferida, e seu envolvimento com o setor parece indiscutível. É novamente na evocação de Geraldina Marx que temos a possibilidade de reconstituir alguns cacos dessa história. Tratava-se de trabalho compartilhado que, sob a liderança de D. Pepa, congregava toda a família, no esforço para produzir mais. Assim relata Geraldina Marx:

[D. Pepa] ia enrolando o fumo turco na cartolina colada à mesa e com uma ponteira de madeira introduzia o tabaco na cigarrilha de papel, cujas sobras das pontas eram aparadas com a tesoura por Margarita [a filha menor, de 13 anos].

Fazia os cigarros para o sírio Elias Jacob \& Cia., firma estabelecida à Rua Florêncio de Abreu. Depois de prontos os cigarros, Lola [a outra filha, mais velha] os acondicionava nas caixas forradas de papel prateado e eram vendidos pomposamente como "cigarros de luxo feitos à mão" ${ }^{\text {165 }}$.

Como vimos, a fabricação de cigarros no domicílio parece ter representando mais um dos nichos encontrados pela mulher economicamente oprimida para ajudar no sustento da família. No EDE, com regularidade observamos solicitações dessa mão-de-obra, em anúncios bastante explícitos: "Se necesita obreras cigarreras que sean competentes. Tratar na Rua dos Imigrantes, 43 (fábrica)"166, aos quais se entremeavam outros específicos: "Procura-se

\footnotetext{
${ }^{162}$ MARQUES, G. Op. cit., s.d. (1 a edição 1957), p. 124.

${ }^{163}$ ALMEIDA, G. “Um carvão de Goya”. In: Cosmópolis. São Paulo: Cia. Editora Nacional, 1929, p. 63.

${ }^{164}$ Depoimento do Sr. Rômulo Carraro. In: A reconstituição da memória estatística, op. cit., vol. 2, p.133.

${ }^{165}$ MARX, G. Op. cit., p. 36.

${ }^{166}$ EDE 27.03.1913.
} 
cigarreiras para fazer cigarros de palha" 167 ou ainda "embaladoras de cigarro, com bastante prática. Fábrica de Tabacos e Cigarros Aliança. Rua José Paulino, $129^{168}$.

Também nesse segmento, florescente, a oportunidade para os pequenos investidores iniciarem e a chance de progresso (quase) garantido. Tivemos a oportunidade de rastrear os anunciantes espanhóis pequenos produtores que, através das páginas do EDE, faziam publicidade de suas pequenas fábricas de tabaco. Notamos porém que, ao surto de novas fabriquetas, verificado nos primeiros anos da década de 1910, não correspondeu o movimento nos anos posteriores, fato que pode estar associado à instalação na cidade da Souza Cruz, cuja concorrência foi praticamente impossível agüentar.

Os nomes atribuídos a essas marcas de cigarros eram bastante excêntricos. "Mima Pancha" era a denominação da Fábrica de Cigarros de Caruso Hermanos existente desde 1912 pelo menos, data do primeiro anúncio, ocupando um imóvel na Rua XV de novembro, ${ }^{\circ} 59^{169}$. Divulgava regularmente seu produto pelo EDE nesse período e consta que fosse detentora de uma marca registrada ${ }^{170}$.

As marcas "Sereia", "Monarca" e "Andaluza", pertenciam ao espanhol José Alvarez, fabricante estabelecido na Rua do Gazômetro, nos no s. 83 e 85" Gasômetro, a Fábrica de Tabaco de Juan José Pereira ${ }^{172}$ e, próximo dali, na Av. Celso Garcia, 93, a famosa Fábrica de Tabacos Progredior produzindo os tipos "puro e cigarrillo"173.

Passada essa fase inicial, contudo, os anúncios publicitários desses fabricantes foram escasseando e praticamente sumiram das páginas do EDE. A isto se seguiu, anos mais tarde, já na década de 1920, anúncios de casas importadoras pertencentes a espanhóis, nas quais havia a "Seção de Tabacos". Anunciavam-se marcas especiais de tabaco em corda ${ }^{174}$ e, especialmente os cigarros da Fábrica Castelões", especialmente os da marca Goal - "Jogadores! Os cigarros Goal contêm em cada carteira o retrato artístico de um jogador paulista. Tabaco escolhido, ótimo sabor. Novo êxito da Cia. Castelões e Aurora" $" 175$.

A Casa Importadora de João Bobadilla (ou “Juan”, nos primeiros anúncios do EDE), é ilustrativa da trajetória de alguns desses bem-sucedidos imigrantes. Estabelecido em 1921, com fábrica e depósito à Rua dos Italianos, 67, 69 e 73 e escritórios à Rua Júlio Conceição, 35, é

\footnotetext{
${ }^{167}$ EDE 15.02.1912. Trad. da autora.

${ }^{168}$ EDE 21.01.1921. Trad. da autora.

${ }^{169}$ EDE 08.01.1912.

${ }^{170}$ EDE 29.01.1914.

${ }^{171}$ EDE 24.08.1912.

${ }^{172}$ EDE 18.10.1913.

${ }^{173}$ EDE 20.06.1914. Cigarrillo é cigarro, em português. Puro talvez fosse o cigarro de palha.

${ }^{174}$ Poço Fundo; Moreira; Carangola; Corina; Ouro Fino e Tacape, eram algumas das mencionadas.

${ }^{175}$ EDE 04.11.1921; EDE 21.02.1922 e outros nesse intervalo de tempo.
} 
difícil de imaginar que, inicialmente, sua família, natural de Logroño (La Rioja) tenha estado em Atibaia, e que, por ocasião do primeiro registro no CGE, já estivesse há 20 anos no Brasil. Provavelmente colonos, esse primeiro registro deu-se pelas mãos do Agente Consular daquela localidade, no ano de 1911, e Juan Bobadilla Martin, casado, comerciante e com 6 filhos, tinha então, 34 anos de idade ${ }^{176}$. Entre esse primeiro registro, de 1911, e o próximo efetuado 10 anos depois, em 1921, já domiciliado na cidade à Rua José Paulino, 22 e pelo qual se declarou industrial, não parece descabido presumir uma trajetória de trabalho e esforço continuado, a que muitos, como ele, se submeteram ${ }^{177}$.

As parteras

Naquele tempo, não havia parteiras diplomadas, apenas práticas, "curiosas", mulheres que entendiam algo sobre o divino mistério da reprodução da espécie (...). A mais popular parteira do velho Belenzinho foi D. Maria Espanhola. Pertencia à família Ângulo e morava na Avenida Celso Garcia, perto da Rua Bresser (...).

-D. Maria está aí!

Um pigarro, um passo pesado e a parteira surgiu no limiar. Era uma muther já madura, nariguda, de óculos, cabelos grisalhos presos ao alto da cabeça em forma de birote, com um olhar malicioso e inteligente e um sorriso amigo nos lábios.

- Entonces, más un brasilerito, hein? - exclamou ao entrar.

-És una primeriza?

D. Maria retirou o xale que trazia às costas, pousou sua valise aos pés da cama e aproximouse da parturiente. Passou-lhe suavemente a mão pelos cabelos e disse sorrindo:

- Vamos a ver como está eso. Le duele mucho la barriga, muñequita?

- Dói, sim... - gemeu a moça.

- Desde quando?

- A noite toda doeu...

- Ah, ah! Hás comido mucha manana, no? Es buena, pero es una fruta muy indigesta, niña.

Margarida esboçou um sorriso meio contrafeito, percebendo a indireta da mulher, que a foi descobrindo, sem cerimônias, pondo tudo à mostra. O marido, discretamente, ia-se afastando da cama, mas a parteira o conteve pela mão:

- Venga, venga, usted já viu tudo. Que Gujo es ese? Puede apreciar su obra.

Os jovens trocaram um othar meio abobalhado, enquanto a parteira, debruçada sobre a moça, examinava tudo cuidadosamente. Afinal, levantou-se e perguntou:

- Que horas são?

- Dez horas, respondeu Joaquim.

- Bien, bien. Parece que la cosa vai sair lá pelo medio dia. Tiene um cigarrito? Apanhou o cigarro que o moço the estendia, acendeu-o e começou a fumar, soltando longas baforadas pelas narinas. A moça continuava gemendo, segurando a mão do marido. D. Maria olhava-os enternecida. De súbito sorriu, parecendo lembrar-se de algo, e disse:

${ }^{176}$ LRC 05.09.1911. Outros “Bobadilla” de Rioja já haviam passado pelo CGE no ano de 1906. Eram eles Andrés Bobadilla Santamaría e Eugênio Bobadilla Gandasegui, sem domić́lio declarado.

${ }^{177}$ LRC 13.07.1921. 
- Eso me hace recordar de um gallego que queria sofrer los mismos dolores de su esposa, quando ella estaba para dar la luz. Que hizo el animal? Amarró una cuerdita a los cojones e prendió la otra extremidad a la mano de la mujer. Quando esta sentia los dolores, tiraba la cuerdita e le apertava las 6olotas. Así, sofriam los dos. Que 6urro!

- Todos riam. A mulher prosseguiu:

- Los índios, entonces, quando la mujer dá la luz, se ponen en una rede e ninguno los saca dali hasta que pase la dieta. La mujer que se arranche! Que malandrones!

- Com essas piadas, D. Maria procurava deixar o ambiente mais alegre, distraindo principalmente a parturiente. Lá pelo meio-dia, as dores tornaram-se mais freqüentes e fortes. D. Francisca já aprontara água quente e uns panos limpos (...). D. Maria, fumando incessantemente, ia dizendo:

- Tá na hora, no se demora, no. Creo que sea uma melindrosa. Está se afeitando, quiere nacer bien bonita, la chica. Como les decia, la manana es muy buena, ma....

Não chegou a concluir a frase, porque um grito agudo da parturiente, que se atirou para trás violentamente, fê-la acudir, rápida, a tempo de receber nos braços o neonato, que se projetara para fora.

Numa figeireza de causar inveja a muita mocinha, em poucos segundos, D. Maria executou o trabalho e deu uma boa palmada na bunda do bebê, que pôs a boca no mundo, demonstrando a excelência dos seus pulmões. Então, ela sorriu prazerosa e disse ao jovem pai, que tremia feito vara verde, palidíssimo:

- Pronto, pronto! Cá está su herdero. Mira que guapo!

O pai, agora, exibia um riso parvo, em que se notava uma pontinha de legítimo orgulho, gaguejando:

-É homem... é homem....

Após o banho, enfaixada a criança, D. Maria voltou suas atenções para a puérpera. Reanimou-a, Cavou-the as partes pudentas e disse ao marido:

- Anda, rapaz, puede besar su mujercita! Ella trabajó bien. O usted piensa que el merito es todo suyo?

Joaquim beijou carinhosamente a testa da esposa que, de lágrimas nos othos, segurou-o fortemente de encontro ao rosto.

Enquanto a parteira também ia se aprontando, contente com o serviço prestado e pelo êxito do parto, as vizinhas comentavam e cumprimentavam os paizinhos (...). Subitamente o moço bateu na testa, como que se recordando de alguma coisa, virou-se para a parteira e perguntouThe:

- Quanto The devo, D.Maria?

- Poca cosa hijo: diez mil réis.

Ele remexeu nos 6olsos, juntou umas moedas de prata e entregou-as à mulher, que as enfiou na bolsa, sem contar. Atirou o xale às costas, despediu-se de todos e lá se foi cantarolando.

Parou na primeira venda que encontrou, para sorver um aperitivo que o vendeiro nem cobrou, pois $\mathcal{D}$. Maria era bastante estimada no 6airro, onde todos a admiravam, pelo seu zelo e bondade. Isto feito, tomou o bonde e foi para casa. Em 1920, ainda ela caminhava lépida pelas ruas (...). 
O ofício de partera, dada a sua natureza e apesar de sua importância constitui, como muitas das atividades femininas daquela época, uma ocupación de difícil mensuração. Muitas delas, como D. Maria Espanhola não eram tão somente "práticas", como a maioria que "atendia nos partos". D. Maria Espanhola, por exemplo, que na verdade se chamava Maria Edo, diplomara-se pela Universidade de Barcelona em 1887, o que muitos ignoravam ${ }^{178}$. Nem todas as mulheres, aliás, podiam ter esse acompanhamento, ainda que fosse irrisória, na primeira década, a quantia cobrada para a assistência aos partos ${ }^{179}$. No mais das vezes, as mulheres davam à luz apenas acompanhadas pela solidária companhia das vizinhas do cortiço ${ }^{180}$.

Havia, contudo, profissionais que atendiam em hospitais, antes mesmo da virada para o Novecentos, indício de que a cidade já comportava uma outra camada social, de hábitos distintos e que podia arcar com os altos custos da internação. Juana Iglesias Martin, viúva, natural de Salamanca e com 44 anos de idade registrou-se como partera no CGE em 1896, indicando como seu domicílio apenas "Maternidade", local onde provavelmente trabalhasse e residisse ${ }^{181}$.

Para os imigrantes e os paulistanos pobres os casos de emergência eram atendidos na Santa Casa de Misericórdia que, a partir de 1884, ganhara um novo prédio na Vila Buarque, transformando-se, a partir de 1913, em hospital-escola da Faculdade de Medicina e Cirurgia para onde afluíam inúmeros pacientes também do Interior do Estado. Para a população endinheirada, entretanto, havia no mesmo período o Hospital Santa Catarina e uma série de clínicas especializadas, apesar de que, para casos de enfermidades mais complexas "é provável que a elite paulistana recorresse a hospitais estrangeiros, fato que pode ser confirmado pela frequiência de registros de transportes de cadáveres da Europa para São Paulo" assinala Cláudio Bertolli Filho, na pesquisa aos Livros de Enterramentos dos Cemitérios Araçá e Consolação ${ }^{182}$.

Ser um médico clinicando na Santa Casa era motivo de respeito e reconhecimento, de cujo mérito se valiam alguns profissionais. Era o caso do jovem Dr. Benedito Montenegro, cirurgião e ginecologista espanhol, atendendo desde 1913 - coincidentemente o mesmo ano em que aquela Instituição transformara-se em hospital-escola -, residindo na Alameda Barros, 97, porém com consultório à Rua Líbero Badaró, 11, em cujos anúncios publicitários sempre

${ }^{178}$ PENTEADO, J. Op. cit., 1963, p. 54.

${ }^{179} \mathrm{O}$ autor comenta que, em 1923, D. Maria Espanhola estaria cobrando 20\$000, porém que, quando nasceu sua irmã Yara, em 1928, D. Maria Portuguesa, outra parteira que assistiu ao parto, cobrou 50\$000. In: Idem, ibidem, p. 54.

${ }^{180}$ A esse respeito, ver relato de MARX, G. Op. cit., pp. 91-92.

${ }^{181}$ Relatório Access 37.

182 BERTOLLI F ${ }^{\circ}$, Cláudio. A gripe espanhola em São Paulo, 1918: epidemia e sociedade. São Paulo: Paz e Terra, 2003, pp. 61 e ss. 
exaltava essa condição: "Médico da Santa Casa de Misericórdia", acrescentando ainda que realizava "partos"183.

Em seu consultório particular, o atendimento era realizado das 14:30 às 16:00 horas. Era filho de Enrique Montenegro e compunha a parcela que se diferenciava da grande maioria dos espanhóis aqui residentes. Sua família viera da Galícia (Vigo), para onde seu pai viajava com regularidade ${ }^{184}$. O reduzido horário de atendimento em seu consultório particular é indicativo provável de uma carteira limitada de clientes.

Também o Dr. Dominguez Lopez "parteiro - moléstias de crianças e sifilíticos" e que atendia na Galeria Cristal, tinha um horário bastante limitado, clinicando apenas das 15:00 às 16:00 horas. Atendia também na Lapa, à Rua da Trindade, local onde provavelmente residisse e que, como vimos, concentraria crescente número de imigrantes espanhóis ${ }^{185}$.

Os problemas de saúde e a necessidade de atendimento aos mais carentes eram tão cruciais que vimos despontar, em todo o período examinado, iniciativas nesse sentido por parte das sociedades beneficentes, que tinham nessa assistência a sua principal razão de ser, conforme veremos no capítulo específico. É o caso da Liga Defensora de los Españoles que, inicialmente instalada no populoso bairro do Brás, à Travessa do Brás, 29, realizava inclusive o "atendimento a domicilio" a seus associados ${ }^{186}$. Como tantas outras, lutava com dificuldades para se manter, alternando constantemente de endereço, tendo se estabelecido, numa das ocasiões, na Rua do Gazômetro, 49-A, “onde residem também seu presidente e secretário, D. Fermín Barnó e D. Eduardo Burgos, estabelecidos com a Sastrería La Villa de Madrid ${ }^{187}$. A questão central residia na manutenção de um corpo de associados que pudesse auxiliar nas despesas - a maior parte de suas receitas vinha de doações - o que, nas condições dadas era praticamente impossível. Esse fato também ocasionava enorme rotatividade no profissional contratado para o atendimento que se via às voltas com pacientes não associados e sem condição de arcar com as consultas. O Dr. Nuno Guerner que sucedeu ao Dr. José de Asprer informava, por isso, que passaria a atender "aos associados mediante apresentação dos cupons" em seu consultório à Rua S. Caetano, $156^{188}$. O Dr. José de Asprer era médico “operador e parteiro” formado em Sevilha e em seus anúncios no EDE gostava de informar que era "médico do Consulado"189.

\footnotetext{
${ }^{183}$ EDE 04.08.1913.

${ }^{184}$ EDE 25.02.1913.

${ }^{185}$ EDE 24.08.1912. Trad. da autora.

${ }^{186}$ EDE 05.04.1913. Trad. da autora.

${ }^{187}$ EDE 29.07.1913. Trad. da autora.

${ }^{188}$ EDE 28.11.1913. Trad. da autora.

${ }^{189}$ EDE 08.01 e 30.01.1912, por exemplo. Trad. da autora.
} 
Nesse mesmo ano de 1913, e revelando que mesmo iniciativas dessa natureza - que não foram escassas - não conseguiam resolver a questão da demanda e tampouco dar atendimento às parturientes, o EDE noticia com certo estardalhaço a "instalação na cidade da Sra. Maria Muñoz Ramos”, à Rua Carneiro Leão, 62, no Brás, “excelente professora em partos, que gozava na Espanha de reputação invejável", recomendando-a às mulheres que necessitassem de seus serviços ${ }^{190}$.

Outras sociedades beneficentes tendo como principal encargo a assistência médica e farmacêutica aos associados serão criadas no período, como é o caso da Beneficência Española (vide fig. 11, p. 295), cujos anúncios acompanhamos desde 1912, e que, como tantas outras, sempre às voltas com questões financeiras insuperáveis e rotatividade médica ${ }^{191}$ apresentava a agravante das freqüentes querelas entre os sócios e as juntas diretivas, e desta entre si, quando não a processos judiciais e a prisões ${ }^{192}$. Esses fatores somados talvez possam ser responsabilizados pelo aparecimento temporário e descontínuo da maioria delas, muitas das quais de efêmera duração.

Estas sociedades necessitavam de constantes "doações”, algumas delas, curiosamente registradas no CGE como "doação para os espanhóis necessitados" ou "doação para a Beneficéncia Española"193. Em 1918, em resumo, continuava a Beneficência Española, sem sede fixa, a comunicar, pelo EDE, nova transferência de sede, depois de tentar uma fusão com o Centro Español ${ }^{194}$, enquanto inalterável permanecia a condição dos novos brasileritos, filhos de emigrantes aqui nascidos. Simultaneamente, era crescente o número de parteiras e médicos particulares, não apenas espanhóis, que utilizava as páginas publicitárias do $\mathrm{EDE}^{195}$.

\section{O trabalho doméstico}

O Censo da distribuição ocupacional da cidade de São Paulo elaborado para o ano de $1893^{196}$, conforme demonstramos, evidenciava o segmento dos "Serviços Domésticos" como

\footnotetext{
${ }^{190}$ EDE 31.10.1913. Trad. da autora.

191 Anúncio do Dr. Custódio Guimarães "médico operador e parteiro", e "médico da Beneficéncia Española”. EDE 05.08.1918

${ }^{192}$ EDE 01.08.1913; 07.08.1913 e 24.08.1912. Ver, a esse respeito, o Capítulo IV.

${ }^{193}$ LRC 07.11.1917. Nesta data, verificamos quatro doadores mencionados, porém as quantias não foram citadas.

${ }^{194}$ Para a Rua Direita, $n^{\mathbf{o}} 2-2^{\mathbf{o}}$ andar "porta com porta com os escritórios do Centro Español". EDE 05.09.1918.

195 Observamos no período um número crescente de médicos e paramédicos especialmente alemães: Parteira Else Schoeller (EDE 28.08.1919); Dr. Max Rudolph, médico operador e parteiro (EDE 01.10.1919); Dr. Walter Seng, médico cirurgião e moléstias de senhoras (EDE 09.01.1920).

${ }^{196}$ Vide Cap. I - Tabela 1. Estrutura Ocupacional em São Paulo, 1893, p. 67.
} 
responsável por um percentual de $25 \%$ da população total da cidade ${ }^{197}, 58,3 \%$ dos quais representado pelos estrangeiros que nela viviam. Para o crescente exército de reserva de mãode-obra acumulado pela cidade, constituído basicamente de homens e mulheres das camadas inferiores, o trabalho doméstico, sem qualquer exigência de qualificação, apresentou-se como uma opção. Os trabalhos domésticos, conforme argumenta Maria Izilda Santos de Matos "eram considerados uma atividade que não necessitava de longa aprendizagem, podendo ser realizados por "qualquer um", principalmente se fosse mulher, porque "exigiam menor esforço"198, imagem esta que, argumenta a autora, deve ser revista, na constatação do cotidiano dessas mulheres.

No período total abrangido pelo levantamento documental dos LRC, a freqüência de registros femininos foi proporcionalmente pequena no conjunto dos 30 anos em pauta, apresentando, contudo, para a última década, um acentuado crescimento ${ }^{199}$. No cômputo geral, no entanto, apresentou, para os domicílios na Capital, um percentual de apenas 19,5\% do total. Não obstante, dessa cifra, a imensa maioria, $84 \%$ daquele total, declarou como ocupación a categoria sus labores (dona de casa). Do restante, um pequeno percentual de jornaleras, porém bastante distanciado da terceira categoria declarada, a de artista e, seguindo-se a esta, a categoria de sirvienta (doméstica) ${ }^{200}$.

É provável que as duas categorias majoritárias - sus labores e jornalera acomodassem temporariamente mulheres em trabalho domiciliar no primeiro caso, e fora do lar, no segundo. Não parece despropositado presumir pelo trabalho domiciliar flutuante e rotativo da mulher que se declarou dona de casa (sus labores). Quanto à jornalera, lembrando das características inerentes a essa ocupación, de prestação de serviços "a jornal" - e portanto, a tarefas também eventuais, transitórias, descontínuas, e até mesmo improvisadas - a única distinção que vislumbramos é quanto ao modo de exercê-la, posto que o cotidiano concreto dessas mulheres pouco se diferenciava, na luta contínua pela superação da miséria.

197 Dos 54.540 indivíduos arrolados nas diversas atividades, 14.104 foram alocados para "Serviços Domésticos". Desse total, 5.879 ou $42 \%$ pertencia aos nacionais e 8.226 ou $58 \%$ aos estrangeiros.

${ }^{198}$ MATOS, M. I. "Na trama urbana: do público, do privado e do íntimo". In: Projeto História. São Paulo: PUC-SP, no 13, 1996, pp. 140 e ss.

${ }^{199} \mathrm{Na}$ primeira década (1893-1902) esse percentual foi de 3,3\%, aumentando para $12,5 \%$ na segunda década (1903-1912). Foi, contudo, na última década considerada, que esse percentual apresentou-se relevante $(22,7 \%)$ compondo, assim, para os 30 anos examinados, uma média de aproximadamente $19,5 \%$ do total.

200 As demais categorias ou modalidades ocupacionais femininas declaradas para as residentes na Capital foram, em ordem numérica decrescente: costurera (com índices muito próximos de sirvienta); seguida de pensionista; religiosa; bordadera; lavadera e comerciante (com cifras bem abaixo de costureiras); e profesora; modista; partera; propietaria e estudiante, com cifras iguais, abaixo das categorias anteriores. Já para as residentes no interior, ainda que a categoria sus labores também prevalecesse (80\%), computamos um expressivo percentual de "jornalera; labradora; campo; colona e bracera" (18,5\%). Cf. Relatório Acess 33. 
Voltando às sirvientas, a análise particularizada dos casos surgidos nos LRC informa que a categoria se configurava, em geral, por mulheres solteiras ou viúvas, melhor dizendo, precocemente viúvas, na faixa dos 30 e poucos anos, algumas manifestando como domicílio locais tipicamente residenciais da cidade (Rua Alagoas, em Higienópolis e Rua das Palmeiras, em Santa Cecília, por exemplo), indicativo de que eram profissionais que residiam na casa de seus patrões.

Em um único registro, de 1899, foi mencionada a "Santa Casa" como domicílio, dado que reforça a hipótese também para o caso da parteira, atrás mencionado. Elas, as sirvientas eram originárias principalmente da Galícia, especialmente da cidade de Orense, seguidas pelas andaluzas e pelas castilhaleonenses ${ }^{201}$.

No período, as atividades domésticas, nem sempre "leves" como se imaginava, foram as responsáveis, depois da categoria dos "carroceiros", pelo maior número de acidentes, deixando muitas mulheres inválidas ${ }^{202}$. Elas requeriam muito vigor físico, daí talvez a razão do requisito juventude ser exigido nos anúncios de solicitação a essas profissionais: "Se necesita criada joven ${ }^{203}$, pedia a família espanhola, sem discriminar a função. E nesses casos, talvez fosse para lavar, engomar, passar (com ferro a carvão), cozinhar - quando em fogão a lenha, elas próprias eram encarregadas de rachar a lenha - função essa responsável por queimaduras provocadas por espiriteiras, “cuja explosão atingia rosto, tórax e braços”, por água fervida, gordura, querosene e álcool ${ }^{204}$.

Às mulheres de mais idade que necessitassem continuar trabalhando para se manter, restavam algumas atividades autônomas que podiam ser realizadas, caso das lavadeiras, ocupação da viúva de 61 anos D. Maria Mellado San Vicente, natural de Salamanca, que residia com a sobrinha de 18 anos na Rua Maria Domitila s/n $\mathrm{n}^{205}$.

As cozinheiras e criadas "espanholas" eram bastante requisitadas pelo EDE no período examinado: "cocinera espanhola"206, "cocinera espanhola para casa de família espanhola"207; "sirvienta espanhola"208. Algumas iniciavam ainda muito jovens, caso da "hespanhola Josephina de 10 anos de idade, que servia de criada e que fora mandada às compras e nessa

${ }^{201}$ Relatório Access 38.

${ }^{202}$ MATOS, M. Op. cit., 1996, p. 141.

${ }^{203}$ Para a Rua Barão de Limeira, 61. EDE 18.05.1918.

${ }^{204}$ MATOS, M. Op. cit., 1996, p. 142.

${ }^{205}$ LRC 1911.

${ }^{206}$ Para a Rua José Paulino, 88. EDE 18.05.1918.

${ }^{207}$ Para a Avenida Brigadeiro Luiz Antonio, 124. EDE 21.01.1919 e para Alameda Barão de Limeira (n/c o no). EDE 04.11.1921.

${ }^{208}$ Para a Rua Visconde do Rio Branco, 56. EDE 01.10.1919. 
ocasião aproveitou a oportunidade para fugir"209. Jovens também eram as "niñeras" requisitadas, com idade entre 14 a 16 anos" $^{, 210}$. As amas-de-leite, lactantes ou criadeiras, uma das mais antigas tradições da Paulicéia, por muito tempo própria de escravas e ex-escravas, passou paulatinamente a ser realizada por mulheres imigrantes. Muitas se registravam no Serviço Sanitário para poderem exercer o ofício, cuja normatização passou a existir de fato somente a partir de 1906, ano em que os inspetores sanitários examinaram 105 nutrizes para serem registradas, das quais 15 eram espanholas ${ }^{211}$. Muitas delas, recém-chegadas da Espanha, ofertavam-se como amas-de-leite para famílias da Capital, ainda vivendo no interior, expediente provável para conseguir alimentação e casa para morar na cidade: "ama-de-leite, há três meses no Brasil, de nacionalidade espanhola [oferece-se] para viver na casa dos patrões. Mora em Conquista, MG, na linha Mogiana"212.

Em O Ateneu, de Raul Pompéia, há clara referência à criadagem espanhola da cidade do Rio de Janeiro ${ }^{213}$, constituída de homens e mulheres. Em São Paulo, há evidências de que muitos casais assim se empregassem, maneira de driblar os altos aluguéis e a falta de emprego. Nas páginas do EDE, essa oferta é recorrente durante o período analisado: "Casal espanhol para qualquer serviço em casa de família. Tratar Rua 25 de março, 01 "214 ou "Casal jovem, espanhol e sem filhos. A mulher para criada e o homem para qualquer trabalho. Pode ser em casas distintas. R. Pedro Álvares Cabral, 19-g. ${ }^{\text {,215 }}$.

O ofício de passadeira (planchadera), explicitado nos anúncios evidencia uma certa especialização e um diferencial importante na hora de conseguir o emprego: "Casal sem filhos se oferece para casa de família, preferência alemã ou espanhola. A mulher é passadeira. Rua Barão de Jaguara, $8^{, 216}$. Onde a oferta excedia a demanda, cresciam as exigências: [Pede-se] "Peritíssimo jardineiro espanhol. Informes R. Itambé, 15"217. O endereço (Rua Itambé), no seleto bairro de Higienópolis, revela que a atividade de jardineiro, responsável pelos serviços de jardinagem, mas incluindo os cuidados com a horta, com o pomar e até com os animais domésticos, era requisitada por famílias abastadas, às quais, dependendo do caso, podiam contratar o casal, concedendo-lhe a moradia. Angel Martinez Moya, jardineiro de Valencia com

${ }^{209}$ O Correio Paulistano, 12.02.1908. Apud: MATOS, M. Op. cit., 1996, p. 144.

${ }^{210}$ Niñera: babá, para cuidar de crianças. Para Rua Aurora, 66. EDE 28.06.1918.

${ }^{211}$ RIBEIRO, M. Op. cit., 1993, pp. 120 e ss. Ver também: BRUNO, E. Op. cit., 1991, pp. 1195 e ss.

${ }^{212}$ EDE 05.04.1913. Trad. da autora.

${ }^{213}$ POMPÉIA, R. Op. cit., 1981. No primeiro caso, a pajem de Murilo Rubião era espanhola; no segundo, o jardineiro andaluz e a camareira canarina eram, ambos, funcionários do diretor do Ateneu, Aristarco.

${ }^{214}$ EDE 30.07.1912. Trad. da autora.

${ }^{215}$ EDE 01.08.1914. Trad. da autora.

${ }^{216}$ EDE 03.03.1919.

${ }^{217}$ EDE 10.02.1914. Trad. da autora. 
53 anos, a propósito, residia com sua esposa na Rua Adolfo Gordo, 07, enquanto José Maria Prieto Perez, de Orense, com 59 anos, trabalhava e residia com a família na Rua Leôncio de Carvalho, $56^{218}$.

A falta de trabalho continuado e a carestia, contudo, não discriminavam camada social ou gênero, e enquanto minguavam as oportunidades, cresciam os atributos pessoais manifestos: "Espanhol de boa idade, educado, instruído e com boas cartas de recomendação, deseja colocarse em casa de família espanhola que queira utilizar seus serviços como escrevente ou educador de crianças" "219. Ou ainda: "Professor de piano e solfejo. Jovem professor de piano e canto, chegado há pouco da Espanha, oferece-se para aulas particulares. Inf. Rua Martin Buchard, 30"220. E havia aqueles com múltiplas habilidades: "professor de espanhol, recém-chegado, oferece-se para lecionar espanhol, francês, aritmética comercial e "razonada", álgebra elementar, álgebra superior, trigonometria, geometria plana e do espaço, analítica, descritiva ${ }^{221}$.

As "artistas"

Um saleroso "passe-doble" enche a sala com as suas notas alegres, fazendo-nos ver mantilhas, andaluzas, touros, castanholas e o sol ardente da Espanha. Esvoaçante... com o "mantón de manilla" enrodilhado sobre os seios, ágil, mal pisando o palco, Manolita aparece garbosa, com um cravo rubro na boca vermelha. "Saca el sombrero" e, num gesto galante, saúda a platéia que a recebe de baixo de um turbilhão de palmas. Sapateando, dança a "malagueña", meneando o corpo, acompanhado-se ao estalar retintante das castanholas. A turba, aplaudindo-a, grita fora de si:

- Dali, dali!... Salerosa!... Con el pase doble, preciosa! Bendita sea tu madre! A multidão delira. Ela continua dançando. O saiote faz-lhe um círculo em derredor do tronco. Mãos ao alto, à altura da cabeça, parecem uma flor emergindo do seu cálice. A um "olé" de repente estaca. Tem o busto empinado, a cabeça para trás, as mãos nos quadris, triunfante, sorri fitando a platéia. Com a revoada de palmas, o teatro parece que vem abaixo. Ela está ofegante. Tem nos olhos um brilho de fulgor estranho; estão palpitantes as asas do seu nariz; os lábios entreabertos. Não é Manola que dança - foi a Luxúria quem bailou... O palco cobre-se de flores. O desejo do Comendador Brito foi alcançado, pois ela esmaga as pétalas que vêem beijar-lhe os pés. As "corbeilles" enviadas por ele são enormes, vistosas, e, tal a quantidade, que a ribalta delas se encheu. Volta à cena, muitas e muitas vezes ${ }^{222}$.

Em 1897 deu-se o primeiro registro de uma "artista" no CGE. Tratava-se de Dolores Del Valle, solteira, de Madrid, idade não declarada, residindo na Rua Vitória, 118. Antes dela, alguns indivíduos do sexo masculino já haviam se inscrito no Consulado, a partir de 1893

\footnotetext{
${ }^{218}$ LRC 1920 e 1921.

${ }^{219}$ EDE 27.06.1912. Trad. da autora.

${ }^{220}$ EDE 19.08.1913. Trad. da autora.

${ }^{221}$ EDE 29.07.1913. "Razonada": Discurso. Trad. da autora.

${ }^{222}$ MARQUES, C. Op. cit., 1944, pp. 60-62.
} 
declarando-se também "artistas". Alguns, neste período inicial, estavam declaradamente em trânsito pela cidade, indicando hotéis como domicílio ${ }^{223}$, prática que se estendeu pelas primeiras décadas, quando então os hotéis citados eram o São José, o Savoy e o Brasil ${ }^{224}$ - , ou indicando o local para onde se dirigiam, em geral cidades do Interior do Estado ${ }^{225}$. Eram, sobretudo, homens de uma faixa etária elevada, entre os 30 e os 50 anos e procediam em maior parte da Andaluzia e de Barcelona.

Observamos também a existência de famílias de artistas mambembes transitando pela cidade, em geral pessoas bastante jovens. É o caso da Família Picat Bernabé - África, Clotilde e Isaac, com 15, 28 e 18 anos respectivamente -, naturais de Valencia, que circularam pela cidade em $1912^{226}$. Afora esses irmãos declarados "transeuntes" observamos outros casos de registros realizados na mesma ocasião, tipicamente familiares, caso das irmãs Adela e Remédios Fos Estarelles, com 16 e 22 anos, de Barcelona e das irmãs Chinchilla, Concepción e Purificación, de Málaga, com 28 e $23 \operatorname{anos}^{227}$.

Em pelo menos um caso, tais "artistas" declararam o local de trabalho. Tratava-se da “Cia. Esperança Trim”, citada em 1921 em dois registros, um masculino e outro feminino ${ }^{228}$ e em dois casos apontou-se para a função exercida: Luisa Fernandez Guerrero, madrilenha, 26 anos, solteira, residente à Rua Conselheiro Crispiniano, 26, declarou-se "artista de cinema"229, enquanto Andrés Lopes Barreta, 20 anos, alicantino, sem endereço declarado, autodenominouse "artista de variedades" 230 .

Como se observa, a rubrica "artista" teve uma aplicação um tanto ambígua no período, a considerar os registros do CGE. Referia-se indistintamente a indivíduos ou grupos de pessoas, artistas amadores que percorriam o Interior do Estado com seus espetáculos teatrais e musicais, mas também, conforme observamos, passou a designar as meretrizes de luxo, algumas delas célebres e que eram escolhidas a dedo pelas caftinas, que davam preferências àquelas que já transitassem pelos ambientes noturnos da cidade, como artistas ou cantoras.

Reafirmando a fama e o prestígio de que gozavam, muitas delas adicionavam ao nome próprio, no ato do registro, a alcunha pela qual eram conhecidas no "mundo artístico", locais em

${ }^{223}$ Hotel Internacional e Bela Jardineira. LRC 1893 e 1894.

${ }^{224}$ LRC 1917, 1919 e 1920.

225 Manuel Rodriguez, 29 anos, de Madrid, citando a Rua do Gasômetro, 128 como domicílio indicava Piracicaba como seu destino e Manuel de Rueda, de Sevilha, com 31 anos, com endereço à Rua dos Gusmões, 62, ia para Botucatu. LRC 1894.

${ }^{226}$ LRC 1912.

${ }^{227}$ LRC 1920.

${ }^{228}$ Tomás Perez Abril, 26 anos, de Múrcia e Casiana Piñero, 25 anos, uruguaia.

${ }^{229}$ LRC 1922.

${ }^{230}$ LRC 1913. 
geral de nomes afrancesados. Margarita Donnay, "La Morita" era madrilenha, tinha 26 anos e residia na Rua Formosa, $64^{231}$. Feliza Pena, "La Morenita", de Granada, tinha 30 anos e não declarou o domicílio ${ }^{232}$. De sua atuação artística, sabe-se que era também cantora, pois em 1921 o EDE informava, por ocasião da divulgação da programação do Teatro Apolo, que ali debutaria a "celebrada artista cantante "La Morenita", que iniciou sua carreira artística nas companhias de zarzuelas organizadas por Sagi-Barba"233 . Josefa Sarrión Gonzalez, que assinou "Pepita Sarrión" no CGE, tinha 38 anos, era de Cádiz e também não declarou domicílio. A Andaluzia apresentava-se como a origem majoritária dessas “artistas” femininas.

Era cançonetista. Todos a tinham por andaluza, de Sevilha, por causa dos olhos, das cançonetas das castanholas...

A minha paixão começou no clube, uma noite. Eu havia terminado, exatamente nesses dias, o meu curso de Direito (...)

Guadalupe - a "Guadalupe" tal como aparecia nos jornais, nos anúncios, nos cartazes. Teria certamente um outro nome, mais curial, de casa - Maria, Carmem, Dolores. Mas ninguém cuidava de sabê-lo. Eu a tratava por "meu amor", "minha glória", "minha vida"! 234 .

As espanholas seguramente eram famosas: havia a "florista, garbosa espanhola"; a "Manolita"; a "Maria Granata, tão salerosa nas granadinas que bailaba"; "a Carmencita, a linda espanhola, inexcedível na jota-aragonesa e nos bailados acompanhados das repinicantes castanholas", ambas do Politeama ${ }^{235}$, prestigiado café-concerto, de agitada vida noturna e movimentados espetáculos que, com o Moulin Rouge, do empresário espanhol Paschoal Segreto, localizado no Largo do Paissandu e inaugurado provavelmente em $1905^{236}$, teve sua fase áurea nas duas primeiras décadas do Novecentos. "Os melhores números mundiais de cafés-concerto transitavam pelo Politeama", com artistas vindos da Europa que faziam o circuito Rio, São Paulo, Montevidéu e Buenos Aires. Eram volantes, cançonetistas, ilusionistas, acrobatas, cômicos excêntricos, malabaristas, e prestidigitadores ${ }^{237}$. Em 1913 foi assinada por Eloy Chaves, Secretário da Segurança, a demissão do $1^{\circ}$ subdelegado do Distrito de Santa Efigênia, João Monteiro, "pelos abusos cometidos contra uma cantora inglesa do Politheama, Luna Lyndon",238.

${ }^{231}$ LRC 03.07.1918.

${ }^{232}$ LRC 1916.

${ }^{233}$ EDE 09.02.1921. Zarzuela: Apresentação dramática e musical em que se alternam canto e fala. Trad. da autora.

${ }^{234}$ MACHADO, Dyonélio. Um pobre homem. $2^{\text {a }}$ ed., São Paulo: Ática, 1995 (1ª ed. 1927), p. 17. Cançoneta: canção ligeira, bem-humorada ou espirituosa, por vezes satírica.

${ }^{235}$ MARQUES, C. Op. cit., 1944, pp. 48, 50, 52 e 56.

${ }^{236}$ FONSECA, G. História da prostituição em São Paulo. São Paulo: Resenha Tributária, 1982, p. 193.

${ }^{237}$ LEME, M Op. cit., 1984, pp. 123-124.

${ }^{238}$ EDE 31.10.1913. Trad. da autora. 
O Moulin Rouge promoveu, com regularidade, intensa divulgação de sua programação pelo EDE, em todo o período examinado. A programação, bastante variada, incluía atrações internacionais, como a "estréia de Anita Esmeralda, completista (sic) espanhola e das Hermanas Claveles, bailarinas espanholas"239 ou "Elda Pasquetti, cantora italiana"240.

No Cassino Antárctica existente na Rua Anhangabaú também se realizavam espetáculos de café-concerto, com a participação de artistas espanholas: "La Valorito" ou Juanita Arevalo, completista (sic) e bailarina espanhola tinha várias apresentações agendadas para o ano de $1913^{241}$.

É provável que esse empresário, ainda na década de 1910, fosse também proprietário de outros teatros, dentre eles, o de Variedades e o Cassino, a considerar as seguintes colunas do EDE:

Ópera, Opereta e Zarzuela. Companhia espanhola de Pablo Lopez se apresentou na cidade com grande sucesso, noticiado também pelo OESP, Fanfulla, Correio Paulistano, Comércio de São Paulo [textos citados literalmente no EDE]. Apresentação no Teatro Variedades, empresa de Paschoal Segreto, grande empresário da noite ${ }^{242}$.

Teatro Cassino, de P. Segreto. Direção: Alfonso Segreto [anunciando baile de carnaval] soberbos bailes à fantasia nos quais tomará parte toda a excelente troupe. O Cassino será transformado no reino da folia, artisticamente engalanado com flores, atendendo a todas as exigências do capricho. Mefistofélica iluminação, batalha de lança perfume, confetes e serpentinas. ¡Ao cassino! ${ }^{243}$.

Nesses cafés-concerto, alguns de início casas exclusivamente teatrais, localizados na Avenida São João e adjacências, apresentavam-se "cantoras românticas estrangeiras (sobretudo italianas), bailados, artistas cômicos ou então espetáculos de acrobacia (...) e teatros de vaudeville $^{\text {,244 }}$. Porém, segundo alguns autores eles representaram, no período, o celeiro que abastecia as mulheres "para os conventilhos". As caftinas aí compareciam aliciando as futuras inquilinas de suas casas, escolhendo preferentemente as que participassem dos espetáculos “artísticos" realizados ${ }^{245}$.

\footnotetext{
${ }^{239}$ EDE 29.08.1912. Ver cuplé, p. 286, nota 344. Trad. da autora.

${ }^{240}$ EDE 07.04.1913. Trad. da autora.

${ }^{241}$ EDE 15.12.1913.

${ }^{242}$ EDE 17.02.1913. Trad. da autora.

${ }^{243}$ EDE 30.01.1913. Trad. da autora.

${ }^{244}$ LEME, M. Op. cit., 1984, p. 123.

${ }^{245}$ Ver, por exemplo, FONSECA, G. Op. cit., 1982, p. 192.
} 
Nos restaurantes, as "caixeiras" eram notadas por sua beleza, como se manifestou Raffard em 1890 a respeito de "uma hermosa hija de Castilla" que à época trabalhava no Terraço Paulista ${ }^{246}$.

Uma caftina famosa foi "Lola, salerosa espanhola" que mantinha uma célebre pensão em sobrado - o não menos afamado " $n^{\circ}$ 15", da Avenida São João - para onde atraía "crescido número de inquilinos e divertia outro não menos numeroso grupo de rapazes e velhos, que lá passava boa parte da noite em alegres patuscadas" ${ }^{\text {247 }}$. Era um negócio altamente lucrativo, cobrava-se de acordo com as posses dos fregueses, grandes proprietários rurais, comerciantes, exportadores, profissionais liberais, enfim, a elite endinheirada da Paulicéia, pródiga e generosa em gastos com as mulheres.

Havia ainda, a "Mima, espanhola truculenta"248 ou a alcoviteira espanhola, já de idade avançada, de nome Santa, "na esquina da rua Vitória, lado ímpar ${ }^{249}$. E havia a mais célebre delas, Mme.Pommery, dona do bordel Au Paradis Retrouvé, "a pequena cocotte descendente de ciganos espanhóis e judeus poloneses" ${ }^{, 250}$, retratada no romance homônimo publicado em 1920 pelo engenheiro José Maria de Toledo Malta (um dos construtores do Martinelli), sob o pseudônimo Hilário Tácito $^{251}$.

(...) nunca ouvira falar em Madame Pommery. Chiquinho então explicou:

- É a cafetina mais rica de São Paulo. Enriqueceu explorando coronéis e vendendo champagne. Daí, seu apelido de Madame Pommery.

- Com champagne?

- Sim, meu caro, e de maneira original: com moscas ensinadas!

- Moscas ensinadas!

- Dizem que ela ensinava as moscas para cair nas taças de champagne. $\mathrm{O}$ fato entretanto era incontestável: na pensão de Madame Sanchez - ela se chamava também Sanchez -, o sujeito entrava, sentava-se na mesa com as fêmeas, mandava vir champagne, enchiam as taças, e daí a pouco, era certo (...)

- E saibam vocês, que ela com esse método e com essas moscas conseguiu comprar vários prédios na Avenida São João ${ }^{252}$.

\footnotetext{
${ }^{246}$ Idem, ibidem, 1988, p. 75.

247 MARQUES, C. Op. cit., 1944, p. 35.

248 FONSECA, G. Op. cit., 1982, p. 109.

249 Idem, ibidem, pp. 186-187.
}

${ }^{250}$ MORSE, Richard M. De comunidade a metrópole. Biografia de São Paulo. Tradução de Maria Aparecida M. Kerbeg. São Paulo: Comissão do IV Centenário, 1954, p. 221.

${ }^{251}$ TÁCITO, Hilário (pseudônimo de José Maria de Toledo Malta). Madame Pommery. São Paulo: Academia Paulista de Letras, 1977; (Coleção da Biblioteca da Academia de Letras, vol. 6); Campinas, SP: Editora da Unicamp; Rio de Janeiro: Fundação Casa de Rui Barbosa, 1997 (1 $1^{\mathrm{a}}$ ed. 1920). A explicação para seu pseudônimo foi-nos dada por DEL FIORENTINO, T. Op. cit., 1976, p. 27: "Tácito, porque aquilo é história e Hilário porque é história alegre", informa a autora com base em Monteiro Lobato.

${ }^{252}$ AMARAL, Edmundo. A grande cidade. Rio de Janeiro: José Olympio Editora, 1950, p. 48. 
O coronel surgia dos opulentos cafezais para tornar-se o senhor pródigo e arrogante da metrópole caótica. Mme. Pommery, a pequena coccote descendente de ciganos espanhóis e judeus poloneses (...) ficou impressionada com esta personagem:

- Que dice Usted? Es coronel el caballero? Pero no tenia el uniforme...

- Não é preciso... Aqui, quando um freguês não é doutor, é coronel...

- Ah! ... Y lo paga todo el coronel?... Como se llama?

- O Coronel Pacheco Izidro; certo que paga tudo. Tem cinco fazendas! Deputado. Chefe político de Butucuara. Director de partido...

- Pero, diame Usted: los hay acá muchos coroneles, muchos dotorescoroneles?

- Oh, sim há!... Está assim!!... (e mostrava os dez dedos apinhados) - Uma fartura!

- Dios mio, caramba! ... que tierra tan bonita! $!^{253}$.

A avenida São João representou, com outras ruas como a Nova de São José (hoje Líbero Badaró), a Conselheiro Crispiniano e os largos do Piques e do Paissandu, uma etapa intermediária na expansão dessa "profissão", que depois tendeu a incorporar pensões ${ }^{254}$, restaurantes, bares e hotéis, alguns deles até luxuosos ${ }^{255}$.

Requinte é o que não faltava ao suntuoso estabelecimento de outra espanhola, Salvadora Rojas y Guerrero, objeto de leilão à sua morte, desejo expresso pela finada ao "doutor testamenteiro" por ocasião de seu falecimento. Tratava-se do Hotel Maxim's.

Salvadora Guerrero!... Quem dela não se lembra e cativo não ficou da sua gentileza e acolhedora camaradagem?!

A sua pensão, o velho "Maxim's" era o lugar preferido pela boemia paulistana e políticos de projeção. Lá, a companhia de Salvadora era requestada em todas as rodadas para alegrá-las com o seu constante bom humor e narrar com a sua verve de autêntica espanhola as cenas boêmias das quais ela foi protagonista, nos bons tempos, em que foi seu amante conhecido escritor português, mais tarde Ministro dos Estrangeiros em Portugal e logo depois Embaixador em Paris ${ }^{256}$.

Algumas "pensões" da época como o Maxim's destacaram-se pela ostentação e luxo, compatíveis com o seleto público (masculino) de figuras importantes e aristocráticas que acolhia. O negócio de Salvadora Guerrero prosperara - como o Mme. Pommery que “conseguiu comprar vários prédios na Avenida São João"257 -, ganhando status de "hotel”. E dos mais chics, conforme atesta o catálogo do leiloeiro, anunciando a data do evento:

${ }^{253}$ MORSE, R. Op. cit., 1954, pp. 221-222 e TÁCITO, H. Op. cit., 1997, p. 63.

${ }^{254}$ Palais Elegant, Pension Royale, Palácio de Cristal, Maison Dorée, Maxim's, foram pensões famosas pela riqueza de suas instalações. $C f$. FONSECA, G. Op. cit., 1988, p. 77.

${ }^{255} \mathrm{Em}$ dois dos casos identificados para o período de 30 anos analisado constam dos LRC dois domicílios em Hotel: Hotel São José (1917, Isabel San José Fernandez, de Madrid) e Hotel Brasil (1920, Dolores Martinez Montenegro, de Sevilla).

${ }^{256}$ MARQUES, Cícero. Tempos passados.... São Paulo: Moema Editora, 1942, p. 147.

${ }^{257}$ AMARAL, E. Op. cit., 1950, p. 49. 
(...) riquíssimos móveis de refinada confecção para salão de refeições, dormitórios e gabinete. Suntuosos aparatos de prata e finos metais para mesa e serviço de banquetes. Riquíssima tapeçaria, profusa e bela coleção de objetos de arte, belíssimos vasos de terracota com palmeiras, finos enfeites para mesa e outros objetos que serão expostos... ${ }^{258}$

Nem todas as prostitutas, contudo, atingiam o status de uma Mme.Pommery ou de uma Salvadora Guerrero, donas do seu próprio negócio. Em maioria, elas se reportavam a um rufião, geralmente donos de bordéis a quem se sujeitavam e quem as espoliava, mantendo-as sob endividamento. Esses prostíbulos de categoria inferior ficavam nas ruas "menos asseadas", a Senador Feijó, a da Esperança, a da Caixa d’Água, a Capitão Salomão e a Rua da Conceição ${ }^{259}$.

A imprensa sistematicamente os denunciava e a polícia passou a exercer verdadeira perseguição aos indivíduos que exploravam o lenocínio, dentre eles um espanhol de nome Eduardo Picón Martinez que, ameaçado de ser deportado, o que acaba acontecendo, impetra um habeas corpus ${ }^{260}$. No mesmo ano de 1913, novamente o EDE insurgia-se contra a polícia que teria prendido a Enrique Castro, sob a mesma acusação ${ }^{261}$, matéria a que se seguiu um editorial reclamando da não permissão da polícia de Santos que - com temor de que alguns dos viajantes em trânsito fossem cáftens expulsos da Argentina que pretendessem permanecer no Brasil - não permitia que aqueles em trânsito pelo Porto de Santos desembarcassem, para visitar a cidade ${ }^{262}$.

Aos poucos as estrangeiras suplantariam as nacionais ${ }^{263}$. Em 1914, houve um primeiro cadastramento policial, ocasião em que 812 prostitutas foram fichadas, e, destas, apenas 303 eram brasileiras. As espanholas, que em 1915 eram em número de 38 aparecendo depois das russas, italianas, alemãs e francesas ${ }^{264}$, em 1922 já seriam $143^{265}$. Neste mesmo ano, 1922, o EDE encabeça campanha para que as casas de tolerância saíssem do centro - enumerando as Ruas Vitória, Vieira de Carvalho, Largo do Arouche e Conselheiro Nébias como os antros onde se mesclavam com as casas de família - e passassem a funcionar em bairros mais distantes da cidade $^{266}$.

${ }^{258}$ EDE 02.09.1913. Trad. da autora.

${ }^{259}$ AMERICANO, J. Op. cit., 1957, p. 141.

${ }^{260}$ EDE 09.08.1913.

${ }^{261}$ EDE 22.09.1913.

${ }^{262}$ EDE 15.10.1913.

${ }^{263}$ A esse respeito, ver: RAGO, Margareth. "Nos bastidores da imigração: o tráfico das escravas brancas". In: Revista Brasileira de História. São Paulo: vol. 9, nº 18, ago/set 1989, pp. 145-180. O texto trata da dinâmica do tráfico que supria o mercado da prostituição no Brasil e na Argentina.

${ }^{264}$ Passim.

${ }^{265}$ ANTONACCI, M. A. e MACIEL, L. A. Op. cit., 1995, p. 185.

${ }^{266}$ EDE 08.02.1922. 


\section{O espanhol na indústria}

Os ibéricos não se adaptavam muito ao trabalho das fábricas nem da lavoura. Preferiam trabalhar por conta própria, exercendo outros misteres, os mais variados tais como saqueiros, cigarreiros, funileiros, remendões, sorveteiros, vendedores de brinquedos, de frutas, além de compradores e revendedores de garrafas, chumbo, metal e cobre. Quem nunca ouviu falar no "rei do ferro velho"? Sempre houve um monarca dessa espécie no Brás... $^{267}$.

$\mathrm{Na}$ manhã seguinte, rumou para a fundição e, perguntando, atingiu a Monsenhor Andrade, onde lhe indicaram uma tecelagem com vagas para não qualificados. Três dias depois, primeiro do mês, deveria começar. Fundidor ou tecelão, pensou, que importa, se o objetivo é possuir um bar? ${ }^{268}$.

O Sumaquero cheio dos "cobres" aos cinqüenta anos. Papai sem tostão, aos setenta. Ambos não vieram ao mesmo tempo para São Paulo? Porque essa diferença? Não podia ser outra cousa. Foram as quixotadas de meu pai teimando em ser tecelão a vida toda $^{269}$.

O espanhol, particularmente a mulher espanhola trabalharam, neste período, em indústrias de vários segmentos, especialmente nas do ramo têxtil. Consta inclusive que, na greve de 1917, teriam sido expulsos um tecelão (Antonio Lopes) e um chapeleiro (José Sarmento Marques), ambos espanhóis ${ }^{270}$.

Com efeito, os registros consulares inicialmente coligidos, referentes à última década do Dezenove, e os subseqüentes, progressivamente exibirão, em suas páginas, alusões a ocupaciones (atividades, ofícios, tarefas, funções) nitidamente identificadas ao emergente setor industrial. Contudo, se por um lado esse aspecto de imediato se evidenciou, por outro, pela natureza de algumas dessas ocupaciones mencionadas, torna-se praticamente impossível distinguir se a alusão está referida a um operário, ao proprietário de uma pequena fabriqueta ou a um trabalhador em uma tarefa ocasional. Desse modo, o aparecimento de inúmeras categorias - cigarreros, caldereros, colchoneros, cordonero, fogoneros, silleros, sombreneros, tabaqueros, taponeros, tejedores, toneleros, torneros mecânicos, vidrieros/cristalero e yeseros - quando avaliadas em seu conjunto impossibilitam qualquer inferência do caráter desse vínculo, a menos que se opere individualmente a algumas delas, previamente selecionadas.

\footnotetext{
${ }^{267}$ PENTEADO, J. Op. cit., 1962, p. 57 e ss.

${ }^{268}$ MAFFEI, E. Op. cit., p. 36.

${ }^{269}$ RIZZO, Paulo Lício. Pedro Maneta. Biografia romanceada. Rio de Janeiro: Imprensa Nacional, 1942, p. 143.

${ }^{270}$ LOPREATO, C. Op. cit., 2000, p. 163.
} 
Assim, procedendo-se à subtração de categorias - caso de obreros/operarios (operário) $^{271}$ e empleados e trabajadores, ambas mencionadas no período inicial dos registros, quando o espanhol começava a chegar à cidade, e que sugerem com maior probabilidade sua vinculação a esse mercado de trabalho como operários -, o enquadramento das demais categorias exigiu cautela e, por essa razão, a qualificá-las indiscriminadamente, buscamos o apoio a outras fontes.

Iniciemos, então, pelas fábricas de fiação e tecelagem que constituíam, à época, as mais importantes da cidade e as de maior porte, pelo alto grau de mecanização exigido e capital investido $^{272}$ sendo as responsáveis, durante a década de 1900, por $70 \%$ das exportações interestaduais de São Paulo especialmente de tecidos, então enviados para vários estados, particularmente para os três estados do sul e para o Rio de Janeiro ${ }^{273}$.

Essas fábricas localizavam-se próximas às estradas de ferro. Pelos trilhos da Central do Brasil, vimos surgir indústrias no Brás, Belenzinho, Tatuapé, Comendador Ermelino e São Miguel Paulista; pela Santos-Jundiaí, também no Brás, mas ainda no Pari, na Moóca, no Ipiranga, em S. Caetano e em S. André. Pela Sorocabana, espraiaram-se pela Barra Funda, Água Branca, Lapa e Osasco ${ }^{274}$.

Em 1912, um relativo parque industrial já operava na cidade. Neste ano ocorreu a realização de um Relatório do Departamento Estadual do Trabalho, o qual detalhou minuciosamente para cada estabelecimento fabril visitado, as condições de trabalho, segurança e higiene dos operários, e as iniciativas patronais de assistência ao trabalhador, produzindo também a partir dos 30 estabelecimentos visitados, algumas estatísticas, fonte valiosa para uma reavaliação necessária da questão no tocante à participação dos espanhóis ${ }^{275}$.

Assim, segundo esse Relatório, na "mais antiga fábrica de tecidos da capital” [referindose, provavelmente, à Fábrica Nacional de Juta Santana], por exemplo, trabalhavam "500 operários, na maioria italianos e espanhóis”. A Fábrica de tecidos de juta para sacaria, a "Sant'Anna", de Álvares Penteado (depois de J. Street) era considerada a maior dentre as têxteis e se apresentava, naquele ano, como a que reunia o maior número de operários espanhóis, 93 no total. Esta fábrica mantinha uma vila operária, construída na década de 1900.

${ }^{271}$ O primeiro registro de obrero é de 1898.

${ }^{272}$ A indústria têxtil ocupava, em 1889,60\% do capital empregado na indústria brasileira, seguida pela de alimentos, com 15\%. Cf. ANDRIGHETTI, Yná. Mulher e trabalho. A operária têxtil paulistana. São Paulo: Dissertação de Mestrado, FFLCH-USP, 1987, p. 29.

${ }^{273}$ LEME, M. Op. cit., 1984, p. 254.

${ }^{274}$ PETRONE, P. Op. cit., 1955, p. 129.

275 PINHEIRO, Paulo Sérgio e HALL, Michael. A classe operária no Brasil (1889-1930). Documentos. Condições de vida e de trabalho, relações com os empresários e o Estado. São Paulo: Brasiliense; Campinas: Funcamp, 1981, Vol. II, pp. 59 e ss. 
Não apenas nesse estabelecimento foram encontrados espanhóis operários: em outro momento, referindo-se a outro estabelecimento não identificado, o Relatório indicava que "entre os 374 operários recenseados, a nacionalidade predominante é a italiana, vindo em seguida a espanhola"276.

Na Fábrica Mariângela, pertencente ao Conde Matarazzo, construída em 1904, no Brás, pela necessidade de produzir sacos para a sua fábrica de farinha, também havia operários espanhóis, contabilizados em número de 50. Referindo-se às condições de trabalho ali reinantes, Jacob Penteado, cuja mãe trabalhou na Mariângela e o levava consigo nos dias em que não havia aula, apontou o perigo representado pela lançadeira que, possuindo uma "ponta de ferro bastante aguda, em forma de pião (...) de quando em quando escapava do tear, projetando-se com incrível velocidade para os lados", indo, numa das vezes, alcançar a cabeça de sua mãe que "por pouco não teve um olho vazado, pois este ficou completamente escondido com a inflamação que se formou no local",277.

A falta de espaço era considerada como um dos fatores para o elevado número de acidentes; nas menores, por razões óbvias, já que normalmente instaladas em dependências inadequadas; já nas maiores, o que ocorria era um aumento da produção desproporcional às suas dependências físicas, provocando o amontoamento das máquinas e dos trabalhadores, a falta de divisão por secções e a exposição do maquinário sem manutenção, "com correias e engrenagens expostas, sem capeamento", ocorrendo, numa das fábricas visitadas pelo inspetor do Departamento Estadual do Trabalho, em 1911, o caso de um empregado que teve a “cabeleira arrancada",278. Considerando-se, a propósito, o período de 1913 a 1919, a indústria têxtil foi a que concentrou o maior número de acidentes do trabalho, seguida, de longe, pela indústria de calçados ${ }^{279}$.

Nesse instante, Carmela voltou-se, dando as costas ao tear. Um grito terrível, doloroso, inumano que sobrepujou todos os ruídos repercutiu agudamente, transmitindo uma rajada fria de pânico e susto. A coisa aconteceu tão repentinamente que estarreceu os que assistiam. Os longos cabelos de Carmela foram colhidos pelas lâminas e repuxados violentamente nas malhas, se enroscaram arrastando a cabeça da operária num torvelinho em que se misturavam a felpuda cabeleira e os fios brancos do linho, introduzindo-se no pente suspenso.

- Desliguem a força

- Parem a for-or-ça-a-a-aa

${ }^{276}$ Passim.

${ }^{277}$ PENTEADO, J. Op. cit., 1962, p.62.

${ }^{278}$ LEME, M. Op. cit., 1984, p. 246.

${ }^{279}$ MOURA, E. Op. cit., 1984, p. 190, Tabela III. No total, para a indústria têxtil foram 281 ocorrências, e 126 para a de calçados. Ver também: pp. 50-56 e 168-178. 
Era um pandemônio. Gritos estridentes se ouviam quando a força foi desligada. Todos se aglomeravam em torno da moça que jazia semi ligada ainda por um fragmento apenas do couro cabeludo, enquanto o resto fora arrancado deslocando-se da cabeça, formando uma pasta sangrenta de cabelos e fios de juta presa à teia da urdidura, numa amostra macabra de um estranho tecido humano. Amparada por Vitório e Lola, Carmela jazia desacordada, o rosto coberto de sangue e aquela chaga exposta e viva do crânio despojado do couro cabeludo ${ }^{280}$.

Em 1913, como que ratificando os constantes acidentes de trabalho ocorridos com operários espanhóis, já circulava, no EDE, propaganda de um advogado, Dr. Adolfo Nardy Filho, com escritórios na Rua Líbero Badaró, 11, oferecendo-se para "tratar de casos de indenizações a operários por acidentes de trabalho" 281 .

No Cotonifício Rodolfo Crespi, construído na década de 1890 no bairro da Moóca primeiro simples tecelagem, passando depois também à fiação - foram contabilizados outros 41 espanhóis nesse ano de 1912. Nesta fábrica trabalhou D. Inês Guerrero Cadina Quiroz, andaluza de Sevilha, que relatou ter ingressado como tecelã na indústria por meio de seu pai, então "domestico, limpiaba el mingitorio de las mujeres", depois de haver fugido de uma fazenda com a família. Ali, esclarece, "había dias en que no ganaba ni para el jabón para lavarme las manos. A veces porque se rompia el telar, otras porque los hilos estaban malos y no rendían", em outras palavras, "pagaban por trabajo hecho, si yo trabajaba, me pagaban". Outra espanhola, D. María Marin, também andaluza, de Jaén, narrou ter iniciado cedo, “doce, trece, catorce [anos]", junto com o irmão, de "once años" na "Penteado", depois de haver trabalhado numa fazenda de café, em Bauru, com a família, tendo vindo para São Paulo após a morte dos pais ${ }^{282}$.

No cômputo geral apresentado pelo informante e considerando apenas o ano de 1912 o espanhol apresentou-se, dentre os estrangeiros, ocupando a terceira posição, evidentemente que distante da primeira, ocupada pelos italianos, contudo bem próximo dos portugueses, em segundo lugar.

Em 1920, do total empregado nas indústrias têxteis da capital (120 mil operários), 60\% constituíam-se de mulheres e, deste total, $40 \%$ eram menores de até 16 anos $^{283}$.

${ }^{280}$ MARX, G. Op. cit., pp. 68-69. Por volta de 1915 as maiores fábricas de fiação e tecelagem da cidade, em sua maioria produzindo juta para os sacos de café, tinham de mil a 2 mil operários, e o maior capital investido era de 6.000 contos, apenas superado pela Cia. Antárctica (10 mil contos já em 1907).

${ }^{281}$ EDE 02.06.1913.

${ }^{282}$ Relato concedido a Maria Antonieta Antonacci na Sociedade Beneficente Rosalía de Castro, em 1997. In: ANTONACCI, M. Op. cit., 2002, pp. 8; 21 e 23.

${ }^{283}$ A esse respeito, ver: "Os pequenos mártires da industrialização". In: PENTEADO, J. Op. cit., 1962, pp. $117-125$. 
Carreira brilhante a de Manoela. Com a idade de 9 anos torcia fio. Com 13 era engrupina, com 17, tecelã. Diziam que sustentava a mãe e até o pai, um homem de "altos negócios" na fértil imaginação... Começara a vida na Assunção e lá se fizera um elemento necessário. (...) Quando D. Mercedes a mestre ficava doente, Manoela a substituía com vantagens (...). "D. Manoela foi sempre minha melhor aluna" ("dona" exigido pelo Assunção e usado por todos os operários), aos quais Manoela, como boa espanhola, fazia questão de responder em escala maior ${ }^{284}$.

Até a década de 1910, a jornada de trabalho estendia-se de 12 a 13h, tendo sido reduzida, após esse período, para 10 a 11h, iniciando-se por volta das 5 ou 5,30h da manhã e terminando entre 5 e $6 \mathrm{~h}$ da tarde. Na Mariângela, o horário de trabalho, neste período, era ainda de 12h, e somente após as greves de 1917 e 1919 é que a maioria das indústrias diminui a jornada para 8 ou $9 \mathrm{~h}^{285}$.

Entre 1908 e 1913 fundam-se a Fábrica de Tecidos Ipiranga, dos Irmãos Jafet, o Cotonifício Gamba, a Maria Zélia, de Jorge Street, e a Belenzinho, também de Matarazzo, constituindo-se em 10 as empresas do ramo, até 1920. A Fábrica de Tecidos Ipiranga, cliente do EDE, e que pelo Relatório de 1912 apresentava-se com 28 operários espanhóis, solicitava "tejedores para fábrica de tejidos y estamparia Ypiranga"286. Esta indústria e outras do Belenzinho protagonizarão uma greve, em 1913, que parou 1.500 tecelões, à qual assim se referiu o $\mathrm{EDE}^{287}$ :

\begin{abstract}
Huelga
Continuan firmes em su justa demanda los obreros tejedores de la Fábrica de Tecidos de Ypiranga. El propietario de aquel establecimiento fabril fijó un anuncio en que decia serían dispensados del trabajo los huelguistas que no se presentasen al mismo el día siete. Esa amenaza no hizo el menor efecto a los obreros, pues ninguno se presentó ayer en la Fábrica.

También anunció el patrono que serían admitidos en su Fábrica cuantos obreros tejedores lo solicitaran. El mismo resultado que el anterior ha tenido ese aviso, pues nadie se ha prestado atraicionar a los huelguistas.

Los guardias de policia, que los primeros días de la huelga cometieron varias violencias con los huelguistas, han sido relevados por otro destacamento que se limita a vigilar, sin cometer el menor abuso, conducta que está siendo elogiada por los habitantes de aquel pacífico barrio.
\end{abstract}

Cumpre ressaltar, como complemento, que foram os trabalhadores têxteis que estiveram à frente das maiores greves ocorridas, tanto em São Paulo quanto no Rio de Janeiro. Entre 1901

${ }^{284}$ RIZZO, P. Op. cit., 1942, p. 91, fala de Manoela, a tecelã andaluz do Assunção, local onde Pedro Martinez (o maneta) chefiava 200 operários.

${ }^{285}$ LEME, M. Op. cit., 1984, pp. 243-244.

${ }^{286}$ EDE 07.04.1913.

${ }^{287}$ EDE 08.05.1913. 
e 1914, apenas na cidade de São Paulo, foram os responsáveis pela promoção de 26 greves e entre 1915 e 1929 , por mais 18 greves $^{288}$.

Segundo Olga Von Simson, um suíço, Henrique Scholk, a quem pertencia a Fábrica de Tecidos e Bordados Lapa, teria mandando importar tecelões diretamente da Espanha, para os quais teria construído uma vila operária à Rua Engenheiro Fox, na Lapa de Baixo, local onde até então só havia uma oficina mecânica da São Paulo Railway "verdadeiro marco de origem dos contingentes operários do bairro, responsáveis pela expansão de seu povoamento". Não se pode descartar a possibilidade de terem pertencido aos quadros funcionais dessa empresa, por sua especialidade declarada, os dois "técnicos en tejidos", pai e filho naturais de Barcelona que realizaram sua inscrição no ano de 1921 no $\mathrm{CGE}^{289}$.

Esses trabalhadores especializados, operários da fábrica de bordados e os empregados de outras pequenas oficinas que foram atraídos para o local, são tidos como os responsáveis pelo início do carnaval na Lapa, o segundo bairro da cidade a promover um evento local de forma planejada, criando o Clube Carnavalesco Lapeano, responsável pelo carnaval de rua que perdurou até finais da década de 1920.

Após o desaparecimento do Clube, algumas manifestações espontâneas ainda permaneceram, como o corso e o desfile de pequenos blocos ou cordões, com 10 a 15 pessoas fantasiadas de maneira igual, às quais comparecia um grupo de foliões espanhóis, moradores da Vila Esperança, a convite dos conterrâneos ali residentes. Foram os responsáveis pela recriação de um hábito tradicional, a "Murga"290, apresentando-se com fantasias confeccionadas com saco de estopa - herança do comércio de sacaria? - portando instrumentos musicais confeccionados com papelão e entoando uma melodia curta e repetitiva, sua característica ${ }^{291}$. O costume de desfilar pelas ruas também acontecia em cidades do Interior do Estado. Em Catanduva - local de concentração de espanhóis no Oeste cafeicultor e objeto de nossa Dissertação de Mestrado - a propósito, acontecia a "Murga dos Doutores", constituída por um grupo popular de músicos que pretendia satirizar os médicos, a qual também teria evoluído para um bloco de carnaval ${ }^{292}$.

${ }^{288}$ ALVES, Paulo. Anarquismo, movimento operário e o Estado. Suas relações no contexto capitalista da Primeira República (1906-1922). Dissertação de Mestrado. FFLCH-USP, 1981, p. 34.

${ }^{289}$ Bordas y Creus, Arturo, 47 anos e Bordas y Freginals, Francisco, 27, ambos casados. LRC 1921.

${ }^{290}$ Literalmente, "murga" quer dizer "músicos de rua".

${ }^{291}$ SIMSON, Olga Rodrigues de Moraes Von. Brancos e negros no carnaval popular paulistano, 19141988. Tese de doutoramento, FFLCH-USP, 1989, p. 40 e ss. No texto da autora não consta o ano da criação da Fábrica de Tecidos e Bordados Lapa, da qual se refere. A esse respeito, ver também: A Reconstituição da Memória Estatística da Grande São Paulo, op. cit., Vol. II, p. 73

${ }^{292}$ RANGEL, Wellman Galvão de França. "Algumas contribuições espanholas ao folclore paulista". In: Revista do Arquivo Municipal de São Paulo, vol. CXLIV, ano XVIII, nov-dez 1951, p. 441. 


\section{Caldereros, Fogoneros e Mecánicos}

Calderero e Fogonero, função atribuída ao operário responsável pelo funcionamento das caldeiras das máquinas a vapor ${ }^{293}$ - utilizadas pela indústria mecanizada até a década de 1890, quando da instalação da usina elétrica de Cubatão - representaram, ao lado de Mecánico, outra daquelas ocupaciones desde cedo declaradas nos LRC. Com efeito, remonta a 1894 o aparecimento dos primeiros caldereros e fogoneros, categorias a início mencionadas indistintamente (e provavelmente significando a mesma coisa), e que já na primeira década de 1900 foram unificadas sob a rubrica única de fogonero $^{294}$. Assim, em 1894, identificamos dois irmãos caldereros, José e Andrés Pacheco, 32 e 24 anos respectivamente, naturais de Málaga, de passagem pela cidade em direção ao Rio de Janeiro. Também de Málaga, neste mesmo ano, procurava o CGE para registrar-se José Sanchez Fernandez, 35 anos, fogonero que informou estar indo a Salto de Itú e José Gómez Sanchez, de Cádiz, com 28 anos e residente na cidade à Rua do Brás, informando, porém, que se dirigia ao Rio de Janeiro.

Esses casos de indivíduos deslocando-se para outras cidades ou Estados evidenciam a dificuldade de absorção, já àquela altura, de uma atividade que se restringia em virtude da obsolescência do processo já que, a partir da década de 1890, indústrias como os três importantes têxteis do período (Santana, Mariângela e Crespi), o Moinho e a Fábrica de óleo Matarazzo, a Cia. Mecânica Importadora, a Vidraria Santa Marina e a Fábrica de fósforos da Vila Mariana, passam a utilizar a energia elétrica.

Contudo, apesar da crescente difusão da energia elétrica, o vapor continua a ser utilizado nas fábricas de chapéus e móveis e nas serrarias, e em algumas fábricas de alimentos, onde é provável, portanto, que ainda pudessem exercer a atividade ${ }^{295}$. Ainda assim é sintomático observar a data dos últimos registros de fogoneros no CGE, o ano de $1906^{296}$. Provavelmente pela escassez de oportunidades na cidade, não tenha diminuído a oferta, que adentrou a segunda década de 1900, desses profissionais no EDE, os quais se ofereciam para trabalhar também em outra cidade: "fogonero, que trabalha com motores a vapor e de ar em qualquer sistema, para a capital ou qualquer outro ponto. Tratar com José Rodriguez, Rua da

293 "Nas fábricas movidas a vapor a força é transmitida da seguinte maneira: a máquina a vapor faz girar uma roldana, que transmite força a um sistema de pequenas roldanas espalhadas na parte superior do estabelecimento industrial, localizadas a vários metros acima das máquinas; ligando estas às roldanas existem correias que se movimentam de forma giratória, devido às roldanas, o que permite, afinal, o funcionamento das máquinas". $C f$. LEME, M. Op. cit., 1984, p. 219.

${ }^{294}$ Fogón: boca da caldeira.

295 Ainda coexistiriam as fábricas antigas e menores utilizando os motores de combustão a gás ou petróleo, e poucas, sobretudo as têxteis do interior, à força hidráulica.

${ }^{296}$ Pertenciam a Fidel Fernandez Alvarez, 26 anos, natural de Orense e Juan Barreto, 24 anos, de Tenerife. LRC 1906 
Moóca, 36 primeiro quarto"297. Talvez ocasionado pela permanência do processo que representava um quinhão de mercado ainda ativo, mas em evidente adaptação aos novos tempos, os cursos por correspondência da International Correspondence Schools divulgados no EDE mantinham as duas possibilidades "manejo de máquinas a vapor e elétricas"298.

As indústrias que se modernizavam repassavam seus equipamentos substituídos às menores, abrindo mercado de trabalho para um outro profissional, o mecânico de máquinas a vapor, profissional requisitado para a manutenção das caldeiras remanescentes, certamente comercializadas para as fábricas de pequeno e médio porte, que ainda as utilizavam. Assim, enquanto alguns tentavam se ajustar com oferta de mão-de-obra "para indústria ou fábrica" (indicando a distinção quanto ao porte), "para a capital ou o interior" 299 , outros mais tarde, em evidente atestado da permanência do sistema a vapor, reaproveitado em empresas menores ainda a finais da década de 1910, ofereciam-se como "ajustador mecânico, para máquinas a vapor ou para oficinas em que se efetuem reparações em máquinas e motores a vapor"300. Tais mecânicos, que se inscreveram no CGE no período, provinham em maioria da Andaluzia (48\%), apresentando o mesmo percentual (9\%) para os naturais da Galícia, de Castilla-León e da Catalunha ${ }^{301}$.

\section{O trabalho nas vidrarias}

- Mas olhe! Não procure vidrarias! É uma exploração! São só nove horas de trabalho mas é uma tapeação. Você entra às seis da manhã, mas se o vidro fundir ao meio-dia, nessa hora é que elas começam a ser contadas. Sairá de noite e descobre então que ficou quinze horas assando. Existem, em todas, capatazes malvados que maltratam menores aprendizes ${ }^{302}$.

Há indícios de que a colônia espanhola tenha produzido boa safra de operários, adultos e menores do sexo masculino para as vidrarias, que trabalharam especialmente na Santa Marina. Surgida em 1895, “a vidraria do Sr. Conselheiro Antonio Prado, em Água Branca, é a única no Brasil" dizia Bandeira Jr. em $1901^{303}$ referindo-se a ela, que começou operando na

${ }^{297}$ EDE 11.09.1914.

${ }^{298}$ A escola oferecia 234 cursos em inglês e 20 em espanhol e situava-se à Rua 11 de agosto, 3-A. EDE 03.02.1914.

${ }^{299}$ Federico Llopis, Rua Nova de São José, 74 (Vila Vida). EDE 19.10.1914.

${ }^{300}$ EDE 15.07.1919. Trad. da autora.

${ }^{301}$ Relatório Access 22.

${ }^{302}$ MAFFEI, E. Op. cit., 1978, p. 36.

${ }^{303}$ BANDEIRA Jr., A. Op. cit., p. XVIII. 
fabricação de garrafas, feitas inicialmente com vidro escuro para o envasamento de bebidas em geral, especialmente o da cerveja ${ }^{304}$.

A rotina de trabalho nas vidrarias era duríssima, dependendo largamente do trabalho manual até 1906, quando então se inicia a progressiva mecanização no fabrico das garrafas. No entanto, ainda em 1917, a produção de vitrais continuava a ser manual ${ }^{305}$.

$\mathrm{Na}$ Vidraria Santa Marina, em Água Branca, as garrafas e outros recipientes grosseiros de vidro que lá se fabricavam eram feitos à força de sopros humanos. $\mathrm{O}$ operário vidreiro passava o dia, de manhã à noite, junto às matérias incandescentes e tinha que encher as bochechas de ar, forçar os pulmões e soprar em canudos, processo desumano de modelar objetos de vidro ali fabricados. Fazia isso durante dez e mais horas por dia, até ficar tuberculoso. Outros iam para seus lugares e, assim, as vidrarias se tornavam fábricas de tísicos ${ }^{306}$.

No capítulo "Os pequenos mártires da industrialização”, Jacob Penteado relatando a sua própria experiência de infância, quando trabalhou em uma vidraria, atestava que o trabalho era executado "no bafo". Os meninos, dizia, sempre foram indispensáveis nas fábricas de vidro: tinham de chegar uma hora antes do que os oficiais vidreiros para encher as tinas em que estes mergulhariam as canas e os ferros de fazer bocas, carregando-as, depois de cheias quando então pesavam de vinte a trinta quilos, molhando-se por inteiro, e também acender os fornos para que as peças fossem reaquecidas para o acabamento. Em dias normais, seu turno era de 10 horas, porém, quando a fusão do vidro retardava, aumentava para 11, 12 e até 15 horas, submetendo-se a toda sorte de maus tratos dos vidreiros oficiais. Eram as crianças quem limpavam as latrinas e varriam o chão. Percorrendo a fábrica o dia todo, "os cacos de vidro espalhados pelo chão representavam outro pesadelo para elas, porque muitas trabalhavam descalças ou com os pés protegidos apenas por alpercatas de corda, quase sempre furadas". Companheiro seu, já havia um “espanholito", dentre vários nomes que enumera ${ }^{307}$.

Os vidrieros, assim declarados no CGE representaram, conforme observamos, uma parcela reduzida quando comparados àqueles que - mesmo admitindo trabalhar na "Santa Marina"; no "Bairro Água Branca - Vidraria"; no "Bairro Água Branca - cristal" ou na "Cristaleria Santa Marina" - declaravam-se jornaleros ou simplesmente empleados.

304 Vidros planos para janelas só apareceriam bem depois, com uma fábrica que se instalou em 1941, no Rio de Janeiro.

${ }^{305}$ LEME, M. Op. cit., 1984, pp. 204 e ss e 239.

${ }^{306}$ RODRIGUES, Edgar. Nacionalismo e cultura social, 1913-1922. Rio de Janeiro: Laemmert, 1972, p. 148.

${ }^{307}$ PENTEADO, J. Op. cit., 1962, pp. 117-125. 


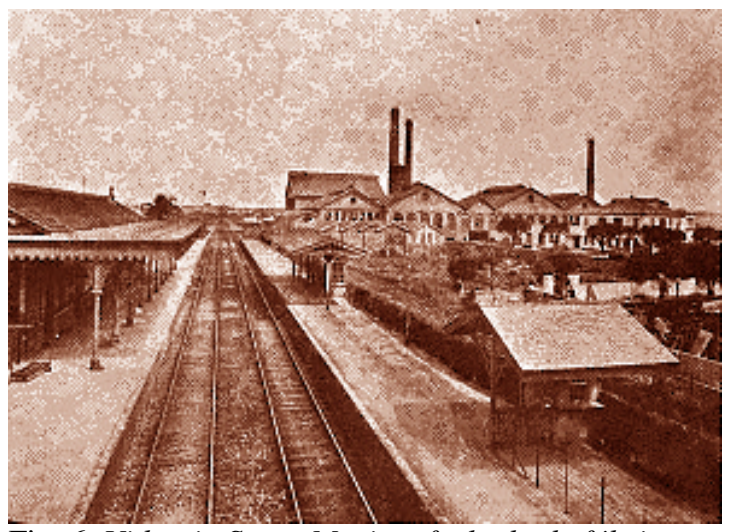

Fig. 6. Vidraria Santa Marina, fachada da fábrica [1916].

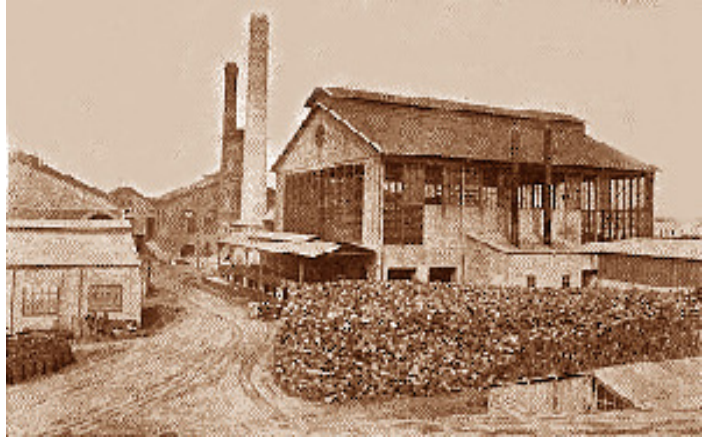

Fig. 8. Vidraria Santa Marina, vista externa dos fornos de garrafas [1916].

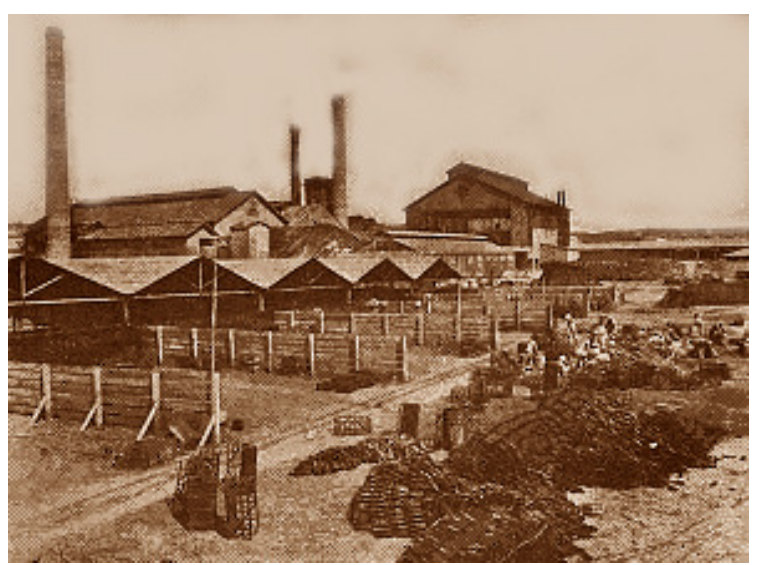

Fig. 7. Vidraria Santa Marina, vista dos fundos da fábrica [1916].

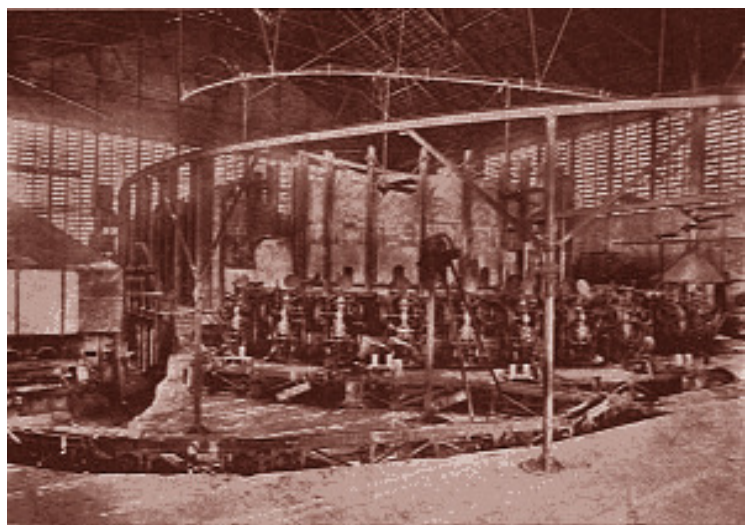

Fig. 9. Vidraria Santa Marina, vista interna dos fornos de garrafas [1916]. 
Há inclusive o caso ilustrativo de dois irmãos, Antonio e Miguel Wiquel Grinner, registrados no mesmo ano de 1917, em que um deles, Antonio, de 46 anos, declarou-se vidriero, e o outro, Miguel, mais velho e então com 49 anos, declarou-se jornalero, indicativo provável da existência de uma distinção acentuada entre aqueles que exerciam a tarefa de oficial vidreiro e os que exerciam outras atividades ${ }^{308}$, possivelmente mão-de-obra desqualificada quando não eventual. O ofício de vidreiro exigia muitos anos de prática: "um oficial de vidreiro não se improvisa. São necessários vários anos de aprendizado", dizia Jacob Penteado ${ }^{309}$ e, enfim, imaginamos que essas outras funções pudessem se relacionar, por exemplo, à extração da areia para o preparo do vidro, bem como da turfa para o combustível, cuja exploração se dava nos brejos e lagoas existentes nas margens dos rios, o que, neste caso, era efetuado no terreno da própria fábrica ${ }^{310}$.

Tratava-se, pois, com exceção dos fornos onde se dava a preparação da massa do vidro, de uma produção exclusivamente manual, técnica que permaneceu até 1906 quando se inicia a mecanização no fabrico das garrafas.

Em 1911 localizamos a inscrição de dois irmãos, empregados da Santa Marina, ambos declarando-se vidrieros: Rufino e Teófilo Saenz Mugarza, 29 e 30 anos respectivamente, naturais de Navarra, assim se declararam, o que comprova a existência de uma hierarquia com relação a esses profissionais e os demais operários de vidrarias.

De todo modo, dois anos após ser fundada, a Santa Marina já contava com espanhóis em seus quadros: é de 1897 a inscrição no CGE de José Grané Fornadas, solteiro, idade não mencionada, natural de Barcelona, domiciliado na Água Branca e vidriero ${ }^{311}$.

Dentre esses, é bom ressaltar, alguns indicativos sugerem que alguns deles viviam nas casas que a Vidraria, por estar situada em local afastado, mantinha para seus funcionários. Em pelo menos dois casos, os inscritos detalharam residir na "Vila Santa Marina" nos números 56 e 61. O primeiro, com registro realizado em 1920, era o vidriero Demétrio Alfonso, 29 anos, de Orense. O segundo a indicar a vila como local de moradia foi o jornalero Antonio Fernandez Dominguez, de 47 anos, analfabeto e também natural de Orense, na Galícia, em 1922.

\footnotetext{
${ }^{308}$ LRC 1917. Ambos eram naturais de Santander, Região da Cantábria, ao norte da Península.

${ }^{309}$ PENTEADO, J. Op. cit., 1962, p. 120.

${ }^{310}$ LEME, M. Op. cit., 1984, pp. 214; 218 e 239.

${ }^{311}$ Relatório Access 28.
} 
A Armour também se instalará na Lapa, porém mais tarde. Para Wilson Suzigan e Tamás Szmrecsányi ${ }^{312}$ o seu estabelecimento faz parte de uma segunda rodada na aplicação de capitais estrangeiros no segmento de processamento de carnes, já que, antes dela, outras iniciativas nessa direção foram observadas. Depois da sua primeira fábrica construída no Rio Grande do Sul, a Armour na cidade de São Paulo terá sua sede no “km. 10” da linha Sorocabana na Lapa, local mencionado como domicílio de muitos declarantes a partir de 1918, somente depois identificado com a sede da empresa.

Com efeito, embora os autores afirmem que "o início de suas operações, previsto para 1920, acabou sendo retardado pela escassez de animais" ${ }^{\text {"313 }}$, os registros de imigrantes no CGE já acusavam, a partir de 1918, diversos inscritos vinculados ao "Frigorífico Armour" ou à "Cia. Armour" ou ainda apenas à “Armour", além do domicílio mencionado - "Bairro Lapa” ou "km. 10". Além desses indicativos, observamos outro domicílio - "Travessa do Curtume, 10" como endereço mencionado, clara alusão ao Curtume Água Branca, fundado em 1889 por Antonio da Silva Prado, fundador da Santa Marina, para cuja matéria-prima, no processamento da pele dos animais, contava com sua própria criação de gado

Dentre os inscritos selecionados dentro desses parâmetros indicativos novamente deparamos uma maioria de jornaleros, mas também carpinteros e albaniles (pedreiros), com idades entre 24 e 51 anos, e de procedência majoritária da Região da Galícia (Orense, Pontevedra e Coruña) ${ }^{314}$.

Entretanto, a estréia da empresa na cidade não poderia ser menos receptiva: sob o título "Sueldos míseros y compañia rica", vasto artigo publicado no EDE denunciava o baixo salário pago a seus operários. Os encañadores (acreditamos ser uma atividade relacionada à lavagem do matadouro da Companhia), afirmava a matéria, recebiam a mesquinharia de 700 réis por hora, ou seja, $5 \$ 600$ por dia, quantia com a qual não podiam se manter ${ }^{315}$.

A Lapa, como extensão da Água Branca, também passará a concentrar um gradativo contingente de espanhóis, com flagrante vinculação ao Frigorífico "Armour". Lembremos que o bairro, a partir de 1913, já contava com uma sede da FE, evidência concreta da concentração, no local, de um número crescente de espanhóis.

\footnotetext{
${ }^{312}$ SUZIGAN, W. e SZMRECSÁNYI, T. Op. cit., 1996, p. 268

${ }^{313}$ Passim.

${ }^{314}$ Relatório Access 28.

${ }^{315}$ EDE 13.12.1920.
} 


\section{O espanhol nos serviços públicos urbanos}

Nos serviços públicos urbanos, setor operado por companhias privadas estrangeiras em regime de monopólio durante a Primeira República, também houve a participação da mão-deobra do imigrante espanhol. A partir de 1872, a The São Paulo Gas Co., Companhia de gás inglesa iniciou as obras para a instalação dos encanamentos, dutos por onde passaria o gás para a iluminação da cidade, até então iluminada por lampiões de querosene. Instalados os 700 lampiões de gás nas ruas de São Paulo, cuja iluminação devido ao monopólio, permanece basicamente a gás até fins da década de 1920, teve início, em 1880, o fornecimento domiciliar para iluminação das casas.

Instalada no Brás, entre as ruas do Gasômetro e da Figueira, ocupando grande terreno no local, a Companhia tinha seus terminais distribuidores e os depósitos de carvão (importado da Inglaterra, como os demais materiais empregados) espalhados pela Avenida Rangel Pestana.

Em 1894 identificamos o primeiro registro realizado no CGE com manifesta vinculação à empresa: "empleado fábrica de gas", era a atividade declarada por Esteban Ferrero Calvo, 41 anos, natural de Zamora (Castilla-León) e residente na Rua São Joaquim, $14^{316}$, sem especificar, no entanto, qual a função exercida.

Essa empresa, com o passar dos anos, estendeu sua atuação ao comércio correlato de fogões e objetos que implicassem o emprego do gás ${ }^{317}$. A propósito, o primeiro anúncio de fogão a gás que circulou no EDE, em 1914, comercializado pela empresa, vinha ilustrado com a imagem do produto e seu preço variava, custando $115 \$ 000$ à vista instalado ou podendo ser parcelado em dez prestações de $12 \$ 000$ por mês ${ }^{318}$.

A partir de 1922 a luz elétrica, em marcha acelerada, foi substituindo a iluminação a gás, expandindo para além da área central o benefício para o conjunto da cidade ${ }^{319}$. Até então, a iluminação das ruas era executada por uma turma de trabalhadores, os gasistas, contratados para percorrerem as ruas, pela manhã apagando e à noite acendendo os lampiões, o que faziam com uma longa vara metálica. Os gasistas - vocábulo inexistente no idioma espanhol, mas utilizado nos LRC -, localizados apenas nos primeiros anos da série consultada, apareceram somente até o ano de 1896 e eram naturais de Barcelona ${ }^{320}$. A rubrica é dúbia e imprecisa, podendo indicar

${ }^{316}$ LRC 1894

${ }^{317}$ LEME, M. Op. cit., 1984, p. 82.

${ }^{318}$ EDE 10.06.1914. O equipamento podia ser adquirido em diversos locais, a saber: Rua do Carmo, 3 ; Rua Amaral Gurgel; Av. Rangel Pestana, 220 e Rua Vergueiro, 275.

${ }^{319}$ PETRONE, P. Op. cit., 1955, p. 148.

${ }^{320}$ Relatório Access 41. 
tanto a atividade do indivíduo que acendia os lampiões, como daquele que instalava ou consertava aparelhos que funcionavam com gás, ou simplesmente os empregados da Companhia em qualquer outra função. Talvez tenha sido substituída por outra, no decorrer do período, porém não conseguimos identificar suas prováveis equivalentes. Lembremos que algumas rubricas como empleado, eram utilizadas indistintamente entre os operários de fábricas. Aliás, ser empleado de uma Companhia desse porte, naquele momento na cidade, especialmente para o filho de um negociante de ferro-velho, tinha alta significação e era motivo de inquietação:

Januário conseguiu empregar Ramón na Companhia de Gás, como mensageiro de rua, entregando cartas.

- Fique firme e trabalhe direitinho que lá você tem futuro. A gente começa de baixo. Agora você precisa estudar um pouco.

- Vou começar a ter aulas à noite com dona Evangelina.

- Agora você se esforce. Isso de um rapaz andar na rua, o dia inteiro, comprando ferro-velho... ${ }^{321}$.

Contudo, o prestigiado emprego não os eximia das fatalidades e o caso de Antonio Perez, espanhol, funcionário da Companhia, é exemplar: perdera a vida em acidente de trabalho, deixando viúva e dois filhos, que agora lutavam junto à mesma para receber a indenização, para que pudessem retornar à Espanha. Com viagem marcada e sem sucesso, a família solicita a interferência da autoridade consular e o caso acabou nas mãos de Eiras Garcia que, pelo EDE, passou a reclamar publicamente a quantia devida de 1:000\$000 (um conto de réis). Esses casos de indenizações por acidente eram morosos, geralmente exigindo a intervenção de um advogado, dos muitos que já se constituíam na cidade com essa “especialização", i.é., "indenizações a operários por acidentes de trabalho", cujos anúncios eram regulares no EDE, em língua espanhola ${ }^{322}$.

Tragédia similar abateu-se sobre a família de José Cabello embora não precisamente por acidente de trabalho. O motorneiro de bonde espanhol residia no Beco do Lucas, $\mathrm{n}^{\mathrm{o}} 18$, no Brás com D. Carolina Augusta e uma filha desta quando, em uma noite do mês de janeiro de 1920 enquanto dormiam, o quarto foi invadido por uma "massa de gás que penetrou por um buraco feito por ratos, procedente dos canos que passam pela Rua da Assunção, que pouco a pouco foi penetrando pela terra até chegar ao lugar indicado". Em conseqüência, a filha de D. Carolina morreu imediatamente asfixiada e José Cabello teve um lado do corpo paralisado,

${ }^{321}$ MARX, G. Op. cit., pp. 102-3.
${ }^{322}$ Dr. Adolfo Nardy Filho. Advogado. Rua Líbero Badaró, 11. EDE 02.06.1913. 
ficando impossibilitado de caminhar, vindo, no entanto, a falecer, meses depois, em consequiência do ocorrido ${ }^{323}$.

Encerrando o século XIX e apesar do monopólio da Companhia de Gás, o primeiro prefeito da cidade, Antonio da Silva Prado concedeu licença à Light and Power Co., empresa canadense, para a construção de uma linha aérea em substituição ao antigo sistema, introduzindo a iluminação e os bondes elétricos para algumas áreas da cidade, cuja força motora a ser utilizada, a das cachoeiras do rio Tietê, deu origem à usina da Vila do Parnaíba, vultuosa obra para a época, inaugurada em setembro de $1901^{324}$.

As primeiras linhas de bonde inauguradas na cidade, em maio de 1900, iam para a Barra Funda, para o Bom Retiro e para a Vila Buarque e se utilizavam dos terminais de energia, antes do término da obra da usina. É, porém, anterior a essa data, o aparecimento dos cocheros nos LRC, surgidos a partir de 1893, indicativo da possibilidade de esses indivíduos terem acompanhado o momento da passagem para o bonde elétrico. Apesar disso, não se pode descartar a hipótese de estarem referidos ao serviço pessoal das famílias endinheiradas, contudo, se como um expressivo número de trabalhadores domésticos, procuravam morar no emprego, neste caso, o local mencionado do domicílio, em sua quase maioria logradouros do bairro do Brás e da Moóca, reduz essa possibilidade. Esses cocheros eram, como os tratadores de caballos que aparecem desde 1894 - atividade provavelmente relacionada aos animais que puxavam os bondes ou, eventualmente, ao Hipódromo de São Paulo - ofício exercido em sua maioria por naturais da Galícia, homens solteiros, jovens e que se apresentavam ao CGE sem documentos $^{325}$. Para a primeira década examinada, verificamos o aparecimento de "conductores",326, categoria que passou a ser utilizada indiscriminadamente ao lado de cocheros.

Os veículos de tração animal, os "bondes de burros", importados dos Estados Unidos ou fabricados pela Casa Rodovalho eram puxados por dois ou mais burros, correndo por trilhos de ferro de bitola estreita. Circulavam na cidade desde 1872, tendo alcançado o bairro do Brás, até a Estação do Norte, já em 1877. Moóca, Campos Elíseos, Santa Cecília, Consolação e Liberdade num primeiro momento, logo depois Bom Retiro, Bela Vista e Avenida Paulista, essas linhas vão atingindo bairros mais distantes, como o Ipiranga, Vila Mariana e Santana,

${ }^{323}$ EDE 02.02 e 20.08.1920

${ }^{324}$ Ver detalhes da implantação da Usina Geradora da Parnaíba, hoje Edgard de Souza, cf. Klintowitz, J. Op. cit., 1988, pp. 30 e ss.

${ }^{325}$ Relatório Access 18.

${ }^{326}$ Relatório Access 41. 
chegando a conduzir, no ano de 1894, dezessete milhões de passageiros. O preço da passagem, inicialmente cobrada pela extensão do percurso, acaba sendo unificada para 200 réis, considerado caro para a época. Esses carros já exibiam marcada distinção da escala social: nos bondes de 200 réis só entrava "quem estivesse bem vestido", enquanto que nos carros bagageiros (que faziam a circulação dos correios, bagagens, pacotes, encomendas, etc.) misturavam-se ao transporte de cargas, passageiros que pagavam apenas 100 réis pela passagem e podiam ingressar nele descalços. Ainda assim, cidadãos mais "graduados" preferiam o tílburis, "carros de dois assentos, com capota, duas rodas e puxados por um só animal". Em 1913 um fabricante espanhol, a empresa J.Garcia \& Cia. fabricava em sua oficina na Rua da Cantareira, 56, “carruagens y coches al estilo español o brasileño”, oferecendo-se também para a "fabricación especial de trolys" 327 .

Outros serviços de transportes coletivos eram realizados pelos trens a vapor que iam para Santo Amaro e para a Cantareira, com composições de quatro a seis vagões, com dois carros de passageiros e outros para carga. A Light inicialmente mantêm algumas linhas de bonde de burro, após encampar a empresa concessionária, substituindo-os paulatinamente, até 1913, inclusive aos trenzinhos de Santo Amaro.

A partir de 1909, aparecem os "bonde para operários", com tabuleta indicativa, os chamados "cara-duras", em sua maioria carros-reboque, onde se podia viajar descalço e cujas linhas foram se espalhando por toda a cidade ${ }^{328}$

$\mathrm{Na}$ "canadense" como pejorativamente passou a ser denominada nas páginas diárias do EDE, a mão-de-obra espanhola era a terceira em importância numérica entre os estrangeiros. Conforme relata Herbert Klein ${ }^{329}$, em 1930 a companhia tinha em seus quadros 381 empregados espanhóis, representando $6 \%$ do total de 6.221 funcionários.

Muitos, extensos e tumultuados casos envolvendo a empresa foram objeto de cobertura pelo periódico, já a partir de 1913. Em comum, o mesmo tom de crítica à Companhia que recebeu, a partir de 1919, coluna exclusiva denominada, não por acaso, "Os horrores da Light". Relatos de acidentes eram comuns. Consta que faltava mão-de-obra especializada, daí a exigência da Prefeitura quanto à habilitação de motorneiro e condutor. Aos motorneiros aplicavam-se provas práticas sobre a "nomenclatura dos aparelhos dos carros e o meio de os

${ }^{327}$ EDE 04.10.1913. Trolys: pequeno carro descoberto, ou plataforma sobre rodas, que desliza sobre os trilhos nas ferrovias, movido a força humana.

${ }^{328}$ Informações obtidas em LEME, M. Op. cit., 1984, pp. 50 e ss.

329 KLEIN, Herbert. "Los inmigrantes españoles en Brasil". In: Revista Estudios Migratorios latinoamericanos. Buenos Aires: 10, n² 29, CEMLA, 1995, p. 94. 
manobrar, principalmente quanto a paradas, cruzamentos de ruas e velocidade a empregar, ${ }^{330}$. Os acidentes afugentavam a população, para quem a energia elétrica, praticamente desconhecida., e que supunham transmitida pelos trilhos, era passível de matar pessoas. Também a velocidade imprimida, em média $25 \mathrm{~km}$ por hora era assustadora, sendo comuns os descarrilamentos, sobretudo nas ladeiras. O motorneiro José Cabello, acompanhado do cobrador, Antonio Romero, ambos espanhóis, saía com seu veículo do Largo do Tesouro e, conforme afirmou, perdeu o freio, chocando-se violentamente com outro veículo, em consequiência do que os passageiros assustados foram saltando e muitos se feriram. Dias depois, o motorneiro, que lamentou o ocorrido atribuindo-o ao "estado de má conservação dos transvias" visitava o EDE, agradecido pela defesa que o diário lhe fizera, atribuindo à Light toda a responsabilidade ${ }^{331}$. A seção "Horrores da Light" prosseguia notificando, desta feita, o falecimento na Santa Casa de Misericórdia, "por trituramento de um tranvia" do menor espanhol Avelino Martinez, de 16 anos $^{332}$. E não poupava a empresa, que acabara de comprar o Teatro São José (onde depois se instalaria), sugerindo que o que realmente deveria ser instalado ali era um hospital para socorro às vítimas dos acidentes provocados pelos tranvias ${ }^{333}$.

Sem trégua, seguia o periódico desfiando pormenorizadamente contra a "canadense" uma série de reclamações: contra atrasos ${ }^{334} \mathrm{e}$ "paradas inesperadas, provocados pela admissão de motoristas e condutores sem capacitação e prática"335, ou reclamando de que no inverno a companhia deveria utilizar "coche com cortinas para proteção do frio",336, etc. etc.

São matérias, algumas em formato de editorial, na primeira página, extensas e detalhadas, caso da ocorrência que envolveu o "carro para operários"- assim equivocadamente denominado; conforme o jornal, deveria chamar-se "carro para porcos" -, aguardado às 6:30h da manhã na rua 25 de março por grande número de mulheres, jovens e "muchachos", operários das fábricas do Ipiranga, cujo atraso impediu que conseguissem ingressar no trabalho, perdendo o dia ${ }^{337}$. Em outra ocasião, logo depois ${ }^{338}$ e novamente reclamando dos atrasos, disparava:

${ }^{330}$ LEME, M. Op. cit., 1984, pp. 69-70.

${ }^{331}$ EDE 12 e 15.05.1913. Saíam do Largo do Tesouro as linhas que iam para a zona leste. Depois de vencida a várzea do Carmo, as que iam para o Brás e Belém seguiam pela Rua do Gasômetro e as que iam para a Moóca seguiam pela Rua da Moóca até chegarem ao Hipódromo. Cf. PENTEADO, J. Op. cit., 1962, p. 293.

${ }^{332}$ EDE 15.03.1920. Trad. da autora.

${ }^{333}$ EDE 26.07.1920.

${ }^{334}$ EDE 06.11.1919.

${ }^{335}$ EDE 12.11.1919. Trad. da autora.

${ }^{336}$ EDE 16.06.1920. Trad. da autora.

${ }^{337}$ EDE 15.01.1920.

${ }^{338}$ EDE 02.02.1920. Trad. da autora. 
Por fim, aparece um "Moóca", completamente cheio, até pelos estribos, de ambos os lados. Um cidadão pretendia ir à frente com o motorman; outro, dependurado atrás como os moleques. Impossível!

Paramos um carreteiro, daqueles que transportam frutas ao mercado e lhe oferecemos um "mata bicho" para que nos deixasse ir em seu veículo, que seguia a direção do tranvia, o que aceitou. Pagar 200 réis para ir ao estribo de um tranvia anti-higiênico, sujeito a quebrar as pernas ou a perder a vida e, ainda por cima, nem conseguir porque estão repletos? Não se poderia constituir outra empresa, rescindindo o privilégio da Light?

\section{Os machinistas e outras ocupaciones (Alto da Serra)}

Procedemos, no Capítulo I, ao exame de algumas regiões onde se declarou domiciliado o espanhol em São Paulo, pontos mais extremos da cidade, áreas periféricas e distantes de onde se concentrava o contingente majoritário, no bairro do Brás e arredores. Dentre os locais citados, o Alto da Serra, onde se desenhou progressivamente uma ativa colônia de espanhóis, naquela oportunidade apenas mencionado, será objeto de exame particularizado nesse Capítulo.

É fato insuspeito que a colônia espanhola radicada no Alto da Serra fora para lá atraída inicialmente pelas oportunidades de trabalho surgidas com a "Cia. Inglesa", assim mencionada nos registros do $\mathrm{CGE}^{339}$. Mesmo sem levar em conta as menções indicando apenas “empleado ferrocarril ${ }^{340}$, observamos um progressivo contingente de pessoas ali residindo desde 1894, muitas das quais o cruzamento dos dados revelou estarem constituídas em famílias: eram os Alvarez Martinez, os Bouzas Cortizo, os Cadavid Tato, os Hurtado Cano, os Lorenzo Pereira, a numerosa família Martinez Fernandez, os Presa Blanco, os Rodriguez Varela, os Vazquez e tantos outros mais. Alguns se declaravam machinistas, outros jornaleros, havia também os canteros e os albañiles $^{341}$, e havia os que, após uma bem sucedida carreira profissional, faleciam no local, indicando tratar-se de um antigo núcleo de concentração de espanhóis. Sobre a "figura de respeito" de D. Eusébio Torres, falecido em 1920, lastimavam-se os conterrâneos, esclarecendo que ele pertencia a uma "família de brilhante posição", tendo exercido durante anos a função de "ajudante de obras de engenharia", antes de ser promovido a "responsável pela guarda e distribuição dos instrumentos de trabalho" na Cia. Inglesa ${ }^{342}$.

Desse modo, se o embrião inicial havia sido a "Inglesa", outros interesses foram progressivamente sendo carreados, constituindo-se um núcleo diversificado, onde não faltavam

${ }^{339}$ Relatório Access 30.

340 A partir de 1906, alguns registros apresentam-se com essa indicação, ainda que não haja como comprovar concretamente se esses casos estão referidos à "Inglesa".

${ }^{341}$ Relatórios Access 30 e 40.

${ }^{342}$ EDE 16.11.1920. Trad. da autora. 
pequenos negócios - bares, quitandas, vendas -, cuja oferta de mão-de-obra circulava com regularidade no EDE: "Se necesita cocinero para Alto da Serra. Se recomenda procurar a D. Joaquin Novo, naquele local"343.

O Alto da Serra era também objeto de menção especial, quando para ali se deslocava algum visitante que, de passagem por São Paulo, não deixava de rever os "antigos amigos" lá radicados, caso de D. Ramón Tomé, em $1912^{344}$.

No entanto, e esse dado foi imediatamente percebido, tratavam-se de indivíduos quase que exclusivamente naturais da Região da Galícia, e, nela, especialmente da cidade de Pontevedra, observação esta que, sugerindo clara especialização, poderia remeter ao estudo de uma tipologia migratória a partir de uma perspectiva regional, iniciativa tentadora, mas que excederia nossos atuais propósitos ${ }^{345}$.

De qualquer modo, apenas gostaríamos de salientar a esse respeito o notável trabalho de Francisco Foot Hardman pelo qual o autor demonstra que, dentre os operários estrangeiros que trabalharam na Estrada de Ferro Madeira-Mamoré, subsidiária da Brazil Railway Co., conglomerado que controlaria acionariamente numerosas estradas de ferro no Brasil, algumas delas no Estado de São Paulo, o espanhol é o que aparece com o maior número de óbitos na estatística do Serviço Sanitário da Companhia, no período entre 1907 e $1912^{346}$ dentre as 50 nacionalidades de que se compunha o contingente ali trabalhando.

Lembremo-nos oportunamente a intensa movimentação de canteros oriundos de Pontevedra que, de passagem pelo CGE, se deslocavam para Belém nos últimos anos do Novecentos $^{347}$ e parece que os cacos desse mosaico começam a tomar forma. Na ferrovia de Cuba concluída em 1907, informa o autor, foram empregados quatro mil galegos, alguns dos quais depois embarcariam para Porto Velho, engrossando o batalhão dos desvalidos. Porém, o mais surpreendente, na apreciação do livro, foi a descoberta do imigrante espanhol Benigno Cortizo Bouzas, autor de um depoimento narrando "cenas do inferno em movimento", a grande aventura de sua experiência na ferrovia ${ }^{348}$, cujo sobrenome coincide com o de muitos espanhóis então residentes em Alto da Serra.

\footnotetext{
${ }^{343}$ EDE 20.03.1912.

${ }^{344}$ EDE 08.01.1912.

${ }^{345}$ Para um primeiro contato com a questão, ver: VAZQUEZ GONZALEZ, Alejandro. "Las dimensiones microsociales de la emigración gallega a America: la función de las redes sociales informales". In: Estudios migratorios latinoamericanos. Buenos Aires: Ano 7, no 22, 1993, pp. 497-533.

${ }^{346}$ HARDMAN, Francisco Foot. Trem fantasma: a modernidade na selva. São Paulo: Cia. das Letras, 1991, p. 142.

${ }^{347}$ LRC 1984 e ss.

${ }^{348}$ HARDMAN, F. Op. cit., pp. 158 e 165.
} 
A colônia mantinha no local um grupo teatral constituído por funcionários da São Paulo Railway, o Lyra da Serra, cujos espetáculos eram divulgados regularmente no $\operatorname{EDE}^{349}$ e cujo presidente, Higino Presas ${ }^{350}$, também galego de Pontevedra, era antigo funcionário ${ }^{351}$. As peças encenadas, como a ocorrida por ocasião da festa de instalação de um "palco cênico" quando houve a "apresentação do drama nacional em três atos Flora", ao que tudo indica, de cunho satírico, configuravam "crítica aos brasileiros com título acadêmico e que aspiravam a ser eleitos senadores e deputados" ${ }^{, 352}$. Como era habitual, aos espetáculos teatrais seguia-se um baile ${ }^{353}$.

Pequenos incidentes ocorridos na comunidade também recebiam cobertura do EDE. Jesus Martinez, por razões não mencionadas, havia sido detido pelo subdelegado e consta que, quando solto, saiu ameaçando a todos do local, insultando sua mulher, disparando as maiores barbaridades contra a colônia espanhola, o EDE e o cônsul ${ }^{354}$.

Alguns empregados da "Inglesa" ali permaneciam até a aposentadoria, quando então, juntavam as economias de uma vida e iam de visita à Espanha. Eram casos narrados pelo EDE que, dessa feita, ano de 1920, referia-se a Manuel Agracio "durante 31 anos ativo empregado da São Paulo Railway" ${ }^{, 35}$, indicando que o afluxo de espanhóis àquele local era anterior à data da criação do próprio CGE e, portanto, de seus registros.

${ }^{349}$ EDE 29.08.1912; EDE 25.06.1914.

${ }^{350}$ Pertencia à Família Presa Blanco, de Pontevedra, tendo-se inscrito no CGE em 1915, então com 37 anos de idade. Declarou-se jornalero.

${ }^{351}$ EDE 20.08.1913.

${ }^{352}$ EDE 03.07.1913.

${ }^{353}$ EDE 25.06.1914.

${ }_{354}^{354}$ EDE 11.02 .1913 .

${ }^{355}$ EDE 19.05.1920. Trad. da autora. 


\section{O espanhol profissional liberal}

De España, de la República Argentina y de otras partes llegaron al Brasil centenares de compatriotas que, no encontrando la colocación para que se creían aptos sobretodo maestros, tenedores de libros y dependientes de comercio, pues carecían de algunas condiciones elementales como el conocimiento del idioma portugués, para poder desempeñar el cargo acudieron a nosotros en solicitud de recomendaciones o de socorros que, si en algunos casos fueron eficaces, en otros no llegaron a mejorar la situación de aquellos desgraciados ${ }^{356}$.

É intrínseca a relação entre a industrialização e a expansão do aparelho urbano de serviços, processo ao qual o setor terciário, compondo inúmeros domínios de atividades foi progressivamente se adaptando, face às crescentes demandas decorrentes do vertiginoso processo de metropolitização da cidade.

Para Décio Saenz, que buscou caracterizar o percurso político da "classe média" brasileira, "personagem fugaz" e cujo exame está ainda por ser levado a efeito, tal tendência poderia ser confirmada através da análise da evolução de categorias como as que compõem, dentre outras, a dos "serviços de consumo individual”, aí incluídos os profissionais liberais ${ }^{357}$, esclarecendo contudo que, até 1920, apenas 1,8\% da população economicamente ativa vivia das profissões liberais $^{358}$.

No caso de São Paulo, especificamente, onde os traços fisionômicos da urbanidade se acentuaram, acelerando-se com a passagem do século XX, período que coincide com o ingresso maciço dos estrangeiros, tais elementos passaram a compor uma camada "diferenciada" ainda que inexpressiva numericamente, cujas relações com os setores burocráticos e a aristocracia dominante local poderiam ser definidas no mínimo como problemáticas e de cujo processo político, os setores médios urbanos, grandes antagonistas da política oligárquica e incapazes de romper com o "círculo de ferro" por ela determinado, permaneceriam marginalizados ${ }^{359}$.

Não bastasse isso, poderíamos ressaltar, no caso do espanhol, de que se tratava de um agregado de indivíduos de frações divididas, portanto, sem unidade interna e que com

${ }^{356}$ EDE 14.05.1913.

${ }^{357}$ SAES, D. Op. cit., 1984., p. 6.

$35870,1 \%$ da população viviam das atividades agrícolas e extrativas e 12,9\% trabalhavam no setor industrial. Recenseamento do Brasil, 1920. Apud: SAES, D. Op. cit., 1984, p. 5.

${ }^{359}$ A esse respeito, ver especialmente: SAES, D. Op. cit., 1973, pp. 7 e ss. 
dificuldade e nem sempre de forma espontânea, logravam manter algumas agendas comuns, em parte dirigidas à grande massa miserável que os cercava.

Perfilavam socialmente ao lado de figuras que iam se salientando, especialmente no comércio, mas também na pequena indústria, personagens com crescente prestígio na colônia e muitas vezes até no conjunto da população de São Paulo, minoria de indivíduos cujo gosto ia se refinando e cujos hábitos passariam a se identificar com as elites grã-finas da Paulicéia, compondo, portanto, esse cenário socialmente mais elitizado da cidade.

Representativa dessa camada, despontava um segmento constituindo atividades e profissões técnicas e/ou intelectuais desenvolvidas "por conta", que se poderia chamar de "liberal" localizado, no caso dos espanhóis, precocemente na cidade, o qual teria se antecipado às grandes levas de indivíduos que passariam a ocupar os setores subalternos da economia aderindo, muitas vezes, a formas precárias de acomodação no corpo a corpo pela sobrevivência. É, pois, com as primeiras décadas do Novecentos, no turbilhão crescente da cidade, que pudemos focalizar mais concretamente a sua presença na cidade, ainda assim, conforme atesta Décio Saenz, bastante reduzida.

Era o caso de Demétrio Justo Seabra, advogado de 27 anos que, embora tenha se declarado natural de Orense (Galícia) na inscrição efetuada no CGE em 1912, admitiu viver na cidade há $25 \operatorname{anos}^{360}$. Em outras palavras, sua família, com quem viera com apenas dois anos, estabelecera-se na cidade em 1887, antecipando-se, portanto, às grandes levas e momento em que São Paulo franqueava generosamente boas oportunidades de favorecimento profissional.

Supomos que o Dr. Seabra tenha cursado a Faculdade de Direito do Largo de São Francisco e, bem postado financeiramente, em 1912 já possuía seu próprio escritório de advocacia, localizado na Rua Conselheiro Furtado, 07, que recebia as credenciais do EDE "recomendamos ese compatriota à la colonia española. Acepta causas civiles y criminales"361. Como tantos outros indivíduos pertencentes às camadas sociais mais favorecidas, o Dr. Demétrio Seabra era membro ativo das sociedades e agremiações da colônia, especialmente do $\mathrm{CE}$, em cujas comemorações comparecia, por vezes como orador oficial, quando habilmente se dizia "em nome das sociedades que representam a colônia". Tato era necessário nessas ocasiões, especialmente quando se celebrava o "Dia da Raça”, com programação presidida pelo Cônsul Geral da Espanha ${ }^{362}$.

\footnotetext{
${ }^{360}$ LRC 1912.

${ }^{361}$ EDE 12.06.1912.

${ }^{362}$ EDE 04.10.1920. Sobre o "Dia da Raça” ver Capítulo IV.
} 
Pouco depois de a família do Dr. Seabra chegar à cidade por volta do ano 1885, ali encontramos estabelecidos mais dois advogados: os Drs. Miguel Clemente Perez, de Cádiz, com 31 anos e o Dr. Gumercindo Iglesias, de 35, natural de Salamanca, com escritório na Rua Conselheiro Nébias, $70^{363}$. Nas redondezas da Praça João Mendes, à Rua 11 de agosto, 2 (sobrado), vizinhos portanto do Dr. Seabra, ficava o Escritório de Advocacia dos Drs. Gastão Madeira y Juvenal do Amaral ${ }^{364}$ e na Rua São Bento, área central e valorizada da cidade, havia mais dois escritórios estabelecidos também na primeira década. No nº 14, o do Dr. Alexandre Marcondes Filho, sobre o qual informava o EDE: "Os espanhóis que careçam de recursos e tenham algum assunto judicial pendente podem solicitar os serviços do referido advogado na redação" ${ }^{\text {365; }}$; e no sobrado n 57 , estavam estabelecidos os Drs. F.H. Ferreira Brandão Filho; J. Ribas de Ávila e B. Jorge Flaquer ${ }^{366}$.

No Palacete Brícola, piso $1^{\circ}$, 12, na Praça Antonio Prado advogava o Dr. J. S. Neves Mauta, localizado nos inícios da segunda década, que ali mantinha "una sección especial" para aquele "súbdito español, [que] desea naturalizarse ciudadano brasileño"367. Longe desse circuito central, numa das localidades periféricas para onde se alastrava a Paulicéia, no bairro de Pirituba, atuava em 1920 o Dr. Antonio Aguirre de La Torre, advogado madrileno de 30 $\operatorname{anos}^{368}$, provável aparentado de D. Manolita de La Torre, esposa do abastado comerciante Raimundo Diez.

Outros profissionais liberais apresentaram-se na cidade antes da passagem do século XX, conforme atestam os registros do CGE. O engenheiro Antonio Cano Santayana, de 29 anos, nascido em Málaga, apresentou-se ao CGE em 1893, declarando-se domiciliado na rua Cel. Mursa, $8^{369}$. Pertencia à Família Cano que, em 1918, teria um representante na FE, Enrique Cano, secretário geral. Em 1905, registrou-se no CGE o Engenheiro Rafael Serna Marin, de Málaga, com $38 \operatorname{anos}^{370}$. A partir do final da primeira década e início da década seguinte, contudo, todas as menções a essa categoria que encontramos se referem ao Escritório Técnico de Engenharia cujo diretor era Héctor Eiras Garcia, filho do proprietário do EDE.

\footnotetext{
${ }^{363}$ LRC 1893 e 1894.

${ }^{364}$ EDE 05.04.1913.

${ }^{365}$ EDE 27.07.1914. Trad. da autora.

${ }^{366}$ EDE 19.09.1913.

${ }^{367}$ EDE 24.03.1922.

${ }^{368}$ LRC 1920.

${ }^{369}$ LRC 1893.

${ }^{370}$ Relatório Access 42.
} 
O primeiro registro no CGE de um inscrito declarando-se "médico" ocorreu apenas em $1917^{371}$. Tratava-se de José Sanchez Gonzalez, de Almería, 39 anos, com "diploma do Ministerio de Instrucción Pública" e que realizava na ocasião uma doação de $20 \$ 000$ para a Beneficéncia Espanhola (BE). Pouco antes, em 1913, contudo, o formando Cesáreo Romero Henares, de Bauru, era festejado nas páginas do EDE, com a notícia de sua formatura em Medicina pela Universidade de São Paulo.

Paulatinamente, a cidade vai assimilando outros profissionais da categoria, alguns até chegando a adquirir certa proeminência, caso do Dr. José de Asprer, formado em Sevilha, “operador e parteiro" e "médico do Consulado", que atendia, em 1912, no Bairro do Brás, à Travessa do Brás, 29 - telefone $1026^{372}$, cuja projeção alçou-o ao posto de vice-cônsul ${ }^{373}$. Era também um dos médicos "oficiais" contratados para o atendimento às pessoas carentes e aos associados, em sociedades beneficentes, caso da $\mathrm{LDE}^{374}$, além de participar ativamente do CE, especialmente nas "Festas de Caridade", que ocorriam no último domingo de cada mês em seus salões, em benefício da Caixa de Socorros, de cuja Comissão Organizadora participava sua esposa, Luisa Castro de Asprer ${ }^{375}$. Observamos que comparecia com assiduidade às listas de contribuições e doações encabeçadas pelo CE, algumas delas endereçadas aos familiares ou sobreviventes da Guerra do Marrocos ${ }^{376}$. Como o Dr. Asprer, outros médicos tinham a mesma função, a do atendimento aos associados das entidades beneficentes: o Dr. Custódio Guimarães “operador e parteiro” era médico da BE ${ }^{377}$ e o Dr. Juan Francisco Recalde, médico adjunto do Hospital do Brás e especialista em "enfermidades internas de senhoras e cirurgia", atendia aos sócios da $\mathrm{SESM}^{378}$.

Os médicos estabelecidos nesse período encarregavam-se em geral de várias enfermidades. O Dr. J. Dominguez Lopes, além de ser "parteiro", atendia os casos de "moléstias de crianças e sifilíticos"379, como também o Dr. Duarte Miranda que além de "operador" e de tratar de "enfermidades de senhoras e crianças" clinicava para pacientes com

${ }^{371}$ Relatório Access 43.

${ }^{372}$ EDE 08.01.1912. Possuir uma linha telefônica era sinal de prestígio numa cidade que, entre 1884 e 1915, tinha apenas 5.901 assinantes.

${ }^{373}$ EDE 15.07.1914.

${ }^{374}$ EDE 28.11.1913. Consta ter sido depois substituído pelo Dr. Benjamin Rubbo, com consultório na Avenida Rangel Pestana. EDE 01.08.1914

${ }^{375}$ EDE 08.08.1920.

${ }^{376}$ EDE 27.10.1921.

${ }^{377}$ EDE 05.08.1918. Residia na Avenida Angélica, 143 e seu consultório situava-se no Largo do Tesouro, 5 sala 6.

${ }^{378}$ Com residência à Rua Vergueiro, 20 (atendimento das 7 às 11h) e consultório à Rua João Brícola, 19 (das 15 às 18h). EDE 21 e 28.02.1922. Como se observa, o horário de atendimento respeita o período após o almoço, conhecido como siesta, e tradicional na Espanha.

${ }^{379}$ EDE 24.08.1912. 
problemas de "sífilis, pele, rins e bexiga ${ }^{380}$. Dentre os especialistas, o Dr. Pedro Pontual "olhos, nariz, garganta" -, atendia desde 1913 na Rua Barão de Paranapiacaba, 10 (caixa d’água), com preços reduzidos para a "clase obrera"381.

Dentre os profissionais liberais da área da saúde, havia os veterinários, que em 1904 eram representados pelo Dr. Pedro Pont Caseres, de Lérida, com $48 \operatorname{anos}^{382}$. Outros mais foram localizados, como o Dr. Emilio Cruz "especialista em moléstias de cavalo, muares e cães", atendendo à Rua Santa Efigênia, $57^{383}$ e o Dr. Juan Antonio Porto "membro da junta diretiva da Sociedade Espanhola" comunicando aos clientes seu afastamento em "viagem de férias" 384.

Farmacêuticos, como Eduardo Garcia Llorente de Valadolid, foram localizados na última década do Novecentos ${ }^{385}$, porém o aumento dessa atividade só ocorrerá aliado a diversos fatores, como os progressos da indústria química e o próprio comportamento da população, que passou a ver com menos resistência o uso de drogas químicas com indicação médica. De todo modo, nas farmácias e boticas podiam ser encontradas toda sorte de medicamentos, ervas, emplastros e purgantes. No EDE, em grandes anúncios, eram comuns as "novidades" veiculadas, os "preparados" e as "fórmulas", aos quais se seguiam os depoimentos de médicos atestando as vantagens do produto divulgado ${ }^{386}$.

A profissão ganhará espaço com a criação da Faculdade de Farmácia que passou a formar quadros também oriundos dos descendentes da população imigrante. $\mathrm{O}$ "licenciado em farmácia” Francisco Perez, é um desses exemplos, mantendo com regularidade seus anúncios no EDE, a partir de 1918. Ele possuía dois estabelecimentos próximos, no prestigiado triângulo $^{387}$, denotando tratar-se de expoente da camada abastada da colônia. Estava, além disso, equipado com "magnífico laboratório, montado com todos os aparelhos para toda e

${ }^{380}$ EDE 04.08.1913.

${ }^{381}$ EDE 18.01.1913.

${ }^{382}$ Relatório Access 44.

${ }^{383}$ EDE 16.08.1918.

${ }^{384}$ EDE 07.04.1913.

${ }^{385}$ Relatório Access 45.

${ }^{386}$ O campeão dos anúncios foi o "Peitoral de Angico Pelotense", remédio para constipações, bronquites e resfriados, com fórmula desenvolvida pelo Dr. Domingos da Silva Pinto, preparado na Drogaria do farmacêutico Eduardo Sequeira, em Pelotas, RS e comercializado em várias drogarias de São Paulo e Santos. EDE 16.04.1918 e outros. Também o "Lactífero", produto para favorecer a produção do leite materno, "precioso descobrimento da farmacêutica Joanna Stamato Bergamo" era vendido na Farmácia de sua propriedade, na Rua Conselheiro Furtado, 111. O "Elixir de Nogueira", "o único que cura a sífilis", era presença constante dentre os anunciantes do ramo. EDE 07.08.1913 e outros.

${ }^{387}$ Rua São Bento, 97-A e Largo de São Bento, 1. 
qualquer manipulação,388. Localizamos, no período, um "praticante de farmácia”, um atendente de balcão, Facundo Gonzaga Velasco, de Salamanca, com 23 anos $^{389}$.

Com relação aos dentistas, os vestígios foram inexpressivos e tardios, considerando-se as demais categorias anteriormente mencionadas, provavelmente porque a Faculdade de Odontologia tenha sido criada apenas em 1934, inicialmente agregada à de Farmácia (até 1962). Desse modo, o primeiro dentista a se inscrever no CGE sequer residia na cidade de São Paulo, mas em Campinas ${ }^{390}$. De um profissional instalado na cidade, o primeiro registro é apenas do ano de 1914: tratava-se de Eduardo Garcia Martin, de 64 anos, natural de Tenerife, nas Ilhas Canárias, residindo com sua família na Rua Maria Teresa, $10^{391}$. Somente nesta segunda década é que se dá o aparecimento dos poucos anúncios publicitários de dentistas na cidade, e não sem razão, em maioria não pertencentes à colônia ${ }^{392}$.

O mercado das profissões "liberais", no entanto, exibia uma outra sorte de categorias desvinculadas das atividades de nível superior, como as tradicionais advocacia, medicina, odontologia, engenharia e farmácia; eram atividades técnicas e intelectuais, algumas estreando na cidade e com participação variável.

No primeiro caso, temos os fotógrafos ${ }^{393}$, categoria expressiva nos LRC já nos primeiros anos consultados, cujos estúdios funcionavam em suas próprias residências. Em 1894, Cristóbal Garcia Uladell e Antonio Garcia Vierna, pai e filho, naturais de Jaén (Andaluzia) inscreviam-se no CGE como "fotógrafos", declarando-se domiciliados na Rua Caetano Pinto, $14^{394}$. A eles, seguiu-se uma série de profissionais assim declarados, também, em sua maior parte, da Andaluzia, como os irmãos José e Cristóbal Cortez Fernandez, de Granada, com 33 e 27 anos que, em 1915, tinham seu atelier no Largo Coração de Jesus, $40^{395}$. Juan Melero Retes, de Cádiz, com 41 anos, em 1914 era o proprietário do Atelier Fotográfico Español, à Rua Benjamin de Oliveira, $118^{396}$. Profissional elogiado pelo EDE, segundo o qual

${ }^{388}$ EDE 04.01.1918. Havia ainda as farmácias de Baldomero Leal Muñoz, de Málaga, à Rua Bonita, 55 (LRC 1912) e a Farmácia Guarany, de Francisco Alvarez, na Rua dos Gusmões, 6 (EDE 18.09.1919). Trad. da autora.

${ }^{389}$ LRC 1921.

${ }^{390}$ Juan Estevez, de Pontevedra, com 38 anos. LRC 1894.

${ }^{391}$ LRC 1914.

392 Dr. Álvaro de Moraes “dentista formado pela Faculdade Medicina do Rio de Janeiro”. Rua Boa Vista, 20 (EDE 29.07.1913) e Mme. Elisabeth Mehlmann Allende "cirurgiã dentista formada em 1902, especializada em dentes a pivot e dentaduras". Rua Direita, 52 - 2 (EDE 18.05.1918). É provável que a Dra. Allende fosse casada com um espanhol, porém não foi possível identificar. O único sobrenome "Allende" que apareceu nos LRC referiase a Federico Allende Sanchez, comerciante, natural de Cádiz, residindo há dois anos na cidade e com domicílio na Rua S. Efigênia, 96 (LRC 1894).

${ }^{393}$ Relatório Access 46.

${ }^{394}$ LRC 1894.

${ }^{395}$ LRC 1915.

${ }^{396}$ LRC 1914. 
trabalharia no sistema “American System Home Portrait, aparelho moderníssimo", lamentava, porém, aquele periódico o fato de seu atelier não estar localizado em ponto mais central e ser mais luxuoso ${ }^{397}$, razão pela qual seu atendimento "para retratos" passou a ser feito a domicilio, na residência do cliente ${ }^{398}$. Em seguida, faria uma sociedade com outro indivíduo (Melero \& Chans) e trocaria o nome fantasia de seu estabelecimento para Fotografia Victoria ${ }^{399}$.

A análise da planilha de dados cumulativos sugeriu pequena incidência de fotógrafos com registro anterior de jornaleros, caso de Manuel Sanchez Matas, de Córdoba, inicialmente residindo em Ribeirão Preto (1914) e depois aparecendo como fotógrafo, já então domiciliado na Rua Caetano Pinto, 53.

No início da terceira década, algumas matérias do EDE começaram a ser ilustradas com imagens ou fotografias. Numa dessas ocasiões, quando da comemoração do "Dois de Maio" o periódico, que cobria o evento, publicou matéria ilustrada com o título "Flores da colônia", estampando a fotografia de "diversas damas da sociedade espanhola local e de Santos", algumas ao piano, outras com leque nas mãos e mantilha na cabeça ${ }^{400}$.

Revendo esses segmentos, parece apropriado ressaltar uma categoria que deve ter enfrentado crescentes dificuldades no período, a dos professores. A primeira iniciativa para a criação de uma escola (noturna) em língua espanhola, inicialmente orientada para os adultos analfabetos, partiu da FE, a cujo ato inaugural compareceram o cônsul e outras autoridades representando as demais entidades espanholas (SESM, BE, LDE) e o diretor do EDE, Eiras Garcia. Sugeria-se, na ocasião, que o cargo de professor fosse atribuído a Antonio Pérez Avilés $^{401}$, ao mesmo tempo em que formalizaram contribuições mensais para a execução e a manutenção do projeto: o EDE concorreria com 20\$000 e o CGE, com outros 50\$000. Isso ocorreu no ano de 1913 e não conseguimos saber se essa escola efetivamente existiu ${ }^{402}$. Poucos meses antes, também no ano de 1913, matéria no EDE informava da inauguração da Academia Española, uma espécie de curso preparatório para o ingresso nas Escolas "Politécnica, do Comércio, Normal, Farmácia e Odontologia"403, que funcionaria no Largo S. Efigênia, 12 -

${ }^{397}$ EDE 02.03.1914.

${ }^{398}$ EDE 09.03.1914.

${ }^{399}$ EDE 10.10.1914.

400 EDE 02.05.1922. Carmen Ares; Josefina Ares, ao piano; Deolinda Eiras Garcia; Encarnación Zambrana; Anita Morales; Iracema López Angulo; Dolores Zambrana; Marina Ares; Cândida Bobadilla, com um leque nas mãos e mantilha na cabeça; Paquito Morales e Leonor Ângulo. Trad. da autora.

${ }^{401}$ Não localizamos qualquer registro no CGE pertencente a esse indivíduo. Da família Perez Avilez, localizamos, em 1913: Arturo Perez Avilez, 32 anos, jornalero, natural de Almeria, residindo há seis meses na Rua Muniz de Souza, 16.

${ }^{402}$ EDE 31.10.1913.

${ }^{403}$ A Escola Politécnica estabelecera-se desde 1893 na Rua Três Rios; a Escola de Farmácia surge em 1904. Cf. LEME, M. Op. cit., 1984, p. 156. 
altos, sob a direção do Prof. D. M. Martinez. De seu programa constavam as seguintes disciplinas: "Português, Francês, Espanhol e Alemão; Geografia, História, Aritmética, Contabilidade, Geometria, Álgebra e Trigonometria" e suas aulas noturnas eram "especiais para empregados, funcionários do comércio e artistas" ${ }^{404}$.

Como no caso da escola anterior, também neste não obtivemos qualquer indicação de seu funcionamento posterior. Contudo, em maio do ano seguinte, 1914, publicava-se um edital "para concurso de professor espanhol de instrução primária para a escola diurna" da FE, cuja remuneração seria de $1 \$ 500$ por aluno até o limite de $100 \$ 000$ mensais. Em caso de mais de um pretendente, alertava o edital, "haverá exame diante de um tribunal formado por prestigiosos membros da colônia` ${ }^{, 405}$. Anteriormente, em abril de 1913, em missiva endereçada a Madrid, o cônsul anunciava a "criação de uma cátedra de língua castelhana" na Escola de Comércio [Álvares Penteado], para a qual se pedia a indicação de um professor ${ }^{406}$.

Pretendentes com certeza não faltaram: em 1911 registrava-se o primeiro professor “normal" no CGE, Augusto Aparício Casanova, de 31 anos, casado e natural de Zaragoza ${ }^{407}$, ao qual se seguiram outros mais, em $1912^{408}$ e $1913^{409}$, antes portanto da iniciativa da primeira escola espanhola na cidade. Neste mesmo período localizamos no EDE anúncios de oferta de professores, um deles "recém-chegado" e o outro que se oferecia "tanto para a capital como para o interior", evidência da dificuldade encontrada pela categoria no escasso mercado de trabalho da cidade ${ }^{410}$. Tentando driblar as dificuldades, José Domingue Gimenez, de Huelva (Andaluzia), com 44 anos, há três residindo na cidade com sua mulher, na Rua Caetano Pinto, 153, passara a dar aulas a domicílio, registrando-se no CGE, em 1914, muito sugestivamente, como "maestro casetero" "411. Contudo, professores de disciplinas específicas também foram encontrados: havia professores de latim, cujos registros localizamos em $1912^{412}$; um professor

${ }^{404}$ EDE 09.08.1913. Trad. da autora.

${ }^{405}$ EDE 05.05.1914. Trad. da autora.

406 AMAE. H-2048. Série Brasil. Correspondencia Embajadas y Legaciones. Memorando enviado pelo cônsul Juan Solórzano ao Ministro de Estado espanhol. Trad. da autora.

${ }^{407}$ Relatório Access 49.

${ }^{408}$ Relatório Access 49. Juan Prat de La Torre, de 28 anos, casado, natural de Jaén e residente na Rua Caetano Pinto, s/n e Julian Zamareño Robles, de Salamanca, 24 anos e casado.

${ }^{409}$ Relatório Access 49. Francisco Escola Romero, de Valencia, 43 anos também residente no Brás, Rua Maria Domitila, 86 e Emilio Rubio, casado, de 42 anos, com três filhos já nascidos na cidade e residente na Rua Mixta, 26.

${ }^{410}$ EDE 29.07.1913 e 18.02.1914. Nos livros consultados apareceriam mais tarde, em 1921 e 1922, os irmãos Orellan e Miguel Navarro y Arellano, de Málaga, 29 e 30 anos respectivamente, residentes no Brás, na Rua Carneiro Leão, 78-A. Trad. da autora.

${ }^{411}$ Relatório Access 49. A palavra casetero provavelmente tenha sido aportuguesada como derivativo de "casa".

412 Relatório Access 49. Marcelino Perez Araíz, de Burgos, com 49 anos, solteiro e Bernardino Sales Vilches, de Granada, com 63 anos. 
“mercantil”, das Ilhas Baleares, este registrado em $1910^{413}$, um professor de equitação ${ }^{414}$, além de professores de música ${ }^{415}$.

Hábito bastante arraigado e cultivado há décadas, a música, como parte do cotidiano das famílias bem postadas da Paulicéia, foi prática assimilada pelos congêneres espanhóis, em cujas festas, recepções e eventos mais importantes, cobertos pelo EDE, tornou-se imprescindível. Era a verdadeira "epidemia de piano" a que se refere Ernani da Silva Bruno ${ }^{416}$, de que se beneficiavam largamente os importadores, como a Casa José Lucchesi que oferecia "pianos, vários modelos importados", e tinha um anúncio específico para o "piano de cauda Steinweg, ${ }^{417}$.

Nas festas realizadas no Palacete de D. Perfecto Ares, abastado comerciante, não faltavam as apresentações musicais, das quais participava sua filha, Josefina Ares ${ }^{418}$ que, a propósito, receberia o título de "notável" por seu desempenho no Real Conservatório de Madrid, para onde se mudara, para aperfeiçoar seus estudos iniciados em São Paulo ${ }^{419}$. Ocasionalmente surgiam na cidade grupos musicais espanhóis que eram então recomendados para as festas familiares ou nas sociedades. Em 1912, foi a vez de um trio composto de gaita, clarinete e tamboril, vindo de Pontevedra ${ }^{420}$.

No período examinado, alguns músicos se registraram no $\mathrm{CGE}^{421}$, bem como um "violinista" em $1922^{422}$ e um "guitarrero", em $1920^{423}$. Este guitarrero, natural de Valencia, talvez tenha vindo a convite da Casa Universal, fábrica de instrumentos de corda (guitarras, bandolins, violas), situada na Rua Santa Efigênia, 89-A, que se orgulhava de importar da Espanha não apenas as cordas para a fabricação dos seus instrumentos, mas também os "operários especialmente contratados em Valencia",424.

${ }^{413}$ Relatório Access 49. Bernardo Obrador Billón, 29 anos, solteiro.

${ }^{414}$ Relatório Access 49. Eduardo Dias Roig, natural de Huelva, residente na Rua São José, 18.

${ }^{415}$ Relatório Access 49. Lázaro Rodriguez Losano, de Almería, com 50 anos, solteiro e Francisco Caracuel Gómez, com 46 anos e viúvo.

${ }_{416}$ BRUNO, E. Op. cit., 1991, p. 1301.

${ }^{417}$ EDE 01.08.1913.

${ }^{418}$ A programação que então se divulgava era, com pequenas alterações, mais ou menos assim: Oscar Pery, violinista e sua mãe Otília de Pery ao piano, acompanhados por Josefina, cantando: Gioconda, de Ponchielli; Schiavo, de João Gomes de Araújo (pianista presente à festa); Traviata e Cair das Folhas, de Verdi; Manon, de Puccini e Carmen, de Bizet. EDE 09.01.1918.

${ }^{419}$ EDE 28.07.1922. Matéria ilustrada com foto. Trad. da autora.

${ }^{420}$ EDE 22.10.1912.

${ }^{421}$ Em 1893, José Puga y Azevedo, madrilenho, solteiro, com 17 anos, residente na Rua Santa Efigênia, s/no e em 1906, Lutgardo Lopez del Toro, de Málaga, 44 anos.

${ }^{422}$ Antonio Vilches Mellado, natural de Málaga, 42 anos, solteiro, residia na Rua Martiniano de Carvalho, 80.

\footnotetext{
${ }^{423}$ Antonio Guzmán, valenciano de 25 anos, solteiro, residia na Rua Asdrúbal do Nascimento, 22.

${ }^{424}$ EDE 02.05.1922. Trad. da autora.
} 
Entre 1919 e 1920, a propósito, nasceriam no interior do Estado, filhos de espanhóis emigrados, os dois irmãos João Salvador e José Perez, que formariam a dupla caipira "Tonico e Tinoco",425.

A colônia manteve durante um certo período de tempo (não identificado) um Conservatório de Música, onde se realizavam festas em benefício dos fundos sociais ${ }^{426}$. Posteriormente, nos salões do Conservatório Dramático e Musical, na Rua do Gasômetro, 64, nas festas ou "funções dramático-dançantes" em benefício dos fundos sociais, era a professora de canto, Elena Parada, que se encarregava dos recitais, apresentando-se acompanhada por outros artistas. Artistas espanhóis eram especialmente convidados para abrilhantar essas ocasiões, exibindo-se em concertos instrumentais, como ocorreu a Josefina Robledo e Fernando Molina, em audição de guitarra e violoncelo ${ }^{427}$.

Tais eventos, inclusive o "baile de máscaras" eram programados pelas senhoras da "Caixa de Socorros" do CE ${ }^{428}$. A Romería, festa típica que se realizava no Parque São Jorge, também contava com diversas atrações musicais e bandas que percorriam a cidade abrindo a festa, algumas delas do Interior do Estado ${ }^{429}$.

Apesar de todo esse ambiente propício, muitos professores, especialmente os que chegavam, não conseguiam colocação para viver de seu ofício: "Jovem professor de piano e canto, chegado há pouco da Espanha, oferece-se para aulas particulares" ${ }^{\natural 30}$. Ou "professor de piano, guitarra e violão" ${ }^{, 431}$.

Dentre as mulheres, contudo, a Prof ${ }^{a}$ Lotito era imbatível: além de "professora superior de música, piano, canto, solfejo e teoria" ${ }^{432}$, era diretora do Externato Lotito, à Rua Prates, 40, com aulas diurnas e noturnas e "cursos preparatórios para ambos os sexos",433.

Outros profissionais com ocupações e ofícios mais especializados, decorrentes das novas e crescentes exigências operacionais e organizacionais das empresas, indústrias e escritórios que avultavam, também aportavam na Paulicéia, diferenciando-se. Para Heloisa de

425 João Pérez nasceu em São Manuel, em 1919 e José Pérez em Botucatu, em 1920. Em 1943 foram lançados no Programa "Arraial da Curva Torta", do Capitão Furtado. $C f$. MORAES, José Geraldo Vinci de. Metrópole em sinfonia - história, cultura e música popular em São Paulo nos anos 30. Tese de doutorado FFLCHUSP, 1997, p.218. O autor também se refere a outros dois descendentes de espanhóis: Raul Torres, p. 216 e Moacyr Braga, p. 263.

${ }^{426}$ EDE 26.06.1912.

${ }^{427}$ EDE 07.06.1919; EDE 15.01.1920 e EDE 16.06.1922. Trad. da autora.

${ }^{428}$ EDE 27.01.1920. Trad. da autora.

${ }^{429}$ EDE 13.08.1920. A respeito da Romería, ver Capítulo IV. Trad. da autora.

${ }^{430}$ EDE 19.08.1913. Residente à Rua Martin Buchard, 30. Trad. da autora.

${ }^{431}$ EDE 03.03.1919. Residente à Rua dos Gusmões, 75. Trad. da autora.

432 EDE 04.02.1918. Rua Martin Francisco, 17. Tomás Lotito, provavelmente seu marido, oferecia-se como "corretor, com boa apresentação", no mesmo endereço. EDE 30.08.1918. Corretor: encarregado de corrigir ou revisar textos. Trad. da autora.

${ }^{433}$ EDE 26.09.1919. Trad. da autora. 
Faria Cruz, era o "letramento" que chegava ao mercado de trabalho ${ }^{434}$ ampliando-o enormemente e orientando uma fatia desse mercado para os indivíduos com alguma escolaridade e preparo técnico. A habilidade específica, no entanto, determinava apenas uma das exigências, onde as "referências" eram igualmente importantes : "muchacha con perfecta ortografia española y sepa escribir a maquina o si no como aprendiza; será retribuída por lo que valga. Inútil si no hay inmejorables referencias, que se ofrecerán junto con circunstancias de la solicitante al correo. Caja Postal, 217”435. Os escribientes, como eram designados os escriturários ou funcionários de escritório dessas organizações estavam radicados na cidade desde $1894^{436}$ e havia uma outra série de profissionais que eram requisitados para essas ainda novas atividades estreantes na cidade: os encuadernadores, por exemplo que, como o próprio nome indica, eram os responsáveis inicialmente pela conservação e encadernação dos livros fiscais, incumbindo-se depois de pequenas restaurações, eram também requisitados nas tipografias, cujas inscrições apareceram no primeiro ano da abertura do CGE, em $1893^{437}$ e os tenedores de libros ou guarda-libros, atividade que representou um dos embriões dos atuais escritórios de contabilidade, cuja função envolvia a escrituração contábil e fiscal da empresa e que teve em Enrique Moreno Adron, de Madrid, residente na Rua Carneiro Leão, 01, seu primeiro representante, inscrito no ano de $1897^{438}$. Essa categoria surpreendentemente organizada, criaria o Clube de Guarda-Livros, local que sediou um "individual" de Pedro Alexandrino, no ano de $1896^{439}$. Era função exercida na empresa ou na residência, que porém não requeria um período integral de trabalho, podendo o interessado acumular outras tarefas correlatas, conforme indica a oferta de um candidato divulgada no EDE: "Disponiendo de algunas horas vagas se ofrece para llevar la contabilidad de negocios, almacenes y sociedades; asimismo se encarga de hacer cobranza mediante comisión; dá fianza; horas útiles, de 1 à 5”. Gutierrez, Rua Barra Funda, $106^{440}$. Era ofício adquirido também na prática cotidiana, como sugere o anúncio do candidato: "Jovem espanhol, possuindo os idiomas português e castelhano,

${ }^{434}$ CRUZ, Heloisa de Faria. Na cidade, sobre a cidade. Cultura letrada, periodismo e vida urbana. São Paulo, 1890/1915. Tese de doutoramento, FFLCH-USP, 1994, p. 67.

${ }^{435}$ EDE 02.03.1912.

${ }^{436}$ Relatório Access 42.

437 Relatório Access 47. Falaremos dessa categoria no Capítulo seguinte, juntamente com a dos "tipógrafos".

${ }^{438}$ Relatório Access 48. Foram apenas três os inscritos no CGE no período de 30 anos analisado: Em 1919, Manuel Gordillo Muñoz, de Cádiz, com 40 anos, residente na Rua dos Andradas, 41 e em 1922 Hilderico Ildefonso Rodriguez, de Pontevedra, com 22 anos, residente na Rua Barão de Limeira, 162.

${ }^{439}$ ROSSI, Mirian Silva. Organização do campo artístico paulistano, 1890-1920. São Paulo: Dissertação de mestrado FFLCH-USP, 2001, p. 64.

${ }^{440}$ EDE 30.01.1912. 
já havendo trabalhado nessa praça como ajudante de contador, deseja encontrar colocação em escritório ou casa comercial”"

A propósito, a cidade já dispunha de uma Escola de Comércio, a Álvares Penteado, fundada em 1902 - e é provável que lá lecionasse o professor "mercantil", natural das Ilhas Baleares, registrado no CGE em $1910{ }^{-442}$, porém a muitos convinha um curso por correspondência, também já oferecido na cidade, o que lhes permitia conciliar com o horário de trabalho: "comércio, mecanografia, taquigrafia e contabilidade" eram disciplinas em alta nas ofertas dos cursos à distância oferecidos pela International Correspondence Schools ${ }^{443}$.

E se multiplicavam as atividades correlatas: Evaristo Asina Cortabitarte, de Vizcaya, 38 anos, era fazedor de libros ${ }^{444}$ - curiosa atividade que talvez se relacionasse ao que Ernani da Silva Bruno identificou como fabricante de "livros em branco"445 -, enquanto Carlos Campos iniciava seu pequeno negócio de fabricação de "tintas para escrever com caneta tinteiro (pluma) ou à máquina, para escritórios, escolas, repartições públicas ou residências", na Avenida Celso Garcia, $197^{446}$ e José Galves Frontiñan, de Cádiz, também morador no Brás, à rua Firmiano Pinto, 44, declarava-se corrector $^{447}$.

Não obstante, não era apenas ao mundo "letrado" que a cidade, em seu ritmo desenfreado, abria-se às oportunidades: na área do entretenimento, dos espetáculos e esportes surgiam reiteradamente nichos a serem ocupados. Um caso exemplar é o dos pelotari. Esse esporte, também conhecido por pelota basca, era composto por times de pelotários formados por indivíduos de origem basca, vindos especialmente de Guipuzcoa e Vizcaya. Concretamente, funcionava pelo lançamento de "uma pequena bola contra uma parede, longe do alcance do adversário que tenta[va] agarrá-la com a ajuda de uma cesta"448. Solteiros e jovens, na faixa dos $22 \operatorname{anos}^{449}$, usavam um uniforme de calça e camisa branca, e calçavam sapatos de lona com sola de corda; alguns usavam boina, à maneira basca. Cícero Marques comenta que seus sapatos eram fabricados pelo "Cozenza", o sapateiro preferido pelos alunos

${ }^{441}$ EDE 06.03.1913. Trad. da autora.

442 Bernardo Obrador Billón, 29 anos, solteiro.

${ }^{443}$ EDE 03.02.1914. Trad. da autora.

${ }^{444}$ LRC 1911.

${ }^{445}$ BRUNO, E. Op. cit., 1991, p. 1174.

${ }^{446}$ EDE 12.11.1913. Trad. da autora.

${ }^{447}$ LRC 1922. Corrector: revisor (de texto).

${ }^{448}$ ARAÚJO, José Renato de Campos. Imigração e futebol: o caso Palestra Itália. Campinas: Dissertação de mestrado, IFCH -UNICAMP, 1996, p. 75.

${ }^{449}$ Não conseguimos dados a respeito do limite máximo de idade permitido para a prática desse esporte. Juan Martin Berna, pelotari em 1894, então com 23 anos, apareceria nos registros do CGE em 1908, aos 37 anos, como comerciario. No entanto, Angel Lorente Eraso, pelotari em 1897, com 19 anos, declarou-se empleado do Frontão, em 1918, aos 40 anos. 
da Escola Americana que lá encomendavam "suas chancas para o jogo de futebol". Os pelotários, informa, haviam constituído seu bairro nas imediações, a maioria deles residindo nas Ruas D. José de Barros e 24 de maio" ${ }^{450}$. O esporte da pelota se difundiria na cidade tendo seu próprio local de prática, o Frontão Boa Vista, localizado no final da rua do mesmo nome, junto à Ladeira Porto Geral. Explorado pela Companhia Frontão Paulista, consta que, em 1894, houve a proibição, por parte da Prefeitura, para funcionamento nos dias úteis, a que recorre a empresa, com ganho de causa ${ }^{451}$. Ernani da Silva Bruno refere-se ao "primeiro frontão" - que conforme ele, ficaria na Rua 24 de maio e se constituía, ao ser inaugurado "como legítima importação espanhola" - como iniciado em 1903. Imaginamos que haja aí algum equívoco ou que talvez o autor estivesse se referindo a um outro "frontão" 452 , porque, em realidade, os registros consulares apontam para o ano de 1894 como o do início do ingresso desses desportistas na cidade que, num primeiro momento mencionavam a Rua do Brás como seu domicílio, mas que, já a partir de 1897 passariam a mencionar como domicílio o termo "Frontão" em alguns casos e em outros a Rua 24 de maio, em numerações variadas ${ }^{453}$.

Alfredo Moreira Pinto apresenta outra versão para a data da inauguração que, conforme ele, teria sido em dez de fevereiro de 1898. Com respeito ao Frontão, sua entrada pela Rua Boa Vista, se daria "por um portão de ferro, feito com arte e elegância, dando ingresso a um espaçoso corredor ladrilhado de mosaico de belo padrão" 454 . E, já no seu interior, no extremo desse vestíbulo "logo à entrada que dava para a "cancha", estava sempre um sujeito mal encarado, sentado numa cadeira de assento de palhinha - era o porteiro", informa Edmundo Amaral $^{455}$.

Em 1903, o esporte já estava disseminado na cidade e a freqüência ao Frontão Boa Vista, permitida para qualquer idade, apresentava-se contudo com restrições, solicitando-se que as pessoas se apresentassem "decentemente trajadas" 456 . Elazari enumera outros locais de prática da pelota no início da década de 1900, além do Frontão Boa Vista que teria sobrevivido aos demais: o Frontão Paulista, o Coliseu Vista Alegre e o Brás Sport. Além disso, enumera, no início do século surgiram clubes de pelota, o Clube Atlético de Pelota, o Clube de Pela, o

\footnotetext{
${ }^{450}$ MARQUES, C. Op. cit., 1944, p. 123.

${ }^{451}$ LEME, M. Op. cit., 1984, p. 102.

${ }^{452}$ BRUNO, E. Op. cit., 1991, p. 1237.

${ }^{453}$ Relatório Access 50 . O número 53 da Rua 24 de maio foi o mais mencionado, porém também foram citados os n's.12, 24 e 26.

${ }^{454}$ PINTO, A. Op. cit., 1979, p. 173. (1 ${ }^{\text {a }}$ ed. 1900).

${ }^{455}$ AMARAL, E. Op. cit., 1950, pp. 57-59.

${ }^{456}$ A vida de hoje, 21.06.1903. Apud: ELAZARI, Judith Mader. Lazer e vida urbana em São Paulo, 1850-
} 1910. São Paulo: Dissertação de Mestrado. FFLCH-USP, 1979, p. 101. 
Centro Paulista Bowing Clube os quais, embora congregassem os amantes do esporte, não possuíam sede própria, praticando-o nos frontões comerciais ${ }^{457}$.

Pelo exposto, e pelas evidências documentais, acreditamos que o esporte da pelota basca tenha sido praticado na cidade antes da passagem do século XX, quando já estavam nela estabelecidos pelo menos três dezenas de pelotários. Também de acordo com esses dados, o esporte parece ter adentrado a terceira década, cuja evidência é a inscrição de mais dez jovens pelotários no ano de 1922, o último da série analisada.

Esse esporte parece ter-se difundido não apenas entre os espanhóis: "Rafaelzinho de Barros, baixo, forte, entroncado, campeão de pelota basca, "cuera" na cortada e ágil no "batepronto" ${ }^{, 58}$ era um dos aficionados freqüentadores.

Alfredo, que pagava o café, perguntou se não queriam tomar alguma coisa.

- Não, disse Laurentino, eu vou com o Geraldo no Frontão. Você não conhece o Geraldo? O moço avermelhado cumprimentou Alfredo com um aperto de mão suada.

- Mas, o que vão vocês fazer no Frontão?

- Vamos assistir a uma "quinela". Quer você vir?

Alfredo nunca tinha ido ao Frontão. Então eles explicaram: era um jogo de pelota, espanhol.

- É um jogo batuta! Comentou Laurentino.

Mas o moço avermelhado informava:

- O Juvenal, na semana passada, pegou quatrocentos mil réis, numa poule!

Alfredo teve uma grande curiosidade. Estava, além disso, com pouco dinheiro. Quem sabe se acertaria uma poule?

- Vamos ver essa joça!

Sua programação era divulgada com regularidade pelo EDE: "variada funcción de dia y denoche; cuadros de pelotaris venidos expresamente de Europa", dizia o anúncio, no ano de 1912, o qual, com algumas pequenas alterações, permaneceu durante todo o período ${ }^{459}$. Em 1920, o periódico dava cobertura, em detalhes, dos resultados da "excelente" reforma pela qual passara o Frontão, na quadra, palcos, arquibancadas, camarins dos artistas, pintura das paredes, buffet, escritório e iluminação. Concluía informando que ao fundo do edifício seria construído um espaçoso terraço "preciosamente ornamentado, com todas as comodidades necessárias para que o público possa admirar o lindo panorama oferecido pelos bairros do Ipiranga, Moóca, Braz, Belém, Pari, Ponte Grande e boa parte do Bom Retiro" ${ }^{, 40}$.

\footnotetext{
${ }^{457}$ Passim.

${ }^{458}$ MARQUES, C. Op. cit., 1944, p. 50.

${ }^{459}$ EDE 08.01.1912.

${ }^{460}$ EDE 04.03.1920. Trad. da autora.
} 
Ninguém se lembra que ali, naquela esquina, no sobradão com janelinhas excêntricas, onde hoje, ao fundo, funciona o Apolo, antigo Cassino, estreou-se, há trinta anos, o primeiro Frontão de São Paulo. (...) virou jogo de azar, tão pernicioso como o "bicho". Mas, noutros tempos, ao ser inaugurado, como legítima importação espanhola, foi o "clou" da elite paulistana. Na Praça da República, havia touradas e no Frontão "torradas" - termo que a gíria denominou as quinélas em que os pelotares entregavam o ponto $^{461}$.

Com o tempo, no entanto, as "torradas" vieram a sofrer uma mortal concorrência com outro esporte que se difundiria rapidamente, fascinando multidões: o futebol. Dizia o reclame: "Quem não for apaixonado do futebol que, além de outros inconvenientes tem o de estar hoje muito "carne de vaca" entre nós, que vá passar o dia amanhã no Frontão Boa Vista", deixando entrever, por outro lado, um certo apelo elitista na mensagem, ainda mais considerando que, à sociedade paulistana, não agradava a adesão maciça do povo à prática do futebol ${ }^{462}$.

As touradas, mencionadas por Paulo Cursino de Moura, outra tradição tipicamente espanhola, eram realizadas na cidade desde o Império, no Largo dos Curros, um vasto descampado limítrofe da área urbanizada da cidade. Marques nos brinda com uma passagem, datada de 1852, narrando uma fatídica tourada lá ocorrida, adjetivando os toureiros como "todos uns míseros amadores" e na qual "o Tam-Tam, um pobre diabo manco de uma perna" e chefe do grupo procedente de Sorocaba "enfiado na sua roupa de galões dourados" acabaria morto pelo animal, num duelo acompanhado por ricos "vestidos de veludo e vidrilho", "cartolas rebrilhantes" e "sobrecasacas solenes" e pela ralé, "apinhada num canto das arquibancadas ${ }^{463}$. Ernani da Silva Bruno por sua vez informa que em 1877 a Câmara negou permissão a Antonio Aragón para "levantar um circo, no Largo da Luz ou no Campo dos Curros, onde pretendia dar corrida a touros". No mesmo ano, porém, a Câmara deliberava que os "espetáculos de corrida de touros" só seriam permitidos caso os animais estivessem "embolados", a fim de que “ocorrências funestas" fossem evitadas. Entre os anos de 1901-1902, comenta o autor, haviam duas praças de touros em funcionamento: uma na Praça da República (Largo dos Curros) e outra em um terreno que dava para a Brigadeiro Luis Antonio, ocasião em que se usavam as bandarilhas, mas não havia morte dos animais ${ }^{464}$.

Pelos poucos indícios e informações obtidos depreende-se que a atividade de toureiro era irregular e improvisada por alguns indivíduos "amadores", que se deslocavam com seu grupo para realizar as apresentações, o que traía grandes platéias. Talvez essa razão, a grande

\footnotetext{
${ }^{461}$ MOURA, P. Op. cit., 1954, p. 170.

${ }^{462}$ A Vida de Hoje, 20.06.1903. Apud: ELAZARI, J. Op. cit., pp. 101 e ss.

${ }^{463}$ MARQUES, G. Op. cit., pp. 122 e ss.

${ }^{464}$ BRUNO, E. Op. cit., p. 1233. Embolar: proteger com chumaço os chifres.
} 
mobilidade, explique o fato de apenas um único toureiro ter-se registrado no CGE em todo o período analisado e, ainda assim, declarando-se "transeunte" em direção à cidade de Guaratinguetá, onde talvez estivesse sediado seu grupo ou fosse realizar alguma apresentação. Isso aconteceu no ano de 1894: Antonio Dominguez Herrera, solteiro, com 27 anos, natural de Madri apresentou-se naquela ocasião sem qualquer documento de identificação ${ }^{465}$.

Em 1914 ainda se realizavam touradas na cidade, as chamadas "temporadas de corrida de touros". Desta feita, nota do EDE informava aos leitores que "devido a grande aceitação do público" haveria a prorrogação da temporada ocorrida em Santo Amaro, do "aplaudido

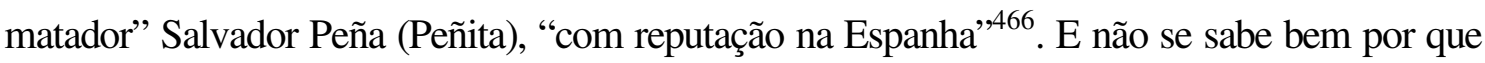
razão ainda em 1922 um espanhol de nome Francisco Gómez anunciava a venda de "Touros Hereford, puro sangue, para cruzamento" ${ }^{, 67}$.

Contudo, podia ser encontrado, nas três primeiras décadas do Novecentos, nos antigos e animados folguedos e carnavais de rua, no meio dos blocos de foliões que desfilavam, pequenos grupos cômicos onde era comum encontrar "um touro personificado por dois elementos cobertos com um pano escuro, levando uma grande caveira de boi com seus chifres, acompanhado pelo seu indispensável toureiro, armado de espada e pano vermelho", grupo que encenava alegres touradas e era muito aplaudido pelo público ${ }^{468}$.

Outra modalidade esportiva praticada na cidade pelos espanhóis, nessas primeiras décadas, era o ciclismo. Em 1913, dois irmãos, Gregório e Antonio Ardanuy, "sócios do Clube Ciclístico Internacional Frera", tendo participado de uma corrida de bicicleta foram os vencedores do primeiro e do segundo lugares. Essa corrida, de 25 quilômetros, saía da Rua das Perdizes até a Avenida Antarctica ${ }^{469}$. De sua proeza oportunamente se aproveitava para anunciar, dias depois no EDE, o "único" importador das bicicletas Frera e Goricke, "as melhores do mundo", Eduardo Taurisano, com loja na Travessa do Brás, $42^{470}$.

Não conseguimos obter maiores informações a respeito desses eventos, se eram ou não realizados com regularidade na cidade, porém, em 1917 localizamos uma inscrição realizada no CGE pelos irmãos acima mencionados quando, surpreendentemente, se declararam jornaleros $^{471}$.

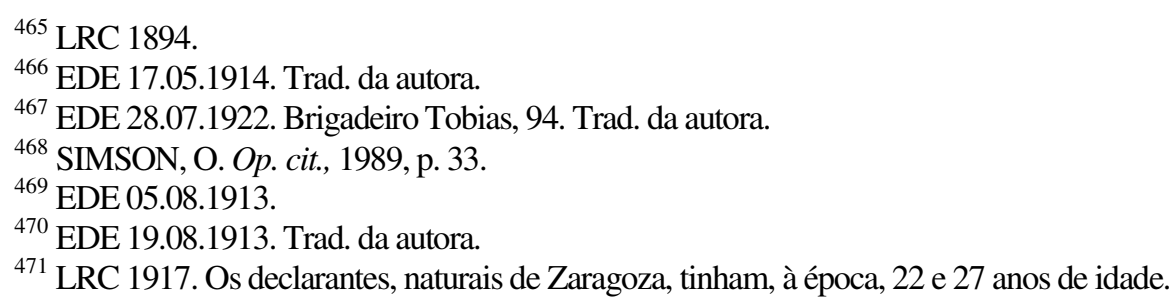


Em 1920, no entanto, do Programa oficial da Romería constava a "corrida de bicicletas", cujos participantes concorriam a "fitas bordadas à seda e a ouro pelas senhoritas da Comissão",472.

Os motoristas de "praça", taxistas e chauffeurs, estes surgidos apenas na primeira década $^{473}$ constituíram outra categoria autônoma, cujo volume tendeu a crescer no início da segunda década. Hegemônicos no transporte individual até o início da década de 1910, os veículos de tração animal serão gradualmente suplantados pelos automóveis, os primeiros surgidos na cidade na década de $1890^{474}$. Em 1905, o número de automóveis na cidade era de apenas 19 unidades, porém, em 1909 já somavam 128, utilizados, em maioria, no serviço de aluguel, que antecedeu o uso particular, difundido somente na década de 1910.

É justamente desta década o surgimento de anúncios de venda de automóveis, de particular para particular, no EDE: "vende-se magnífico automóvel, sistema torpedo, de 24 cavalos efetivos, da reputadíssima Fábrica Isota Fraschini, quase novo" informava-se aos interessados que, para maiores detalhes, deveriam falar com Eiras Garcia ${ }^{475}$.

Grandes marcas e sistemas, especialmente franceses - Torpedo/Limousine - passaram a ser comercializados na cidade e anúncios de importadores passaram a circular nas páginas do periódico, enaltecendo os avanços técnicos, como "chassis com partida automática e iluminação elétrica". Dessas empresas importadoras, uma delas pertencia a Antunes dos Santos, também ele proprietário de uma outra, sediada em Lisboa e com sucursal em Gibraltar encarregada, dessa feita, do rentável negócio do transporte de imigrantes, e que mantinha convênio com o Governo do Estado desde 1897, sendo a responsável pela travessia de milhares de espanhóis, muitos dos quais clandestinamente, fato que provocava sérios desentendimentos com as autoridades sanitárias, no porto de Santos.

Surpreendentemente, a empresa - atacada diversas vezes em matérias pelo EDE, contra as condições precárias do transporte dos "brancos traídos a serviço dos empresários Orcy, Antunes \& Cia.", muitos dos quais "faleciam a bordo", outros "chegavam enfermos" e todos "passavam fome e sofriam maus tratos" não apenas no comércio de automóveis, negócio secundário quando comparado ao de

\footnotetext{
${ }^{472}$ EDE 13.08.1920.

${ }^{473}$ A primeira inscrição de um chauffeur no CGE deu-se em 1911: tratava-se de José Madueño, malaguenho de 37 anos.

${ }^{474}$ Eram "obsoletos e nada práticos, funcionando com motor elétrico, baterias ou a vapor". $C f$. LEME, M. Op. cit., 1984, pp. 74-75.

${ }^{475}$ EDE 13.04.1914. Trad. da autora.

${ }^{476}$ EDE 26.05.1920. Trad. da autora.
} 
transporte de emigrantes. Numa dessas ocasiões, Eiras teria ido pessoalmente aguardar no cais um desses "navios negreiros", o Aquitaine, que trazia grande contingente de espanhóis recrutados e embarcados clandestinamente em Gibraltar por Antunes dos Santos ${ }^{477}$. Tanto o Aquitaine quanto o Provence, "navios imundos", estariam proibidos de atracar "nos portos de Montevidéu e Buenos Aires", esclareceria matéria posteriormente publicada ${ }^{478}$. Reiteradamente o jornal se posicionava a respeito desse contratador, muitas vezes divulgando matérias publicadas em outros periódicos, como desta feita, reproduzindo matéria do A Platéia:

Se essa gente se acomoda em estado enfermo a bordo de transatlânticos, suas condições sanitárias se agravam morbidamente durante a travessia marítima, quer por sua modestíssima alimentação, quer pelas péssimas e infectas instalações que lhe são destinadas na famosa " 3 a classe" dos navios que contratam o transporte de tal gente ${ }^{479}$.

No tocante aos motoristas e chauffeurs, enfim, acreditamos que, dentre os inscritos nesse período no CGE, muitos trabalhassem como motoristas particulares, em atendimento às famílias de posses que possuíam seus próprios veículos, carros ou tílburis.

O primeiro anúncio de uma "auto-escola", localizada na Rua Uruguaiana, 40, no Brás, data de 1919, oferecendo aos "aprendizes a chauffeur lições práticas e teóricas"480. Entrementes, os acidentes de trânsito e atropelamentos cresciam enormemente na cidade: na avenida São João foi apanhado por um veículo o espanhol Manuel Carretero; no Largo da Sé o operário Ildefonso Domingo e na mesma edição, mais uma criança era atropelada "pelo auto $\mathrm{n}^{\circ}$ 702"481. Esses motoristas (particulares), assim autodenominados nos registros consulares, provavelmente residissem nas casas de seus patrões, haja vista os endereços que citavam como domicílio: Rua Pamplona, 122; Avenida Paulista, 85; Rua Jaguaribe, 90 ou Sete de abril, 15.

Havia aqueles que trabalhavam para os hotéis, no transporte dos clientes desembarcados nas ferrovias - Hotel Brasil, por exemplo -, e outros que "faziam ponto" em determinados locais da cidade - não sabemos se com veículo próprio ou não. Esse era o caso do espanhol taxista do carro $n^{\mathbf{0}} 783$, estacionado na Estação da Luz que, desde os finais de 1914, mantinha anúncio no EDE convocando a todos os conterrâneos para que o distinguissem com a sua preferência quanto aos demais lá também estacionados ${ }^{482}$. Os primeiros pontos de táxi, aliás, veículos abertos lembrando carruagens e assemelhando-se "a caixas negras, com lanternas

\footnotetext{
${ }^{477}$ EDE 26.04.1920.

${ }^{478}$ EDE 04.06.1921.

${ }^{479}$ EDE 26.05.1920.

${ }^{480}$ EDE 02.09.1919. Trad. da autora.

${ }^{481}$ EDE 03.02.1922.

${ }^{482}$ EDE 04.01.1915 e outros.
} 
vermelhas do lado",483 apareceram na cidade apenas em 1906 e permaneciam estacionados geralmente nas esquinas ou nos largos, à espera de passageiros ${ }^{484}$. O serviço foi sendo ampliado e aperfeiçoado: "elegantes carruagens" - Autotorpedo 983, Landaulet e Limousine 157 integravam a Garage Central, à Rua Líbero Badaró esquina com Avenida São João, que dispunha de um telefone, de número 1968, para chamadas a domicílio. A função também incluía um serviço de "mensageiros”, para entrega de mensagens, recados e pequenos volumes, além de mudanças e transportes ${ }^{485}$.

Os viajantes (ou representantes comerciais, como também apareceram), outra dessas categorias gestadas no trepidante ritmo assumido pela cidade, eram indivíduos que, em visita às localidades do Interior ou de outros Estados - o que justifica a sua designação - divulgavam os produtos ou as mercadorias das indústrias instaladas na cidade de São Paulo que representavam, com a finalidade de incrementar as vendas. Consta que as fábricas maiores possuíam um corpo de viajantes exclusivos que, em alguns casos, chegava a 30 elementos. Algumas dessas empresas, de maior porte, possuíam filiais na Capital do País, a cidade do Rio de Janeiro ${ }^{486}$, porém, grande parte delas operava com os representantes de vendas ou viajantes. Na cidade, para a distribuição dos produtos, algumas fábricas possuíam loja de varejo no próprio local, ou então no centro da cidade, junto aos escritórios ${ }^{487}$.

Não foram muitos os espanhóis que localizamos no exercício dessa função no período, porém os primeiros apareceram antes mesmo da passagem do século XX. Antonio Bustamante Lopez, de Málaga, foi o titular do primeiro registro de viajante no CGE, realizado ainda em 1896. Não conseguimos pelo cruzamento da documentação viabilizar detalhes de sua atuação enquanto representante, porém, curiosamente, fomos encontrá-lo novamente, a finais da primeira década, desta feita como notícia no EDE, sendo apresentando como um "famoso treinador de cavalos", a quem se cumprimentava "pela vitória do cavalo Madrigal", dirigido pelo jóquei Lourencinho na corrida do turf paulista ${ }^{488}$.

Há indícios, contudo, de que o mercado consumidor representando pela São Paulo que se agigantava atraía viajantes de outros locais que aqui vinham na tentativa de explorar o filão, colocando seus produtos. Nesse particular, observamos casos de indivíduos assim denominados

${ }^{483}$ SCHMIDT, A. Op. cit., 2003, p. 42.

${ }^{484}$ LEME, M. Op. cit., 1984, p. 75.

${ }^{485}$ EDE 09.01.1918. Trad. da autora.

${ }^{486}$ As empresas Matarazzo possuíam, excepcionalmente, filial também em Buenos Aires, apenas para aquisição de matéria-prima; A. Siciliano teria filial em Londres. Cf. LEME, M. Op. cit., 1984, p. 254.

${ }^{487}$ LEME, M. Op. cit., 1984, p. 254.

${ }^{488}$ EDE 20.03.1919. Trad. da autora. 
que, domiciliados em outras localidades, declaravam-se transeuntes no CGE, estando temporariamente instalados na cidade, geralmente em hotéis. Um caso, para ilustrar, é o de Fernando Torras Molas, natural de Barcelona, com domicílio em Belo Horizonte, hospedado no Hotel Central em $1918^{489}$.

Diferentemente de outras categorias, com menor freqüência, o aparecimento - no período total abrangido pelo levantamento documental dos LRC - da categoria religiosos, curas ou presbíteros foi expressivo e dos que se manteve com maior regularidade nos anos consultados, oscilando apenas o contingente anual encontrado.

No total, a categoria somou 246 registros, iniciados em 1897, com picos nos anos de 1911 (75 registros) e 1915 (35 registros). Seus representantes, indivíduos com idade entre 19 e 75 anos, eram membros da Congregação dos Agostinianos. Dos primeiros registros até 1911 consta que ficavam domiciliados na Rua Jaguaribe, 33. A partir de 1911 e até 1917, seu domicílio alterou-se para o $\mathrm{n}^{\circ} 73$ da mesma Rua, a partir do que passou a ser citado o Convento Santo Agostinho que acreditamos seja o local onde hoje se situa, na Rua Vergueiro, o Colégio e a Igreja homônimos. Sua procedência majoritária era do norte da Península, com expressiva participação da Região de Navarra (20\%), da Província de Burgos (15\%), da Região de Rioja $(10 \%)$ e da Província de Alava, País Basco $(8 \%)^{490}$. Não obtivemos qualquer informe sobre sua atuação na cidade, de onde é provável que fossem enviados para paróquias no interior do Estado. Citações, menções, ou referências a esses indivíduos foram quase inexistentes na documentação consultada.

Sequer consta que participassem das campanhas que eram encabeçadas pelos dirigentes das sociedades beneficentes. A única ressalva fica por conta de uma homenagem ao Padre Girón para a qual fora convocada toda a colônia pelo EDE e que seria realizada nos salões do CE, na Rua XV de novembro, 50, altos. O motivo não ficou claro, contudo se informava de seu livro Por los fueros de la verdad, obra que teria dedicado à colônia. Assinavam ao chamamento os três Presidentes das principais sociedades: Miguel Gutierrez pelo CE; Manuel Godoy, pela FE e Juan Rivero, pela SESM ${ }^{491}$.

Quanto às religiosas, em menor quantidade no período tiveram, diferentemente dos curas, seus primeiros registros iniciando apenas no ano de 1913, indicando como domicílio

\footnotetext{
${ }^{489}$ Relatório Access 53.

${ }^{490}$ Relatório Access 51.

${ }^{491}$ EDE 25.05.1922.
} 
"Los hermanos de la esperanza" provavelmente alguma associação de caridade, sediada na Rua da Consolação, $36^{492}$.

O período contabilizou inúmeros outros registros de profissionais liberais ou de indivíduos atuando autonomamente - ou não; há casos em que essa distinção mostrou-se problemática - alguns de pouca expressividade numérica, dos quais, para ilustrar, poderíamos

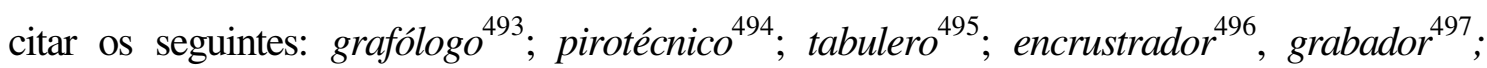
notario $^{498}$, delineante ${ }^{499}$ corredor $^{500}$, químico ${ }^{501}$ e molinero ${ }^{502}$, dentre outros. Apresentou ainda outras categorias como a dos tipógrafos, e atividades correlatas - impresores, encuadernadores, litógrafos e dibujantes - que serão especialmente examinados no capítulo seguinte.

${ }^{492}$ LRC 1913 a 1921.

${ }^{493}$ EDE 04.08.1913. Anúncio do grafólogo Professor A. Detourt, Rua Conselheiro Nébias, 24 - residência particular. Consolação, 702.

${ }^{494}$ LRC 1921. Atividade declarada de Pedro Abad Visiedo, de Almería, residente com a esposa na Rua da

${ }^{495}$ Em 1893 apresentou-se o primeiro tabulero no CGE, Joaquim Cortés Sicarén, de Málaga, 33 anos, há seis meses na cidade, residente na Rua da Fábrica, 9. Imaginamos que sua atividade se relacionasse à fabricação de tabuleiros para o comércio miúdo de doces e salgados praticado pelos ambulantes. LRC 1893.

${ }^{496}$ A palavra não existe no idioma espanhol, foi aportuguesada. Talvez se referisse ao profissional que então trabalhasse com pedras, na confecção de jóias. Vicente Iturbe Pascual, de Burgos, declarou ser essa a sua atividade, em registro realizado em 1911. Residia na Rua Capitão Matarazzo, 27. LRC 1911.

497 Pode indicar o profissional que trabalhasse com estamparia em tecidos. Carlos Mellado Ibañez, malaguenho de 36 anos e residente na Rua Riachuelo, 38, exercia esse ofício na cidade, em 1912.

498 Escrevente de cartório. A categoria aparecerá uma única vez nos LRC. José Benitez y Benitez, de Huelva, 24 anos, com domicílio na Rua Barão de Jaguará, 202. LRC 1921.

${ }^{499}$ Os delineantes ou desenhistas industriais, apareceram nos LRC a partir de 1893; poucos, o primeiro deles era Franciso Grillo y Cordero, de Cádiz, com 52 anos e casado, residente à rua do Brás, 47.

${ }^{500}$ Impossível identificar a que modalidade de esporte ou atividade se dedicavam os corredores, se praticavam o pedestrianismo, se eram jóqueis ou se participavam de corridas de touros, etc. LRC 1911; 1919 e 1920.

${ }^{501}$ Um único inscrito foi localizado para essa categoria. De passagem pela cidade, o químico "transeunte" que se registrou no CGE, Emilio Pellicer Bolanger, era natural de Barcelona.

${ }_{502}$ Inscrito em 1894, Valentin Hidalgo, o molinero de 44 anos, era casado, natural de Huelva e residente na Rua Bresser, 72; apresentou-se ao CGE sem qualquer documento de identificação. 


\section{De Grão em GRÃo: O ESPANHOL EMPRESÁRIO}

\section{Segmentos da pequena indústria e comércio}

Los españoles nunca abrieron ninguna brecha importante en la propriedad de las industrias paulistas. La impresión que uno tiene de la trayectoria ocupacional de los españoles es que se concentraron principalmente en la propriedad rural y en las actividades comerciales en las ciudades del interior y en la capital ${ }^{l}$.

... Daí que se acham espalhados pelos campos do território paulista uns 200 mil espanhóis e que nossa importância coletiva na capital seja modesta, pois não figuramos, como devíamos, no comércio e na indústria, e não contamos na Capital com o número de ricos que existem no interior do Estado à frente de suas estâncias. Se, ao invés de se encaminharem para as zonas agrícolas, tivessem ficado na capital para aumentar o número de comerciantes, industriais, ou até mesmo dedicando-se ao mascate, à venda de bananas, jóias falsas ou outras atividades do mesmo quilate, certamente seria outra a consideração para com os espanhóis ${ }^{2}$.

O exame do processo de industrialização paulista, sobretudo a partir da década de 1960, foi o responsável pela produção de inúmeros trabalhos e múltiplos enfoques. De consensual, esses autores $^{3}$ parecem comungar o entendimento da estreita vinculação entre o grande aumento da produção cafeeira e o ingresso maciço de imigrantes europeus, considerados, ambos, fatores essenciais para o alavancamento das indústrias. No que esses autores não concordam, no entanto, é no que respeita ao "peso" de cada uma dessas variáveis - economia cafeeira ou imigração? -, como impulso à gênese da industrialização.

Para Celso Furtado, o processo teria sido desencadeado pelas crises na economia cafeeira (queda nas exportações) e pela retração nas importações de artigos industriais gerando

\footnotetext{
${ }^{1}$ KLEIN, Herbert. Op. cit., 1995, p. 94 . O autor fundamentou-se em amostra de 330 empresas constituídas na cidade entre abril e setembro de 1917, por origem dos sócios; destas, apenas 10 pertenciam a espanhóis.

${ }^{2}$ Matéria publicada pelo EDE a 16.07.1921, com o título "Braços Espanhóis" a propósito do desembarque de 750 clandestinos, embarcados em Gibraltar. Trad. da autora.

${ }^{3}$ A esse respeito, $c f$. LUZ, Nícia Vilela. A luta pela industrialização do Brasil: 1808 a 1930. São Paulo: Alfa-Omega, 1975 (1 a edição em 1960); IANNI, Otávio. "Fatores humanos da industrialização no Brasil”'. In: Revista Brasiliense. São Paulo: v. 30, 1960, pp. 50-66; CARDOSO, Fernando Henrique. "Condições sociais da industrialização de São Paulo”. In: Revista Brasiliense. São Paulo: v. 28, 1960, pp. 31-58; DEAN, W. Op. cit., 1971; MARTINS, José de Souza. Conde Matarazzo. O empresário e a empresa. São Paulo: Hucitec, 1976 e PEREIRA, Luiz Carlos Bresser. "Origens do empresariado paulista”. In: Revista de Administração de empresas. Rio de Janeiro: 13(1), jan./mar.1973, pp. 57-66, dentre outros.
} 
estímulo à produção industrial interna ${ }^{4}$. Há, por outro lado, quem entenda que o avanço da industrialização teria ocorrido justamente nos períodos de prosperidade da economia cafeeira, atribuindo-se à elite rural a origem do empresariado e considerando os importadores os pioneiros de nossa industrialização. Essa convicção, expressa por Warren Dean fundamentou-se em estudo apontando que, de 21 fábricas têxteis criadas entre 1900-1917, 16 eram de importadores e que das 13 ainda em funcionamento em 1917, 11 "eram controladas por firmas importadoras ou por empresários que tinham começado como importadores”. Conforme ele, "poucos dos primeiros empresários industriais não iniciaram suas carreiras como comerciantesimportadores", apontando a ocorrência de casos em que a iniciativa partia de grandes agricultores, responsáveis pela abertura dessas empresas que depois eram vendidas aos importadores, muitos deles imigrantes. Quanto a esses empresários imigrantes, de origem pequeno-burguesa, o autor esclarece terem sido "pouquíssimos [os] que tivessem começado como operários de fábricas ou mascates", Martins, para quem "as possibilidades da indústria no Brasil referem-se sem dúvida à supressão do trabalho escravo e à imigração estrangeira para atender a demanda de mão-de-obra, pelo alargamento da faixa dos consumidores-compradores", esclarecendo, em seu estudo sobre o Conde Matarazzo, que foram os ingleses que forneceram os créditos necessários para a instalação de suas fábricas ${ }^{6}$.

Para Fernando Henrique Cardoso os tentáculos da economia cafeeira com seu sistema de articulações entre o Oeste Paulista e o Porto de Santos, tendo à frente os fazendeiros, obrigou-os a inverterem somas na construção de estradas de ferro, como a Paulista e a Mogiana. A crescente comercialização do produto, por sua vez, passou a exigir uma rede de casas comissárias de exportação e de bancos para o financiamento. Nessas condições, o fazendeiro do Oeste Paulista passava a gerir sua propriedade rural através de administradores e capatazes, ocupando-se, na cidade, mais diretamente com a aplicação e o rendimento financeiros. Ele esclarece:

As afirmações que fiz não implicam, contudo, que a industrialização de São Paulo tenha sido realizada apenas através dos fazendeiros de café que, como capitalistas, passaram a se interessar pela produção de máquinas para a agricultura ou pela produção de bens de consumo em geral. Não existem dados suficientes para que se avalie a importância da

\footnotetext{
${ }^{4}$ FURTADO, Celso. Formação econômica do Brasil. São Paulo: Cia. Editora Nacional, 1971, pp. 177 e ss.

${ }^{5}$ DEAN, Warren. "As origens da burguesia imigrante”. In: Op. cit., 1971, pp. 57 e ss. Ver também pp. 28, $30,47,93$ e 108 .

${ }^{6}$ MARTINS, J. S. Op. cit., 1976, especialmente pp. 29 e 70.
} 
participação direta dos fazendeiros nos primórdios da indústria paulista. Pode ser até menor do que muitos supõem. Quis ressaltar apenas que as modificações no sistema econômico de produção operadas nas fazendas do Oeste Paulista criaram condições para o desenvolvimento do capitalismo industrial ${ }^{7}$.

De certo modo esta é a convicção de Wilson Cano e João Manuel Cardoso de Mello ${ }^{8}$, para quem o que houve foi um "transbordamento" do capital cafeeiro para o capital industrial, ponto de vista também compartilhado por Zélia Cardoso de Mello que, ilustrando com uma série de casos, reafirma que "os fazendeiros examinados não se dedicavam exclusivamente aos negócios agrícolas", considerando que, mesmo que a riqueza dos fazendeiros tivesse uma origem agrária, seus investimentos eram de natureza variada, ocasionando rendimentos de natureza "urbana", como juros, aluguéis e dividendos. Ela distingue, em seu trabalho", fazendeiros como "grandes acionistas, através de ligações familiares, ou ainda como diretores, nas diversas sociedades fabris, financeiras e companhias de transporte e serviços públicos que apareceram nos últimos trinta anos do século passado [XX]"10.

Fator fundamental na criação de um mercado consumidor, mão-de-obra industrial, mas também origem de importantes empresários industriais: para Bresser Pereira são atributos inalienáveis da imigração estrangeira, em cujo trabalho ${ }^{11}$ procurou delinear as origens étnicas dos fundadores das empresas paulistas, concluindo que cerca de $84 \%$ delas teve origem estrangeira, diretamente ou através de descendentes, capitaneadas pelos italianos $(34,8 \%)$, pelos alemães $(12,8 \%)$ e pelos portugueses $(11,7 \%)$.

Dirceu Lino de Mattos também assim concluiria na sua análise dos "capitães de indústrias" paulistas, para quem muitos deles aqui chegaram como imigrantes, às vezes na penúria" ${ }^{\prime 2}$, iniciando quase sempre por modestos estabelecimentos fabris, verdadeiras oficinas de artesanato urbano ${ }^{13}$, tese que encontra ressonância nos trabalhos de Boris Fausto ${ }^{14}$ que

${ }^{7}$ CARDOSO, F. H. "Condições sociais da industrialização de São Paulo", op. cit., 1960, p. 42.

${ }^{8}$ CANO, Wilson. Raizes da concentração industrial em São Paulo. São Paulo: Difel, 1977; MELLO, João Manuel Cardoso de. O Capitalismo tardio. Contribuição à revisão crítica da formação e do desenvolvimento da economia brasileira. São Paulo: Brasiliense, $3^{\text {a }}$ edição, 1984.

${ }^{9}$ MELLO, Z. São Paulo, 1845-1895: Metamorfoses da riqueza. Tese de doutorado, FEA-USP, 1981, pp.133 e ss.

${ }^{10}$ Passim.

${ }^{11}$ BRESSER PEREIRA, L. "Origens étnicas". In: Empresários e administradores no Brasil. São Paulo: Brasiliense, 1974, pp. 70-87 e "Origens étnicas dos dirigentes das empresas paulistas". In: Revista de Administração de empresas, op. cit., 1973, pp. 57-66. Também cf. SUZIGAN, Wilson e SZMRECSÁNYI, Tamás (org.) Op. cit., 1996, pp. 261-283.

1954, p. 13.

MATTOS, Dirceu Lino de. "O parque industrial paulistano". In: AZEVEDO, Aroldo de (org.). Op. cit.,

\footnotetext{
${ }_{11}^{13}$ Idem, ibidem, pp. 10-11.

${ }^{14}$ Especialmente em Trabalho urbano e conflito social, op. cit., 1977, pp.17 e ss.
} 
defende que os imigrantes, devido às dificuldades impostas ao acesso à propriedade da terra, voltar-se-iam para a cidade, onde aplicariam sua poupança no setor comercial e industrial ${ }^{15}$. "Não são poucos os casos de imigrantes que vieram a empregar seus pequenos recursos acumulados, em anos difíceis de trabalho, na implantação de atividade industrial", reafirma Manuel Dieguez Júnior ${ }^{16}$.

De qualquer forma, e em que pesem as divergências sobre a questão, desde a última década do Oitocentos, pelo menos numericamente, verificou-se expressivo impulso à indústria, sobretudo com o Encilhamento, período em que se multiplicaram vertiginosamente empresas de toda sorte, sendo inegável a presença de prósperos fazendeiros na direção de grandes indústrias, caso da fábrica de sacos de juta, a Fábrica Santana, criada em 1895 e tida como a maior do Brasil até 1910. Pertencente a Antonio Álvares Penteado, cafeicultor e industrial, era nela, a propósito, conforme Relatório do Departamento Estadual do Trabalho, onde se empregava, em 1912, a maioria dos espanhóis operários ${ }^{17}$.

O clássico trabalho A indústria no Estado de São Paulo, de Bandeira Jr., datado de 1901, à luz do exaustivo levantamento realizado no parque industrial então existente, introduz novos elementos nessa polêmica. Nesse inventário, o autor que percorreu os estabelecimentos industriais então existentes no Estado, atribuía o seu progresso ao "espírito empreendedor do paulista e à imigração italiana"18, destacando contudo que, no tocante à Capital, era “incalculável o número de tendas de sapatarias, marcenarias, fábricas de massas, de graxa, de óleos, de tintas de escrever, fundições, tinturarias, fábricas de calçados, manufaturas de roupas e chapéus, que funcionam em estalagens, em fundos de armazéns, em resumo: em lugares que o público não vê"'19.

Lino de Mattos $^{20}$, com base no trabalho de Bandeira Jr. procedeu, para os 108 estabelecimentos inventariados no Estado, a distribuição setorial por proprietários, brasileiros e estrangeiros (vide Tabela 11), esclarecendo que somente 4 das indústrias eram anteriores a 1870 e que outras 41 haviam sido fundadas entre os anos de 1870 e 1890, concluindo, em outras palavras, que o arranque do progresso industrial do Estado, coincidindo com a maciça entrada de imigrantes, havia ocorrido após o ano de 1890.

\footnotetext{
15 Também cf. SODRÉ, Nelson Werneck. Formação histórica do Brasil. São Paulo: Brasiliense, 1963 (3ª ed.), p. 336 e PRADO JR., Caio. História econômica do Brasil. São Paulo: Brasiliense, 1974 (17ª ed.).

${ }^{16}$ DIEGUES JR., M. Op. cit., 1964, p. 235.

${ }^{17}$ LEME, M. Op. cit., 1984, p. 254.

${ }^{18}$ BANDEIRA JR., A. Op. cit., 1901, p. X.

${ }^{19}$ BANDEIRA JR. Op. cit., p. XI.

${ }^{20}$ MATTOS, Dirceu Lino de. Op. cit., 1954, p.13.
} 
Tabela 11. Parque industrial paulista, 1901

\begin{tabular}{lccc}
\hline \hline \multicolumn{1}{c}{ Tipos de Indústria } & \multicolumn{2}{c}{ Proprietários } & Total \\
\hline Alimentação & 6 & 16 & $\mathbf{2 2}$ \\
Artigos de vestuário & 8 & 10 & $\mathbf{1 8}$ \\
Metalúrgicas e Mecânicas & 7 & 6 & $\mathbf{1 3}$ \\
Químicas e Farmacêuticas & 6 & 6 & $\mathbf{1 2}$ \\
Têxteis & 4 & 6 & $\mathbf{1 0}$ \\
Gráficas & 0 & 6 & $\mathbf{6}$ \\
Vidros e Cristais & 1 & 2 & $\mathbf{3}$ \\
Diversos & 6 & 18 & $\mathbf{2 4}$ \\
\hline Total & $\mathbf{3 8}$ & $\mathbf{7 0}$ & $\mathbf{1 0 8}$ \\
\hline \hline Fonte: MATTOS, Dirceu Lino de. Op. cit., p.13.
\end{tabular}

Há realmente indícios concretos de que, em seus primórdios, muitas indústrias pertencentes a imigrantes existiram como fabriquetas, segundo o comentário de Heitor Ferreira Lima a propósito do levantamento de Bandeira Jr.: "todas estas oficinas e pequenos estabelecimentos manufatureiros, alguns não ocupando trabalhadores a não ser o proprietário e membros de sua família, aqui catalogados como fábricas" se situam "longe, em muitos casos, desta verdadeira denominação, na acepção que hoje se dá ao termo..."21. Contudo, parece apropriado ressaltar uma outra questão qual seja, a de que os estabelecimentos controlados pelos fazendeiros, ainda que pouco numerosos, diferentemente daqueles iniciados pelos imigrantes, eram os maiores, face aos vultuosos capitais originários das lucrativas safras de café. Em 1895, Antonio da Silva Prado, fazendeiro e acionista da Cia. Paulista de Estrada de Ferro funda a Vidraria Santa Marina - considerada a primeira fábrica de garrafas do Brasil que empregará muitos imigrantes, dentre eles espanhóis - e em 1889 o Curtume Água Branca para cuja matéria-prima contava com sua própria criação de gado. Transforma-se, em 1899 no primeiro prefeito da cidade, permanecendo no cargo até 1911. Também Lacerda Franco, fazendeiro e corretor de café, dono do Banco União (1890), abriu a Estamparia e Alvejaria Votorantim, em 1894 e outra indústria têxtil em Jundiaí. A Cia. Antárctica, fundada em 1891, tinha como acionistas majoritários Campos Sales, Teodoro Sampaio, Asdrúbal do Nascimento, A. Rocha Miranda e P. França Pinto, enquanto Zerrener, Büllow \& Cia. tinham apenas 1\% das ações.

Para Mamigonian, que analisou detalhadamente a constituição de cada uma dessas primeiras indústrias têxteis, acabando por concluir que, de fato, elas pertenceram à aristocracia 80.

${ }^{21}$ LIMA, Heitor Ferreira. Evolução industrial de São Paulo e outros estudos. São Paulo: Martins, 1954, p. 
rural, a iniciativa dos fazendeiros na gestão das suas indústrias mostrou-se desastrosa, com quase a maioria perdendo seus negócios ${ }^{22}$. De todo modo, esclarece, o papel dos imigrantes, em sua maioria lavradores, mas também artesãos e comerciantes - que preferiram emigrar pelo esvaziamento da vida econômica de muitas regiões agrícolas (italianas, no caso) ${ }^{23}$, provocado pela saída em massa de seus habitantes - que aqui vieram refazer suas vidas, foi fundamental, num primeiro momento, como sólido mercado consumidor da indústria paulista e, naturalmente, como mão-de-obra.

Seja como for, e sem pretender alongar infinitamente a discussão acerca dessa problemática, tarefa que excederia os limites e propósitos desse trabalho, buscaremos singularizar, dentro das limitações impostas pela documentação, alguns casos protagonizados pelos espanhóis, os quais, de per se, podem oferecer elementos adicionais para o exame da questão.

Com efeito, e retomando o Capítulo I, lembremos de que no primeiro decênio considerado, iniciado em 1893 - quando então, conforme vimos, os espanhóis representariam apenas $3,7 \%$ da população total da cidade, representada por $45 \%$ de italianos -, a análise ao banco de dados do CGE indicou uma crescente participação de elementos com ocupación declarada de " $p$. industrial" e "industrial", número que tendeu a dobrar no segundo decênio e praticamente quadruplicar, quando contabilizado o período referido aos últimos dez anos investigados, isto é, de 1913 a $1922^{24}$. Essa indicação, apenas quantitativa, já seria significativa mesmo como dado bruto: afinal são parcos os indícios que orientam qualquer inferência nessa direção. Raras e superficiais são as menções a esse grupo no exercício de qualquer atividade dessa natureza. De todo modo, se a mera indicação da existência de um restrito, porém crescente, grupo de industriais espanhóis na cidade, já significa um avanço e um importante componente a ser considerado, esse dado bruto pouco esclareceu sobre a origem dos capitais empregados, a natureza da inversão e em que setores atuavam, a composição da empresa, se societária ou não, sua dimensão, enfim, componentes qualitativos cujos aspectos puderam em parte ser apreendidos e examinados a partir da segunda década, mais precisamente a partir de 1912 quando, para sua avaliação, passamos a nos valer do cruzamento do banco de dados do

${ }^{22}$ MAMIGONIAN, Armen. "O processo de industrialização em São Paulo”. In: Boletim Paulista de Geografia. São Paulo: nº 50, 1976, pp. 83-101. A propósito, e conforme demonstrou Warren Dean, dos 9 cotonifícios fundados pelos fazendeiros até 1910, 7 deles já estavam no controle de imigrantes em 1917.

${ }^{23}$ Idem, ibidem, pp. 90-91. O autor cita os exemplos de F. Matarazzo, comerciante em Castellabate; de A.Pereira Ignácio, filho de sapateiro, em Baltar; J. Palermo, sapateiro em Trechina, na Calábria e R. Crespi, de Milão, então representante comercial de tecidos, dentre outros mencionados.

${ }^{24}$ Relatório Access 8. 
EDE (anúncios publicitários e matérias de outra natureza) com elementos captados nos registros do CGE.

No entanto, em que pesem as dificuldades e as restrições para o acompanhamento da maioria dos casos que se apresentaram como passíveis de análise, ainda assim alguns indicadores importantes foram evidenciados, primeiro quanto à sua origem, mas também quanto à sua trajetória anterior, do que nos valemos também dos dados constantes na Tabela Cumulativa.

Sua proveniência inicial, no primeiro decênio destacado, indicou que em sua composição se enfileiravam indivíduos originários de diversas Regiões espanholas, apresentando, contudo, uma tendência que se acentuará no segundo e no terceiro decênios, a da composição majoritária de originários da Andaluzia, com 42\% - especialmente de Málaga e Granada - Região que, como já apontamos, compunha o grosso da população espanhola da cidade, reunindo acentuado percentual de jornaleros, associando-se, em decorrência, ao perfil do emigrante com menor capacitação e qualificação técnica. Nesse particular, parece oportuna a apreciação de que "o europeu de classe inferior que fosse empreendedor, descobria que a sociedade paulistana oferecia então considerável capilaridade econômica e mesmo social" ${ }^{, 25}$, sendo bastante provável que a essa característica se possa atribuir a constituição dessas primeiras (pequenas) indústrias, das quais lamentavelmente os dados são escassos.

Seguindo-se à Região andaluza, porém com percentual bastante inferior, encontramos a da Catalunha, encabeçada por Barcelona, apresentando-se com 15,8\% desse contingente, a que se seguiu a Região de Navarra, com 10,5\%, a de Valencia, com 7,9\% e só depois encontramos a Galícia, apresentando-se com 5,3\% desse total.

Assim, de posse desses indicadores apenas quantitativos buscamos examinar a tabela de registros cumulativa do CGE, tentando viabilizar o acompanhamento de alguns casos individuais. $\mathrm{O}$ complemento a essa sondagem mostrou-se exequível em alguns casos mediante o cruzamento com dados obtidos no EDE, permitindo, assim, embora em pequenos fragmentos e nem sempre de modo linear, evidenciar alguns elementos que singularizaram ou tipificaram o percurso de alguns desses indivíduos.

Para ilustrar, conforme observamos em alguns casos, ao exercício da atividade de pequeno industrial e de industrial pode ter antecedido o da atividade comercial - do mesmo modo que observamos o inverso ocorrer em alguns casos. Porém, e isso pareceu pontuar muitos casos, o exercício de determinados ofícios autônomos esteve na gênese de muitas pequenas

\footnotetext{
${ }^{25}$ MORSE, Richard M. Op. cit., 1954, p. 189.
} 
fabriquetas. Podemos citar, por exemplo, o caso de José Aguilera, natural de Barcelona que, pela primeira vez no CGE, em 1894, declarou-se marmolista para, 11 anos depois, em outro registro, declarar-se industrial, dado que permite conjecturar acerca das condições materiais alavancadas a partir do exercício desse ofício por anos seguidos, cujo investimento aplicou na abertura do seu próprio negócio. São inúmeros casos pessoais assemelhados a esse que, revelados pela documentação do CGE, se validam pelos indícios levantados no exame da documentação periodística. Ainda assim, a análise, ao privilegiar os negócios que, por sua própria condição financeira ou outros envolvimentos de seus proprietários na esfera social, tiveram a prerrogativa de arcar com o custo da propaganda veiculada pelo jornal, pode estar obscurecendo inúmeras iniciativas de menor porte ou incipientes.

De modo geral, salvo poucas exceções, o espanhol buscou aplicações em empresas relacionadas a bens de consumo direto - alimentos, chapéus, colchões, móveis, têxteis, calçados e cigarros - que se amoldavam às necessidades mais imediatas de um nascente mercado consumidor, funcionavam com tecnologia simples e para cuja constituição não necessitavam de grandes investimentos iniciais. É provável que alguns, aproveitando-se das dificuldades impostas pelo conflito mundial na importação de produtos, tenham aberto ou expandido negócios já existentes. $\mathrm{O}$ acirramento na veiculação da propaganda de determinados produtos naquele período pode ser indicativo relevante. Contudo, a par dessas oficinas e indústrias de bens de consumo imediato que constituíram a maioria, é visível a emergência de uma indústria paralela de artigos e objetos mais ao gosto de uma população endinheirada, como a de móveis "finos" e instrumentos musicais, por exemplo.

Destacando-se de imediato do conjunto por diversos indicadores, pudemos perceber muitos deles envolvidos com a indústria de calçados. Tratou-se, com efeito, de um dos ramos mais prestigiados pela propaganda levada a efeito no período, do qual há evidencias comprovando que, em alguns casos, toscas oficinas operando inicialmente no próprio domicílio evoluíram para fábricas de calçados de porte variável e, mais que isso, que o ofício de zapatero, um dos mais citados no CGE, esteja na sua origem.

O embrião da fabriqueta de calçados pertencente a Antonio Gimenez e Ângelo Guerrero - A. Gimenez \& Comp., instalada na Rua do Gasômetro, $\mathrm{n}^{\circ} 21$ em 1920²6, já existia em $1894^{27}$ na Rua Tenente Morais, 19, domicílio do primeiro, citado no CGE. Zapatero, Gimenez, ou melhor, Antonio Gimenez Paes, natural de Málaga, tinha então 42 anos. A sua

\footnotetext{
${ }^{26} \mathrm{EDE}$ 02.05.1920.

${ }^{27}$ KLEIN, H. Op. cit., 1995, p. 95.
} 
associação posterior com Ângelo Guerrero parece sugerir uma composição típica dessas empresas, na qual um dos sócios ingressava com o capital, e o outro com o conhecimento do ofício, o chamado "sócio-trabalho". Mas pode, ocasionalmente, indicar uma ampliação do negócio, com o ingresso de mais capital.

O anunciante sapateiro mais antigo que localizamos foi Miguel Bolaño, proprietário da Zapatería Española, localizada à Rua S. Francisco, $230^{28}$, contudo foi na Rua do Gasômetro que encontramos a maior parte das fábricas de calçados pertencentes aos espanhóis, a qual junto com a Avenida Rangel Pestana, concentrou, neste período, o grosso do comércio do Brás.

Instalado em 1918 com a sua Fábrica de Calçados Grand Prix, na Rua do Gasômetro, $n^{\text {o }}$ 25, Juan Espejo ${ }^{29}$, natural de Múrcia, anteriormente, em 1908 - com 25 anos de idade, solteiro e então residente à Rua da Moóca, 19, Chácara Osório - havia se declarado zapatero em inscrição no CGE, numa clara indicação da escalada que promovera em 10 anos.

No $n^{\circ} 71$ da mesma rua, localizamos a Fábrica de Calçados Royal, de Lucas Tabuenca $^{30}$, natural de Zaragoza, conforme registro no $\mathrm{CGE}^{31}$; no no 95 , e instalada desde 1904 pelo menos, ano em que aparece com anúncio no LTE, a El Cánon, especializada em calçados sob medida ${ }^{32}$ pertencia a Juan Navajas, natural de Burgos, o qual, em registro no CGE datado de 1897, quando ainda residia em Mogi das Cruzes, afirmara ser zapatero. Seu irmão, Basílio Navajas, registrado na mesma ocasião e residente na mesma localidade, também se declarou zapatero.

Ainda na Rua do Gasômetro, em dois endereços, nos nº 110 e 112, a Grande Fábrica de Calçados Bebe, de Juan Rivero ${ }^{33}$. Esse industrial, natural de Granada, residia na Rua do Carmo, 69, e havia perdido quase toda a família (mulher, quatro filhos, um neto, um sobrinho), na gripe espanhola ${ }^{34}$.

A Fábrica de Calçado Oriental, de A. Ornila (ilegível), funcionava na Avenida Rangel Pestana, $n^{\circ} 139$, e seria, por certo, uma empresa de médio porte, a considerar a anunciada festa programada por seu proprietário aos funcionários, a realizar-se no Bosque da Saúde, local onde, à época, se realizavam piqueniques ${ }^{35}$. Também no Brás, a Fábrica de Calçados Fernandez e Hijo "especializada em calçados finos para senhoras e crianças" funcionando na rua

\footnotetext{
${ }^{28} \mathrm{EDE}$ 04.08.1913.

${ }^{29}$ EDE 01.01.1918.

${ }^{30}$ EDE 02.05.1920.

${ }^{31}$ LRC 1920, 1921, 1922.

${ }^{32}$ LTE 09.01.1904.

${ }^{33}$ EDE 02.05.1920.

${ }^{34}$ EDE 18.12.1918.

${ }^{35}$ EDE 01.04.1918.
} 
Wandenkolk, 47 e a Fábrica de Calçados Sul-Americano, de Antonio España instalada na Rua Santo André, 28 e 30- $\mathrm{A}^{36}$. O ofício acompanhava a família España havia algum tempo. Ramón España y Hermano, em 1904, eram os proprietários da La econômica, fábrica de alpargatas e sapatos de lona, então localizada à Rua Rangel Pestana, $53^{37}$. No entanto, dez anos antes, em 1894, ambos, Antonio e Ramón, naturais de Málaga, declararam-se tejedores, ou seja, tecelões e provavelmente operários de alguma fábrica de onde, possivelmente montando uma sociedade e com um pequeno capital, partiram para seu próprio negócio, investindo no ramo de calçados de lona, aproveitando-se para tanto da experiência adquirida no setor de tecelagem. Em finais da primeira década, já então se declarando comerciantes, mantinham com regularidade os anúncios de sua fábrica no EDE.

A confecção de alpargatas, calçado mais popular e, portanto, mais acessível às camadas socialmente inferiores, era um negócio que florescia, impulsionado pelos anúncios publicitários exibidos cada vez com maior assiduidade no EDE. Em sua maioria funcionando no Brás, local onde residia a massa de população pobre de São Paulo, esse calçado, mais barato, era muito utilizado. Geraldina Marx, na descrição do personagem Garcia, carroceiro espanhol que trabalhava recolhendo resíduos pelas ruas da cidade, comentava que ele "arrastava as alpargatas de corda que pesavam como chumbo" 38 .

Em 1898, José Cerdán, um alpargatero de Málaga, casado, dirigiu-se ao CGE para realizar o seu registro. Indicou como domicílio a Rua Carneiro Leão, $\mathrm{n}^{\mathbf{o}} 2$, local onde possivelmente também funcionasse sua incipiente oficina. As primeiras décadas iriam revelar espanhóis como proprietários de diversas fábricas de alpargatas, dentre as quais algumas de porte razoável e já apresentando um produto mais bem acabado, mais sofisticado ${ }^{39}$ : a Fábrica de Alpargatas de José Mesa, por exemplo, também instalada na Rua do Gasômetro, no no 104, comercializava, além do produto acabado, os solados trançados e "artigos referentes a esse ofício, como tranças feitas à máquina” ${ }^{\star 40}$. De seu filho José Mesa Hijo (sic), provável sucessor nos negócios, a Gran Fábrica de Alpargatas, "movida à eletricidade", tinha produção diária de 90 dezenas de pares, e estava instalada na Rua Maria Domitila, 105. A Alpargatería de Miguel Morales, na Rua Carneiro Leão, 9, operava “com depósito de tranças e de todo material para a

\footnotetext{
${ }^{36} \mathrm{EDE}$ 02.05.1920.

${ }^{37}$ LTE 09.01.1904.

${ }^{38}$ MARX, G. Op. cit., p. 39

${ }^{39}$ Indício da hegemonia dos espanhóis no ramo da fabricação de alpargatas é a existência, ainda em funcionamento, no Bairro do Brooklin, da Alpargatería Cervera, pertencente a descendentes de espanhóis.

${ }^{40}$ EDE 28.06.1918. Trad. da autora.
} 
fabricação de dito artigo"41 . Na mesma rua, Carneiro Leão, no n 56, a Fábrica de Alpargatas de Eusebio Murillo, fabricava "alpargatas imitação, e de primeira qualidade" mantendo “depósito de todo o material do ramo" "42. A trajetória de Eusébio Murillo Continenti é exemplar: natural de Zaragoza, esteve por diversas vezes no CGE, a primeira em 1912, declarando-se então jornalero e, depois, alpargatero até transformar-se em p. industrial, em 1921.

Setores complementares, para abastecimento das alpargatarias, passavam a funcionar, caso da Torcedora La valenciana, de Orozco y Blanes, que produzia "cordas, bramantes e [era] especializada em cordas de juta"43 e a Fábrica de cordelería pertencente a Francisco Amaro Jr., instalada na rua Vicente de Carvalho, $47^{44}$.

Correlato ao de calçados, o ramo da fabricação de chinelos manteve-se em alta crescente no período, provavelmente pelo baixo custo desse tipo de calçado. Não por acaso, a fábrica de chinelos existente na Rua 25 de março, 76, necessitando aumentar a produção para expandir suas vendas solicitava "cortadores e oficiais"45 pelo EDE, em 1912.

Concentrada basicamente no Brás e em particular na Rua do Gasômetro uma das principais ruas de comércio daquele populoso bairro e em suas adjacências, a pequena indústria calçadística deve ter sido daquelas atividades bastante representativas da colônia. Uma das transversais da Rua do Gasômetro, a Rua Vasco da Gama, é hoje significativo pólo atacadista de matéria prima para sapatos e bolsas, com larga concentração de produtos derivados de couro e materiais correlatos. A concentração de espanhóis no bairro, significante, justificava os três primeiros pontos de venda do EDE instalados na cidade no ano de 1913, dois dos quais em fabricantes de calçados, pontos estes que, conforme Nelson Werneck Sodré, eram disputadíssimos $^{46}$ : na Zapatería española (Rua Maria Marcolina, 151); na Alpargatería española (Rua Monsenhor Anacleto, 96) e um terceiro, na Distribuidora de bebida Antonio Sancha (Av. Celso Garcia, 139).

A indústria alimentícia compôs outro dos ramos básicos da produção industrial da Primeira República. Constituindo-se em geral de pequenos estabelecimentos, o espanhol que investiu nesse setor preferiu dedicar-se à produção de uma culinária típica em atendimento à demanda então existente. Especializou-se, sobretudo, na fabricação de doces.

\footnotetext{
${ }^{41}$ EDE 16.03.1920.

${ }^{42}$ EDE 16.03.1920. Trad. da autora.

${ }^{43}$ LTE 09.01.1904. Bramante: barbante muito fino feito de cânhamo. Trad. da autora.

${ }^{44}$ EDE 17.01.1918.

${ }^{45}$ EDE 22.03.1912.

${ }^{46}$ SODRÉ, Nelson Werneck. História da imprensa no Brasil. Rio de Janeiro: Civilização Brasileira, 1966, p. 260.
} 
Nas páginas do EDE foi comum encontrar pequenos estabelecimentos produtores de alimentos então requisitando "camaradas" e "aprendizes". Desses, um anúncio pertencia à fábrica de galletas (biscoitos) localizada na Rua Conceição, 93- ${ }^{47}$. Dentre os produtos fabricados, A Imperial, indústria de biscoitos com sugestivo nome fantasia produzia, desde $1912^{48}$, as Orejas de Abad ${ }^{49}$, iguaria que anunciava em grandes anúncios. Fabricando a “incomparável ensaimada de Mallorca”, Boz \& $\operatorname{Hermanos}^{50}$, operavam a sua fábrica de doces e guloseimas na Rua Oriente, 67 e Juan Bobadilla - cujo prenome, nos anúncios do EDE, foi sendo aportuguesado para simplesmente "João"-, mantinha a Gran Fábrica de Bolachas $e$ Balas especializada em "biscoitos e bolachas finas", com "fabricação de confites ${ }^{51}$, caramelos $^{52}$, bombones, turrones de almendras e crocantes", produtos oferecidos à clientela em “caixas à fantasia" para a época do natal ${ }^{53}$. Ocorrido aliás em sua fábrica, o acidente de trabalho que resultaria em incapacidade parcial permanente do operário brasileiro Adolpho Indalécio, foi objeto de apelação cível, conforme relata em seu trabalho Esmeralda B.B. de Moura ${ }^{54}$. Bobadilla, além de proprietário da fábrica, acumulava funções de comerciante e importador, mantendo seção de gêneros nacionais e estrangeiros, especialmente espanhóis e portugueses ${ }^{55}$ e de tabacos ${ }^{56}$. Também negociava com cereais, que recebia em consignação, comissão e conta própria, ilustrando característica peculiar do período, a do exercício cumulativo de diversas atividades, muitas vezes não correlatas.

Seus escritórios localizavam-se na Rua Júlio Conceição, 35, em local distinto da fábrica e dos depósitos, então à Rua dos Italianos, 67, 69 e 73. A União Hispano-Brasileira Collazos, Bobadilla \& Gonzalez, importadora que passa a atuar no ramo de máquinas de beneficiar café e arroz e moinho de fubá, no mesmo endereço anterior, traduz uma sociedade constituída para fortalecer e ampliar seus negócios de importaçãa ${ }^{57}$. Transitava na camada mais prestigiada da colônia, acabara de ser eleito tesoureiro do CE, participando e encabeçando com freqüência subscrições abertas em benefício de alguma causa, ocasiões em que chegava a doar até um

${ }^{47}$ EDE 26.06.1912.

${ }^{48}$ EDE 22.10.1912.

${ }^{49}$ Oreja de Abad: guloseima de massa frita.

${ }^{50}$ EDE 21.10.1913. Ensaimada de Mallorca: bolo de massa folhada, em forma de espiral ou caracol. Manuel Boz Martin era natural de Málaga. LRC 1921.

${ }^{51}$ Confites: guloseimas em geral.

${ }^{52}$ Caramelos: balas.

${ }^{53}$ EDE 04.11.1921.

${ }^{54}$ MOURA, E. Op. cit., 1984, pp. 176 e ss.

${ }^{55}$ Oferecia: vinhos da Rioja e finos de Jerez, azeitonas, azeites, sardinhas e navalhas de Albacete, conservas e rolhas.

${ }^{56}$ Oferecia marcas especiais de tabaco em corda: Poço Fundo; Moreira; Carangola; Corina; Ouro Fino; Tacape e cigarros da Fábrica Castellões, especialmente os da marca Goal e Aurora.

${ }^{57}$ EDE 02.05.1922. 
conto de réis geralmente em favor "de las víctimas de la guerra de Marruecos" iniciativa da Caixa de Socorros do $\mathrm{CE}^{58}$. Fazia-se acompanhar, nessas ocasiões, de outros membros de prestígio da colônia que também destinavam generosas doações em campanhas e atos comemorativos, depois divulgados pelo EDE.

Às famílias dessas figuras de projeção que participavam dos mais importantes eventos festivos da colônia também era dedicado espaço especial no EDE, do qual fazia parte Cândida Bobadilla, sua filha que, em coluna ilustrada, aparecia de leque nas mãos e mantilha na cabeça, por ocasião da comemoração do "Dois de Maio",59.

Outros proeminentes comerciantes e industriais a ele se juntavam nessas ocasiões, como Joaquim Collazos $^{60}$, seu sócio na firma União Hispano-Brasileira, e proprietário da Casa Pio $X$, na Rua Direita, com confecção de bordados e venda de artigos religiosos e vinhos finos. Galego de Coruña, Collazos que saíra "em viagem de recreio"61 para Barcelona com seu amigo Juan Llaverías, industrial lá nascido, era saudado no retorno pela coluna "Viajeros distinguidos", seis meses depois ${ }^{62}$. Tais indivíduos compunham a "nata" favorecida da colônia, que costumeiramente viajava de férias para a Europa, onde permanecia por até seis meses. Joaquim Collazos, sócio de Bobadilla, residia na Avenida Paulista, 139, quando, em 1918, ocuparia por algum tempo o cargo de vice-cônsul na Capital de São Paulo, do qual se demitiu, sendo substituído por Perfecto Ares ${ }^{63}$.

Juan Llaverías, o outro "viajero distinguido" nascido em Barcelona era industrial e proprietário de uma fábrica de móveis de luxo, com loja na Rua Barão de Itapetininga, 58 (fábrica na Rua Sérgio Meira, 16, na Barra Funda). Juan Mestres Llaverías e seu irmão Francisco, ambos marceneiros, registraram-se no CGE pela primeira vez em janeiro de 1900 . O primeiro tinha 33 anos, o segundo, 24. Residiam então na Rua São João, 149. Nos dois registros seguintes, de 1906 e 1913, Juan Llaverías declarou-se industrial, residindo na Rua São João, 225 com a família composta de mulher e três filhos; no registro de 1915, declarou-se

${ }^{58}$ EDE 27.10.1921. A quantia arrecadada nesta ocasião específica, de 5:211\$000 seria depositada no Banco Comércio e Indústria em favor de Pedro Cavanilles então cônsul geral. Às famílias dos mortos em combate na Guerra de Marrocos residentes no Brasil, era solicitada, através de correspondência do cônsul ao Ministro de Estado espanhol, a pensão correspondente, cujos valores desconhecemos. Porém, a demanda era morosa, haja vista a quantidade de missivas enviadas referentes a um mesmo oficial. No caso da família de Eduardo Muellas Corbella, $2^{\circ}$ Tenente de Infantaria falecido em combate em julho de 1909, a comunicação da concessão somente aconteceu em dezembro de 1912. AMAE. H-2048. Série Brasil. Correspondencia Embajadas y Legaciones. Correspondência entre o Cônsul Emilio da Mota e o Ministro de Estado Espanhol, de 21.02.1911; 29.04 e 19.12.1912.

${ }^{59}$ EDE Edição Especial de 02.05.1922.

${ }^{60}$ Diferentemente de Juan Bobadilla Marin que era natural de Rioja, Joaquim Collazos Fariñas era galego de Coruña. LRC 1913, 1919, 1921e 1922.

${ }^{61}$ EDE 07.04.1913. Trad. da autora.

${ }^{62}$ EDE 29.10.1913. Trad. da autora.

${ }^{63}$ EDE 30.08.1918. Trad. da autora. 
comerciante, indicando o endereço da Rua Barão de Itapetininga, 58, onde se situava a loja da fábrica de móveis, pelos anúncios do EDE.

Também catalão de Barcelona e vizinho de seu conterrâneo na mesma Rua São João, M. Torné operava a Gran Fábrica de Confecciones de Ropas para Señoras y Ninas, onde fabricava "manteaux, gabanes" ${ }^{64}$ chaquetas $^{65}$, batas $^{66}$, blusas, vestidos completos, delantales ${ }^{67}$ e infinidad de artículos pertenecientes al ramo ${ }^{68}$. "La Barcelonesa", nome fantasia que homenageava sua cidade natal, era anunciante do EDE desde as primeiras edições consultadas, em $1912^{69}$.

Assíduo freqüientador das colunas do EDE, Félix Zambrana ${ }^{70}$, comerciante de tecidos "a varejo e atacado" estabelecido na Rua do Gasômetro, 19, como seu colega Bobadilla freqüientemente era visto nas listas de subscrição realizando generosas doações. Sua esposa, Remédios, e suas filhas Encarnación e Dolores, atuantes na Caixa de Socorros, faziam parte do grupo de mulheres que participava das "festas de caridade" realizadas no $\mathrm{CE}^{71}$ e Zambrana, anos depois, seria eleito tesoureiro da $\mathrm{FE}^{72}$.

No ramo do comércio fino os Hermanos Funcia - Angel, Francisco e Sebastian, naturais de Zamora - se destacavam com A Cearense, casa de encajes (rendas/passamanarias), com sortimento de rendas e bordados, aplicações, cobre jarra e bandeja, tudo "feito à mão", localizada na Rua Sebastião Pereira, 14 ${ }^{73}$. Há menos de dez anos, Angel Funcia em 1912 quando tinha 23 anos, e seu irmão Francisco em 1913 com 20 anos, haviam se declarado, ambos, jornaleros no primeiro registro que efetuaram no CGE.

Outras figuras de destaque, algumas se declarando industriais nos LRC transitavam com freqüência nas páginas do EDE, em artigos e matérias divulgando sua participação em eventos, geralmente vinculada às sociedades beneficentes ou referindo-se a doações que realizavam em benefício de alguma causa. Suas viagens a Europa quer a passeio, quer para o estabelecimento de contatos comerciais, geralmente com produtores espanhóis para a importação de comestíveis e bebidas, eram precedidas de notícias que detalhavam o roteiro e o

\footnotetext{
${ }^{64}$ Gabanes: roupa masculina, túnica de homem, sobretudo.

${ }^{65}$ Chaqueta: paletó, casaco.

${ }^{66}$ Bata: bata, guarda-pó, roupão, robe. Utilizado pelas mulheres na Espanha enquanto estão em casa.

${ }^{67}$ Delantal: avental.

${ }^{68}$ EDE 23.11.1912 e várias outras edições posteriormente. A Fábrica situava-se na Rua São João, 247.

${ }^{69}$ Manuel Torné Berenguer, natural de Barcelona, registrou-se no CGE em 1912; tinha então 29 anos e informava ser comerciante. LRC 1912.

${ }^{70}$ Félix Zambrana Valle, natural de Cádiz, casado, 42 anos. LRC 1921.

${ }^{71}$ EDE 08.08.1920.

${ }^{72}$ EDE 07.05.1922.

${ }^{73}$ EDE 02.05.1922.
} 
motivo da viagem. O comerciante e importador Raimundo Díez, por exemplo, em 1913 comunicava sua viagem a "várias capitais européias" para "tratar da compra de artigos para seus armazéns" ${ }^{\text {"74 }}$. Outra nota de viagem, esta de 1920 cientificava de outra viagem sua à Europa "pelo Vapor Lamburgia", desta feita "acompanhado de suas filhas" com a finalidade de "se reunir com a esposa, Manolita que lá se encontra"75.

Em 1914, José Garcia "rico proprietário e comerciante nesta capital”, embarcava “de férias" para Valladolid ${ }^{76}$, sua terra natal. José Garcia Dominguez fez sua primeira inscrição no CGE em 1905, quando então se declarou comerciante. Em um dos registros seguintes, o de 1916, citou a cidade de Palmital como domicílio, acrescentando a informação "serraria". Em 1919 nota no EDE comunicava sua mudança para a Capital, onde "passará a residir, na Rua Vergueiro, 190” e se encontrará “à disposição das pessoas com quem tem relações comerciais e dos amigos",77. É bastante provável que Garcia, agora residindo na "cidade", à moda dos barões de café, dali passasse a gerir seus negócios no interior. Residindo na cidade, aumentavam seus tentáculos de prestígio: meses depois, neste mesmo ano de 1919, outra nota no EDE informava da realização da Assembléia da LDE para a eleição da junta diretiva, onde ocuparia o cargo de Presidente $^{78}$.

A gastronomia espanhola é diversificada e rica. Alguns hábitos alimentares transportados pelos espanhóis foram mantidos nas primeiras décadas do Novecentos quando pratos e comidas típicas eram consumidos no reduto dos lares ou em pequenas barraquinhas para comercialização e quando alguns dos itens foram recriados pelas indústrias alimentícias que se estabeleceram na cidade ou mesmo importados no atendimento a uma camada de maior poder aquisitivo.

Na Festa de Casaluce "a santa dos italianos", realizada na Rua Caetano Pinto, por exemplo, na barraquinha de churros dos espanhóis havia "regurgitação e movimento notáveis". No período de natal, as donas de casa preparavam alguns doces típicos, como os borrachuelos $^{79}$ e os mantecaus. Na semana santa, o espanhol não passava sem o bacalhau em suas diversas variações, muitas vezes feito em bolinho frito e servido com a sopa de grão de bico ou puchero. Como bebida, a tradicional sangria, feita com vinho, compunha o cardápio adotado nas datas

\footnotetext{
${ }^{74}$ EDE 02.06.1913. Trad. da autora.

${ }^{75}$ EDE 21.05.1920. Trad. da autora.

${ }^{76}$ EDE 31.03.1914. Trad. da autora.

${ }^{77}$ EDE 24.04.1919. Trad. da autora.

${ }^{78}$ EDE 18.10.1919.

${ }^{79}$ Borrachuelo: bolinho com farinha, erva-doce, açúcar e pinga. Cf. MARX, G. Op. cit., p. 139.
} 
especiais, nas festas, na Páscoa e nos Natais pela maioria dos imigrantes ${ }^{80}$. O pão "era sagrado" às refeições, conforme a narrativa dos espanhóis de Villa Novaes, observação, aliás, reiterada por Ernani da Silva Bruno ${ }^{81}$. A tortilla ${ }^{82}$ permaneceu ainda por muito tempo como hábito alimentar do imigrante pobre, talvez por se constituir prato de baixo custo, diferente de muitos outros, cujos ingredientes certamente pesavam no orçamento de uma família de poucos recursos. Isto certamente não constituía problema para a família de Juan Llaverías, cuja esposa, Rosa, assídua nas colunas sociais do EDE, costumava festejar o dia do seu santo "abrindo a casa para suas numerosas relações de amizade, para que todos fossem obsequiados com um esplêndido lunch" ${ }^{, 83}$.

Os empreendimentos eram gestados com dificuldades, mas sobretudo com tirocínio empresarial. Explorando o jogo de bilhar que disseminava na cidade, praticado por todas as esferas sociais, muitos pequenos comerciantes improvisavam, num mesmo local, a venda de bebidas e vinhos e a exploração do jogo. Na Rua General Osório, 69, por exemplo, Saturnino Perez, mantinha uma mesa de bilhar no comércio de bebidas de Eliseo Alvarez e Benjamin Lopez $^{84}$, enquanto José Rueda, um cocinero de Málaga, que havia estado no CGE pela primeira vez em 1906, em 1913 era proprietário do Bilhares Internacional, na Avenida Rangel Pestana, $39^{85}$. De maior porte e para clientela mais seleta, o Majestic Bilhar, de Antonio Garcia, inaugurado em 1914, estava instalado no “antigo salão de banquetes da Rotisserie Sportsman”. Com doze bilhares, o serviço de salão também se encontrava nas mãos de um espanhol, José Torrens, conforme anunciava no $\mathrm{EDE}^{86}$.

Em função dos modismos de ocasião, os pequenos empresários, sempre sequiosos de oportunidades, procuravam adaptar-se visando um melhor retorno financeiro. Instalado com sua fábrica de móveis finos de luxo, torneiras e tornearia ${ }^{87}$ na Rua dos Gusmões, 49, telefone 1894 , a Estepa, Blois \& Cia. passa também a produzir e a divulgar regularmente pelo EDE a

${ }^{80}$ Idem, ibidem, pp. 47;139-140; 151; 205 e 225. Ver também: “Alimentação local, sabores espanhóis". In: CÁNOVAS, M. Op. cit. ,2005, pp. 286 e ss. e OLIVEIRA, S. Op. cit., 2002, p. 101, referindo-se aos hábitos alimentares dos antigos espanhóis de Sorocaba.

${ }^{81}$ BRUNO, E. Op. cit., 1991, p. 1355.

${ }^{82}$ MARX, G. Op. cit., p. 39.

${ }^{83}$ EDE 06.09.1921. Trad. da autora.

${ }^{84}$ EDE 15.04.1913. Trad. da autora.

${ }^{85}$ EDE 01.08.1913. Trad. da autora.

${ }^{86}$ Situava-se à Rua Líbero Badaró, 94, com entrada também pela São Bento, 61. EDE 26.01.1914. Trad. da autora.

${ }^{87}$ EDE 28.06.1913. Trad. da autora. 
fabricação paralela de mesas de bilhar, tacos, bolas de marfim e demais acessórios ${ }^{88}$, fabricação que lhe rendeu a medalha de ouro na Exposição Nacional do Rio de Janeiro.

Por meio das listagens de subscrições, adesões e doações em prol das mais variadas causas, podem ser reconhecidas as figuras mais proeminentes da colônia, comerciantes e industriais de variado porte e mesmo profissionais liberais. Nessa ocasião específica, em que se levantavam fundos para os soldados da guerra do Marrocos, causa inesgotável, também desfilou, com mais 500 mil réis de doação, Teófilo Saenz Mengarza que, em 1913 foi presidente da $\mathrm{FE}^{89}$. Sua trajetória não difere muito das demais a que tivemos acesso. Apareceu pela primeira vez nos LRC em 1911 como vidriero, residente na Água Branca (provavelmente empregado na Santa Marina), tinha 30 anos, casado, dois filhos e era natural de Navarra ${ }^{90}$. Nesta primeira década Saenz compareceu por diversas vezes ao CGE, porém apenas em 1920 declarou-se pequeño industrial, residente então na Rua Canindé, 45, porém, como não era anunciante publicitário do EDE, não foi possível identificar a que ramo de atividade se dedicava.

O crescimento da atividade comercial na cidade acompanhou de perto as mudanças nela introduzidas, intensificando-se e se diversificando continuamente. Pela via do comércio, importante meio de ascensão social e prestígio, os imigrantes alcançavam visibilidade e reconhecimento, muitas vezes não apenas entre seus conterrâneos. Muitos prósperos comerciantes adquirem status social de pessoas refinadas, passando a adotar hábitos de vida próprios da elite, que tentavam imitar.

Representando parcela considerável do conjunto de anunciantes do EDE no qual divulgavam com regularidade seus negócios, recebiam, em contrapartida, a cobertura do periódico para assuntos da esfera social, que lhes dedicava colunas exclusivas, caso da Viajeros distinguidos, da qual já comentamos, ou ainda da Españoles que triunfan. Tratava-se de uma relação de reciprocidade entre o anunciante e o veículo por ele prestigiado, da qual não podia faltar o público leitor, a quem em suma se dirigia não apenas o anúncio do produto, mas a própria figura do anunciante que, enaltecida pelo jornal, era associada à imagem do progresso e um exemplo a ser seguido para a ascensão social.

Nessa dimensão em que "imagem" e "aparência" se transformam em atributo de distinção social e de prestígio, alcançado mediante o acesso a determinados bens de consumo

\footnotetext{
${ }^{88}$ EDE 09.07.1920. Trad. da autora.

${ }^{89}$ EDE 07.04.1913. Trad. da autora.

${ }^{90}$ LRC 25.08.1911.
} 
mais refinados, comerciantes perspicazes passam a explorar esse filão simbólico de mercado. É o que ocorreu a Matias Lorenzo, outro assíduo subscritor e proprietário da casa homônima de "papéis pintados e depósito de vidros para cristalería e telhas de vidro, para clarabóias", situada na Rua São João, $253^{91}$, e cuja esposa Aurora Lorenzo, participava ativamente dos chásdançantes promovidos pelas senhoras da Caixa de Socorros do $\mathrm{CE}^{92}$. Os artigos que comercializava, como se observa, não eram para qualquer consumidor.

Dirigindo-se a seu público-alvo como "a casa que mais preferência tem merecido para as instalações dos melhores palacetes", a Casa Verde, de Antonio Soares \& Cia., instalada na Rua São Bento, 56 também definia um outro segmento emergente de mercado, muito bem representado na colônia pelo comerciante de cereais e importador Perfecto Ares, em cujo "palacete" recebia seus convidados em grande estilo. Oferecendo "o maior estoque de papéis para forrar paredes. Tapetes, peles, oleados, capachos, quadros, espelhos, cortinas, bris-bris, damasco [tipo de tecido]", além de fabricar "móveis estofados de qualquer estilo",93, Antonio Soares ou Antonio Suarez Saurit, galego, viajava regularmente para a Europa, melhor dito, para $\mathrm{Vigo}^{94}$, porto de passagem da Cia. Transatlântica de Barcelona que, inaugurando essa linha em 1913, teria como agente de viagem na Capital a própria empresa Antonio Suarez \& Cia. ${ }^{95}$. Em $1912^{96}$ ele já representava uma outra companhia espanhola, a Vapores Correos Españoles, empresa de Cádiz pertencente a Pinillos, Izquierdo \& Co., cujos barcos, até julho de 1913, chegavam a Santos apenas duas vezes por mês.

A empresa de Pinillos investia pesado em publicidade, com grandes e freqüentes anúncios, dentre os quais o que apresentou o novo transatlântico de duas hélices ${ }^{97}$, o Infanta Isabel, que acomodava 150 passageiros de primeira classe; 120 de segunda; 120 de segunda econômica e ...1.500 emigrantes ${ }^{98}$. Também se distinguiu por possuir, para a época, um marketing agressivo: o comandante do Valbanera, vapor de sua frota reunia costumeiramente no Porto de Santos vários espanhóis de "significación", autoridades e a imprensa espanhola, a quem brindava com "esplêndido almoço", para todos os gostos - "huevos a la andaluza; arroz.

\footnotetext{
${ }^{91}$ EDE 02.05.1922. Cristalería: vidros em geral ou vitrines para loja. Trad. da autora.

${ }^{92}$ EDE 28.07.1922.

${ }^{93}$ EDE 02.05.1922. Trad. da autora.

${ }^{94}$ EDE 25.02.1913.

${ }^{95}$ EDE 01.12.1913.

${ }^{96}$ EDE 08.01.1912.

97 Sobre a introdução da hélice, ver: VAZQUEZ GONZALEZ, Alejandro. "De la vela al vapor. La modernización de los buques en la emigración gallega a América, 1835-1939”. In: Revista Estudios Migratórios Latinoamericanos. Buenos Aires: CEMLA, ano 9, nº 28, 1994, p. 580. Paquete: navio.

${ }^{98}$ EDE 15.01.1920.
} 
a la valenciana; bacalao a la vizcaina; espárragos a la riojana; chuletas de cerdo a la catalana", etc. $^{99}$

Mantendo comércio de tecidos com "importação direta" mas também fabricando sombrinhas, guarda-sóis e bengalas, assim se constituía, em 1913, a Fábrica de Miguel Gaeta, fundada em 1893, instalada na Rua Ipiranga, 93 ${ }^{100}$. Instalada em 1913 no Brás, à rua Cel. Mursa, 14, a fabriqueta Corcho Nacional de A.P. Machado vinha fabricando colchões, colchonetes para viagem, colchas, travesseiros, salva-vidas, etc. ${ }^{101}$.

Diversas fábricas e lojas de pequeno e médio porte de sombrero (chapéu) pertencentes a espanhóis faziam divulgação regular nas folhas diárias do EDE porém, surpreendentemente, o ofício declarado de sombrerero apareceu somente nos primeiros 10 anos examinados.

A produção de chapéus, praticamente artesanal, ocorre a partir da primeira década de 1900, em unidades de pequeno e médio porte, sendo utilizadas na sua confecção inicialmente as peles de lebre, castor e lontra, substituídas antes ainda da Primeira Guerra, pela lã ${ }^{102}$, então secundada por outros materiais como o feltro, o pêlo e a palha. $O$ chapéu de palha, de produção pequena, era produzido, já na década de 1890 , por Dante Ramenzoni ${ }^{103}$. Referindo-se à indumentária habitual no período, Everardo Vallim P. de Souza comenta dos "enormes sombreiros, à moda castelhana, dobrado pala ao ombro durante o dia, substituído à noite por ampla capa sevilhana", costume que, conforme afirma, era típico dos estudantes gaúchos ${ }^{104}$.

Em 1912, a Fábrica de Chapéus de Felipe Navarro, existente pelo menos desde $1904^{105}$ estabelecida na Rua do Gasômetro, 70 fazia a comunicação oficial, pelo EDE, da sociedade "com um brasileiro" "106. Com produção essencialmente artesanal, a Sombrerería Española instalada no endereço residencial de seu proprietário Francisco Murcia Nóvoa, funcionava da mesma forma à Rua do Gasômetro, no ${ }^{\circ}$ 98, ainda em $1914^{107}$, enquanto a Sombrerería Alberto comunicava aos clientes a mudança de endereço, da Praça Antonio Prado, onde o

${ }^{99} \mathrm{EDE}$ 06.03.1913.

${ }^{100} \mathrm{EDE}$ 06.03.1913.

${ }^{101}$ EDE 18.01.1913. Corcho: cortiça.

102 A lã, utilizada em larga medida para a fabricação de chapéus era importada da Europa, dos Estados Unidos, Argentina e Uruguai; paulatinamente, com a criação de carneiros no Rio Grande do Sul, passa a haver certo suprimento da lã em bruto. $C f$. LEME, M. Op. cit.,p. 211.

${ }^{103}$ Idem, ibidem, p. 228.

${ }^{104}$ SOUZA, E. "Reminiscências acadêmicas (1887-1891)". In: Revista do Arquivo Municipal. São Paulo: XCIII, p. 117.

\footnotetext{
${ }^{105}$ LTE 1904.

${ }^{106}$ EDE 23.11.1912. Trad. da autora.

${ }^{107}$ EDE 05.11.1914.
} 
prédio em que se situava seria derrubado para as obras da Avenida São João, para a Rua Direita, 39-B, endereço "chic" da cidade ${ }^{108}$. Ao chapéu elegante, a Casa da Mme. Olga instalada à Rua Líbero Badaró, 107, atendia clientela feminina mais abastada ${ }^{109}$. Também no centro, na Travessa do Comércio, um episódio envolvendo um chapeleiro espanhol é narrado por Guido Fonseca, segundo o qual José Tácia, o dono, ao final do expediente, quando fechava as portas de seu estabelecimento, foi atacado por dois desconhecidos que após o derrubarem, agrediramno a pontapés, imobilizando-o; depois, passaram ao redor de seu pescoço um pedaço de cadarço, envolveram sua cabeça e outras partes do corpo com peças de roupa, amarrando, por fim, suas mãos e pés por trás, obrigando-o a permanecer sob o balcão enquanto tiraram do baú a quantia de $106 \$ 000$ e um relógio de ouro, abandonado a seguir o local. Na Delegacia, Tácia, bastante machucado pelos pontapés recebidos, disse não ter condições de reconhecer os agressores que, no entanto, aparentavam ser "napolitanos"110.

A Família Ângulo constituía, como outras, a nata da colônia. Os irmãos Anacleto e Marcelino haviam se estabelecido, cada qual com seu próprio negócio. Anacleto era o proprietário da Al Crisántemo, fábrica de flores artificiais e coroas mortuárias na Avenida Celso Garcia, 187-A, assídua anunciante do $\mathrm{EDE}^{111}$; já seu irmão era o proprietário da Casa Marcelino na Praça Antonio Prado, 14, onde operava com compra e venda de jóias de segunda mão, brilhantes e pedras preciosas, trabalhando também com penhores ${ }^{112}$, tendo comparecido uma única vez no CGE, no ano de 1912, quando se declarou natural de Alava, na Região Basca. Faziam-se representar, nas notas sociais do EDE pelas duas Ângulo, Iracema e Leonor, provavelmente suas esposas.

A respeito do aumento das joalherias, ourivesarias e relojoarias neste período, Marisa Deaecto comenta que esse fenônemo "testemunha o grau de refinamento a que chega a sociedade paulistana"113 . Representava, por outro lado, outro nicho de mercado, de que se aproveitou Mariano Galindo Martinez, de Barcelona, antes inscrito como artista e que agora, em 1917, já instalado na XV de Novembro, 37-A, declarava-se joyero.

Localizada inicialmente no Triângulo, à Rua XV de novembro, 29, a Casa Laurito em cujos anúncios, de grande porte, anunciava a venda de "relógios, cordões, relógios de parede,

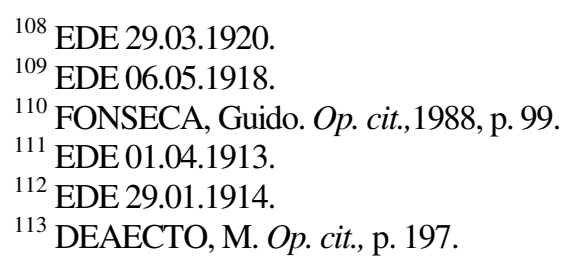


bolsas, anéis, gramofones, discos, pulseiras, despertadores"114, mudou-se em 1913 para a Rua Direita, 49-B. Aproveitando-se da mudança, a joalheria promoveu uma "rebaja" (liquidação) e expôs ao público a enorme variedade de produtos que comercializava: anéis de cadenita, prata, ouro; alianças; alfinetes para pescoço e gravata; abotoaduras; binóculos; taças; colares; cordões; despertadores; estátuas de bronze; óculos; porta-retratos; rosários; relógio para homem; relógio de bolso; relógio de parede; santos; serviço de mesa (talheres). Gramofones, discos e agulhas ${ }^{115}$.

O centro, especialmente o "Triângulo", passa progressivamente a concentrar um comércio diversificado e requintado, constantemente revigorado pelas "novidades", muitas das quais importadas, com o qual atraia e mantinha cativa uma clientela que, através do "refinamento", buscava se alinhar às principais tendências ditadas pela "moda" européia. Essa clientela, com estilo de vida sofisticado e receptivo às novidades do consumo, alimentava um comércio identificado com o supérfluo e o luxo, dinamizando uma multiplicidade de negócios e ocupações, além de estimular a importação da Europa.

Para Odilon Nogueira de Matos, a cidade se transformava "num centro comercial cheio de vida, onde o dinheiro começava a correr em abundância e uma parcela da população dava-se a requintes e a certos luxos até então desconhecidos" ${ }^{\text {116. }}$.

A publicidade acompanhava de perto essas modificações exibindo as novidades e os gêneros de luxo, geralmente importados, que passavam a ser ostentados por uma camada média ascendente, pela imposição de um padrão de vida diferenciado. Esse consumo mais sofisticado, aliado ao modismo, como forma simbólica de ascensão ao modo de vida reinante nas grandes cidades - aspecto rapidamente percebido pela publicidade $^{117}$-, vinculava-se à necessidade de distinção e hierarquização social das camadas médias, por meio do que reafirmavam a sua identidade. Nesse particular, como veremos, o setor de importação foi dos mais aquinhoados no período. O vocábulo "moda" ganha status, elasticidade, espaço na publicidade, passando a ser expresso em numerosos anúncios, fosse qual fosse o produto: comércio de "modas"; taller de "modas"; o confeti da "moda"; Brahma Fidalga, a cerveja da "moda", assim transitava o vocábulo no imaginário do consumidor. El Hogar y la moda era também o nome da revista semanal ilustrada e encadernável que desde

${ }^{114}$ EDE 08.01.1912. Trad. da autora.

${ }^{115}$ EDE 10.12.1913. Trad. da autora.

${ }^{116}$ MATOS, O. Op. cit., 1955, p. 111.

${ }^{117}$ Ver, a propósito: LOTITO, Márcia Padilha. A cidade como espetáculo - publicidade e vida urbana na São Paulo dos anos 20. São Paulo: Dissertação de mestrado, FFLCH-USP, 1977 e CRUZ, Heloisa de Faria. "A cidade do reclame: propaganda e periodismo em São Paulo, 1890-1915”. In: Revista Projeto História. São Paulo: n. 13, PUC-SP, jun.1996, pp. 81-92. 
1914 podia ser encontrada nos postos de venda da cidade ${ }^{118}$. "Refletindo as modas dominantes no momento atual", dizia grande anúncio do Mappin Stores, na reabertura da loja após o incêndio que ocorrera havia dois meses, esclarecendo que, graças aos compradores que mantinha em Paris e Londres, as clientes poderiam, sem prejuízo, apreciar o grande estoque de mercadorias já reposto ${ }^{119}$.

Essas transformações no estilo do consumo da cidade não passaram desapercebidas pela autoridade consular que, sensível a isto, buscava implementar os contatos comerciais da Espanha com o Brasil. Atento à avalanche de oportunidades criadas pela cidade, o então cônsul da Espanha em São Paulo, Sr. Emílio de Motta, elabora e envia ao Ministério de Estado uma publicação denominada $O$ Estado de São Paulo - Su enorme progreso, juzgado por un funcionario español - Informe interesante a los exportadores españoles. Essa publicação vinha em apenso ao Relatório Memória Comercial de 1910 que será depois publicado em Madrid pelo Centro de Informação Comercial ${ }^{120}$. Tratava-se de Relatório previamente elaborado para recomendar aos exportadores espanhóis o mercado paulista, especialmente o paulistano, apontando as possibilidades concretas de investimento e negócios, mas, em particular alertando a todos os importadores espanhóis para que reconhecessem em São Paulo um mercado privilegiado, fato que, conforme informava, já fora percebido por dezenas de países que vinham continuamente incrementando esses contatos. Referia-se objetivamente ao levantamento anteriormente elaborado pelo consulado inglês da cidade - Veinte años de progreso constante $^{121}$. Totalmente traduzido pelo EDE e publicado na íntegra, o documento foi remetido a varias cidades espanholas. O Relatório de Emílio de Motta ainda continha um comparativo, listando a carteira de importações do Estado de São Paulo, indicando que a Espanha se situava em $13^{\circ}$ lugar; os comestíveis representariam a maior parte dessas importações ${ }^{122}$, seguidos por algumas matérias-primas ${ }^{123}$ e poucos manufaturados ${ }^{124}$.

A autoridade consular não negligenciava diante de qualquer oportunidade que se apresentasse, para reiterar a capacidade do mercado paulista. O EDE, nesse caso ao menos,

\footnotetext{
${ }^{118}$ EDE 26.01.1914.

${ }^{119}$ EDE 05.04.1922. Trad. da autora.

${ }^{120}$ EDE 30.03.1912.

${ }^{121}$ EDE 17.02.1912.

${ }^{122}$ Estes seriam os produtos então exportados pela Espanha: avelãs; castanhas; nozes; vinhos; vinagre; conservas de pescado; frutas secas; frutas verdes e sal comum.

${ }^{123}$ Chumbo; cortiça (corcho) bruta; mercúrio; peles e couro.

124 Tecidos de lã, juta e cânhamo e rolhas (tapones).
} 
parecia aceitar as investidas oficiais, tomando posição favorável ao incremento das exportações espanholas para São Paulo. Em $1912^{125}$, em editorial, assim se pronunciava:

Quanto à indústria espanhola é de se esperar que pronto ocupe o lugar que lhe corresponde (...); um exemplo da importância dessa indústria é a Cia. Hispano-Suiça estabelecida na Espanha e fabricante de automóveis, a qual acaba de vender para a firma J. Faria, de São Paulo, 60 veículos, dos quais 12 para transporte de carga, 10 ônibus e 38 automóveis para aluguel, dentre os quais alguns de grande luxo para festas de casamento, batizados, etc.

As tentativas de abocanhar parcela desse florescente mercado consumidor, que se metamorfoseava dinamizando uma multiplicidade de negócios, especialmente no setor das importações, foram freqüentes no período. É ainda da década de 1910 outra iniciativa desta feita conduzida pelo cônsul Juan Solórzano, o qual publica um livreto denominado El Estado de São Paulo que, como os anteriores, teve larga divulgação na Espanha ${ }^{126}$.

Manifestando-se, assim, na preocupação com a aparência e no empenho por parecer elegante, sinônimo de civilizado ${ }^{127}$, a "moda", como vimos, era ditada pela Europa e manifestava-se em várias instâncias, como na arquitetura, no mobiliário e nos hábitos.

Por ocasião da inauguração do Grand Hotel Ausonia, pertencente a dois investidores espanhóis, Sebastião Prat e Juan Guerrero, construído em edifício "com características de um palácio", na esquina das ruas dos Gusmões e do Triunfo, quase em frente à Sorocabana, não se furtaram seus proprietários a equipá-lo com "cadeiras da Áustria e da Suécia; serviço de mesa (baixelas gravadas com o logotipo do Hotel), cristais e adornos de cristal e vidro, de Milão; tapetes, da Itália; toalhas de mesa, guardanapos e cortinados de Monza, na Itália". Nesse rol de importações, restaria para a Espanha apenas as roupas de cama, vindas da Catalunha ${ }^{128}$. Esse mercado potencial, mal explorado, era aspecto muito bem percebido pela autoridade consular.

Os móveis para os 43 apartamentos do luxuoso Ausonia de Sebastian Prat, no entanto, foram fabricados de imbuia nacional, pelo Taller de muebles de carpintaria de Ramón Monconill, Rua Paula Souza, 75, impressionando a tal ponto o repórter do EDE destacado para a cobertura do evento, que ele os descreveu "como parecendo móveis importados da Inglaterra" ${ }^{129}$. Ramón Monconill Ollé residente na cidade pelo menos desde 1909 quando

\footnotetext{
${ }^{125}$ EDE 17.02.1912. Trad. da autora.

${ }^{126}$ EDE 12.01.1914.

${ }^{127}$ Cf. DEAECTO, M. Op. cit., p. 171.

${ }^{128}$ EDE 13.04.1914.

${ }^{129}$ EDE 13.04.1914. Trad. da autora.
} 
realizou seu registro no $\mathrm{CGE}^{130}$, declarou-se industrial; como Sebastian Prat Arre ${ }^{131}$ era catalão de Barcelona, tinha 45 anos e residia na Rua dos Andradas, 9. Declarou também ter embarcado de terceira classe, menção importante na identificação dos embarcados como “imigrantes”.

${ }^{130}$ LRC 10.02.1909.

${ }^{131}$ LRC 15.01.1915. Nessa ocasião, ele se declarou com 46 anos e residindo na Rua Conselheiro Nébias, 123. 


\section{Os atacadistas de cereais}

No Brás não moravam só italianos. Os portugueses, em São Paulo, não tinham uma grande colônia, como em Santos e no Rio de Janeiro. No Brás, os portugueses ficavam nas padarias e nos bares. Eram poucos. Mais espanhóis que portugueses. Os espanhóis ficavam nos armazéns de cereais (...) A maioria preferia se estabelecer por conta própria. Abriam uma portinha de cebolas na Santa Rosa ${ }^{132}$.

Tarde de noroeste na Rua Santa Rosa. Rosa? Cheiro de aniagem e cebola. As sacas abrem as bocas de cereais, bocejam pançudas, empanturradas, nas portas dos armazéns; as réstias escorrem dos tetos, enroscam-se nas paredes sujas, recendem forte como tranças suadas. Montes de sacas, franjas de réstias em todas as casas, em todas. Iguais, todas iguais: duas portas largas, antigas, de pau pintado de verde; uma balança décimas - o básculo: trono dos atacadistas - no lugar de honra, firme sobre o cimento e cercada de sacas e réstias - feijão, milho, arroz, batata, cebola e alho; homens em mangas de camisa transpirando dinheiro; carroções e caminhões carregando e descarregando sacas e réstias.

Tudo igual, sempre igual. Tudo assim, sempre assim. Toda uma rua longa feita só de sacas e réstias. E este cheiro poeirento, seco, de aniagem e cebola, que pesa em tudo $(\ldots)^{133}$.

A Santa Rosa, rua ainda hoje existente, constituiu com outra, a Paula Souza, um reconhecido reduto de espanhóis dedicados ao comércio atacadista de cereais na Paulicéia. Situada numa travessa da Avenida Mercúrio, próxima ao atual Mercado Municipal, essa rua margeava a várzea do Tamanduateí, saindo da Rua do Gasômetro. Consta que a partir da década de 1880, por ocasião do arruamento do trecho entre a Rua do Gasômetro e a São Paulo Railway, no ponto de travessia do Rio Tamanduateí foram instalados os primeiros armazéns da estrada de ferro, sendo daí o seu surgimento, rente à várzea, local onde, durante certo período, as mulheres se juntavam para lavar roupas ${ }^{134}$.

Não se tem notícia exata do momento dos primeiros estabelecimentos comerciais dos espanhóis naquela região. É possível, porém, que quando o comerciante espanhol José Fernandez de Castro que tinha um negócio de molhados na ladeira da Tabatinguera, na beira do Tamanduateí faleceu, em 1899, seus conterrâneos já irradiassem seus pequenos negócios na região. Na casa em que morava e mantinha seu negócio de molhados, em frente ao hospício,

132 “Lembranças do Sr. Amadeu”. In: BOSI, Ecléa. Op. cit., 1979, pp. 94-95. Seu Amadeu era filho de imigrantes italianos, e metalúrgico.

${ }^{133}$ ALMEIDA, G. "Um carvão de Goya". In: Op. cit., 1929, pp. 59-60.

${ }^{134}$ LEME, M. Op. cit., pp. 24 e 151. 
Fernandez vendia vinho, aguardente, Fernet, vinho do Porto e cerveja preta Guiness. Também tinha velas, querosene, vassouras, sardinha e azeitonas em lata. Ao morrer viúvo e sem filhos, Fernandez também deixaria pequenas casas de aluguel, duas na própria ladeira e quatro do outro lado do rio, na Rua da Moóca ${ }^{135}$.

Nelson Nozoe, que analisou detidamente os exercícios fiscais referentes aos anos de 1914, 1929 e 1933, valendo-se dos livros de impostos da Recebedoria de Rendas da Secretaria da Fazenda do Estado de São Paulo, afirma que os dois primeiros anos assistiram a um número crescente de "estabelecimentos especializados em um único grupo de produtos alimentícios" que passaram a transacionar também com cereais ${ }^{136}$. Remonta contudo a 1894, muito anteriormente portanto ao primeiro ano mencionado, o aparecimento "oficial" na documentação examinada do primeiro registro referido à Rua Santa Rosa, e com clara indicação de que já, àquela altura, se praticava o comércio de cereais que a tornaria famosa: tratava-se do registro de Patrício Carrera, natural de Navarra que, ao instalar-se no $\mathrm{n}^{\circ} 8$ da Santa Rosa declarando-se negociante pode ser considerado como o precursor que, saindo à dianteira, anteciparia o papel que assumiriam estas duas vias e suas adjacências no negócio de cereais, praticamente monopolizado pelos espanhóis nas décadas seguintes. Demonstra ainda, nesse momento, primórdios da mercantilização da agricultura de subsistência, notável visão de mercado e de senso de oportunidade. Nesse mesmo ano de 1894 outros registros mais se referiram à Rua Santa Rosa, todos com numeração baixa, provável indício de sua criação recente. Tais registros tenderam a crescer, sobretudo a partir da década seguinte e, associado a eles as rubricas comercio; comerciante; p. comerciante; negociante; p. negociante ${ }^{137}$ - que confirmariam a sua vocação.

No final do segundo decênio analisado, período de 1903-1912, seus números já se estendiam até a casa de $\mathrm{n}^{\circ} 98$ indicando clara concentração de indivíduos procedentes da Província de Salamanca, na Região de Castilla-León - exatamente 50\% do total -, Região em que, segundo Carina Frid de Silberstein, em seu trabalho sobre os espanhóis na Argentina,

${ }^{135}$ OLIVEIRA, M. Op. cit., 2003, pp. 40-41.

${ }^{136}$ NOZOE, Nelson Hideiki. São Paulo: economia cafeeira e urbanização. Estudo da estrutura tributária e das atividades econômicas na capital paulista (1889-1933). São Paulo: PNPE - Programa Nacional de Pesquisa Econômica-USP, 1984, p. 105.

137 Não se colocou, durante o período analisado, uma clara distinção entre essas categorias. Não observamos um critério nem hierárquico nem temporal entre elas, após a análise de vários casos, parecendo que a citação era indiscriminada e não indicava uma condição particular. Como veremos, dois dos mais prósperos atacadistas de cereais, incluindo Perfecto Ares, alternaram as rubricas em seus registros no período considerado. Relatórios Acess n's. 5, 6 e 7. 
predominava fortemente a produção cerealífera ${ }^{138}$. Contudo, como veremos, essa foi uma característica apenas da fase inicial.

Analisando os registros anteriores dos (novos) declarantes que passaram a se estabelecer naquela via, especialmente a partir de 1910, pudemos constatar que, parte daqueles que aí se encontravam domiciliados, em registros anteriores haviam se declarado jornaleros, e que, provavelmente em decorrência do negócio que passariam a ter, parcela deles quando tornavam a se registrar, ao invés de jornalero, se diziam em geral p. negociante. Esse "pequeno negociante" que antes fora um jornalero revela uma probabilidade indisfarçável, a de que a carreira desses indivíduos, alguns dos quais se tornariam prósperos e prestigiados, teria iniciado de maneira humilde e de forma precária. Nessa perspectiva, buscamos então, através do cruzamento com as demais fontes consultadas, especialmente com a periodística, recuperar algumas dessas trajetórias e nesse intento, esbarramos em Perfecto Ares, cujo percurso parecenos exemplar. Informando estar domiciliado na cidade de São Paulo em seu primeiro registro no ano de 1894, esse galego de Orense, então com 38 anos, era casado e afirmava ser jornalero. Seu curioso domicílio, mencionado no ato, é ainda um enigma indecifrável: Arrienda Intendéncia, algo próximo a "locação da Prefeitura" que, no entanto, pouco esclarece ${ }^{139}$. Da data desse registro ao próximo que localizamos passaram-se 12 anos, e assim, em 1906, Perfecto Ares já estava instalado na Rua Santa Rosa, no nº 98 no qual permanecerá durante todo o período consultado com seu armazém atacadista. Neste registro, de 1906, já se declarou negociante. Na década seguinte, a de 1910, pudemos acompanhar mais de perto os desdobramentos de sua biografia, quando se expandiu extraordinariamente, pavimentando uma carreira meteórica, construindo um verdadeiro império econômico, cujos testemunhos pudemos captar na apreciação da fonte periodística onde, com assiduidade, era objeto de notícia. Em 1912 (o primeiro dos anos consultados) por exemplo, já era o Presidente do Centro Galego $(\mathrm{CG})^{140}$. Sua casa comercial freqüentava com regularidade as páginas publicitárias do EDE, em que apareceu inicialmente como "comissionista" (vendia o produto mediante comissão) de café e cereais. Nesta época iniciou a importar produtos espanhóis (vinhos tintos de Rioja, sardinhas e vinhos da Galícia, azeites e azeitonas de Sevilha, licores, conservas, etc.). Em $1914^{141}$, embarca para Vigo, em viagem de férias, e em $1918^{142}$, já residindo em um "Palacete", onde promovia

${ }^{138}$ A autora cita também as Províncias de Zamora, León e Soria. SILBERSTEIN, Carina Frid de. Op. cit., 1999, p. 112.

${ }^{139}$ LRC 13.02.1894. Trad. da autora.

${ }^{140}$ EDE 24.07.1912. As sociedades beneficentes serão analisadas no Capítulo IV.

${ }^{141}$ EDE 29.04.1914.

${ }^{142}$ EDE 09.01.1918. 
festas com extensa programação musical ${ }^{143}$, passou a freqüentar as colunas "sociais". Também em $1918^{144}$ o EDE publica nota do convite que recebera para ocupar o cargo de vice-cônsul em São Paulo, vacante pela demissão de Joaquim Collazos. Tendo aceitado, no registro que efetuou em 1919, declarou-se vice-cônsul e comerciante, então residindo na Rua Artur Prado, 99. Pouco depois passa a ocupar o prestigiado endereço da Rua Líbero Badaró, 31 - $3^{\circ}$ andar no qual, ficou evidenciado mais tarde, funcionavam os escritórios de sua casa comissária e exportadora - negociando algodão, café, mamona e cereais ${ }^{145}$ - simultaneamente ao da Rua Santa Rosa, 98, local que passou a concentrar progressivas indicações de espanhóis instalados com comércio de cereais. Considerando apenas os anunciantes do EDE no período abrangido pela série consultada (1912-1922) e percorrendo a rua do início ao fim - imaginamos que não tivesse mais de 100 metros - havia espanhóis instalados nos seguintes números: 24, 29, 30, 31, 31-A, 33, 38, 42, 44, 56, 67, 74, 78, 88 e 98, este último o do armazém de Perfecto Ares.

Disputando a primazia com a Santa Rosa, a Rua Paula Souza, antes Chácara de D. Maria de Paula Souza, também foi aberta em virtude dos armazéns da São Paulo Railway, fazendo a ligação com a Rua Florêncio de Abreu ${ }^{146}$. O primeiro registro referido a esta rua apareceu bastante depois, se comparado com os da Santa Rosa, ou seja, somente em 1908. Tratava-se do comerciante, Domingo Hernandez Toríbio, casado, 40 anos, natural de Salamanca. Nesta rua, no número 51, deu-se a escalada de Aparício Martí, também ele comerciante de cereais, cuja trajetória, em certa medida, difere da de Perfecto Ares. Seu primeiro registro, de 1897, atesta que então já se dedicava ao comércio, residindo à Rua do Brás, 24.

Natural de Valencia, havia, no entanto, se criado em Córdoba (Inajar) na Andaluzia e tinha 28 anos quando efetuou este primeiro registro no CGE, data que deve ter sido muito próxima à da sua chegada à cidade ${ }^{147}$.

Em Córdoba Marti havia, quando jovem, fundado com um grupo de rapazes oriundos de familias acomodadas uma instituição filantrópica que mantinha um pequeno hospital/albergue no qual acolhiam pessoas idosas, enfermas ou feridas. A par dessa iniciativa, o

${ }^{143}$ Nestas festas apresentavam-se violinistas e pianistas contratados (Oscar Pery e Otília de Pery, sua mãe, ao piano) e eram entusiasticamente acompanhadas por sua filha Josefina que cantava e tocava piano. João Gomes de Araújo, pianista, era um dos freqüentadores de seu Palacete. EDE 09.01.1918.

${ }^{144}$ EDE 30.08.1918

${ }^{145}$ EDE 21.10.1921.

${ }^{146}$ LEME, M. Op. cit., pp. 24-25.

${ }^{147}$ LRC 12.05.1897; EDE 02.03.1922. 
grupo teria criado uma companhia teatral, com cujas apresentações pretendiam manter os abrigados. Em 1893, no entanto, quando tinha 23 anos, estalou a rebelião dos rifenhos, habitantes das regiões montanhosas do Marrocos, obrigando-os a se dirigirem ao campo de batalha ${ }^{148}$, de onde poucos retornariam vivos. Marti, um dos sobreviventes, "apesar de desfrutar em seu país de uma posição comercial em dia", resolveu casar-se e vir para o Brasil. Aqui chegando, ingressou numa casa comercial, como gerente e contador, até estabelecer-se por conta própria $^{149}$, o que deve ter ocorrido pouco tempo depois de seu primeiro registro em 1897 quando ainda era funcionário, trabalhando no comércio, pois em 1900 já o encontramos na Rua Monsenhor Andrade, 15, e se declarando negociante. No ano seguinte, em novo registro, apenas se alterara seu endereço para Rua Monsenhor Anacleto (continuação da rua Carneiro Leão).

No espaço de tempo compreendido entre esses registros e o último realizado em 1920, Aparício Marti alavancou uma carreira de sucesso comercial e prestígio social. Já estava instalado então na Rua Paula Souza, 51. Embora não possamos precisar a data exata em que se estabeleceu, imaginamos que tenha sido na primeira década porque em 1912, ano a partir do qual iniciamos a consulta ao $\mathrm{EDE}^{150}$ já se apresentava como proprietário da Casa Española estabelecida naquela rua. Em seus anúncios informava que seu sistema de trabalho era o de “comissões e consignações”, como o de Perfecto Ares e bastante freqüente no período, recebendo para comercializar feijão, milho, arroz e batatas. Em $1913^{151}$, em editorial, o EDE noticia a visita dos representantes da Casa América de Barcelona que, sob pretexto de verificar a situação dos imigrantes espanhóis no Estado, procuravam estimular contatos para implementar a venda de produtos espanhóis na cidade. Tais contatos frutificarão mais tarde, em 1922, quando a empresa Hispano-Suiza efetuará a venda de automóveis, conforme veremos. À visita dessa missão da Casa América se sucederá veemente discurso de Aparício Martí, provavelmente representando alguma associação de classe dos comerciantes espanhóis na

148 Assim eram denominadas as tribos do Rif, cadeia montanhosa existente próxima a Tetuán, no Marrocos, zona sob influência espanhola. Por extensão, a denominação de rifenho se refere a qualquer dos habitantes de toda a zona montanhosa do norte de Marrocos. Em 1921 haveria de estourar uma outra rebelião, antecedente das reivindicações nacionalistas do Marrocos, que dá lugar a uma efêmera independência de território, a República del Rif.

${ }^{149}$ Dados obtidos na reportagem que se seguiu ao seu falecimento, no Sanatório Santa Catarina, publicada no EDE em 02.03.1922. Trad. da autora.

${ }^{150}$ EDE 15.02.1912.

${ }^{151}$ EDE 06.05.1913. 
cidade, em que lamentava o pouco tempo de estadia que teria impossibilitado negociações mais concretas; na ocasião, apresentava diversas sugestões para a viabilização desse intercâmbio ${ }^{152}$.

Seu nome aparecerá relacionado à criação do CE em $1918^{153}$, quando da publicação da convocação à colônia para uma reunião - na Rua del Carmen (Rua do Carmo?), no Salão Celso Garcia -, para tratar da constituição de uma sociedade de caráter recreativo e cultural que congregasse a todos os espanhóis. Este Centro será inaugurado em dezembro de $1918^{154}$, e José Aparício Martí será seu primeiro secretário. Instalado à Rua do Gasômetro, o CE reunia as famílias "em tertúlias" aos domingos à tarde ${ }^{155}$ e organizava festas em homenagem ao patrono da Espanha, São Tiago Apóstolo ${ }^{156}$, porém sua atuação, que antecede propriamente ao ato formal de sua inauguração, extrapolou muito rapidamente o caráter recreativo, em face, provavelmente, das necessidades dos espanhóis imigrados. Em outubro de $1918^{157}$ e em diversas edições anteriores, sob o título "La influenza", o jornal relata a triste condição da cidade sob o impacto da gripe espanhola, relacionando os espanhóis enfermos e convalescentes e, com relação à colônia, informa das várias medidas então tomadas sob a iniciativa da SESM para facilitar medicamentos gratuitos aos necessitados.

Lamentava, contudo, que o CE não tenha podido tomar as providências que seriam aguardadas porque seus membros diretivos encontravam-se todos acometidos pela gripe ${ }^{158}$. Sucediam-se no EDE, nesse período, as listas de donativos em meio às notas de falecimento, enquanto se enaltecia a atitude de membros da colônia, como Raimundo Diez, outro comerciante, que teria colocado "seu automóvel à disposição da Beneficência e Cruz Vermelha Espanhola"159.

Componente da diretoria do CE, Aparício Marti solicita e obtém permissão do Governo para fundar a Câmara Oficial de Comércio, Indústria e Arte, com objetivo imediato de instalar uma exposição permanente de produtos espanhóis na cidade. Insistia na questão e, justificandose, afirmava que o CE não se dedicava exclusivamente a atos recreativos, a celebrar com pompa as festas literárias e musicais, a sustentar uma caixa de socorros para órfãos, viúvas e enfermos com contribuições mensais, mas que estaria em vias de instalar a Câmara de Comércio: "como não poderia deixar de ser não poderíamos ficar de braços cruzados diante da grande soma de

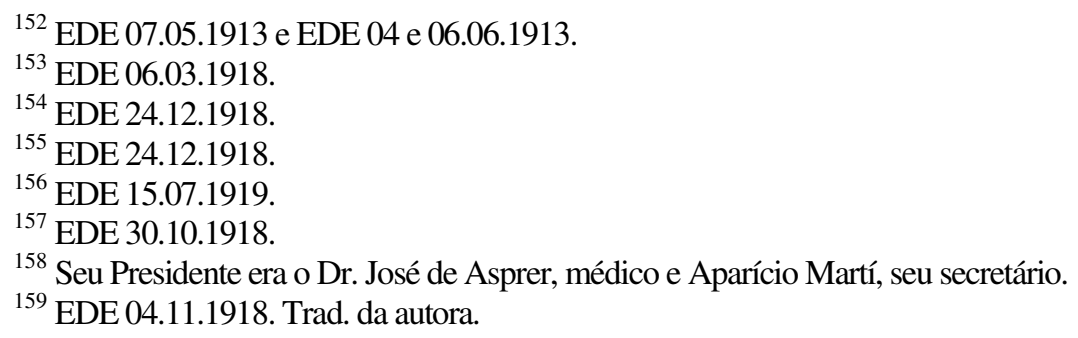


esforços que realizam as nações européias, Estados Unidos e Ásia na conquista de novos mercados no continente americano", discursava ${ }^{160}$.

Na mesma trilha dos dois anteriores, integrando um perfil de homens que prosperaram e ascenderam socialmente, tendo como trampolim o comércio de cereais e grãos em geral, passando, depois, a ocupar diversos postos dirigentes nas sociedades beneficentes e agremiações da colônia, poderíamos incluir a figura de Raimundo Díez que, como Perfecto Ares, mais tarde se tornará importador. O primeiro registro que realizou no CGE foi em 1893, tinha então 24 anos de idade, era solteiro, natural de Zamora (Castilla-León); não declarava seu domicílio, porém já se dizia comerciante. Pelo cruzamento dos dados, no entanto, chegamos a um seu irmão mais velho que, no ano seguinte, se declarou labrador, residindo na Rua da Estação, hoje Rua Mauá ${ }^{161}$, indício provável de sua origem modesta.

O sistema de trabalho mais adotado no período por esses comerciantes, conforme se patenteou foi o de "comissão" e "consignação", cuja eleição parece indicar uma possibilidade de atuar no ramo com pequeno investimento. Também ficou evidente ser possível comercializar com cereais e grãos mesmo sem ter um ponto fixo de venda. Esse tipo de negócio era realizado até nos hotéis da cidade, certamente com pagamento de comissões a seus proprietários. Em alguns casos, os proprietários desses hotéis, eles próprios, aproveitavam-se do "ponto" para negociar. Esses "pontos" ou armazéns, pelo menos no início do período considerado, não apresentavam uma localização uniforme, espalhando-se por distintos locais da cidade, sobretudo no Brás ${ }^{162}$. Em alguns casos, valia diversificar o produto e o local de comercialização: "José Ramirez, o espanhol dos limões possui três barracas nas feiras livres, para defender as mercadorias que recebe: ovos, limões, frutas e aves. Rua Visconde de Parnaíba, 116"163.

Queremos crer que as ruas Paula Souza e Santa Rosa representassem o estágio máximo, o apogeu dessa escalada, o objetivo cobiçado a ser atingido. O cruzamento dos dados do CGE (a partir de 1893) com os do EDE (a partir de 1912), foram valiosos no sentido de dotá-los de alguns traços comuns, embora fique evidente que essa análise por si só é restritiva porque incide apenas sobre os anunciantes do EDE no período, o que naturalmente elimina os que não se

\footnotetext{
${ }^{160}$ EDE 21.06.1920.

${ }^{161}$ LRC 21.02.1894.

${ }^{162}$ Inventariamos as seguintes ruas no Brás e adjacências, com armazéns de cereais: Ruas Américo Brasiliense; Antonio Paes; Benjamin de Oliveira; Carneiro Leão; João Teodoro; Rangel Pestana e São Caetano.

${ }^{163}$ EDE 03.02.1921. Trad. da autora.
} 
utilizavam desse veículo por um lado e aqueles que o fizeram em período anterior, não disponível para a pesquisa.

Os estabelecimentos congêneres localizados fora da região delimitada pelas duas ruas eram em geral designados pelos nomes de seus proprietários: "Novo armazém de cereais, de Francisco Collado, à Rua Carneiro Leão, $45^{\text {"164 }}$. Esse pode ter sido o início de muitos. Um pequeno armazém em área densamente povoada a partir do qual começavam a diversificar a atuação, passando a receber em consignação produtos (grãos, cereais e outros) enviados do interior. Nesses casos, estipulava-se um valor mínimo ao qual era acrescido o lucro do comerciante e o que não fosse vendido, era sumariamente devolvido, sem prejuízo deste. Em outras palavras, o comerciante estava isento de riscos. Trabalhando em "comissão" imaginamos que essa modalidade se dava apenas com produtos de oferta mais restrita - o preço era estipulado de comum acordo entre produtor e comerciante, e este recebia uma porcentagem pela venda: “Ortiz \& Cia., rua Paula Souza, 65, com filial em Santos, compra e vende cereais, café e algodão, pagando os melhores preços da praça, cobrando comissões mínimas e prestando contas rápidas", dizia o anúncio, atestando a crescente concorrência no negócio ${ }^{165}$.

Em muitos casos, valia apenas a experiência anterior e algum capital para iniciar no negócio que, como vimos, estruturava-se na base da "comissão e consignação": "Casa Española de Romero, Aviléz \& Sanchez, estabelecida na Rua Dr. Almeida Lima, informa que recebe à comissão qualquer produto que lhe enviem e que deseja estabelecer relações comerciais com firmas exportadoras de produtos de todas as regiões do Brasil e com compradores de ovos e aves do Estado"166.

No fundo, esse comerciante era o atravessador, aquele que se colocava entre o produtor e o consumidor final. Disso logo se aperceberam os produtores do interior com algum trânsito ou conhecimento na cidade de São Paulo. A venda direta, e sem intermediários, era garantia de maior lucro. Desse modo, assistimos a um grande movimento de indivíduos inicialmente domiciliados no interior estabelecendo-se com pequenos armazéns na cidade. Muitos deles, é bom frisar, com passagem prévia pelo CGE, onde haviam se declarado jornaleros.

Alguns exemplos ilustrativos: Miguel Chacón, natural de Almería e proprietário, em 1919, do armazém existente na Rua Santa Rosa, n 42, registrara-se em 1913 no CGE como jornalero indicando que residia há seis anos em Guaratinguetá ${ }^{167}$. Também Alfonso Podaderas

\footnotetext{
${ }^{164}$ EDE 02.06.1913. Trad. da autora.

${ }^{165}$ EDE 12.03.1922. Trad. da autora.

${ }^{166}$ EDE 31.10.1919. Trad. da autora.

${ }^{167}$ LRC 29.01.1913.
} 
Miranda, de Málaga, com armazém em 1922 à Rua Paula Souza, 73, em 1911 estivera no CGE declarando-se jornalero; residia em São Manuel e informava estar no Brasil há 23 anos ${ }^{168}$. Luiz Lozano Dominguez, também de Almería, com armazém na Rua Santa Rosa, 44 era, em 1918, um ano antes desse registro, um negociante residindo em Serra Azul ${ }^{169}$, onde provavelmente já se iniciara no ramo. O mesmo ocorreu a Arturo Arias Cenóz, de Pontevedra, com armazém na Rua Santa Rosa, 88 em 1919 que, em 1915, registrara-se como comerciante residindo em Monte Verde ${ }^{170}$.

Esses casos multiplicaram-se, evidenciando a incidência de comerciantes estabelecidos na Capital com passagem prévia pelo colonato para onde foram enviados para o trato do cafezal. Alguns, conforme destacamos, tornam-se negociantes nessas cidades, provavelmente comercializando gêneros alimentícios plantados pela própria família, nas "roças" de mantimentos - cultivo permitido pelos fazendeiros nas ruas dos cafezais novos - ou no pequeno quinhão de terra que conseguiam adquirir depois de anos trabalhando no colonato.

Outros mais passariam a atuar como uma espécie de cooperativa, passando a revnder a produção dos demais. Em Catanduva, por exemplo, o caso de Miguel Parra, indivíduo que conseguira enriquecer intermediando negócios de compra e venda de "mantimentos" e café era rememorado por todos os velhos imigrantes com quem estivemos ${ }^{171}$. Ramón Sanchez era outra dessas figuras emblemáticas, recordada por todos. Esse rico espanhol estabelecido com várias fazendas nos arredores de Villa Adolpho (hoje Catanduva) e de quem ouvimos muitas referências e narrativas "comprava a produção de todos [os pequenos proprietários espanhóis que residiam nas proximidades]"172. Seu prestígio extrapolava a região: em 1913, na seção Notas de viaje, mantida com irregularidade pelo EDE, há menção de Sanchez, como um dos grandes proprietários da região ${ }^{173}$. Em 1919 era ele próprio quem comparecia informando que acabara de abrir "casa de cereais, comissões, consignações e por conta própria", com depósito e escritórios na rua dos Protestantes, 18 e matriz em Catanduva. Comunicava também do funcionamento do Ingenio Alfonso XIII, constituído por "modernas máquinas e aparatos para

${ }^{168}$ LRC 16.01.1911.

${ }^{169}$ LRC 11.06.1917.

${ }^{170}$ LRC 18.08.1915.

${ }^{171}$ CÁNOVAS, M. Op. cit., 2001, p. 297.

${ }^{172}$ Estivemos em Catanduva, no ano de 1981, com o Sr. Manuel Martinez, então com 80 anos, que havia sido um dos colaboradores mais próximos de Sanchez e que nos franqueou detalhes de sua trajetória, narrativa que alinhavamos aos dados dos livros de escrituração fiscal e aos documentos cartoriais locais, então examinados. CÁNOVAS, M. Op. cit., 2001, pp. 268 e ss; 279 e ss; 294 e 323.

${ }^{173}$ EDE 04 e 06.06.1913. 
beneficiar arroz e café" que mantinha naquela localidade ${ }^{174}$. Logo depois ele se estabeleceria, na Rua Carlos Garcia, 34, com "importação direta de vinhos, azeites e azeitonas espanholas", valendo-se sempre do EDE para a divulgação de seus empreendimentos ${ }^{175}$.

É possível que essa experiência acumulada os tenha estimulado à ampliação do negócio, e, assim, tendo a Capital como maior mercado consumidor e referência, para ali se trasladavam abrindo pequenos empórios, primeiro no próprio domicílio da residência, em bairros onde o aluguel era mais acessível, até finalmente atingirem as prestigiadas ruas Santa Rosa e Paula Souza e suas adjacências (ruas da Alfândega e da Cantareira, por exemplo). Não descartamos a hipótese de também residirem nesses locais, cumprindo "tradição já bastante antiga, de manter a dupla funcionalidade dos edifícios assobradados daquela época"176.

Em alguns casos, a manifestação do EDE cumprimentando pela inauguração do estabelecimento ou comunicando de sua mudança, é lapidar: "Casa de cereais de Antonio Figueredo, Rua Benjamin de Oliveira, 10, com sucursal em Catanduva (...)"177. Ou: "Eugenio Giles, comunica à sua numerosa clientela do interior que traslada sua casa de comissões e consignações de Bragança para São Paulo, à rua dos Protestantes, 20"178.

Alguns, previamente estabelecidos no Brás, muitas vezes ainda com pequenos empórios, ao se mudarem para o circuito prestigiado das ruas Paula Souza ou Santa Rosa acabavam conservando ambos os pontos, caso de Miguel Sanchez, com empório no Brás, à Rua Santa Rita, 64, e armazém na rua da Alfândega, $77^{179}$ ou de Jacinto Paes Manso, com armazém de cereais na Rua Pirineus, 10 e na Rua Paula Souza, $70^{180}$.

Outros casos demonstram claramente o percurso que antecedia ao estabelecimento de um ponto de cereais na Santa Rosa e o impulso rápido que daí se obtinha: em fevereiro de $1918^{181}$, o Armazém de Cereais de Gabriel Perez \& Cia., estava estabelecido à Rua São Caetano, 288, de onde comunicou a mudança, meses depois, para a mesma rua ${ }^{182}$. Porém, em 1920, dois anos depois, já estava, finalmente, estabelecido com seu comércio na rua Santa Rosa, $78^{183}$ e, já em 1922, seu negócio alavancara novos segmentos e se diversificara: "Comerciantes

\footnotetext{
${ }^{174}$ EDE 16.05.1919. Trad. da autora.

${ }^{175}$ EDE 02.05.1922. Trad. da autora.

${ }^{176}$ DEAECTO, M. Op. cit., p. 156.

${ }^{177}$ EDE 04.03.1920. Trad. da autora.

${ }^{178}$ EDE 02.02.1920. Trad. da autora.

${ }^{179}$ EDE 12.03 e 23.04.1922.

${ }^{180}$ EDE 02.05.1922.

${ }^{181}$ EDE 04.02.1918.

${ }^{182}$ EDE 22.04.1918.

${ }^{183}$ EDE 04.04.1920.
} 
e industriais, importadores e exportadores de café, algodão, mamona e cereais em geral. Benefício de arroz e moinho de fubá. Rua Santa Rosa, $78^{\text {"184 }}$.

Inúmeras estratégias, artifícios e práticas podem ser contabilizadas na constituição dessas casas comerciais, atestando situações, circunstâncias e condições diversas. Era comum, por exemplo, a formação de sociedades ( \& Co. ou \& Cia.) cuja necessidade se impunha como condição, quer para o levantamento do capital necessário para a abertura do negócio, para a divisão das despesas ou para a divisão de tarefas, as quais envolviam habilidades diferenciadas, como conhecimento do ramo, do produto e dos fornecedores, alguma prática relacionada ao trato dos valores envolvidos, perícia para cálculo de comissões e prestação de contas, enfim, aspectos contábeis correlatos. Por todos essas questões, era bastante comum a sua constituição em " $\& C o$ " observada desde os primeiros anúncios publicitários, e até uma certa circularidade de elementos no setor: "Domingos Vazquez (ex-sócio: José Galdeano).Rua Paula Souza, 61"185; ou "Manuel Rubio, [comunicando] à praça a organização de uma sociedade comercial com S. Viudes (Viudes \& Rubio), para continuar o negócio de comissões e consignações por conta própria, já existente na Rua Américo Brasiliense, 32"186; ainda: "Casa de cereais de Remigio Fernandez, rua Paula Souza, 05 [aviso da] dissolução da firma Fernandez, Haro \& Co., [sendo que] um dos sócios continuaria com o comércio" "187.

Inúmeros outros casos demonstravam ser essa uma artimanha, uma fórmula encontrada para a constituição dessas firmas: "Luis Lozano \& Cia., de Luis Lozano e Juan Botello, rua Santa Rosa, 44 - compra e venda de cereais e outros gêneros" "188; "F. Petisco \& Comp. Comércio de cereais e demais gêneros. Trabalha por comissões ou consignações. Com armazém na Rua João Teodoro, 35”,189; “Casa Gabriel Perez \& C., Rua Santa Rosa, 78”190; "Ribeiro, Artacho \& Cia. - cereais, algodão, mamona. Rua Santa Rosa, 88"191, etc.

A constituição de empresas familiares revelou-se outra prática bastante utilizada: “Antonio Benegas \& Irmão, comissões, consignações e conta própria. Rua Santa Rosa, 56”"192; “Armazém de Cereais de Carrillo \& Irmão. Av. Rangel Pestana, 19. Comissões, consignações

\footnotetext{
${ }^{184}$ EDE 02.05.1922. Trad. da autora.

${ }^{185}$ EDE 09.09.1912. Trad. da autora.

${ }^{186}$ EDE 04.01.1913. Trad. da autora.

${ }^{187}$ EDE 25.10.1918. Trad. da autora.

${ }^{188}$ EDE 02.12.1918. Trad. da autora.

${ }^{189}$ EDE 12.04.1918. Trad. da autora.

${ }^{190}$ EDE 04.04.1920. Trad. da autora.

${ }^{191}$ EDE 25.10.1919. Trad. da autora.

${ }^{192}$ EDE 06.09.1919. Trad. da autora.
} 
e conta própria"193; "Armazém de cereais de Angel Garcia e Hijos. Comissões, consignações e conta própria. Rua Santa Rosa, 42"194; “Juan Perez y Hermano, Rua Santa Rosa, 24 comissão, consignação e conta própria, cereais, batatas, cebolas, sacos vazios" ${ }^{\text {,195 }}$. Como se pode observar, não apenas irmãos, mas também pai e filhos se associavam na constituição dessas empresas ${ }^{196}$.

Também não foi incomum localizar dois armazéns funcionando em um único endereço, para o barateamento do aluguel. Arturo Arias Cenóz, Comissões e consignações de cereais em geral e Antonio Figueiredo \& Co., Comissários, consignação e conta própria, estavam ambos instalados, na mesma data, na Rua Benjamin de Oliveira, $10^{197}$.

Com o tempo, o padrão de atendimento foi sendo aperfeiçoado: "enviamos lista de preços a quem solicite", dizia o anúncio do Armazém de Cereais à Comissão, Consignação e Conta Própria de Garcia \& Filho, na rua da Cantareira, 58-A.

Negociar "por conta própria" por certo integrava um procedimento diferenciado, praticado por atacadistas de maior porte que arrematavam quantidades maiores de mercadorias e, em consequiência, barganhavam preços melhores: "por conta própria, temos os melhores preços da praça”, dizia o anúncio da Casa Comercial de A. Perez \& Co., da Rua Santa Rosa, 38, com representantes no Rio de Janeiro, Bahia e Pernambuco ${ }^{198}$.

No entanto, a trajetória desses sujeitos nem sempre foi linear. Entre um caso e outro, enredos variados puderam ser apreciados. Natural de Málaga e se registrando no CGE pela primeira vez em $1894^{199}$, José Rojas Gutierrez, 47 anos, solteiro e jornalero, indicava a cidade de Santos como última residência, informando estar em trânsito para Belém. Contudo, anos mais tarde, mais exatamente em $1921^{200}$, vamos encontrá-lo estabelecido como proprietário de armazém de cereais, na Rua Visconde de Parnaíba, 67, no Brás, partindo para o ramo das importações.

${ }^{193}$ EDE 21.03.1920. Trad. da autora.

${ }^{194}$ EDE 04.03.1920. Trad. da autora.

${ }^{195}$ EDE 21.12.1921. Trad. da autora.

${ }^{196}$ Para Marisa Saenz Leme (Op. cit., p. 201) "grande parte das empresas maiores, antes organizadas sob a forma de sociedade limitada [\& Hijos; \& Hermanos; \& Cia., etc.], transforma-se em sociedades anônimas, numa forma mais moderna de organização do capital, permitindo maior geração e concentração de recursos". Com efeito, a constituição em sociedades anônimas indica uma outra estrutura de negócio, podendo esta empresa captar recursos de terceiros no mercado, ainda que o controle permaneça nas mãos dos sócios majoritários.

${ }^{197}$ EDE 08.04 e 19.05.1919. Trad. da autora.

${ }^{198}$ EDE 12.11.1920. Trad. da autora.

${ }^{199}$ LRC 07.03.1894.

${ }^{200}$ EDE 09.08.1921. 


\section{O comércio de sacaria, cebola e sementes de cebola}

Todos os homens em São Paulo, que compram sacos usados são assim. E moram por ali. Moram nos fundos das casas, entre varais com roupas dançando, e cercas de lata enferrujada. E tem uma velha que conserta as estopas furadas com uma agulha comprida, um fio comprido e uma paciência comprida (...).

Compradores de sacaria ou empalhadores de móveis - eles vão chegando. Um velho traz nas costas estreitas uma pilha marrom de sacos dobrados. Outro velho traz nos ombros sungados uma cadeira austríaca e, na mão, um rolo de palhinha... ${ }^{201}$.

Ramo correlato ao do comércio de cereais, o comércio de sacos para acondicionamento, atividade a que muitos passariam a se dedicar, surgiu em complemento e em decorrência do anterior. Nozoe, já citado, levantou para 1914 o montante desses estabelecimentos cadastrados, concluindo que havia 21 estabelecimentos de venda de "sacos usados" no período. Seu estudo não forneceu o número de estabelecimentos que comercializavam sacaria "nova" que, acreditamos, fosse muito maior. De todo modo, pudemos observar certa inclinação de agregar ao comércio de cereais preexistente, o ramo de sacaria que, afinal, lhe complementava. Nessa diversificação, outro produto convergente foi representado pela cebola, cujas sementes protagonizarão um vasto capítulo no percurso de muitos desses cerealistas.

Miguel Gutierrez, natural de Granada e residente na cidade de Piracicaba em 1907 onde se dizia comerciante ${ }^{202}$ reapareceria na cidade de São Paulo em 1921, exatamente no funeral de Eiras Garcia de cuja oração final se encarregara ${ }^{203}$. Em 1922, Gutierrez, já proprietário do armazém situado na Rua Paula Souza, 4-A e 4-B ${ }^{204}$, em que trabalhava como a maioria "por consignação e comissão com cereais" investia, em paralelo, no ramo da sacaria, mantendo depósito de "novos e usados" para, finalmente, agregar ao seu negócio a comercialização da “cebola", ramo que proliferou na cidade a partir de 1919.

Em seu trabalho sobre Sorocaba, Sérgio Coelho de Oliveira, a propósito, fala do "cheiro da cebola restiada e espalhada ao sol em plena rua", referindo-se aos espanhóis da "antiga Rua dos Morros", do "Além Ponte" ou da "Vila Hortência", localidades que passaram a concentrar esses produtores naquela cidade ${ }^{205}$.

${ }^{201}$ ALMEIDA, G. “Um carvão de Goya”. In: Op. cit., p. 61.

${ }^{202}$ LRC 15.10.1907.

${ }^{203}$ EDE 23.12.1921.

${ }^{204} \mathrm{EDE}$ 15.12.1922.

${ }^{205}$ OLIVEIRA, S. Op. cit., 2002, p. 11. Pesquisamos, destacando os registros específicos para aquela cidade, a "Rua dos Morros" e verificamos que efetuaram registro no CGE três indivíduos ali residentes no período: 
Paralelamente à venda da cebola, a venda de sementes de cebola teve enorme impulso, transformando-se numa verdadeira febre, num momento em que a crise do setor cerealista era acentuada, apresentando baixas seguidas nos preços, "por causa das grandes safras". Nos inícios de 1920, sequer se fornecia uma cotação de mercado dos produtos. O EDE, com base na Bolsa de Mercadorias passa a publicar, no lugar da cotação, a informação "nominal" significando que não havia preço estipulado para o comércio de cereais, "cada um fazendo seu negócio como pode" 206 .

Este pode ter sido um momento crucial, quando os negócios trocavam de mãos, e as mãos, de negócios. O fato é que o comércio de sementes de cebola crescia enormemente.

As cebolas eram importadas ou das Ilhas Canárias (as "amarelas") ou da Argentina (chamadas as "coloridas", acreditamos que seja a roxa) e chegavam em "latas de dez quilos",207. Em menor escala, também se vendiam as cebolas do Rio Grande do Sul.

Alguns importadores mantinham rede de distribuição, caso de Antonio Trujillo Clemente, um dos primeiros a fazer a divulgação da venda de sementes de cebola pelo jornal, divulgando os pontos de venda no Interior do Estado: Sorocaba, São João da Boa Vista, Rio Preto, Mirassol, Jaboticabal, Cosmópolis, Pederneiras, Mombuca e São Roque, localidade onde residia em $1905^{208}$. Nesta oportunidade, declarou-se lavrador, com 36 anos, casado e natural de Tenerife, nas Ilhas Canárias. É provável que tenha sido o precursor da importação das sementes de cebola das Canárias, utilizando-se de conhecimentos e contatos locais porque, a partir dessa data, 1919, avolumam-se os anúncios para sua venda no EDE. Sementes de cebola eram embarcadas diretamente de Tenerife para determinados comerciantes da Capital e do Interior, caso de Juan Costal, de Mocóca ${ }^{209}$. Alguns tinham sucursais no interior especialmente para venda de semente de cebola, caso de Gabriel Perez instalado na capital à rua São Caetano, 144, com filial em Bauru ${ }^{210}$. A demanda era grande e os lucros, garantidos: até os Hermanos Eiras Garcia e Perfecto Ares ${ }^{211}$, passaram a comercializá-la ${ }^{212}$.

No entanto havia, a par dessas grandes empresas constituídas há algum tempo e que foram introduzindo a atividade como complemento à venda de cereais, indivíduos

Cristobal Morón Moreno, de Granada (LRC 11.01.1913); José Antonio Gonzalez Gil, de Almeria (LRC 20.01.1919) e Antonio Rodriguez y Rodriguez, de Granada (LRC 30.06.1919).

${ }^{206}$ EDE 21.03.1920. Trad. da autora.

${ }^{207}$ EDE 27.10.1921. Trad. da autora.

${ }^{208}$ EDE 31.10.1919.

${ }^{209}$ EDE 13.10.1919.

${ }^{210}$ EDE 28.09.1920.

${ }^{211}$ EDE 27.10.1921.

${ }^{212}$ EDE 21.01.1921. 
aparentemente sem qualquer lastro ou conhecimento anterior, como Manuel Santaella Diaz, jornalero, analfabeto, nascido em Granada e registrado em 1920, apresentando, como único documento na ocasião uma cédula do Consulado de Santos de 1914, instalado com sua "venda de cebola argentina" na Av. Rangel Pestana, $15^{213}$.

Proliferavam pontos de venda de semente de cebola, sobretudo na Rua Santa Rosa, lado a lado ${ }^{214}$, na mesma proporção que se multiplicavam os pontos de comercialização de sacos na rua Paula Souza: sacos vazios, no depósito de Julián Sierra, no $\mathrm{n}^{\circ} 106^{215}$; sacos "finos e grossos de cânhamo e barbante", no de Juan Villadangos, no no $17^{216}$; nos no s. 4-A e 4-B, Miguel Gutierrez combinava à venda de cereais e sementes de cebola, a sacaria ${ }^{217}$.

Conforme comentávamos atrás, três expressivas fortunas haviam-se constituído com base no comércio de grãos em geral e, dentre elas, em pelo menos dois casos, observamos uma expansão para o comércio de importação. Na Rua Líbero Badaró - que, após ter sido praticamente reconstruída, passou a atrair diversas empresas, dentre elas, as do ramo de representação e comissão -, como vimos, estava instalado, desde 1921, Perfecto Ares, com escritório próprio; contudo, é bom lembrar, as sementes e os primórdios dessa expansão estavam nos grãos da Rua Santa Rosa onde, a partir de 1914, passara a investir no ramo da importação. Denominava-se, então, “comissionista e importador", reunindo os dois segmentos em que atuava, o de grãos, em comissão, e o da importação de produtos espanhóis.

Contudo, a partir de 1921, desde sua instalação na Rua Líbero Badaró, percebemos, pelos anúncios publicitários, uma alteração no âmbito de atuação de seu escritório, que passara a se denominar "Comissário, exportador e importador". Não se tratava, conforme pudemos deduzir, apenas de uma atualização da terminologia (de comissionista para comissário). Na realidade, a questão era de escala e de alcance: sua empresa passara a ser a representante oficial de outras tantas do exterior para a representação e venda de seus produtos no Brasil, do mesmo modo que atuava com empresas similares em outros países, na mediação de negócios de

${ }^{213}$ EDE 03.02.1921. Trad. da autora.

${ }^{214}$ Juan Perez y Hermano, no n ${ }^{\circ} 24$, também comercializava com sacos vazios; Moreno \& Magán, no n 30 e Francisco Vinuesa, no $\mathrm{n}^{\mathrm{o}}$ 33, apenas para ficar nos primeiros metros daquela via. EDE 28.09.1920 e EDE 21.12.1921.

${ }^{215}$ EDE 02.05.1922. Trad. da autora.

${ }^{216}$ EDE 02.05.1922. Trad. da autora.

${ }^{217}$ O levantamento dos imóveis comerciais ocupados por espanhóis na Rua Paula Souza, entre 1912 e 1922, por meio dos anúncios publicitários - parcial, portanto - os indica ocupando as seguintes numerações: 4-A, 4B, 5, 15, 17, 28, 37, 50, 51, 56, 61, 65, 70, 73, 75 e 106, 108. Relatório Access 29. 
exportação de produtos e gêneros brasileiros. Em outras palavras, passara a exercer atribuições correlatas à exercida por uma atual empresa de comércio exterior.

Eles, os comissários, trabalhando sob a forma de comissão e representação, "formavam o grupo mais próspero no meio comercial", afirma Deaecto, para completar depois: "E também no industrial e agrícola" ${ }^{218}$. Esses depositários, como também eram chamados aqueles a quem se confiava a representação de determinada empresa ou mercadoria, passam a aparecer nos anúncios publicitários do EDE a partir das primeiras edições examinadas, em 1912, pelos quais divulgavam um variado sortimento de produtos, desde gêneros alimentícios até máquinas. $\mathrm{Na}$ verdade, era em Santos que se localizava a maioria de seus escritórios, também assíduos nas páginas do EDE, onde compareciam com grandes anúncios, proporcionais ao extenso inventário de produtos que representavam e/ou importavam. Apenas para constar, uma das maiores, senão a maior delas, a Troncoso \& Hermanos, pertencia aos irmãos Secundino e Silvano, espanhóis, cuja diversidade de funções era admirável: "importadores"; "agentes marítimos"; "consignatários de empresas de navegação"; "casa de câmbio", além de serem representantes de diversas marcas de produtos alimentícios espanhóis ${ }^{219}$.

Em São Paulo, na década de 1920 já havia grandes importadores, caso de Zerrener Büllow \& Co. Importadores, com sede também em Santos, em cuja fazenda, propriedade do Sr. Zerrener Büllow, situada a dez quilômetros de Bauru, na Noroeste, viviam "250 famílias, a maioria espanhóis de Almeria e Granada"220.

${ }^{218}$ DEAECTO, M. Op. cit., p. 124.

${ }^{219}$ EDE 08.01.1912 e outros mais, no período examinado. Trad. da autora. Em Santos os espanhóis representavam, em 1890, $10 \%$ da população da cidade. $C f$. LANNA, Ana Lúcia Duarte. "Santos - transformações urbanas e mercado de trabalho livre, 1870-1914”. In: SILVA, S. e SZMRECSÁNYI, T. (org). Op. cit. 1996, p. 306.

${ }^{220}$ EDE 28.09.1913. Trad. da autora. 


\section{Importadores, exportadores e casas comissárias}

No setor de importação, os espanhóis ensaiavam os primeiros passos, importando produtos específicos, marcas conhecidas, sobretudo de azeites e vinhos, que anunciavam: Isaac G. López, reiteradamente divulgava as marcas de azeite Cruz Branca e Cruz Verde, de Sevilla; os vinhos de Jerez; La Praviana e San Felipe, de Rioja e a sidra champagne El Guirrio ${ }^{221}$, anúncios que se tornavam mais freqüentes às vésperas das festas, como a de Natal. Antonio Ribas Pajés, Rua do Hipódromo, 70, era o representante exclusivo do azeite de oliva G. Sensat Hijos, de Barcelona, os primeiros anúncios ilustrados a aparecerem no $\mathrm{EDE}^{222}$. Ribas Pajés registrara-se no $\mathrm{CGE}^{223}$, declarando-se natural de Barcelona, indicativo de que, muito provavelmente, antigos hábitos ou conhecimentos influenciassem na eleição do produto a importar.

A Mariano Conti, pertencente a espanhóis e instalada na cidade com anúncios regulares no EDE a partir de 1913, esclarecia serem os seus produtos encontrados "sem a vergonhosa especulação que se efetua em outras casas do gênero", colocando à disposição da clientela variada gama de produtos regionais: passas e sidra de Astúrias; frutas secas e figos de Málaga; castanhas e uvas de Almería; vinhos Málaga; azeitonas de Sevilha; pimentão, chorizo, conservas de pescado, frutas em lata, de Rioja; azeites, grão-de-bico, etc. Eram representantes exclusivos da Casa Gabrain y Olaondo, de San Sebastian, no País Basco ${ }^{224}$. Inicialmente instalada na Rua 24 de maio, 42, esta importadora passará a oferecer duas opções aos clientes: rua Dom José de Barros, 16 e rua Piratininga, $132^{225}$.

A especulação que girava em torno da comercialização dos gêneros, acirrada pela Primeira Guerra, obrigou o então secretário da fazenda, Dr. Sampaio Vidal, na tentativa de "pôr freio aos especuladores que têm elevado os preços dos gêneros de consumo", a ameaçar-lhes com a cassação da licença, informando, ademais, que "os riquíssimos comerciantes importadores dessa praça” Srs. Matarazzo, Pinotti Gamba, Pugliesi e Crespi, proprietários dos

${ }^{221} \mathrm{EDE} 23.11 .1912$.

${ }^{222}$ EDE 07.04.1913.

${ }^{223}$ LRC 09.01.1913. Casado, 39 anos, três filhos e residente a Rua do Hipódromo, 178, declarou ser [do] comércio.

${ }^{224}$ EDE 03.01.1913. Trad. da autora.

${ }^{225}$ EDE 15.02.1921. 
grandiosos moinhos de farinha, colaborarão para que o produto não falte, nem aumentarão o preço $^{226}$.

Perfecto Ares e Raimundo Diez, ambos importadores, ofereciam desde 1913 diversos produtos europeus importados. Diez viajava regularmente à Espanha e a "várias capitais européias para tratar da compra de produtos para seus armazéns",227. Paulatinamente foi incorporando em seu catálogo produtos italianos e portugueses ${ }^{228}$. Em 1922, em franca expansão, Diez associa-se. Sua empresa passa a chamar-se então Casa Raimundo Diez, Le Voci \& Cia. Importadores e Exportadores, Comissões, Consignações e Conta Própria, ganhando mais duas numerações na mesma rua Brigadeiro Tobias, seu tradicional endereço $\left(n^{\circ} \mathrm{s} .88,90 \mathrm{e}\right.$ 92).

Curiosamente Diez, diferentemente das maiores fortunas cerealistas, jamais se estabelecera na Santa Rosa ou na Paula Souza, mas na Rua Brigadeiro Tobias, a mesma em que funcionava o EDE. Antiga Rua Alegre, a Brigadeiro Tobias, depois da chegada da ferrovia e devido à sua proximidade, passou a receber moradores ilustres que aí construíam os seus Palacetes, como o do Barão de Piracicaba. Alguns importantes hotéis também estavam ali estabelecidos, como o Albion que promovia concertos instrumentais aos domingos à noite ${ }^{229}$.

Assim, ocupando três imóveis na mesma rua, Diez passava a maior parte de seu tempo viajando para ativar seus contatos comerciais e incrementar a importação "direta" de "vinhos, licores, champagnes, sardinhas, azeites, azeitonas, cidras, conservas, produtos medicinais e de serralheria. Azeitona "Tigre", sementes de alfafa de Murcia, navalhas de Albacete, baralhos espanhóis e ... anisados" ${ }^{\text {230 }}$, este último um licor preparado com anis, bastante apreciado e consumido nas casas das famílias espanholas:

- Um licorzinho, seu Demétrio. Coma um biscoito.

- Ótimo esse anisete..., dizia o senhorio dando estalos com a língua.

- De que marca é?

- É da Destilaria Andaluza. Fica ali no 53 da Rua Piratininga, informou-lhe amavelmente Lola ${ }^{231}$.

Contudo, em sua maioria, os importados atendiam somente a uma seleta e endinheirada clientela. Sebastián Prat, proprietário da Casa Ausonia, importadora de diversos produtos

${ }^{226}$ EDE 07.08.1914.

${ }^{227}$ EDE 02.06.1913. Trad. da autora.

${ }^{228}$ EDE 02.05.1922.

${ }^{229}$ OLIVEIRA, M. Op. cit., p. 311.

${ }^{230}$ EDE 02.05.1922. Trad. da autora.

${ }^{231}$ MARX, G. Op. cit., pp. 36-37, narrando diálogo entre Lola, mulher de Garcia, o "ferro-velho" e o grego Demétrio, dono do cortiço onde residiam. 
regionais, instalara-se na Rua S. Efigênia, 66, no mesmo ano (1913) em que se inaugurara o viaduto, o que trouxe àquela região um aspecto revitalizado ${ }^{232}$. Dos produtos que importava, divulgados com regularidade pelo EDE, didaticamente já esclarecia ao leitor: "a culinária espanhola é elaborada com ingredientes caros e difíceis de serem produzidos no Brasil, necessitando, portanto, serem importados; além do mais, muitos deles não são pratos comuns na mesa do brasileiro, como o peixe". Essa constatação, de certo modo, sugeria que a maioria dos produtos caros, por ele importados, jamais teria como destino a mesa simples dos emigrados comuns. Esse diagnóstico pode, de certo modo, também explicar o porquê da tão restrita manutenção da tradição culinária espanhola na cidade, quando comparada à dos italianos, por exemplo. E Prat prosseguia com suas "pérolas", anunciando sua importadora com curiosa estratégia de marketing: “a que tem de contínuo no depósito o riquíssimo e puro vinho espanhol destinado ao sacrifício da missa, o preferido por todos os párocos e recomendado pelo bispo da Diocese"233. Importava, então, o vinho de mesa Rioja Clarete; vinhos finos de Jerez e Málaga, mas também turrones de Alicante e Ujona; chorizos e conservas de pescado e de frutas e o azeite Sensat. A finais da segunda década, já exibia um segundo endereço comercial, a Rua das Palmeiras, $4^{234}$.

Um pouco mais tarde, no ano de 1919, quem se estabelece com Casa Comissária, em sociedade, são os filhos de Eiras Garcia, fundando a Hermanos Eiras Garcia \& Mestres, de propriedade de Héctor e José Eiras Garcia Filho e Luis Mestres. Luis Serrano Mestres, natural de Madrid deve ter exercido alguma função no EDE, pois em registro no CGE de dois anos antes, $1917^{235}$, declarou-se empleado e mencionava o endereço do jornal, Rua Brigadeiro Tobias, 85. Era casado e tinha 33 anos na ocasião.

Com sede à Rua Brigadeiro Tobias, 93, portanto próximo do local onde funcionava o EDE que, a essas alturas passava por graves dificuldades financeiras, a Casa Comissária trabalhava no sistema de comissões, consignações e representações, acumulando funções de embarque de café para portos da Espanha; ordem de pagamento e compra de passagens; representações de fábricas e casas comerciais; despachos da aduana de Santos e seção de engenharia - contrato de medição e demarcação de terras e compra de máquinas agrícolas,

\footnotetext{
${ }^{232}$ Cf. LEME, M. Op. cit., p. 106.

${ }^{233}$ EDE 05.11.1913. Trad. da autora.

${ }^{234}$ EDE 03.01.1920.

${ }^{235}$ LRC 24.03.1917.
} 
motores, etc. ${ }^{236}$, seção essa a cargo de Héctor Eiras Garcia, engenheiro formado pela Escola Politécnica. Também comercializavam com gêneros "do país", os quais enumeravam com o cuidado de identificar em português aqueles cuja grafia fosse muito distinta em espanhol exemplo de "feijão" (frijol, em espanhol) - que colocavam entre aspas. Possuíam "grandes armazéns" para depositar as mercadorias, mantendo em estoque, regularmente, os seguintes produtos:

Vinhos espanhóis, das marcas Rioja Medoc e Seleto, tinto, em quintos ${ }^{237}$ de 80 litros; farinha argentina, de primeira e segunda; azeite espanhol, em lata de dois quilos; fósforos em caixa e latas Olho, Trevol e Pinheiro; sal estrangeiro, grosso e moído; velas Brilhante e Paulista; banha marca Roça; pimentão em pó, doce e picante; enxadas, foices, podadeiras, enxadões e cabos; petróleo; balanças; sacos vazios, novos e usados.

Meses depois, em anúncio de página inteira, anunciavam as novas representadas, empresas espanholas de diversas Regiões ${ }^{238}$, rol ao qual acrescentariam pouco tempo depois uma série de novas empresas depositárias e/ou representadas, desta feita americanas. Suas representadas eram fabricantes de veículos; de acessórios para automóveis; de lubrificantes; de materiais de aço estampado para tetos e paredes exteriores, ornamentos, material galvanizado, estampado e pintado. Também havia fábricas de anilinas, corantes e de produtos químicos. Eram, em suma, produtos industrializados para o atendimento à crescente demanda apresentada pela cidade, em seu acelerado ritmo de crescimento.

É de causar estranheza, nesse momento de crise financeira anunciada, a desenvoltura dos filhos de Eiras Garcia na expansão de negócios reconhecidamente onerosos e dispendiosos, como o da criação e manutenção de uma Casa Comissária Importadora e Exportadora, quando observamos as reiteradas campanhas de esclarecimento público que eram levadas a efeito pelo jornal, desde 1918, relatando aos assinantes e leitores toda ordem de dificuldades enfrentadas "pela carestia do custo do papel importado do EUA [de 24\$000 o fardo, passou para 150\$000] e por estar o periódico incluído numa "lista negra"; em outras palavras, informava-se que o EDE "não possuía as garantias de que gozava a imprensa brasileira" posto que uma das penas da inclusão "nessa lista dos indesejados é a alta no preço do papel". Por causa disso, o custo da assinatura "já quase empata com o custo do jornal", afirmava Eiras Garcia, justificando a

\footnotetext{
${ }^{236}$ EDE 08.04.1919. Trad. da autora.

${ }^{237} \mathrm{EDE}$ 18.06.1919. O termo correto seria quintas, que significa barris ou tonéis.

${ }^{238}$ De Málaga; Jerez de La Frontera; Madrid; Valdepeñas; Alcalá La Real; Barcelona; Valencia; Réus e Tarragona.
} 
redução das edições diárias para três páginas apenas, como medida para controle das despesas $^{239}$.

Sua situação não se equilibrava. Assim, prosseguia com matérias de primeira página a exortar a colônia, numa provocação simulada às autoridades e aos "perseguidores", que reiteradamente denunciava. "Unica publicación diaria española existente en el Brasil", e, mais abaixo: "Este diario, por su tirada, ocupa el cuarto lugar entre los diarios de gran circulación de este Estado" ${ }^{240}$, dizia, convocando, em editorial, aos leitores e à colônia para que aderissem à "emissão de ações de empréstimo", então "oferecidas aos compatriotas que estejam em condições de nos prestar auxílio". À custa dessas intervenções, Eiras Garcia logrou manter em circulação quase todas as edições de 1918, embora em duas páginas ${ }^{241}$.

Somente em 1919, o jornal retoma a publicação de edições com quatro páginas, porém, ato contínuo, oferece em sorteio, aos assinantes que antecipassem a assinatura anual, "quatro máquinas Singer", presente às mulheres que "têm demonstrado ser entusiastas e amigas dessa publicação" 242 . Novas campanhas arrecadatórias e mais brindes aos que antecipassem o pagamento das assinaturas se sucediam, desta feita, um cerdo reprodutor Duroc-Jersey, cedido por Ernesto Rolff, e mais alguns presentes ${ }^{243}$. No entanto, a recuperação demonstrava-se difícil, e Eiras Garcia resolve abrir mão de seu patrimônio pessoal, anunciando a venda de duas propriedades: a primeira, um lote de três mil metros na Estação da Água Branca, à Rua Guaicurús, "própria para uma fábrica" 244 e, logo depois, ofereceria 500 alqueires de terras situadas "a pouco mais de três léguas da Estação Lusanvira, na Noroeste, próprias para o café $^{245}$. E assim prosseguiu o jornal, de crise em crise, tentando equilibrar-se, o que, bem ou mal, foi conseguido até a morte de Eiras Garcia, em dezembro de 1921, fato que representou a agonia do jornal, que deixaria de circular meses depois.

De qualquer modo, como dizíamos, causa surpresa diante da crise financeira enfrentada, aqui sucintamente ilustrada, o fato de dois de seus filhos, também redatores do periódico que a essa altura já ultrapassava o seu terceiro decanato, optarem por um investimento dispendioso e concorrido. O jornal de Eiras Garcia, já sabemos, não sobreviveria ao passamento

${ }^{239}$ EDE 18.05.1918. Trad. da autora.

${ }^{240}$ EDE 30.08.1918. O preço da assinatura do EDE: Anual (Brasil: 20\$000; exterior: 30\$000). Semestral (Brasil 12\$000; exterior: 20\$000); Trimestral (Brasil 7\$000 ; exterior: 10\$000).

${ }^{241}$ EDE 11.09.1918

${ }^{242}$ EDE 23.08.1919. Trad. da autora.

${ }^{243}$ EDE 28.08.1919.

${ }^{244}$ EDE 18.10.1919. Trad. da autora.

${ }^{245}$ EDE 01.12.1919. Trad. da autora. 
do seu criador. O que não conseguimos saber foi no que resultaram as empresas então fundadas por dois de seus filhos.

Outro dos setores de importação que apresentou enorme impulso no período, multiplicando os pontos de venda, especialmente para o atendimento à clientela do Interior, foi o de maquinários e implementos agrícolas. Capitais diversificavam-se e eram investidos no ramo: Antonio Garcia Portela, ex-administrador do EDE e ex-diretor do El Comercio Español, que anteriormente havia investido no atrativo mercado de gêneros alimentícios em consignação - Casa Comercial de Antonio G. Portela \& Co. - rapidamente percebeu o filão a ser explorado e ágil tratou de se antecipar, introduzindo-se no ramo de "compra e venda de máquinas e ferramentas de todas as classes". Seu cliente típico localizava-se no Interior, seja o comerciante estabelecido em uma das cidades que brotavam no rastro dos trilhos, seja o pequeno proprietário que necessitava de maquinário para produzir em seu quinhão de terra. Convencido de que se tratava de mercado promissor, Portela, instalado então na Rua Conselheiro Ramalho, 102", adiantava-se, intermediando as aquisições "por conta dos comerciantes do interior" ${ }^{, 246}$. Em geral, esses representantes de maquinários encarregavam-se da sua importação e também da sua instalação, no caso de empresas de maior porte. Encomendadas por catálogo, muitas dessas peças chegavam trocadas, causando grandes transtornos tanto para o importador quanto para o cliente, na instalação.

João Bobadilla, atrás mencionado, também diversificara o seu negócio inicial, a sua indústria alimentícia, estabelecendo-se no ramo das importações (e também das exportações). Inicialmente, passara a importar alimentícios mantendo para pronta entrega inúmeros produtos nacionais e estrangeiros, estes especialmente os portugueses e espanhóis, incluindo-se os vinhos de Rioja, sua terra natal. Para fortalecer e ampliar seus negócios montara uma sociedade com mais dois conterrâneos abrindo a União Hispano-Brasileira Collazos, Bobadilla \& Gonzalez. através da qual passa a atuar no ramo de importação de máquinas para beneficiar café e arroz e moinho de fubá. Sua empresa, como parece ter sido de praxe, mantinha os escritórios - à rua Julio Conceição, 35 - separados da fábrica e do depósito dos produtos, localizados na rua dos Italianos, 67, 69 e $73^{247}$, ambos no Bom Retiro.

Conforme observamos, os grãos plantados próximos à várzea da cidade germinariam, produzindo empresas diversificadas e de variado porte, muitas das quais evoluindo para firmas

\footnotetext{
${ }^{246}$ EDE 18.02.1918. Trad. da autora.

${ }^{247}$ EDE 21.02.1922.
} 
comissárias de importação e exportação. Essa amostragem, viabilizada pelo entrecruzamento dos dados que ensejou o exame particular de um certo número de casos, permitiu traçar a trajetória de alguns inicialmente pequenos, e muitas vezes improvisados, "negócios" de cereais e grãos, descortinando um momento de oportunidade, uma ocasião propícia muito bem percebida por uns tantos indivíduos que, com astúcia e se valendo de inúmeros artifícios, dele se aproveitariam para galgar alguns degraus da escala social, atingindo certo status e projeção social. 


\section{Comércio varejista: vendas, empórios e armazéns Um estudo de caso}

Noite na Espanha de São Paulo. Mas noite que não caiu do céu: subiu dos telhados rasteiros, negríssimos dos gasômetros, e veio vindo, numa fuligem fosca de crepe, que se esgarçou toda no ar abaixo. Noite de hulha. Noite preta e pobre que riscou o carvão irônico de Goya. Noite realista de uma Espanha sem rondallas, nem luar de prata nas flores de azahar. Noite de fechar as portas dos armazéns; de varrer os cimentos dos armazéns, de acender a lâmpada elétrica dos armazéns... A lâmpada elétrica triste, tristíssima, atrás dos vidros sujos das bandeiras, pendurada num fio de moscas sobre a escrivaninha dos guarda-livros, e parada, amarela, idiota, entre sacas e réstias, toda assombrada de teias de aranha... ${ }^{248}$.

A venda do Gimenez nunca me fora desconhecida. A clássica lâmpada de 40 velas, num pendente de moscas; vários sacos de juta expondo os mantimentos; um armário envidraçado tendo em cima seis boiões de balas e dentro três prateleiras com doces, pães e chocolates, tudo velho; o balcão coberto de mármore esburacado com cálices em desordem na pia de ágata; lingüiças penduradas num cabo de vassoura seguro ao teto alto encardido por dois longos fios de arame qual trapézio de circo; mesas de ferro pintadas de marrom e poucas coisas mais. Venda sem higiene como as outras... ${ }^{249}$.

Proliferaram no período as pequenas vendas de bairro, como a do espanhol Gimenez. Constituíam-se de modestos armazéns onde ser vendia de tudo. Geralmente instalados em pequenos cômodos, guardavam um aspecto de pouco asseio, e muitos eram conhecidos pelos nomes de seus donos. Um desses pequenos vendeiros de bairro era Mariano Briz. Instalado com sua portinha à Rua Carnot, 67, é provável que adotasse o sistema de "consignação" para mantêlo, melhor dizendo, é provável que só conseguiu abri-lo mediante a adoção desse sistema, pelo qual se negociava sem ter de investir na compra dos produtos. Investia, isso sim, na confiança dos fabricantes ou criadores que deixavam seus produtos ou animais para serem por ele vendidos sem ver, de imediato, a cor do dinheiro, e nos anúncios pagos que veiculava pelo EDE oferecendo-se para "colocar na praça todos os referidos artigos que sejam enviados pelas pessoas do interior". Comercializava com "aves, ovos, cabritos e leitãozinhos"250. Poderíamos apostar que os negócios de Mariano Briz não se restringiriam apenas à sua portinha da Rua Carnot.

\footnotetext{
${ }^{248}$ ALMEIDA, G. “Um carvão de Goya”. In: Op. cit., 1929, pp. 64-65.

${ }^{249}$ RIZZO, P. Op. cit., pp. 119-120.

${ }^{250}$ EDE 21.01.1921. Trad. da autora.
} 
Os homens não pareciam ter primazia nesse pequeno comércio. Mulheres também eram proprietárias desses humildes estabelecimentos, caso da espanhola Maurícia Gilda Villagen, proprietária de uma espelunca na Rua 25 de março, onde morava, e foi encontrada morta ${ }^{251}$. Alguns desses armazéns especializavam-se em determinados artigos. "Grande armazém de louça" dizia a chamada do anúncio de Antonio Rojo López, que vendia cristais e louças na Rua Piratininga, $180^{252}$, enquanto Manuel Bos, da Rua Oriente, 127, aproveitava-se das vésperas das festas de natal para fabricar e vender "variado sortimento de mantecados a la española, torrones e pão doce cheio de frutas" ${ }^{, 253}$. A maioria, porém, reunia, num só local, diferentes funções: aceitando "pensionistas", Antonio Regos, galego de Coruña, e residente na cidade em 1896, data de seu primeiro registro consular, mantinha em 1904 o seu "Almacen y Restaurant de Mis Amigos" em dois endereços: nas Ruas Benjamin Constant, 14 e Quintino Bocaiúva, 21-A ${ }^{254}$.

Mais afastado, no bairro do Ipiranga, à rua Bom Pastor, 23, estava o Emporio Españolel rey de los barateros, de Antonio Lopez Campillo. Natural de Múrcia, chegado em 1906, ali se estabeleceu em 1910, e, a partir de 1912, tornou-se anunciante freqüente e regular. Teria elegido o Ipiranga quer pela concentração de fábricas no local e/ou eventualmente de espanhóis, quer porque os aluguéis fossem ali mais baratos

Seu empório, típico de bairro, comercializava de tudo, inclusive alguns produtos espanhóis, destacadamente das Regiões que representavam a maioria dos emigrados da cidade, produtos que certamente Lopez Campillo adquiria de algum importador. Lá podiam ser encontrados "aceites y aceitunas de Sevilla, vinos de Rioja y Málaga, y sardinas de las ríos gallegas" . Mas ali também podiam ser encontradas "lozas nacionales y extrangeiras" (de que estaria falando?) e "gran surtido de ropa hecha para hombres, mujeres y niños"255. Enfim, Lopez Campillo que, como vimos, partiria do subúrbio do Ipiranga para estabelecer-se com sua própria indústria, ali também teria iniciado o aprendizado de que se valeu para tornar-se um porta-voz atuante das causas de seus conterrâneos.

Os empórios ou armazéns, nesse período, concentravam em si não apenas as funções de abastecimento, não eram apenas o local onde se recorria para adquirir algum produto alimentício ou não. Como bem pontua Maria Luiza Oliveira ${ }^{256}$ o dono do armazém, numa

${ }^{251}$ Correio Paulistano, de 09.05.1902. Apud: FONSECA, G. Op. cit., 1988, p. 104.

${ }^{252}$ EDE 01.03 e 12.04.1918.

${ }^{253}$ EDE 15.12.1922.

${ }^{254}$ LTE 09.01.1904.

${ }^{255}$ EDE 15.02.1912. Trad. da autora.

${ }^{256}$ OLIVEIRA, M. Op. cit., pp. 241 e ss. 
cidade que primava pela inconstância no mercado de trabalho, era aquele sujeito com o qual se precisava manter um bom relacionamento, dado que, era desse vínculo que, em tempos de crise ou desemprego, se garantiria o suprimento da família. Era no armazém, conforme a autora, que se conseguia o dinheiro "para pagar a escola do filho, o enterro do cônjuge, os remédios", enfim, era naquele espaço que se socializavam as agruras do dia-a-dia.

O aprendizado de Lopez Campillo deve ter sido aperfeiçoado atrás dos balcões de seu empório, pelos causos que rotineiramente por ali desfilavam. Eles o transformaram num sujeito comprometido com algumas causas e que costumava a elas dedicar-se com afinco, utilizando-se para tanto das páginas do EDE, onde comparecia pessoalmente manifestando-se. Um desses episódios, depois denunciado, o deixara enfurecido: tratava-se da proibição, do condutor da tranvia da Light, para o embarque de um ancião sob o argumento de que ele "estaba trajado de blusa, al estilo del obrero de España”. Ocorre que o indivíduo a quem não foi permitido subir no bonde, se dirigia à Estação da Luz para apanhar o trem que o levaria a Santos, onde embarcaria de volta à Espanha. E sucede que a passagem, quem a havia conseguido, através de uma subscrição realizada, era o próprio Lopez Campillo que, furioso com o ocorrido, retrucava indignado, em artigo pelo EDE, de que fora informado "de que não era permitido andar de tranvia apenas bêbados e descalços" 257 .

O estilo engajado e eloqüente, e os contatos que estabelecia, dentro e fora da colônia, garantiram a ele um certo prestígio que se consolidou socialmente conforme expandia os seus negócios. Em pouco tempo, já podia ser percebido circulando em esferas mais privilegiadas. Assim, em 1914, após ter participado de um batizado de que fora padrinho, realizado na Matriz do Brás, narrava que "os convivas em elegantes automóveis foram conduzidos à casa do Sr. Cappucci" (italiano?) que os recepcionou com "esplendidez haciéndose derroche de vinos de todas clases, cerveza, licores, finas pastas y aromáticos habanas", seguida de "alegre y animadísima fiesta" 258 .

Para a ampliação do seu negócio, Lopez Campillo deve ter necessitado admitir empregados para algumas funções - porventura relacionadas ao negócio de ferro-velho que iniciaria? - os quais "depois de querer matar seu patrão [ele próprio] em um acerto de contas, fugiram do Ipiranga, sem ajustar contas no negócio de minha propriedade e deixando abandonadas suas mulheres e filhos". Em nota publicada no EDE em $1913^{259}$ Lopez Campillo

\footnotetext{
${ }^{257}$ EDE 18.06.1912. Trad. da autora.

${ }^{258}$ EDE 26.02.1914.

${ }^{259}$ EDE 19.08.1913. Trad. da autora.
} 
avisava aos "negociantes e patrões do Estado” do ocorrido, envolvendo José Aviléz e Manuel Soto, ambos de Granada.

Cedo iniciou a diversificação do seu negócio, passando a investir na compra e venda de ferro, novo e velho, cujos anúncios ocupavam páginas inteiras do EDE, atividade que deve ter iniciado anteriormente, pois em 1913 em matéria intitulada "Grande leilão de louça esmaltada" notificava do leilão público em que venderia "grande quantidade de ollas, cacerolas, jofainas e outros recipientes de diversas classes pelo leiloeiro matriculado, no depósito judicial, à Rua Piratininga $^{260}$. Nesse negócio permaneceria por algum tempo, conservando com regularidade os anúncios em que informava comprar "ferro batido, fundido, canos, arcos de "cartola" e barricas, arame galvanizado, metais de todas as qualidades, trilhos, etc. etc., aos melhores preços da praça” mantendo para tanto, um “depósito junto à Estação do Norte - Brás, tel. 474 (Brás)"261 .

Prosperava como negociante de sucata, atividade na qual operava uma rede bem articulada de indivíduos, encabeçada pelos carrinheiros, tarefa na qual se concentravam muitos espanhóis, que vasculhavam a cidade puxando seus carrinhos - alguns dos quais cedidos pelos próprios donos de depósitos, daí não se descartar a hipótese dos empregados foragidos terem trabalhando nessa função - recolhendo produtos e materiais que eram descartados, para depois oferecê-los aos donos de depósitos. Estes os recebiam, classificavam e preparavam para a revenda, enviando-os para os comerciantes, os quais prensavam os metais, de onde seguiam para as usinas de fundição, local de onde a massa prensada seguia para a laminação. Configurava-se aí uma hierarquia que ia do carrinheiro, geralmente o imigrante recém-chegado, passando pelo depositário, o receptor da sucata bruta recolhida pelo carrinheiro, que a separava para ser encaminhada ao comerciante de resíduos industriais, alcançando seu estágio terminal na fundição ${ }^{262}$.

Não por acaso, em 1918, Lopez Campillo que, habilmente passara a controlar as diversas fases do processo, é visto estabelecendo-se com uma pequena oficina de fundição, uma "forja”, registrada com "20 contos de réis na Associação Comercial”. Instalada na Rua Uruguaiana, 33, seu estabelecimento, de nome São Paulo, passaria a fabricar utensílios de ferro e aço para a agricultura, especialmente foices e enxadas ${ }^{263}$.

Ficava assim demonstrado, através de Lopez Campillo, o alcance de um segmento inicialmente "invisível" que, transitando pelos subterrâneos da economia, se apropriando do que

${ }^{260}$ EDE 24.07.1913. Panelas, caçarolas, bacias ou vasilhas. No EDE 24 e 28.07.1913, há o anúncio do mesmo leilão em Santos. Trad. da autora.

${ }^{261}$ EDE 12.04.1918. Trad. da autora.

${ }^{262}$ A esse respeito ver: NASCIMENTO, J. L. Op. cit., 2002, especialmente pp. 385 e ss.

${ }^{263}$ EDE 30.06.1920. Trad. da autora. 
era descartado pela sociedade para o reaproveitamento, vinha à tona, alcançando os últimos degraus da hierarquia no universo dos resíduos industriais. Lopez Campillo, o exemplo, foi mais adiante. Alavancando experiência e capitais nos vários estágios da sucata, abriria com um conterrâneo a Importadora Solana \& Lopez, com escritórios bem localizados, na Rua Álvares Penteado, $42-2^{\circ}$ andar, através da qual diversificava seus investimentos, operando com grande número de produtos importados ${ }^{264}$.

Consta, como todos os seus compatriotas que atingiram alguma notoriedade granjeada pela posição econômica, ter sido membro de quase todas as sociedades espanholas então existentes da cidade. Pertenceu às juntas diretivas da SESM, da BE, da CRE e da FE, tendo sido presidente destas duas últimas. Na Federação foi atuante: iniciou a publicação do "seu órgão na Espanha" (não conseguimos saber qual foi, porém imaginamos que se tratasse de algum informativo), organizou a seção de futebol e, ao entregar seu mandato, a deixava com 700 sócios.

Fazia verdadeira cruzada contra os "antiespanholistas" - que se orgulhava de ter "eliminado" dos quadros da FE - apelando para os paisanos, a quem não dava trégua invocando-os a se irmanarem e a participarem dos eventos que eram promovidos, especialmente da Romería para "demonstrar nossa solidariedade, nossa pujança e que não somos o que dizem e sim o que devemos ser em terra estranha: espanhóis orgulhosos de sê-lo, filhos de uma Espanha única e indivisível"265, apregoava, em claríssima alusão às contendas e cisões que marcaram, com altos e baixos, avanços e recuos, a existência dessas sociedades. Insistente, publicava após a realização da Romería, coluna comentando do seu sucesso, "idéia acolhida com indiferença que não logrou se concretizar antes" justificava, "um pouco por razão da guerra", ou "porque la colonia española no estuviera preparada para celebrarla, sea porque las sociedades españolas estuviesen un tanto divorciadas unas de otras ${ }^{\text {,266 }}$, enfatizava.

${ }^{264}$ EDE 06.09.1919. Alimentícios; couros; essências; tecidos; cordas para instrumentos; artigos cirúrgicos; vidros; balanças de precisão; microscópios; instalações completas de hospitais; sanatórios; formos crematórios; aparelhos de desinfecção; estufas de cultivo; esterilizadores de alta pressão; material para bombeiros; mangueiras "Cobra" ; automóveis; escadas; bombas à vapor; artigos de serralheria; máquinas para fabricar comprimidos; filtros para produtos químicos; vinhos; engenhos de açúcar; azeite; moinhos a martelo; britadeiras; compressores e bombas; motores verticais para gasolina; petróleo; gás e álcool; cabos metálicos de ferro e de aço galvanizados; máquinas para fabricação de tubos de cimento.

${ }^{265}$ EDE 12.05.1920. Trad. da autora.

${ }^{266}$ EDE 20.08.1920. 


\section{Setor hoteleiro, de entretenimento e lazer}

Os investidores do ramo hoteleiro e de entretenimento e lazer ocuparam importante espaço na Paulicéia, em sua tumultuária transformação. A crescente urbanização e o trânsito constante de gente endinheirada pela cidade, fazendeiros do interior em maior escala ou indivíduos que vinham realizar negócios na cidade, transformaram tais ambientes em cenário de reunião da fina flor. Instalados em sua maior parte na região central da cidade, tais investidores beneficiaram-se das desapropriações e demolições das antigas construções do centro que, conjugadas às iniciativas oficiais de regulamentação do comércio ocorridas entre 1890 e 1914/5, visavam a atraí-los, especialmente pela isenção de taxas.

A par disso, os reclames e anúncios publicitários, participando "ativamente do processo de formulação das novas linguagens do viver urbano" patenteiam a "crescente fruição de bens e serviços" ${ }^{267}$ dimensão que, por meio do EDE numa intersecção com as demais fontes, permitiu a apropriação de elementos da atuação espanhola no setor.

Em primeiro lugar, ficou claro que a exploração do ramo hoteleiro na cidade foi monopolizada por determinados indivíduos ou famílias. Celestino Costa, um desses indivíduos, era galego de Coruña, tinha 21 anos e se declarou negociante no primeiro registro que fez no CGE, no ano de $1896^{268}$. Nos registros subseqüentes assim continuaria se apresentando e em $1901^{269}$ declarou-se domiciliado na Rua Brigadeiro Tobias, 104, local depois identificado como sendo a sede do Hotel España ${ }^{270}$. Não conseguimos saber se esse Hotel España é o mesmo Hotel de España que pertenceu a Eiras Garcia. De todo modo, em 1912 Celestino adquire com um sócio, Manuel Lopez ${ }^{271}$ o hotel antes pertencente a Eiras Garcia, que passara a se chamar Grande Hotel Eiras Garcia. Nesse mesmo ano localizamos anúncios de mais dois outros hotéis de sua propriedade, provavelmente recém-adquiridos, o Hotel dos Viajantes - "con cocina a la española" - e o Hotel Continental, ambos na Rua da Conceição ${ }^{272}$.

O caso de Eiras Garcia destaca-se, como veremos, desse conjunto, e talvez por isso, não tenha permanecido no setor. O Hotel de España ou Grande Hotel Eiras Garcia, depois adquirido por Celestino Costa (1912), sofrera um incêndio em 1882, relatado por Ernani Silva Bruno ${ }^{273}$ e,

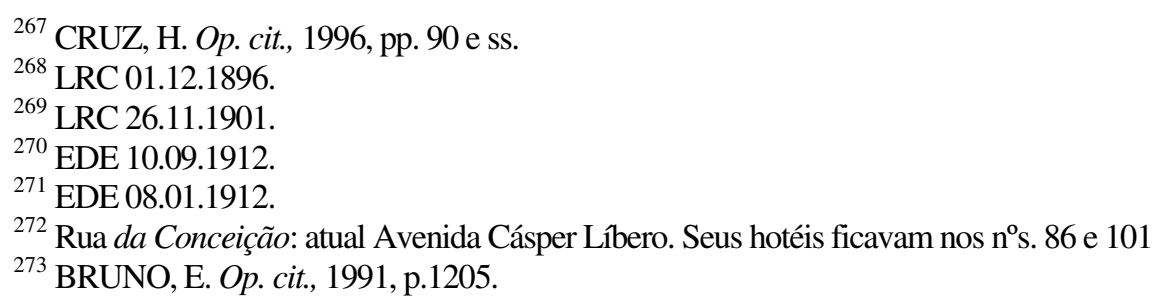


portanto, existia há pelo menos três décadas, tendo sido adquirido por Eiras Garcia, após sua chegada em São Paulo de outro proprietário, provavelmente espanhol, dado o seu nome fantasia.

Contudo, os negócios de Celestino progrediam e assim ele compraria mais outro estabelecimento, o Grande Hotel Paulista, à rua Mauá, 99. Como se evidencia, esses hotéis localizados próximos da ferrovia (Santos-Jundiaí) atendiam a uma clientela que, movida por diversos interesses, se deslocava continuamente entre o interior e Santos, mantendo São Paulo como referência e ponto de apoio. Talvez por isso, esses hotéis acumulassem funções que extrapolavam à de simples hospedagem, fazendo com que seus proprietários se dedicassem a atividades paralelas, sobretudo ao comércio. Anúncios do Grande Hotel Paulista indicam que Celestino, no mesmo local, comercializava "vinhos superiores e legítimos"274, produto perfeitamente adaptado a um clientela mais seleta.

Esta, porém, não foi a única indicação nesta direção. Outros já haviam lhe antecedido: Juan Falcón, malaguenho 275 e proprietário do Hotel España ("antigo Brasil da Luz"; é provável que seja o mesmo estabelecimento atrás mencionado como pertencente a Celestino, que o vendera), informava, no EDE, que comercializava por "conta própria" (ou seja, comprava para depois revender, espécie de atravessador) "arroz, feijão, batatas, milho, cebolas e demais gêneros" ${ }^{276}$.

Como ponto de encontro, eram nos hotéis que se realizavam negócios de diversas naturezas, alguns pouco usuais, como a "venda de touros Hereford, puro sangue, para cruzamento", cujo anúncio indicava o endereço do Hotel Londres, Rua Brigadeiro Tobias, 94 para o contato com o vendedor, Francisco Gómez ${ }^{277}$. Também em hotel se hospedava o vendedor que oferecia seu cinematógrafo: "Se vende una esplendida machina marca Pathé y todos los demás aparatos para luz esférica o eléctrica. Tiene además tres mil metros de magníficas cintas cinematográficas. Para ver y tratar en el Hotel Eiras, Rua Brigadeiro Tobias, 83, de 3 a 6 de la tarde”. E completava: “El precio es una verdadera garga, pues su dueño tiene necesidad de marcharse à Europa"278.

Fixavam-se na cidade, hospedados em hotéis, candidatos que se ofertavam ao mercado de trabalho - "Carpinteiro recém-chegado da Argentina, com muita prática de projetos (planos); trabalhou como empreiteiro (contratista), possuindo certificados. Dirigir-se a Manuel Porto,

${ }^{274}$ EDE 04.02.1918. Trad. da autora.

${ }^{275}$ LRC 14.01.1911 e 16.07.1915.

${ }^{276}$ EDE 10.09.1912 e 30.01.1913. Trad. da autora.

${ }^{277}$ EDE 28.07.1922.

${ }^{278}$ EDE 06.06.1913. Em outro anúncio, oferecia ainda "tres mil metros de cintas cinematográficas de asuntos dramáticos, cómicos, mágicos, aparato Pathé Fréres à luz elétrica”"(sic). EDE 07.11.1913. 
Hotel dos Viajantes, Rua da Conceição, 86",279 - como também ali podiam ser avistados os próprios empreiteiros à procura de mão-de-obra - "[Precisa-se] bons trabalhadores para a construção de uma estrada que vai a Minas Gerais. Tratar Rua Conceição, 121-A"[endereço do Hotel Continental] ${ }^{280}$.

Seus espaços, contudo, eram receptivos a finalidades menos pragmáticas: em 1913 o Grande Hotel acolheu a exposição do pintor José Pinelo, membro da Academia Espanhola de Belas Artes $^{281}$. O mesmo acontecera a Vila y Prades, outro pintor espanhol, que, um ano antes, encerrara carreira no Hotel Majestic, onde se exibira, informando satisfeito que "todo o material

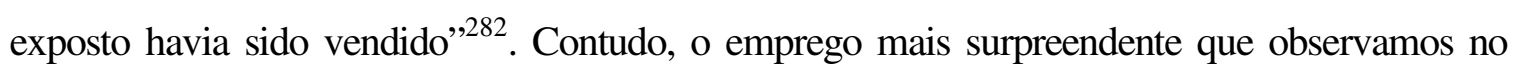
período foi quanto à acomodação do Consulado Espanhol, no ano de 1913, em um hotel situado na Rua Augusta, $205^{283}$.

A família Alvarez y Álvarez, de Pontevedra, representava um clã que investia maciçamente no setor hoteleiro. Também instalado na Rua da Conceição, o Hotel Continental, no $\mathrm{n}^{\mathrm{o}}$ 101, pertencia a Agapito Alvarez ${ }^{284}$. Na mesma rua, nos números 121 e 121-A, Emílio Alvarez dirigiria o Hotel América, explorando, no térreo, o setor de entretenimentos com mesas de bilhar, além de comercializar "variado sortimento de vinhos, licores e cervejas",285. Seu irmão, Leandro Alvarez, proprietário do Hotel do Porto, instalado na Rua 24 de maio, 56, publicava nota no EDE convocando àqueles que possuíssem baús e malas guardados no mesmo que fossem retirá-los. A casa, informava, entraria em "obras para ponerla en acuerdo con las exigencias modernas", avisando que tudo iria a leilão depois do prazo concedido ${ }^{286}$.

$\mathrm{Na}$ Rua Washington Luis, o empresário Mariano Fernandez mantinha em sociedade com Serafín da Cruz, em 1913, o Hotel Europeo instalado no no $16^{287}$ e o Hotel Esmeralda, nos $\mathrm{n}^{\circ} \mathrm{s} 25$ e 27-A, antes instalado na Rua Brigadeiro Tobias e com filial em Santos ${ }^{288}$. O mesmo Mariano Fernandez se associaria a outros dois espanhóis para adquirir a Pensão Americana, depois denominada Hotel Londres, que se localizará na Rua Brigadeiro Tobias, $94^{289}$.

${ }^{279}$ EDE 28.11.1913. Trad. da autora.
${ }^{280}$ EDE 20.09.1920. Trad. da autora.
${ }^{281}$ EDE 18.01.1913.
${ }^{282}$ EDE 24.08.1912. Trad. da autora.
${ }^{283}$ EDE 06.08.1913.
${ }^{284}$ EDE 08.01.1912. LRC 30.07.1917.
${ }^{285}$ EDE 28.09.1920. Trad. da autora.
${ }^{287}$ EDE 28.06.1913.
${ }^{288}$ EDE 29.01.1913.
${ }^{289}$ EDE 16.12.192.1919. 12.05.1920. 
A clara preferência do investidor espanhol por empregar seu capital em hotéis de padrão médio, revelada por esses indicadores, não impediu, contudo, uma iniciativa orientada para um outro patamar de clientela, associado a um padrão mais elevado.

Luxuosíssimo, o Grande Hotel Ausonia, localizado na esquina das Ruas dos Gusmões e do Triunfo e pertencente a Sebastião Prat e Juan Guerrero ganhava notória publicidade, em forma de reportagem ${ }^{290}$ por ocasião de sua inauguração, em 1914, com entusiasmada adjetivação por parte do repórter que o visitou, que descrevia o edifício como tendo as "características de um palácio" $^{291}$. No dia da inauguração, com pomposa comemoração e seletos convidados, exibia-se nova reportagem ${ }^{292}$, exaltando as "finas acomodações", as "baixelas gravadas com o logotipo do hotel" e a mobília, em grande parte importada.

Esses dados são reveladores e sugerem, para além do exposto, o papel da publicidade num momento em que transformações profundas nos padrões de vida se configuravam na cidade - operando como "consolidação de status e de valores de referências". Para Lotito, ao "divulgar comportamentos e certa domesticação de gostos e de costumes", ela atendia ao mesmo tempo "às necessidades do discurso de legitimação do projeto civilizador das elites paulistanas e às necessidades da população,"293.

O estilo de vida consistia num dos aspectos mais relevantes na conjugação desses referenciais, expondo inúmeras dimensões dos novos hábitos cosmopolitas. É evidente que tais empresários estavam perfeitamente sintonizados com a nova realidade e com as novas expectativas de seus consumidores. A "exclusividade" da construção do hotel, fato alardeado, denota a intenção de desvincular a sua imagem dos demais estabelecimentos hoteleiros, quase sempre funcionando em imóveis adaptados, geralmente assobradados. A majestade de um "palácio"; o esplendor das finas acomodações; o luxo da mobília "parecendo importada da Inglaterra"; o refinamento da louçaria, também importada e personalizada com o logotipo do hotel; os serviços de cama e mesa importados, enfim, todo o fausto descrito pela reportagem, refletindo não apenas o orgulho que representava a sua inauguração para a colônia e para a cidade, punha em destaque o indisfarçável excitamento provocado pelo que passaria a representar. Como metáfora da modernidade e refletindo o modo de viver elegante dos grandes centros, imediatamente estabelecia uma relação de cumplicidade com seus prováveis clientes sequiosos por se sentirem numa cidade que espelhasse o progresso. Buscava-se o novo, exaltava-

${ }^{290}$ Sobre a prática "pioneira de marketing" de fazer "reportagens" sobre estabelecimentos comerciais, inaugurada nas revistas de variedades, ver: CRUZ, H. Op. cit.,1996, p. 89.

${ }^{291}$ EDE 13.04.1914. Trad. da autora.

${ }^{292}$ EDE 23.04.1914. Trad. da autora.

${ }^{293}$ LOTITO, M. Op. cit., p.16. 
se o que se diferenciava dos velhos hábitos que já não condiziam com a cidade em vias de transformação. "Espaço por referência das representações, a publicidade caracterizou-se como o lugar da idealização, mas, também, como um campo de embate entre as diversas expectativas e experiências que conviviam no espaço urbano da São Paulo que se adensava", proclama Lotito $^{294}$.

Integrando a paisagem urbana, como os hotéis, como novos espaços de sociabilidade e lazer e, sobretudo, como pontos de encontro e locais de afirmação dos novos tempos, as confeitarias, os cafés, os bares, e os restaurantes, além dos cafés-concerto, já mencionados, estavam instalados na área central da cidade, tendo o Triângulo e, nele, o Largo do Rosário, como ponto preferido para sua instalação. Era dali que partiam as principais linhas de bonde e que saía a Avenida São João e onde se situavam as mais finas confeitarias da cidade, freqüentadas com elegância pelas camadas abastadas, cujo serviço compreendia chá, café e leite ou chocolate, torradas, biscoitos e pão, geléias, manteiga, etc. e, em algumas delas, também salgadinhos, empadas, croquetes, doces e guloseimas ${ }^{295}$.

Havia ambientes para todos: em alguns, reinava a farra dos estudantes da Faculdade de Direito; em outros, a cerimônia, o ar pomposo e empolado. "Os moços não ousavam manifestarse ruidosamente, tal qual acontecia no Café Guarani”, afirmava Cícero Marques, comparando-o ao Progredior, da elite paulistana ${ }^{296}$. Era também ali, no descontraído Café Guarani, que se reuniam, conforme Afonso Schmidt ${ }^{297}$ os tipógrafos e os gráficos nas madrugadas que, quando não ali, se encontravam no "velho Fernandes, da Rua de São João", este o "centro obrigatório da boemia jornalística" 298 .

Referindo-se às suas instalações, Afonso Schmidt comenta de seu enorme salão, com mesas de mármore e cadeiras austríacas. E compridos bancos laterais com espaldares de couro. A orquestra situava-se ao fundo, num palco com grades ${ }^{299}$.

O Café Guarani pertencia a um galego, Severo Alonso Dominguez, natural de Pontevedra, que esteve pela primeira vez no CGE em $1894^{300}$, declarando-se marinero. Tinha então 36 anos, era solteiro e estava domiciliado no Hotel São Paulo, na Estação da Luz, 19,

\footnotetext{
${ }^{294}$ Passim.

${ }^{295}$ LEME, M.S. Op. cit., p. 99.

${ }^{296}$ MARQUES, C. Op. cit., 1942, p. 114.

${ }^{297}$ SCHMIDT, A. Op. cit., 2003, pp.158-159.

${ }^{298}$ MARQUES, C. Op. cit., 1942, p. 115.

${ }^{299}$ SCHMIDT, A. Op. cit., 2003, p. 111.

${ }^{300}$ LRC 1894.
} 
indicando que provavelmente acabara de chegar à cidade. Anos mais tarde, no registro que efetuou em $1903^{301}$, dizia-se comerciante, e citava o Café Guarani, então já localizado na Rua $\mathrm{XV}$ de novembro, 50, como domicílio. É provável que tenha se tornado proprietário do estabelecimento no período entre as duas datas, porém é quase certo que fora referida ao seu estabelecimento a informação de que Eiras Garcia, também ele galego, "com meia dezena de espanhóis" havia se reunido "em um café na rua XV de novembro, em 1898, para fundar a Sociedade Española de Socorros Mútuos”,302. Assim, imaginamos que em 1920, quando constatamos um outro registro seu no $\mathrm{CGE}^{303}$, então com 58 anos, afirmando ser proprietário e indicando o mesmo endereço, Alonso Dominguez já estivesse por duas décadas à frente do Café Guarani. Todavia, ele estava se despedindo da cidade naquele mesmo ano. Partiria em poucos dias para a Espanha, com a família, informava o $\mathrm{EDE}^{304}$, o "ex-proprietário do Café Guarani”.

Eram, na verdade, dois "Cafés". Alonso Dominguez teria aberto uma filial do seu Café no bairro do Brás, e isso só foi revelado porque o estabelecimento, que levava o mesmo nome, foi objeto da queixa de um leitor do EDE, no ano de 1914, reclamando do atendimento a ele dispensado e mencionando o endereço da Avenida Rangel Pestana, 122. Nesta ocasião, informava, um dos proprietários teria dito que não poderia ficar sentado na mesa sem consumir $^{305}$. Deduz-se, assim, que provavelmente Alonso Dominguez tivesse um sócio, responsável por essa filial, o que não foi complicado descobrir. Em registros realizados nos anos de 1917 e 1919 e declarando como domicílio o Café Guarani, encontramos Salomón Benigno Carrera, também natural de Pontevedra, então solteiro e com 30 anos, o mesmo sujeito que, tendo adquirido a outra parte na sociedade, apareceria logo depois da viagem de Alonso Dominguez, em 1921, declarando-se então o novo proprietário do estabelecimento ${ }^{306} \mathrm{e}$ reiterando em seus anúncios: "a casa tem 30 anos de existência"307.

Também de galegos era o Café Elite, que nunca freqüentou as páginas do EDE. "Depois das danças, íamos comer uns saborosos camarões à baiana, bem acebolados, no Café Elite, do bom galego Manolo", dizia Jacob Penteado ${ }^{308}$. Inaugurado em 1913 e também de espanhóis, o Café Colón, localizado na "rua São Bento, esquina com o Largo" e pertencente a

\footnotetext{
${ }^{301}$ LRC 1903.

${ }^{302}$ EDE 22.12.1921. Trad. da autora.

${ }^{303}$ LRC 1920.

${ }^{304}$ EDE 19.05.1920. Trad. da autora.

${ }^{305}$ EDE 15.01.1914. Trad. da autora.

${ }^{306}$ EDE 27.10.1921.

${ }^{307}$ EDE 12.03.1922. Trad. da autora.

${ }^{308}$ PENTEADO, J. Op. cit., 1963, p. 49.
} 
“dois jovens espanhóis", teve a cobertura do EDE no evento ${ }^{309}$. Pertencente a Luiz Ruiz \& Co., transformou-se em assíduo anunciante neste período inicial; seus anúncios, bem elaborados e ilustrados, pediam a "atenção da laboriosa colônia espanhola, da qual espera[va] merecer todo o apoio" que buscava conquistar com “chocolates, mingaus, gemadas, leite, etc."310.

Fora do cinturão central localizamos outros cafés, também conduzidos por espanhóis. Eram cafés menores, mais populares, localizados em locais menos nobres, apresentando-se esporadicamente nas páginas do EDE. Era o caso do Gran Cerveceria Café Ibérico, de Manuel Vaz, na Rua São Caetano, 135; do Café São Paulo, de Antonio Regos, no Largo da Sé, $3^{311}$ e de um Café na Rua Piratininga, 134, esquina com Rangel Pestana, então posto de venda do $\mathrm{EDE}^{312}$.

Havia confeitarias pertencentes a espanhóis em número crescente espalhadas pela cidade. Em 1913, anúncio no $\mathrm{EDE}^{313}$ informava da inauguração da Confeitaria de Juan Perez Ruiz, na Rua dos Andradas, 82. Já a Confeitaria Bom Gosto Oriente, de Manuel Boz \& Hermano, na rua Oriente, 67, apresentava-se, inicialmente, com "grande sortimento de doces, bebidas finas nacionais e estrangeiras encarregando-se do serviço de bodas, batismos e festas comemorativas" atendendo a "botequins e demais estabelecimentos análogos"314, incorporando, às vésperas do natal e em atendimento à colônia, "variado sortimento de mantecados a la española, torrones e pan dulce lleno de frutas para la celebración de las fiestas $^{315}$.

Na Confeitaria do Oeste, no Largo São Bento, podia-se comprar "ostras frescas, recebidas diretamente da Ilha da Lage (Santos)", pagando-se "600 réis a dezena, com o respectivo limão"316. Na Líbero Badaró, 153, havia a Spanier, com "chops, lanches, bebidas finas, sanduíches"317.

Afora essas, os bares. Os famosos, como o Bar do Teatro Municipal "o mais luxuoso no gênero e o mais concorrido pela melhor sociedade paulistana"318, em que, no ano de 1919 ,

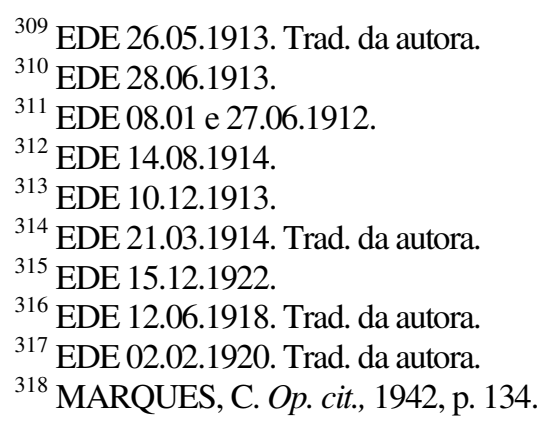


apresentou-se a harpista espanhola Lea Bach $^{319}$ e inúmeros outros, simples botecos, nos bairros populares, exemplo do "Bar e Bilhares de Antonio Lujano" na Rua do Gasômetro, 32, também posto de venda do $\mathrm{EDE}^{320}$. E as padarias. Aliás, em uma delas, localizada na Rua Oriente, o empregado Federico Serrano "teve sua mão direita atingida por cilindros que, prensando-lhe os dedos índice e polegar, os triturou" ${ }^{, 321}$.

E havia as charutarias/tabacarias, ramo em franco crescimento, para cujo funcionamento aparece a primeira resolução municipal em 1892, "confirmando a superação do uso de fumo de rolo ou de corda pela população citadina que aos poucos assimila os cigarros, charutos, cachimbos"322. Havia a do "Gonçalez" (sic), freqüentada pelos acadêmicos da Faculdade de Direito ${ }^{323}$ enquanto noutra, mais popular, na Rua Piratininga, Melchior, o proprietário que "passava o dia preparando o fumo em corda, no balcão em meio a cigarreiras e piteiras", à noite era pelotaris “freqüentando o Frontão Nacional, à rua Boa Vista, como o ídolo dos freqüientadores" 324 .

Membros mais abastados da colônia, comerciantes, importadores e demais setores emergentes deleitavam-se com os piqueniques ou passeios ao litoral, onde encontrariam dois estabelecimentos pertencentes a espanhóis: o Recreio Astúrias, de Nicolás López, "passando o morro das pedras", no Guarujá, um "bar e restaurante exclusivamente familiar, situado no recanto mais pitoresco da praia do Guarujá", de onde "se avistam todos os navios que entram e saem do porto de Santos" e "construído na própria rocha, em forma de gruta, com ampla entrada para automóveis”, ${ }^{\circledR 25}$. Os aficionados por jogo podiam dispor ainda do Petit Casino, também no Guarujá, pertencente a Francisco Lasso de la Vega, com "grande terraço para pic nics,"326.

O cinema inaugura a década de 1910 e se difunde com extrema velocidade. Em 1905, no entanto, Francisco Serrador, espanhol desembarcado em 1900, exibia filmes como

${ }^{319} \operatorname{EDE} 31.10 .1919$.

${ }^{320}$ EDE 14.08.1914.

${ }^{321}$ EDE 23.02.1922. Trad. da autora.

${ }^{322}$ DEAECTO, M. Op. cit., p. 167.

${ }^{323}$ SOUZA, Everardo Vallim Pereira de. "Reminiscências acadêmicas 1887-1891". In: Revista do Arquivo Municipal. São Paulo: XCIII, p. 116.

${ }^{324}$ MARX, G. Op. cit., p. 82.

${ }^{325}$ EDE 07.03.1922. Trad. da autora.

${ }^{326}$ EDE 12.03.1922. Trad. da autora. 
ambulante com seu projetor de fitas, com o qual excursionava pelo interior. Animado com o sucesso de suas andanças e retornando à Capital, em 1907, Serrador passa a exibir seus filmes no Teatro Santana, à Rua Boa Vista. A fita Paixão de Cristo, colorida, permanece nesse período 40 dias consecutivos em cartaz com lotação esgotada. Tamanho êxito levou-o a arrendar um barracão no início da Ladeira de São João onde funcionava o Eldorado, antigo teatro de variedades, surgindo assim a primeira sala comercial de exibições da cidade, em 1907, com enorme sucesso e aceitação da população paulistana. Depois veio o Bijou, na Avenida São João, após o qual Serrador aluga o teatrinho da Associação dos ex-alunos dos padres salesianos, transformando-o em seu terceiro cinema. O Coliseu Campos Elíseos foi o último dessa série, digamos, experimental e resultou da encampação de um circo que se apresentava na cidade fazendo-lhe concorrência, para cujo barracão Serrador transportou o cinema. Depois do Coliseu antes da inauguração do Bijou-Theatre - construído em barracão novo, moderno e aparelhado especialmente para cinema, na Rua Visconde do Rio Branco - ele ainda adquiriria mais dois outros, o Radium e o Íris, na Rua São Bento e São João, respectivamente ${ }^{327}$. Serrador também passou a investir na produção de películas, tendo produzido em 1909, o primeiro filme brasileiro de longa metragem, $O$ Crime da Mala, baseado em fato real.

Imaginamos, assim, que em 1913 ele já fosse o proprietário dos três estabelecimentos que, em nome da Cia. Cinematográfica Brasileira, provavelmente de sua propriedade, e representando a "Fábrica Patê Freres" os divulgava pelo EDE: "Íris-Theatre, Rua XV de novembro; Radium, Rua São Bento; Colyseu dos Campos Elíseos - locais onde se exibem diariamente as mais surpreendentes fitas cinematográficas"328.

Com o avultamento de seus negócios, Serrador passa a importar diretamente os filmes da Europa e dos Estados Unidos, prática altamente lucrativa, que logo chamou a atenção de outros investidores que passam a fazer-lhe concorrência. Galvão assegura: "No que diz respeito à exibição, Serrador domina incontestavelmente; no campo da importação, terá um concorrente à sua altura: Matarazzo"329.

O surto do cinema deslocava-se do centro. Em 1912, das catorze salas existentes na cidade, apenas três permaneciam na região central (as de Serrador) ${ }^{330}$. No bairro do Brás, após o Colombo, surge o Cine Popular, ambos na Rangel Pestana, e o Ideal, na rua do Gasômetro, este

${ }^{327}$ Informações obtidas em GALVÃO, M. Op. cit., 1975, pp. 21 e ss; 36 e ss. e 279.

${ }^{328}$ EDE 29.07.1913. Trad. da autora.

${ }^{329}$ GALVÃO, M. Op. cit., p. 37.

${ }^{330}$ BREFE, Ana Cláudia. A cidade inventada. A paulicéia inventada nos relatos memorialistas. Campinas: Dissertação de mestrado, IFCH -UNICAMP, 1993, p. 139. 
pertencente a uma Companhia Espanhola ${ }^{331}$. Cobrava-se nos bairros um preço mais acessível que nas salas do centro, e aí se costumava apresentar as fitas antes lá exibidas. Em algumas salas de cinema também se apresentavam peças de teatro ou recitais de música. O Cine Recreio situado na Rua Major Diogo, em 1913, recepcionava a Cia. Artística de Baile e Toque Andaluz, de Granada, dirigida por Pepe Amaya, na qual se apresentavam músicos e bailarinos ${ }^{332}$. Essa troupe apresentou-se também no Circo Tavares ${ }^{333}$ e no Circo Naski, na Avenida Celso Garcia, onde "foram assistidos por quatro mil pessoas" 334 .

O Cine Avenida, inaugurado também em 1913, pertencia ao espanhol Pedro Julián. Localizava-se na Avenida Rangel Pestana, $111^{335}$ e o preço do ingresso era de 400 réis para adultos e 200 para as crianças ${ }^{336}$. Consta ter existido um Cine Alhambra, designação claramente sugestiva indicando um provável proprietário espanhol ${ }^{337}$.

Em finais da primeira década, José Medina, descendente de espanhóis, fotógrafo e pertencente ao grupo amador de teatro Gil Vicente, e então proprietário de uma casa de pinturas, associa-se a Gilberto Rossi, na criação da Rossi Film, de cuja associação "iriam surgir as obrasprimas do nosso cinema mudo, 338 .

Território do lazer e das novas formas de sociabilidade era no centro, especialmente no Triângulo, que borbulhava uma agitada vida noturna e boêmia e foi nesse espaço que, refletindo e incorporando os novos hábitos da Paulicéia, observa-se o gradual aparecimento de casas de espetáculos e teatros. Destacando-se por seu luxo e grandiosidade o Santana, inaugurado em maio de 1900, na rua Boa Vista, funcionará até 1911, ano da inauguração do Teatro Municipal, sendo demolido no ano seguinte ${ }^{339}$. A inauguração do Teatro Municipal, aliás, ofuscará os demais teatros existentes, atraindo seus freqüientadores e concentrando, principalmente nas temporadas de ópera lírica de inverno - as mais caras e consideradas as mais nobres - as famílias da elite paulistana.

${ }^{331}$ LEME, M. Op. cit., p. 162 e ANTONACCI, M.A. Op. cit., 2002, p. 14.

${ }^{332}$ EDE 23.07.1913. Trad. da autora.

${ }^{333}$ EDE 22.09.1913.

${ }^{334} \mathrm{EDE} 29.07 .1913$.

${ }^{335}$ EDE 03.01.1913.

${ }^{336}$ EDE 17.02.1913. Nesta edição, a película anunciada era "Un drama en el mar".

${ }^{337}$ LEME, M. Op. cit., p. 121.

${ }^{338}$ GALVÃO, M. Op. cit., p. 35. Nas pp. 261 e ss. a autora enumera a filmografia do período e cita os seguintes filmes como sendo dirigidos por Medina: "Carlitinhos"; "Como Deus Castiga" (com Eugênio Fonseca Filho); "A culpa dos outros"; "Do Rio a São Paulo para casar"; "Exemplo regenerador"; "Fragmentos da vida"; "Gatuninha do Brás"; "No silêncio da noite"; "Nos pantanais de Mato Grosso" e "Perversidade".

${ }^{339}$ MAGALDI, Sábato e VARGAS, Maria Thereza. Cem anos de teatro em São Paulo, 1875/1974. São Paulo: Editora Senac São Paulo, 2000. 
O Teatro Cassino, de propriedade do empresário da noite Paschoal Segreto, outro espanhol, localizava-se na Rua São João, então uma das mais importantes do circuito de estabelecimentos noturnos da Paulicéia, divulgando sua programação com regularidade no EDE desde inícios de $1912^{340}$. No início da segunda década Segreto era também proprietário de outro estabelecimento, o Teatro Variedades, este no Largo do Paissandú esquina com a Rua D. José de Barros. Há indícios de que o Variedades chamara-se anteriormente Moulin Rouge, tendo sido inaugurado por Segreto em 1905, quando então anunciava a exibição das "estrelas de caféconcerto mais em evidência e as mais extraordinárias atrações mundiais”341.

Não se tratava propriamente de teatro dramático, gênero deixado em segundo plano pela superprodução de operetas e revistas, encenadas especialmente por companhias estrangeiras (portuguesas, italianas e espanholas). "O público não exigia novidade. O repertório era comum a todas as companhias, sem prejuízo para nenhuma. Interessavam aos espectadores, como na ópera, as diferentes interpretações, as diversas vozes, a riqueza do conjunto e as comparações que pudessem depois ser estabelecidas entre uns e outros intérpretes" ${ }^{, 342}$. Para Jorge Americano, referindo-se às revistas nacionais "eram uma triste e miserável e longínqua imitação de qualquer revista teatral francesa ${ }^{, 343}$.

No Variedades apresentaram-se, em uma só noite, o Trio Ortega acompanhado de bailarinas espanholas, e duas cantoras, também espanholas, Carmencita e Luisa Blanco, esta cupletista $^{344}$, enquanto que no Cassino, sob a direção de Alfonso Segreto ocorria, quase simultaneamente, a estréia de Anita Esmeralda, cupletista e das Hermanas Claveles, bailarinas, ambas anunciadas como atrações internacionais ${ }^{345}$. Ali, onde havia função em qualquer dia da semana, não se apresentavam somente artistas espanhóis. Elda Pasquetti, cantora italiana, estava programada para se apresentar em plena segunda-feira, a 07 de abril de $1913^{346}$.

Também ali, no Variedades, exibiam-se regularmente outras companhias espanholas, como a Cia. de Pablo Lopez de Ópera, Opereta e Zarzuela que se apresentou na cidade com grande sucesso, anunciado por diversos veículos como O Estado de São Paulo, o Correio

\footnotetext{
${ }^{340}$ EDE 08 e 30.01.1912.

${ }^{341}$ FONSECA, G. Op. cit., 1982, p.193 e MARQUES, C. Op. cit.,1944, p. 115.

${ }^{342}$ MAGALDI, S. e VARGAS, M. Op. cit., p. 60.

${ }^{343}$ AMERICANO, J. Op. cit., 1957, p. 247.

${ }^{344}$ EDE 24.07.1912. Cuplé: canção curta e ligeira, com letra satírica e pícara.

${ }^{345}$ EDE 29.08.1912.

${ }^{346}$ EDE 07.04.1913.
} 
Paulistano e o Comércio de São Paulo ${ }^{347}$ e a Cia. Lírica Espanhola de Operetas e Zarzuelas em que figurava como primeiro ator e diretor o artista Carlos Freixas ${ }^{348}$.

Era no Cassino, porém, que ocorriam os bailes de carnaval, divulgados com estardalhaço: "soberbios bailes a fantasia en los cuales tomara parte toda la excelente troupe. El Casino será transformado en el reino de la folia, artisticamente engalanado con flores, atendiendo a todas las exigencias del capricho. Mefistofélica iluminación, batalla de lanza, perfume, confettes y serpentinas. ; Al Casino! ${ }^{349}$. Eram bailes muito concorridos que vieram substituir, na primeira década, o carnaval de rua. Com o desfile dos préstitos - e seus carros alegóricos de "28 palmos de altura" e "arcos de iluminação a gás" - organizado pelas sociedades carnavalescas nas ruas centrais da cidade, inaugurava-se o hábito de se assistir, passivamente, à passagem do corso. O carnaval de rua sobreviveria somente nos bairros ${ }^{350}$, enquanto o carnaval de salão limitava a participação da população porquanto era preciso ser sócio de algum clube ou pagar a entrada, cujo preço variava de local para local e de acomodação para acomodação.

As companhias espanholas de comédia, drama e peças musicadas há muito visitavam o Brasil, apresentando-se especialmente no Rio de Janeiro, desde o Império. As zarzuelas ${ }^{351}$ fizeram grande sucesso na então Capital do país, e muitas das tiples ${ }^{352}$ que as entoavam acabaram permanecendo no Brasil, ingressando em companhias nacionais, caso de Nina Pancha, que virará marca de cigarro na cidade de São Paulo, produzida pelos Hermanos Caruso e com comercialização na Rua XV de Novembro, $59^{353}$. Companhias espanholas de zarzuelas apresentavam-se também no Teatro Colombo, inaugurado em 1908 no Brás, fora do circuito central. Em 1913, lá se apresentava a Cia. Espanhola de Zarzuela, Óperas e Operetas, exibindo "la conocida zarzuela La Tempestad"354, retornando em 1914 com uma opereta em três atos, com a participação de Mercedes Tressols, prestigiada artista da companhia ${ }^{355}$. "Las bellegas y

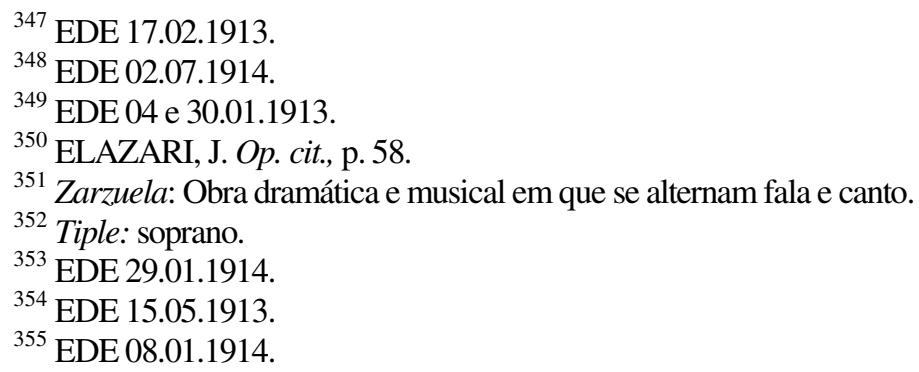


los simpáticos duetistas Los Madrilleños" era programa familiar, de dança e canto, em horário de matinê $\hat{e}^{356}$.

No cotejo dos programas dos diversos teatros, presume-se que essas companhias permaneciam longo período na cidade, com temporadas seguidas, em alguns casos com até dois espetáculos por noite, caso da Companhia de Zarzuelas e Operetas dirigida pelo barítono Joaquim Valle, apresentando as sopranos Encarnación Sisto e Maria Roig, na opereta em dois atos Molinos de Vento e Tirana em duas sessões no Teatro Apolo, na Rua D. José de Barros, $8^{357}$. A mesma companhia inaugurara no dia anterior, uma sexta-feira, o Palace Theatre em que se apresentara a soprano Ursula Lopez com as obras De España al Cielo, Bazar Exposición e La Tierra del Sol ${ }^{358}$. Esta mesma Companhia estivera na cidade no ano anterior, apresentando-se no Politeama, com a Ópera Marina ${ }^{359}$, no mesmo dia em que, no Cassino Antarctica, na rua Anhangabaú, apresentava-se a cupletista espanhola Juanita Arevalo ( $\mathrm{La}$ Valorito $)^{360}$. Algumas destas companhias eram exclusivamente contratadas para a realização de espetáculos cuja arrecadação destinavam às obras sociais. Em 1918, a Cia. Salvat-Olona, dirigida pelos atores Manuel Salvat e Concepción Olona exibiu-se no Teatro São José em programa organizado pela Comissão Executiva em benefício da Casa de Espanha ${ }^{361}$.

Uma das mais famosas atrizes espanholas que, tendo vindo para o Brasil com o propósito de ficar apenas durante o período de seus contratos, acabou permanecendo, foi Pepa Ruiz, natural de Badajóz que, segundo consta, teria vindo de Portugal, onde trabalhava numa revista, apresentando-se no Rio em 1881 pela primeira vez, tendo retornado em outras oportunidades, exibindo-se também em São Paulo, como estrela de uma companhia portuguesa, até decidir-se por fundar, no Rio, a sua própria companhia e permanecer, ali falecendo em $1923^{362}$. Consta que neste intervalo de tempo a atriz, já então com mais de cinqüenta anos de idade, teria formado parte do elenco da Companhia Teatral Paulista, criada em São Paulo por volta de $1911^{363}$.

${ }^{356}$ EDE 08.01.1912.

${ }^{357}$ EDE 23.10.1914, anunciando apresentação para 24.10, um sábado.

${ }^{358}$ EDE 23.10.1914.

${ }^{359}$ EDE 15.12.1913.

${ }^{360}$ EDE 15.12 .1913

${ }^{361}$ EDE 20.09.1918.

${ }^{362}$ SILVA, Lafayette. História do teatro brasileiro. Rio de Janeiro: Serviço Gráfico do Ministério da Educação e Saúde, 1938, pp. 207; 234; 265; 284-5 e CARVALHO, Afonso José de. "São Paulo Antigo (18821886)". In: Revista do Instituto Histórico e Geográfico de São Paulo. São Paulo: Imprensa Oficial do Estado, 1949, p. 50.

${ }^{363}$ MAGALDI, S. e VARGAS, M. Op. cit., p. 53. 
No teatro esteve a gênese do cinema desenvolvido na cidade a partir da segunda década, quanto às características da temática, à formação dos atores e à encenação - tratava-se de um “teatro filmado", segundo Maria Rita Galvão ${ }^{364}$.

$\mathrm{O}$ exercício de atividades relacionadas à pequena indústria, mas especialmente ao comércio, representaram importante meio de ascensão social e prestígio para os imigrantes que, através dele, alcançavam visibilidade e reconhecimento social, muitas vezes para além do círculo limitado constituído pela colônia. Muitos prósperos comerciantes adquirem status social de pessoas refinadas e enquanto exibem seus automóveis e viajam para a Europa de férias elementos que traduzem a "apreensão" e a prática de um novo código social e de sociabilidade - fundam e dirigem agremiações e sociedades culturais e beneficentes e são homenageados publicamente em tom de exaltação pelo EDE, cujo diretor também compunha essa esfera social, no sentido do reforço de sua representação, a própria imagem do progresso estampada. Essa necessidade de diferenciação das camadas inferiores e a adesão a símbolos de aproximação simbólica com as camadas de elite respondem ao desejo de auto-afirmação de uma (pequena) camada média emergente que se insinuava e que, a despeito de seu crescente poder econômico, não tinha garantido qualquer poder político.

${ }^{364}$ GALVÃO, M. Op. cit., pp. 31-32. 


\section{CAPÍTULO IV}

\section{Cenários da Vida pública: PRÁTICAS ASSOCIATIVAS E DE LAZER}

As associações étnicas dos emigrados configuram, indubitavelmente, um marco de territorialidade simbólica ${ }^{1}$, espaços sociais circunscritos e sujeitos a um "permanente processo de co-construção e significação"2. Contextos de interação que em geral acolhem e acomodam universos heterogêneos, fruto de distintas histórias de vida de seus elementos e dos diferentes grupos aí envolvidos, tais sociedades fundamentam-se, não obstante, na consciência do pertencimento e na percepção das semelhanças, decorrente do compartilhar comum a um determinado processo - tal como as mudanças e/ou as adversidades provocadas pelo ato emigratório ou as motivações comuns da expatriação, por exemplo. Entendidas, assim, como uma unidade, as práticas, discursos e mediações, enfim, os signos coletivos produzidos em seu interior podem significar o grau de conformidade e pertencimento dos membros de dada coletividade aos padrões culturais do seu grupo podendo, eventualmente, indicar como cada grupo reage e reatualiza elementos ancestrais de seu universo cultural simbólico frente ao novo ambiente, à nova realidade - neste caso, dupla: um país diferente e um meio estranho, urbanizado.

Para Magnani, a problemática do deslocamento para o grande centro, no caso do migrante, não se esgotaria numa maior ou menor capacidade de adaptação às exigências do trabalho urbano. Ela resultaria em profundas mudanças no seu modo de vida, pelo acréscimo de novas necessidades, implicando um "reordenamento de todo o seu estoque simbólico" de cujo processo se junta ao velho o novo, na reconstrução de uma nova identidade. Nessa dinâmica, diz o autor, "algumas coisas permanecem, muitas se transformam, outras ainda desaparecem"3.

Interessa reter, nesses casos, a dinâmica que passa a operar entre os diferentes grupos constituídos no novo espaço (turbulento e conflituoso) da cidade em transformação, o modo e a intensidade como alguns, diferentes de outros (grupos) e em diversos graus, articulam, se

${ }^{1}$ CHEBEL, M. La formation de l'identité politique. Paris: Éditions Payot \& Rivages, 1998. Apud: BALLINA, Sebastián. "Etnicidad y estratégias identitarias: modalidade de estructuración en un grupo eslavo de Berisso, Argentina”. In: Revista del Cesla - Centro de Estudios Latinoamericanos. Varsóvia: n.8, Universidad de Varsóvia, 2006, pp. 65 e ss.

${ }^{2}$ CHARTIER, Roger. Escribir las prácticas. Buenos Aires: Ediciones Manantial SRL, 1996, p. 78.

${ }^{3}$ MAGNANI, José Guilherme Cantor. Festa no pedaço. Cultura popular e lazer na cidade. São Paulo: Unesp/Hucitec, 1998, pp. 24-26. 
apropriam e fazem a mediação entre os seus valores e padrões culturais, na implementação de estratégias identitárias ressignificadas no novo contexto, e a maneira como se configuraram tais continuidades, descontinuidades e rupturas ${ }^{4}$. Para Magnani, para quem as mudanças não podem ser vistas como a "deturpação de uma forma já fixada em sua pureza original" e nem "consideradas como elemento de desagregação" ou como "sintomas da progressiva diluição das tradições populares", a cultura, mais que uma soma ou "acervo de produtos acabados e cristalizados, alheios às mudanças das condições de vida de seus portadores" é "processo de sua constante recriação, num espaço socialmente determinado",5.

Em sua obra Transterrados y ciudadanos, Patrícia Fagen destaca muito apropriadamente que, onde quer que se reúnam três espanhóis, inevitavelmente surgirão pelo menos duas associações ${ }^{6}$. Na Paulicéia nascente, especialmente quanto às agremiações beneficentes, onde contabilizamos inúmeras delas, não foi diferente, e, apesar de numerosas, pouco se conhece de sua atuação no período.

Entretanto, em que pese essa obscuridade, há menção de sua existência em informes oficiais, conforme indica o trabalho de Tânia R. de Luca que consultou os Estatutos dessas associações, publicados no Diário Oficial do Estado de São Paulo de 1890 a 1935, concluindo pela existência de quatro delas pertencentes a espanhóis ${ }^{7}$, das quais somente de duas, da SESM e da BE, já anteriormente mencionadas, obtivemos informações adicionais pelo exame das fontes examinadas. Do Círculo Espanhol e da Sociedade Beneficente Espanhola de São Paulo, a que a autora também fez referência, nada foi localizado.

Por outro lado, na investigação que levamos a efeito no EDE, no período de 1912 a 1922, vimos proliferar um sem-número de sociedades e agremiações, que utilizavam as suas folhas diárias para as mais diversas finalidades. Em alguns casos, com reduzida freqüência, aparecendo esporadicamente vez ou outra, em curto espaço de tempo; em outros, com aparições esparsas, porém em período maior de tempo, mais da metade dessas agremiações teve, por

\footnotetext{
${ }^{4}$ Foge ao âmbito desse preâmbulo o exame aprofundado de categorias de análise tais como "etnicidade" ou "grupos étnicos". No caso específico aqui considerado, a sua adoção, ainda que leve em conta a heterogeneidade cultural e/ou racial e/ou ideológica do "grupo" espanhol emigrado, já evidenciada, se apropriará desse dispositivo discursivo, tomando-o como unidade de análise i.é., entendendo-o como uma "comunidade imaginária", operando em relação aos demais grupos. A esse respeito, ver: HALL, Stuart. "Desconstruindo a "cultura nacional": identidade e diferença. A identidade cultural na pós-modernidade. Rio de Janeiro: DP\&A, 2003, pp. 57 e ss.

${ }^{5}$ MAGNANI, J. Op. cit., pp. 24-26.

${ }^{6}$ FAGEN, Patrícia. Transterrados y ciudadanos: los republicanos españoles en México. México: Fondo de cultura Económica, 1974, p. 84. Apud: GAMBI, Esther. "La inmigración española en Brasil a través de sus asociaciones". In: Revista Brasil Espanha. São Paulo: ano I, 2006, pp. 10-11. Disponível em: www.camarabrasilespanha.com

${ }^{7}$ Sociedade Espanhola de Socorros Mútuos; Sociedade Beneficente Espanhola de São Paulo; Sociedade Beneficência Espanhola e o Círculo Espanhol. In: LUCA, T. O sonho do futuro assegurado (o mutualismo em São Paulo). São Paulo: Contexto; Brasília, DF: CNPq, 1990, p. 126.
} 
assim dizer, vida útil bastante irregular, o que nos leva a conjecturar acerca das dificuldades envolvidas na sua constituição e manutenção, levando-se em conta sobretudo que a composição majoritária de seus associados era de gente simples que sofria as alternâncias de um mercado de trabalho instável e descontínuo. É compreensível desse modo que à maioria delas faltasse até mesmo recursos para viabilizar os custos da veiculação dos informes no periódico, daí a nossa suposição de que muitas das publicações constituíssem cortesia do EDE, pela vinculação direta de Eiras Garcia à grande parte dessas agremiações.

Representando as associações com exíguo aparecimento no EDE no período pesquisado, temos, por exemplo, o Centro Republicano Español (CR), cujos membros, segundo notícia circulada em $O$ Estado de São Paulo teriam se manifestado ruidosamente a favor da vitória aliada, comemorando o término da Primeira Guerra. Irritado, Lopez Campillo vinha a público (novamente) para um categórico esclarecimento, segundo o qual tratava-se de apenas "meia dúzia de espanhóis" que "convertidos em republicanos, não representariam, em absoluto, a colônia da cidade", ${ }^{\Perp}$, cuja imagem de unidade esforçava-se por preservar, mas que, conforme vai-se descortinando pela documentação, apresentava indisfarçáveis rachaduras ideológicas.

Desconhecemos a sua composição e antecedentes, contudo há evidências de que as relações entre o CR e as demais sociedades espanholas já viessem estremecidas há mais tempo. Meses antes, por ocasião da fundação da Casa de Espanha (CDE), tentativa de unificação das diferentes entidades, em reunião ocorrida nos salões da FE que contou com o comparecimento de distintos membros diretivos das associações e órgãos constituídos ${ }^{9}$, a única ausência notada foi exatamente a do CR, que delegou a sua representação ao presidente do Conselho Federal ${ }^{10}$. Teria subsistido até 1938, sem deixar qualquer vestígio, ocasião em que, em função da "vitória das tropas nacionalistas na Espanha" fora proibido de funcionar, quando então, conforme Gallego $^{11}$ seus membros passaram a atuar no CG recebendo, a partir de então, nova denominação: Centro Galego-Democrático Espanhol, alteração que revela, não apenas a já declarada facção antimonarquista, mas desta feita sem disfarce ou simulação, o seu manifesto caráter regionalista.

Outra agremiação que, a considerar a freqüência nos anúncios ou menções em outras matérias do EDE, teve vida efêmera, foi a Liga Defensora dos Espanhóis (LDE). Seu

\footnotetext{
${ }^{8}$ EDE 07.12.1918. Trad. da autora.

${ }^{9}$ Sociedade de Socorros Mútuos; Sociedade Espanhola de Beneficência; Federação Espanhola; Grupo Dramático Cervantes; Centro União Catalã; Centro Espanhol; Centro União Espanhola; Cruz Vermelha Espanhola; Sociedade Artística Isaac Peral; Revista Espanhola Ilustrada; Diário Espanhol e Conselho Federal.

${ }^{10}$ EDE 20.06.1918. Não há qualquer indício sobre as origens e funções deste denominado "Conselho Federal”. É provável que se tratasse de um órgão regulador oficial que visasse normatizar as diferentes associações de estrangeiros, criado pelo Decreto no 173 de 10.09.1893.

${ }^{11}$ GALLEGO, A. Op. cit., 1995, pp. 44-45.
} 
aparecimento nas páginas do periódico concentrou-se apenas no ano de 1913, limitando-se a avisos aos associados sobre seus benefícios, especialmente a assistência médico-farmacêutica. Localizava-se no Brás, na Travessa do Brás, 29, e praticava, em casos de emergência, atendimento a domicílio $^{12}$. A sociedade não permaneceria muito tempo neste endereço; meses depois, em flagrante evidência de que passava por dificuldades financeiras, informava da mudança "temporária" para a Rua do Gasômetro, 49-A, local onde provavelmente mantivessem sua oficina de alfaiataria seu presidente e secretário, Fermín Barnó e Eduardo Burgos estabelecidos com a Alfaiataria La Villa de Madrid ${ }^{13}$. O derradeiro contato com essa sociedade ocorreu, como vimos, também em 1913, em anúncio pelo qual se apresentava o novo médico, Dr. Nuno Guerner, com consultório à Rua São Caetano, 156, “onde atenderá aos sócios, mediante apresentação dos cupons" ${ }^{\prime 14}$.

Essa entidade foi contemporânea de outra, a Beneficência Espanhola $(\mathrm{BE})$, com sede à Rua Fernandes Silva, 17, cuja criação foi interpretada pelo vice-presidente da SESM, Antonio Acuña, como "el deseo manifiesto de perjudicar la de Socorros Mutuos"15. Não demoraria muito para que esses “dissidentes" retornassem solicitando a fusão das duas associações.

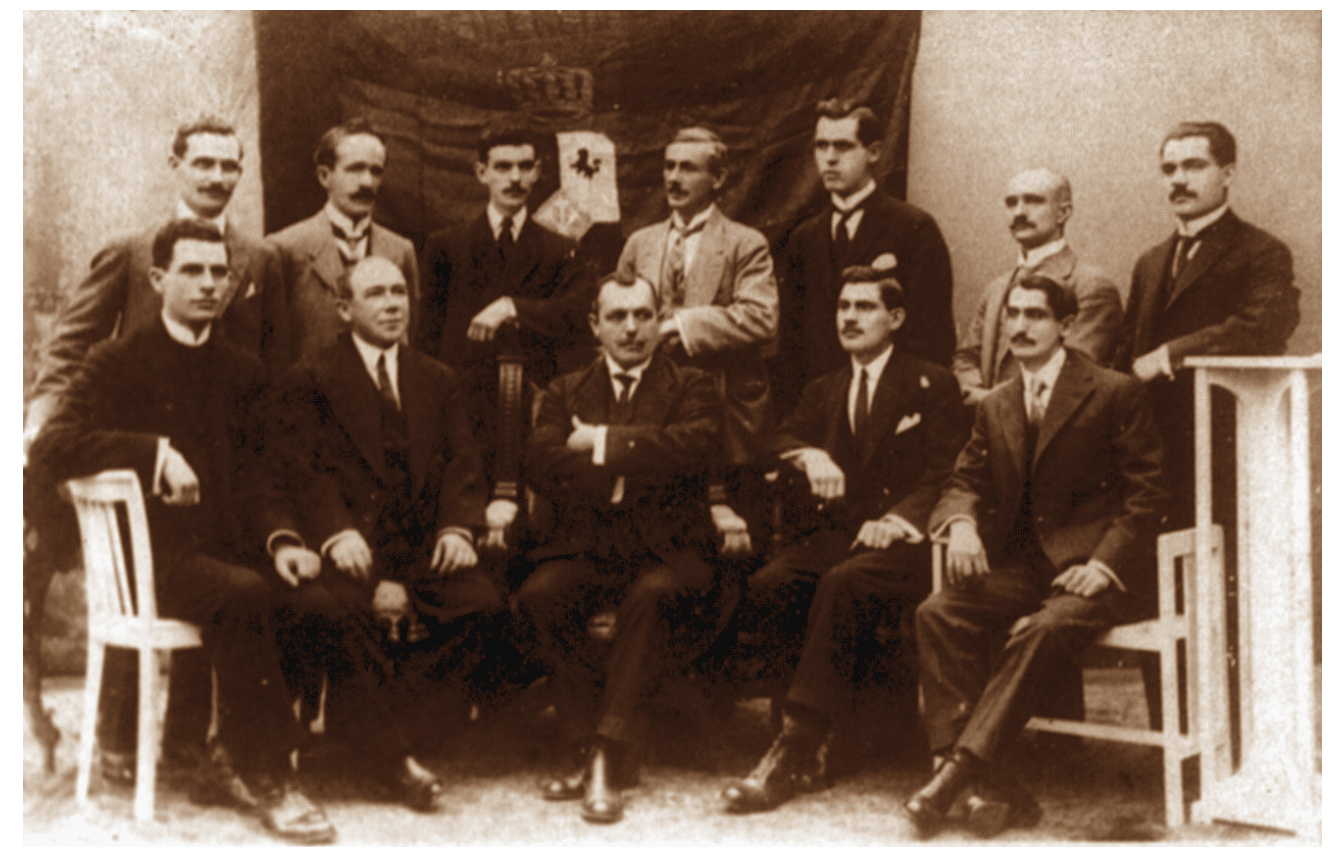

Fig. 10. Diretoria da Sociedade Beneficência Espanhola. São Paulo (SP), 1919.

\footnotetext{
${ }^{12}$ EDE 05.04.1913.

${ }^{13}$ EDE 29.07.1913.

${ }^{14}$ EDE 28.11.1913. Trad. da autora.

15 As informações sobre as Assembléias da SESM foram extraídas de anotações coligidas por Marco Antonio Costa Ferreira (in memoriam), cedidas à autora.
} 
A primeira aparição da BE no periódico, no ano de 1912, foi tumultuada ${ }^{16}$, tratando-se de uma denúncia do seu então presidente Antonio Garcia Gimenez de que uma assembléia fora convocada sem a sua permissão, por "pessoas não autorizadas", sócios destituídos de seus cargos ou eliminados, e que, portanto, seria anulada. Na mesma edição, o suposto principal acusado, Emílio Valenzuela, reclama do acusador, anuncia a sua destituição e convoca os associados para uma Assembléia Geral Extraordinária ${ }^{17}$.

Esse episódio renderia um desdobramento jurídico: por haver publicado anteriormente no EDE a Ata da Junta na qual se deliberava sobre a expulsão de seu antigo presidente, Antonio Garcia Gimenez, denunciando "sua má conduta", o diretor-substituto do EDE, Manuel Rodríguez, foi por ele processado, e condenado em sentença proferida pelo juiz Dr. Gastão de Mesquita a quatro meses de prisão e ao pagamento de multa no valor de 500 mil réis $^{18}$. Manuel Rodriguez, além de redator do EDE, agora substituindo a Eiras Garcia, fora com ele o fundador da SESM, tendo sido também o responsável pela fundação, junto com Antonio Dias, do periódico LTE. Aragonês, tendo vivido muito tempo em Barcelona, uma vez na cidade Rodriguez trabalhou por muitos anos no jornal O Comércio de São Paulo ${ }^{19}$. O fato, destacado de seus desdobramentos concretos, revela o grau de tensão e intolerância reinante entre os componentes de uma mesma associação que, aparentemente movidos por picuinhas pessoais, se esqueciam de seus verdadeiros propósitos. Ou será que motivos de outra natureza os moveriam? De igual modo ou pior, deduzimos, agiriam os integrantes de associações distintas. Neste caso em particular, e provavelmente com o reforço dos noticiários, a opinião pública tendeu a apoiar o jornalista (Manuel Rodriguez). Em sucessivas edições posteriores, o EDE publicaria as congratulações que foram enviadas a seu diretor, reproduziria as felicitações enviadas pelos leitores do outro periódico, $\mathrm{o} \mathrm{LTE}^{20} \mathrm{e}$ iniciaria uma subscrição para fazer frente às custas de seu processo, cujos nomes e respectivas contribuições, incluindo listas iniciadas em cidades do interior - com destaque para Santos e Rio de Janeiro - seriam divulgadas em diversas edições $^{21}$. Em 1914, o EDE publica, a respeito da BE, o anúncio da nomeação de um médico para os associados, Dr. Benjamin Rubbo, com consultório no Brás, à Avenida Rangel Pestana, $102^{22}$.

\footnotetext{
${ }^{16}$ EDE 24.08.1912. Trad. da autora.

${ }^{17}$ EDE 24.08.1912.

${ }^{18}$ EDE 01.08.1913.

${ }^{19}$ EDE 23.09.1922.

${ }^{20}$ EDE 07.08.1913.

${ }^{21}$ EDE 23.10.1913, por exemplo.

${ }^{22}$ EDE 01.08.1914.
} 


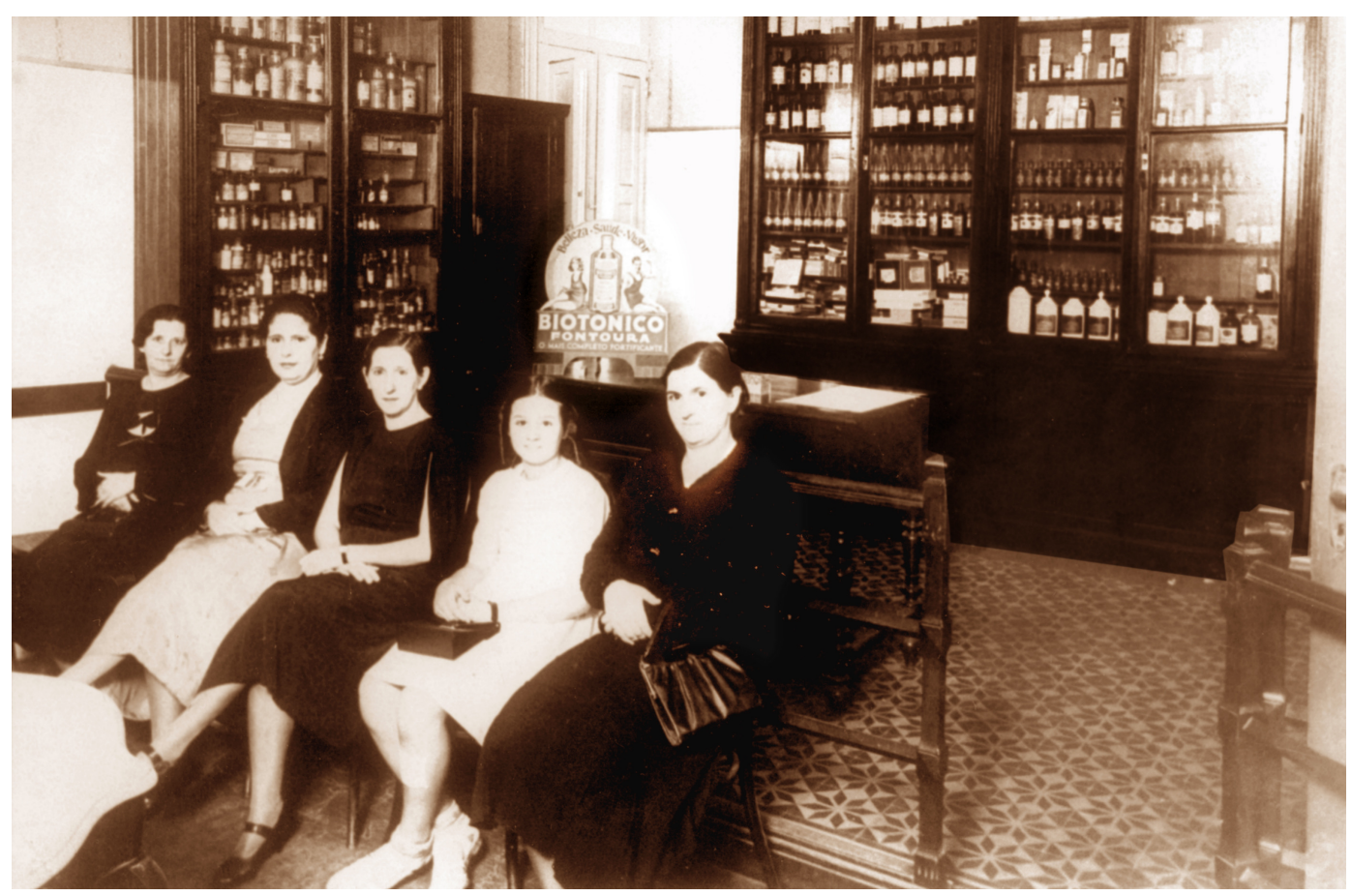

Fig. 11. Associadas da Sociedade Beneficência Espanhola, aguardando atendimento assistencial elou médico. São Paulo (SP), s.d.

Anos depois, em 1919, a BE será oficialmente integrada à $\mathrm{SESM}^{23}$, em reunião presidida por Manuel Rodrigues e Aparício Marti (representando a SESM) e Valentin Diego (por parte da $\mathrm{BE})^{24}$, evento celebrado por "grande festival" comemorativo ${ }^{25}$. O jornalista processado, Manuel Rodrigues, um dos fundadores da SESM, seria o presidente eleito após a fusão das duas associações e Everardo Dias o primeiro secretário.

Meses depois, contudo, ocorreria a deportação de Everardo Dias, de que a (nova) diretoria, constituída após a fusão das duas associações, pró́be qualquer manifestação a respeito. Coexistia, neste período, a propósito, um CR, com sede no Largo da Sé, que tratou de enviar um ofício à Sociedade comunicando de sua separação definitiva de uma tal Unión Republicana, pelo qual a recriminava de ser a responsável pelo fato de que "la república en España esté considerada como un sueño", acrescentando a informação da sua adesão ao Partido Radical $^{26}$.

As subscrições ou listas encabeçadas por um ou mais proponentes com a finalidade de levantamento de recursos para algum fim, geralmente procurando amenizar a crítica situação dos miseráveis, constituíram prática rotineira no período, cujas iniciativas eram veiculadas pelos

${ }^{23}$ EDE 08.11.1919.

${ }^{24}$ Ata de Assembléia de 18.04.1919. A primeira reunião das sociedades já integradas, seria no Centro Español, Rua XV de novembro, 50.

${ }^{25}$ EDE 25.10.1919. Trad. da autora.

${ }^{26}$ As informações sobre as Assembléias da SESM foram extraídas de anotações coligidas por Marco Antonio Costa Ferreira (in memoriam), cedidas à autora. 
periódicos - e muitas vezes por sua própria iniciativa - que informavam o nome do beneficiário e a razão do encaminhamento, além de publicar as quantias arrecadadas e seus respectivos cedentes. Algumas dessas iniciativas se dirigiam para emigrantes residentes em cidades do interior, e, em sua maioria envolviam questões de saúde. Foi o caso da subscrição iniciada por Manuel Garcia, residente em Ariranha em benefício de Juan Fontana, enfermo, residente em Itajobi, de que participam diversos subscritores com quantias de $1 \$$ a $5 \$ 000^{27}$. Dependendo do caso, as quantias podiam crescer enormemente, o que ocorria quando as questões envolviam principalmente ilícitos penais (infrações, delitos, crimes). Aconteceu dessa maneira quando do assassinato de Manuel Garcia Gonzalez, cujo crime ocorreu na Rua Condessa de São Joaquim, mobilizando a todos "inclusive brasileiros e italianos". Neste caso, a iniciativa da subscrição curiosamente partia do CGE, em favor da viúva e dos sete filhos do casal. Iniciada em fevereiro de 1913, a lista prosseguiu por dois meses, atualizando-se regularmente, até atingir a quantia de $1.567 \$ 700$, em abril do mesmo ano ${ }^{28}$. Neste mesmo mês de abril, à continuação, abria-se uma outra subscrição, cujo favorecido era Gaspar Sanchez Muriel que "no bairro do Cambuci" cometera "um homicídio em legítima defesa" 29 e no mesmo ano, meses depois, apenas para ilustrar, publicava-se a lista dos participantes da subscrição levantada em favor da família de Francisco Manzano Rodriguez, que fora assassinado, e a informação de que "a colônia" contratara um advogado, Dr. Octávio Nogueira de Guimarães, para acompanhar a causa ${ }^{30}$.

Sucediam-se iniciativas em benefício de alguma causa. Convocando a colônia a ajudar com mantimentos e roupas, o EDE acorria em favor de cinco órfãos de pai e mãe (Antonio Gutierrez e Maria Martin), o maior deles com apenas onze anos, que aguardavam para ser repatriados, "recolhidos" na Rua São Caetano, $179^{31}$. "Adoentado, cadavérico no fundo da cama” e vivendo com a família num "quintal da Rua Caetano Pinto, 70” de aluguel, assim o articulista do EDE noticiava o lastimoso estado em que encontrou a Federico Martin e solicitava a todos que se compadecessem dele e o ajudassem como pudessem ${ }^{32}$. Invocando a caridade da comunidade, o EDE informava da condição "do compatriota José Miranda, atacado de paralisia", vivendo "na miséria e na fome" na Rua Joaquim Carlos, 268, com a mulher e três filhos $^{33}$.

${ }^{27} \mathrm{EDE}$ 18.06.1912.

${ }^{28}$ EDE 12.04.1913.

${ }^{29}$ EDE 29.04.1913. Trad. da autora.

${ }^{30}$ EDE 07.08.1913.

${ }^{31}$ EDE 14.02.1914.

${ }^{32}$ EDE 19.12.1919. Trad. da autora.

${ }^{33}$ EDE 16.12.1920. Trad. da autora. 
Por vezes, o próprio beneficiário se dirigia ao periódico, solicitando a publicação: Donata Cabrera, com seis filhos, marido gravemente enfermo, residentes à rua Rocha, 45 e não podendo sair para trabalhar por ter de cuidar da sogra, D. Maria Martinez, também de cama e com 88 anos de idade "pede auxílio às pessoas caridosas"34.

Em vista das crescentes demandas, fruto da extrema penúria, indigência e desamparo em que se encontrava grande parte da colônia na cidade, eventualmente ocorriam contribuições espontâneas de pessoas mais favorecidas, caridade informal daqueles que demonstravam ter preocupação tutelar de "socorrer aos pobres que acodem ao EDE": A sra. Ana Ballesteros de Rubio, por exemplo, encaminhou razoável quantia em dinheiro ao EDE, parte da qual (30\$000) seria de pronto enviada "à viúva do conterrâneo Augusto Aparecido Casanova, falecido recentemente e que deixou sua família na maior miséria" e a fatia maior (100\$000) foi entregue à família residente num quintal da Rua Caetano Pinto, atrás mencionado ${ }^{35}$. Mais generosa foi a dotação realizada pela "dama da sociedade" D. Manolita Diez (mulher de Raimundo Diez, o da casa importadora) às vésperas de embarcar para a Espanha, quando teria destinado $1.000 \$ 000$ para a $\mathrm{SESM}^{36}$. A nota do EDE que divulgava a doação, também enaltecia a comiseração e a filantropia de certas famílias de posses.

Contudo, no conjunto, exceto em casos mais extremos de urgência, ou uma ou outra doação bondosa, era mesmo através das associações que se operavam as funções assistencialistas, de proteção e auxílio aos menos favorecidos e desamparados. Tais associações foram regulamentadas pelo Decreto $\mathrm{n}^{\mathrm{o}} 173$ de 10.09.1893, que previa a elaboração de um estatuto, condição de constituição jurídica, no qual deveria constar o nome da sociedade, objetivos de sua constituição, requisitos exigidos para se fazer parte do seu quadro social, como se efetuaria a sua administração e a condição para sua extinção ${ }^{37}$. Resulta redundante comentar a respeito dos "objetivos" que norteavam a criação dessas associações, centrando-se basicamente na condição de penúria da maioria desassistida dos imigrantes que aportava na cidade, daí seu caráter assistencial, zelando especialmente pela saúde dos sócios, que refletia os precários padrões de vida em moradias insalubres, com alimentação deficiente e escassa que acabava por enfraquecer o organismo, tornando-o debilitado e sem resistência.

Daí a proliferação de entidades de cunho assistencial ou de socorros mútuos criadas no vácuo ou na inércia do poder público (local e espanhol, representado por suas autoridades constituídas) em atender à multiplicação da miséria e aos profundos desajustes sociais

\footnotetext{
${ }^{34}$ EDE 30.09.1918. Trad. da autora.

${ }^{35}$ EDE 27.01.1920. Trad. da autora.

${ }^{36} \mathrm{EDE} 21.03 .1920$.

${ }^{37}$ LUCA, T. Op. cit., pp. 13 e ss.
} 
provocados pelo elevado grau de pauperização e altos índices de desemprego a que estavam submetidos esses indivíduos.

Por esta razão, em seu estudo correlato, Luca, ao agrupar em algumas dezenas de itens a finalidade declarada dessas Associações, concluiu que "prestar auxílio a doentes" revelara-se a categoria com maior porcentagem, 56,9\%, seguida de perto pela segunda, com 51,6\%, "fazer o funeral dos sócios". A modalidade seguinte, com 42,7\%, referia-se ao fornecimento de "tratamento médico" aos sócios, categoria que, de certo modo, pouco se distingue da primeira. O item seguinte na classificação, "fornecer medicamentos", com 32,5\%, completava os principais propósitos estatutários dessas associações ${ }^{38}$, pondo em relevo e qualificando como a questão central a saúde, elemento vital para que o sujeito pudesse se manter na ativa, no processo produtivo, condição para sua sobrevivência. Apesar de sua expressividade, no entanto, do ponto de vista historiográfico, essas formas de organização não se têm distinguido como objeto de estudo, ocupando, ao contrário, interesse secundário. Para Boris Fausto isto se deve à importância dedicada a temas congêneres envolvendo a classe operária e o sindicato, na preferência dos historiadores: "Em face das sociedades de resistência, as formas de associação de tipo assistencial e previdenciário tenderam a ser encaradas como entidades de menor importância ou mesmo desviantes", afirma ${ }^{39}$.

Surpreendentemente contudo, no caso espanhol basta analisar, como veremos, a composição diretiva das sociedades e agremiações de cunho beneficente e assistencial criadas no período para se presumir que, em sua constituição, combinavam-se aos demais os mesmos sujeitos que trouxeram em sua bagagem a experiência da militância. Um dos casos mais notórios reside na figura de Everardo Dias que, embora militante e ativista e apesar de todas as restrições impostas a manifestações dessa natureza no seio das associações, atuava diretamente em muitas delas, exasperando-se por vezes contra as "tendências puramente utilitaristas de independência econômica" dos emigrantes, face ao desinteresse destes quanto à premente necessidade de reformas sociais. Lembremo-nos também de Eiras Garcia que, como muitos gráficos e tipógrafos, ativistas indesejáveis em seus países, refugiaram-se ou foram deportados por questões políticas e de tantos outros que, em função do seu trabalho tinham, no mínimo, tido contato com as teorias sociais da época e, portanto, estavam informados dos movimentos ocorridos na Europa. Esses indivíduos, para abreviar, teriam fundado uma associação de classe

38 Passim.

39 FAUSTO, B. Historiografia da imigração para São Paulo. São Paulo: Série Imigração, Sumaré/FAPESP/Instituto de Estudos Econômicos, Sociais e Políticos de São Paulo, 1991, p. 41. 
na década de 1890 cuja atuação, afirmavam, era "meio beneficente, meio de resistência", evidência concreta da tênue fronteira de atuação que não dissimulava o claro engajamento ideológico ${ }^{40}$.

Alejandro Fernández ${ }^{41}$, que estudou alguns modelos de associacionismo espanhol deste período, em diversos países americanos, esclarece que apenas uma minoria dos espanhóis que aportaram na América conhecia a experiência associativa ou havia participado de alguma associação na Espanha. Para ele, as sociedades de base étnica, imbuídas do auxílio social aos menos favorecidos, procuraram imprimir nos emigrados uma consciência de pertencimento étnico por meio do processo de construção cultural da etnicidade, o que se dará prioritariamente na conjuntura das emigrações em massa.

A construção da etnicidade, acrescenta, não se constituiu um processo linear e permanente, já que dependeu da importância que foi assumindo a colônia espanhola em cada um dos países. Também dependeu do tipo de relações mantidas com as classes dirigentes dos mesmos, e da consideração de que foi objeto o espanhol no imaginário coletivo, aspecto esse que ganhou importância conforme foram se desfazendo ou se revertendo os preconceitos antihispânicos nas antigas colônias e à medida que ocorreu o enorme, porém vão, esforço coletivo de colaborar com a metrópole na guerra de 1898 contra os Estados Unidos, resultante de um "reforço do hispanismo" em quase toda a América Latina, que ultrapassou o período da guerra e culminou na criação das "instituições culturais" espanholas nas cidades latino-americanas ${ }^{42}$. Quanto ao Brasil, pontua o autor, foi sobretudo no Estado de São Paulo que o associacionismo espanhol alcançou expressividade desde finais do Oitocentos, marcado pelo modelo mutualista propagado em regiões da Argentina e do Uruguai e por ter concentrado, no período das imigrações em massa, até o ano de 1920, o maior contingente originário daquele país, quase $80 \%$ do total ingressado no Brasil. Consta ter sido a cidade de Santos, de forte concentração de imigrados espanhóis, a primeira do Estado a exibir uma agremiação étnica - a Sociedade Centro Espanhol criada em 1895 - em cuja esteira seguiram-se outras, tanto na Capital, caso da SESM, fundada em 1898, como em cidades do interior tributárias do café e fortemente marcadas pela presença de imigrantes contratados pelas fazendas ${ }^{43}$.

\footnotetext{
${ }^{40}$ Essas questões estão aprofundadas no Capítulo V.

${ }^{41}$ FERNANDEZ, A. "Mutualismo y Asociacionismo". In: VIVES, Pedro; VEJA, Pela y OYAMBURU, Jesús (coord.) Historia General de la emigración española a Iberoamérica. Madrid: Historia 16, vol. 1, pp. 331 -357.

${ }^{42}$ Passim.

${ }^{43}$ Campinas; Ribeirão Preto; Monte Azul; São Carlos do Pinhal (Sociedade de Socorros Mútuos); Jaú (Sociedade Protetora Beneficente); Itatiba (Centro Espanhol de Beneficência); Catanduva (Federação Espanhola); Olímpia (Sociedade de Socorros Mútuos); Presidente Alves; Duartina; Rio Claro e Araçatuba (Comissão Espanhola). Cf. GALLEGO, A. Op. cit., 1993, p. 40.
} 
Assim, se a criação dessas associações, às quais se seguiriam outras tantas nas primeiras décadas do Novecentos, podem ter sido, como quer o autor, inspiradas e impulsionadas pelo sentimento cívico de solidariedade com a pátria - ferida pela perda sucessiva de suas possessões coloniais nas Filipinas e em Porto Rico, fator acirrado pela guerra contra os Estados Unidos não resta dúvida de que subsistiram nutridas pela penúria dos compatriotas desterrados. 
1. As sociedades beneficentes, culturais, artísticas e recreativas

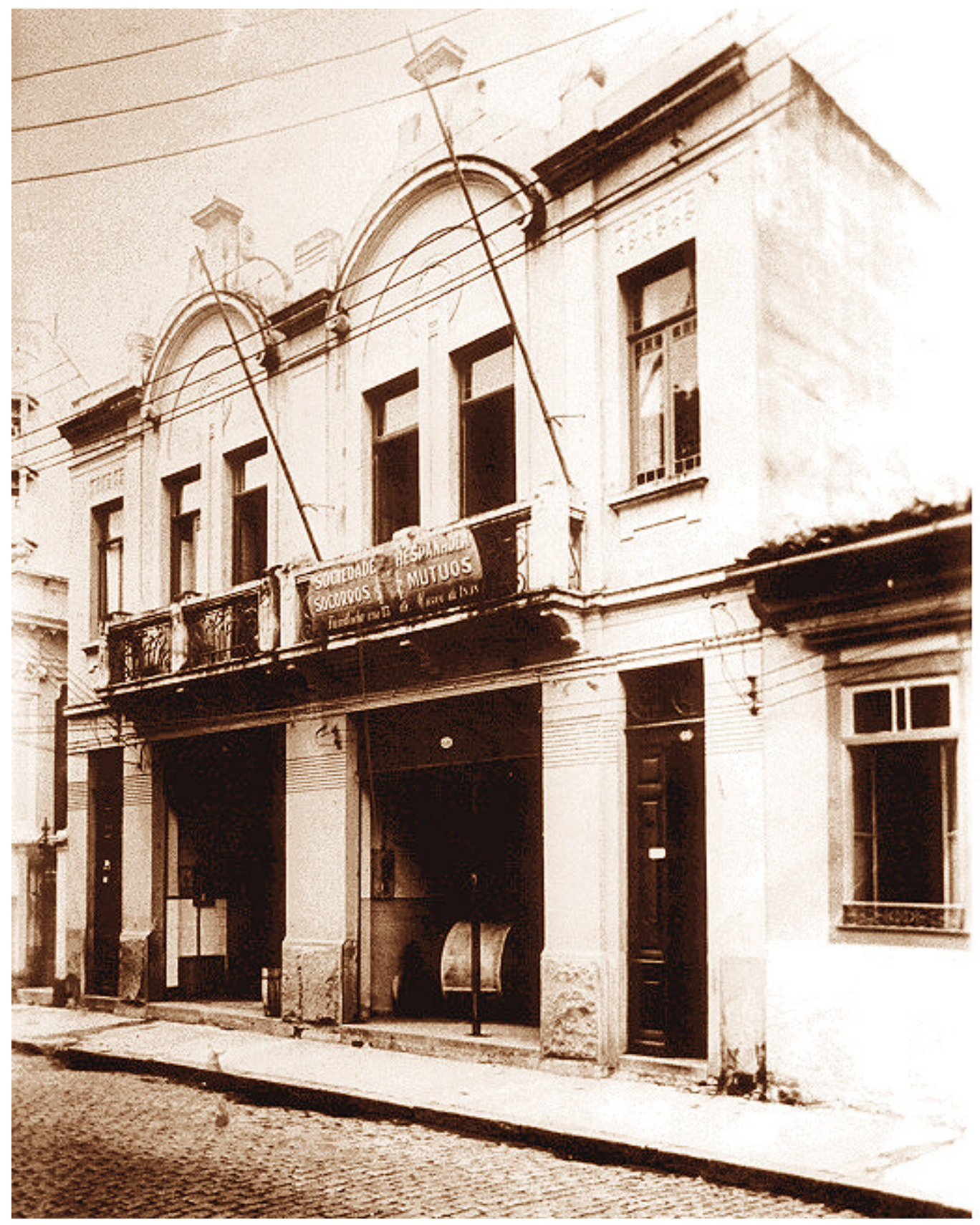

Fig. 12. Fachada da primeira sede da Sociedade Espanhola de Socorros Mútuos. Rua Silveira Martins. São Paulo (SP), s.d. 


\subsection{A Sociedade Espanhola de Socorros Mútuos e Instrução (SESM)}

A 13 de março de 1898 reunia-se uma comissão organizadora para viabilizar a criação do que viria a ser a Sociedade Espanhola de Socorros Mútuos e Instrução (SESM). Reunida à Rua Benjamin Burcharot, $\mathrm{n}^{\circ}$ 14, dela faziam parte figuras conhecidas e outras que depois se destacariam especialmente no comércio, como José Aparício Martí, seu primeiro tesoureiro. Também tipógrafos, como o próprio Eiras Garcia, o primeiro vice-presidente da Sociedade ${ }^{44}$ e José Valentin Diego, fundador e presidente da Associação das Artes Gráficas e Anexas ${ }^{45}$ e responsável pela publicação do jornal O Trabalhador do Livro. Ativista, Valentin fundaria com Everardo Dias, um ano depois, o jornal El Grito del Pueblo, tendo participado do segundo Congresso Socialista realizado em São Paulo, no ano de $1902^{46}$. Deixou vários registros em periódicos apontando as "dificuldades do movimento operário em São Paulo"47, cujos impasses, a seu ver, eram gerados no seio das próprias organizações operárias pelas hostilidades étnicas entre os imigrantes de distintos países ${ }^{48}$. Valentin também já havia fundado com seu irmão Isidoro, gráfico como ele, o jornal La Tribuna Española $(\mathrm{LTE})^{49}$ e trabalharia, anos mais tarde, na redação do EDE, da mesma maneira que Manuel Rodriguez, por muitos anos braço direito de Eiras, também membro desta Comissão Organizadora ${ }^{50}$.

Outro componente da Comissão - que, segundo informação veiculada no próprio EDE, estaria reunida no Café Guarani do galego Alonso Dominguez ${ }^{51}$, ponto de encontro de tipógrafos - era Joaquín Aparício Mallol, que será seu primeiro presidente; Mallol chegara ao Brasil em 1891. Valenciano de Castellón realizou um único registro no CGE em 1893, cinco anos antes da fundação da SESM, quando se declarou deficiente. Residia então na Rua da Glória, 42, era casado e tinha 30 anos de idade ${ }^{52}$. Outro integrante também com uma única passagem no CGE era Juan Bautista Perez. Em 1904, quando isso aconteceu, portanto seis anos

${ }^{44}$ A primeira Diretoria da Sociedade assim se compunha: Presidente: Joaquín Aparício Mallol; VicePresidente: José Eiras Garcia; Secretário: José Artacho Plasencia; Tesoureiro: José Aparício Martí; $2^{\circ}$ Secretário: Higino Bisbal; Vogais: José Roldán, Francisco Bouzas, Fermín Estevez, Hilário Millán, Miguel Reyes e Ciriaco Dueñas; Comissão de Contas: Nicolas Castaños, Paulino Moyano e Antonio Jimenéz. Informações obtidas em: “Síntesis Histórica de la Sociedad'. In: Sociedad Hispano-Brasileira de Socorros Mútuos, Instrução e Recreio. s.d., [p.1], mimeo.

${ }^{45}$ FERREIRA, M. A imprensa operária no Brasil (1880-1920). Petrópolis: Vozes, 1978, pp. 112-113.

${ }^{46}$ HAHNER, J. Op. cit., p. 248.

47 MARAN, Sheldon Leslie. Anarquistas, imigrantes e o movimento operário brasileiro, 1890-1920. Tradução de José Eduardo Moretzsohn. Rio de Janeiro: Paz e Terra, 1979, pp. 19-20.

${ }^{48}$ HALL, M. The origins of mass immigration in Brazil, 1871-1914. PHD Th., Columbia University, 1969, pp. 395; 397-398.

${ }^{49}$ FERREIRA, M. Op. cit., p. 123.

${ }^{50}$ EDE 15.10.1920.

${ }^{51}$ EDE 22.12.1921.

${ }^{52}$ LRC 1893. 
depois da criação da SESM, esse galego de Coruña declarou-se com 51 anos, viúvo e carpintero $^{53}$. Do último indivíduo a compor a comissão organizadora, Juan Roldán Rocoy, nada pudemos reunir ${ }^{54}$.

Não obstante, o elenco acima apresentado revela-se suficiente para ilustrar as distintas experiências de vida e de formação pessoal e profissional e, portanto, os diversos, e muitas vezes divergentes, interesses e expectativas que motivava a cada qual na criação e participação dessas associações.

Após a fundação dessa primeira associação espanhola na Paulicéia, muitas outras se sucederão. Um rápido olhar sobre os elementos que comporão outras entidades congêneres é o bastante para demonstrar serem quase sempre os mesmos elementos que gravitam e se alternam em seus postos diretivos, exemplo bem acabado na figura de Aparício Marti, aqui o fundador e seu primeiro Tesoureiro, e lá adiante, como veremos, fundando o Centro Español (CE).

Nesta data, portanto, reunia-se essa comissão, cujos membros haviam previamente subscrito uma circular endereçada aos imigrantes residentes na cidade, informando dos propósitos da sua constituição, basicamente, nesse momento, o amparo aos associados em caso de doença e morte, objetivos que, mesmo levando-se em conta o ainda pequeno percentual de espanhóis então radicados na cidade - o oferecido pelos órgãos oficiais, pelo menos - ou que por ela transitavam, evidenciava o perfil desse contingente, em grande parte mergulhado em extrema pobreza. Por outro lado, destacava uma outra face da questão: o desamparo a que se viam submetidos pelo poder público, tanto do país de destino - para quem o (indesejado) imigrante que passa a habitar os centros urbanos representava, de certo modo, o elemento que, burlando as determinações, punha em relevo a "falha" do eficiente aparato oficial montado para a captação de braços para a lavoura cafeeira - quanto do seu próprio país de origem, aqui representado pela autoridade consular, também ela, estarrecida, clamando por atenção e verba para o corpo diplomático, ele próprio relegado a plano secundário pelo Estado espanhol.

Esse aspecto é flagrante nos memorandos enviados ao Ministro de Estado daquele país pelos diversos cônsules que passaram pela cidade no período. Neles, estes relatavam a precária situação financeira do CGE sem dispor, por vezes, de condições materiais sequer para os expedientes de rotina. Esse quadro faz sentido se levarmos em conta que, a esta altura, todo o empenho e as reservas do Estado espanhol se direcionavam para a manutenção de seu já

\footnotetext{
${ }^{53}$ LRC 1904.

${ }^{54}$ Informações obtidas em: "Síntesis Histórica de la Sociedad”, op. cit., s.d., [p.1], mimeo.
} 
bastante comprometido império colonial, deixando de lado qualquer outro assunto. Sobre o imigrante, a propósito, disseminou-se na opinião pública uma imagem negativa, a do sujeito que emigrava para não ser convocado, daquele que fugia à obrigação cívica de defesa militar a tais possessões, enfim.

Dessa ótica, a atitude oficial do Estado espanhol quanto à emigração nunca deixou margem a dúvidas: reiterada pela Real Orden de 11.07.1891, quando já não se podia mais conter a aluvião que se esvaía pelos portos, atribuía-se então ao governo o encargo de orientá-la para "los límites del próprio suelo o dirigirla a nuestras posesiones ultramarinas" $"$. Em todo caso, como medida preventiva, procurava-se antepor uma série crescente de exigências restritivas ao pretenso candidato que quisesse fazê-lo legalmente, o qual, sem alternativa acabava por evadir-se clandestinamente "obligado a tomar pasaje en el puerto de Gibraltar porque el Gobierno de nuestra Patria viene favoreciendo el infame tráfico que se lleva a cabo con los infelices expatriados en aquel puerto ingles".

A inícios da segunda década do Novecentos, era ainda desta maneira que grande parte dos espanhóis conseguia partir, depois que se dilapidasse tudo ou o pouco que lhe restara, pela rede de exploradores que atuavam nas imediações de Gibraltar. Eiras insurgia-se protestando contra a imprensa e os governantes espanhóis a quem responsabilizava por obrigar o imigrante a ter de "huir clandestinamente, dejándole indefenso, sin protección ni valladar alguno a la voracidad de quienes ven en los españoles así embarcados seres repudiados de sua propia Pátria". E completava a matéria repudiando como "crimen manifiesto" qualquer proibição à liberdade individual de "todo ciudadano al derecho de trasladarse a donde le venga en gana"

Não obstante, inconscientemente até, esse sujeito era portador da marca da acusação que lhe pesava, e assim, mesmo ao desamparo procurará evitar, no país de destino, os contatos com a autoridade estabelecida, prescindindo de seu apoio - ela própria, preocupada com suas questões “internas” tampouco demonstrará interesse por ele. Restava a esse indivíduo, portanto, em casos extremos, recorrer a alguns conterrâneos, figuras públicas em melhor posição social e financeira como Eiras Garcia, por exemplo.

A opinião pública certamente se deixava influenciar pela imprensa espanhola da época que não procurava questionar as teses oficiais reiterando por décadas, ao contrário, segundo Eiras Garcia "com misto de desdém e piedade" a concepção segundo a qual "os que emigravam

55 SANCHEZ, B.A. "La visión contemporánea de la inmigración española”. In: Revista de Estúdios Migratórios Latinoamericanos. Buenos Aires: n. 13, 1989, p. 445.

${ }^{56}$ EDE 19.09.1913. 
eram os fracassados, os inadaptáveis, os pobres de espírito", até finalmente perceber que seu país se despovoava, quando passa então a "denegrir com calúnias os países da América, receptores dos emigrantes". Lamentando a "sangria diuturna de sua população" e "tentando amedrontá-los com notícias escabrosas e títulos como Los horrores de la emigración", buscavam, finalmente, estancar a corrente que se esvaía pelos portos ${ }^{57}$. Inutilmente, conforme Eiras, que se pronunciava denunciando o calamitoso estado de coisas que se observava naquele país, fruto da empresa "imperialista estúpida y trágica", preocupada tão somente na construção de navios de guerra, na compra de canhões e em construir fortalezas militares na falaciosa “misión civilizadora” da África ${ }^{58}$.

Era, afinal, com esse propósito que o governo chamava de retorno ao país através de decretos "de voluntariado" àqueles que, em idade de recrutamento militar, preferissem não incorrer nas penalidades reservadas aos desertores. A campanha previa alcançar 12 mil "voluntários" vivendo na América nessas condições, apenas no ano de $1913^{59}$.

Não obstante a nítida indignação que exalava dos artigos de seu diário pelos quais imputava ao governo espanhol a responsabilidade pelo caos nacional, por outro lado, Eiras não tolerava que esse mesmo governo fosse alvo de deboche por parte da imprensa nacional. Às vésperas de nascer o filho da Infanta Beatriz, um jornal local, identificado apenas como um "portento del periodismo vermelho", assim se manifestava, em tom de galhofa: "Quer dizer que daqui a uns trinta dias mais ou menos serão chamados aos aposentos da infanta mãe as damas do palácio, os mordomos, os copeiros, os cozinheiros, os estribeiros, os pajens e mais quem o deseje por curiosidade, para assistirem, "de visu” o momento solene de "délivrance” (...). A partir daí, satirizava seu autor, haveria "mais um comensal dos orçamentos do Reino, mais um herdeiro do ódio dos republicanos", e finalizava, provocando: "são praxes, mas bem condenáveis... bem, por que não dizer, ridículas?".

Enfurecido, Eiras classificou o artigo um disparate e obra de "estos chicos de la prensa indígena", tratando de devolver no mesmo tom - de ironia - e, afirmando que estes não sabiam como fazer para demonstrar o "grandioso cúmulo de afecto que nos profesan", declarava ser balela a alardeada "franca hospitalidade" de que eram objeto os imigrantes, protestava com veemência contra o ultrajante tratamento e a falaciosa receptividade conferida ao "convidado" numa "casa donde fue llamado"60.

${ }^{57} \mathrm{EDE}$ 04.12.1913.

58 "Para la historia del imperialismo". EDE 02.09.1913. Assim se manifestando, Eiras tomava uma posição contrária a quem, monarquista e de ultradireita, apoiava as guerras imperialistas espanholas do período.

${ }^{59} \mathrm{EDE} 21.07 .1913$.

${ }^{60}$ EDE 24.10.1913. 
Não foi, contudo, apenas com a "prensa indígena" que Eiras se desentendeu. Em pelo menos um episódio ficou demonstrado que suas relações com o Fanfulla, ou melhor, com "o proprietário do jornal" da colônia italiana, eram tensas. $\mathrm{O}$ estopim do revide referia-se ao "desborde de ofensas" de que teria sido vítima a "nación en que nacimos" em artigo veiculado pelo periódico que, conforme Eiras, "de hambriento gacetillero", se elevara a "periodico muy rico".

Acusando a audácia de seu proprietário, "individuo tan cobarde y tan bajo" e "cujo ideal de acumular riqueza" teria sido alcançado servindo-se de meios ilícitos, que estariam provocando repugnância à própria colônia italiana, a qual havia deixado de adquirir e ler o periódico, Eiras insinuava, em matéria veiculada dias depois dessa primeira investida, que a questão remontava às alianças da Primeira Guerra: "pode-se ver que a economia da Itália progrediu de modo notável desde que firmou sua aliança política com a Alemanha e a ÁustriaHungria" apregoava, "e que a Rússia se desenvolveu sob o compromisso político firmado com a Inglaterra e França". A Espanha, não obstante, "rechaçou acordos dessa índole que iriam se traduzir em secretas inimizades contra um determinado povo", prosseguia em seu ataque.

Consultamos a esse respeito, a propósito, Consolmagno que, em seu trabalho sobre o Fanfulla confirma mudanças significativas na orientação do periódico após a Primeira Guerra. Para a autora "a ascensão do Fascismo e sua posterior vitória envolveu novos e antigos setores nacionalistas, incluindo-se o Fanfulla que aderiu à nova ordem, como, aliás, amplos segmentos dos emigrados italianos em diferentes países”. Esse fenômeno alteraria o perfil inicial do jornal "que se definia pela ideologia liberal" $"$, simpatizante do ideal fascista durante a década de 1920.

É compreensível desse modo que, em seu contra-ataque, Eiras evocasse não apenas a alteração da postura ideológica do jornal, mas insinuasse a respeito da expansão imperialista italiana para o norte da África (Líbia), que o Fanfulla não apenas apoiava, mas defendia, em substituição à emigração para o Brasil.

Enfim, retornando à associação que fundara, a SESM, esta contava em 1901, três anos após a sua criação, com 285 sócios cadastrados ${ }^{62}$. As mulheres também foram aceitas como sócias, desde 1898, desde que sem direito a voto. Em 1902, o regulamento sofre reformulações, passando a aceitar também os filhos de espanhóis nascidos no Brasil e elementos de outra nacionalidade, desde que casados com espanholas. Houve moção de um sócio no sentido de se

\footnotetext{
${ }^{61}$ A esse respeito, consultar: CONSOLMAGNO, M. Op. cit, pp. 145 e ss

${ }^{62}$ LUCA, T. Op. cit., p. 134.
} 
vetar a ocupação dos cargos de direção da Sociedade por jornalistas e redatores da imprensa espanhola, clara indicação de que essa participação poderia encerrar problemas para a mesma. Sem sede própria, as reuniões de suas assembléias eram realizadas em sedes por empréstimo, como a realizada a $1^{\circ}$ de janeiro de 1899 , na sede da Sociedade Portuguesa Vasco da Gama, na rua Rangel Pestana, 116, cedida por sua direção. Nas assembléias seguintes, novamente a itinerância: a de março ocorreria no Teatro Eldorado, na Rua São João, local considerado "neutro" - imaginamos que fosse na sala de exibição de Serrador - e a de agosto, na Sociedade Grêmio Gil Vicente, na Rua Líbero Badaró, 20, enquanto que as ocorridas em outubro e novembro de 1900 ocorreriam na Liga Lombarda, situada na Rua Conselheiro Crispiniano, $7^{63}$. Já então operava uma farmácia para o fornecimento de medicamentos a seus afiliados - a mesma que em 1918, durante a epidemia de gripe espanhola, foi disponibilizada para qualquer pessoa. Em 1902, sob a presidência de Aparício Martí, é criada a Caixa de Repatriações, fundo específico para fazer frente à monta de solicitações que recebia a Sociedade que, neste ano "realizó las repatriaciones" daqueles que, por diversas razões - enfermidade, mutilação, viuvez, abandono do cônjuge, distúrbios psíquicos, dentre outros - eram obrigados a retornar ao país de origem "sin contar con ningún auxilio oficial".

Essa questão, conforme teremos oportunidade de examinar, era das mais complexas, exigindo soluções imediatas, tanto assim que, neste mesmo ano de 1902, é criada uma outra sociedade com o mesmo caráter e finalidade, sediada na cidade de Santos.

Para sua gestão, no entanto, a SESM necessitou continuamente da mobilização da comunidade para enfrentar as crescentes dificuldades de caixa, haja vista que sua manutenção dependia em grande parte da contribuição dos (poucos) sócios, estes em maioria sujeitos às oscilações de ganhos provenientes de ocupações e empregos casuais e sobrevivendo em estágio de pobreza permanente. Desse modo, na obtenção dos recursos necessários para a manutenção da sociedade que, embora recém-criada, já passava por graves dificuldades, sua diretoria tratou de programar eventos beneficentes como a corrida de touros realizada em "plaza improvisada" [na Praça da República], em $1902^{64}$.

Eram igualmente contínuas as investidas para sensibilizar os expoentes mais favorecidos da colônia em prol do crescente contingente de miseráveis, o que se depreende do teor do Boletim n $n^{o}$ 01, de maio de 1902 que, sob o título "Adelante compatriotas!" conclamava, em tom didático: "Folgamos em declarar que entre nossos novos consórcios se acham, além dos

\footnotetext{
${ }^{63}$ As informações sobre as Assembléias da SESM foram extraídas de anotações coligidas por Marco Antonio Costa Ferreira (in memoriam), cedidas à autora.

${ }^{64}$ Dia 12.05.1902. In: "Síntesis Histórica de la Sociedad', op. cit.
} 
compatriotas para quem as condições econômicas tornam imperiosa esta classe de associações, outros que se acham fora das necessidades inerentes à pobreza". E prosseguia, dirigindo-se a estes em tom de cumplicidade: "os quais se convenceram de que a melhor obra de humanidade e patriotismo que se pode fazer é a de pertencer a esta instituição espanhola". E, conciliador, completava, ciente das questões que pairavam sem solução: "Redobremos nossos esforços e já que nos separam na vida aspirações diversamente cristalizadas por nossa razão, e ainda interesses contrários, unamo-nos para a consecução daquilo que não deve nos dividir: a defesa da saúde física e moral, conseguida pelo esforço da associação,

Em 1903, na tentativa de cortar despesas, discute-se em Assembléia a possibilidade de entregar o prédio alugado na Rua Florêncio de Abreu, 29, e, por sugestão de um sócio passarem a se reunir no CG ou no Liceu Español, ambos com sede própria. Apesar de um diretor comentar do embaraço que isso causaria - "é sabido que as inimizades nos devoram" - a mudança ocorreria para a sede do Liceu, à Rua do Gasômetro, 54 .

Questões de envolvimento político já tumultuavam as suas assembléias, razão para uma oportuna alteração nos regulamentos, que passam a exigir "imparcialidade" dos sócios. Só na aparência! Tanto assim que, em 1909, se levantava continuamente em assembléia a necessidade de ajuda financeira aos filhos dos presos de Barcelona, provável alusão ao episódio que culminou no fuzilamento do educador Francisco Ferrer ${ }^{66}$, questão que desandou em profunda crise, redundando em demissão do presidente e do tesoureiro da Sociedade ${ }^{67}$. Pouco antes, em 1907, já fora com grande dificuldade que houvera, em Assembléia, a leitura de um ofício do CG pelo qual se comunicava a organização de um espetáculo em benefício de Eiras Garcia, então preso por tomar partido, por meio do EDE, em defesa de vários espanhóis, colonos do interior do Estado, que solicitavam ajuda para as custas dos processos que moviam contra os fazendeiros. Isidoro Diego, sócio e irmão de Valentin que, como Eiras, era um dos fundadores, usou da palavra, em sessão de agosto de 1907, tentando persuadir os renitentes da importância em não se permanecer indiferente diante da violência da prisão de Eiras. Finalmente, é aprovada uma comissão para visitá-lo, em nome da Sociedade.

Provavelmente motivada pela prisão de Eiras, que mobilizou toda a colônia da Capital e do interior do Estado, é proposta por Valentin Diego e aceita pela diretoria uma "ampliação do

\footnotetext{
${ }^{65}$ LUCA, T. Op. cit., p. 142.

${ }^{66}$ Ver a respeito o Capítulo V.

${ }^{67}$ As informações sobre as Assembléias da SESM foram extraídas de anotações coligidas por Marco Antonio Costa Ferreira (in memoriam), cedidas à autora.
} 
Regulamento" da SESM, pela qual caberia à mesma a "defesa dos associados em caso de manifesta perseguição ilegal por parte de qualquer poder ou entidade"68.

Constava ainda daquele mencionado Boletim a intenção de reunir-se ao CG, fusão perfeitamente plausível, não apenas aquiescendo à plataforma de conciliação proposta, mas também no plano concreto, se pensarmos que a unificação das duas sociedades traria inevitável economia na gestão dos (parcos) recursos, ainda mais agora em que se acabara de criar a Caixa de Fundos, destinada ao atendimento de viúvas e órfãos não apenas do corpo societário, mas de qualquer "espanhol necessitado". Contudo, o CG, criado em 1903 e fusionado à SESM, apareceria ainda como sociedade autônoma no EDE desde as primeiras edições consultadas, portanto, a partir de 1912. Neste ano, a propósito, era seu presidente o comerciante e importador Perfecto Ares ${ }^{69}$, naturalmente galego, e sua sede funcionava à Rua da Conceição, $83^{70}$, ocasião em que se convocavam os ex-sócios para que providenciassem as suas baixas do cadastro da agremiação. No ano seguinte, a propósito, seu presidente vinha a público para fazer o anúncio da "Grande festa de Santiago Apóstolo",71 . Desse modo, se tal fusão ocorreu, ela teve duração efêmera, frustrando a primeira tentativa de reunificação, pois em março de 1918, o próprio Perfecto Ares apresentava-se candidato à vice-presidência da SESM ${ }^{72}$.

Foram inúmeros os problemas enfrentados por essas sociedades, sempre às voltas com crises financeiras que demandavam um sem-número de arranjos e artifícios para o encaminhamento das questões mais prementes, como campanhas arrecadatórias, subscrições e pedido de doações. Outro problema incontornável dizia respeito à oscilação que se observava na carteira de associados da SESM, evidenciando claramente a flutuação nas condições financeiras de seus afiliados. Em 1904, seis anos após a sua criação, eram apenas 270 associados, porém, sete anos depois, em 1911, já seriam 452. No entanto, em 1916, o número de associados da SESM havia baixado enormemente, eram apenas pouco mais de 300 sócios $^{73}$. A causa? Dentre muitas outras, os declarados antagonismos de toda ordem, fator de dispersão de forças e que faziam proliferar associações. Desse modo, tão logo uma pauta defendida por determinada facção encontrasse resistência em outra, ocorria a cisão que, no mais das vezes, redundava em criação de uma outra sociedade, sem opositor. Essa outra se empenhava na captação dos associados, redistribuindo-os, porém quase sempre tinha vida efêmera, o que provocava o descrédito na instituição, em prejuízo de todas.

\footnotetext{
${ }^{68}$ Assembléia de 26.09.1908.

${ }^{69}$ EDE 24.07.1912.

${ }^{70}$ EDE 18.06.1912.

${ }^{71}$ EDE 31.07.1913.

${ }^{72}$ EDE 30.08.1918.

${ }^{73}$ LUCA, T. Op. cit., pp. 134-135.
} 
De qualquer modo, há claras evidências de que o montante arrecadado através das contribuições mensais dos sócios esteve longe de fazer jus às despesas, especialmente àquelas destinadas ao atendimento à saúde dos sócios, em geral debilitada pelas péssimas condições de vida e de moradia, em habitações coletivas e locais insalubres.

Em 1914, uma Assembléia determinava que se evitasse o desligamento dos sócios por falta de pagamento, negociando e ampliando os prazos, em virtude da crise da falta de trabalho revelar-se grande na cidade ${ }^{74}$. Em 1916, quem se manifestava era o próprio Manuel Rodrigues, um dos fundadores da SESM, cujo diagnóstico vem reforçar as flagrantes questões que rondavam não apenas aquela associação: "La causa del decrecimiento social han sido los grupos antagónicos, las luchas intestinas, los caprichos de Juan o Pedro. La prueba más irrefugable de lo que dice es que la junta no pudo acabar su mandato por esas mesmas rencillas y pasiones malas". Nesta mesma Assembléia, Aparício Marti, depois de declarada ausência de seis anos, dizia-se surpreso com o estado de coisas encontrado ${ }^{75}$. Um ano depois, atestando o que comentávamos, ele fundaria o Centro Español.

Além da questão da saúde, outro problema grave a ser enfrentado dizia respeito às repatriações. Consta que as companhias de navegação eram taxadas em $8 \%$ de imposto sobre o valor da passagem e que este valor era repassado ao Governo espanhol em bônus, os quais eram distribuídos aos diversos consulados, encarregados das repatriações. O CGE, em sua prestação de contas do exercício anual referente ao ano de $1913^{76}$ declarava, em publicação ao EDE, ter providenciado a repatriação de 535 indivíduos, número que certamente ficava muito aquém das reais necessidades. Esse fenômeno não era exclusivo do caso brasileiro. No ano de 1912, teriam retornado à Espanha "aproximadamente 50 mil emigrados, partindo de diversos países da América”, desembarcados nos seguintes portos: "Em Vigo, 15 mil; Coruña, 4,5 mil; Barcelona, 8,6 mil; Cádiz, 17 mil e no Porto de Almeria, 4.611 pessoas"

O número dos repatriados pelo CGE não cobria, em absoluto, o número de pedidos encaminhados, aumentando a defasagem, ano a ano. Para dar vazão à demanda, há evidências de que uma sociedade de repatriação tenha se constituído em finais da segunda década.

${ }^{74}$ Assembléia de 20.09.1914.
${ }^{75}$ Assembléia de 26.11.1916.
${ }^{76}$ EDE 13.04.1914. Da prestação de contas, constava: a) O envio de 833 comunicações, assim distribuídas: Ministério de Estado: 100; Legación de sua Majestade: 54; Ao Patronato Agrícola e ao DET: 180; Aos agentes e correspondentes consulares: 202; Aos asilos e hospitais: 10; Às companhias de navegação e ao Vice-Consulado de Santos: 137; A autoridades diversas: 150; b) O recebimento de 307 cartas, solicitando notícias ou formulando reclamações, e, destas, 275 foram respondidas; as demais não o puderam ser por estarem ilegíveis ou sem o endereço para resposta; c) Diversos: Internados no asilo: 4; Internados em hospitais: 3; Recolhidos temporariamente à Hospedaria, por solicitação do Consulado: 32; Bilhetes distribuídos para diferentes lugares do interior para espanhóis sem recursos: 16.

${ }^{77}$ EDE 27.02.1913. Trad. da autora. 
Denominada Sociedad de Repatriación e Instrucción, tinha sede social na Rua Carneiro Leão, 5 - $\operatorname{altos}^{78}$, e, em face da extrema precariedade de recursos com que alguns compatriotas recémchegados do interior se apresentavam, era necessário acolhê-los ali mesmo. Foi o que ocorreu a Manuel Díaz, mulher e três filhos que "carecendo de albergue, pernoitaram na instituição", cuja diretoria abria uma subscrição, encabeçada com "20\$000 dos fundos sociais, esperando a adesão de todos"

Além do mais, no tangente ao CGE, há indicação de que os citados indivíduos repatriados tenham desembolsado durante algum tempo parte do valor da passagem ou mesmo o seu valor integral, conforme se patenteou no rumoroso episódio envolvendo o cônsul Juan N. Solórzano y Costa, denunciado por Eiras Garcia, em 1914, flagrado comercializando passagens com os candidatos à repatriação. Segundo sua denúncia, quando os repatriados que, por lei, deveriam pagar apenas o equivalente ao valor de meia passagem, já pactuado com as companhias de navegação, recorriam ao CGE, aquele lhes exigia um importe, para completar o custo da meia passagem, quase equivalente ao preço da passagem inteira. Em outras palavras, de posse dos bilhetes repassados pelo governo espanhol, o cônsul negociava com os candidatos à repatriação, que desconheciam seus direitos, uma passagem inteira a custo menor que o do mercado, ficando, portanto, com a diferença.

Aos repatriados, por lei, as companhias de navegação deveriam cobrar apenas 50\% do valor da passagem, e era obrigatório o transporte de pelo menos $20 \%$ de repatriados em cada travessia. Portanto, o repatriado não era obrigado - e, na sua condição, dificilmente poderia arcar com os custos da passagem. Porém, conforme se depreende da matéria estampada no EDE “o cônsul parece ter-se transformado em negociante de passagens marítimas. Aproveitando-se da meia passagem gratuita, vende passagens inteiras a preços mais econômicos que as companhias de navegação".

Essa denúncia foi fatal para Solórzano que, uma semana depois da sua divulgação foi visto no Brás, bairro onde residia a maioria dos espanhóis pobres, ameaçando-lhes de prisão ou deportação, caso "desafiassem a sua autoridade". Dias depois, o EDE anunciava a entrega do cargo pelo cônsul, que então embarcava para a Espanha ${ }^{80}$, em clara demonstração da força e do alcance do periódico de Eiras Garcia. Contudo, a revanche não tardaria: provavelmente em

\footnotetext{
${ }^{78}$ EDE 04.05.1919.

${ }^{79}$ EDE 25.08.1920. Trad. da autora. Consta ter existido, anteriormente a esta, a Sociedad de Repatriación de la Lapa por volta do ano de 1909, ano em que é citada nas Assembléias da SESM. Informações extraídas das anotações de Marco Antonio Costa Ferreira (in memoriam), cedidas à autora.

${ }^{80}$ EDE 15.07.1914.
} 
represália a esta e a muitas outras denúncias que fazia circular, valendo-se de seu periódico, consta ter sido negado, a ele e a seu filho Heitor, o registro no CGE, em maio de $1917^{81}$.

Estes indivíduos miseráveis e maltrapilhos, recém-chegados da roça, sem qualquer conhecimento da cidade, em sua maioria sem conhecido algum nela, assustados e despreparados e que, muitas vezes, não possuíam sequer o necessário para se manter antes do embarque de volta, eram alvo de toda sorte de abuso e exploração de espertalhões, quando necessitavam ali permanecer ou pernoitar antes de seguirem viagem para Santos. Desde 1912, a propósito, o EDE já se insurgia contra os corretores e agenciadores de hotéis de "vigésima ordem”, quase todos "italianos e espanhóis", que os esperavam nas estradas de ferro, a certa distância da Estação da Luz, oferecendo-lhes bilhetes de passagem, ou propondo-lhes a troca de moeda brasileira por libra ou moeda italiana, ambos falsificados ${ }^{82}$.

Era mais uma oportunidade para Eiras reagir com eloqüência, disparando contra o cônsul e os vice-cônsules do interior ${ }^{83}$. Essas criaturas, muitas vezes constituindo remanescentes de famílias destroçadas, procuravam arranjar-se como podiam, até a hora do embarque que, até 1913, ocorria somente duas vezes por mês, pela Pinillos ${ }^{84}$. Despachados do interior em condições de extrema pobreza e privação, humilhados pela degradante condição de candidatos à repatriação que pressupunha o fracasso e o malogro de seu almejado projeto de melhoria de vida, tendo de apelar às autoridades para a obtenção da passagem, ao desfecho dramático e humilhante desses sujeitos ainda se somava a incerteza e a vergonha do retorno. Esse era o caso da viúva Maria Alcázar, recém-chegada do interior, onde teria falecido seu marido, com cinco filhos menores, o maior com apenas sete anos, que vivia como indigente perambulando pela cidade, e a quem o consulado oferecera tão-somente meia passagem para voltar à Espanha! $!^{85}$. Do mesmo modo, em degradante penúria, abandonadas, e aguardando pela repatriação, viviam cinco crianças, a maior com 11 anos, que ficaram órfãos de pais e encontravam-se "recolhidas" à Rua São Caetano, 179, necessitando de mantimentos e roupas ${ }^{86}$.

\footnotetext{
${ }^{81}$ LRC 07.05.1917.

${ }^{82}$ A respeito da existência de quadrilhas de falsificadores e da proliferação de cédulas falsas, ver: PINTO, M.I. Op. cit., 1984, pp. 217 e ss. Trad. da autora.

${ }^{83}$ EDE 10.09.1912.

${ }^{84}$ Em julho de 1913, foram repatriadas 15 famílias espanholas da Andaluzia. O pagamento de suas passagens foi feito metade por conta do governo brasileiro e a outra metade pelo CGE. Os repatriados foram: Francisco Gómez; Miguel Pavón; Agustín Gonzáles; Juan Moya; Miguel Moya; Francisco Arena; Antonio Rodriguez; Antonio Garcia; Francisco Ramirez; José Castillo, ambos com mulher e filhos. EDE 06.08.1913.

${ }^{85}$ EDE 06.10.1921.

${ }^{86}$ EDE 14.02.1914.
} 
Essa questão, a do repatriamento ${ }^{87}$, se arrastava por décadas, era de difícil solução e revelava em alguns de seus desdobramentos, para além das vicissitudes dessa massa de população pobre e desamparada, os inúmeros arranjos e subterfúgios empregados para sua resolução, alguns com claro apelo pessoal. Valendo-se de seu prestígio e dos conhecimentos profissionais, Raimundo Díez, abastado importador, aproveitava-se para obter vantagens, benefícios e cortesias das companhias de navegação, o que lhe rendeu a concessão do "título de honra" em solenidade pública promovida pela SESM por "su poderosa influenza delante de los propietarios de la compañía naviera Pinillos Izquierdo \& Co., de Cádiz, para que sus buques transportasen a los infelices que tenían de retornar al seno de los suyos " ${ }^{88}$. Podemos, de qualquer modo, imaginar as condições em que esse transporte de cortesia devia ocorrer, se levarmos em conta as condições de transporte do pessoal pagante.

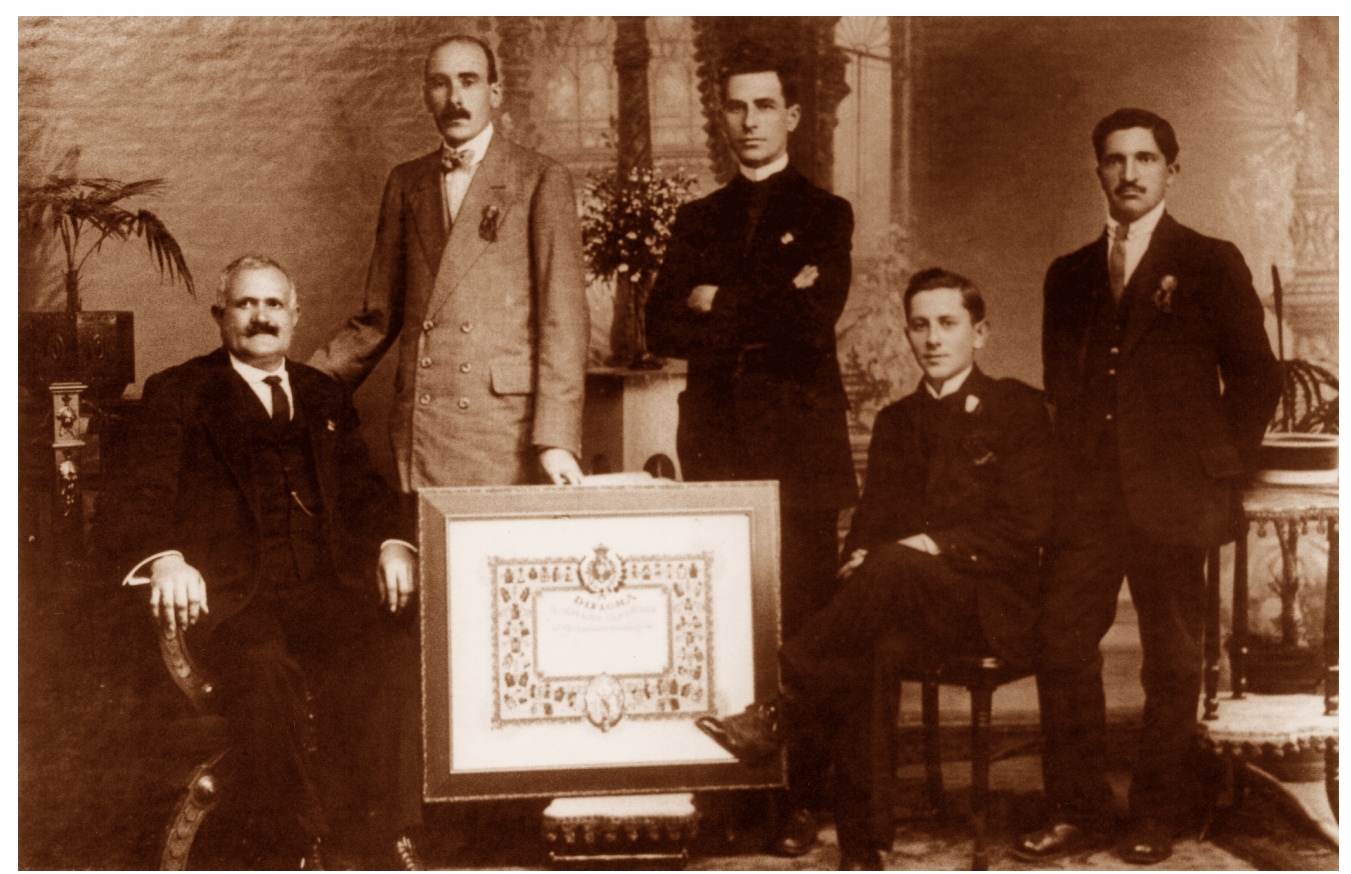

Fig. 13. Entrega de diploma oficial da Sociedade Espanhola de Socorros Mútuos a um membro da coletividade pelos relevantes serviços prestados à comunidade espanhola de São Paulo. São Paulo (SP), 1923.

${ }^{87}$ Para um melhor exame da questão, ver: MERTZIG, Lia R. As dificuldades de adaptação do imigrante no Estado de São Paulo: repatriação e reemigração, 1889-1920. São Paulo: Dissertação de Mestrado, FFLCHUSP, 1977.

${ }^{88}$ EDE 26.05.1920. 
Nem todos, no entanto, logravam retornar, malgrado sua condição de indigência. Consta, no caso italiano, a existência de cônsules que, ao invés de repatriarem os imigrantes, os internavam na Santa Casa de Misericórdia, e outros que os confinavam na Hospedaria de onde, desesperados, retomavam o caminho de volta às fazendas ${ }^{89}$, devolvendo o "problema" para os agentes consulares ou vice-cônsules do interior. Como se pode observar, o problema não era exclusividade dos espanhóis.

Ocorre, porém, que o cargo de Agente Consular no Interior era atribuição não remunerada e ocupada por indicação, no mais das vezes por pequenos comerciantes locais os quais, além de não terem disponibilidade de tempo para intervirem nas querelas dos colonos com os fazendeiros, também não estavam dispostos a enfrentá-los, até porque, quase sempre, eram os seus melhores fregueses. É imperioso lembrar que a criação das sociedades de repatriação foi, em alguns casos, ela própria, fruto de amargas e dolorosas experiências pessoais revertidas em iniciativas que visavam a amparar e amenizar desafortunados em igual situação:

Meus bisavós estiveram na Fazenda Monte Alto, por volta de 1893/5. Comeram o pão que o diabo amassou ali. A mãe da minha "bisa" perdeu dois filhos de febre amarela e foi banida para o mato com eles queimando de febre. Os dois morreram e ela os enterrou cavando as suas sepulturas com as próprias mãos. Fugiram dali a pé até a cidade de Santos, onde se estabeleceram e meu "bisa", Enrique Alvarez Corisco, fundou a Sociedad Española de Repatriación ${ }^{90}$.

Esse exemplo é ilustrativo. Essa Sociedade foi fundada na cidade de Santos em 1902, como vimos. Seus sócios, cuja contribuição mensal era de 2.000 réis, podiam requerer a repatriação, motivada por doença, ou viuvez da mulher com filhos pequenos, após dois anos de contribuição, regra que era flexibilizada em casos especiais de doença que impossibilitasse o exercício do trabalho. A média de repatriações foi de 35 a 40 pessoas por ano, até a guerra civil $^{91}$. Em 1919, essa Sociedade contava com 716 sócios e havia repatriado, no exercício 1917/8, a 15 deles e 9 indigentes ${ }^{92}$.

As repatriações, ou melhor, as expatriações ou deportações, que ocorriam motivadas por processos impetrados pelas autoridades brasileiras por questões políticas, constavam daquele rol de temas evitados, ou melhor, vetados nos estatutos das associações, os quais previam a neutralidade política, fator de embaraços e conflitos entre seus dirigentes.

\footnotetext{
${ }^{89}$ TRENTO, A. Op. cit., 1989, p.165.

${ }^{90}$ DIEGUEZ, Márcia. Fragmento de depoimento, citado.

${ }^{91}$ GALLEGO, A. Op. cit., 1995, pp. 50-51.

${ }^{92}$ EDE 29.01.1919.
} 
Nessas primeiras duas décadas qualquer estrangeiro, até prova em contrário, era considerado anarquista e agitador perigoso, elemento pernicioso à ordem pública, entendendose por isso até mesmo os desempregados, melhor dizendo, os "vadios". Estes, como aqueles, desde que considerados “inconvenientes” à ordem pública poderiam, e foram, expulsos do país.

Imaginamos como seria penoso a reconhecidos militantes como Everardo Dias, proposto como sócio na SESM em 1908, sociedade da qual se tornaria $1^{\circ}$ secretário em $1911 \mathrm{e}$ novamente em 1916 e que, pouco depois, em 1920, será deportado do país - malgrado sua condição de cidadão brasileiro, por ser naturalizado - manter-se em posição de neutralidade diante de seus pares, nas reuniões das agremiações, face à realidade dos colonos, às contendas entre estes e os fazendeiros e à miserável condição de vida da maioria dos imigrantes na cidade, muitos dos quais, como ele próprio, perseguidos pela polícia.

Esta talvez tenha sido a razão da criação, em 1903, da Liga Española de Defensa Mutua, criada com o fim precípuo de oferecer assistência jurídica a seus associados e instalada com subseções funcionando em cidades do interior para atender a demanda de reclamações dos imigrantes contra os fazendeiros. Da sua fundação participaram notórios militantes, ambos gráficos e jornalistas - o próprio Everardo Dias, mais Valentin Diego, Manuel Rodriguez e Antonio Dias, os dois últimos colaboradores do EDE e do LTE.

As querelas com fazendeiros avolumavam-se, tanto é assim que, em ata de reunião de julho do mesmo ano, se informava da intenção em contratar um destacado advogado, atuante em outras "causas difíceis", a quem se atribuía, "por justa razón”, ser "amante de la colonia española". Gallego, que examinou algumas de suas atas, menciona que trocavam regularmente os locais de reuniões e conservavam seus documentos protegidos e em local seguro ${ }^{93}$, fato que deixa transparecer o cuidado com que tratavam de certos assuntos "proibidos", evitando-se assim, previsíveis represálias. Como muitas outras, essa liga desapareceria sem deixar maiores vestígios documentais.

Como diretor de periódico, não obstante, Eiras Garcia apresentava por vezes atuação incisiva, como no ruidoso episódio ocorrido em 1913 envolvendo Eduardo Picón Martinez e Enrique Castro, acusados de cáftens pela polícia e ameaçados de serem deportados em que, em diversas edições, o periódico se lançara em sua defesa ${ }^{94}$.

Eiras, tendo à frente seu periódico, conforme destacamos, era figura central, em torno da qual se aglutinavam distintos interesses e iniciativas. Descontente com o que denominou "nossa debilidade coletiva" investia, em 1913, através de suas folhas diárias especulando a

\footnotetext{
${ }^{93}$ GALLEGO, A. Op. cit., 1993, p. 42.

${ }^{94}$ EDE 09.08; 22.09; 28.09 e 01.10.1913.
} 
respeito das "causas do ceticismo" e da apatia que se abatia sobre a comunidade. Em seu discurso, falava em "vazio da colônia", exultando seus pares à união e a comungarem interesses coletivos. Insurgia-se especialmente contra a "estreita visão das sociedades criadas que, ao invés de unir, nos tem dividido, alimentando a discórdia"95.

A ausência de sócios nas assembléias era questão sempre na ordem do dia, ocasião em que alguns se levantavam pedindo providências à diretoria para que essa apatia fosse superada: em assembléia de março de 1913, ficou registrada a eloqüente manifestação do sócio Ramón Monconill - o industrial proprietário da fábrica de móveis - que revoltado, protestava contra esse estado de coisas: "Nuestra Sociedad es un vivero de niños raquíticos a quienes desarrolla por médio de la Emulsion Scott y otros específicos, y estos niños, llegados a la maioridad, miran con la mayor indiferencia a la Sociedad a quién deben la existencia"96. Tal indignação revelava a motivação apenas utilitária da associação, cujos sócios se afastavam tão logo pudessem prescindir da assistência temporária que motivara a sua aproximação e filiação.

Em junho de 1918, a SESM, ainda funcionava em sede alugada, comunicando mais uma mudança, desta feita para o Largo da Sé, $9-2^{\circ}$ andar, local onde prosseguiria no atendimento médico e no serviço farmacêutico de seus associados ${ }^{97}$. As diversas tentativas de adquirir uma sede própria esbarravam inapelavelmente na falta de recursos, que mal davam para cobrir as crescentes despesas. Não obstante, em 1920, a diretoria da SESM finalmente anunciaria a compra ${ }^{98}$ de dois sobrados geminados, adquiridos por 120 contos de réis, na Rua das Flores, n's 68 e 70: "Se trata del primero edificio adquirido en esa Capital por nuestras corporaciones representativas", afirmaria Raimundo Díez, comerciante e importador, então seu Presidente, cuja esposa, D. Manolita Díez, conforme vimos, às vésperas de embarcar para a Espanha a passeio fez um doação de 1 conto de réis em seu favor ${ }^{99}$.

Desconhecemos os detalhes e as tratativas envolvidas nesse compromisso de compra, porém a anunciada aquisição do imóvel para a futura sede da SESM, conforme constatamos, foi realizada sem que o montante correspondente ao pagamento estivesse em caixa. Assim, para a viabilização do negócio, pudemos notar intensa mobilização, que culminará na realização da grande festa Romería Campestre Española, cuja primeira edição se dará neste mesmo ano de 1920 e contará com a adesão de grande número de espanhóis, muitos dos quais residentes no Interior do Estado.

\footnotetext{
${ }^{95}$ EDE 27.02.1913. Trad. da autora.

96 Assembléia de 30.03.1913. As informações sobre as Assembléias da SESM foram extraídas de anotações coligidas por Marco Antonio Costa Ferreira (in memoriam), cedidas à autora.

${ }^{97}$ EDE 28.06.1918.

${ }^{98}$ EDE 03.05.1920.

${ }^{99}$ Rua das Flores: atual Rua Silveira Martins, travessa da Praça da Sé.
} 
Lopez Campillo, então Presidente da FE, comparecia quase diariamente no EDE, disparando matérias nas quais conclamava os compatriotas, tentando persuadi-los a se engajarem na idéia da realização da grande festa que pudesse estreitar os vínculos entre os membros da colônia, aproximando-os, e que atuasse como elemento unificador. Esforçava-se por convencê-los a demonstrar "a pujança", a "nossa solidariedade", e que "não somos o que dizem" e sim "o que devemos ser em terra estranha", ou seja, tentava forjar junto à comunidade - e promover fora dela - uma imagem coesa da colônia. Essa questão, porém, para cujo encaminhamento se empenhava reduzido grupo, era irremediável e nessas circunstâncias, demonstrar, como era sua expectativa, que "somos filhos de uma Espanha única e indivisível" pareceria - mais que uma idéia de difícil esposamento em ambiente constituído por um mosaico de interesses mais que inconciliáveis, conflitantes ${ }^{100}$-, um delírio.

Foi também com esse intuito que se havia tentado a unificação das diversas sociedades e agremiações preexistentes, pela criação, novamente, de outra associação, a Casa de España, em 1918. Paradoxalmente, contudo, neste mesmo ano de 1918, surgiria mais uma agremiação: tratava-se do Centro União Espanhola (CUE), estabelecido à rua da Quitanda, 4, que teve como primeiro presidente o filho mais velho de Eiras Garcia, José Eiras Garcia Filho, evento que contou com a presença do cônsul da Espanha, Sr. Pedro Satorras, em "grandioso baile de gala", depois fartamente comentado pelo EDE, que enumerou os presentes, citando-os nominalmente "y familia"101. Os programas de suas festas "artístico-musicais" assemelhavam-se ao das demais, trazendo, como novidade, a introdução de canções brasileiras e italianas. Composta por duas partes, essa programação antecedendo ao baile que adentrava a madrugada "sob uma afinada orquestra", desenrolava-se da seguinte maneira: a primeira parte da programação, dividida em cinco sessões, consistia de uma peça de concerto - La primera lágrima - executada ao piano pela professora Narcisa Arraz de la Torre Quintella, seguida por La jota del guitarrillo, pelo Sr. Cristóbal Torres ${ }^{102}$; depois, um número de canto, o monólogo La tempestad, pelo jovem Luis Arranz de la Torre Quintella; declamação de poesia, La caña de manzanilla, pela Sra. Encarnación Román de Martí e outro número de canto, desta feita a canção brasileira Geni, pelo Sr. Cristóbal Torres. A segunda parte, dividida em seis sessões, também iniciava com uma peça de concerto - Capricho español era executada ao piano pela mesma professora, que depois acompanharia o Sr. Cristóbal Torres em Ciúmes, canção brasileira; seguiam-se Delírio de Abelardo, poema recitado pelo jovem Luis Arranz de La Torre Quintella e Prueba artística,

\footnotetext{
${ }^{100}$ EDE 12.05.1920. Trad. da autora.

${ }^{101}$ EDE 04.06.1918.

${ }^{102} \mathrm{Jota}$ : baile popular de Aragón e de outras regiões espanholas.
} 
pela senhora Encarnación Román de Martí. Intercalava-se outra canção, desta feita Alma de Dios (el vagabundo), cantado pelo Sr. Emilio Martí e se encerrava a programação, antes do aguardado baile, com a canção napolitana Torna a Sorrento pelo Sr. Cristobal Torres ${ }^{103}$.

Apesar dos bem programados eventos, o CUE, como muitas outras agremiações, deve ter tido vida efêmera, desaparecendo no ano seguinte. A última aparição nas folhas do EDE ocorrerá em 1919, por ocasião da convocação de uma assembléia para a eleição da nova junta diretiva $^{104}$.

Quanto à Casa de España (CDE), para sua fundação simbólica, realizada por iniciativa da FE em junho deste ano (1918) em seus salões e com o comparecimento de representantes das demais entidades (exceto do CR), foi eleita uma Comissão Executiva presidida pelo cônsul Marquês de Bellpuig que ofereceu as instalações do CGE para as demais reuniões de trabalho. Acordou-se em abrir uma subscrição colonial, espécie de contribuição que deveria ser depositada mensalmente no Banco do Brasil ${ }^{105}$, enquanto que, patrocinados pelo cônsul e com o apoio das demais associações e do EDE para divulgação, vasto programa foi proposto pela Comissão para o levantamento de fundos.

Há indicativos de que pretendiam construir uma sede para a CDE, evidenciada pela existência de uma "comissão organizadora das obras", a qual passa a organizar eventos, como tômbolas pela loteria federal ${ }^{106}$ e promover espetáculos para exibição de artistas espanhóis especialmente convidados. Em setembro de 1918, exibia-se no Teatro São José, em benefício da CDE, a Cia. Salvat-Olona, de Manuel Salvat e Concepción Olona. Na lateral do anúncio da divulgação do evento - ocasião em que a empresa de tranvias, a pedido da comissão, se comprometia a operar um serviço especial de carruagens - uma nota destacava a doação de Eduardo Garcia Millán “reputado industrial há muito estabelecido em São Paulo" que se oferecia para mobiliar um dos salões da futura agremiação ${ }^{107}$. Alguns empresários facilitaram a ida de seus empregados à apresentação "que causou grande ansiedade no Brás", adquirindo os convites e os distribuindo, caso de Pascual Gómez, proprietário de Agência de Passagens à Rua Boa Vista, 58 (matriz em Santos) ${ }^{108}$.

${ }^{103}$ EDE 05.09.1918.

${ }^{104}$ EDE 18.10.1919.

${ }^{105}$ EDE 16.08.1918.

${ }^{106}$ EDE 12.11.1919. Os prêmios eram: mil pesetas para o primeiro prêmio; escopeta Búfalo, calibre 12; cofre guarda-jóias; cigarreira damasquinada; carteira de senhora; porta-retrato; punhal de Toledo; bomboniere; relógio; pistola de Eibar; relógio de pulseira; pendentif de senhora; prendedor de gravata; lápis. Todos os objetos, fabricados em Eibar (ou Elbar) e Toledo, levavam “incrustações de ouro e são de alto valor artístico”.

${ }^{107}$ EDE 20.09.1918. Trad. da autora.

${ }^{108}$ A Empresa Pascual Gómez \& Cia. (agentes marítimos e despachantes de aduana), com importação de gêneros nacionais e estrangeiros já era anunciante do EDE desde 1913. Seus escritórios ficavam na Praça da República, $1-1^{\circ}$ andar. EDE 31.07.1913. Trad. da autora. 
Ainda a princípios de 1922, em reunião na sede da CDE sob a presidência do vicecônsul, Sr. Pedro Lopez e à qual compareceram representantes da maioria das agremiações ${ }^{109}$ exceto Aparício Marti (CE) e Antonio Dias (LTE) -, Juan Gutierrez, da SESM, fazendo uso da palavra, insistia na conveniência da fusão da CDE com a SESM, sendo imediatamente rebatido pelo vice-cônsul e demais membros da comissão, que determinaram pela suspensão do assunto até a próxima reunião. Juan Gutierrez era antigo sócio da SESM, a qual já presidira, de 1904 a $1906^{110}$. Desconhecemos o que ocorreria à CDE daí por diante, porém é certo que, até então, a única fusão concreta ocorrera entre a BE e a SESM, em 1919.

Sentimentos regionalistas latentes nutriam-se de notícias separatistas que circulavam na imprensa espanhola e eram reproduzidas no EDE. No mesmo ano de 1918, a par das iniciativas de arregimentação para a fundação da $\mathrm{CDE}$, os ânimos eram acirrados com matérias estampadas, cujo título - "Los regionalistas gallegos y catalanes" $" 111$ - punham em relevo uma questão que pairava acima dos mais eloqüentes e altruístas interesses comuns. Nessa ocasião, em particular, comemorava-se a Semana Galega em Barcelona, em cujo banquete, oferecido pelos anfitriões, manifestaram-se vários representantes das duas regiões em "favor do restabelecimento da nacionalidade ibérica, permitindo a cada região desenvolver-se livremente", concluindo, quanto à Galícia que "os trabalhos de propaganda em favor da idéia regionalista realizados nas províncias do norte encontram-se bastante adiantados".

Na cidade de São Paulo, por essa época já funcionava o Centro União Catalã (CUC) que, originalmente denominado de Centro Artístico Catalão em Gay Saber, teria sido criado em 1917, a considerar a festa em comemoração do quinto aniversário, anunciada em 1922, a realizar-se no "Salão Lyra"112.

Com sede à Rua do Carmo, a agremiação "conseguiu fundar um coro ao estilo do célebre orfeão catalão, de Barcelona" e mantinha "um quadro dramático"113 que, nas festas $\operatorname{programadas}^{114}$ aos associados " $y$ familia" ${ }^{115}$, realizava apresentações teatrais coroadas pela realização do baile familiar ${ }^{116}$. O programa completo desses eventos, divulgado pelo $\mathrm{EDE}^{117}$,

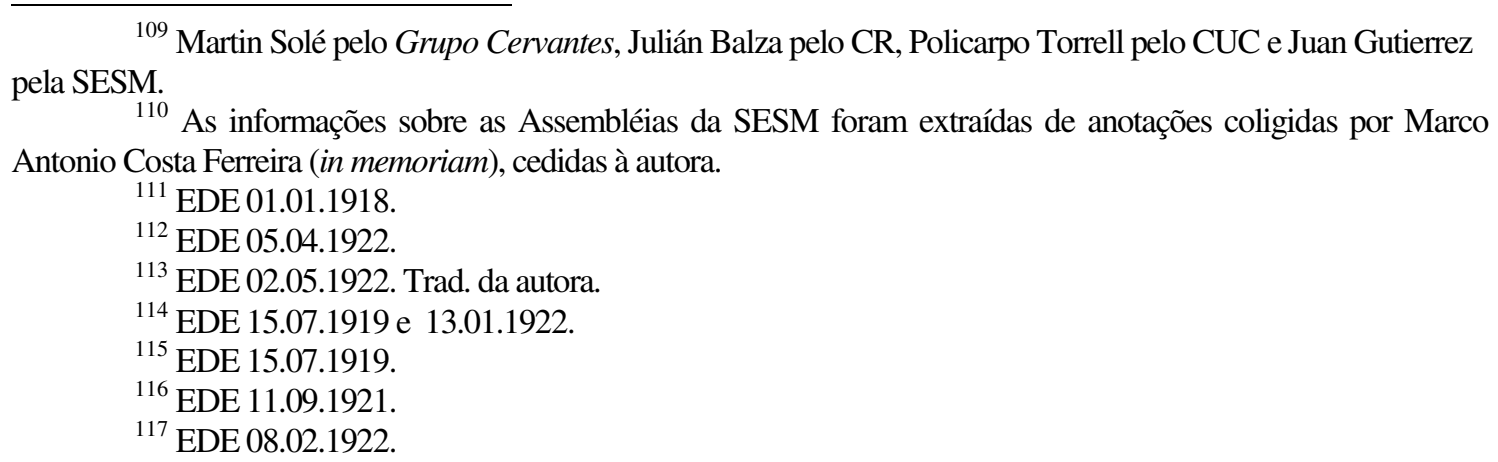
pela SESM.

${ }^{109}$ Martin Solé pelo Grupo Cervantes, Julián Balza pelo CR, Policarpo Torrell pelo CUC e Juan Gutierrez

${ }^{110}$ As informações sobre as Assembléias da SESM foram extraídas de anotações coligidas por Marco Antonio Costa Ferreira (in memoriam), cedidas à autora.

${ }^{111}$ EDE 01.01.1918.

${ }^{112}$ EDE 05.04.1922.

${ }^{113}$ EDE 02.05.1922. Trad. da autora.

${ }^{114}$ EDE 15.07.1919 e 13.01.1922.

${ }^{115}$ EDE 15.07.1919.

${ }^{116}$ EDE 11.09.1921.

${ }^{117}$ EDE 08.02.1922. 
se compunha de uma "Sinfonia", com orquestra; um "episódio dramático em um ato, em verso - versão castelhana, original de Eduardo Jackson Cortez "Filho por filho"; a exibição de uma comédia em um ato, em prosa, original de José Asmarats "A ca la modista" [segue-se o elenco], para, finalmente, dar-se início ao grandioso baile.

De qualquer modo e retornando à SESM, não percebemos no período qualquer outro evento ou iniciativa que tenha tido maior repercussão na colônia, em termos de adesão e participação, do que a Festa da Romería Campestre, programada para levantar fundos em benefício da sede própria da SESM. Herança da tradicional e remota festa popular que nos pueblos se traduz pela viagem ou peregrinação a algum santuário, em devoção a algum santo, esse legado que ainda se conserva, é celebrado anualmente em muitas localidades da Andaluzia.

Congregando indivíduos pertencentes a distintas agremiações, tanto da Capital quanto do interior, atraindo diferentes sociedades ${ }^{118}$ que dela participaram, sua primeira edição, ocorrida a 15 de agosto de 1920, contou com enorme participação popular, considerando-se que, até meados de julho ${ }^{119}$, já haviam sido vendidos 7.000 ingressos na Capital e no interior, número que atingiria 20.000, somente de espanhóis, e mais 10.000 de não espanhóis, contabilizados até o dia do evento $^{120}$. A lista de doações e brindes, além de dinheiro, enviados para os sorteios, barraquinhas, gincanas e brincadeiras programadas, foi relevante. À Comissão Organizadora foi preciso imaginação para ordenar as mais inusitadas ofertas, dentre as quais constava o extravagante recebimento de um lobo vivo, medindo $1,15 \mathrm{~m}$. de comprimento, trazido por um colono espanhol do interior.

Com intensa cobertura pelo EDE, informava-se aos interessados em "alquillar puestos para ventas" para que fossem ter diretamente com o Presidente da Comissão de Festas, D. Lucas Tabuenca, na Rua das Flores, 68, “de 1 a 2 de la tarde, o de 8 a 9 de la noche”, provável indicação de que se observava o horário da siesta, período de descanso após o almoço, típico da Espanha. O variado programa dos festejos previa "gaitas, bandas de música, bailes al estilo español, fuegos artificiales, paseos de barco por el lago y rio, subasta de prendas y foot-ball', este um dos eventos mais aguardados, e cujo embate se daria entre Corinthians e MackenziePortuguesa. Nesse sentido, parece evidenciar-se uma preferência dos espanhóis no período, a torcida pelo Corinthians, indicativo reiterado pelo Sr. Amadeu, em seu testemunho a Ecléa Bosi, segundo o qual "no Corinthians estava a massa: os pretos e os espanhóis"121.

\footnotetext{
${ }^{118}$ Da primeira edição participaram o CUC, o CE e a CRE.

${ }^{119}$ EDE 14.07.1920.

${ }^{120}$ EDE 25.08.1920.

121 “Lembranças do Sr. Amadeu”. In: BOSI, Ecléa. Op. cit., p. 89.
} 
Sua programação, prevista para iniciar às $7 \mathrm{~h}$ da manhã era aberta por uma banda de música dirigida pelo maestro Mascagni, que percorreria a cidade anunciando a festa. Às $8 \mathrm{~h}$ tranvias especiais partiriam do Largo da Sé, com a "comissão de senhoritas" e outra banda de música, diretamente para o Parque São Jorge, local de sua realização. Das 9 às 16 h, a programação, já no Parque, consistia de corridas de bicicleta em que se disputavam "ricas fitas bordadas à seda e ouro pelas Srtas. Julián, da comissão, filhas do "apreciado industrial Pedro Julián" - então o proprietário do Cine Avenida, na Avenida Rangel Pestana, 111, inaugurado no início da primeira década ${ }^{122}$.

Da programação, constavam ainda: corridas de cavalo; pau de sebo ou cucaña, com um disputadíssimo jamón como prêmio; corridas de saco e finalizando, jogo "amistoso" de futebol entre os quadros da FE e do Sírio, em disputa de uma "artística taça gravada".

Nos intervalos da programação, estavam previstas apresentações de grupos folclóricos regionais como o do Centro União Catalã, com a apresentação de sardanas, dança em coro tradicional da Catalunha; sevillanas, tocadas em guitarra, cantadas e dançadas; rondalla e gaita galega, com seus respectivos grupos de baile. A propósito, um grupo de entusiastas Filhos de Galícia, havia contratado o conjunto de gaita do professor José Vázquez Barredo; Jota, baile popular de Aragão e um grupo de Rondalla aragonesa que, informava o EDE, vinha efetuando ensaios de música da região pirenaica. Também se apresentariam músicas e coplas em acompanhamento à dança, entoadas pelo "famoso cantante" El Andorrano. Além disso, estavam confirmadas três bandas de música, rondalla de panderetas e bandurrías (instrumento musical semelhante à guitarra, porém menor e com 12 cordas), apresentação de guitarras e quartetos de gaita, além da exibição de Francisco Sanchez Muñoz, o niño de Alcalá, "famoso cantor, profundo conhecedor da música regional andaluza”, presença já confirmada. Extraoficialmente informava a matéria, diversos empregados da Cia. Paulista acabavam de aderir à festa.

Barraquinhas e quiosques ao ar livre já tinham sua participação garantida pela organização e não faltariam "bebidas, comidas, churros, buñuelos, dulces, bombones, café, chocolate Lacta e cigarros Castellões". Pedia-se às senhoras e senhoritas que comparecessem à quermesse vestidas de mantilhas e trajes típicos das regiões espanholas.

Analisando as manifestações sobre o êxito do empreendimento que teria redundado em sucesso de público, Lopez Campillo lamentava, como não podia deixar de ser, apenas não tê-lo realizado antes, "por causa da guerra", mas também porque, concluía, alfinetando, "la colonia

${ }^{122}$ EDE 03.01.1913. Trad. da autora. 
española no estuviera preparada para celebrarla, sea porque las sociedades españoles estuviesen un tanto divorciadas unas de otras"123.

O resultado da primeira Romería, apesar de estrondoso, não logrou arrecadar quantia suficiente para a quitação do imóvel adquirido pela SESM, razão que o motivara. Programou-se então a reedição do evento para maio do ano seguinte, 1921. Algumas novidades foram introduzidas, então. A festa realizar-se-ia no mesmo local, o Parque São Jorge, porém teria a duração de três dias, de sexta-feira a domingo. Iniciaria às 7 h da manhã com o disparo de 21 tiros de canhão. Paralelamente, numerosas bandas percorreriam as principais ruas do Brás, tocando variado repertório de música regional e às 9h sairiam da sede social da SESM, no Largo da Sé, vários tranvias especiais, com a comissão de senhoras, um quinteto de gaita e uma banda de música, em todos os dias do evento. Corridas de bicicleta; conjuntos de música regional exibindo-se nos tablados instalados; jogos de futebol com o time da FE e um time convidado, desta feita disputando a taça "Socorros Mútuos"; barracas de comidas, bebidas e refrescos, a programação da Romería seguia o modelo do ano anterior, agora presidida por Lucas Tabuenca, proprietário da Fábrica de Calçados Royal, na Rua do Gasômetro, $71^{124}$.

Apesar da reedição da Romería, cuja arrecadação foi destinada ao ativo da SESM, prosseguiram os "chamamentos patrióticos e humanitários à colônia espanhola" pelo EDE, apelando aos conterrâneos, através de vasta exposição de motivos, para a mobilização na ajuda à manutenção da sociedade e ao bom andamento dos serviços que vinha prestando aos sócios (e "não sócios", informa o registro), sobretudo nas questões relacionadas à saúde e repatriação dos “inúteis para o trabalho, crianças, velhos, etc.”. Isto posto, a SESM emitiria uma série de bônus, no valor de 10.000 réis cada que "com a quantia arrecadada nas Romerías e festas anuais" deixaria "a sociedade livre do compromisso da aquisição das casas da Rua das Flores, onde pretende se instalar" ${ }^{, 25}$. A crise financeira continuava. Neste mesmo ano de 1921, meses mais tarde, nova chamada, nova emissão de bônus para empréstimo à SESM, agora com garantia das casas recém-adquiridas e com juros de $6 \%$ ao ano que seriam amortizados por sorteios realizados de seis em seis meses ${ }^{126}$.

A questão deve ter repercutido satisfatoriamente porque, nos inícios de 1922, a comissão executiva da SESM publicaria o resultado do sorteio dos primeiros 100 bônus do “empréstimo patriótico", cujos beneficiários deveriam apresentá-los para cobrança ${ }^{127}$. Porém,

\footnotetext{
${ }^{123}$ EDE 20.08.1920.

${ }^{124}$ EDE 02.05.1922. Trad. da autora.

${ }^{125}$ EDE 30.06.1921. Trad. da autora.

${ }^{126}$ EDE 12.10.1921.

${ }^{127}$ EDE 03.02.1922.
} 
em paralelo, a diretoria agendava uma reunião na sede da CVE sob a presidência do vice-cônsul Pedro López e na ocasião, na presença das demais entidades, seu delegado, Juan Gutierrez, após larga exposição, manifestava novamente a conveniência de uma fusão da SESM com a CDE, idéia que, como já vimos, foi rejeitada até mesmo pelo presidente daquela entidade a qual, até onde os registros permitem entrever, fora criada exatamente com esse propósito ${ }^{128}$. A questão central, imaginamos, talvez estivesse no rombo das contas da SESM que, em que pese todas as iniciativas, continuavam em desequilíbrio, tanto é fato que já se programava, no Teatro Santana, um grande espetáculo em seu benefício ${ }^{129}$. Nesse período, a meados de 1922, Juan Rivero, que perdera toda a família (mulher, quatro filhos, um neto e um sobrinho) na gripe espanhola e era o proprietário da Fábrica de Calçados Bebe, estabelecida na Rua do Gasômetro, 110 e 112 , era o seu Presidente ${ }^{130}$.

${ }^{128} \mathrm{EDE}$ 08.02.1922.

${ }^{129}$ EDE 08.02.1922. Com a apresentação da Companhia Aura Abranches, com a "finíssima comédia em três atos" de Gregório Martinez Sierra "Sonho de uma noite de agosto", terminado o qual haveria a apresentação de um ato de variedades, constituído pelos seguintes números: "Egípcia", cantos e danças espanholas; "Sara e Ivone", bailes clássicos a rigor; "Tonadillera", canção popular espanhola e a apresentação de Mr. Humberto e sua troupe canina. Preços: frisas e camarotes: $36 \$$; Balcão: $8 \$ 500$; Platéia: $6 \$ 500$ e Geral: $2 \$ 300$.

${ }^{130}$ EDE 25.05.1922. 


\subsection{A Federação Espanhola (FE)}

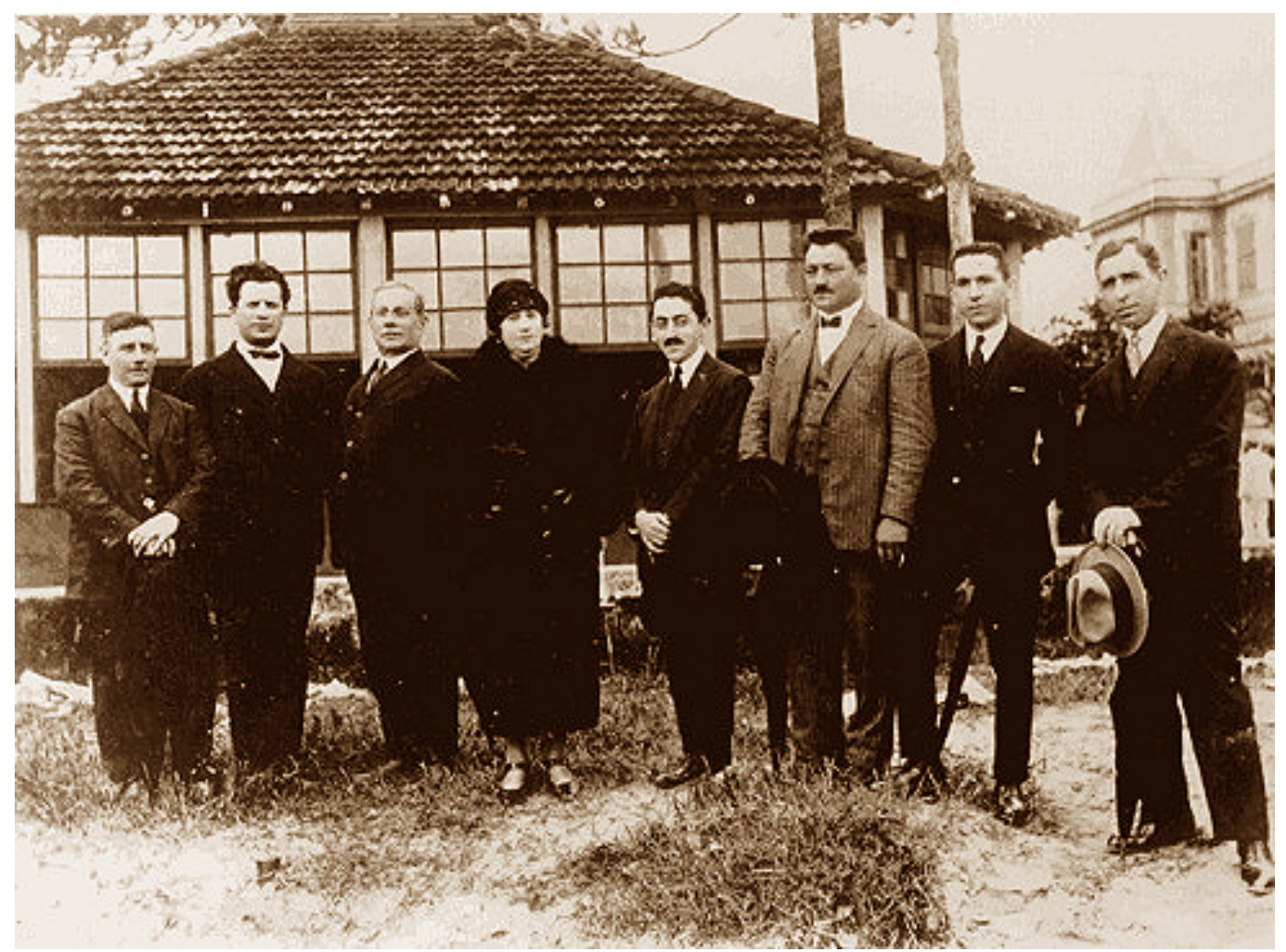

Fig. 14. Grupo lírico-dramático da Federação Espanhola. Excursão a Santos, SP, s.d.

A FE, fundada a 12 de fevereiro de 1912 teve, portanto, uma existência paralela a da SESM. Instalada na Rua do Gasômetro, 42-A (sobrado), apareceria dias depois pela primeira vez no $\mathrm{EDE}^{131}$, em convocação aos espanhóis para que nela ingressassem como associados. Teófilo Saenz Mugarza, seu presidente interino, era natural de Navarra, e estivera pouco antes no CGE, em 1911, onde se declarara vidriero ${ }^{132}$. Residente na Água Branca, para onde se cogitou instalar uma seção da FE em 1913, tudo indica que Mugarza fosse empregado da Santa Marina, a única vidraria então existente naquele local ${ }^{133}$. Por sua iniciativa, os interessados residentes no Brás poderiam encaminhar-se a Pablo Cornadó que se oferecera para o cadastramento das adesões. Estabelecida na Avenida Rangel Pestana, 109-B, a Livraria Española ${ }^{134}$ de Cornadó, sofreria por parte dos Correios uma "apreensão sem causa justificada"

\footnotetext{
${ }^{131}$ EDE 15.02.1912.

${ }^{132}$ EDE 24.07.1912. Rubrica que se alterou para $p$. industrial no registro realizado em 1920.

${ }^{133}$ EDE 28.11.1913. A Assembléia para o encaminhamento da proposta se realizaria na Rua Sertão, 2.

${ }^{134}$ EDE 15.02 e 11.04 .1912$.
} 
de pacotes contendo revistas espanholas que importava, razão pela qual se desculpava com os $\operatorname{assinantes}^{135}$.

A FE breve se destacaria por iniciativas de caráter cultural: em outubro de 1913, seus dirigentes enviam convite a Eiras Garcia para o ato inaugural de instalação de uma escola noturna, em língua espanhola ${ }^{136}$, que passaria a funcionar no mês seguinte, em cuja inauguração compareceria o cônsul e demais autoridades representativas das entidades espanholas. Já então seu Presidente mudara: era Luis Sánchez, assessorado por Hermino Poveda, no cargo de secretário.

É curioso que a FE tenha convidado Eiras para as festividades de instalação desta escola. Havia entre eles um estremecimento declarado, em virtude da subvenção que o EDE recebera do governo do Estado de São Paulo, não concedido ao LTE, “órgão da FE”, de acordo com o memorando expedido pelo cônsul ao Ministro de Estado espanhol relatando a tensão existente entre os dois periódicos ${ }^{137}$. A FE vinha reclamando ao cônsul das dificuldades em conseguir associados no interior - cuja carteira reduzia-se a apenas 400 ou 500 obreros atribuindo esse fato ao EDE. "Os comerciantes, os industriais e os de posição independente se retraem”, reproduzia na missiva oficial o cônsul Juan Solórzano, as queixas da FE. O cônsul ia mais longe em seu relato, notificando à autoridade espanhola das "dissensões que existiam e ainda existem (...) entre os membros dessa numerosa colônia”. Não obstante, há indícios de que os estranhamentos vinham paulatinamente se atenuando, pelo menos formalmente, entre a FE e Eiras (ou o EDE/SESM) pois em setembro, pouco mais de um mês antes do convite, o EDE divulgaria uma mensagem recebida "pelo correio" enviada pelo presidente e pelo secretário da FE solidarizando-se com a campanha que o jornal vinha realizando contra as arbitrariedades da polícia no caso, já mencionado, da deportação de Picón ${ }^{138}$. Não foi possível rastrear como teria permanecido, neste momento, as relações do EDE com o outro periódico, o LTE, porém, quernos parecer que entre Eiras e a autoridade consular, especificamente falando do cônsul Juan Solórzano, elas definitivamente se azedariam, haja vista a denúncia que Eiras levaria a efeito a respeito das vendas de passagens para os repatriados, que redundaria na sua retirada do país ${ }^{139}$. Contudo, pelo menos no tangente à questão da atuação da polícia, um dado circunstancial evidenciaria o consenso entre Eiras e a autoridade diplomática. Em um registro do CGE de

${ }^{135}$ EDE 12.08.1913. Trad. da autora.

${ }^{136}$ EDE 31.10.1913. Antes desta, a única indicação da abertura ou funcionamento de uma escola que obtivemos foi a do Liceo Español, fundado em 1903, com sede na Rua do Gasômetro, 54. Cf. RODRIGUES, Edgar. O anarquismo na escola, no teatro e na poesia. Rio de Janeiro: Edições Achiamé Ltda., s/d, p. 142 e ss e 231.

${ }^{137}$ AGA. Caja 1691. Memorando de 08.04.1913.

${ }^{138}$ EDE 28.09.1913.

${ }^{139}$ EDE 04.07.1914. 
1915, do malaguenho Salvador Murcayo, de 40 anos, residente na Rua Silvio, 40, a seguinte anotação foi feita no alto da página: "não fornecer cédula, porque é policial"140.

Os conflitos e rusgas entre os diretores do periódico LTE e a SESM já vinham de longa data, esta os acusando de soltar notas desabonadoras a seu respeito em suas folhas, e insinuando que todos conheciam "los móviles de aquel periódico". Seria Eiras Garcia?

Mas, voltemos à inauguração da escola da FE. Há indicativos, pelos discursos que analisamos, de que se tratava de uma escola para adultos e de que suas aulas eram orientadas à alfabetização. Na ocasião, diversas contribuições mensais, para sua implementação, foram formalizadas, tanto por parte do EDE (20\$000), quanto do CGE (50\$000). Particulares presentes também participaram da subscrição ${ }^{141}$. No ano seguinte, contudo, o lançamento de um edital para professor espanhol de "instrução primária" para uma escola diurna indica a sua ampliação. Esse professor receberia a remuneração de $1 \$ 500$ por aluno, até o limite de $100 \$ 000$ mensais.

Somente em $1914^{142}$ é que foram publicados seus estatutos. Divulgados na íntegra no EDE, compuseram-se de 7 capítulos e 35 artigos desmembrados em diversos itens. É provável que se pretendesse com a sua promulgação uma correção de rumo, aquietando os ânimos de alguns afiliados que há menos de um ano - em protesto à "lei federal de expulsão de estrangeiros" editada em virtude das "últimas greves em Santos"- tinham a intenção de organizar um grande "mitin de protesto", cujo manifesto, tendo como signatários os sócios da FE, saiu publicado no $\mathrm{LTE}^{143}$.

Seu lema era “Respeta y hazte respetar”. Profilático, determinava no primeiro capítulo: "esta sociedad no tiene carácter político ni religioso, prohibiéndose terminantemente dentro del local social las discusiones que atañan a esos puntos (...)”. Coerente com essa propositura, em 1914, em matéria publicada no EDE sob o título "No quieren pasar por anarquistas", alguns dirigentes vieram a público para repudiar o recebimento de exemplares da revista A Rebelião, por entenderem ser a mesma de orientação anarquista ${ }^{144}$.

Em seus postulados estatutários privilegiavam-se temas como a "defesa dos direitos dos espanhóis em qualquer circunstância em que se sintam lesados"; o "auxílio financeiro", quando necessário; o "nível intelectual de seus associados" (a criação da escola noturna, primeira iniciativa já se adiantara a este objetivo) e a criação de um "albergue noturno onde pudessem

\footnotetext{
${ }^{140}$ LRC 1915. Trad. da autora.

${ }^{141}$ EDE 07.11.1913.

${ }^{142}$ EDE 18.03.1914.

${ }^{143}$ AGA. Caja 1691. Memorando de 08.04.1913 do cônsul ao Ministro de Estado espanhol.

${ }^{144}$ EDE 05.05.1914.
} 
pernoitar os espanhóis sem recursos e que não estivessem embriagados, por 15 dias, no máximo" ${ }^{\text {"145. }}$

Quanto à escola de "instrução primária”, há indícios de que tenha se mantido durante 7 anos, de 1914 a 1922, ocasião em que seus dirigentes, lamentando seu encerramento, comentavam que seu desaparecimento poderia "transformar-se em obstáculo à propagação do idioma espanhol na Capital" e imputavam a responsabilidade à "apatia de nossos compatriotas que, na crença de que não haverão de voltar a nossa querida Espanha preferem que seus filhos

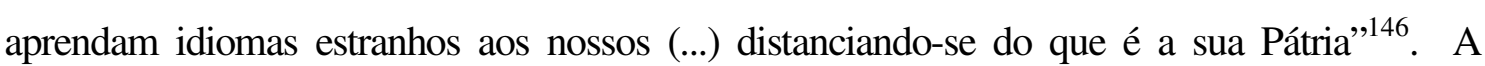
iniciativa da criação de escolas por parte de grupos de imigrantes europeus se dava, segundo Maria Luiza Marcílio, pela insuficiência de escolas públicas e devido ao seu ensino precário, mas também para a manutenção do idioma pátrio, de sua cultura e tradições ${ }^{147}$.

Um corte vertical no ano de 1918 indica que a freqüência à escola pública, gratuita, pelos filhos dos imigrantes representou o dobro da registrada para filhos de pais brasileiros (respectivamente 9.951 e 18.067 alunos), cujos professores relembram os "inúmeros sobrenomes italianos, alemães, espanhóis, sírios e outros, de seus antigos alunos". Contudo, destaca Demartini, referindo-se especialmente ao bairro do Brás, "a clientela de seu grupo escolar era predominantemente de classe média" ${ }^{\text {"48 }}$. Dessa constatação presume-se quão reduzida seria a clientela composta dos filhos das famílias imigrantes, a cuja renda mensal necessitavam somar o salário por eles auferido para o sustento da casa, razão esta que pode estar na raiz da "apatia" aludida pelos dirigentes da FE, por ocasião do encerramento da sua escola primária.

Pelos estatutos, os jovens, mesmo os filhos de espanhóis aqui nascidos, acima de 15 anos poderiam fazer parte da FE. Em 1914, um grupo desses jovens sócios solicitou e obteve permissão da diretoria para promover "bailes familiares" aos finais de semana, em sua sede, das 19 às $22 \mathrm{~h}$.

Pelos dados que pudemos dispor para o período, essa sociedade mantinha intensa atividade cultural e recreativa. Já em $1912^{149}$ se anunciavam em suas páginas as matinês familiares "con las célebres bailarinas españolas Las Bellezas y los simpáticos duetistas Los

${ }^{145}$ EDE 18.03.1914. Itens destacados do Capítulo II do referido Estatuto. Trad. da autora.

${ }^{146}$ EDE 07.05.1922. Trad. da autora.

${ }^{147}$ MARĆ́LIO, M. L. História da Escola. Em São Paulo e no Brasil. São Paulo: IMESP/Instituto Braudel, 2005, pp. 202-204.

${ }^{148}$ DEMARTINI, Zeila de Brito Fabri. "A procura da escrita e da leitura na Primeira República: recolocando questões". In: Cadernos Ceru. São Paulo: série 2, n.9, 1998, p. 70.

${ }^{149}$ EDE 08.01.1912. 
Madrileños". Pouco depois ${ }^{150}$, anunciava-se a presença, na cidade, de três músicos galegos de Pontevedra, tocadores de gaita, clarinete e tamboril, dois deles cegos, e a quem o periódico recomendava para festas em sociedades ou em casas de família.

A música, os músicos e notadamente os artesãos espanhóis tinham crescente prestígio na cidade, a ponto de os fabricantes de instrumentos musicais, em particular os de corda, veicularem nos reclames a presença de "operários especialmente contratados em Valencia" para a fabricação de "guitarras, bandolins e violas", além da importação direta "da Espanha", de "cordas para todos os instrumentos"151.

As festas familiares, "ocasiões de grande relacionamento social" realizavam-se "num clima de camaradagem e grande intimidade". Promovidas para celebrar algum acontecimento de importância particular "reafirmavam as relações de parentesco, de vizinhança e de amizade entre os participantes"152. A presença dos músicos, garantindo a agitação, eram indispensáveis à animação desses bailes e dos "assustados familiares" "153 que ampliavam os contatos sociais e consolidavam os laços familiares e de amizade.

Os eventos festivos eram aguardados com ansiedade. Muito apreciados, permitiam à população, sobretudo das camadas inferiores, fugirem à penosa e fatigante rotina de trabalho, desobrigando-se por algumas horas das tensões cotidianas, transformando-os em animados momentos de compartir a alegria e exorcizar a tristeza. Animar um "choro" ou "assustado" em casa de família era incumbência para a qual os tocadores de instrumento, especialmente "os bambas do violão" eram convidados com antecedência e recebidos pela dona da casa com "um anisete para adoçar a boca”, antes de iniciar o arrasta-pé, iluminado à luz de lampião a querosene e no chão previamente alisado por um "punhado de fubá"154.

Os licores, especialmente aqueles feitos de anis, que resultavam no famoso "anisete" eram também fabricados em casa, pelas mulheres, com receita tradicional. A intensificação do consumo do anisete fomentava o aumento da importação do "anis em grão", diretamente de Valencia, de que se encarregava a firma Hermanos Eiras Garcia $^{155}$ e foi motivo da denúncia do fabricante do produto original e patenteado, de "imitação de marca" que estaria sendo praticada pelos fabricantes do licor Anis del Mono que, segundo aquele, comercializavam o produto com embalagem semelhante ${ }^{156}$, enganando o cliente. O gradual consumo do produto levará à sua

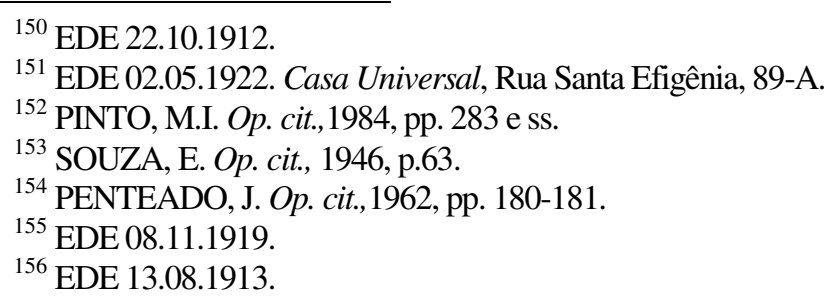


comercialização nos empórios e vendas de bairros, especialmente no Brás, caso da Casa Española de Jacinto Añe Puig, na Avenida Celso Garcia, 381 ${ }^{157}$. O mesmo se dava em restaurantes, que introduziam o comércio de bebidas ${ }^{158}$, ao mesmo tempo em que as importadoras abasteciam o mercado de "anisados" importados diretamente da Espanha ${ }^{159}$.

Aos poucos, porém, os próprios comerciantes espanhóis foram diversificando a oferta de bebidas em seus estabelecimentos, a ponto de Antonio Nieto Cortés - o mesmo que residia na Penha, onde tinha uma finca com gruta em devoção de Nossa Senhora - estabelecerse com o Ingenio Central de Garapa, onde produzia o caldo de cana fresco, servindo-o gelado ou, a critério do cliente, dispunha do "morrão" (cachaça), puro ou com limão ${ }^{160}$.

Nessas ocasiões festivas, em que se ampliava a convivência, reunindo famílias inteiras, adultos, jovens e crianças, cujos pares bailavam indistintamente entre si, a preferência recaía sobre as "músicas quentes" que provocavam "grande movimentação, como as polcas, marchas militares, dobrados, xótis, maxixes e lundús"161.

O hábito de festas em família era cultivado também na camada da colônia socialmente melhor situada. Pudemos observar que, pretextando diversos tipos de comemoração, convidava-se familiares e amigos para festas e reuniões íntimas, preparadas previamente com esmero, e nas quais não podia faltar, além de boa comida e bebida, diversificada programação cultural e de entretenimento. "Vinos de todas clases, cerveza, licores, finas pastas y aromáticos habanas" não faltaram à festa oferecida em comemoração ao batizado realizado na Matriz do Bráz em que Lopez Campillo, o mentor intelectual da Romería, fora padrinho. Terminada a cerimônia religiosa, os convidados, "em elegantes automóveis" foram conduzidos à residência do Sr. Capucci (italiano?), o anfitrião, onde participaram de "alegre e animadíssima festa"162.

Aos poucos, o hábito de se preparar uma festa desse padrão em casa revelou-se muito trabalhoso e, percebendo aí uma oportunidade, um nicho de mercado regular e de bom poder aquisitivo, alguns comerciantes passaram a fornecer sob encomenda não apenas os "bebes", mas também os "comes", serviço ao qual se especializara a confeitaria de Manuel Boz \&

${ }^{157}$ EDE 05.11.1913.

${ }^{158}$ EDE 29.10.1913. Restaurante de José Montero e Ana Pino. Avenida Rangel Pestana, 64.

159 EDE 02.05.1922. Casa Raimundo Diez, Le Voci \& Cia. Importadores e Exportadores, Comissões, Consignações e Conta Própria.

${ }^{160}$ EDE 08.08.1922.

${ }_{161}$ PINTO, M.I. Op. cit., p. 287.

${ }^{162}$ EDE 26.02.1914. Trad. da autora. 
Hermano, da Rua Oriente, 67, passando a encarregar-se "do serviço de bodas, batismos e festas comemorativas"

Perfecto Ares também recebia com freqüência em seu Palacete, para comemorações as mais diversas, em animados saraus musicais. Contratava-se para a ocasião músicos destacados e reconhecidos na sociedade: Oscar Pery ao violino e sua mãe Otília, ao piano, com seleção musical de clássicos - Bizet, Puccini, Verdi -enobreciam as festas na residência de D. Perfecto Ares ${ }^{164}$. Para abrilhantar tais festas, havia uma opção a mais, o gramofone, invento já comercializado da cidade ${ }^{165}$ que encantava e provocava admiração.

Para comemorar o retorno de uma viagem à Espanha, D. Antonio Nieto Cortés Ruano, proprietário de uma finca no bairro da Penha, ofereceu uma recepção "a que concorreram pessoas da elite da capital". A festa iniciada às $9 \mathrm{~h}$ da manhã com missa solene na "esplêndida capela" que construíra na gruta dedicada a Nossa Senhora de Lourdes, prolongou-se por todo o dia com fogos de artifício "em diversas horas" e bandas de música. Às 5 h da tarde uma procissão de "extenso percurso fora da gruta" dava por encerrado o dia festivo ${ }^{166}$.

Festejando o "dia do seu santo", D. Rosa de Llaverías, esposa de Juan Llaverías, proprietário de fábrica e loja de móveis, abria regularmente sua casa "para suas numerosas relações de amizade" $"$. A comemoração em homenagem ao "patrono da Espanha" Santiago Apóstolo era ensejo para festas que se realizavam, com regularidade no mês de julho, sob a batuta do CG (leia-se Perfecto Ares) ${ }^{168}$.

$\mathrm{Na} \mathrm{FE}$, as festas ou veladas ${ }^{169}$ mensais eram ansiosamente aguardadas. A programação, divulgada com antecedência nas páginas do EDE, transcorria com a apresentação de diversas peças teatrais, até três na mesma ocasião, mesclando os gêneros comédia e drama, a que se seguia o baile familiar. "Naquele tempo havia muitos bailes familiares e, praticamente, íamos todos os sábados na FE, onde revíamos amigos de nossa terra”, atesta D. Florentina Robles Castanho, espanhola nascida em 1897 - aposentada como operária de uma indústria têxtil, depois de 30 anos de serviço ${ }^{170}$.

${ }^{163}$ EDE 21.03.1914. Trad. da autora.

${ }^{164}$ EDE 09.01.1918.

${ }^{165}$ Em grande anúncio, a Casa Laurito, localizada na Rua XV de novembro, 29, divulgava, a princípios de 1912, grande variedade de discos e gramofones. EDE 08.01.1912.

${ }^{166}$ EDE 26.02.1920. Trad. da autora.

${ }^{167}$ EDE 06.09.1921. Trad. da autora.

${ }^{168}$ EDE 31.07.1913 e 26.07.1919, por exemplo.

${ }^{169}$ Velada, expressão comumente utilizada no periódico, significa festa ou espetáculo noturno.

${ }^{170}$ In: A Reconstituição da Memória Estatística da Grande São Paulo, op. cit., v. 2, p. 143. 
Comentando acerca desses bailes, Maria Inez Pinto revela a série de normas de conduta que ditavam o comportamento de seus freqüentadores, aos quais os dirigentes faziam cumprir um código de costumes que não depusesse o bom nome de suas associações "incentivando as boas maneiras, o comedimento, a sobriedade e o senso de cortesia", não permitindo brigas, pileques, gracejos e nem achegamentos apaixonados em seu interior, tentando exorcizar a má fama que acompanhava alguns salões de baile públicos, os chamados "freges", de péssima reputação dado ao comportamento licencioso dos freqüentadores ${ }^{171}$. Jacó Penteado enumera os ritmos costumeiramente dançados: "tango, rancheira, fox-trot, one-step, two-step, rag-time (...), charleston, habanera e maxixe", estilos mais modernos que foram gradualmente introduzidos no lugar de "chotes, polcas, mazurcas, quadrilha, lanceiros e pás-de-quatre" ${ }^{172}$, destacando o baile, mas também o cinema, o futebol e o teatro de amadores como a diversão da massa da população, nesse período. Consta que nesses "salões" eram "os espanhóis os mais divertidos, primando no trajar: apareciam com chapéu de fandanguistas e coletes de veludo transpassados, curtos na cintura, faixas largas de cetim”, relembra Zélia Gattai ${ }^{173}$.

Referindo-se especificamente aos bailes de carnaval que ocorriam no Brás nas primeiras décadas do Novecentos, Olga Von Simson destacou que, para aqueles que se realizavam na FE, eram enviados convites exclusivamente para os sócios, permitindo-se, no máximo, o comparecimento de parentes e amigos ${ }^{174}$.

Em inícios de 1918, a FE já possuía um grupo dramático que se apresentava regularmente $^{175}$, a provável origem da agremiação artística Círculo Dramático Recreativo Isaac Peral (ou Sociedade Artística, como também aparece), criada em maio de $1918^{176}$, que se constituiu num dos mais famosos grupos teatrais amadores existentes na cidade, nas primeiras décadas ${ }^{177}$.

Outro grande evento comemorativo e de extensa e variada programação era a Fiesta de la raza, tradicional celebração nacional em comemoração ao descobrimento da América, que adquirira, depois da guerra, forte sentimento nacionalista. A considerar o programa oficial "do grandioso festival" realizado em 1920, antecipadamente divulgado no EDE, a abertura

${ }^{171}$ PINTO, M.I. Op. cit., 1984, pp. 288-292.

${ }^{172}$ PENTEADO, Jacob. Op. cit., 1963. pp. 47-48.

${ }^{173}$ GATTAI, Zélia. Anarquistas, graças a Deus. $11^{\text {a }}$ ed., Rio de Janeiro; Record, 1980. Fandango: música, dança e cantos espanhóis de origem árabe, em compasso ternário, acompanhados de guitarra ibérica e castanholas.

${ }^{174}$ SIMSON, O. Op. cit., 1989, p. 31.

${ }^{175}$ EDE 09.01.1918.

${ }^{176}$ EDE 24.05.1918. O Círculo Dramático Recreativo Isaac Peral, fundado a 01.05.1918, homenageava o famoso engenheiro elétrico Isaac Peral y Caballero, falecido em 1895, responsável pela criação de inúmeros projetos e inventos, dentre os quais o de um submarino com propulsão elétrica que, segundo consta, foi desautorizado pela marinha espanhola.

${ }^{177}$ Cf. GALVÃO, M. Op. cit., p. 30. 
aconteceria com a apresentação da "Marcha Real Espanhola" tocada por uma orquestra, exibição a que se sucederia uma conferência com o "orador oficial, Don Antonio Diaz" - o mesmo que participara da criação da Liga Española de Defensa Mutua -, seguido de um número de poesia com Don Antonio Lopez; de um monólogo (El pescador), pela Srta. Rosa Veronês e da apresentação, pelo grupo dramático da FE, da comédia em dois atos El padrón municipal para, finalmente, acontecer o grande e aguardado baile, com a banda La Internacional $^{178}$.

Sua realização, com os anos, não sem razão, passou a ser identificada com elementos alinhados ao regime monárquico, atribuída a simpatizantes do franquismo, fato que aprofundará ainda mais as divergências entre esses e os republicanos, identificados como seguidores de ideologias de esquerda (comunistas, socialistas ou anarquistas).

Os programas podiam sofrer alguma variação de conteúdo, dispensando a "conferência", se fosse o caso - dificilmente o baile que era o apogeu da festa, estendendo-se muitas vezes até a madrugada. No anúncio da festa de aniversário da FE, também em $1920{ }^{179}$, após a apresentação do "Monólogo Dramático", apresentou-se o conjunto musical Las Hermanas Fernandez, exibição a que se seguiu a conferência, para em seguida apresentar-se o tenor Pedro Forgas com repertório em "português, italiano e espanhol", culminando com o baile.

Tudo era motivo para a realização dos bailes: por ocasião do anúncio de um "grande festival" em benefício da reparação "do palco cênico", à apresentação do drama em cinco atos $O$ conde de Montecristo, de Dumas, seguiu-se a realização do baile familiar. Relembrava D. María Martín, em seu testemunho ${ }^{180}$, da ocorrência de uma "fiesta de la flor", em benefício de "los hambrientos del Cearâ". Como neste caso, a atuação da FE teria sido efetiva em diversas outras ocasiões e em favor de diversas causas, especialmente sob o impacto da gripe espanhola $^{181}$.

Atribuía-se a Lopez Campillo, seu presidente, outros méritos mais, como o de ter "eliminado" da FE “os elementos antiespanholistas" - leia-se republicanos, identificados como antimonarquistas; de esquerda; comunistas; socialistas ou anarquistas - além de tê-la livrado das "enormes dívidas" que herdara das gestões anteriores, de ter organizado o seu time de futebol -

\footnotetext{
${ }^{178}$ EDE 04.10.1920.

${ }^{179}$ EDE 16.12.1920. Trad. da autora.

${ }^{180}$ Concedido a ANTONACCI, M. Op. cit., 2002, p 30.

${ }^{181}$ EDE 07.05.1922.
} 
consta que o time da FE participava inclusive de campeonatos ${ }^{182}$ - e de que, em seu mandato a FE teria atingido 700 sócios.

A Festa em comemoração ao Día de la Raza, também se contabilizava como iniciativa de sua gestão, cujo evento recebia toda a divulgação do EDE que cobria em detalhes a programação realizada nas diversas regiões espanholas ${ }^{183}$.

Outra data comemorativa era o Dois de Maio ${ }^{184}$. Numa dessas ocasiões, o EDE (Eiras Garcia), após a publicação da programação, manifestava-se em nota ${ }^{185}$, lamentando a ausência do convite para que comparecesse às festas que se realizariam em homenagem à data, tanto da FE quanto a do Grupo Dramático Cervantes.

A finais da segunda década Lopez Campillo transformara-se em ardoroso defensor do estreitamento dos laços e de um melhor entendimento entre os dirigentes das distintas associações, não tendo medido esforços para a fundação da Casa de Espanha, da mesma forma que se empenhara para a realização da primeira Romería, cujos resultados seriam aplicados na quitação dos imóveis adquiridos pela SESM. Também é de sua responsabilidade a abertura, em 1918, de uma "Agência de Colocações", serviço gratuito destinado à oferta de postos de trabalho, ao qual recorriam não apenas os desempregados, mas também os "industriais, fabricantes ou fazendeiros" ${ }^{\text {"186 }}$ que necessitassem de mão-de-obra.

A Cruz Roja Española (CRE), segundo consta também nasceu "nos salões da Federação”. Há indícios de que isto tenha ocorrido no ano de 1917, a considerar um convite enviado pela presidenta de sua Comissão de Damas, D. Elena Melian de Motta, para uma missa solene a realizar-se "en la iglesia del Sagrado Corazón de María, para bendecir la bandera de esta institución, la cual será apadrinada por el interventor oficial, Exmo. Sr. D. Antonio de Motta, cónsul de España en esta capital'. Esposa do cônsul, D. Elena fazia através do convite uma convocação para que todos os espanhóis aderissem à nova agremiação, dirigindo-se à sua secretaria provisória, na Rua do Gasômetro, 49 “donde se informará de todos los requisitos indispensables" ${ }^{\prime 187}$. Em 1918, sob o impacto da gripe espanhola teve atuação marcante ao lado da SESM e da FE no socorro às vítimas, no fornecimento de medicamentos gratuitos aos espanhóis necessitados.

${ }^{182}$ EDE 03.01.1919. O EDE registra um jogo do time da FE com o da Associação Atlética Pró-Vercelli, em 1919.

${ }^{183}$ EDE 04.10.1920. O Día de la Raza era também comemorado em Campinas (cf. EDE 16.11.1920).

${ }^{184}$ A "Dois de Maio" de 1866 a Espanha, em sua empresa imperialista fincou, pela primeira vez, sua bandeira no Pacífico.

${ }^{185}$ EDE 03.05.1921.

${ }^{186}$ EDE 25.07.1918. Trad. da autora.

${ }^{187}$ Convite Original. A missa seria realizada a 03.11.1917. Acervo do CGE. 
No entanto, depois disso, poucas iniciativas foram atribuídas à agremiação (CRE), tanto assim que, em maio de 1922, o EDE comentando sobre seu "flaco desempeño", novamente levantava a bandeira da desunião, alegando estar aí o ponto de estrangulamento responsável pela apatia das entidades: "Hora es ya de que todas las sociedades españolas de São Paulo dejando a parte ciertas rencillas y ciertos antagonismos, propios en asuntos particulares (...) cooperen y trabajen de común acuerdo" pronunciava-se, reclamando a construção da hospedaria ou abrigo "para acoger las familias pobres que vagan mal trapillas por las calles", cujo terreno já estava comprado ${ }^{188}$. Tem-se notícia, depois dessa reprimenda pública, de uma festa de gala ${ }^{189}$, realizada em algum teatro da cidade, porém, até a última edição examinada, nada constou em favor da obra do abrigo.

${ }^{189}$ No EDE 08.09.1922, publicou-se o resultado desta festa patrocinada pelas senhoras da sociedade. 


\subsection{O Centro Espanhol (CE)}

Surpreendentemente, enquanto setores da colônia buscavam equacionar, pela criação da Casa de Espanha, um modo de aglutinar as várias sociedades e agremiações como uma maneira de somar esforços, mais uma associação era criada na cidade, neste mesmo ano de 1918. Tratava-se do Centro Espanhol (CE) ${ }^{190}$, para cuja criação houve a convocação da colônia para, numa reunião, (novamente) "tratar da constituição de uma sociedade de caráter recreativo e cultural que congregasse a todos os espanhóis", a realizar-se no Salão Celso Garcia, na Rua do Carmo. Sua abertura deu-se em dezembro desse mesmo ano ${ }^{191}$, tendo como Presidente o médico José de Asprer, enquanto José Aparício Martí, outro dos fundadores - o mesmo indivíduo que participara com Eiras Garcia da comissão organizadora da SESM - será seu primeiro secretário.

Consta que, inicialmente estabelecidos à Rua do Gasômetro, reuniam as famílias "em tertúlias" aos domingos à tarde ${ }^{192}$ e organizavam festas em homenagem ao patrono da Espanha, Santiago Apóstolo ${ }^{193}$, porém sua atuação, que antecede propriamente ao ato de sua inauguração, extrapolou muito rapidamente o caráter recreativo, em face, provavelmente, das necessidades dos espanhóis imigrados. Assim, em princípios de 1920 já se notava uma mobilização distinta sendo patrocinada pela Seção das Senhoras em Socorro aos Enfermos, as patrocinadoras da Caixa de Socorros que, através da realização de festas de caridade, buscavam arrecadar fundos para o amparo aos necessitados e carentes da colônia, crianças em especial.

Referindo-se a essa sociedade, Galvão - que a citava de passagem contextualizando o modo como Medina, da Rossi-Film, havia conhecido, justamente no CE a Zambrana, espanhol comerciante de tecidos e membro ativo daquele Centro -, afirmava não se tratar de uma "sociedade operária" e que "pelo contrário, era freqüientada pela colônia do mais alto nível"194. Assim é que às festas promovidas pelas senhoras de sociedade compareciam membros prestigiados da colônia e representantes das demais agremiações, cujos nomes eram sistematicamente divulgados no EDE.

Estas denominadas "festas da caridade", realizavam-se aos sábados à noite, por vezes nos salões do Conservatório Dramático-Musical - que passará a funcionar em $1906{ }^{195}$.

\footnotetext{
${ }^{190}$ EDE 06.03.1918. Trad. da autora.

${ }^{191}$ EDE 06.03.1918.

${ }^{192}$ EDE 24.12.1918.

${ }^{193}$ EDE 15.07.1919. A data dessa comemoração é 25 de julho. Santiago Apóstolo é também o patrono da

${ }^{194}$ GALVÃO, M. Op. cit., p. 218.

${ }^{195}$ Cf. BRUNO, E. Op. cit., 1991, p.1288.
} Galícia. 
Reunindo a nata da colônia, transformara-se em local de encontro de nomes como Bobadilla, Zambrana, Lorenzo, Villadangos, etc., mas também de Marti, Ares, Diez, ensejo desfrutado por muitos deles para exibirem-se "artisticamente" em números de poesia e monólogos, apresentações de piano, recitais de canto ou esquetes de peças teatrais ${ }^{196}$, enquanto a junta de senhoras anunciava a distribuição de mais de 100 trajes completos, confeccionados ou arrecadados, às "crianças pobres da colônia" no dia de reis ${ }^{197}$.

As festas de caridade podiam sofrer alguma variação de conteúdo, dispensando a "conferencia", se fosse o caso - dificilmente o baile que era o apogeu da festa, estendendo-se muitas vezes até a madrugada. Nesta, de 1920, composta de três partes, iniciava-se com uma sinfonia, à qual se seguiram várias apresentações dramáticas numa das quais se apresentaram as filhas de Perfecto Ares (Carmen e Josefina) e Aparício Marti. A segunda parte, aliás, era inaugurada por ele mesmo, com a declamação de uma poesia "inédita" de sua autoria. Em seguida, Josefina Ares se apresentaria ao piano acompanhada pelo maestro João Gomes de Araújo. Em seguida, era a vez da Família Diez, mãe e filha ao piano (Manuela e Manolita). Entrava Medina, o sócio da Rossi-Film com um monólogo e, por fim, o sorteio de prêmios pela tômbola e o baile Familiar ${ }^{198}$.

Em seus salões também se organizavam chás beneficentes, aos domingos, em favor dos fundos da Caixa de Socorros, a cujo encargo ficavam jovens senhoritas que tinham por missão conseguir tirar o maior valor possível de dinheiro, ao servirem "o sexo feio"199.

Sobressaia-se das demais sociedades, especialmente por seu caráter elitista, agrupando socialmente a fina flor da colônia, representada por suas "honrosas damas que dirigen los destinos de esa sociedad" que, irmanadas e convencidas da missão que lhes coubera e que lhes distinguia socialmente, "no se olvidaran de los niños pobres de nuestra colonia (...) y prepararan una hermosa árbol de natal con regalos que serán dados a los presentes al

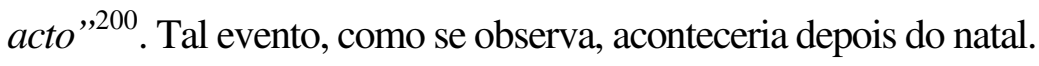

Por essa época, inícios de 1922, sua sede social havia se transferido para a Rua XV de Novembro, 50, local mais condizente ao escol das "honrosas damas"201 que, não obstante, para

${ }^{196}$ EDE 27.01.1920 e 16.06.1922, dentre outros.

${ }^{197}$ EDE 03.01.1920. Trad. da autora.

${ }^{198}$ EDE 27.01.1920. Havia os "bailes infantis", realizados nos salões do Centro Espanhol, Rua XV de novembro, 50, patrocinados pelas "honrosas damas que regem os destinos desta sociedade (...) não se esqueceram das crianças pobres de nossa colônia (...) prepararam uma formosa árvore de natal com presentes que serão dados às crianças presentes". EDE 05.01.1922.

${ }^{199}$ EDE 08.08.1920. Deste evento, participaram as senhoritas Enmingarda e Elena Rodriguez, Carmem Aparício, Nené Lebert, Carmen Cubero, Anita Guastim, dentre outras. Trad. da autora.

${ }^{200}$ EDE 05.01.1922. O evento estava programado para o dia 6 de janeiro, ou seja, depois do Natal.

${ }^{201}$ EDE 05.01.1922. Trad. da autora. 
festas especiais, costumavam alugar os salões do Club Germania ${ }^{202}$. Seu presidente, então, era Miguel Gutierrez. Há 13 anos no Brasil, Gutierrez, com 38 anos, fora Agente Consular em Piracicaba, onde residira anteriormente até palmilhar sua ascensão social na Rua Paula Souza, onde era vizinho de Martí.

Sob os auspícios do CE artistas espanhóis vinham especialmente para exibirem-se nos salões do Conservatório Dramático-Musical. Josefina Robledo e Fernando Molina que encerravam os concertos de "guitarra e violoncelo", faziam uma última apresentação em “despedida do público espanhol", alusão à assiduidade da frequiência de parcela da colônia a esses eventos ${ }^{203}$.

Nesse universo engalanado, por vezes registrado em película pela Rossi-Film ${ }^{204}$, também podiam ser reconhecidos circulando seus dois sócios, o espanhol Medina e o italiano Rossi $^{205}$, os quais, juntamente com Zambrana, membro atuante do CE e rico comerciante de tecidos da cidade - e que anteriormente oferecera um financiamento para a Rossi-Film, recusado por Medina - dirigiram uma convocação "aos industriais, comerciantes e a todos os espanhóis" para uma reunião em seus salões, na qual a Fábrica Rossi-Film faria a exposição dos detalhes do "magno e patriótico projeto" que pretendiam levar a cabo ${ }^{206}$.

Semanas depois, matéria veiculada pelo EDE esclarecia o alcance do misterioso projeto, lamentando o baixo quorum à reunião do $\mathrm{CE}$ presidida por Gutierrez. A intenção da Rossi-Film era claramente comercial: rodar uma película cinematográfica que pusesse em "manifesto a importância da colônia espanhola no Brasil" registrando seus "centros de cultura, de beneficência e recreio, suas casas comerciais, fábricas, oficinas e explorações agrícolas" para, desse modo, impressionar positivamente o governo espanhol, o que o obrigaria a "consignar maior quantidade para o sustento das funções consulares e conceder autorização para o definitivo estabelecimento da Câmara de Comércio". Por outro lado, aproveitaria as celebrações do centenário da Independência do Brasil para a exibição da película, fato que redundaria em excepcional publicidade que inevitavelmente renderia dividendos aos anunciantes, então convocados a participar do "magno e patriótico projeto"207.

${ }^{202}$ EDE 11.05.1922.

${ }^{203}$ EDE 07.06.1919. Trad. da autora.

${ }^{204}$ EDE 28.07.1922.

${ }^{205}$ Para GALVÃO, M. (Op. cit., pp. 35 a 41 e 218) Gilberto Rossi associa-se a José Medina, em 1919, então fotógrafo e ator de teatro amador do Grupo Gil Vicente, de cuja associação iriam surgir as obras-primas de nosso cinema mudo.

${ }^{206}$ EDE 03.02.1922. Trad. da autora.

${ }^{207}$ EDE 19.02.1922. A empresa Rossi-Film seria a responsável por uma série de registros, alguns silenciosos, contendo imagens de São Paulo, alguns dos quais restaurados pela Cinemateca Brasileira. 
Por essa época, a Rossi realizaria a gravação da "finíssima comédia" de J.G. Mendes de Almeida "Do Rio a São Paulo para casar", dirigida por Medina e operada por Gilberto Rossi, feito que anunciava antecipadamente em grande anúncio ilustrado, pelo $\mathrm{EDE}^{208}$. A empresa disparava em todos os sentidos, aproveitando-se do surto novidadeiro das reportagens cinematográficas, produzindo uma série de documentários que denominava "película oficial", na verdade trabalhos encomendados pelo Governo do Estado de São Paulo - como a filmagem da eletrificação da Estrada de Ferro Sorocaba a Votorantin, que contou com a presença de Washington Luis. No mesmo reclame, divulgava o registro do terremoto ocorrido na cidade a 27 de janeiro do mesmo ano, 1922, e as últimas corridas realizadas no Joquey Club Paulistano, eventos que seriam exibidos no Cine República e nos Teatros Congresso e Mafalda ${ }^{209}$.

Aqui no $\mathrm{CE}$, como na FE, também se celebrava a Fiesta de la raza, no dia 12 de outubro, em comemoração à descoberta da América. Eram cerimônias programadas com antecedência com os representantes das demais agremiações, sendo presididas pelo cônsul, neste caso, D. Manuel de Caabeyro ${ }^{210}$. Incluíam discursos, leitura de fragmentos literários e poesia, apresentações musicais e, completando o evento, o baile. A celebração de 1921, em particular, fora programada para ocorrer no Teatro Colombo, nos dias 11 e 12 de outubro, e, antecipando-se, o CE oferecia parte da receita à SESM, não se omitindo porém da "obra patriótica de prestar auxílio a todos os irmãos de nacionalidade que, vítimas do seu heró́smo, caem nos campos de batalha de Marrocos"211. Era a senha para mais uma lista de subscrição, cujos doadores apareceriam dias depois, por ordem de quantia doada, estampados no EDE. Neste caso, era encabeçada por Juan Bobadilla, com um conto de réis ${ }^{212}$.

A guerra do Marrocos, apesar de distante do cotidiano desses indivíduos, os comovia sobremaneira e, por razões talvez ligadas à sua própria opção de emigrar, sentiam-se em certa medida responsáveis pela desgraça e infortúnio dos que partiam para a frente das batalhas, retornando feridos ou mutilados, e pelos que morriam, deixando órfãos. Era em favor destes que vimos proliferar nas folhas diárias do periódico inúmeras listas de contribuições, de imigrantes residentes não apenas na Capital, mas também no Interior do Estado. O EDE atualizava diariamente as notícias da guerra que, a finais de 1921, deixavam transparecer a série de “desacertos contínuos e erros enormes" que, somados aos abusos da jovem oficialidade - "que

${ }^{208}$ EDE 05.02.1922.

${ }^{209}$ EDE 19.02.1922.

${ }^{210}$ EDE 04.10.1920.

${ }^{211}$ EDE 17.09.1921. Trad. da autora.

212 EDE 27.10.1921. A seguir, com 500 mil réis, vinha: Miguel Gutierrez; Joaquin Collazos; Félix Zambrana; Arturo Navajas; José Garcia Dominguez; Matias Lorenzo; Teófilo Saenz; José de Asprer e a Caixa de Socorros das Senhoras do Centro Espanhol. A listagem trazia inúmeras contribuições menores. 


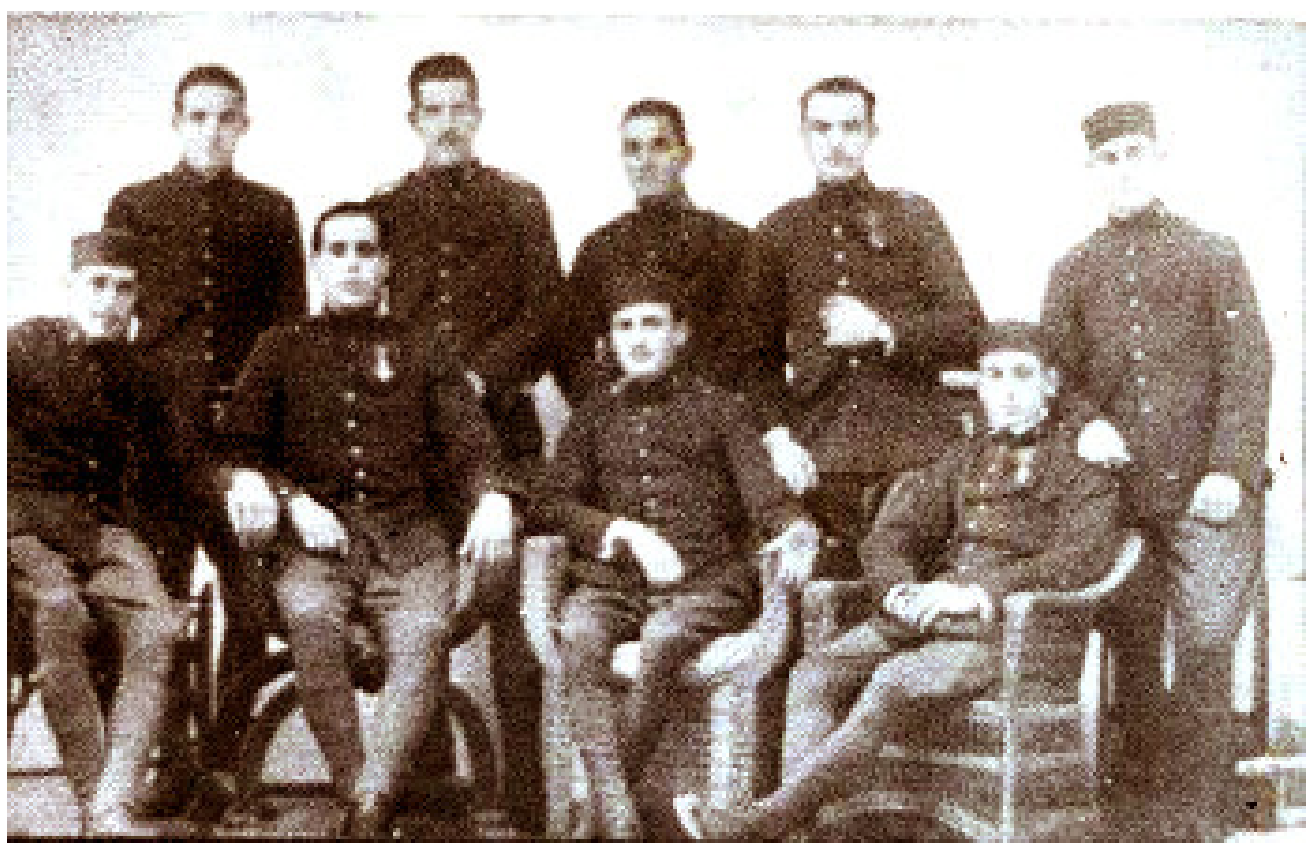

Fig. 15. Grupo de espanhóis na África, 1919.

tinha transformado Melilla em um centro de recreio" -, acabavam por "exacerbar o ódio dos marroquinos, 213 .

Em outras comemorações cívicas nacionais, como na do descobrimento do Estreito de Magalhães, a festa, também presidida pelo cônsul, reunia altas autoridades, como o prefeito da Cidade e o governador do Estado, além do corpo diplomático de diversas repúblicas $\operatorname{americanas}^{214}$.

Das festas profanas há evidências de que, como na FE, o Carnaval já conquistara lugar de destaque: eram quatro dias de folia, e para todas as idades e perfis. Dois bailes à fantasia, para adultos (no sábado e na terça-feira à noite); outro à fantasia para as crianças (domingo à tarde) e duas "reuniões familiares", realizadas no domingo e na segunda-feira, à noite. Todas as comemorações eram "exclusivamente para os sócios e suas famílias", de conformidade com o anúncio veiculado pelo $\mathrm{EDE}^{215}$.

Diferentemente das demais agremiações, contudo, o CE distinguiu-se por inúmeras iniciativas na esfera comercial. Em 1920, o EDE publicaria uma carta enviada pelo diretor da Revista Comercial Ibero-Americana Mercurio, de Barcelona, ao diretor do CE, oferecendo-se para divulgar com informações e imagens, notícias da "semana espanhola", a fim de dar a maior promoção possível. Aparício Martí, então secretário do CE, e sob a coordenação de quem ficaria o evento, em resposta à consulta adiantava que, àquela altura, já havia obtido

\footnotetext{
${ }^{213}$ EDE 04.11.1921. Trad. da autora.

${ }^{214}$ EDE 02.12.1920.

${ }^{215}$ EDE 24.02.1922. Trad. da autora.
} 
permissão para a criação de uma Câmara Oficial de Comércio, Indústria e Arte na Capital cujo propósito seria a instalação de uma exposição permanente de produtos espanhóis na Cidade de São Paulo que pudesse tutelar o provável comprador, apresentando-lhe todas as informações necessárias, mas que, a par disso, também assistisse o fabricante espanhol, fornecendo-lhe os parâmetros quanto às normas e exigências oficiais brasileiras.

Essa iniciativa denotava a persistência de determinados setores da colônia no estabelecimento de novos mercados para a Espanha que, conforme afirmavam, perdia terreno frente às outras nações que se adiantavam por implementar o comércio com o Estado de São Paulo. Como muito bem pontuava Aparício Martí a esse propósito, “o CE não se dedica exclusivamente a atos recreativos", celebrando "com a maior pompa festas literárias e musicais em dia de festa". "Não poderíamos ficar de braços cruzados", concluía, "diante da grande soma de esforços que realizam as nações européias, os Estados Unidos e a Ásia na conquista de novos mercados no continente americano" 216 .

Nessa esteira, compreende-se que, por iniciativa do mesmo CE, especialmente de seu presidente à época, Miguel Gutierrez ${ }^{217}$, convocava-se uma comissão executiva para realizar estudos tendo em vista a criação de uma casa bancária espanhola na Cidade ${ }^{218}$. Esse projeto, o da criação do Banco Hispano-Brasileiro, rápido ganhou as primeiras páginas do $\mathrm{EDE}^{219}$, porém desconhecemos se acabou se concretizando.

Há questões e aspectos eloqüentes que saltam aos olhos, e de grande interesse para reflexão, quando examinamos os elementos constitutivos do percurso dessas associações. Inevitável reconhecer em sua dianteira a existência de um segmento dinâmico, constituído por setores emergentes da colônia, cujo estilo de vida inspirava-se mais e mais no comportamento da elite nacional. Contudo, impossível não distinguir também entre eles, um outro segmento, de indivíduos que aqui aportaram trazendo suas ideologias e, portanto, claramente identificados com a militância - caso exemplar de Everardo Dias. E, se não bastasse essa composição incompatível de qualquer ponto de vista, nada impede imaginar as adversidades de ordem pessoal e comportamental que surgiam, ainda mais se, a tudo isso, ainda acrescentarmos pitadas de latentes sentimentos regionalistas, que pontuaram o período. Mostrar suas particularidades, evidenciar no pormenor e no detalhe as suas especificidades, na interface com as condições locais, são indicadores que podem informar maior nitidez à trajetória desse contingente.

\footnotetext{
${ }^{216}$ EDE 21.06.1920. Trad. da autora.

${ }^{217}$ EDE 25.05.1922.

${ }^{218}$ EDE 09.10.1922.

${ }^{219}$ EDE 10.06.1922.
} 


\subsection{As associações culturais, artísticas e recreativas, e os grupos amadores de dramaturgia}

A par da prerrogativa central, e da plataforma recorrente e concreta, responsável em última análise pela criação desses núcleos étnicos - amparo aos conterrâneos nas questões urgentes e inadiáveis, que avultavam à proporção que cresciam os problemas da cidade em seu salto desordenado de crescimento - pudemos constatar que, alguns deles, foram progressivamente incorporando novas atividades, revelando-se espaços de sociabilidade, no âmbito dos quais passaram a ser desenvolvidas atividades culturais, artísticas e de lazer.

A comemoração das festas nacionais; a reverência aos santos padroeiros locais; a homenagem dos grupos artísticos a personalidades espanholas ${ }^{220}$; a manutenção de tradições e costumes genuínos ligados à música, à dança, às artes cênicas, à gastronomia, aos jogos, ao uso de uma indumentária regional, tais práticas, enfim, expressando a afirmação da identidade do grupo parecem indicar a tentativa de preservação de alguns quadros referenciais, em que as festas e os bailes, eventos típicos do período e freqüentados pelas diversas camadas da população imigrante, consagrando inúmeras atividades correlatas, representavam momentos privilegiados.

Diversos grupos de teatro amador e centros de dramaturgia dirigidos por espanhóis despontaram no período. Esses artistas amadores eram bastante influenciados pelas "divas" e pelos "divos" que se exibiam no teatro comercial. Elazari sublinhando as sociedades que apresentavam espetáculos teatrais amadores no período, lembra do Grêmio Dramático Gil Vicente (1900), segundo ela, pertencente a espanhóis ${ }^{221}$. Há, contudo, notícia de que já em 1903 ocorriam apresentações teatrais nos salões do Liceu Espanhol, neste momento de teor acentuadamente político $^{222}$. Já comentamos sobre o grupo dramático mantido pela FE (Isaac Peral) iniciado em 1918. De conformidade com registros coletados no EDE, entretanto, atuavam na cidade com programação regular a partir de 1912, quando iniciamos a consulta, diversos grupos dentre os quais o Centro Dramático Espanhol Cervantes apresentando-se, naquele mesmo ano ${ }^{223}$ com a peça La Dolores com cenografia elaborada por cenógrafo vindo especialmente da Espanha, no Conservatório de Música na Rua São João. "El Chiquillo" diminutivo de chico, significando criança; menino; guri; moleque ou piralho - peça encenada

${ }^{220}$ Alfonso XIII, Cervantes, Isaac Peral foram algumas das denominações utilizadas.

${ }^{221}$ ELAZARI, J. Op. cit., pp. 167 e 169.

${ }^{222}$ LIMA, Mariângela Alves de e VARGAS, Maria Thereza. "Teatro operário em São Paulo". In: PRADO, Antonio Arnoni. Libertários no Brasil-memória, lutas , cultura. São Paulo: Brasiliense, 1987, p. 238. Ver, a respeito, o Capítulo $\mathrm{V}$.

${ }^{223}$ EDE 18.06.1912. 
logo depois, sugere a provável destinação dos fundos do evento ${ }^{224}$. Em muitos dos casos, aliás, suas funções eram realizadas "em benefício dos fundos sociais", indicativo provável da existência, em seu corpo dirigente, de elementos também pertencentes a alguma das sociedades beneficentes.

Como muitas outras, essa agremiação deve ter sofrido em seu percurso alguma interrupção temporária. $\mathrm{O}$ fato é que permaneceu durante anos em recesso das páginas do EDE, surgindo novamente apenas em 1918, indicando, talvez, questões financeiras que impediam o investimento em reclames. A matéria então publicada "Os incansáveis cultivadores da arte cênica”, informava da posse da nova diretoria para o biênio $1918 / 9^{225}$, a partir do que a agremiação ressurgiria com extensa programação, instalada em sede própria à Rua do Gasômetro, 64: "drama em um ato"; "esquete chistoso" e "ato variado de ilusão e magnetismo pelo transformista Solé", eram alguns dos prólogos da "grande função dramático-dançante".

O corpo cênico dessas sociedades era constituído pelos próprios associados e, como vimos, os saraus dramáticos compunham apenas um dos elementos de diversão e lazer oferecidos por essas associações a seus afiliados. Para os inúmeros grupos teatrais amadores que se formavam na cidade, a obtenção do texto a ser encenado, em espanhol, era uma terrível dificuldade. Recorreram, então, a Eiras Garcia que, “em vista dos constantes pedidos”, tratou de adquirir, a partir de 1914, diretamente da Sociedade de Autores Espanhóis, os direitos autorais de uma série de obras, especialmente de autores como Benavente e Dicenta, que passou a disponibilizar para aquisição ${ }^{226}$.

O baile, como sempre, o ponto alto, vinha após a função dramática, e desta feita, o desfecho ficaria por conta de "Toribio e Carlitos", provavelmente uma dupla de músicos instrumentistas. Assim descrevia a matéria encerrada pelo informe do "grande baile de máscaras" que se realizaria em fevereiro ${ }^{227}$. Tratava-se de uma agremiação das mais prestigiadas da cidade, merecendo menção especial de Jacob Penteado: “... eram numerosas as sociedades dançante-recreativas no Brás, dentre as quais a tradicional Cervantes" ${ }^{, 22}$, dizia, referindo-se ao ano de 1921.

Também em funcionamento neste mesmo ano de 1912 e estabelecido muito próximo do Cervantes, estava o Grupo Dramático Alfonso XIII, à Rua Rangel Pestana, 265. Em

\footnotetext{
${ }^{224} \mathrm{EDE} 26.06 .1912$.

${ }^{225}$ EDE 14.05.1918. Trad. da autora.

${ }^{226}$ EDE 04.06.1914.

${ }^{227}$ EDE 15.01.1920. Trad. da autora.

${ }^{228}$ PENTEADO, J. Op. cit., 1963 , p. 47.
} 
aparição única no periódico nesta segunda década, fazia a divulgação de uma festa ${ }^{229}$. Como no anterior, também os reclames deste grupo sofreram longo período de interrupção, reaparecendo anos depois, já incorporando a prática do tradicional baile familiar seguido ao espetáculo teatral; nesse caso, exibia-se um drama em três atos, de Nuñez de Arce, denominado "Dívidas de honra" ${ }^{, 230}$.

Em 1913 localizamos no n $^{\mathbf{3}} 3$ da Rua Martin Buchard - a mesma onde ainda se situava a SESM - o Centro Lírico-Dramático Alfonso XIII, informando da apresentação do drama "La Muerte Civil",231, ao que se seguiu matéria assinada por um tal "Moyano", talvez um crítico teatral, na qual comentava o desempenho de cada um dos atores do "grupo teatral do Centro" na apreciação que fazia da exibição de "Amor Loco" "232. Esses dois eventos resumiram as aparições desse Centro no período examinado.

Iniciado em 1912 e anunciando a sua primeira função dramática, com grande elenco de atores espanhóis (ou com sobrenomes espanhóis), apareceu uma única vez no EDE o Centro Dramático Maria Guerrero, funcionando na Rua Florêncio de Abreu, $45^{233}$. Maria Guerrero já era atriz famosa na Espanha e em Paris, onde se apresentara no Renaissance, quando chegou ao Rio de Janeiro, em 1908, apresentando-se, então, no Teatro Lírico, em 31 de julho, com La dama boa (sic), de Lope de Vega, apresentação a que se seguiram inúmeras outras, em diversos teatros daquela cidade. Ali, apresentou "quase exclusivamente peças espanholas, fugindo à tentação dos confrontos com Sara Bernhardt, a Duse e a Réjane, nas heroínas que estas animavam"234, após o que deve ter-se trasladado para São Paulo, onde fundou o Centro Dramático que levou o seu nome. Não obtivemos maiores detalhes sobre sua atuação no período; uma única indicação, entretanto, sugere que a atriz fazia parte, em 1922, do elenco do Circo Americano, então na Rua das Palmeiras ${ }^{235}$. A Atriz teria morrido em Madrid, em $1928^{236}$.

\footnotetext{
${ }^{229}$ EDE 17.02.1912.

${ }^{230}$ EDE 04.01.1921. Trad. da autora.

${ }^{231}$ EDE 21.08.1913.

${ }^{232}$ EDE 24.10.1913.

${ }^{233}$ EDE 29.11.1912.

${ }^{234}$ SILVA, Lafayette. Op. cit., 1938, pp. 405-409.

${ }^{235}$ EDE 16.05.1922.

${ }^{236}$ SILVA, L. Idem, ibidem.
} 


\section{O lazer e a vida cotidiana}

O crescente turbilhão que marcará o processo de metropolização da Paulicéia implicará modificações acentuadas no lazer da sua população. Em seu estudo, Judith Elazari ${ }^{237}$ pontuou que o período que antecedeu a virada do século dezenove caracterizou-se por manifestações coletivas de lazer, sem distinção entre os "diferentes grupos sociais". Nas festas religiosas (N. S da Penha, Divino Espírito Santo) e nas profanas, como no Entrudo; nos esportes então praticados (o bilhar, o boliche e a peteca, típicos do período), nos passeios públicos e até mesmo simplesmente nadar no rio para aqueles que se arriscavam, representavam manifestações compartilhadas, porém de iniciativa particular, que não sofriam a interferência do governo municipal.

Esse quadro tendeu a alterar-se. A metamorfose da cidade atingiu também os divertimentos populares, modificando a sua natureza ao mesmo tempo em que, simultaneamente, iam sendo introduzidas novas modalidades de lazer que passam a competir com as antigas e tradicionais formas de divertimento popular. $\grave{A}$ diversificação que progressivamente foi sendo observada nos hábitos de lazer da população da cidade seguiu-se, como já tivemos oportunidade de apontar, a sua exploração comercial, implicando a segregação de parte da população que, alijada de determinados eventos e ambientes, em alguns casos foi transformada de participante em espectador - lembremos dos préstitos carnavalescos que atraíam o povo para as ruas por onde passava o corso de carros alegóricos com suas luxuosas fantasias. Neste caso, havia até quem alugasse a porta de seu estabelecimento comercial para a assistência das famílias, ali instaladas em verdadeiros "camarotes”. Entre 1910 e 1915, o corso foi transferido para a Avenida Paulista, iniciando às $4 \mathrm{~h}$ e seguindo até às $9 \mathrm{~h}$ da noite ${ }^{238}$, acompanhado por uma platéia popular cuja participação restringia-se à observação.

O período que analisamos contempla exatamente o momento em que esse conjunto de mudanças foi constatado nos hábitos de lazer da população. Alguns hábitos, resistindo às formas do lazer comercial, conservaram-se ainda durante certo tempo, mantidos em espaço regido por outra lógica, no âmbito da família, da vizinhança e do entorno, muitas vezes com pequenas "adaptações" que evocavam e exprimiam o universo e as tradições do imigrante, caso das festas religiosas, conforme veremos. Não obstante, já deslanchava uma outra maneira de preencher o tempo livre, marcadamente vincada ao consumo, que encontrou terreno fértil, alcançando êxito pela mão de empresários que passaram a explorar outros segmentos menos

${ }^{237}$ ELAZARI, J. Op. cit., pp. 185 e ss.

${ }^{238}$ AMERICANO, J. Op. cit., p. 262. 
"populares" e que se traduziam, dentre outros, pelo lazer dispendioso das casas de espetáculos e dos teatros, cujo acesso era economicamente vedado à maioria da população comum ${ }^{239}$ e que, ainda assim, possuíam crescente demanda nas camadas mais abastadas, a considerar que no início do século XX já havia cambistas de teatro negociando com os ingressos ${ }^{240}$.

Os espetáculos teatrais passaram a ocupar grande espaço na mídia impressa; em alguns veículos havia colunas especiais para sua divulgação. Inicialmente, por volta das décadas finais do Oitocentos, considerado como "uma escola de bons costumes", as queixas maiores se concentrariam, todavia, na falta de variação das peças, merecendo críticas dos jornais que os chamavam de "dramas aposentados", reclamando igualmente dos altos preços cobrados e da frequiência excessiva dos acadêmicos que "acenderam seus charutos e mimosearam as famílias presentes com baforadas de fumaças, ou proferiram palavras obscenas e mais tarde agrediramse a bengaladas" 241 .

A elite paulistana aderiu ao teatro, malgrado o baixo nível dos espetáculos. Dramas, operetas, zarzuelas e revistas antecederam o café-concerto, nova forma de espetáculo teatral, que reacendeu os ânimos, aparecendo como "consolo à monotonia da vida noturna da capital, carente de casas de espetáculos, de recreios e diversões", vaticinava o jornal Vida Paulista, em $1905^{242}$. No romaneio das peças encenadas na Paulicéia, apresentado por Elazari ${ }^{243}$, pudemos constatar muitas delas no idioma espanhol - El Valle de Andorra, El juramento, El loco de la Guardilla, Buenas noches Dr. Simon, Hijas d'Eva, El annijo (sic) de hierro, En las hastes del toro, El pastillón de la Rioja, Ya somos tres, Los Magyares, El monoquito, Fan Fan la tulipaevidenciando a existência de uma platéia potencial. Lamentavelmente não temos maiores indicativos dos locais onde teriam sido encenados tais espetáculos, exibidos prematuramente na cidade, a considerar o levantamento da autora, que chega apenas até 1910. Imaginamos, contudo, que a frequiência a ambientes noturnos onde eram exibidos os espetáculos teatrais fosse prática permitida apenas às camadas mais elegantes da sociedade, restando aos menos favorecidos participar apenas indiretamente. Comentar sobre os "artistas", por exemplo, virara costume irrestrito, de toda a gente. Afonso Schmidt diz que "o palco atraía todas as atenções" e se comentava sobre os "méritos dos atores em voga" em todos os locais ${ }^{244}$.

- Olhem essa artista que bonita! - exclamou Lola.

${ }^{239}$ ELAZARI, J. Op. cit., pp. 185 e ss.

${ }^{240}$ LEME, M. Op. cit., p. 117.

${ }^{241}$ Passim.

${ }^{242}$ ELAZARI, J. Op. cit., pp. 147-148.

${ }^{243}$ Idem, ibidem, pp. 157 e ss.

${ }^{244}$ SCHMIDT, A. Op. cit., 2003 (1 ${ }^{\text {a }}$ ed. em 1954), p. 138. 
- Essa é a Theda Bara. Que vestido lindo! Parece até com o da dona Delícia quando foi ao teatro na outra noite - mostrava Sofia.

- Quando você a viu?

- Ela estava saindo com um vestido preto cheio de vidrilhos e um colar de pérolas comprido que chegava na barriga.

- Mas como você viu tudo isso? - perguntou Lola

- Eu fui à casa dela para levar a camisa do dr. Arruda que minha mãe engomou. Eles foram ao Teatro Municipal para assistir a uma ópera; o dr. Arruda ia de preto, com uma camisa branca que deu um trabalhão pra minha mãe engomar todos aqueles babadinhos $^{245}$.

Era também de uma elite bastante reduzida da sociedade paulistana a frequiência às exposições de artistas plásticos, interesse que progressivamente crescia na cidade, justificando a criação de uma Pinacoteca, em 1911. Por essa época era flagrante o entusiasmo do diretor do EDE com os pintores espanhóis que passaram a freqüentar os espaços destinados às exposições de arte na cidade, entendendo ser esta uma evidência da "influência artística espanhola" deste lado do oceano: "Nos hemos referido exclusivamente a tratar esas relaciones desde el punto de vista comercial aunque pudiéramos probar que la influencia intelectual española también va ganando lugar aquí, por el mayor aumento de lectores que tienen los libros españoles, así como la artística, por las exposiciones de cuadros de nuestros grandes pintores ${ }^{, 246}$.

Em 1911 ocorreu a primeira Exposição de Arte Espanhola na cidade, organizada por José Pinello Llul - artista que anteriormente já houvera circulado por Nova York, Buenos Aires e Rio de Janeiro - compondo uma das 24 exposições coletivas de artistas estrangeiros ocorridas no período entre 1890 e 1920.

Inaugurada em 24 de dezembro daquele ano, esta Exposição ocorreu simultaneamente à primeira Exposição Brasileira de Artes no Liceu de Artes e Ofícios e ao seu vernissage acorreram as mais altas autoridades da cidade e do Estado, inclusive seu governador à época, Albuquerque Lins, além de artistas, setores da imprensa e representantes da elite paulistana. Tratava-se de uma coletiva em que Pinello exibia obras de diversos outros pintores espanhóis, num total de 94 trabalhos. Uma das telas apresentadas, a Igreja de Nossa Senhora do Pilar de Saragossa, de Olivier Aznar foi doada para a Pinacoteca do Estado. Outra obra, Madalena, de Luiz Mascerá foi adquirida por um colecionador particular, Carlos de Campos. Nestas ocasiões, o Estado incorporava ao acervo diversas obras, seja para a Pinacoteca, o Museu Paulista, o Palácio dos Campos Elíseos ou as secretarias, seja para outros edifícios públicos. Nesta oportunidade foram as seguintes as aquisições públicas: de José Pinello Llul, Pátio da

\footnotetext{
${ }^{245}$ MARX, G. Op. cit., pp. 31-32.

${ }^{246}$ EDE 17.02.1912.
} 
Sultana; de José Moreno Carbonero, D. Quixote e Sancho Pança; de Valluerca, Gado; de Muñoz Lucena, Sonata e de Francisco Pradilla y Ortiz, Loucura de amor ${ }^{247}$.

Em janeiro deste mesmo ano, 1911, os Irmãos Salinas, Augustin e Pablo, haviam exposto suas obras no Palacete Martinico, no Largo do Rosário, o primeiro prédio de escritórios da cidade. Realizavam "coisas eternas" dentro do mais "puro classicismo", como paisagens urbanas e marítimas. Eles já haviam estado na cidade no ano anterior, 1910, expondo na Casa Verde $e^{248}$. Consta que seu pincel incluía retratos de pessoas ilustres como Freitas Valle, datado de 1911 e hoje pertencente ao acervo da Pinacoteca do Estado ${ }^{249}$. De Pablo Salinas, a obra $O$ Concerto foi adquirida pelo conde de Prates, presidente do Automóvel Clube, fundado em 1908, para a sede da entidade ${ }^{250}$.

A freqüência com que se repetia a presença desses artistas na cidade indica a existência de um mercado de arte que fazia jus ao grande investimento da empreitada.: "além dos custos da produção e da montagem de uma exposição, contavam-se o armazenamento e transporte da obra, os riscos da travessia, os direitos de alfândega, os custos com hospedagem, alimentação e locomoção", pontua Mirian Rossi em seu estudo, esclarecendo que muitos deles vinham com a família e que, no intervalo de tempo aceitavam encomendas particulares, necessitando, portanto, de "um espaço mínimo que fizesse as vezes de atelier",251.

Em janeiro de 1912, o EDE pronunciava-se a respeito da coletiva que fora "um sucesso" ocorrida na Escola de Artes e Ofícios reunindo os Irmãos Salinas e José Pinello juntamente com Julio Villa y Prades $^{252}$ o qual, neste mesmo ano, em agosto, apresentava-se em individual no Hotel Majestic, na Rua São Bento, 61, cujo encerramento seria coberto pelo EDE segundo o qual "todo o material exposto havia sido vendido"253.

Tais exposições atraíam cada vez mais compradores de outros Estados e nesta, em especial, Villa y Prades venderia o quadro Charito para a Galeria Nacional, no Rio de Janeiro, pelo valor de $4.000 \$ 000^{254}$. Na coletiva anterior, de janeiro, o artista havia vendido para o governo do Estado de São Paulo, a obra Alma Tranqüila, adquirida com duas obras de Luiz Graner y Arrufi, As últimas notícias e Lua Cheia ${ }^{255}$. Graner retornaria outras vezes à cidade, em

${ }^{247}$ Informações constantes em: ROSSI, M. Op. cit., pp. 35; 46-48; 59-60; 64; 66; 78; 89; 98; 105.

${ }^{248}$ ROSSI, M. Op. cit., p. 59.

${ }^{249}$ Freitas Valle "advogado, deputado estadual, senador da República, homem de língua e literatura francesas e colecionador”, já fora retratado por outros pintores. Cf. ROSSI, M. Op. cit., p. 128.

${ }^{250}$ ROSSI, M. Op. cit., pp. 68; 102; 114; 119; 121; 128 e 147.

${ }^{251}$ Idem, ibidem, p. 13.

${ }^{252}$ EDE 08.01.1912.

${ }^{253}$ EDE 24.08.1912. Trad. da autora.

${ }^{254}$ ROSSI, M. Op. cit., p. 99.

${ }^{255}$ Passim. 
duas individuais: em 1913 apresentou-se na "Rua Boa Vista, 52, esquina com Porto Geral"256 e em 1920, exibiu-se no Edifício do Clube Comercial, à Rua São Bento, 59, integrando "magnífica coleção de quadros que o artista pintou no Rio de Janeiro"257.

Em setembro deste mesmo ano, Augustín Salinas apresentava-se em individual ${ }^{258}$ e nos inícios de 1913 eram destaque os painéis por ele realizados para a "parte externa da galeria de pintura da residência" do senador Freitas Valle ${ }^{259}$.

José Pinello retornaria à cidade e novamente o EDE manifestava-se entusiasticamente; "um êxito", assim descrevia o evento, ocorrido no Grande Hotel, em dezembro de $1912^{260}$. Organizada pelo proprietário da Galeria Jorge, do Rio de Janeiro no luxuoso hotel situado na Rua São Bento, esquina com a Rua Miguel Couto - que exibia em sua galeria de hóspedes a atriz Sarah Bernhardt, em 1886 - essa coletiva teria apresentado 107 quadros de pintores nacionais e estrangeiros ${ }^{261}$. A este evento, seguiu-se um outro, no final de 1913, na Rua São Bento $^{262}$ e novamente outro, nos Salões Mascarini, Rua São Bento, 85, nos inícios de $1914^{263}$. A Casa Mascarani - para o periódico "Mascarini” - era considerada a nossa "galérie d'art” e consta que nesta coletiva, de 1914, teria disponibilizado quatro salas para José Pinello, seu organizador, estando o edifício "completamente remodelado, embelezado e iluminado à luz elétrica", diferentemente das ocasiões anteriores ${ }^{264}$.

Nos mesmos salões luxuosos do Grande Hotel realizou-se, em agosto de 1913, a individual de outro artista espanhol, Antonio Ribas Prats ${ }^{265}$. Neste mesmo ano, em outubro, o valenciano Ernesto Valls, então com 22 anos, era elogiado em matéria de $O$ Piralho, reproduzida pelo $\mathrm{EDE}^{266}$, pelo sucesso de sua individual na Casa Mascarani, ocasião em que realizou a doação de diversos quadros para sorteio em benefício da construção do Hospital Infantil Tostão Nacional, da Cruz Vermelha Brasileira ${ }^{267}$. É provável que tenha permanecido

${ }^{256}$ EDE 02.04.1913. Trad. da autora. O endereço refere-se ao “antigo prédio da Rotisserie Sportsman", provavelmente alugado pelo artista, na falta de outro espaço mais apropriado. Cf. ROSSI, M. Op. cit., p. 67.

${ }^{257}$ EDE 06.09.1920. Trad. da autora.

${ }^{258}$ EDE 09.09.1912. Trad. da autora.

${ }^{259}$ ROSSI, M. Op. cit., p. 107.

${ }^{260}$ EDE 18.01.1913. Trad. da autora.

${ }^{261}$ ROSSI, M. Op. cit., p. 64.

${ }^{262}$ EDE 24.12.1913. Na Rua São Bento, no 56 situava-se a Casa Verde, local que recebeu várias exposições no período. Não sabemos, assim, se este evento realizara-se aí ou na Casa Mascarani, localizada na mesma rua.

${ }^{263}$ EDE 08.01.0914.

${ }^{264}$ ROSSI, M. Op. cit., p. 59.

${ }^{265}$ EDE 19.08.1913.

${ }^{266} \mathrm{EDE} 15.10 .1913$.

${ }^{267}$ Foram as seguintes as obras doadas : Saindo do banho; Jardim; Mercado valenciano; Volta da pesca do camarão; A barca do peixe seco (aquarela); Mercado de frutas (aquarela); Castelo em ruínas e Subindo para a capela (costumes valencianos). Cf. ROSSI, M. Op. cit., p. 90. 
na cidade, pois no mês de março do ano seguinte, 1914, realizaria coletiva com diversos pintores nacionais e estrangeiros ${ }^{268}$.

A emergência da Primeira Guerra Mundial interrompeu em parte esse fulgurante trânsito de pintores europeus, tanto assim foi que muitos deles só retornariam à cidade em finais da segunda década, quando já então se gestavam os sinais para uma "autonomia do campo artístico", estruturado em concepções emancipacionistas da arte estrangeira ${ }^{269}$. Após o conflito mundial, entretanto, dois eventos, em 1919, exibiram pintores espanhóis, ocasião em que um dos irmãos Salinas teria vendido a tela a óleo Descanso do baile para Marina Crespi ${ }^{270}$, provavelmente adquirido na exposição que ambos realizaram no Palacete Guanabara, na Avenida São João ${ }^{271}$; no mesmo ano Ribas Prats, expôs no Mappin Stores, então em seu novo prédio, à Rua São Bento ${ }^{272}$.

Conforme observamos, o ambiente artístico e de fruição das artes plásticas configurando circuito exclusivo e freqüentado por setores abastados e cultos da sociedade, de modo algum se identificava com a massa comum, de que se compunha a maioria da colônia aqui instalada que, assim constituída, via-se obstada de usufruir a "influência intelectual" festejada por Eiras.

É provável que ocorresse de modo distinto com os "livros espanhóis", também mencionados por ele, cujo aumento de leitores celebrava e cujo consumo incentivava através da divulgação das remessas trazidas diretamente da Espanha, muitas das quais adquiridas em suas viagens. Não se tratava apenas de livros escolares - Silabario; Segundo Libro; Tercer Libro; Juanito; Guia de Artesanato; Geografia; Historia de España; Gramática; Catecismo; Tabla de Cuentas e Aritmética, num primeiro momento, depois acrescidos de uma variedade enorme de outros títulos $^{273}$ - venda provavelmente intensificada pela instalação na cidade da Academia Española, no Largo de Santa Efigênia, 12 - altos, desde $1913^{274}$, e pelas escolas noturna e diurna da FE, criadas no mesmo ano. Aproveitava essas ocasiões para colocar à venda outros gêneros como os almanaques ${ }^{275}$, os romances ${ }^{276}$ e as Revistas Taurinas, de Plácido Isasi, obra

${ }^{268}$ Idem, ibidem, pp. 59-60.

${ }^{269}$ Idem, p. 176.

${ }^{270}$ Idem, p. 170 .

${ }^{271}$ Idem, p. 69.

${ }^{272}$ Idem, p. 56.

${ }^{273}$ EDE 18.01.1913. Urbanidad; Guia de Artesanato; Geografia en colores; El amigo de los niños; Guia de la primera enseñanza (geometria); Rudimentos de Geografia e Gramática castellana para textos de la primera enseñanza, além de Álbum de la Guerra de Melilla; Lujoso cuadro del Rey y Canalejas (oleografia), Cuadernillos de papel para aprender a escribir e Cuadernos sueltos.

${ }^{274}$ EDE 09.08.1913.

${ }^{275}$ EDE 11.04.1912.

$276 \mathrm{EDE}$ 24.07.1912. Os livros foram embarcados pelo Vapor Cádiz que aportaria em Santos em 05.08.1913. 
que saía por $5 \$ 000$, e se destinava aos "aficionados" - trazendo informações das "temporadas taurinas de 1905 a $1908^{, 277}$ - estoque que tratava de renovar com encomendas regulares, indício de que a demanda por livros crescera. Em 1914 o EDE anuncia a abertura de um escritório comercial, na Rua XV de novembro, 37-A, não apenas para a captação de assinaturas e anúncios para o periódico, mas também para a venda de "livros e publicações espanholas e estrangeiras" 278 .

As assinaturas mensais de revistas espanholas já eram feitas anteriormente, na Librería Española, situada na Avenida Rangel Pestana, 109-B, cujo proprietário, Pablo Cornadó, vivia às turras com os atrasos do correio, provocados pelas apreensões "sem razão", conforme ele ${ }^{279}$. Em seu "centro de subscriçãa" aceitava assinaturas para as seguintes publicações: Por esos mundos; Blanco y Negro; Nuevo Mundo; Mundo Gráfico; Unión Ilustrada; Los Sucesos; Sol y Sombra; El Motim e Alrededor del Mundo ${ }^{280}$. E também para as Revistas Taurinas.

Na mesma Avenida Rangel Pestana, $n^{\circ}$ 134, localizava-se outra livraria, pertencente a Francisco A. da Costa, também posto de venda do $\mathrm{EDE}^{281}$ e consta ter havido ainda uma outra, localizada na Rua Paula Souza, 15, a Librería Española de Cueto \& Marti, especializada em "livros escolares"282. A Família Cueto, a propósito, residia no local pelo menos desde 1915, data do primeiro registro de Vicente Cueto Romero, comerciante natural de Cádiz, e então com $52 \operatorname{anos}^{283}$. Por estar localizada na Rua Paula Souza, local onde também se situava o depósito atacadista de Aparício Marti, é de se supor que ele fosse o outro sócio, cujo sobrenome era citado na razão social da empresa.

A demanda por essas publicações não deixa de causar surpresa, se levarmos em conta o universo considerado. Eram realmente poucos os espanhóis alfabetizados, algo em torno de $20 \%$ do contingente então habitando na cidade, de acordo com a análise de amostras escolhidas dos registros consulares em períodos selecionados ${ }^{284}$. Desse modo, parece razoável aceitar a existência da prática da leitura compartilhada, de tantas evocações memorialísticas e que parece ter-se constituído costume rotineiro nas camadas populares: "era hábito, naquele tempo, as famílias reunirem-se, à noite, para leitura de romances, principalmente os de folhetins"

${ }^{277}$ EDE 17.02.1912. Trad. da autora.

${ }^{278}$ EDE 14.12.1914. Trad. da autora.

${ }^{279}$ EDE 12.08.1913.

${ }^{280} \mathrm{EDE} 29.01 .1914$.

${ }^{281}$ EDE 14.08.1914.

${ }^{282}$ EDE 03.11.1920. Trad. da autora.

${ }^{283}$ LRC 1915. Seu filho Julio Cueto Diaz, de 31 anos, informou também residir no mesmo local.

${ }^{284}$ Nem todos os escreventes preenchiam adequadamente as colunas do livro de registro. Por isso, esse dado foi obtido pela análise a períodos determinados de tempo (recortes), de diversos anos nos quais, ou o declarante assinou o seu registro, ou confirmou que sabia "ler e escrever". 
declarava Jacob Penteado ${ }^{285}$. O folhetim, forma que assume o romance em seu novo meio de difusão, o jornal - fazia sucesso também entre as amigas da mãe de Zélia Gattai: “À tarde, não havendo outros compromissos, dona Angelina reunia em sua casa algumas vizinhas interessadas em romances de folhetim (...). Quatro fascículos eram comprados por semana"286. "O romance de folhetim significa uma democratização sem precedentes da literatura e um nivelamento quase absoluto do público leitor", diria Hauser ${ }^{287}$, o que concretamente se constatava no cortiço onde residia a família do carroceiro Juan Garcia, local em que o entregador de romances em fascículos era aguardado às quartas-feiras, causando alvoroço entre as mulheres, na expectativa de ler a continuação dos episódios. Pagava-se 700 réis por dois fascículos semanais, que trocavam entre si. À noite, uma das filhas do casal, Lola ou Margarita, lia em voz alta para D. Pepa, esposa de Garcia, que não sabia ler, mas se derramava em lágrimas pelas desventuras narradas ${ }^{288}$.

Marlyse Meyer, apoiada em testemunhos coletados sugere que, por meio dessas histórias, habilmente selecionadas pela capacidade inventiva do folhetinista, os leitores reencontravam-se através do imaginário com um universo não de todo desconhecido deles, mantido pela leitura coletiva e a oitiva das "lacrimosas desgraças dos folhetins, das desventuras da entregadora de pão, e de tantas seduzidas e abandonadas"289.

Para Thompson, a propósito, "as tradições se perpetuam em grande parte mediante a transmissão oral, com seu repertório de anedotas e narrativas exemplares. Sempre que a tradição oral é suplementada pela alfabetização crescente" afirma, "os produtos impressos de maior circulação - brochuras com baladas populares, almanaques, panfletos, coletâneas de últimas palavras`e relatos anedóticos de crimes - tendem a se sujeitar a expectativas da cultura oral, em vez de desafiá-las com novas opções" ${ }^{, 290}$.

Dentre as práticas que se reproduziriam ao longo das gerações, nada impede imaginar, diz Meyer, que estivesse também a lembrança da leitura ou oitiva coletiva dos romances oitocentistas e, ainda que seus parâmetros analíticos tenham ilustrado apenas o caso do imigrante italiano, vale ressaltar de que há, do mesmo modo, indicações de que a prática da leitura em grupo fosse habitual em algumas regiões da Espanha, ocorrendo especialmente nos períodos de colheita, quando "se recogen aqui algunos segadores, y siempre hay alguno que

${ }^{285}$ PENTEADO, J. Op. cit., 1962, p. 108.

${ }^{286}$ GATTAI, Zélia. Op. cit., p. 109.

${ }^{287}$ HAUSER, Arnold. Historia social de la literatura y el arte. Madri: Guadarrama, v.3, 1969, pp. 28-29.

${ }^{288}$ MARX, G. Op. cit., pp. 82; 131 e 169.

${ }^{289}$ MEYER, Marlyse. Folhetim: uma história. São Paulo: Cia. das Letras, 1996, pp. 341 e ss.

290 THOMPSON, Edward P. Costumes em comum. Estudos sobre a cultura popular tradicional. São Paulo: Companhia das Letras, 1998, p. 18. 
sabe leer, el cual coge uno de estos libros en las manos y rodeámonos de él más de treinta, y estámosle escuchando con tanto gusto que nos quita las canas". Tratava-se de jornais mais “populares, democráticos ou operários" informa Maria Cruz Seoane ${ }^{291}$, posto que o exemplar de um periódico aristocrático (La Epoca, por exemplo), chegava apenas ao subscritor, geralmente o cabeça da família, que destinaria à sua mulher somente os folhetins. É do próprio La Epoca o seguinte comentário, que endossa o costume existente nas últimas décadas do Oitocentos: "Llegan a la villa, al pueblo, a la aldea; uno de los dos o tres que saben leer reúne en derredor a los que no tienen más ideas que las que el outro le transmite; se leen los artículos o sueltos en que se reniega de todo, desde el Evangelio hasta la última Encíclica,292.

O costume transpôs o século, atualizando-se nos inícios do Novecentos, quando "70 ou $80 \%$ não sabia ler", sem que isso fosse obstáculo insuperável: "El entuasiasta analfabeto compraba su periódico y lo daba a un compañero”. Este, mais instruído, nas folgas do trabalho durante o dia, ou em serão noturno após o jantar, lia em voz alta, e era ouvido pelos demais com muita atenção. Não satisfeito, o "leitor" analfabeto pedia ao companheiro que assinalasse o artigo que mais lhe agradara e depois se dirigia a um outro para que repetisse o texto algumas vezes para que o memorizasse até que, finalmente, se punha a recitá-lo aos que não o conheciam. Essa rotina, descrita por Diaz del Moral - em seu Historia de las agitaciones campesinas andaluzas - mencionado pela autora, referia-se basicamente às aldeias daquela região, de onde era proveniente a maioria dos imigrantes que desembarcaram em São Paulo, e, portanto, parece razoável concluir pela experiência prévia trazida por alguns deles em sua bagagem imaginária.

Aos domingos, enquanto preparava o almoço, D. Pepa, mulher do carroceiro Garcia, também ouvia com satisfação as notícias que eram lidas e comentadas por Januário, amigo da família que chegava trazendo $O$ Estado e $O$ Correio Paulistano enquanto oferecia ao amigo Garcia "um rolinho de fumo em corda" vindo de Piracicaba ${ }^{293}$. A propósito do Correio Paulistano, Meyer sugere a existência de um "duplo público" leitor que foi sendo conquistado, mencionando a iniciativa do periódico em manter um jornalista italiano no atendimento à "sua clientela italiana, provavelmente já uma classe burguesa, a consumir o conceituado jornal do

${ }^{291}$ SEOANE, Maria Cruz. Historia del periodismo en España, II. El siglo XIX. Madrid: Ed. Alianza, 1983, pp. 14 e ss.

${ }^{292}$ Passim.

${ }^{293}$ MARX, G. Op. cit., pp. 169; 82; 131. 
PRP”, público este para quem Mussolini transmitia mensagens, mal disfarçando as simpatias fascistas, também do jornal ${ }^{294}$.

A livraria pertencente ao EDE oferecia, como vimos, exemplares que importava de grandes nomes do romance estrangeiro que disputavam a preferência dessas mulheres imigrantes. Destes, não faltava o célebre Ponson du Terrail e suas mais importantes obras: Hazañas de Rocambole; Resurrección de Rocambole e La Última Palabra de Rocambole ${ }^{295}$. Eles também eram publicados em fascículos pelo Correio Paulistano para quem, como para muitos outros órgãos da imprensa escrita, o folhetim tornara-se indispensável, em cujos repertórios, porém, "não excluíam a produção nativa"296. Voltando ao periódico, este já dispunha de Os mistérios de Paris, de Eugène Sue, outro ilustre escritor (um dos romances mais caros, custava 6\$000) e Don Quijote de la Mancha, este o preferido de Margarita, filha de Garcia (3\$500), enquanto publicava, em capítulos, A mulher adúltera, de Pérez Escrich ${ }^{297}$.

Meyer considera múltiplas as faces a explorar, engendradas por detrás do progressivo gosto pelo romance ficcional, dentre as quais, evocando Gramsci, ilustra com uma delas, a questão da "evasão":

A evasão da vida cotidiana é uma explicação que tanto se pode aplicar ao romance popular como à literatura artística: do poema cavalheiresco (Dom Quixote não busca ele também, evadir-se, até praticamente, do esmagamento e da estandardização de uma aldeota espanhola?) até o romance folhetim. Toda literatura e toda poesia não seriam por conseguinte um estupefaciente contra a banalidade cotidiana? ${ }^{298}$.

O folhetim lentamente ia conquistando o grande público, fato que foi descoberto pela imprensa nacional, e, pelo que observamos, também pela imprensa étnica, transformando-se,

${ }^{294}$ MEYER, M. Op. cit., p. 326.

${ }^{295}$ EDE 18.01.1913. Nesta mesma edição eram oferecidos romances "escolhidos", como os de Ponson du Terrail já mencionados, e mais: La liga del asesino (Xavier de Montepin); Historia de um crimen (Victor Hugo); El collar de la reina (Alexandre Dumas) e Memorias del diablo (Federico Soulié), treze títulos de Fernán Caballero, Carlos Magno, Paulo y Virginia e El verdadero horóscopo, sem identificar os autores. Afora estes, os mais caros, a 5\$500: Juana de Arco, resenha histórica; Aladino o la lámpara maravillosa; Simbad, el marino (con el cuento de Alí Baba y 40 ladrones); Historia de tres príncipes e Los senderos de la fortuna. Por 4\$000, oferecia-se El judio errante. Por 3\$000, ilustrados com gravuras e lâminas: Cuentos de una buena madre; Leyendas de Flandres; Viajes y aventuras e Cuentos de la Alhambra. Por 2\$500: Martín, el tonelero; Rosa de Tanemburgo; Cristóbal Colón e Cien hechos notables de la Historia de España. Por 2\$000: Leyendas de noche buena; El Castillo de Montrichard e Novelas orientales. Por 1\$500, El Libro de las adivinanzas ó sea La Buenaventura. Por 1\$000: Los huevos de Pascua; Cuentos de Carlos Perrault; Cuentos de la condesa D’Aulnoy; El ángel bueno y el ángel malo; El pájaro azul e Novelas caballerescas e a $1 \$ 000$ as obritas encadernadas e com título dourado La rosa de los vientos; La torre negra; El sueño de cien años; El niño robado, El compadre de la muerte; El doctor longevo; El caballero del cisne; El cazador furtivo; El visitante misterioso; La virgen de los espinos; El caballero de Lys e El tesoro. Finalmente, dois dos seguintes romances por 2\$000: Los dramas del amor e Amar hasta morir (Luis do Val); Maria, la hija de um jornalero (Aygüals de Izco); Las arrepentidas (Francisco Entrala); La maldición de Diós (Manuel Fernandez y Gonzalez); Fe, esperanza y caridad (Antonio Flores); Al toque de ánimas (Juan de la Puerta Vizcaino);

${ }^{296}$ MEYER, M. Op. cit., p. 381.

${ }^{297}$ EDE 01.01 e 12.04.1918.

${ }^{298}$ MEYER, M. Op. cit., p. 414. 
conforme Nelson W. Sodré "no melhor atrativo do jornal, o prato mais suculento que podia oferecer, e por isso o mais procurado"299 . "Inventado pelo jornal, e para o jornal" afirma Marlyse Meyer em seu precioso trabalho sobre o folhetim, o qual, nascido na França nos começos do século XIX, sob o formato original de matéria mais leve, mais recreativa e, portanto, mais acessível, passou a ser designado pelo espaço no jornal onde era colocado, le feuilleton, o rodapé, geralmente na primeira página, local destinado ao entretenimento e a várias formas de diversão: piadas, charadas, receitas de culinária, enfim. Fórmula de sucesso, novidade à qual todos buscavam aderir, evoluiria depois para a publicação de ficção em pedaços, fatiada, aprimorada progressivamente, à "genial adaptação à técnica do suspense" e ao rápido e amplo ritmo folhetinesco dos grandes temas românticos: o herói vingador ou purificador, a jovem deflorada e pura, os terríveis homens do mal, os grandes mitos modernos da cidade devoradora, a História e as histórias fabulosas, etc."300 . Constituíam fragmentos publicados com regularidade, mantendo os artifícios narrativos do corte e da suspensão em momento crucial, ativando a curiosidade do leitor que os adquiria, recortava e guardava, tratando-se, pois, segundo Meyer, de prática "reativadora do desejo"301.

A esta fórmula também se dedicaria com maestria o EDE, cujas séries "fatiadas" sucederam-se no período examinado. Em outubro de 1914, por exemplo, o jornal, apoiando-se em apurada estratégia mercadológica oferecia aos novos assinantes a possibilidade da remessa antecipada, inteiramente grátis, dos exemplares publicados até o final do ano, "acompanhados dos folhetins do El Cura de la Aldea", de Pérez Escrich ${ }^{302}$. Valenciano, Escrich era sucesso absoluto. Tendo escapado ao domínio francês dos folhetins, passara a produzir o "carro-chefe" do gênero "novela por entregas", largamente difundido por jornais e fascículos, em Madri e Barcelona $^{303}$.

Escrich converteu-se em romancista popular, os editores começaram a disputar-se suas obras. Os leitores estavam cansados de crimes e horrores à Ponson de Terrail. Escrich, variando de rumo, apresentava as cenas da vida com naturalidade, os seus personagens comiam com apetite, dormiam bem, viviam, enfim, dentro das condições normais e o público que estava acostumado a achar em cada página dois adultérios, uma dúzia de suicídios, vinte roubos, trinta violações e uma grosa pelo menos de crimes pequenos, deleitava-se contemplando os quadros que Escrich traçava, todos bonitos, limpos, ordenados com simetria, adornados com florzinhas; e, ainda que também contivessem crimes, adultérios e vícios, como apareciam aos seus olhos poetizados e como sempre havia personagens que pregavam a moral, que recordavam a cada instante os preceitos

\footnotetext{
${ }^{299}$ SODRÉ, N. Op. cit., 1966, p. 279.

${ }^{300}$ MEYER, Marlyse. Op. cit., p. 31.

${ }^{301}$ Idem, ibidem, p. 315

${ }^{302}$ EDE 21.10.1913. Trad. da autora.

${ }^{303}$ MEYER, M. Op. cit., p. 321.
} 
do Evangelho, os leitores proclamaram Escrich como romancista moral, e 10 ou 12 mil exemplares de seus romances se espalhavam por toda a Espanha com a celeridade que $o$ correio podia empregar em os distribuir pelos domicílios ${ }^{304}$.

A obra de Escrich chegou ao Brasil, onde se publicariam inúmeras edições. A partir de 1901 (e até 1918) o jornal O Estado de São Paulo exibiria seis romances de Escrich, sob a forma de folhetim ${ }^{305}$. Em 1913, os exemplares do El Cura de la Aldea trazidos da Espanha por Eiras, já eram o da $8^{\text {a }}$ edição da obra, que depois, dada a larga aceitação, seria exibida, em fragmentos, durante toda a segunda década pelo EDE.

Do mesmo autor, a livraria do EDE também oferecia La calumnia (também na $8^{\mathrm{a}}$ edição, obra ilustrada com doze cromos e dez cores), La caridad cristiana e Los que ríen y los que lloran $^{306}$.

Os folhetins tinham grande apelo popular: em finais de 1913, o EDE passaria por uma série de reformulações técnicas, estéticas e de conteúdo, anunciadas a seus leitores com grande alarido e antecipação. Dentre elas, informava-se, passaria a publicar em fatias "a popularíssima obra" El barquero de Cantillana, cujo herói, um bandido célebre, fora vítima do caciquismo e das injustiças típicas das pequenas aldeias, lançando-se ao mundo do crime, vivenciando aventuras e perigos, em constante ambigüidade de sentimentos ${ }^{307}$. Além desse, de enredo tipicamente folhetinesco, o periódico, como chamariz aos novos assinantes, prometia publicar, também em fascículos, El pan de los pobres e El rey de los bandidos, de Ortega y Frias, obra que evocava os seqüestradores da Andaluzia ${ }^{308}$. As três obras, informava-se aos leitores, se compradas avulsas custariam $20 \$ 000$, menos do que a assinatura anual do jornal, então saindo a $15 \$ 000$.

O período da Primeira Guerra estrangulou a importação de livros, fortalecendo a publicação fatiada de romances folhetinescos no periódico. Perez Escrich, contudo, se mantinha em alta, alternando-se, nos inícios de 1918, com Manuel Fernandez y Gonzalez, de Los siete niños de Ecija - este já publicado, conforme Nelson W. Sodré, no Jornal do Brasil, em finais do Oitocentos ${ }^{309}$ - , na seção recém-inaugurada, agora intitulada Folhetim do Diário Espanhol $^{310}$. Sobre o estrondoso sucesso de Escrich, assim se pronunciou Monteiro Lobato: "Em Escrich ama-se com furor, pelos processos embriagadores do "romantismo do coração". A

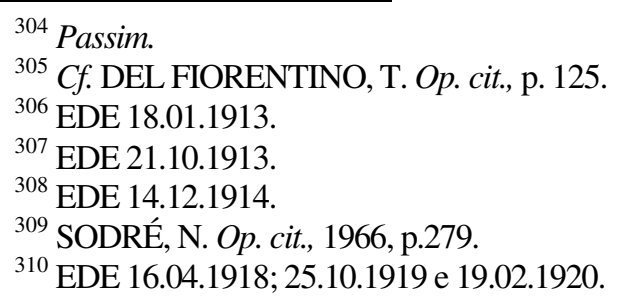


vida ali é uma cousa só: amor. A ação: amar. O objetivo, o fim supremo de tudo: cair nos braços do objeto amado, ou traduzindo isso na linguagem utilitária da mulher: casar",311.

Explorando novos nichos de mercado, o jornal passará a estampar, desde finais da segunda década, um conto infantil completo (não-picadinho) em edições alternadas, que teve em Las tres plumas a primeira experiência ${ }^{312}$.

A leitura compartilhada de partes de romances e folhetins ou de notícias de jornal, conforme ficou demonstrado consistia, desse modo, num daqueles momentos do cotidiano dessa camada humilde em que se abria espaço para algum lazer no pouco tempo disponível da fatigante labuta do dia-a-dia. Outra prática igualmente a encantava: as longas conversas relembrando o passado, também integradas ao seu espaço de convívio diário, dimensão onde ocorria, para Maria Inez Pinto, a maioria dos seus divertimentos, largamente integrado nas experiências do dia-a-dia, nas relações diretas e no compartilhar de experiências comuns de sobrevivência ${ }^{313}$.

Nas horas de folga, os mais velhos costumavam rememorar fatos do passado e lembranças da mocidade. Acontecimentos fora da rotina, e noticiário policial também entravam no cardápio. Guardavam-se os recortes de jornal destes eventos, como a notícia do desabamento da catedral que havia soterrado vários operários, dentre os quais alguns espanhóis. Nos domingos à tarde, formava-se uma roda de cadeiras e os vizinhos reuniam-se, na entrada do cortiço, onde eram desfiadas narrativas das mais diversas, algumas que atraíam particularmente às crianças, como os causos de assombração ${ }^{314}$.

Havia os que preferiam visitar os amigos, compartilhar as horas de descanso jogando $\operatorname{cartas}^{315}$. A guerra de Cuba sensibilizava não apenas os dirigentes das sociedades beneficentes. As guerras em geral constituíam-se farta munição para conversas informais: "Estourou a guerra", informava um interlocutor a outro. - "Que guerra?" respondeu-lhe este - "Entre os Estados Unidos e a Espanha, não viu nos jornais? Vamos ver agora os espanhóis apanharem até o céu da boca. Daqui a pouco começam a cair por aqui braços e pernas estraçalhados pela artilharia americana". "Mas os americanos", contestou o outro, "não têm exército permanente,

311 "A onda verde”: jornalismo. São Paulo: Revista do Brasil, Monteiro Lobato, 1921, pp. 162-162. In: DEL FIORENTINO, T.A. Op. cit., 130-131.

${ }^{312}$ EDE 18.10.1919.

${ }^{313}$ PINTO, M. Op. cit., p. 283.

${ }^{314}$ MARX, G. Op. cit., p. 71.

${ }^{315}$ Passim. Ver também "Vida privada e vida pública". In: RIBEIRO, S. Op. cit., 1994, p. 103. 
nem esquadra que valha. E a Espanha é uma grande potência!" - "Bravatas de espanhol!", concluiu o primeiro ${ }^{316}$.

Atrações como o circo também se afiguravam, para essa população, como ocasiões raras que os fazia se libertarem das tensões cotidianas. Nestes momentos de diversão, suspendia-se temporariamente a faina diária, a dura lida que envolvia suas vidas de labor incessante. Pela cidade, no período, circularam circos famosos ${ }^{317}$, cuja presença transformavase em grande acontecimento. A divulgação dos programas dava-se diretamente, no boca a boca ou através dos próprios palhaços que, para a farra da gurizada, circulavam pelas ruas montados em jumentos enfeitados "sentados às avessas, de frente para o rabo, os pés quase tocando o chão", conforme Zélia Gattai que se intrigava com o "sotaque espanhol dos animadores de

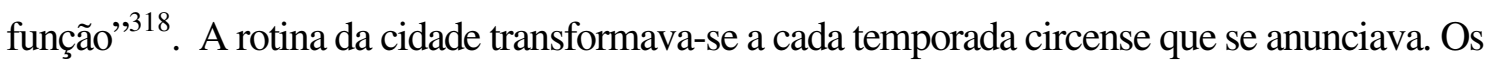
mais articulados, como o Queirolo, em cuja porta juntavam-se os vendedores ambulantes de cuscuz, quentão e pastéis ${ }^{319}$, divulgavam suas “arriscadas funções” no $\mathrm{EDE}^{320}$.

No Circo Alcibíades, dentre outros números, apresentavam-se com sucesso dois equilibristas, James Oller e Luis Lapeña ${ }^{321}$. Também conhecido como Circo Atenas, neste ano de 1922, seu proprietário haveria de alugar um terreno baldio na Moóca, onde instalou o vagãocasa, com a sua família - a mulher "Clotilde, o cavalo Diamante, o carneiro Janjão e a cadelinha Lili" ${ }^{322}$. Ao fundo, armaram-se os camarins de lona para os artistas.

No início da segunda década, havia se apresentado na cidade, no Circo Naski, na Avenida Celso Garcia ${ }^{323}$ e depois no Circo Tavares ${ }^{324}$, a Companhia Artística de Baile e Toque Andaluz, de Granada, dirigida por Pepe Amaya, em cujas apresentações de música e bailado compareciam até quatro mil pessoas. $\mathrm{O}$ sucesso fora tão estrondoso que interessava a várias empresas “do interior" contratá-los para apresentações.

Nas tardes de domingo, entretanto, quando em folga do trabalho, desfrutava-se da mais sensacional novidade da época, o cinematógrafo, uma das maravilhas do mundo moderno. Apresentado ao paulistano num dos "salões de variedades" era assim, no Paulicéia Fantástica

\footnotetext{
${ }^{316}$ AMERICANO, J. Op. cit., 1957, p. 387-388.

${ }^{317}$ Para uma apreciação do número de espetáculos circenses que se apresentou na cidade e das atrações que eram oferecidas, a partir de 1850, ver: ELAZARI, J. Op. cit., pp. 122-131.

${ }^{318}$ GATTAI, Z. Op. cit., pp. 37-38.

${ }^{319}$ BATINI, T. Op. cit., 1943 , p. 51.

${ }^{320}$ EDE 15.07.1919. Trad. da autora.

${ }^{321}$ EDE 16.05.1922.

${ }^{322}$ MARX, G. Op. cit., p. 95.

${ }^{323}$ EDE 29.07.1913.

${ }^{324}$ EDE 22.09.1913.
} 
que Afonso Schmidt nascido em 1890, ele próprio, havia tomado contato com a invenção: "a tela era pequena, engruvinhada. O projetor ficava atrás do público, fazia muito barulho. Antes de começar a exibição, vinha um homem com um canudo e esguichava água no pano. De repente a tela se iluminava, apareciam figuras trêmulas e saltitantes que pareciam atacadas de dança de São Vito",325.

E assim foi: até instalar-se em salas de teatro, que tinham a necessária infra-estrutura física, o cinematógrafo engatinhou ambulante pelas mãos de Francisco Serrador, imigrante espanhol que chegara em 1900 e que, até 1905, corria mundo com seu projetor de fitas.

Neste ano, sediado na cidade, organiza uma trupe ambulante, a Empresa Richabony, partindo para exibições no interior - Amparo, Ribeirão Preto, São Carlos e outras cidades, que assim conheceriam o cinema. Animado com a receptividade de sua engenhoca, Serrador retorna à Capital em 1907 e passa a adquirir, como vimos, vários barracões para as projeções. Com sucesso estrondoso e sessões lotadas, Serrador finalmente inaugura o Bijou-Theatre, construído especialmente como sala de cinema: "O cinematógrafo caiu nas graças do público: não há hoje em dia quem se recuse a visitar o Bijou-Theatre, centro predileto das principais famílias do high lif (sic) paulistano, ali passando horas de alegre diversão com os excelentes films da acreditada empresa Serrador", era matéria que circulava na Revista Vida Paulista, no ano de 1908. "O mesmo se dá no Brás”, completava a nota, “com o Teatro Colombo, que noite a noite, apanha boas enchentes ${ }^{\text {} 326}$. Note-se que o Colombo, no Largo da Concórdia, com capacidade para 2.400 pessoas, acabara de ser inaugurado, em fevereiro do mesmo ano de $1908^{327}$.

Serrador, em 1909, dono de um "cinematógrafo Richebourg", além de se apresentar no Bijou-Theatre para uma clientela mais seleta, com "variadas sessões, das seis e meia da tarde em diante", comercializava as fitas, vendendo ou alugando-as "tanto para a Capital como para o Interior, 328 .

Sua fina visão de mercado o faria trasladar seu projetor também para o populoso bairro do Brás onde, no Teatro Colombo seus freqüentadores contavam com sessões diárias, a preços módicos $^{329}$ : "Não podia ser mais auspiciosa a estréia do cinematógrafo da Empresa Richebourg, realizada na quinta-feira neste teatro. A casa estava completamente cheia e os diferentes números do variado programa muito agradaram ao público", anunciava a Revista

${ }^{325}$ SCHMIDT, A. Op. cit., 2003, p. 114.

${ }^{326}$ Vida Paulista. São Paulo: v.3 n.119, maio de 1908. Apud: DEL FIORENTINO, T. Op. cit., pp. $52-53$.

${ }^{327}$ ELAZARI, J. Op. cit., p. 151.

${ }^{328}$ O Estado de São Paulo, 27.09.1909. Apud: ELAZARI, J. Op. cit., p. 177-A.

${ }^{329}$ Em média, o preço de uma sessão de cinema, neste final de primeira década, era de $\$ 500$ a cadeira para adulto e \$200 para crianças, valor “bastante diminuto" para ELAZARI (Op. cit., pp. 180-181). 
Cri-Cri, em $1908^{330}$. Aborreciam-se, no entanto, com a banda de música que tocava "todas as noites a mesma peça" durante a exibição comprometendo, por conseguinte, o desfrutar das fitas - Aeronauta Amador, Totó Fumega, Uma noite em apuros; ou os dramas Os dois órfãos, $O$ órfão e Vingança de Angelina - de um "cômico irresistível"331. Nem reparavam as péssimas condições da projeção, com aparelhos que trepidavam, e nem se importavam com as acomodações bastante improvisadas nestas primeiras salas fixas que vieram substituir a projeção ambulante.

Maria Rita Galvão afirma que a "novidade" do cinema, abraçada de imediato entusiasticamente pela população mais privilegiada foi perdendo terreno aos poucos, transformando-se numa “diversão de crianças e das pessoas mais humildes", fato que associa ao preço dos ingressos, anunciados com estardalhaço nos jornais da época como "diversão ao alcance de todas as bolsas", o que teria provocado insuspeita rejeição daqueles que pretendiam identificar-se com o "gosto burguês", que os qualificava como "malcheirosos e ninhos de

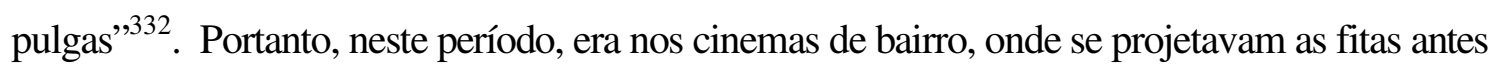
exibidas nos cinemas centrais, que ocorriam as concorridíssimas matinês que costumavam lotar a sala, ambiente de ampla sociabilidade e ponto de encontro, freqüentado por adultos e crianças, entre sorvetes, pipocas, excitação, suspiros e até desmaios pela emoção de ver na tela o famoso galã Rodolfo Valentino. "De diversión, mi única diversión fue el cine” comenta D. Maria Angelita Esparrel López, mencionando os então existentes no Brás, o Ideal, o Piratininga e o Olímpia, locais que freqüentava com sua irmã e uma amiga ${ }^{333}$.

O filme em pedaços, interrompido no momento de maior suspense, tal como o folhetim, era garantia de público no próximo domingo: "Não percam, no próximo domingo, a continuação de Tom Mix - O Cavaleiro do Texas", exibia o letreiro tremulante, para decepção geral $^{334}$.

Os filmes também apresentavam bom enredo para uma conversa. Quem não podia ir ao cinema, aguardava que alguém lhe contasse sobre a fita. E, quando no cinema, a platéia que não tinha leitura, agrupava-se em torno de quem soubesse ler os letreiros, tal como fazia a mãe de Zélia Gattai, em voz alta para pequena audiência que a circundava ${ }^{335}$.

Para os leitores do EDE aquele era um anúncio inusitado. Muitos sequer sabiam do que se tratava: a venda de um cinematógrafo completo, “una espléndida máquina marca Pathé

\footnotetext{
${ }^{330}$ Apud: ELAZARI, J. Op. cit., p.177.

${ }^{331}$ O Sorriso, 19.04.1908. Apud: idem, ibidem, p. 180.

${ }^{332}$ GALVÃO, M. Op. cit., p. 24.

${ }^{333}$ ANTONACCI, M. Op. cit., 2002, p.14.

${ }^{334}$ MARX, G. Op. cit., pp. 127-128.

${ }^{335}$ GATTAI, Z. Op. cit., p. 27.
} 
Fréres y todos los demás aparatos para luz esférica o eléctrica" acompanhada de "3000 metros de magníficas cintas cinematográficas" ${ }^{\circledR 36}$. Provavelmente se tratasse, como toda novidade, de um equipamento de custo elevado, pois ainda que o vendedor insistisse em esclarecer que " $e l$ precio es una verdadera garga, pues su dueño tiene necesidad de marcharse à Europa", meses mais tarde retornaria a sua veiculação, apenas acrescentando tratar-se de fitas de "asuntos dramáticos, cómicos y mágicos ${ }^{\text {337. }}$.

O Brás efervescia igualmente em outros momentos, embalado pelas festas religiosas. Ainda que não conste ter havido, como ocorreu à colônia italiana, a construção de uma igreja para a comemoração do santo padroeiro da Península, ou de alguma de suas Regiões, o espanhol ainda assim encontrou momentos privilegiados para a sua celebração. A festa da Romería, em sua origem tipicamente religiosa, constituiu-se uma dessas ocasiões que usufruía, ainda que, em sua concepção, tenha incorporado maciçamente elementos de festas profanas. Era no entanto, na festa da Virgem de Casalucce, a santa dos italianos - que tornava intransitável a Rua Caetano Pinto - onde a espanholada, misturada ao povaréu, renovava habilmente formas de culto ancestrais. Nela comparecia toda a família de Juan Garcia, o carroceiro e sua mulher, D. Pepa, reverenciava a santa, fazendo os "pequenos beijarem os pés da Virgem". Nela também se instalava a "barraca dos espanhóis", com enorme movimento e na qual o dono, um homem "gordo e corado, que sorria alvarmente com um dente de ouro bem à mostra, batia com a concha de ferro numa frigideira fazendo com que sua voz saltasse sonora e forte superando o barulho: - churros, churros, chu-uu-rri-tos". Garcia, aliás, trabalhava nesta barraca, ajudando o conterrâneo a fritar as longas argolas que eram despejadas em azeite fervente, enquanto a filha Lola participava da venda de prendas em benefício da igreja e Ramón, o outro filho do casal, tentava escalar o pau-de-sebo, sob o olhar atento e preocupado da mãe. Nestas horas, seu coração se transportava, evocando o outro filho, Rogelio, morto em acidente na queda do segundo andar do andaime de um edifício da Rua Líbero Badaró, onde trabalhava. Finalmente Ramón conseguia chegar ao alto e apanhar o prêmio em dinheiro, que seria ofertado ao pai, para pagamento do aluguel atrasado. Lola, que aos domingos freqüentava a missa das dez na Igreja do Brás, havia feito promessa para arranjar emprego, e agora ia todas as noites até a Igreja dos Enforcados, no Largo da Pólvora, em novena.

\footnotetext{
${ }^{336}$ EDE 06.06.1913. Trad. da autora.

${ }^{337}$ EDE 07.11.1913.
} 
Dentre as festas profanas, contudo, o Carnaval era a de maior afluência e participação popular, primazia conquistada pelo bairro do Brás, que se firmou como importante reduto da folia, a partir de inícios da segunda década ${ }^{338}$. Com antecedência começava-se a preparar a fantasia para os blocos, geralmente de sobras de retalhos conseguidos nas fábricas. Aos bailes às segundas-feiras, que se estendiam até de madrugada - como no Brás Politeama, no Largo da Concórdia - as moças, as "colombinas", devidamente acompanhadas por suas respectivas mães apresentavam-se em grupo, com meia-máscara e bailavam ao som da banda de música em que se tocava trompete, pistão, trombone, bumbo e prato ${ }^{339}$. Outras sociedades, no Brás, também realizavam atividades de salão no Carnaval, dentre as quais o Teatro Colombo e o Salão Celso Garcia. Na FE realizavam-se bailes para os sócios, ou para amigos e parentes dos mesmos, sobre quem se responsabilizavam, porém "reuniam elementos (...) relativamente bem situados na escala social do bairro, ${ }^{, 340}$. Tais bailes eram anunciados com antecedência no EDE e através deles procurava-se reavivar elementos culturais do país de origem, premiando-se "as fantasias masculina e feminina que melhor representem as regiões espanholas". Às mulheres, sugeria-se que comparecessem "com mantón ou mantilla"341.

No Teatro Cassino, de Paschoal Segreto "artisticamente engalanado con flores" os "soberbios" bailes à fantasia, com vasta divulgação, prometiam atender "a todas las exigencias del capricho" no "reino de la folia" com "mefistofélica iluminación, batalla de lanza, perfume, confettes y serpentinas" 342 . As "numerosas familias españolas" compareciam aos "bailes de disfraz" tanto no Teatro Cassino quanto no Teatro Colombo ${ }^{343}$.

$\mathrm{Na}$ terça-feira era o dia de assistir ao corso de automóveis abertos, caminhonetes e caminhões enfeitados “com festões de flores de papel, arcos de bambu, bandeirinhas coloridas e recoberto com colchas e tapeçarias" que tinha início na Rangel Pestana, acompanhado, em todo o percurso, por iluminação especial e pelas bandas de música estrategicamente postadas.

Essa prática, segundo Simson, surgira em decorrência do corso da Avenida Paulista no qual desfilavam "os burgueses endinheirados" em elegantes carros abertos, luxuosamente ornamentados e pertencentes às famílias da elite cafeeira e aos industriais, "para divertir o povo que se postava nas calçadas" ${ }^{344}$.

\footnotetext{
${ }^{338}$ SIMSON, O. Op. cit., p. 27.

${ }^{339}$ MARX, G. Op. cit., pp. 149-151.

${ }^{340}$ SIMSON, O. Op. cit., p. 31.

${ }^{341}$ EDE 18.01.1919.

${ }^{342}$ EDE 04.01 e 30.01.1913, dentre outros no mês de janeiro.

${ }^{343}$ EDE 03.02.1913. Disfraz: máscara.

${ }^{344}$ SIMSON, O. Op. cit., pp. 28 e 184.
} 
Surpreendentemente constatamos que, já em 1913, grupos de espanhóis organizados em associações carnavalescas também desfilavam "en el corso de la Avenida Paulista" sendo "muy aplaudidos": "Vai ou Racha, Los Legionarios del Averno y Los Excêntricos”, estes com "22 carruajes ${ }^{345}$. Infelizmente não conseguimos reunir qualquer informação adicional a seu respeito. Enquanto isso se dava com esse grupo, minoritário imaginamos, no Brás, outros mais remediados alugavam carros com motorista para os três dias de folia. A grande maioria, contudo, fazia o percurso a pé, dançando e brincando, em blocos ou cordões familiares, de vizinhança ou de colegas de trabalho que se formavam para a ocasião. Pudemos observar que, também aqui, a colônia se mobilizava, organizando "comparsas compuestas de connacionales nuestros" uma das quais "muy numerosa y ricamente ataviada con trajes de la época del descubrimiento, cantaba coplas patrióticas y de fina critica" e a outra, uma "excelente y chistosísima murga" era "dirigida por Don José Ruis" as quais "en todas partes fueron muy aplaudidas y vitoreadas",346.

Comentando sobre a coexistência pacífica entre grupos sócio-econômicos por vezes tão distintos no Carnaval do Brás - na Avenida Paulista "as classes sociais se mantinham separadas", não havendo nenhuma interação entre a platéia assistente e os participantes, nos carros -, Simson evoca a narrativa de um "informante espanhol", segundo o qual "os ricos aqui do Brás eram aqueles que tinham uma casa de calçados ou uma metalúrgica, mas eles também já tinham sido pobres. Então, não tinha problema, todo mundo se dava muito bem”. O corso era, definitivamente, o auge dos festejos de Carnaval; para a sua informante "a rua era mais divertida" comparada aos bailes nos salões. Nas ruas do bairro desfilavam pequenos grupos cômicos, para deleite da molecada e também dos adultos: "Aquellos lindos carnavales en Brás! Cada uno llevaba su silla a la esquina. Carneiro Leão, calle Caetano Pinto! En la esquina y listo! Nos sentábamos, mira, serpentinas hasta esta altura pisando! (mostrando con la mano aproximadamente diez centímetros del piso). Era una belleza!”, na imagem rememorada por uma espanhola, D. María Marín, referindo-se à década de vinte ${ }^{347}$.

Nestas ocasiões, era comum encontrar-se, no meio da agitação "um touro personificado por dois elementos cobertos com um pano escuro, levando uma grande caveira de boi com seus chifres, acompanhado pelo indispensável toureiro, armado de espada e pano vermelho; o pequeno grupo encenava alegres "touradas" pelas praças e ruas do bairro"348. Gattai, a propósito, comenta da fantasia de toureiro “com capa e chapéu bicorne de veludo negro, todo

\footnotetext{
${ }^{345}$ EDE 03.02.1913. Averno: inferno. Notar a denominação aportuguesada da associação "Vai ou Racha".

${ }^{346}$ EDE 03.02.1913. Comparsa: bloco ou cordão; murga: músicos.

${ }^{347}$ Silla: cadeira. ANTONACCI, M. Op. cit., 2002, p. 30.

${ }^{348}$ SIMSON, O. Op. cit., pp.28-33; 184.
} 
bordado de miçangas e lantejoulas" que surpreendera na sacola presenteada por rica família paulistana, proprietária da Drogaria Baruel, a uma sua antiga criada, então casada com um irmão de seu pai ${ }^{349}$. As fantasias mais elaboradas eram confeccionadas ou podiam ser adquiridas nas lojas, que anunciavam com antecedência: "Executa-se qualquer figurino, por mais original que seja"350. Lança-perfume marca "rodo" nacional; serpentinas "Íris", “Anakonda" e "Condor"; confetes de cores variadas e dourados; máscaras e demais artigos, também passavam a frequientar as páginas do periódico nas semanas que antecediam o Carnaval $^{351}$.

D. Pepa, para o corso do Brás, vestia os meninos, Pablo e Juanito, de palhaços feitos dos retalhos coloridos, fantasia que se complementava com um cone de papelão preso à cabeça, reclame da Companhia Antárctica; levavam um lança-perfume Pierrot e confetes, para as brincadeiras feitas entre os carros.

À noite, a família não perdia o desfile dos carros alegóricos, que se iniciava por volta da meia-noite, no centro da cidade. Deslumbravam-se com os carros, sobretudo com o dos Tenentes do Diabo, uma associação de amigos, delirantemente aplaudidos pelo público.

Foram três dias de preguiçosa loucura, três dias em que a maioria dos populares procurava reagir contra a apatia da crise e com os olhos faiscantes, lábios cheios de riso e de pilhérias e de bolsos cheios ... de vento ia se divertindo como podia na eterna máscara da aparência mostrar haveres e mostrar sossegos que jamais tirara ${ }^{352}$.

Simson, em seu trabalho, pontuou que a Lapa, local em que se fundou até um clube, seria o segundo bairro a promover um carnaval de forma planejada, responsável pela realização dos festejos de rua até o final da década de 1920. Em seus primórdios, no entanto, constituíra-se por operários das oficinas da ferrovia (São Paulo Railway) e pelos espanhóis da Fábrica de Bordados Lapa do suíço Henrique Scholk, que os mandara importar diretamente da Espanha e para os quais havia construído uma vila operária na Rua Engenheiro Fox, na Lapa de Baixo. A autora comenta a respeito do desfile anual dos foliões espanhóis, que estes se exibiam com fantasias feitas com sacos de estopa e no qual se recriava a "Murga" para a qual confeccionavam réplicas de instrumentos musicais feitos de papelão e "com os quais executavam uma curta melodia aguda e repetitiva que se tornara a sua marca",353.

Também em Catanduva, no Oeste Paulista, localidade de concentração de espanhóis, verificamos a existência de uma "murga", grupo popular de músicos que teria evoluído para um

\footnotetext{
${ }^{349}$ GATTAI, Z. Op. cit., pp. 40-41.

${ }^{350}$ EDE 15.02.1922. Anúncio da Casa Guerra, Rua São Bento, 84 e 86. Trad. da autora.

${ }^{351}$ EDE 21.02.1922. Anúncio da Casa do Japão, Rua São Bento, 46. Trad. da autora.

${ }^{352}$ ELAZARI, J. Op. cit., pp. 50-51.

${ }^{353}$ SIMSON, O. Op. cit., pp. 44-47.
} 
bloco de carnaval, cujos elementos satirizavam os representantes das camadas abastadas, num primeiro momento tendo, em seguida, assumido expressão política, quando entre seus seguidores alguns passaram a apoiar a falange franquista no poder e outros se mostravam declaradamente favorável aos republicanos, fato que teria rachado a colônia em dois blocos na cidade, provocando tremenda confusão quando o Centro Español local fez menção de colocar o retrato do caudilho (Franco) numa das suas salas ${ }^{354}$.

A sexta-feira santa era data muito respeitada pela colônia, como ademais por toda a gente. Procurava-se fazer silêncio, em sinal de respeito. Até mesmo os vendedores não apregoavam suas mercadorias em voz alta; sequer os automóveis tocavam buzinas. Todos se

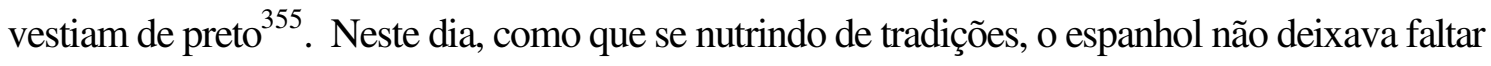
à mesa o bacalhau e o grão-de-bico: "Se não tinha grão-de-bico e bacalhau na quinta e na sextafeira santa, não tinha nada pra mim. Nunca comi arroz e feijão nesse dia, desde criança; minha mãe fazia; depois, meu marido era espanhol, gostava muito e eu sempre fazia", declarou D. Teodora, nascida no Brasil em 1905, ano da chegada de seus pais, naturais de Cáceres, na Extremadura $^{356}$. O bacalhau fora descoberto pelos bascos, região considerada o berço da culinária espanhola e daí se disseminou para toda a Espanha, por ser alimento de fácil conservação, apenas à base de sal.

Toda a família comparecia à procissão do Senhor Morto, que saía da Igreja do Brás às seis horas da tarde, com banda de música, seguindo pela Avenida Rangel Pestana até alcançar a Rua Monsenhor Andrade, daí retornando pela Rua do Gasômetro - à qual comparecia D. Pepa com a mantilha de renda negra que trouxera da Espanha ${ }^{357}$. Vinham devotos até do interior para participar da "procissão do enterro", a qual era acompanhada por famílias inteiras de imigrantes, especialmente italianos, portugueses e espanhóis, "profundamente religiosos", aos quais se mesclavam "pessoas que pertenciam às irmandades, crianças vestidas de anjinho, pagadores de promessas, casais da elite, enfermos recém-curados, fiéis de todas as classes sociais, gente pobre rezando terços, mendigos com uma vela numa das mãos e a outra estendendo o chapéu para esmolas, trôpegos e aleijados apoiados em muletas", seguidos pela banda de música ${ }^{358}$. Após o cortejo, a descontração, a cidade voltava ao normal com seus ruídos, e os fiéis, que haviam

\footnotetext{
${ }^{354}$ CÁNOVAS, M. Op. cit., 2001, p. 326.

${ }^{355}$ AMERICANO, J. Op. cit., 1957, pp. 268 e ss.

${ }^{356}$ Fragmento de depoimento à autora. Villa Novaes, 1980.

${ }^{357}$ MARX, G. Op. cit., pp. 45-55; 131;137; 151-152. Ver também: AMERICANO, J. Op. cit., 1957, pp.

${ }^{358}$ PINTO, M. Op. cit., pp. 159 e ss (citando Jorge Americano).
} 268-271. 
jejuado, já podiam dirigir-se aos carrinhos e tabuleiros dos vendedores ambulantes estacionados nas proximidades.

O sábado de Aleluia era aguardado pelas crianças, excitadas com o "Judas", que surgia em cada esquina e no poste da entrada do cortiço. Aguardava-se a autorização oficial para a malhação, pelo repicar dos sinos, que liberava a molecada ansiosa por estraçalhar o boneco de pano $^{359}$. No interior, o espanhol comemorava a Aleluia obstruindo as estradas com grossos troncos de árvore, arrancando mata-burros, trancando porteiras ${ }^{360}$.

Era no Natal, porém, que essas criaturas procuravam aproximar-se das raízes pátrias, na evocação das lembranças e dos sentidos guardados em sua bagagem imaginária, das imagens, gostos, sabores e temperos da culinária ancestral, estreitando os vínculos que não se querem perdidos.

Os hábitos alimentares do imigrante podem ser considerados como o aspecto mais persistente em seu processo de aculturação ${ }^{361}$. "Dentre as diferentes formas de memória coletiva, uma das mais persistentes é a memória culinária" que "com sua variedade de sabores, aromas e cores" resistiria "ao impacto do tempo e até mesmo ao desenraizamento cultural e geográfico" que, "por não se diluírem no contato com o outro, mantém a tensão da alteridade, do convívio multicultural" ${ }^{\prime 362}$.

E, assim, de véspera, já se iniciavam os preparativos. D. Pepa caprichava algumas receitas elaboradas em datas especiais, herdadas num aprendizado que se perpetuara de geração a geração. A cozinha do dia-a-dia, contudo, também se baseava em práticas milenares, recebendo, porém, a cada manhã, frente aos parcos recursos dessas mulheres, inventivas e habilidosas adaptações, versatilidade que se impunha como condição de subsistência.

As sardinhas "que unia pela cauda em feixe de três, formando um leque que passava no ovo e em seguida na farinha", iam sendo fritadas no "azeite quente" um dos quais acolhia o puchero, espécie de sopa elaborada à base de grão-de-bico, cozido muito popular na Andaluzia: "me criei com o carbón e a lenha, tínhamos o braseiro e minha mãe pegava o puchero, um balde de barro ou de ferro, deixava de noite tudo preparado, o fogo

${ }^{359}$ AMERICANO, J. Op. cit., 1957, pp. 266-271 e MARX, G. Op. cit., p. 152.

${ }^{360}$ ALMEIDA, A. Tavares de. Oeste Paulista, a experiência etnográfica e cultural. Rio de Janeiro: Alba Editora, 1943, p. 189.

${ }^{361}$ FRANCO, Ariovaldo. De caçador a gourmet. São Paulo: Editora Senac, 2001, p. 24. Apud: CORNER, D. Op. cit., p. 18.

${ }^{362}$ HECK, Marina e BELLUZZO, Rosa. Cozinha dos imigrantes. Memórias \& Receitas. São Paulo: Ed. Melhoramentos, 1999, p. 13. Apud: CORNER, D. Op. cit., p. 82.

${ }^{363}$ MARX, G. Op. cit., p. 19. 
aceso e ia dormir; de manhã estava tudo macio, bem cozido, ${ }^{\text {364 }}$. Desse modo, valendo-se do domínio do saber adquirido, D. Pepa, como tantas outras mulheres emigrantes, reproduziam no seu cotidiano, através da culinária, imagens, momentos e sabores, forma de transmutar a dura realidade, tornando-a mais suportável. "O aprendizado" diria Thompson, "não se restringe à sua expressão formal na manufatura, mas também serve como mecanismo de transmissão entre gerações. A criança faz seu aprendizado das tarefas caseiras primeiro junto à mãe ou à avó”. Nesse momento, esclarece, "a educação formal, esse motor da aceleração (e do distanciamento) cultural, ainda não se interpôs de forma significativa nesse processo de transmissão de geração para geração" e as "tradições se perpetuam em grande parte mediante a transmissão oral”365.

A permanência de elementos da cozinha regional, trazidos na memória, e reproduzidos por mãos habilidosas, muitas vezes improvisando ingredientes ou substituindo por outros mais acessíveis, reatualizava o passado dessas criaturas, e mantinha o elo com a pátria distante: "pela manhã, café com pão feito em casa, com qualquer coisa, tinha chocolate também; no almoço, as migas com sardinhas ou pimentões. À noite, um prato chamado olla com legumes e um pedaço de carne de porco salgada ou uma morcilla”. As migas, alimento barato e de fácil preparo, mantiveram-se à mesa dos menos favorecidos, recebendo inusitados ingredientes locais na sua formulação: "os mais pobres faziam as migas de fubá e farinha, que era mais gostosa e sustentava mais", declara D. Rosário, acrescentando que "comia migas todos os dias", preparadas com migalhas de pão, que ia colocando na frigideira, mexendo e virando com "óleo do bom”. Costumava acompanhar o prato com azeitona, salada de alface, de tomate, lingüiça, bacalhau ou sardinha, numa evidente combinação a elementos da culinária local ${ }^{366}$.

O pão e o azeite eram fundamentais na cozinha andaluza: "óleo do bom", no dizer popular, significava o uso do ingrediente correto na preparação alimentar tradicional. "En principios del siglo, los jornaleros andaluces, que fueron un grupo de los que más inmigrô", afirma Jesus Contreras Hernandez, estudioso de gastronomia e alimentação da Universidade de Barcelona, "tenían una cocina hecha con aceite y pan". Absolutamente correto. "Echar el aceite en el pan y mojar el pan en el plato ${ }^{\circledR 367}$, traduzia hábito alimentar imemoriável trazido pelas levas de imigrantes andaluzes, presente no cotidiano de muitas gerações.

\footnotetext{
${ }^{364}$ Fragmento de depoimento. Sr. José Luis Almansa Esquetino, Don Pepe, andaluz de Málaga e proprietário do Restaurante La Alhambra, na Capital Paulista. In: CORNER, D. Op. cit., pp. 33 e 111-112.

365 THOMPSON, Edward P. "Costume e Cultura”. In: Op. cit., 1998, pp. 13-24.

${ }^{366}$ Fragmento de depoimento. Sra. Maria del Rosário Rodriguez Benitez, chegada ao Brasil, em 1923, com dez anos de idade. In: CORNER, D. Op. cit., pp. 34, 43 e 138.

${ }^{367}$ Fragmento de depoimento. In: CORNER, D. Op. cit., p. 42.
} 
A região andaluza é a maior produtora de azeite de oliva da Espanha, tradição que remonta à invasão romana pela qual foram irrigadas terras da costa leste para o plantio de oliveiras, disseminando, em consequiência, o hábito alimentar decorrente, que ainda hoje tipifica a cozinha daquele país.

Em suas lembranças rememoradas, o Sr. Ildefonso Blasquez Sanchez insistia em que muitos dos que emigraram, compatriotas com os quais acabara se encontrando na mesma localidade no interior de São Paulo (Villa Novaes), não necessitariam tê-lo feito, porque "tinham para viver, tinham bastante azeitona, engordavam porcos, vendiam azeite, vendiam toicinho", lamentando a opção, a seu ver equivocada, de alguns indivíduos que "largavam de comer aquela azeitona, presunto (jamón), vinho de primeira, pão de primeira que era de farinha de trigo moída lá no rio, no moinho" para vir para o Brasil "comer arroz, feijão e mandioca...."368.

O período inicial, de adaptação, era dos mais difíceis; muitos não conseguiam se acostumar à culinária local, desaprovando categoricamente certos pratos usuais da mesa brasileira como o arroz, a mandioca, a carne seca ${ }^{369}$, ou o "jiló, abobrinha e miúdos de boi”370, por exemplo.

Temperos tradicionalmente usados também não eram encontrados, como a páprica e o açafrão, este paulatinamente substituído pelo colorau ${ }^{371}$ nas modestas casas da população pobre, mas que, aos poucos, por iniciativa das casas importadoras, passavam a freqüentar a mesa das famílias abastadas ${ }^{372}$.

Enquanto isso se dava, nas camadas inferiores, até mesmo para a elaboração do pão, alimento tão caro aos espanhóis, faltava o ingrediente básico, a farinha de trigo que, por isso, heresia suprema, passava a ser misturada ao fubá, fato que chegou a ser objeto da satirização de um bloco de carnaval ou "murga", cordão popular de músicos, que compôs os seguintes versinhos, zombando do ocorrido ${ }^{373}$ :

${ }^{368}$ Nascido em Cáceres, na Extremadura, em 1905, aos nove anos o Sr. Ildefonso emigrou com a família, dirigindo-se para uma fazenda do Oeste Paulista. Fragmento de depoimento. In: CÁNOVAS, M. Op. cit., 2005, p. 101.

${ }^{369}$ Cf. "Alimentação local, sabores espanhóis". In: CÁNOVAS, M. Op. cit., 2005, pp. 286 e ss.

${ }^{370}$ CORNER, D. Op. cit., p. 90.

${ }^{371}$ Fragmento de depoimento. Sra. Maria del Rosário Rodriguez Benitez, chegada ao Brasil, em 1923, com dez anos de idade. In: CORNER, D. Op. cit., p.107.

${ }^{372}$ EDE 08.11.1919. A importadora Hermanos Eiras Garcia, dentre sua carteira de importações, vinha trazendo regularmente da Espanha o açafrão e outras especiarias mais como o cominho, a pimenta moída, a pimenta em conserva; além disso, raiz de genciana (antipirético) e o anis em grão (de Málaga e de Alcalá La Real). Trad. da autora.

${ }^{373}$ RANGEL, W. Op. cit., 1951, pp. 395-446. 


\begin{abstract}
Ahora los panaderos
nos venden el pán

con el noventa por ciento

de puro fubá

Como es costumbre

que ya tenemos

aunque sea malo

nos lo comemos

$Y$ podeis creer

que nos parecemos

con un tico-tico

comiendo farelo

O pão fazia-se acompanhar em todas as refeições, mas era também habitual na preparação de alguns alimentos tradicionais, constituindo, com o azeite, a base do gaspacho, espécie de "sopa fria" preparada com "pepinos, tomates, vinagre, azeite de oliva e pão",374, testemunha diária do humilde cotidiano submisso e silencioso da população jornalera do campo andaluz, aspectos que, em detalhes, pudemos recuperar através do vigoroso e impagável retrato pintado por Blasco Ibañez, de que destacamos um pequeno trecho na íntegra ${ }^{375}$ :
\end{abstract}

Trabajar todo el día bajo el sol ó sufriendo frío, sin más jornal que dos reales y cinco como retribución extraordinária e inaudita en la época de la siega! Era verdad que el amo daba la comida, pero, que comida(...)

En verano, durante la recolección, les daban un potaje de garbanzos, manjar extraordinário, del que se acordaban todo el año. En los meses restantes, la comida se componía de pan, sólo de pan. Pan seco en la mano y pan en la cazuela, en forma de gazpacho fresco o caliente, como si en el mundo no existiese para los pobres otra cosa que el trigo. Una panilla escasa de aceite [...] servía para diez hombres. Había que añadir unos dientes de ajo y un pellizco de sal ...

Tres comidas hacían al dia los braceros, todas de pan: una alimentación de perros. A las ocho de la mañana, cuando llevaban más de dos horas trabajando, llegaba el gazpacho caliente, servido en un lebrillo. Lo guisaban en el cortijo, llevándolo adonde estavan los gañanes [...].

A mediodía era el gazpacho frío, preparado en el mismo campo. Pan también pero nadando en un caldo de vinagre, que casi siempre era vino de la cosecha anterior que se había torcido. Unicamente los zagales y los gañanes, en toda la pujanza de su juventud, le metían cucharada en las mañanas de invierno, engulléndose este refresco, mientras el vientecillo frío les hería las espaldas. Los hombres maduros, los veteranos del trabajo, con el estómago quebrantado por largos años de esta alimentación, manteníanse á distancia, rumiando un mendrugo seco.

\footnotetext{
${ }^{374}$ CORNER, D. Op. cit., p. 113.

${ }^{375}$ BLASCO IBAÑEZ, V. Op. cit. Apud: CÁNOVAS, M. Op. cit., 2001, pp. 86-87.
} 
Y por la noche, cuando regresaban á la gañancia para dormir, otro gazpacho caliente: pan guisado y pan seco, lo mismo que por la mañana. Al morir en el cortijo alguna res cuya carne no podía aprovecharse, era regalada á los braceros, y los cólicos de la intoxicación alteraban por la noche el amontoamiento humano [...].

Los hombres empezaban de pequeños el aprendizage de la fatiga aplastante, del hambre engañada.

Base da alimentação, como vimos, também era o azeite, um dos primeiros produtos a ser importado da Espanha, com marcas exclusivas de Sevilha, na Andaluzia - "Cruz Blanca" e “Cruz Verde", por exemplo ${ }^{376}$, claro indício de sua demanda.

D. Pepa, assim, esmerava-se no preparo dos pratos. Valendo-se do aprendizado ancestral caprichava na elaboração dos borrachuelos, bolinhos de farinha, erva-doce, açúcar e pinga e dos mantecaus, biscoitos feitos de manteca (banha), que haveriam de ser compartilhados com a vizinhança do cortiço onde residia, em noite festejada pela troca de pequenos regalos e grandes evocações. Eram pratos modestos, populares e tradicionais. Essa gente simples, menos favorecida economicamente, procurava compor um cardápio com ingredientes baratos, fáceis de obter, alguns adaptados às novas circunstâncias. Para aqueles de dispunham de alguma reserva, instalara-se na cidade uma fábrica de doces e biscoitos típicos, oferecendo para as festas de final de ano os tradicionais "torrones de amêndoas que dispunha em caixas à fantasia próprias para presente" ${ }^{\text {377 }}$.

Como vemos, também na doçaria a influência dos dominadores fez-se presente. Não apenas no ingrediente, as amêndoas, mas nos procedimentos de fabricação, o torrone, assim como o churro - feito em casa por Lola, filha de D. Pepa e do carroceiro Garcia e consumido na festa da Virgem de Casalucce na "barraca dos espanhóis" - revelam seu berço distante da Península ${ }^{378}$.

O retorno da missa do galo iniciava a reunião, em cuja mesa se dispunham os pratos preparados pelos demais vizinhos do cortiço, italianos, portugueses e espanhóis, e onde se insinuava até mesmo um cuscuz encomendado de uma baiana pelo amigo negro da família.

${ }^{376}$ EDE 23.11.1912. O anunciante importador era Isaac G. Lopes.

${ }^{377}$ EDE 04.11.1921. Para o período das festas natalinas "João" Bobadilla à testa de sua "Gran Fábrica" esmerava-se em especialidades doces, que divulgava pelo EDE. Trad. da autora.

${ }^{378}$ Ainda hoje na cidade de São Paulo, pode-se comer o autêntico churro espanhol - em caracol e sem recheio nenhum - nas madrugadas dos finais de semana. Fabricado há 44 anos pelo Toninho dos Churros, numa pequena portinha escondida da Rua Ana Neri, na Moóca, ali, em meio a grande número de clientes servidos diretamente no balcão, o descendente de espanhóis, pelas mãos de quem se conserva uma das mais tradicionais e populares receitas da culinária espanhola, quando indagado a respeito, não hesita em se considerar "um caipira de Bragança". 
Comendo, bebendo, conversando e jogando tômbola varavam a noite ${ }^{379}$, em ambiente amigável que era a expressão da diversidade, mas também da autonomia cultural de grupos emigrantes oriundos de distintos universos.

Em outros pontos da cidade, em endereços mais conceituados, a mesa tradicional no período das festas de final de ano (e imaginamos que também em outras ocasiões), era composta com maior requinte e variedade, fato atestado pela intensificação na veiculação de reclames pelas casas especializadas na importação de produtos típicos, de diversas regiões: "pasas; sidra de Astúrias; frutas secas; higos de Málaga; castañas; uvas de Almeria; vinos Málaga, manzanilla, Jerez; aceitunas sevillanas; pimientos; chorizos; conservas de pescado; frutas en latas de Rioja; aceites; garbanzos; únicos representantes de los vinos de la renomada casa Gabrain y Olaondo, de S. Sebastian" ${ }^{380}$.

Trata-se de uma variedade enorme, cuja diversidade obedece a especificidades regionais, fruto de diferentes tipos de clima, solo, temperatura, frequiência de chuvas, proximidade do mar, altitude e que, além do mais, rende-se a tradições históricas, conjunto de variáveis determinante para esse fenômeno. Atesta um imigrante "lo dificil que ha sido y sigue siendo identificar una cocina española. Porque aquí mas bien diríamos, la cocina ha estado diríamos no descompuesta: sino que hay como catalana, vasca, gallega, etc. Y además se perciben como diferentes unas cocinas de otras" ${ }^{381}$.

Para Dolores Corner, que investigou detidamente esse aspecto, mais que isso, trata-se mesmo de reconhecer particularidades tipicamente locais, microrregionais, consolidadas por meio do intercâmbio que acabou se estabelecendo após o descobrimento da América, quando diversos ingredientes e componentes penetraram na culinária local, mas, fato anterior, há que se considerar toda a influência dos invasores, os mouros em particular, que permaneceram por longos séculos em determinadas regiões da Península. Da América, dentre outras influências, o espanhol deve-lhe seu prato símbolo, a tortilla, posto que "se não fosse a América" de onde foi introduzido o cultivo da batata "não haveria a tortilla espanhola, que não passaria de um omelete ${ }^{382}$. Prato tradicional - que na cidade servia de almoço ao andaluz Juan Garcia, no intervalo da lida cotidiana, quando parava a sua carroça e se sentava em uma mesinha vaga de qualquer botequim onde pudesse abrir o embrulho preparado por D. Pepa ${ }^{383}$ a tortilla clássica,

\footnotetext{
${ }^{379}$ MARX, G. Op. cit., p. 140.

${ }^{380}$ EDE 03.01.1913. Marino Conti \& Irmãos. Importadores de Gêneros Espanhóis.

${ }^{381}$ Fragmento de depoimento. Sr. Jesus Contreras Fernandez. In: CORNER, D. Op. cit., p. 97.

${ }^{382}$ Idem, ibidem, p. 94.

${ }^{383}$ MARX, G. Op. cit., 1996, p. 39.
} 
fazia-se acompanhar, em seu preparo bastante simples, do uso de ingredientes próprios de cada região, "como pimentões vermelhos, verduras, bacalhau, alho-poró, tomates ou aspargos"384.

Não escapa à simples observação este fato, revelado pela análise dos produtos e gêneros alimentícios que passaram a ser importados da Espanha, um verdadeiro caleidoscópio, ilustrando hábitos e preferências mas, por outro lado, também indicativo das origens regionais desse consumidor. Cumpre acrescentar que algumas casas importadoras, em expansão, tratavam de instalar uma filial - sucursal, como chamavam - no bairro do Brás, na qual dispunham de todos os produtos encontrados na Matriz, esta em geral instalada na zona central $^{385}$. Porém, residindo onde residisse, a esses produtos não tinham acesso os menos favorecidos, cuja magreza de ganhos era insuficiente para prover as necessidades mínimas do próprio sustento e o de sua família e que, evocando uma tradição ancestral de hábitos rurais, procurava, dentro das condições, manter uma pequena criação de animais domésticos, além de um pequeno roçado de mantimentos (verduras, mandioca, batata-doce, milho, banana, feijão), hábitos mais comuns no emigrante que permaneceu no interior, não desprezado, porém, por aquele que se fixou na cidade.

A carne de porco sempre representou alimento importante na culinária espanhola, cuja matança constituía prática milenar nas aldeias, com a participação de toda a comunidade. $\mathrm{O}$ hábito foi transportado pelos imigrantes que se estabeleceram com pequenos sítios no interior do Estado. As falas dos emigrantes, nos depoimentos que coletamos, evidenciaram esse aspecto: "Lá [no sítio] tinha muita fartura; nós era pobre, o sítio era pequeno, mas tinha fartura de tudo", relata D. Teodora Dias. E prossegue: "a cada três meses meu pai matava um cerdo de sete, oito arrobas, que enchia três latas de gordura de vinte litros e minha mãe fazia aquelas baciadas de lingüiça que dava gosto, espanhola legítima! Ela temperava, enchia aquelas tripas grossas, bem lavadas com limão, ou vinagre..." 386.

É do seu pernil, curado durante longo período de tempo, que se originou uma das mais saborosas iguarias da culinária espanhola, o jamón ${ }^{387}$, evocado com saudades pelo $\mathrm{Sr}$. Ildefonso, de Villa Novaes, e disputadíssimo, como prêmio, no pau-de-sebo (ou cucaña) da festa da Romería, realizada na cidade pela primeira vez nos anos finais da segunda década.

Vestígio indicativo desse arraigado hábito alimentar, ainda hoje podemos encontrar em funcionamento, na cidade de São Paulo e também no interior, especialmente na região de

${ }^{384}$ CORNER, D. Op. cit., p. 104.

${ }^{385}$ A Importadora Marino Conti \& Irmãos, por exemplo, com sede em 1913 à Rua D. José de Barros, 16, aparece em 1921 com uma sucursal na Rua Piratininga, 132, especializada em "vinhos espanhóis, conservas, queijos, jamones". EDE 03.01.1913 e 15.02.1921, respectivamente.

${ }^{386}$ Fragmento de depoimento. D. Teodora Dias. In: CÁNOVAS, M. Op. cit., 2005, p. 287.

${ }^{387}$ Muitas das informações foram obtidas em: CORNER, D. Op. cit., pp. 96 e 113. 
Catanduva, no Oeste Paulista, frigoríficos de imigrantes espanhóis especializados na fabricação, não apenas do jamón, mas também de charcutaria, como lingüiças, chorizos (espécie de salame) e morcillas (embutido à base de sangue) ${ }^{388}$.

Além das festas - religiosas e profanas -, multiplicavam-se as formas de lazer e sociabilidade do emigrante, nos intervalos concedidos pela faina cotidiana. No contato com a natureza, ao ar livre, desenrolavam-se muitas dessas possibilidades de recreação, tranqüilidade e até romance. A cidade possuía alguns locais - recreios, parques, jardins e passeios públicos em que eram comuns as reuniões, os piqueniques, as comemorações, ou o simples bate-papo. Uniam o lazer a certo exercício de criatividade, aproveitando-se de que a cidade possuía nos seus arredores matas e campos, locais que permitiam unir, ao desfrute do lazer, o aproveitamento para consumo de diversos animais que podiam ser caçados nessas áreas, abundantes de pássaros e de caça de pêlo. Além disso, outros alimentos e ervas podiam ser coletados, além de lenha e madeira, experiência baseada na tradição que muitos imigrantes traziam de sua terra natal.

Comentando acerca das cozinhas populares da Andaluzia rural, Isabel Turmo identificou, nas várias regiões, uma alimentação básica, composta de "pan, aceite, legumbres, arroz, patatas, ajos, cebollas, tomates, pimientos y algunas hortalizas más”, diferenciada, contudo, em alguns casos, por características locais diretamente ligadas a seu meio natural, “gracias a la caza, la pesca a pequeña escala (...)”389. Reproduzindo aqui alguns desses hábitos ancestrais, alguns imigrantes, pelo desconhecimento do entorno e do meio, poderiam ser repentinamente surpreendidos pela fatalidade, perdendo-se na mata, tal como aconteceu a Francisco Rodriguez Galvez, cuja família, em desespero, solicitava ajuda no EDE, informando que ele havia saído para caçar "com um compadre seu, na Serra de Taipas, linha inglesa" e desaparecera $^{390}$.

A autora mencionada informa também a respeito de outros alimentos como "tocino, chorizo, morcilla y queso" que compunham, com os "tostones" (pão torrado em pedaços) acompanhados de "aceite con ajo asado o crudo para restregar", as "sardinas" e o "bacalao seco", a base das cozinhas "campesinas y marineras",391.

${ }^{388}$ Ver, a esse respeito: CORNER, D. Op. cit., pp. 134 e ss.

${ }^{389}$ TURMO, Isabel González. "Movimientos migratórios y culturas del trabajo en las cocinas populares. El caso de Andaluzia". In: ARANDA, Antonio Garrido (comp.). Cultura alimentaria de España y América. Huesca: La Val de Onsera, 1995, p. 325. A esse respeito, consultar também: FLORENCIO, Rafael Nuñez. Con la salsa de su hambre: los extranjeros ante la mesa hispana. Madrid: Alianza, 2004.

${ }^{390}$ EDE 05.03.1914. Trad. da autora.

391 TURMO, I. Op. cit., p. 327. 
Desse modo, evocando prática ancestral, buscava-se a margem dos rios para usufruir o tempo livre, na qual "pachorrentas criaturas alugando anzóis, horas permaneciam pescando céleres lambaris" ${ }^{\prime 392}$. Os passeios de barco e os piqueniques, especialmente às margens do Rio Tietê consistiam agradáveis opções de lazer barato para a população que, de resto, ainda voltava para casa com o produto da pesca.

Imaginamos que muitos espanhóis, especialmente aqueles oriundos de Regiões de grande desenvolvimento da indústria pesqueira, caso da Galícia, e de onde, com insistência, refluíam notícias provenientes de determinadas Províncias - El Ferrol, por exemplo - dando conta da extrema miséria provocada pela falta do pescado "por causa da pesca a dinamite",393, que prejudicava especialmente os pescadores de sardinhas, e do propósito de sua gente em emigrar à América do Sul, enfim, imaginamos que esses indivíduos, uma vez na cidade, passassem a se utilizar da experiência ancestral, na exploração do meio para o complemento de sua subsistência diária.

A pesca revelava-se farta nos dois principais rios da cidade, e fácil em determinados trechos, sobretudo no Rio Tietê entre a Vila Maria e o Tatuapé, local preferido para as animadas pescarias coletivas e onde se multiplicavam peixes de várias espécies, incluindo-se os cascudos que eram em maioria agarrados à unha. Eram também abundantes os camarões de água doce, nas épocas de vazante, para cuja captura eram utilizadas peneiras, camarões estes com os quais se preparavam omeletas, servidas no almoço e no jantar, nas épocas das "vacas magras"394.

O desconhecimento do meio, no entanto, por vezes transformava essas incursões em tragédia. Muitos morriam afogados, talvez por estarem desacompanhados à pescaria, ou por desconhecerem os locais mais profundos e perigosos, o fato é que, como Paulo Vaz, tipógrafo que perdeu a vida por afogamento no Tietê $\hat{e}^{395}$, este rio deve ter sido testemunhas de inúmeras outras ocorrências fatais no período.

O consumo do peixe era prática observada também nas camadas mais bem posicionadas - que, naturalmente, não apreciariam a sua captura primitiva nos rios da cidade tanto que, dentre os produtos e comestíveis importados da Espanha, relacionados na Memória Comercial de 1910, denominada Informe a los exportadores españoles e preparada pelo CGE

${ }^{392}$ SOUZA, E. Op. cit., 1946, p. 62.

${ }^{393}$ No EDE 04.09.1912, matéria similar referindo-se ao pueblo de Vivero; no EDE 21.03.1914, ao pueblo de Ares.

${ }^{394}$ PENTEADO, J. Op. cit., 1962, pp. 163 e ss.

${ }^{395}$ EDE 23.02.1922. 
para informar das potencialidades do mercado paulistano, constavam as "conservas de pescado", naturalmente dirigidas a um consumidor com maior poder aquisitivo ${ }^{396}$.

Quanto aos locais públicos destinados ao lazer, conforme comentávamos, estes, no início, localizavam-se na zona central da cidade, mas o progressivo afluxo de pessoas exigiu a abertura de novos espaços em locais mais retirados: o Parque da Cantareira, área onde, além do elemento natural foram instalados aparelhos para a prática do atletismo, trapézio, paralelas e barras; o Bosque da Saúde, onde havia mesas para piquenique e onde se instalarão restaurantes de culinária estrangeira; o Parque Antárctica, espaço reservado pela Companhia Antárctica Paulista ao lado de suas instalações que, a partir de 1902, passa a oferecer inúmeras atrações como rinques de patinação, carrossel para crianças, coretos para bandas de música, restaurantes, salões de baile e até um esporádico cinematógrafo quando ainda era novidade na cidade, enfim, tal leque de opções constituíam as atrações que passaram a ser freqüentadas também por elegantes senhoras da sociedade paulistana. Mais tarde ocorreriam, aos domingos, partidas de futebol e a afluência foi se popularizando. Por fim, o Jardim da Aclimação, aberto ao público por volta de $1910^{397}$, onde tocava uma banda de música, havia fotógrafos ambulantes e um "parque zoológico improvisado com um casal de leões e muitos bichos da terra: capivaras, coatís, tamanduás, carneiros, cabritos, macacos, jacarés" ${ }^{\text {398 }}$; por fim, os campos e a represa de Santo Amaro e os jardins do Museu do Ipiranga.

As próprias associações recreativas passariam a organizar passeios a esses locais para seus sócios, transformando os piqueniques nos arredores um divertimento bastante apreciado. Alguns pequenos industriais também reuniam seus funcionários para um dia agradável, organizando uma festa ao ar livre, tal como a ocorrida no Bosque da Saúde pelo proprietário da Fábrica de Calçado Oriental, na Avenida Rangel Pestana, 139, o espanhol A.Ornila ${ }^{399}$. Geraldina Marx comenta de um parque que teria havido na Vila Galvão, local para onde se dirigiram, num domingo bem cedo, de trem, os funcionários da "Santa Rosa". Lotados, os vagões acolheram um grupo de rapazes tocando bumbo e cantando. Passeios de bote nos lagos; caminhadas pelos bosques; passeios de charrete; jogo de futebol e o restaurante "do Clube Penteado", eram inúmeras as atrações do imenso parque, regadas a "pinga com limão e açúcar". Depois, o almoço compartilhado: Lola levara uma torta que sua mãe fizera de véspera e um

\footnotetext{
${ }^{396}$ EDE 30.03.1912. Trad. da autora.

${ }^{397}$ LEME, M. Op. cit., p. 179. ELAZARI, J. Op. cit., pp. 67 e ss.

${ }^{398}$ PINTO, M. Op. cit., pp. 157 e ss.

${ }^{399}$ EDE 01.04.1918.
} 
cesto com laranjas, que juntou ao almoço dos demais. Entre pedaços de frango, pastéis e cervejas, o passeio foi encerrado ao entardecer.

Outro passeio muito aguardado era para a cidade balneária de Santos. Os emigrantes de primeira geração conheciam o mar, haviam cruzado um oceano e talvez dele não guardassem as melhores recordações. Porém, a idéia de um dia na praia deslumbrava os filhos do carroceiro Garcia, aqui nascidos. Os preparativos iniciavam na véspera. D Pepa preparava os frangos com farofa, prato com aroma à brasileira, enquanto Lola fritava os churros, o mesmo que ocorria na casa das outras vizinhas. Às $5 \mathrm{~h}$ da manhã todos eram acordados para iniciar a longa jornada até a praia. Levando cachos de bananas, garrafões com água e litros de vinho, além de caixas, pacotes e cestos com alimentos, caminhavam em direção à Estação da Luz, àquela hora já lotada. Haveria uma parada na Estação de Paranapiacaba, no Alto da Serra, local onde residiam muitos espanhóis, antes de o trem iniciar a descida da serra. Uma vez na cidade, ainda necessitavam tomar o bonde em direção da praia do José Menino, finalmente alcançada para deslumbramento geral. Tinham alugado no Brás, na loja de uns polacos, as roupas de banho ${ }^{400}$.

Já nesta época, havia os que buscavam as praias do litoral, Santos e já também o Guarujá, não apenas para a realização de piqueniques mas também para o restabelecimento da saúde. D. Manolita Díez, esposa de Raimundo Díez, comerciante e importador, informava a nota no EDE, convalesceria de uma enfermidade "nas praias santistas" 401 , destino de muitos ricaços em temporadas "de inverno" que também se realizavam no Guarujáa ${ }^{402}$ onde esses setores emergentes da colônia, imbuídos do viver elegante das nobres famílias paulistanas, contavam no início da segunda década com dois locais pertencentes a espanhóis: O Recreio Astúrias, bar e restaurante e o Petit Casino, este com "grande terraço para piqueniques".

O Guarujá virou ponto de encontro do grupo cafeicultor. Empreendimento iniciado pelo Grupo Prado \& Chaves nos finais do século XIX, já era bastante freqüentado em temporadas pelas famílias abastadas, conforme correspondência de Nesita Pacheco e Chaves à sua sogra, em 1905: "Todos os dias fazemos longos passeios a pé, num dia deste fomos até o fim da Enseada, para amanhã está projetado um passeio ao Guaiúba (...) tomamos banho todos os dias", 403 .

Como é facilmente presumível havia, também dentre os espanhóis, como certamente entre os demais grupos imigrantes, um segmento composto de uma camada média emergente cujo estilo de vida inspirava-se no comportamento de uma elite nacional, reproduzindo hábitos e

\footnotetext{
${ }^{400}$ MARX, G. Op. cit., pp. 57-60.

${ }^{401}$ EDE 21.01.1921. Trad. da autora.

${ }^{402}$ LEME, M. Op. cit., p. 184.

${ }^{403}$ Citado por: HOMEM, M. Op. cit., 1996, p. 60.
} 
códigos ditados por modismos europeus. Como estes, viajar para o exterior, especialmente para a Espanha, em longas temporadas, simbolizava, para aqueles emergentes, o alumbramento máximo.

Dentre todos os locais públicos destacava-se, no entanto, na preferência popular, o Jardim Público da Luz (antes denominado Jardim Botânico) criado na década de 1870, o primeiro e durante muito tempo o único lugar de lazer urbano da população que, por isso mesmo, virou ponto de convergência, com inúmeras atrações, como quermesses e festas populares, mas principalmente pelos concertos de música, muito frequientados sobretudo nos finais de semana e nos feriados ${ }^{404}$. Consta que sucessivas administrações municipais procuraram embelezá-lo e que "ele foi se enriquecendo não só de árvores e de flores novas, como de estátuas, portões monumentais e até de um observatório". Atraía gente até do interior, interessada em subir no Canudo, o mirante amarelo de cinco andares ${ }^{405}$. Mais tarde, construiuse um coreto, para a apresentação da Banda da Força Pública, aos domingos ${ }^{406}$, cujo repertório se compunha, na primeira década, de música erudita e clássica, mais ao gosto musical de uma elite $^{407}$.

O local não era muito aprazível às crianças: “correr atrás dos bichinhos soltos no parque - qual a graça? - comer lanche trazido de casa numa cesta (...) e de vez em quando [tirar] retrato num dos lambe-lambes...", recorda Gattai, que preferia o Parque Antárctica, "o melhor de todos para mim"408. Entretanto, tirar retrato no lambe-lambe representava, para outros, uma experiência fascinante e inesquecível:

O fotógrafo espanhol se aproximou de chapéu na mão. Seu Dagoberto concordou logo. Porém Silvana relutou. Tinha vergonha. Diante de tanta gente. Só se fosse mais longe. O espanhol demonstrou que o melhor lugar era ali mesmo (...). A família deixou os pacotes no banco e se perfilou diante da objetiva. O fotógrafo não gostou da posição. Estudou o efeito. Ótimo. Enfiou a cabeça debaixo do pano. Magnífico. Atenção. Aí Jujú derrubou a chupeta (...); quinze minutos depois estava firme de novo às ordens do artista [que] solicitou a gentileza de um sorriso artístico. Silvana colocou as mãos na boca e principiou a rir sincopado (...). Depois da sexta tentativa, o retrato saiu tremido e o espanhol cobrou doze mil réis por meia dúzia ${ }^{409}$.

\footnotetext{
${ }^{404}$ ELAZARI, J. Op. cit., pp.67 e ss.

${ }^{405}$ CARVALHO, A. Op. cit., 1949, p. 51.

${ }^{406}$ BRUNO, E. Op. cit., 1991, p. 969.

${ }^{407}$ ELAZARI, J. Op. cit., pp. 131 e 138-139.

${ }^{408}$ GATTAI, Z. Op. cit., p. 38.

${ }^{409}$ MACHADO, A. Op. cit., 1928, pp. 168-169.
} 
O parque também reservava algumas surpresas. Por ali haviam passado alguns aeronautas estrangeiros, pilotando balões. Inicialmente um mexicano, Zeballos, que com suas experiências, provocava sérios prejuízos à população, pousando-lhe sobre os telhados, um dos quais, desmoronando à queda, surpreendeu os moradores à mesa do jantar. Nos anos finais do século XIX foi a vez de um espanhol, um tal Capitão Martinez, que efetuou ascensões em diversas ocasiões, acompanhado pela mulher. Ocorre que, num dado domingo, anunciou que a mulher subiria sozinha no enorme aeróstato, proeza que a criatura apavorada, na hora de largar, sentiu-se desencorajada de realizar, atirando-se para fora do balão, aos gritos. "El Capitán", então, quis obrigá-la a subir, no que foi obstado pela platéia que, revoltada com sua insistência, aplicou-lhe violenta surra. $\mathrm{O}$ caso foi parar na delegacia ${ }^{410}$.

A prática de modalidades de jogos ou de esportes e mesmo a de jogo esportivo de caráter lúdico constituíam atividades de lazer, divertimento e distração a que os indivíduos, como participantes ou como espectadores buscavam se dedicar nas horas livres das obrigações da vida cotidiana. O século XIX inaugurou na cidade inúmeras formas de lazer vinculadas a essas práticas. Falava-se até mesmo em "esportemania" e "febre esportiva", fenômeno que grassava na cidade, ainda não permitindo que se distinguisse muito bem nos periódicos, que passaram a apresentar seções específicas, as categorias "jogo" - associada em geral à prática da pelota, do bilhar, boliche, futebol, peteca, etc. -, das de "esporte", vinculadas às corridas de cavalo, bicicleta e carro, regatas, patinação, esgrima, mas também à pelota, ao futebol, ao bilhar.

O jogo da pelota representou um daqueles jogos que rapidamente se disseminou e de que hoje sequer se tem conhecimento. Arrebanhou muitos adeptos, tornando-se moda entre os jovens, conforme evidencia um trecho de uma obra de 1918: "Quem, dos atuais moços, não andou em criança com uma camisa de malha, calças brancas, uma boina petulante na cabeça e uma cestinha na mão?", indagava-se então, já àquela altura surpreso pelo quase completo desaparecimento do "delírio pelo esporte da pelota", Antonio Figueiredo ${ }^{411}$. Representava uma daquelas modalidades ao alcance de todos: era possível assistir gratuitamente a um jogo de pelota no Frontão Boa Vista, em $1910^{412}$.

De todos os divertimentos esportivos populares o bilhar sagrou-se dos primeiros e mais importantes, passando a funcionar em diferentes pontos, até mesmo em botequins, oferecidos

\footnotetext{
${ }^{410}$ PENTEADO, J. Op. cit., 1962, pp. 206 e ss.

411 "História do foot-ball em São Paulo". Apud: ARAÚJO, J. Op. cit., 1996, p. 75.

${ }^{412}$ ELAZARI, J. Op. cit., pp. 92 e ss.
} 
por seus proprietários. Bares e hotéis progressivamente adeririam à idéia. Em 1914, Antonio Lujano, com bar à rua do Gasômetro, 32, colocava à disposição uma mesa de bilhar, legítimo chamariz da clientela masculina ${ }^{413}$, concorrendo com o Salão Internacional, próximo dali, na Avenida Rangel Pestana, 39, pertencente a José Rueda, outro espanhol, existente desde $1913^{414}$. Exatamente neste ano, a firma Billares Estepa Blois y C., também de espanhóis - Rua dos Gusmões, 49, com telefone 1894 -, fabricante de "mesas de bilhar, tacos, bolas de marfim e demais acessórios", acabara de ser premiada na Exposição Nacional do Rio de Janeiro - Grand Prix, com a medalha de ouro ${ }^{415}$. Era produto caro: para as sedes improvisadas em fundos de barracões de estabelecimentos comerciais em que funcionavam os clubes de várzea, a aquisição de uma mesa de bilhar "de preço caro e fora do alcance do exíguo numerário com que contavam" seus sócios era uma façanha e "enquanto não podiam adquiri-la, contentavam-se com o cavalete de pingue-pongue" ${ }^{416}$, esporte aliás bastante apreciado e objeto de diversos torneios, já a partir de $1904^{417}$. Nos pátios das fábricas, era comum às mulheres, como Lola, filha do carroceiro Garcia, reunirem-se em seu horário de almoço, para o jogo da peteca ${ }^{418}$.

No antigo salão de banquetes da Rotisserie Sportsman, à Rua Líbero Badaró, 94, o espanhol Antonio Garcia acabara de instalar o Majestic Bilhares, com doze bilhares em serviço, cujo "serviço de salão" estava nas mãos de José Torrens, outro espanhol ${ }^{419}$. Era uma evidência de que o bilhar se constituía, então, esporte para todas as camadas sociais. No Hotel América, pertencente a Emilio Alvarez, na Rua Conceição, 121 e 121-A, o proprietário instalara no térreo, ao lado do café, mesas de bilhar para entretenimento dos freqüientadores ${ }^{420}$, e no Guarujá, o também espanhol Francisco Laso de la Vega, dono do Petit Casino mantinha, para desfrute de sua clientela, mesas de bilhar em suas exclusivas instalações ${ }^{421}$.

Mas foi sem dúvida o futebol, esporte introduzido por ingleses residentes na cidade indivíduos geralmente ligados à "administração das primeiras empresas multinacionais (...) burocratas que estavam espalhados pelo mundo" cujo "perfil diferenciava-se da grande massa

\footnotetext{
${ }^{413}$ EDE 14.08.1914.

${ }^{414}$ EDE 01.08.1913.

${ }^{415}$ EDE 04.08.1913. Trad. da autora.

${ }^{416}$ MARX, G. Op. cit., p. 87.

${ }^{417}$ ELAZARI, J. Op. cit., p. 118.

${ }^{418}$ MARX. G. Op. cit., p. 189.

${ }^{419}$ EDE 26.01.1914. Trad. da autora.

${ }^{420}$ EDE 28.09.1920.

${ }^{421}$ EDE 12.03.1922.
} 
de europeus imigrantes presentes"422 - que acabaria se apoderando das massas desde as últimas décadas do Novecentos, depois de encampado pelos filhos das "distintas famílias" paulistanas.

É de 1901 a criação da Liga Paulista de Futebol e do ano seguinte a realização do primeiro campeonato, porém até 1910 não há qualquer alusão ao futebol profissional, que conservava apenas seu caráter lúdico-amadorístico. Nesses primórdios, o público das arquibancadas constituía-se "quase que exclusivamente por gentis representantes do belo sexo" algumas das quais "passavam a maior parte do tempo de pé, pois não queriam perder a bola de vista por um momento sequer" 423 .

Entre o povo, aumentava enormemente o número de praticantes que improvisavam, em qualquer terreno baldio, um campo de várzea que logo atraía empolgados torcedores para as pelejas geralmente marcadas para os finais de semana. Tais combinações eram programadas previamente às quartas-feiras quando, no final do dia, vindos do trabalho, os jogadores encontravam-se na Rua Rangel Pestana, esquina com a Gomes Cardim, para fixar o calendário $^{424}$.

Diversos desses times passam a jogar regularmente na Várzea do Carmo. Em geral, os times varzeanos tinham péssima reputação. Eram tidos pela elite de torcedores dos times profissionais (oficiais), compostos por jogadores ingleses ou alemães, ou ainda por filhos das nobres famílias paulistanas e cujos jogos realizavam-se no Velódromo, como "reunião de

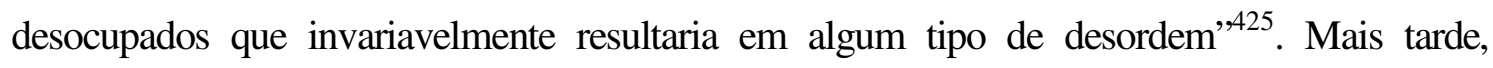
também no Parque Antárctica ocorreriam competições de futebol, que atraíam famílias inteiras, casais com crianças de colo inclusive, que para lá se deslocavam, tomando o bonde que desde cedo circulava com o triplo de sua capacidade ${ }^{426}$. Somente por volta da década de 1920 é que teria havido a aceitação de jogadores de várzea na composição dos quadros profissionais das equipes oficiais ${ }^{427}$.

Consta que na Lapa se formaram vários times, o União da Lapa Futebol Club encabeçando a série deles. No Bom Retiro, na várzea do Tietê, surge o Corínthians cujo nome, conforme Jorge Americano $^{428}$ seria inspirado em um time homônimo da África do Sul que

${ }^{422}$ ARAÚJO, J. Op. cit., 1996, pp. 73 e ss.

${ }^{423}$ ELAZARI, J. Op. cit., pp.113 e ss. e LEME, M. Op. cit., pp. 159 e ss.

${ }^{424}$ RIBEIRO, S. Op. cit., p. 93.

425 O velódromo foi o primeiro estádio de futebol da cidade; ficava na Rua da Consolação, onde provavelmente hoje se situe o Hilton Hotel. Fora construído para sediar provas de ciclismo, por iniciativa do Conselheiro Antonio Prado, cujo filho, Antonio Prado Jr., que retornara da Europa em temporada de estudos, era aficionado. ARAÚJO, J. Op. cit., 1996, p. 87.

${ }^{426}$ AMERICANO, J. Op. cit., 1957, pp. 226-227.

${ }^{427}$ ARAÚJO, J. Op. cit., p. 89.

${ }^{428}$ AMERICANO, J. Op. cit., 1957, p. 348. 
estivera na cidade, em 1914 ou 1915. Essa informação é rebatida por José Renato Araújo ${ }^{429}$ que atribui a origem do nome ao mais famoso e poderoso, embora ainda amador, time da Inglaterra, que excursionara pelo Brasil, em 1910, e que a tal ponto teria entusiasmado os sportmen paulistanos que acabaram fundando um time com o mesmo nome no Bom Retiro.

Torcidas organizadas passam a se constituir de acordo com times criados por categorias profissionais ou por grupo étnico. Dentre os principais times de várzea, surge o Madri, formado pelos carvoeiros espanhóis da Rua Santa Rosa ${ }^{430}$. Em suas reminiscências, o sr. Amadeu narrou para Ecléa Bosi também haver jogado no Madri, "time dos espanhóis da Santa Rosa" composto de "carroceiros", sendo depois convidado para dirigi-lo, isto já por volta da década de $1930^{431}$.

Valia a força bruta, era esporte "para machos, pois a violência campeava, predominando o fator físico", informa Jacob Penteado. "Por ocasião dos escanteios (então corners), investiam quatro ou cinco jogadores, de pés levantados, de sola, e até de soco para cima do arqueiro (chamava-se "gorquipe", corruptela de goal-keeper), que ia parar no fundo da rede (quando as havia), fortemente contundido", prossegue, enumerando os diversos truques e agressões que então substituíam a técnica.

Rivalidades étnicas também se manifestavam em dias de jogos. Suzana B. Ribeiro comenta que, ao verem fotografias antigas, moradores da Rua Caetano Pinto manifestaram-se lembrando da reação dos espanhóis, que dividiam o bairro do Brás com os italianos, por ocasião do jogo entre o Palestra Itália e o Juventus, este o "time da colônia espanhola". A cada gol do adversário, relata, os torcedores espanhóis, provocativamente, “colocavam um boneco vestido com o uniforme do Palestra Itália dentro de um caixão e com ele percorriam, diversas vezes, a Caetano Pinto, de uma ponta à outra"432.

Querelas eram comuns por qualquer razão, em qualquer ocasião. Assim é que, no grupo que se reunia diariamente às noites na casa de seu Lino para jogar tômbola, havia Ramiro, um marceneiro espanhol, "tipo de galã mexicano, que jogava sempre agarradinho a uma sua patrícia, a Paca". Esse indivíduo, por certo bastante espirituoso, quando cantava o número, designava-o por "dos carabazas" - que ninguém jamais soube do que se tratava. "Calabaza", supomos que pronunciasse com ironia, é palavra ambígua, podendo significar "pessoa ignorante" ou, curiosamente, "abóbora", e, neste caso, a insinuação poderia expressar a aversão que a maioria dos espanhóis nutria por essa fruta, base de muitas receitas de pratos brasileiros.

\footnotetext{
${ }^{429}$ ARAÚJO, J. Op. cit., p. 76.

${ }^{430}$ REALE, E. Op. cit., 1982, p. 41.

${ }^{431}$ BOSI, E. "Lembranças do Sr. Amadeu". In: Op. cit., p. 88.

${ }^{432}$ RIBEIRO, S. Op. cit., 1994, pp. 110-111.
} 
Em ambiente de maioria italiana ocorreu uma ocasião de alguém reclamar do "chulé do milanês, que ninguém mais agüenta", e, enquanto alguns concordavam e outros saíam em sua defesa, argumentando, por exemplo, "hoje não é sábado" (para tomar banho), o espanhol, irreverente, observou: "creo que usa meias cativas", provocação a que o milanês, até então calado, mesmo após diversos apartes, reagiu furiosamente: "Na sua terra ninguém toma banho! Fedem de longe!"433.

No Belém, na primeira década, surgiria o Flor do Belém, time de futebol composto por elementos da colônia espanhola, onde se destacavam os irmãos Perez, Folia e Ricardo, e os irmãos Montesinos ${ }^{434}$. A Federação Espanhola também mantinha seu time de futebol, que se apresentou, na Romería, jogando com o Clube Sírio. Na segunda edição da festa, em 1922, também no Parque São Jorge, cobrou-se ingresso para o jogo de futebol: arquibancada, a 1\$100 e gerais, a $\$ 600^{435}$, demonstração evidente da sedução crescente que exercia sobre as massas.

Muitas outras atividades esportivas foram incorporadas à grande festa da colônia, especialmente as "corridas": a de "bicicleta", que tinha na cidade, para sua prática, um velódromo, fundado em 1893, na Rua da Consolação, com arquibancada para 800 espectadores $^{436}$, contabilizava dois campeões na colônia, Gregório e Antonio Ardanuy, vencedores do primeiro e segundo lugares da corrida promovida pelo Clube Ciclístico Internacional Frera, com o percurso de 25 km, com chegada na Avenida Antarctica ${ }^{437}$. Mas havia também a de "cavalo", cujo jóquei-clube funcionava na Moóca desde 1876, para onde se ia a cavalo ou de tróli, com programação limitada de corridas anuais que, a partir de 1890 elevaram-se a vinte. Com subvenção oficial, a partir de 1893, instituiu-se o Grande Prêmio Anual, com grande afluência. Na corrida de 1919 do "turf paulista", o treinador espanhol, Antonio Bustamante, foi o responsável pela vitória do cavalo Madrigat $^{438}$. E, finalmente, a de "touros", conforme já vimos, era realizada na cidade desde o tempo do Império, no Largo dos Curros, num vasto descampado, para cujo espetáculo se apresentavam galantemente vestidos "uns míseros amadores", em duelo acompanhado pelas mais altas camadas da sociedade e pelo povaréu apinhado em um canto das arquibancadas ${ }^{439}$.

No limiar do século XX, depois de um período de proibições em que se procurava evitar "ocorrências funestas", duas praças de touros passaram a funcionar na cidade, a dos

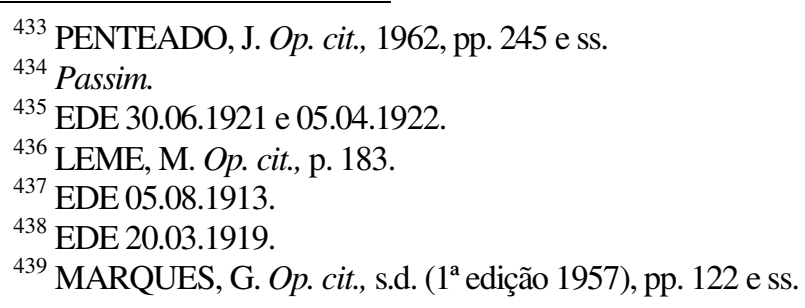


Largo dos Curros e a do terreno localizado na Avenida Brigadeiro Luis Antonio, quando então eram permitidas as bandarilhas, mas não a morte dos animais ${ }^{440}$. Conforme tivemos oportunidade de observar pelos informes colhidos no EDE, ainda em 1914 ocorriam touradas na cidade, realizadas em Santo Amaro, as denominadas "temporadas de corrida de touros", nas quais se apresentavam toureiros - como Salvador Peña (Peñita), o "aplaudido matador", de reputação internacional $^{441}$. 


\section{CAPítulo V}

\section{EXPRESSÕES DA MILITÂNCIA E PROPAGANDA \\ LIBERTÁRIA}

"Procuren el nuevo disco para gramofones, de un sensacional episódio histórico español: el fusilamiento de Ferrer. Primeira parte: la sentencia; segunda parte: la ejecución", era o reclame da Casa Edison veiculado repetidas vezes, a partir de janeiro de 1913, pelo EDE ${ }^{1}$. Porém, essa não seria a primeira notícia a respeito de Francisco Ferrer y Guardia que circulava pela cidade, provocando intensa mobilização da militância, ainda que fosse das poucas divulgadas pelo EDE, que fizera rápida menção, há exatamente um ano ${ }^{2}$ ao confisco a que haviam sido submetidos os seus bens pelo governo espanhol. Mas, afinal, quem fora Ferrer para merecer tamanho interesse, anos depois de seu fuzilamento ocorrido em 1909, e o que o levou a ser fuzilado com um único voto a favor de seu indulto pelo conselho de ministros de Alfonso XIII? $?^{3}$.

Ferrer, nascido em Barcelona, no ano de 1859, em família de camponeses católicos, recebera educação religiosa e autoritária da qual relembraria depois, afirmando: "eu só tinha de fazer o contrário do que vivi”. Fazendeiro, operário de indústria têxtil e ferroviário, em contato, desde tenra idade com as idéias libertárias, passa a preocupar-se gradualmente com o tema da educação. Militante republicano, tendo participado de uma manifestação contra a monarquia em 1886, é obrigado a exilar-se na França, passando a viver em Paris, onde ministraria aulas particulares de espanhol para sustentar sua família. Dentre seus alunos haveria de estreitar laços de amizade com uma viúva abastada e sua filha, com quem passou a viajar por diversos países da Europa, realizando proveitosos contactos e conhecendo os mais avançados centros de ensino, interessando-se por todas as experiências de inovação pedagógica ${ }^{4}$. Essa senhora, a quem inspirara grande admiração intelectual ao falecer, em 1901, deixou-lhe considerável herança em

\footnotetext{
${ }^{1}$ EDE 29.01.1913. A Casa Edison ficava na Rua XV de novembro, 66. O disco custava $6 \$ 000$ (seis contos de réis).

${ }^{2} \operatorname{EDE} 30.01 .1912$

${ }^{3}$ Alfonso XII, o monarca espanhol, governou de 1872 a 1901, falecendo antes da maioridade do herdeiro, Alfonso XIII que, por isso, foi regido até assumir o trono. Primo de Rivera, militar, foi quem, na verdade, governou no período de Alfonso XIII. Seu filho, José Antonio, fundou a "Falange", uma das bases da ditadura franquista.

${ }^{4}$ No campo da educação as propostas libertárias ganharam expressão através do francês Paul Robin, seu precursor, que iniciou a aplicação de seus princípios em um orfanato, de nome Prévost, nos arredores de Paris, nas décadas finais do Novecentos.
} 
franco-ouro, importância que lhe permitirá fundar a Escola Moderna, também chamada de Racionalista cujo método, inteiramente desvinculado da influência das idéias religiosas (igreja católica) e das escolas oficiais, entendidas como baseadas no misticismo e na bajulação política, a fez prontamente aceita pelos anarquistas. Seu princípio fundamental residia na liberdade da criança, no desenvolvimento de sua independência e de seu espírito crítico, através da educação integral, e com ênfase nas atividades físicas e manuais. Sua sede em Barcelona ficava num antigo convento, tendo iniciado suas atividades em outubro de 1901, com 30 alunos. Expandindo-se rapidamente, em 1904 a escola já contava com 126 alunos, possuindo 147 sucursais na Província de Barcelona, difundindo-se em seguida para outras Regiões espanholas, para Portugal, Lausanne e Amsterdan.

Essa fulgurante expansão seria interrompida em 1906. Naquele ano, por ocasião do casamento de Alfonso XIII, o bibliotecário da Escola Moderna arremessaria uma bomba sobre o cortejo real, atentado entendido como um "revide às perseguições e aos crimes do governo (...) uma advertência de um povo massacrado e oprimido". Seria o estopim: milhares de populares, trabalhadores e anarquistas seriam presos e a Igreja acusaria a Escola Moderna como "a raiz do atentado".

Em consequiência, Ferrer foi detido e sua escola-mãe fechada. Vozes do mundo inteiro uniram-se em defesa do "renovador do ensino" que, libertado, muda-se inicialmente para Londres, retornando porém no início de 1909 para o lugarejo onde havia nascido, Alella, fixando-se com a família. É momento de grande efervescência na Catalunha. Ferrer é novamente detido neste mesmo ano, julgado a portas fechadas, condenado e fuzilado em Montjuich" $^{5}$ acusado de chefiar a insurreição ocorrida em Barcelona denominada de "Semana Trágica", , alegação do Governo Espanhol para a sua execução ${ }^{7}$.

O fato teve repercussão internacional. De todo o mundo partiram protestos, e greves gerais foram organizadas em várias capitais da Europa, em repúdio à atitude do governo espanhol. Também na cidade de São Paulo, uma série de comícios e conferências foi organizada pelos líderes dos movimentos operários e pelos anarquistas. Ato simultâneo, iniciase na cidade extensa programação, coordenada por um comitê e sob a direção de Everardo Dias, cuja finalidade era levantar fundos para a construção de uma escola nos moldes do ensino racional. Esses eventos, denominados "Festas de propaganda" ou "Festas Pró-Escola Moderna"

\footnotetext{
${ }^{5}$ Sobre a vida, a morte por fuzilamento e sua repercussão, e a trajetória de Ferrer enquanto fundador da Escola Moderna, examinar: RODRIGUES, E. O anarquismo... op. cit., s.d., pp. 13-83, dentre as inúmeras obras do autor, um militante anarquista.

${ }^{6}$ A esse respeito, ver: 'La Semana Trágica”. In: Cuadernos Historia 16. Madrid: TEMI, 1985. p. 161.

${ }^{7}$ RODRIGUES, Edgar. Socialismo e sindicalismo no Brasil, 1675-1913. Rio de Janeiro: Laemmert, 1969,
} 
eram geralmente programados para o Salão Celso Garcia e incluíam programação variada (apresentação cênica, conferência, coro, declamação, quermesse e, algumas vezes, baile) ${ }^{8}$.

\section{Los Conspiradores: o anarquista perigoso}

Desde a passagem do século XIX já se vinha observando um certo "movimento" que agitava o cenário político local. No Liceu Español, fundado em 1903 e estabelecido à Rua do Gasômetro, 54, também era grande a movimentação, nesta primeira década. Às festas programadas aos associados vinham-se incorporando apresentações teatrais de teor acentuadamente político. Tais festas libertárias recebiam diversas denominações - "soirée social", "festa de propaganda", "festa operária", "festa dramática", ou simplesmente "festa" - e se iniciavam com uma encenação como ocorreu em 1905 com o espetáculo apresentado em espanhol Los Conspiradores, escrito por Felipe Morales, sapateiro e militante. O argumento produzia uma crítica às autoridades policiais e governamentais brasileiras, insinuando que preparavam falsos complôs para justificar repressões e deportações de trabalhadores e intelectuais 9 .

O título da peça não podia ser mais oportuno! Produto de um discurso construído pela imprensa conservadora e pela polícia na Primeira República, a teoria da "conspiração" estrangeira era uma concepção que tinha simpatizantes em diversas instâncias, de autoridades de diversos escalões, passando pelo clero e grande parte do empresariado. Entre eles, a noção generalizada da emergência de iminentes "conspirações", para debilitar o Brasil. Até mesmo entre a classe trabalhadora a idéia germinava, pelo estímulo aos sentimentos nativistas, provocando o ressentimento dos brasileiros contra os estrangeiros, que dominavam o movimento sindical. Os jornais ligados ao governo, caso do Correio Paulistano em São Paulo, formavam forte corrente de opinião para combater o anarquismo ${ }^{10}$, e a figura do anarquista

\footnotetext{
${ }^{8}$ Ver programação detalhada, ano a ano, a partir de 1910, em: RODRIGUES, Edgar. O anarquismo... op. cit., s.d., pp. 154 e ss.

9 Trata-se contudo, de "mais um drama desaparecido" do qual só se tem notícia pelas matérias publicadas em jornais, conforme as autoras de Teatro Operário em São Paulo, Mariângela Alves de Lima e Maria Thereza Vargas. (In: op. cit., 1987, p. 238). Outras encenações dramáticas em espanhol ocorridas no Liceu, ainda neste primeiro qüinqüênio, foram Acabóse e Hambre, encenadas em agosto de 1904. Cf. "Operários e anarquistas fazendo teatro". In: Cadernos AEL. Campinas: n.1. Centro de Pesquisa e Documentação Social. Arquivo Edgard Leuenroth, 1992, pp. 7 e 40. Ver também: RODRIGUES, Edgar. O anarquismo... op .cit., s.d., p.143 (Hambre).

${ }^{10}$ Anarchos, do grego, significa sem governante. Na verdade, as teorias do inglês Willian Godwin, considerado o pai do anarquismo e posteriormente as de Kropotkin, Tolstoi e Max Stiner não tinham a pretensão de estabelecer o caos, porém os estereótipos criados incorporaram no imaginário popular esse significado. A influência maior trazida pelos anarquistas imigrantes inspirava-se nas idéias de Bakunin, bastante difundida na Península Ibérica e na Itália. Dos anarquistas italianos que atuaram na cidade de São Paulo, destacaram-se Erico Malatesta e Oreste Ristori os quais, após o exílio na Argentina, chegaram à cidade, onde fundaram o jornal La Battaglia, em 1904. Gigi Damiani, outro italiano, com passagem prévia pela Colônia Cecília, foi grande colaborador de Ristori, no jornal, o
} 
perigoso, associada ao estrangeiro, estigmatizado como elemento nocivo aos trabalhadores e à ordem pública, excitava segmentos conservadores da sociedade, fornecendo munição à estratégia montada para justificar a repressão, pressuposto para a instauração de mecanismos legais de controle ao movimento operário brasileiro. Isso acabaria por enquadrar outras categorias sociais subalternas e "transgressoras" da ordem pública - os subempregados, os desempregados, os "vadios", os capoeiras, e mesmo os empregados ${ }^{11}$. Passou a ser crime até mesmo a simples tentativa de reivindicar por seu salário: "presos como anarquistas pela polícia de Ouro Preto três funcionários de uma linha férrea apenas porque pleiteavam o pagamento de seus salários", dizia em matéria o EDE, e, afirmando "não saber se eles eram ou não anarquistas, mas que jamais haviam cometido algum delito", cobrava providências do então Ministro da Justiça, Herculano de Freitas ${ }^{12}$.

Por princípio constitucional, os estrangeiros considerados "inconvenientes" à ordem pública poderiam ser banidos e, no caso dos anarquistas, difusores do "credo execrando", a lei previa a expulsão a quem professasse seus princípios ou os difundisse, tomados que eram por "agitadores" $"$, mito que atormentava o sono das elites. O trabalhador brasileiro "disciplinado e de boa índole, está sendo minado pela ação deletéria de alguns estrangeiros", afirmava o jornal O Paiz ${ }^{14}$.

Cunhados pela imprensa como "arengador[es] de massas", ou "indesejáveis", também se procurava obstar o desembarque de imigrantes politizados e de sindicalistas nos portos, conforme evidencia a nota divulgada no EDE informando que a polícia do Rio de Janeiro havia impedido o desembarque de três conhecidos anarquistas espanhóis que haviam embarcado em Coruña (Galícia) e que a polícia de Santos também fora avisada ${ }^{15}$. Notícias enviadas por telégrafo da Espanha acentuavam o caráter temerário desses "anarquistas perigosos", como lá também eram chamados. Desde as primeiras edições analisadas (a partir de 1912) o EDE

qual já havia dirigido anteriormente com Everardo Dias o Livre Pensador, publicado a partir de 1903. Dos libertários portugueses destacou-se Neno Vasco, advogado de Coimbra, de família abastada. Ristori, Neno Vasco e Everardo Dias foram colaboradores do jornal anarquista A Lanterna, dirigido por Edgard Leuenroth, filho de imigrantes alemães, nascido no Brasil. Este periódico também receberia a colaboração de José Oiticica, professor do Colégio D.Pedro II, no Rio de Janeiro. Cf. PASCAL, Maria Aparecida Macedo. "A pedagogia libertária: um resgate histórico". In: I Congresso Internacional de Pedagogia Social. Ano I, 2006, pp.2-4. Disponível em: http://www.proceedings.scielo.br/scielo.

${ }^{11}$ A esse respeito, consultar: "Imigração e criminalidade". In: FONSECA, G. Op. cit., 1988, pp. 45-143.

${ }^{12}$ EDE 05.11.1913. Trad. da autora.

13 A esse respeito, ver também: KENEZ, Kátia. "O anarquista como inimigo social". In: Movimento operário em 1919 - Repressão e controle social. Dissertação de mestrado. FFLCH-USP, 2001, pp. 112-167.

14 "O mito do agitador: na imprensa e nas fábricas, anarquistas e socialistas aglutinam os operários". Apud: Nosso Século. A Memória Fotográfica do Brasil no século XX. São Paulo: n. 36, Editora Abril, 1980, p. 84.

${ }^{15}$ EDE 16.08.1913. Seus nomes: Juan Lopez, Tardina e Queijo. 
apresentava com regularidade notícias envolvendo prisões de operários assim acusados, geralmente ocorridas em Barcelona.

A partir de 1890 o anarquismo já conseguira, a propósito, considerável penetração na Catalunha e em algumas outras Regiões espanholas, como na Andaluzia, ainda que o imigrante médio pouco ou nenhum contato tivesse tido com organizações sindicais em seu próprio país. Esse imigrante médio, especialmente aqueles saídos dos pueblos andaluzes, como o carroceiro Juan, trazia as marcas das cicatrizes dos desajustes sociais de seu país, porém pouco conhecia do que representava o processo que vivenciavam. Em uma passagem de Os Humildes, Geraldina Marx reproduz um diálogo entre ele, o "ferro-velho" e sua filha Lola, quando esta tentava explicar-lhe o motivo do feriado de 21 de abril: "É que mataram um homem que se chamava Tiradentes e o enforcaram com uma corda", disse ela. "E por quê?”, indagou Juan. “É que ele queria a liberdade. Não queria o rei", retrucou a moça. "Isso acontece aos bons e valentes. Um assim devíamos ter na Espanha", disparou o carroceiro, que, confuso, aplaudia o republicano, sendo ele próprio um monarquista declarado que, em outro momento, discutindo a respeito da conjuntura política brasileira de 1922, reagira: "Por eso me gusta la monarquia. Los reyes son los que deben de gobernar... Y no hay tititi... y tantos relíos",16

A "nefasta influência" dos indesejáveis ocorria sobretudo em São Paulo e no seio da colônia aqui instalada, representando um claro divisor de águas, uma arena na qual coexistiam interesses opostos, quando não conflitantes. Havia entre seus integrantes elementos que, até mesmo por sua trajetória pregressa na Espanha, eram tidos no mínimo como simpatizantes ao movimento. A estes, que também compunham as associações étnicas criadas na cidade, juntavam-se outros, frontalmente contrários ao anarquismo ou mesmo às idéias libertárias, e que se negavam terminantemente a discuti-las, deixando patente a sua posição, até mesmo por temerem as represálias. $\mathrm{O}$ ocorrido com os membros da FE - no episódio já mencionado da manifestação pública de repúdio pelo recebimento de exemplares do A Rebelião - é exemplar nesse sentido, legitimando uma postura que procurava evitar qualquer comprometimento "externo", mas que, certamente produzia inevitáveis choques e rachaduras "internas"17. Esse microcosmo na verdade espelhava a situação notoriamente anômala vivenciada em seu país de origem que, na década de 1930, se tornaria o símbolo de uma luta global, suscitando os principais problemas políticos da época, em que duas forças opostas - de um lado democracia e revolução social, de outro, a reação, inspirada na ultraconservadora Igreja Católica - davam o

\footnotetext{
${ }^{16}$ MARX, G. Op. cit., pp. 20 e 100.

${ }^{17}$ EDE 05.05.1914.
} 
tom do caminho excêntrico trilhado tanto pela ultra-esquerda anarquista quanto pelo carlismo, movimento monarquista e ultratradicionalista, com forte apoio camponês ${ }^{18}$.

A lei de expulsão dos estrangeiros (ou Lei Adolfo Gordo, como passou a ser designada) incidia diretamente sobre os elementos ligados ao movimento operário. A estratégia da expulsão, dotando "de sentido uma verdade construída", em outras palavras, transformando "a crença na existência de perigosos anarquistas em fato real"19, foi oficializada pelo Decreto 1641, de 07 de janeiro de 1907. Neste ano, a cidade de São Paulo experimentaria a sua primeira greve geral, reivindicatória da redução da jornada de trabalho e de aumentos salariais setoriais variáveis $^{20}$, o que, a rigor, não se constituía em proposta de conteúdo libertário. O resultado parcial revelou-se positivo: sabe-se que os gráficos, através da União dos Trabalhadores Gráficos, conseguiram aumentos de até $100 \%$ e a concessão de um novo horário de trabalho ${ }^{21}$.

Não obstante, em seu primeiro ano em vigor, foram expulsos, através da Lei Adolfo Gordo, 132 estrangeiros, dentre os quais 27 espanhóis. Antes mesmo da passagem do século XIX o governo federal vinha sendo pressionado a deportar anarquistas estrangeiros presos em São Paulo. A campanha era então liderada no Congresso pelo negociante conservador paulista Adolfo Afonso da Silva Gordo. A lei, depois sancionada, levaria seu nome e, de conformidade com ela, cabia ao Governo Estadual enviar para o Ministério da Justiça Federal suas requisições, acompanhadas tão-somente de um relatório policial. Tal procedimento, visando agilizar a tramitação das deportações, teve a aprovação do Presidente da República, Afonso Pena $^{22}$, e vigorou com pequenas alterações até $1921^{23}$.

${ }^{18}$ HOBSBAWM, Eric. A era dos extremos. O breve século XX, 1914-1991. São Paulo: Companhia das Letras, 1995, pp. 157 e ss.

${ }^{19}$ ALVES, Paulo. A verdade da repressão. Práticas penais e outras estratégias na ordem republicana (1890-1921). Tese de doutoramento. FFLCH-USP, 1990, p. 150.

${ }^{20}$ Ver, a esse respeito: "Um exemplo da atuação libertária: a greve de 1907 em São Paulo". In: MAGNANI, Silvia Ingrid Lang. O movimento anarquista em São Paulo (1906-1917). São Paulo: Brasiliense, 1982, pp. 111 e ss.

${ }^{21}$ Passim.

${ }^{22}$ HAHNER, J. Op. cit., 1993, p. 290.

${ }^{23}$ Alguns desses processos de expulsão do Ministério da Justiça estão disponíveis no Arquivo Nacional, no Rio de Janeiro (Série Expulsão IJJ, período: 1907-1930). Numa rápida consulta a eles, relacionamos, para o período entre 1907 e 1920, os seguintes, pertencentes a homens e mulheres de nacionalidade espanhola: Alves, José (1907); Antas, Adolfo (1913); Ayala, Mercedes Vaya (1915); Bernardes, Amadeu (1912); Casas, Antonio (1917); Castillao, Mariano Saturnino (1907); Castro, Henrique de (1914); Cid, José (1919); Correa, Sonia (1920); Cortez, Francisco Agostín (1913); Crespo, José (1907); Dias, Henrique (1907); Dias, José Maneiro (1907); Câmara, Antonio (1919); Fernandez, Antonio (1919); Fernandez, Henrique (1914); Ferreira, Francisco (1920); Garcia, Manoel (1907); Garcia, Manoel (1910); Garcia, Manoel (1920); Garcia, Manoel Oliva (1913); Garrido, Miguel (1919); Gómez, Luiz Coelho (1920); Granha, Antonio Soares (1919); Hija, Dolores (1907); Ibona, Rafael (1920); Iglesias, Indalecio (1920); Lopez, Antonio Blaz (1919); Lopez, Rafael Pedro (1919); Lopez, Ramón (1908); Machin, José (1920); Machini, Julio (1907); Marques, José Sarmento (1917); Martinez, Antonio (1907); Martinez, Manoel (1917); Mota, Guilherme da (1907); Navarro, Manoel (1910); Novo, Turíbio (1919); Nunes, José (1907); Peralta, José (1917); Perez, João 
Os inquéritos policiais eram "montados", baseando-se em denúncia formal feita por delatores que trabalhavam para a polícia, ou resultavam da investigação dos "secretas" agentes múltiplos que se prestavam tanto a fiscalizar locais de aglomeração pública, quanto a acompanhar autoridades policiais a locais suspeitos, como o pátio de fábricas onde estivessem os grevistas, ou mesmo a reprimir manifestações.

Esses eram os "oficiais". Havia também os agentes "não-oficiais", pertencentes ao mundo do crime e da contravenção ${ }^{24}$, geralmente recrutados para missões especiais, cujo emprego era freqüente na vigilância dos grupos anarquistas. A categoria compunha-se até mesmo de operários, dentre eles, um espanhol "confidente da polícia”,25. Eventualmente, porém, também eram utilizadas as "testemunhas", em sua maioria preparadas pela Polícia que, valendo-se delas, montava um dossiê do acusado $^{26}$. Foi desse modo que se fundamentou o inquérito policial que instruiu o Processo de Expulsão do espanhol Antonio Prieto, exmotorneiro da Light, expulso em 1919, cuja exposição de motivos, amparada em uma "testemunha", assim dizia ${ }^{27}$ :

... que conhece Antonio Prieto, espanhol, natural de Pontevedra [que] é um homem maleducado, violento, indolente, que tem explorado nesta capital, praticando o curandeirismo, a boa-fé de muitas pessoas à custa das quais tem vivido. Freqüenta com assiduidade a "Liga Operária" da Light no Largo de São Francisco e se distingue dos companheiros pela violência da linguagem, pela insinuação do degolamento dos burgueses e pela repartição imediata da propriedade que estes tem adquirido pela fraude...

Mais do que a expulsão, interessava imprimir sobre os acusados a marca da lei e o estigma de perigosos e também "esculpir no imaginário das pessoas o significado e o sentido negativo que o ideário anarquista representava, ou seja, produzir a figura do estrangeiro perigoso" 28 .

Caramez (1907); Perez, Manoel (1919); Picón, Manoel Moleiro (1919); Ramos, Rogelio (1917); Ramos, Vicente Ruiz (1910); Ribas, José Gomes (1908); Rodriguez, Agapito (1907); Rodriguez, João José (1920); Rodriguez, João Pavão (1909); Rodriguez, Nicanor (1909); Rojo, Ismael Monserrat (1920); Romero, José (1919); Romero, Manoel Rodriguez (1907); Romero, Rafael (1907); Ruiz, Salvador (1907); Saavedra, Manuel Perdigão (1920); Salcedo, Dolores Navarro (1913); Sanchez, Manoel (1907); Sixtelo, José Gandana (1914); Soares, Sobrinho Manoel (1907); Tobarnela, Pedro (1913); Vale, José Oliver (1907); Veja, Joaquim Redondo (1913); Velasco, Manoel (1910); Vergara, Tomaz Martins (1907); Vidaurreta, Gregório Severiano (1909). Procuramos manter a grafia dos nomes conforme consta da relação de processos examinada, considerando todavia que, na tradição espanhola, seriam grafados com dois sobrenomes, na observância do patronímico em primeiro lugar.

${ }^{24}$ AMERICANO, J. Op. cit., 1957, p. 162.

${ }^{25}$ PINHEIRO, P. e HALL, M. Op. cit., 1981, p. 269.

${ }^{26}$ ALVES, Paulo. "Estratégias de expulsão de estrangeiros". In: Op. cit., 1990, pp.156-182.

27 Processos de Expulsão - Ministério da Justiça. Série Expulsão IJJ, período: 1907-1930. Arquivo Nacional, RJ.

${ }^{28}$ ALVES, P. Op. cit., 1990, p. 174. 
Assentadas, assim, em bases pouco sólidas, afinal os inquéritos policiais eram em sua maioria fraudulentos, essas deportações indiscriminadas debilitariam ainda mais o movimento operário e, em decorrência, ocorreria uma diminuição das greves, em parte pela legitimação que o Estado procurava dar à repressão, mas também porque nesse momento de crise, especialmente a partir de 1908, o desemprego grassava. A taxa de sindicalização, por outro lado, era inexpressiva. As lideranças operárias constantemente reclamavam das dificuldades de adesão ao movimento, fato esse atribuído, por Maran, ao fraco sindicalismo "que requer uma força de trabalho relativamente estável, que veja na sua participação um meio necessário de melhorar sua posição econômica"29.

A condição transitória dos imigrantes era outro dos problemas enfrentados. Maran ilustra esse aspecto indicando o pequeno número de imigrantes que se naturalizou no período: pelo Censo de 1920 consta que apenas 6.441 dos 444.374 estrangeiros residentes nas cidades de São Paulo e Rio de Janeiro adotaram a cidadania. Assim, de passagem pelo país e com os olhos voltados para o retorno à sua terra, sem outro objetivo senão o de melhorar sua posição econômica (e de sobreviver apenas, em muitos casos), eles demonstravam relutância ou mesmo desinteresse em se envolver nos movimentos.

De fato, a repressão crescia nos períodos de maior atividade grevista, o que ocorreu entre os anos de 1906 a 1908 e de 1912 a 1913, acirrando-se notadamente entre 1917 e 1921 , ano em que o movimento foi aniquilado, momento em que, para Maran, o trabalhador nacional, por tanto tempo desprezado pelas elites, foi subitamente alçado à categoria de operoso e patriótico, superior ao estrangeiro, falso e desleal, numa acirrada exacerbação da campanha nativista ${ }^{30}$.

A morte de Ferrer eclodiu, portanto, em meio a esse clima repressivo ao imigrante estrangeiro e ao movimento operário, e era precisamente Ferrer, o "mártir de Montjuich" quem agora, um ano depois de sua morte, mobilizava a militância provocando eloqüentes manifestações na cidade, em forma de comícios $^{31}$, muitos dos quais liderados por gráficos ou tipógrafos espanhóis, como Manuel Moscoso, Carlos Dias ${ }^{32}$ e Everardo Dias. Foi dele, aliás, a conferência pronunciada em outubro de 1910, no Templo da Loja União Espanhola (maçônica) "para comemorar o martírio do grande educador", de cuja tribuna acusava as duas assassinas - a

\footnotetext{
${ }^{29}$ MARAN, S. Op. cit., p. 33. O autor examinou o impacto e a influência do anarquismo e dos imigrantes sobre o movimento operário em três cidades, dentre elas na cidade de São Paulo, no período 1890-1920.

${ }^{30}$ Idem, ibidem, p. 160.

${ }^{31}$ A esse respeito, examinar: "Solidariedade internacional contra a reação na Espanha". In: RODRIGUES, E. Op. cit., 1969, pp. 259 e ss.

${ }^{32}$ FERREIRA, M. Op. cit., 1978, p. 124.
} 
monarquia tirânica e a Igreja corrompida ${ }^{33}$. Foram também dele as concepções que norteavam a organização das escolas livres anarquistas no Brasil, experiência de pedagogia alternativa transplantada de Barcelona para São Paulo, as chamadas escolas "modernas" ou "racionais", para cuja constituição foi organizado um Comitê Pró-Escola Moderna criado em novembro de 1909, portanto após o fuzilamento de Ferrer. Sua função era alavancar recursos para a construção de uma escola que seria fundamentada nos moldes do ensino racional, para que pudesse "triunfar tão generosa iniciativa (...) na cidade que parece destinada a continuar sendo o ludíbrio dos sucessores do padre Anchieta, de sanguinária memória”34.

Evidenciavam-se aqui claramente os pressupostos da pedagogia libertária, contrários aos da escola oficial reprodutora dos interesses do Estado e da Igreja. Revelava-se grande a preocupação dos libertários com o analfabetismo do povo, entendendo não haver "liberdade possível onde está a ignorância, onde assenta o fanatismo, onde se crê em fantasmas, onde reside a torpeza ${ }^{, 35}$. Sua proposta de classes mistas (portanto, para ambos os sexos), buscava desenvolver um ensino "sem exames, sem promoções, sem castigos ostensivos, combinando um currículo convencional com a difusão dos princípios anarquistas" ${ }^{, 36}$, desvinculado, contudo, das "pregações religiosas e do Estado", este entendido como a autoridade máxima do Capitalismo. A luta anticlerical fazia parte dos postulados das correntes anarquistas que se constituíram na cidade. Crítica voraz à Igreja, a elas interessava a disseminação das conquistas da ciência (o que as ligava de certo modo aos intelectuais positivistas), na busca de reformas das instituições sociais. Para tanto, era necessário laicizar a educação.

Tem-se notícia no entanto de que, uma vez implantadas na cidade, tais escolas conseguiriam manter-se apenas até 1918 , quando foram fechadas pelas autoridades ${ }^{37}$ e sob intensa perseguição da igreja católica que, através de sua imprensa denunciava, referindo-se a elas como as "casas de perversão do povo"38.

${ }^{33}$ DIAS, Everardo. "Francisco Ferrer e sua obra". In: Semeando... Palestras e Conferências. Rio de Janeiro: Oficina Gráfica da Escola Profissional Maçônica José Bonifácio, 1921, pp. 29-48.

${ }^{34}$ CARONE, Edgard. Movimento operário no Brasil (1877-1944). São Paulo: Difel, 1979, p. 44, citando o jornal A Terra Livre, de 01.01.1910.

${ }^{35}$ PASCAL, M. Op. cit., pp. 4 e ss., citando o jornal $O$ amigo do povo.

${ }^{36}$ FAUSTO, B. Op. cit., 1977, p. 82.

${ }^{37}$ Sobre a questão cultural no início do movimento operário brasileiro, o discurso da vanguarda anarquista e as propostas libertárias no campo do ensino e da educação, ver: HARDMAN, Francisco Foot. Nem pátria, nem patrão. Vida operária e cultura anarquista no Brasil. São Paulo: Brasiliense, 1983.

${ }^{38}$ RODRIGUES, E. O anarquismo... op. cit., s.d., p. 69, citando artigo publicado no Jornal A Lanterna que reproduzia matéria de três folhas católicas. 
A utopia anarquista ou a "tradição libertária do comunismo", para Hobsbawm", pregava uma ordem social alternativa, um ideal de sociedade autônoma que se autogovernasse, sem qualquer organização que implicasse exploração, hierarquia e autoridade ${ }^{40}$. Os anarquistas buscavam introduzir mudanças estruturais na sociedade e, repudiando toda organização burguesa, não reconheciam o Estado como o regulador supremo das relações entre indivíduos livres, propondo novas bases para a organização social, através da ação econômica direta e da disputa ideológica (e não política), de modo que a associação e a cooperação entre os indivíduos livres pudessem substituir a ação e a autoridade do Estado $^{41}$.

Importa destacar que, na verdade, sob a designação de anarquismo reuniam-se diferentes escolas de pensamento, que partilhavam em comum a não aceitação de qualquer forma de autoridade sobre os indivíduos ou grupos sociais, agrupando, dessa maneira, diferentes concepções de mundo e de propostas de reordenação social, às vezes discordantes entre si. $\mathrm{O}$ "anarquismo-libertário", noção aqui empregada, refere-se à doutrina formulada a partir de meados do Dezenove no bojo do conjunto de idéias socialistas originadas das contradições da sociedade capitalista, que procuravam reformar.

Os libertários em geral rejeitavam a organização político-partidária dos operários, por entender que assim agindo estariam legitimando o Estado burguês. Caberia às vanguardas revolucionárias, aos líderes, a função de conscientizar o povo, difundir as idéias, provocar a revolução no seio das massas, conduzindo-a para sua organização autônoma.

Em síntese, esses seriam os pressupostos do anarquismo-libertário que se cindiu em tendências ou variantes, dentre as quais o anarco-comunismo e o anarcossindicalismo ou sindicalismo revolucionário, a corrente que acreditava ser o sindicato o único meio de revolução social, órgão de luta, mas também núcleo básico da sociedade do futuro. Foi a corrente que mais se desenvolveu em São Paulo, propugnando, em tese, a ação direta e os métodos violentos de conquista, divergindo, portanto, do anarquismo "clássico" ou revolucionário, doutrina que visava eliminar o próprio regime de trabalho assalariado ${ }^{42}$. Com intensa atuação e se constituindo na espinha dorsal da liderança militante até os anos iniciais da década de 1920, os anarcossindicalistas superariam as suas divergências com as demais correntes efetivamente nos

\footnotetext{
39 HOBSBAWM, E. Revolucionários - Ensaios Contemporâneos. Trad. de João Carlos Garcia e Adelângela Saggioro Garcia. Rio de Janeiro: Paz e Terra, 1985, p. 67.

${ }^{40}$ ROLNIK, Raquel. Cada um no seu lugar (São Paulo, início da industrialização: Geografia do poder). São Paulo: Dissertação de mestrado. Faculdade de Arquitetura e Urbanismo-USP, 1985, pp. 157 e ss.

${ }^{41}$ HAHNER, J. "Resistência dos trabalhadores e liderança operária". In: Op. cit., 1993, pp. 249-323.

${ }^{42}$ ROLNIK, R. Op. cit., 1985, pp. 160 e ss.
} 
momentos de rebelião ${ }^{43}$, sendo que era sobretudo por meio do jornal A Terra Livre, fundado por dois militantes espanhóis, Isidoro Diego e Manuel Moscoso, que circulou em São Paulo e no Rio de Janeiro entre 1906 e $1911^{44}$, que seus integrantes veiculavam seus postulados.

Não obstante as muitas iniciativas em prol de sua criação, que se produziram com a morte de Ferrer, em 1909, a primeira Escola Moderna da cidade surgiria apenas em 1912 "não só para romper com as formas obscurantistas de ensino clero-estatais, mas também para possibilitar aos trabalhadores analfabetos e aos seus filhos alcançar uma instrução livre e sadia". Situava-se no Brás, na Avenida Celso Garcia, 262 e chamava-se Escola Nova. Após esta primeira experiência, seria criada a escola do Belém, à Rua Saldanha Marinho, 58, chamada de Escola Moderna $n^{o} 1$, vindo a seguir a da Rua Müller, 74, designada de Escola Moderna $n^{o} 2$ embora esta apareça como funcionando, em 1917, na Rua Maria Joaquina, 13, no Brás ${ }^{45}$. Consta ter existido, em 1915, uma Universidade Popular de Cultura Racional e Científica, instalada à Rua da Moóca, 292-A (sobrado). Divulgada na imprensa libertária, não se sabe se efetivamente funcionou ${ }^{46}$. Sua finalidade era a formação dos professores e estava a cargo, dentre outros, do "educacionista" Florentino de Carvalho ${ }^{47}$, pseudônimo do espanhol naturalizado Primitivo Raimundo Soares (ou Suarez), utilizado para despistar a polícia. Florentino, também escritor e divulgador do ideário anarquista, teve a maioria dos seus livros apreendidos. Na greve geral de 1917 é perseguido e preso, refugiando-se na Argentina para

${ }^{43}$ Para estabelecer a distinção entre as duas orientações anarquistas mencionadas, divergências e troca de acusações e estratégias comuns entre ambas, ver: LOPREATO, C. Op. cit., 2000, pp. 18 e ss.

${ }^{44}$ Em MAGNANI, S. (op. cit., 1982) um primoroso guia para o estudo da ideologia anarquista. É desse texto, somado a alguns outros anteriormente mencionados, que nos baseamos para essa parte do trabalho. A respeito do A Terra Livre, ver o trabalho de BARRIGUELLI, José Cláudio. Subsídios à História das lutas no campo em São Paulo, 1870-1956. São Carlos: Arquivo de História Contemporânea, UFSCar, 1981, especialmente o segundo volume.

${ }^{45}$ RODRIGUES, E. "Introdução do racionalismo de Ferrer". In: Op. cit., 1972, pp. 43-76. Teriam sido fundadas com o auxílio do Sindicato dos vidreiros e dos barqueiros. $C f$. LEME, M. Op. cit., p. 165 . No jornal anarquista $A$ Rebelião, de 17.06.1914, há o anúncio de duas escolas: a Escola Moderna $\mathrm{n}^{\circ} 1$ "para meninos e meninas, à Rua Saldanha Marinho, 66" e a "Escola Moderna no 02 (ensino racionalista)" à rua Müller, 74. Cf. RODRIGUES, E. Passim.

${ }^{46}$ Em 1913 seria fundada a Escola Moderna e em 1920, a Escola Livre, em Petrópolis; em 1919, as de Porto Alegre (RS) e a de Belém (PA) e em 1920, a Escola Nova de Porto Alegre. Consta que também em Bauru (SP) teria existido uma Escola Moderna, porém não conseguimos maiores detalhes a respeito. No entanto, foram muitos os estabelecimentos de ensino que empregaram os métodos utilizados na pedagogia libertária funcionando nas duas primeiras décadas do Novecentos em Porto Alegre (RS); Franca e Sorocaba (SP); Rio de Janeiro; Niterói (RJ) e Salvador (BA). Cf. RODRIGUES, E. Passim.

${ }^{47}$ Dados extraídos de RODRIGUES, Edgar. $O$ anarquismo... op. cit., s.d., para cuja pesquisa o autor teria utilizado periódicos anarquistas do período. Outras obras do autor: Alvorada Operária. Os congressos operários no Brasil. Rio de Janeiro: Mundo Livre, 1979; Os anarquistas: trabalhadores italianos no Brasil. São Paulo: Global, 1984; Nacionalismo e cultura social, op. cit., 1972; Nova aurora libertária (1945-1948). Rio de Janeiro: Achiamé, 1992. Novos Rumos (historia do movimento operário e das lutas sociais no Brasil, 1922-1946). Rio de Janeiro: Mundo Livre, s.d.; Quem tem medo do anarquismo? Rio do Janeiro: Achiamé, 1992; Socialismo e sindicalismo no Brasil, Op. cit., 1969 e Trabalho e conflito - pesquisa histórica, 1906-1935. s.d.e s. 1. 
escapar da repressão. Acaba sendo expulso daquele país, ingressando clandestinamente no Brasil, de onde é deportado no mesmo ano $^{48}$. Neste episódio pode estar a origem do estrangulamento da Escola Moderna, fechada um ano depois. Além de lecionar na Escola Moderna do Brás onde também seria diretor, ele teria sido professor da Escola Nova, da Moóca $^{49}$.

Sobre a Escola Nova, revela Maria Luiza Marcílio de que este movimento de renovação do ensino - cujas idéias foram sendo gradualmente introduzidas no Brasil a partir dos últimos anos do Novecentos - recriminava o funcionamento de escolas em prédios "caros e suntuosos", metáfora, segundo seus seguidores, da elitização da educação. Segundo a autora, em seu primoroso trabalho História da Escola em São Paulo e no Brasil, esse anseio dos escolanovistas - cujos princípios vêem a adquirir força, na cidade, depois de 1930 - só depois seria realizado, com a construção de edifícios escolares mais simples e funcionais ${ }^{50}$.

Para a manutenção das Escolas Modernas empregavam-se os meios mais variados: contribuições, festas e conferências pagas. A difusão das idéias pedagógicas de Ferrer e de sua metodologia racionalista realizava-se em sindicatos e centros de estudo pelos libertários, os quais promoviam debates, conferências e círculos de estudo, além de propagá-las por meio de folhetos, jornais e livros, pela imprensa operária e anarquista ${ }^{51}$.

No entanto, e apesar de essa instrução alternativa ter atuado por algum tempo na cidade, exatamente até 1918, como vimos - sendo considerada mesmo uma "das poucas opções de educação da classe trabalhadora, tendo em vista a omissão do Estado neste aspecto" ${ }^{\text {"52 }}$ - as Escolas Modernas foram fechadas pela polícia, acusadas da propagação de ideologia perigosa. Em que pese esse fato, a figura de Ferrer permaneceria sendo reverenciada até mesmo em muitas residências da cidade, nas quais seu retrato, em forma de medalhão, destacava-se na parede da sala principal, ao lado de uma "alegoria anarquista", conforme nos relata de sua própria experiência, Zélia Gattai ${ }^{53}$.

Também por iniciativa das lideranças, foram criados os "círculos de estudo", veículos de divulgação cultural, patrocinados pelos sindicatos, e ligados aos jornais operários, cuja

${ }^{48}$ HARDMAN, Francisco Foot e PRADO, Antonio Arnoni (orgs.) Contos anarquistas. Antologia da prosa libertária no Brasil (1901-1935). São Paulo: Brasiliense, 1985, pp. 127-128.

${ }^{49}$ RODRIGUES, Edgar. Op. cit., 1969, p. 266.

${ }^{50}$ MARCÍLIO, M. L. História da Escola em São Paulo e no Brasil. São Paulo: Instituto Braudel/Imprensa Oficial do Estado, 2005, pp. 181-182; 217-220; 149; 329 e 331.

51 Sobre a escola racionalista, ver: TRAGTENBERG, Maurício. Francisco Ferrer e a pedagogia libertária. In: Educação e sociedade, 1 (1): 17-49, 1978.

${ }^{52}$ PASCAL, M. Op. cit., p. 6.

${ }^{53}$ GATTAI, Z. Op. cit., 1980, pp. 165-167. 
finalidade transcendia a luta reivindicatória. Mantinham bibliotecas abertas ao público, com várias obras das doutrinas anarquista e socialista, e também romances. Da literatura social libertária do início do Dezenove poucas referências restaram; era, contudo, divulgada pela imprensa operária, que noticiava o lançamento de "romances sociais" e outras obras dessa vertente literária $^{54}$. Jacob Penteado evoca o que essa militância ficara devendo à literatura: “...de todos quantos li, na infância, nenhum deles me influenciou tanto o espírito como $O s$ miseráveis, que um vizinho, o barqueiro Cêncio emprestou-me", testemunha ${ }^{55}$, evidenciando como o tema da miséria humana estabeleceu estreita ligação entre a literatura romântica e naturalista do Dezenove e a prosa libertária. Em Contos anarquistas. Antologia da prosa libertária no Brasil (1901-1935, seus organizadores ${ }^{56}$ afirmam não ser o romance "o gênero de frente da ficção libertária", conclusão a que chegaram pela evidência da origem circunstancial do texto libertário, na "sucessão dos embates que vão preenchendo a pauta militante dos jornais operários". Os autores, preferentemente anônimos (“alma coletiva” ou "espírito popular") são "pequenos cronistas, operários anônimos, leitores ocasionais, líderes do movimento, jornalistas e intelectuais militantes". Importa observar neste caso, concluem, não a elaboração estética do texto, mas a "decisão militante que repercute no gesto de escrever".

Também os "salões", espaços destinados a "conferências", números musicais e que depois também incorporariam o teatro militante ${ }^{57}$ representaram importante função na divulgação das idéias libertárias: "salões exíguos, pobres de ornamentos, escuros, com algumas cadeiras e bancos toscos, pequena mesa ao fundo, poucos concorrentes" era a imagem que deles ficara para Everardo Dias, meio século depois ${ }^{58}$.

Geralmente as "conferências" realizadas nesses salões faziam parte de uma programação mais extensa da velada ${ }^{59}$, expressão de origem espanhola que parece ter se propagado, cabendo ao conferencista abordar os complexos temas das teorias libertárias em meio a apresentações musicais, récitas de poesia e espetáculos dramáticos, desfile de gêneros distintos que culminavam pelo "baile" sempre aguardado. Tais veladas ocorriam geralmente aos sábados, iniciando às $20 \mathrm{~h}$ e terminando às $5 \mathrm{~h}$ da manhã de domingo.

Não eram locais exclusivos porquanto há indícios de que outros eventos sociais ocorriam em suas dependências. No Salão Celso Garcia, das Classes Laboriosas, situado na

\footnotetext{
${ }^{54}$ HARDMAN, F. Op. cit., 1983, p. 117.

${ }^{55}$ PENTEADO, J. Op. cit., 1962, pp. 183-184.

${ }^{56}$ HARDMAN, Francisco Foot e PRADO, Antonio Arnoni, já mencionados.

${ }^{57}$ A esse respeito, ver: "Boca de Cena. (um estudo sobre o teatro libertário, 1895-1937)", de CHALMERS, Vera Maria. In: Cadernos AEL, Op. cit., pp. 105-118.

${ }^{58}$ DIAS, Everardo. História das lutas sociais no Brasil. São Paulo: Editora Edaglit, 1962, p.15.

${ }^{59}$ Velada, expressão regularmente utilizada no periódico, significa festa ou espetáculo noturno.
} 
Rua Roberto Simonsen, 22 (antigo $\mathrm{n}^{\mathrm{o}} 39$ da Rua do Carmo) ${ }^{60}$, local onde se deram inúmeras "Festas Pró-Escola Moderna", era também onde ocorriam as festas da Sociedade Beneficência Espanhola $(\mathrm{BE})^{61}$ - que protagonizará com a SESM a primeira fusão de que se tem notícia entre as várias associações espanholas, em $1919^{62}$.

Tratava-se de espaços compartilhados, freqüentados pela militância, pelos líderes das associações étnicas, pelos operários ou por pessoas comuns, o que não implicava necessariamente interesses e pressupostos políticos convergentes. Esse universo, assim, ensejava uma tensão contínua, por vezes redundando em atritos manifestos. Pode-se supor que o mesmo ocorresse no interior das sociedades e agremiações, em cujo percurso fomos tropeçando em incidentes ocorridos, que sugerem casos manifestos de intolerância, que a custo disfarçavam as divergências de fundo ideológico.

Basta relembrar do episódio envolvendo Manuel Rodrigues que, quando à testa do EDE, publicara a Ata da Reunião em que se havia deliberado pela expulsão do Presidente da $\mathrm{BE}$, iniciativa de cujo desdobramento já nos referimos anteriormente, e que redundaria em processo, instaurado pelo implicado que se sentira lesado, em condenação e prisão. E não estamos falando de um cidadão comum, mas de Manuel Rodrigues, figura respeitada, e homem de confiança de Eiras, a quem este incumbira a direção do EDE em seu afastamento.

Há indicadores de que essa confiança, germinada aqui, frutificava sementes plantadas na Espanha. Na Paulicéia eles se aproximaram, provavelmente por compartilharem ideais políticos, palmilhando, desse modo, uma trajetória coerente com os mesmos. Juntos, e com Antonio Dias, tipógrafo e ativista como Rodrigues, haviam fundado a SESM, de quem Rodrigues era sócio honorário $\mathrm{n}^{\mathrm{o}} 1$.

Os dois, Rodrigues e Dias, trabalhariam também no jornal militante La Tribuna Española (LTE), o qual, anteriormente, motivara mais um episódio daqueles que, extrapolando o universo doméstico da colônia, fora parar, pela mão do cônsul da cidade, na mesa do ministro de Estado espanhol, em cuja correspondência oficial, aquele se referiria ao LTE como "inimigo declarado" do EDE, porque este, tendo obtido um subsídio do Governo do Estado de São Paulo, passara a editar números extras, "fazendo o elogio desse país"(sic). Por esse motivo, o LTE que, por razões não explicitadas na missiva, havia sido eleito o órgão oficial da FE - organização que, como tantas outras criadas e recriadas no período, "ansiava reunir todos os espanhóis residentes no Estado" -, reagia em sua defesa, argumentando contra o fato de esta vir

\footnotetext{
${ }^{60}$ Informações obtidas em: LIMA, M. de e VARGAS, M. Op. cit., 1987, p.167 e ss.

${ }^{61}$ EDE 20.06.1914.

${ }^{62}$ EDE 25.10.1919.
} 
encontrando resistências para aumentar o número de associados no interior do Estado entre os "comerciantes, os industriais e os de posição independente", o que a obrigava a estar "reduzida a apenas quatrocentos ou quinhentos obreros $" 63$. À primeira vista, a leitura de tal memorando poderia denotar uma simples divergência entre diretores de dois periódicos de colônia porque, afinal, um deles fora agraciado por um benefício, não estendido ao outro. Porém, o subtexto parece indicar outros interesses por trás da atitude do LTE, nesse momento em defesa da FE, se levarmos em conta o prestígio de Eiras e o fato de ter sido ele o sócio-fundador da SESM. De todo modo, e mais uma vez, o imbróglio poria em relevo as sinuosas relações e os obscuros interesses que pautavam essas relações.

Manuel Rodriguez jamais realizou inscrição no CGE, no período examinado. Sabemos dele que era aragonês, tendo vivido em Barcelona, onde trabalhara por muitos anos no comércio $^{64}$, informação que pode orientar uma pista para o entendimento de sua militância, se considerarmos que em Barcelona, terra de Ferrer, se centrava o foco da ebulição política da Espanha, naquele período.

Tais fatos e a ligação de Rodrigues com a militância podem estar na raiz do processo do qual fora vítima por parte de um correligionário, posto que a simples publicação da Ata de sua expulsão no EDE, por Rodrigues, acompanhada da exposição de motivos que o derrubaram da Direção da BE, não parece motivo suficiente para o desdobramento que se seguiu ao episódio.

Quanto a Dias, ou melhor Antonio Dias Lopez, conforme seu registro no CGE, pudemos verificar tratar-se de um galego, como Eiras, porém nascido em Lugo. Também como Eiras, Dias indicaria ser tipógrafo ${ }^{65}$, em sua primeira passagem pelo CGE, em 1895; era casado, tinha 33 anos e embarcara de quarta classe. Esses indícios e a ligação posterior com Eiras com quem empreendeu várias iniciativas conjuntas, das quais podemos destacar a fundação da SESM, em 1898, da qual também Rodrigues participara, podem sugerir que também ele, como Eiras, pudesse representar mais um caso de exílio político.

Lamentavelmente, pouca informação conseguimos do LTE, periódico no qual trabalharam Dias e Rodrigues. Ele teria sido fundado por Valentin Diego, irmão de Isidoro Diego, ambos ativistas. Em 1899, Valentin também fundara, com Everardo Dias, o El Grito del Pueblo, jornal sindicalista. Everardo Dias, militante, era muito próximo de Eiras que, a inícios da década de 1900, viria a público investindo contra o então diretor do LTE, Higino Bisbal.

\footnotetext{
${ }^{63}$ AGA. Caja 1691. Correspondência datada de 08.04.1913.

${ }^{64}$ Essas informações foram publicadas no EDE por ocasião de seu falecimento; foi enterrado no Cemitério do Araçá. EDE 23.09.1922.

${ }^{65}$ LRC 21.04.1895.
} 
Essa informação foi obtida junto a uma edição que localizamos, datada de janeiro de 1904, segundo a qual constava que o periódico, circulando às quintas-feiras em São Paulo e Santos, tinha como proprietário Higino Bisbal e que era editado na Rua Monsenhor Anacleto, 27.

Higino Bisbal Martinez esteve por dois anos seguidos no CGE. No primeiro, em $1916^{66}$, portanto muitos anos depois de residir na Capital de São Paulo, manifestou-se natural de Valencia, tinha, então, 48 anos de idade, era casado e residia na Rua Maria Domitila, 72. Provavelmente já dirigisse o LTE em 1902, ocasião em que, por intermédio de uma edição avulsa do La voz de Espana, pudemos acompanhar a acusação que então lhe dirigira Eiras, censurando-o por defender a um vice-cônsul "indefendible", alusão à venda de credenciais a agentes consulares do interior, por parte de Teixeira de Carvalho, o vice-cônsul empossado a contragosto da opinião pública, provavelmente por ser brasileiro. Esse episódio também resvalaria para o expediente do Ministro de Estado espanhol, pela missiva que lhe enviou o embaixador Antonio Benitez ${ }^{67}$.

Este pode ter se constituído em mais um evento isolado por meio do qual afloravam as "diferenças" entre esses indivíduos e que acabavam transparecendo nas páginas dos periódicos que editavam ou nos quais trabalhavam. Nesse caso, veremos, as escaramuças aparentemente foram superadas quando da anunciada intenção da fusão entre os dois periódicos, que, afinal, desconhecemos se acabou ocorrendo. Nessa época, final da primeira década, consta que o $\mathrm{La}$ Voz de España era dirigido por Eiras e Dias.

O La Voz de España, também teria sido fundado por Eiras - não sabemos se individualmente ou em sociedade - e seu primeiro número circulou em 01.07.1900 ${ }^{68}$. Circularia por menos de um ano, interrompendo-se a sua publicação em 31 de março do ano seguinte. Reapareceria novamente em outubro de 1905, reiniciando com o número 1. Há evidências de que este semanário tenha circulado simultaneamente ao EDE (diário) e que, mais tarde, tenha ocorrido a fusão das duas publicações. A partir de 1912, quando iniciamos a consulta ao EDE, ele já assim se denominava (El Diario Español) e por diversas ocasiões encontramos menção ao LTE em suas páginas, nenhuma delas desabonadora. A recíproca parece ter sido verdadeira: em 1913, por exemplo, o EDE reproduzia matéria publicada no LTE em que este o elogiava pelas grandes reformas então instauradas em seu parque gráfico, que o colocava "à altura dos

${ }^{66}$ EDE 10.02.1916. O outro registro é de 09.02.1917 e os dados permanecem os mesmos.

67 "Los vendedores de agencias consulares". In: La voz de España, 16.10.1902; AMAE. Série Brasil. Correspondencia Embajadas y Legaciones. H-2048. Memorando enviado a 20.10.1902.

${ }^{68} C f$. informação obtida da consulta de um exemplar avulso localizado no AMAE, datado de 16.10.1902 (edição de $\mathrm{n}^{\mathrm{o}}$ 124). A sede do jornal ficava na Rua XV de novembro, 58. Localizamos também números avulsos, de 07.01.1904 e 16.03.1908, quando a redação então se localizava na Rua Bráulio Gomes, 4. 
melhores que existem em São Paulo" ${ }^{\text {, }}$, convocando toda a colônia para que o prestigiasse em seus anúncios. Assim, em que pese o mal-entendido anterior, circunstancial ou não, o fato é que no LTE também trabalharam dois dos colaboradores do EDE e amigos pessoais de Eiras Garcia, ambos “jornalistas-operários”, Antonio Dias e Manuel Rodriguez.

Essa constatação é indicativo de que esses indivíduos mantinham, em paralelo ao exercício regular de sua profissão, em periódico "comercial", a atividade militante. E como veremos no caso de Isidoro Diego, conciliavam a militância até mesmo com uma atividade comercial.

$\mathrm{Na}$ lógica contraditória dessas complexas, ambíguas e por vezes tumultuadas relações interpessoais - de leitura quase sempre subliminar - que pautaram a convivência desses "líderes" da colônia no período examinado, poderia até parecer natural que da festa de fusão das duas sociedades, SESM e BE, ocorrida no Salão Celso Garcia em $1919^{70}$, tenha participado o grupo dramático recém-criado da $\mathrm{FE}^{71}$, o Círculo Dramático Recreativo Isaac Peral, o mesmo que abrilhantaria a festa de aniversário da FE, com a apresentação do monólogo dramático Criminal, de Francisco Guerrero, de flagrante coloração libertária. Aquela associação, a propósito, vetava terminantemente segundo seu Estatuto, qualquer envolvimento "político" de seus associados e dirigentes.

$\mathrm{Na}$ comemoração, mesclada à extensa programação, a "conferência" seria apresentada por José Solé $^{72}$, o mesmo que anteriormente, na direção do Grupo Dramático Cervantes, em 1909, promovera grande festa no Teatro Colombo, em favor das "vítimas da reação espanhola" (leia-se Ferrer e os demais ativistas, assassinados e presos) ${ }^{73}$.

A família Solé, oriunda de Tarragona, a propósito, poderia ser considerada, em que pesem os parcos indícios documentais que conseguimos reunir, como a síntese das múltiplas e paradoxais articulações que se estabeleciam, conforme temos apontado, entre membros da colônia aqui instalada e muitas vezes, como é o seu caso, entre pessoas da mesma família.

Martin Solé Ivalles declarou-se encuadernador quando se registrou pela primeira vez no CGE, em 1906; tinha então 33 anos e era solteiro. Seu irmão, o acima citado "conferencista" - eufemismo para militante - José Solé Ivalles que ora se apresentava na comemoração de aniversário da FE, sociedade em cujos estatutos, repetimos, proibia-se esse tipo de participação,

${ }^{69}$ EDE 09.08.1913. Trad. da autora.

${ }^{70} \mathrm{EDE}$ 08.11.1919.

${ }^{71}$ EDE 24.05.1918.

${ }^{72}$ EDE 16.12.1920.

${ }^{73}$ RODRIGUES, E. $O$ anarquismo... op. cit., p. 154. A respeito da atuação dos demais grupos dramáticos de aparição esporádica no EDE, pouco pudemos reunir. Seriam: O Grupo Maria Guerrero e o Grupo Dramático Alfonso XIII, designação já indicativa de sua orientação. 
também se registrou no CGE no mesmo dia, declarando-se igualmente encuadernador. Era mais velho, tinha 36 anos e era casado ${ }^{74}$. Contudo, aparentemente o status social da família evoluíra desde aquela primeira aparição. Martin Solé progredira. Coluna do EDE, em 1913, informava da inauguração, em "concorrido banquete ao qual compareceram destacados membros da colônia", do seu taller gráfico, situado na Avenida Rangel Pestana, 244, com serviços de encadernação, papéis pautados, fábrica de livros em branco (acreditamos que sejam livros para uso em lançamentos contábeis) e material escolar; também mencionava a importação de papéis para gráficas e escritório ${ }^{75}$. Esse detalhe talvez tivesse motivado a alteração de sua ocupación para o próximo registro. Realizado em 1915, o encuadernador Martin Solé agora se declarava comerciante provavelmente porque passara a trabalhar com importação de papel. Seus negócios continuaram crescendo. Na ampliação, a mudança de sua oficina gráfica para o $\mathrm{n}^{\mathrm{o}} 318$ da mesma avenida, em local mais apropriado ${ }^{76}$. Transformara-se, portanto, num próspero comerciante. No entanto, seu irmão José, também encuadernador e que provavelmente trabalhasse em suas oficinas gráficas, era um reconhecido ativista, um palestrante respeitado, requisitado para inúmeras "conferências" e "festas". E para completar a família Solé, do próspero Martin e do militante José, havia ainda Mercedes, irmã de ambos, que se apresentava como artista, componente da trupe feminina que desenvolveu, a partir da primeira década do Novecentos, o teatro amador de timbre anarquista ${ }^{77}$.

No caso da FE, desnecessário ressaltar, a situação era de crônica desobediência aos estatutos por parte da militância que se infiltrava em seus quadros associativos e diretivos. Fundada em 1912, teve seus estatutos publicados na íntegra no ano seguinte no $\mathrm{EDE}^{78}$, em cujo capítulo I indicava, sem rodeios: "esta sociedad no tiene carácter político ni religioso, prohibiéndose terminantemente dentro del local social las discusiones que atañan a esos puntos (...)". Além disso, demonstravam ter preocupação também para com a "boa conduta" de seus associados, respaldados pelo artigo 6 do Capítulo III de seu Estatuto, que pontuava: "No se admitirá como socio a quien por su conducta y proceder público desdore el buen nombre de la colectividad española y si alguno de los ya socios cometiese actos que perjudiquen a esta Sociedad, la Junta Directiva podría acordar su expulsión”.

${ }^{74}$ EDE 02.03.1906. Tinham um outro irmão, Andrés Solé Ivalles, 30 anos, que também se registrou no mesmo dia, declarando-se hojalatero (funileiro).

${ }^{75}$ EDE 10.11.1913.

${ }^{76}$ EDE 02.05.1922.

${ }^{77}$ Citada por CORREIA, Francisco. "Mulheres libertárias: um roteiro". In: PRADO, A. Libertários no Brasil, Op. cit., 1987, p. 44.

${ }^{78}$ O Estatuto da Federação Espanhola constituía-se de 7 capítulos e 35 artigos distribuídos em diversos itens e foi publicado no EDE 07.09.1913. 
Formalmente coerente com essa orientação, procurava a FE celebrar com "grandioso festival" o "Día de la raza", data nacional espanhola em que se comemorava o descobrimento da América, distinguindo, apesar disso, como orador oficial da comemoração exatamente a Antonio Dias, reconhecido militante ${ }^{79}$. Talvez nessa dubiedade de orientação ideológica, ou na impossibilidade de conter a manifestação dos militantes, malgrado a proibição estatutária, resida o diagnóstico de Edgard Rodrigues para quem os salões da FE foram um dos mais utilizados para a divulgação da filosofia anarquista. Ali aconteceria, destarte, em maio de 1920, um festival, "organizado pelo Centro Feminino Jovens Idealistas", com a apresentação da peça Hambre (comédia em um ato, em espanhol). No mesmo ano, em agosto, outro festival, desta feita em benefício da União dos Chapeleiros, "com tômbola e baile" e, em 1923, encenação de A Greve, com apresentação do Grupo Teatro Social, organizado pelo Centro Libertário Terra Livre $^{80}$. Em ambos os eventos, a flagrante vinculação com a militância anarquista!

Nessa mesma trilha de atitudes observadas a contrapelo, que acabaram revelando a ausência de congruência como a tônica das relações estabelecidas, notamos que, em outra "data nacional" festejada, o "Dois de Maio", o FE, inexplicavelmente, havia omitido da lista de seus convidados o nome de Eiras Garcia, o qual, contrariado, se pronunciaria depois pelo EDE, fato que também reflete com nitidez os obscuros contornos que nortearam as relações que vigoraram no seio da camada ilustrada da colônia ${ }^{81}$.

E acrescentando mais um fragmento a esse mosaico de dados aparentemente díspares e contraditórios, não poderíamos deixar de mencionar que, considerada sob os ânimos provocados pela morte de Ferrer, de pouca divulgação no EDE mas de intensa repercussão na cidade, soa espantosa a inesperada cobertura concedida pelo periódico em todo o primeiro semestre de 1913 a Adolfo Vazquez Gómez, "paladino das idéias liberais, ilustre propagandista do livre-pensamento, que vem a São Paulo para "conferências", no Salão Germânia" "82 . A estas, se sucederiam outras no Salão Celso Garcia também anunciadas com antecedência, cujo tema "novos problemas sociais" abordaria as "teorias de K. Marx, Engels, Kautski, Jaurés, Pablo Iglesias, Keir Hardie e outros mestres das doutrinas modernas...", além de se discutir "o grandioso triunfo que os socialistas acabam de alcançar na República Argentina nas últimas eleições, para senadores e deputados" ${ }^{\wedge 3}$. Essa suspeita e inesperada cobertura do EDE, prudente em assuntos correlatos, até onde pudemos constatar, só pôde ser compreendida, agora, como

\footnotetext{
${ }^{79}$ EDE 04.10.1920.

80 “Operários e Anarquistas fazendo teatro". In: Cadernos AEL, op. cit., pp. 40; 25 e 38.

${ }^{81}$ EDE 03.05.1921.

${ }^{82}$ EDE 05.04.1913. Trad. da autora.

${ }^{83}$ EDE 07.04.1913. Trad. da autora.
} 
uma "liberalidade" (ou manifesta transgressão?) de Manuel Rodrigues, notório ativista, e que, no período, vinha substituindo a Eiras Garcia na direção do periódico.

Adolfo Vázquez Gómez permaneceria algum tempo no país, visitando cidades do interior, onde conferenciaria para platéias de imigrantes, com cobertura integral do EDE. Em agosto do mesmo ano, anunciava-se uma conferência que seria proferida no Centro Galego do Rio de Janeiro ${ }^{84}$; não consta, contudo, que tenha proferido alguma palestra em qualquer das sociedades locais, nem mesmo no Centro Galego da cidade que, à época, tinha Perfecto Ares como presidente ${ }^{85}$.

Notícias esparsas e fragmentadas dão conta de que seria um exilado, por haver participado de movimentos antimonarquistas na Espanha. Era considerado um dos "colaboradores constantes" do periódico, trabalhando "desde os pontos em que se encontra em missão", fato ainda mais curioso se levarmos em conta as implicações, para Eiras Garcia, dessa escolha ${ }^{86}$.

Em 1920, no entanto, quase duas décadas passadas da primeira encenação de Los Conspiradores no Salão do Liceu Español, o quadro político pouco se modificara, acirrando-se as perseguições e as deportações aos estrangeiros. A peça Os Conspiradores, agora encenada em português, mantinha-se, assim, atualizada e passava a ser exibida em outros salões da cidade, caso do Itália Fausta, na Rua Florêncio de Abreu, 45, com ampla divulgação da imprensa militante, simultaneamente à outra, $O$ Mártir de Montjuich cuja exibição era proibida pelo cônsul espanhol de Santos "por conter injúrias ao rei da Espanha"87.

\section{O Teatro Social}

A atividade teatral militante protagonizada por imigrantes na cidade é anterior à existência da imprensa operária, praticamente a única fonte para sua investigação. Introduzido pelas associações étnicas como instrumento didático e de entretenimento, o teatro operário representou uma das mais expressivas formas de divulgação ativista, cuja atuação é de difícil recuperação, dada a devassa a que todo esse material foi submetido pela Polícia Política do

${ }^{84}$ EDE 19.08.1913.

${ }^{85}$ No EDE 24.07.1912, anúncio da nova diretoria.

${ }^{86}$ EDE 04.08.1913. Trad. da autora. Ao lado deste "correspondente" o periódico mantinha outros Nemesio Alvarez (o Abate Ferri) em Madrid e Fernando Gonzalez, no Rio de Janeiro, além de expandir constantemente seus quadros para as localidades do interior: Tayuva, Monte Alto, Araguari e Araraquara, as estações Colina, Inácio Uchoa, Itambé, Dona Luisa, Botafogo, Andes e Monte Verde, eram as que acabavam de ter seu próprio correspondente para o $\mathrm{EDE}$.

87 "Operários e Anarquistas fazendo teatro". In: Cadernos AEL, op. cit., pp. 21 e 49. 
Estado Novo, nas bibliotecas sindicais e particulares dos militantes anarquistas e nos Centros de Cultura $^{88}$.

A recuperação desses registros, portanto, data do aparecimento da imprensa operária e de alguns poucos depoimentos deixados por contemporâneos, dentre os quais destacam-se, pelo conjunto da obra, os trabalhos de Edgar Rodrigues, antes mencionados, fundados não apenas na consulta de diversos jornais ácratos do período (A Plebe e A Lanterna, este o veículo mais consistente do anticlericalismo anarquista, editado entre 1901 e 1935, alcançando a tiragem de 26 mil exemplares), mas junto a diversos militantes então ainda vivos na década de 1950 quando iniciou parte de sua obra. "O teatro social no Brasil começou com a chegada dos emigrantes libertários" assinala, acrescentando: "por isso, existem grandes dificuldades para apurar a data dos primeiros espetáculos, já que eles não eram divulgados na imprensa burguesa e a operária estava começando, aparecia esporadicamente" ${ }^{\Perp 99}$. Seus primórdios apontam para dramatizações entre "companheiros de idéias", em forma de teatro repentista. Nos episódios da representação cênica, em que predominava a função "didática" enquanto instrumento de divulgação dos princípios libertários, relegava-se a um plano secundário a qualidade plástica do espetáculo. Informando as reivindicações dos trabalhadores, estreitamente ligado ao seu cotidiano $^{90}$ e buscando a transformação social pela prática política "os princípios filosóficos do anarquismo pensam a arte como uma função natural, comum a todos os indivíduos e vinculada à necessidade expressiva" $"$.

Em sua maior parte eram textos importados aqui traduzidos, que se antecederam aos textos de autores nacionais. Era nas fábricas, diretamente, ou pela imprensa operária que se dava a divulgação das encenações, que ocorriam em diversos Estados do país, datando da última década do Oitocentos. Oscilando a atuação entre períodos agudos e fases de tolerância, nas quais a polícia "permitia a reorganização e depois caía em cima dos operários tomando seus pertences", desse modo instável e descontínuo sobreviveriam tais grupos, alternando os locais

${ }^{88}$ A maior parte desses acervos encontra-se no exterior, para onde foram levados, única maneira de não serem destruídos. O maior arquivo do movimento operário, contendo material não especificado, mas que incluía boa parte do acervo do Centro de Cultura Social, até 1969, foi o de Edgard Leuenroth, adquirido pela Unicamp em 1974. Cf. palestra proferida por Jaime Cubero, no Encontro de Arquivos do Estado de São Paulo, na Universidade de São Carlos, em julho de 1987 (mimeo). Tal acervo hoje constitui o Arquivo Edgard Leuenroth, daquela Universidade

${ }^{89}$ RODRIGUES, E. O anarquismo... op. cit., s.d., pp.106-107.

${ }^{90}$ O autor enumera os diversos "temas" então enfocados: "cenas com patrão e empregado; ateu e religioso; camponeses e fazendeiros; política e anarquismo; ensino estatal e livre; governo e povo; o poder da greve como método de luta e de solidariedade; o militarismo e o soldado, frente a frente, em diálogos candentes, debates de persuasão ideológica". In: O anarquismo... op. cit., s.d., pp. 106-107.

${ }^{91}$ LIMA, M. e VARGAS, M. Op. cit., 1987, pp. 167 e ss. 
de encontro e com nomes diferentes, até que, novamente, eram descobertos e tinham tudo confiscado $^{92}$.

Segundo Edgard Rodrigues, no Salão do Liceu Espanhol, em festa libertária de 1904, era encenada, entre outras, no idioma espanhol, a peça Hambre ${ }^{93}$, enquanto o Grupo Dramático Cervantes exibia, em 1905, “dramas sociais” de José Dicenta, autor cujos títulos, como também alguns de Benavente, foram adquiridos da Sociedade dos Autores Espanhóis por Eiras Garcia, em meados da primeira década, "en vista de los constantes pedidos",94.

O Salão Celso Garcia foi palco de inúmeras encenações no período, não obstante a parca documentação existente. Consta estar entre os cinco salões mais utilizados pelos anarquistas, seguido do salão da Federação Espanhola ${ }^{95}$. Algumas das peças, encenadas nas festas desses dois salões, eram em língua espanhola, dentre as quais consta: Criminal (monólogo social), de José Sanches, com o Grupo Dramático Idea Moderna. Festival com récita, conferência, quermesse e baile (01.11.1912); La morte (sic) de Francisco Ferrer. Apresentação do Grupo Dramático Libertário Mario Rapizardi. Festa promovida pelo Sindicato de Ofícios Vários, em comemoração à conquista de oito horas, com conferência, récita e baile (10.05.1913); Arlequin el salvage (sic), comédia em três atos de crítica social. Grupo Os Semeadores. Festival, com hino, conferência, quermesse e baile (19.04.1919); Hambre $^{96}$, na festa em comemoração ao primeiro aniversário da União dos Trabalhadores Gráficos, com baile (17.07.1920) e Los malos pastores (drama social em cinco atos). Apresentação do Grupo Ibérico. Com música, conferência e baile (09.06.1923) ${ }^{97}$.

As datas das encenações e dos anúncios relacionados aos eventos ocorridos no Salão Celso Garcia parecem sugerir alguma interrupção em suas atividades, durante os anos de 1914 a 1917, período que pode ser relacionado com a conflagração mundial, pelas dificuldades enfrentadas para levar a efeito a sua programação, porém não podemos descartar o acirramento do controle e da perseguição policial neste período.

Nas sociedades nas quais havia apresentações de teatro operário também se organizavam programações de lazer a seus associados. Recebendo variada denominação, tais festas iniciavam-se com uma encenação, prosseguiam com a "conferência", à que se seguia algum passatempo (rifa de algum objeto, por exemplo). Recomeçava-se, depois, com a

\footnotetext{
${ }^{92}$ RODRIGUES, E. O anarquismo... op. cit., pp. 227-228.

${ }^{93}$ Essa peça teria sido uma das dez mais encenadas no período. $C f$. RODRIGUES, E. O anarquismo. .. op. cit., p. 231.

${ }^{94}$ EDE 04.06.1914.

${ }^{95}$ RODRIGUES, E. O anarquismo... op. cit., p. 231.

${ }^{96}$ Hambre figura entre as dez peças mais encenadas no período. $C f$. RODRIGUES, E. O anarquismo... op. cit., p. 231

${ }^{97}$ Cf. "Operários e anarquistas fazendo teatro". In: Cadernos AEL, op. cit., pp. 22, 55, 13, 35 e 48.
} 
apresentação de outra peça teatral, e, por fim, acontecia o baile familiar. Enumerando alguns desses salões nos quais ocorriam as festas destinadas às famílias dos associados, alguns dos quais eram alugados para a realização de espetáculos teatrais operários, Elazari cita, dentre eles, o Salão Alhambra, designação que sugere relação com a colônia espanhola, em funcionamento em 1906 ${ }^{98}$; havia ainda o Salão do Centro Galego (1908) e o do Liceu Espanhol (1903$1904)^{99}$.

Algumas vezes, as peças apresentadas fugiam à temática revolucionária, o que desagradava profundamente aos representantes dos jornais operários: "se quiséssemos como qualquer repórter de jornal burguês fazer a crônica da festa avaliando-a pela execução do programa e pela concorrência, com um "bravo" e um "parabéns" aos organizadores, teríamos dito tudo", reclamava o redator de O Amigo do Povo. Contudo, prosseguia ele, como se trata de uma "sociedade operária de resistência, apraz-nos examinar se os seus atos correspondem ao fim para que foi criada e contribuir com o nosso grão de areia para a energia dos operários conscientes". E, ainda não satisfeito, arrematava: "Ora, excetuada a conferência, todo o sarau foi comparado às banais festarolas organizadas por uma das sociedades recreativas que pululam pela cidade" ${ }^{\prime 100}$. No entanto, a receptividade à encenação do drama anticlerical Todos los medios son buenos, de autoria do anarquista Filomeno Collado, em festa realizada pelo grupo Amantes do Progresso, foi distinta. Segundo o jornalista "a sala estava repleta e o espetáculo, coroado por um baile, pôde-se contar entre as melhores festas de propaganda aqui realizadas" ${ }^{, 101}$.

\section{Os profissionais gráficos espanhóis na imprensa operária}

Os gráficos, geralmente ex-sindicalistas europeus, alguns refugiados, outros deportados ou foragidos, por questões políticas - lembremo-nos de Eiras Garcia - aqui aportavam trazendo em sua bagagem idéias libertárias propagadas na Europa, especialmente nos países de menor concentração industrial, caso da Espanha. Terão grande influência no movimento operário, além da proporção do seu número, compondo também um significativo segmento da liderança socialista e anarquista ${ }^{102}$. Resultante da situação de penúria dos trabalhadores, as três últimas

\footnotetext{
${ }^{98}$ Consta que esse Salão funcionava na Galeria Cristal, à Rua Marechal Deodoro, 2 ou 21. Cf. Cadernos AEL, op. cit., p. 97.

${ }^{99}$ ELAZARI, J. Op. cit., pp. 170 e ss.

${ }^{100}$ O Amigo do Povo, 09.07.1904. Apud: ELAZARI, J. Op. cit., p. 172.

${ }^{101}$ Passim.

102 Socialismo e anarquismo eram ideologias importadas, trazidas por imigrantes, intelectuais e trabalhadores, no final do século XIX. No início do século, os "círculos socialistas tinham se transformado em ligas de resistência e federações de trabalhadores, apoiando greves e cooperativas de consumidores". Cf. HAHNER, J.
} 
décadas do século XIX foram profundamente marcadas pela presença de movimentos extremistas, cujos ativistas, indesejáveis em suas pátrias, tiveram que se refugiar em outros países.

O trabalhador estrangeiro, imigrante com maiores conhecimentos técnicos e ideológicos, trouxe também a sua contribuição política ao Brasil. Não vieram para nosso país apenas calabreses ou minhotos primitivos; também operários asturianos, catalães, renanos, lombardos e vênetos, radicais perseguidos nas suas regiões de origem $^{103}$.

Conforme ficou demonstrado no Capítulo IV, por detrás da criação das associações e entidades beneficentes espanholas, quase sempre vislumbramos, ao lado de indivíduos de aparente isenção ideológica e/ou claramente contrários a qualquer manifestação dessa natureza que os pudesse comprometer, outros claramente envolvidos com a militância - caso de Everardo Dias. Desses, muitos se vinculavam, de alguma forma, à imprensa, como gráficos, tipógrafos, jornalistas ou linotipistas. O resultado dessa composição ideológica heterogênea foi fator que implicou, no limite, a clivagem ideológica entre os diversos componentes das associações, exacerbando, ainda mais, os estranhamentos de natureza diversa observados no período.

Tais profissionais gráficos encontrariam ambiente extremamente propício na Paulicéia. Nas últimas décadas do século passado, como apropriadamente observa Heloisa de Faria Cruz "a escrita, e principalmente a palavra impressa, estabelece novas articulações na vida cotidiana da cidade" e, na base da disseminação da escrita e principalmente dos materiais impressos, localiza-se o rápido desenvolvimento das artes gráficas, processo que implicou o crescimento do número de tipografias e litografias na cidade, fenômeno que repercutiu na demanda por profissionais especializados ${ }^{104}$.

Estes teriam nas madrugadas seu ponto de encontro no Café Guarani, um dentre os muitos que existiram na cidade, este que, conforme Afonso Schmidt, funcionou entre os anos de 1904 e 1924, pertencia a um espanhol e se localizava "defronte a travessa do Comércio". Ali se reuniam diversos segmentos do periodismo da cidade, porém, depois das duas da madrugada permaneciam animadas apenas as mesas do fundo "com rapazes da esquerda que vinham das

\footnotetext{
"Resistência dos trabalhadores e liderança operária". In: Op. cit.,1993, pp. 249-323. Ver ainda, sobre essa questão: MARAN, S. Op. cit. 1967, p. 313

${ }^{103}$ CHACON, Vamireh. História das idéias socialistas no Brasil. Rio de Janeiro: Civilização Brasileira,

${ }^{104}$ CRUZ, H. Op. cit., 1994, p. 64 e ss.
} 
reuniões sindicais" e com os redatores, tipógrafos e revisores dos jornais que iam chegando, muitos sem dinheiro sequer para a "média com pão quente"

A vida de gráfico era bastante sacrificada. Até os anos 1920 morriam precocemente, em média aos 35 anos, por causa do chumbo contido nos tipos. Como à época os jornais tinham circulação diária, eles não desfrutavam sequer de uma folga semanal, obtida somente pela greve de 1921. Analisando essas categorias por via dos LRC verificamos que metade deles residia em habitações coletivas. Em um desses endereços (Rua do Brás, 47), para se ter uma idéia, residiram ao mesmo tempo, entre os anos de 1893 e 1894, sete indivíduos: dois tipógrafos (os irmãos Sierra Alba, Rodrigo e Rafael) junto dos quais morava um taponero; dois jornaleros; um barrilero e um delineante. Destes, dois ainda eram casados. Tomando-se um segundo domicílio, a Rua 25 março, 01, verificamos que ocorria o mesmo: lá residia Modesto Ruano Moscoso e Vitorino Diaz Duran, ambos tipógrafos de Málaga, o primeiro provável aparentado de Manuel Moscoso, junto dos quais vivia um comerciante; um sombrerero e um zapatero, todos solteiros e com idade entre 19 e 30 anos.

No cômputo geral, considerados os 30 anos analisados, a proveniência desses tipógrafos era prioritariamente da Andaluzia e da Galícia ${ }^{106}$, em percentuais bastante próximos, aparecendo Barcelona logo depois com metade do contingente, seguida por inúmeras localidades de origem com pequena representatividade ${ }^{107}$. Constatamos também que, paralelamente à categoria de tipógrafo e periodista, os registros do CGE passaram a exibir funções correlatas, como a de impressor, dibujante (desenhista, cartunista) e litógrafo (responsável pelas imagens e reproduções gráficas), geralmente ocupadas por indivíduos na faixa dos 25 anos.

A imprensa tipográfica, desse modo, transforma-se com a cidade, refletindo a sua transformação. Desprendendo-se gradativamente da Academia e da cultura letrada e se imiscuindo mais e mais na vida da cidade, vai abrindo espaço e dando expressão aos novos sujeitos sociais que nela passariam a habitar. Em decorrência, emerge uma imprensa étnica, fruto da presença dos estrangeiros na nova configuração da vida social urbana, e se dá o aparecimento de uma imprensa operária, pela mão desses novos elementos, imigrantes em maioria, que ingressariam no mercado gráfico. Muitos deles, por sua condição qualificada, acabariam por tornarem-se jornalistas, caso de Edgard Leuenroth. No entanto, eram os gráficos

\footnotetext{
${ }^{105}$ SCHMIDT, A. Op. cit., pp. 158-159.

${ }^{106}$ Eiras Garcia e Everardo Dias eram galegos de Pontevedra. Antonio Dias, de Lugo; já as famílias Ortega e Moscoso, com vários representantes tipógrafos, eram de Málaga.

${ }^{107}$ Relatório Access 3. Na ordem essas localidades seriam: Santander; Madrid; Baleares; Zaragoza; Lérida; Tenerife e León.
} 
ou "jornalistas-operários", que nada tinham a ver com os profissionais da "grande imprensa", com quem aliás mantinham estreitas relações, os que editavam os jornais operários; em outras palavras, o movimento operário produziu os seus próprios jornalistas ${ }^{108} . \mathrm{O}$ mercado, promissor, exigia constante e rápido aprimoramento técnico. Às vezes, exigia também improvisações, especialmente na linguagem, frente à "velocidade" das inovações geradas pelo progresso. Ao falar de aviação, por exemplo, por vezes utilizavam a denominação "batida" ou "capotamento" no lugar de colisão.

Foi exatamente perseguindo as inovações que, em 1913, são modernizadas as oficinas gráficas do EDE, fato alardeado em grande manchete - "Siempre Adelante, Nuestros Progresos" - pela qual se fazia a divulgação dos novos equipamentos importados recémadquiridos $^{109}$, ao mesmo tempo em que se ampliava a oferta de serviços oferecidos, com a elaboração de "etiquetas, programas, natalícios, envelopes, talonários, papel de carta, faturas, folhetos, livros, menus, prospectos, convites, circulares, recibos, livros, memórias, etc.”, enfim, uma infinidade de impressos que gradualmente passavam a ser utilizados ${ }^{110}$.

Em 1908, quando ainda se chamava La Voz de España, o jornal, fundado em 1899 por Eiras Garcia e então dirigido por ele e Antonio Dias - os quais, por esta época, demonstravam a intenção de fundi-lo ao La Tribuna Española - já anunciava a "importação de modernos equipamentos gráficos da Alemanha", para, assim, instalar as "oficinas tipográficas que servirão para a impressão do futuro El Diário Español, sucessor do La Tribuna Española e do La Voz de Espana". A máquina para impressão, completava a matéria, "imprime 4.000 exemplares por hora". Os demais equipamentos "de impressão, para costurar livros e cortar papel, assim como grande quantidade de tipos chegarão em abril, comprados da Alemanha". A tipografia, informava, “começará a funcionar na próxima semana na Rua Bom Retiro, 19, e executará toda classe de trabalhos".

Foi expressiva a liderança dessa categoria sobre as demais no movimento operário, vistos como os principais agentes de mobilização. Eram valorizados pelas outras categorias profissionais porque, afinal, dominavam a palavra escrita, uma das principais ferramentas de reivindicação do período. Foi, a propósito, por meio desse atributo, que haviam tido contato com as teorias sociais da época, cujo ideário passariam a divulgar através de jornais que criavam e dirigiam. "Mais importantes talvez do que o frágil sindicato, o jornal constitui um dos

${ }^{108}$ FERREIRA, M. “Sobre os gráficos como jornalistas”. In: Op. cit., pp. 109-143.

109 EDE 21.07.1913. Com relação aos avanços técnicos das artes gráficas na cidade e do papel desempenhado pela imprensa periódica enquanto processo cultural, ver: CRUZ, H. Op. cit., 1994.

${ }^{110}$ EDE 08.01.0914. 
principais centros organizatórios anarquistas e de difusão da propaganda", pontua Boris Fausto, esclarecendo que, em muitos casos, esse veículo de expressão escrita transformava-se em veículo oral, "ao ser lido em voz alta para os trabalhadores analfabetos""111.

Alguns desses jornais foram publicados em espanhol, como o El Grito del pueblo, editado em 1899 por Everardo Dias e Valentin Diego, outro jornalista militante, circulando simultaneamente em São Paulo e Curitiba. Editado por Florentino de Carvalho e circulando em São Paulo e Rio de Janeiro, em 1913, temos também o La Rebelión. Editados em português, porém de militantes espanhóis, foram os seguintes: O Livre Pensador (Everardo Dias, 1903); A Terra Livre (Isidoro Diego e Manuel Moscoso, 1905); O jornal Operário (Isidoro Diego, 1905); Luta Proletária (também Isidoro Diego, 1906, como principal redator); A Revolta (Florentino de Carvalho, editado em Santos, em 1911); Germinal (Florentino de Carvalho, 1913) e O Livre Pensamento (Everardo Dias, 1915) ${ }^{112}$, dentre outros.

A categoria dos tipógrafos, assim, concentrava grande número de anarquistas que "pela sua própria profissão, achavam-se fortemente intelectualizados”. Eram eles, a propósito, quem "imprimiam os volantes e manifestos clandestinos que apareciam durante os movimentos grevistas", informa Jacob Penteado, militante operário, reconhecendo, dentre eles, alguns "intelectuais espanhóis" como "Everardo Dias e Florentino de Carvalho, "idealistas sinceros, sempre marcados pelos policiais" $" 113$.

De Florentino também se recorda José Oiticica, também ele um anarquista militante e prestigiado professor de universidades estrangeiras, em seu livro Ação Direta (Meio século de pregação libertária), cuja admiração passou a dedicar-lhe desde que o conheceu freqüentando os comícios em praça pública e as conferências que ministrava ${ }^{114}$.

Alguns desses militantes, compondo-se por uma maioria de imigrantes italianos, alguns espanhóis e portugueses, muitos dos quais trabalhavam em jornais na cidade e haviam, como vimos, deixado seus países por questões políticas, tentaram fundar, em 1891, uma associação de classe, iniciativa que só veio a se concretizar em 1896 e cuja estratégia de atuação era "meio beneficente, meio de resistência", evidenciando a latente convergência das preocupações sociais pontuando seu universo. Valentin Diego, ativista espanhol, registrado no CGE em 1907 como tipógrafo, então com 52 anos, solteiro e se declarando natural de Madrid ${ }^{115}$, foi um dos

\footnotetext{
${ }^{111}$ FAUSTO, B. Op. cit., 1977, p. 91.

${ }^{112}$ FERREIRA, M. Op. cit., pp. 92 e ss e 103. As datas informadas pela autora referem-se ao ano de início da publicação.

${ }^{113}$ PENTEADO, J. Op. cit., 1962, p. 154.

114 OITICICA, José. "Florentino de Carvalho". In: A ação direta (meio século de pregação libertária). Rio de Janeiro: Germinal, 1970, pp. 135 e ss.

${ }^{115}$ Seu nome era Valentin Diego Alascal. LRC 18.12.1907.
} 
fundadores dessa associação - Federazione dei Lavoratori del libro - de maioria italiana e responsável, em 1898, pela publicação do jornal $O$ trabalhador do livro. Não teria vida longa. Em 1901 surgiria a Associação das Artes Gráficas e Anexas, cujo primeiro presidente, também Valentim Diego, seria o responsável pela fundação, em 1903, do Centro Tipográfico Paulistano que, fundido àquela Associação resultaria, anos depois, na União dos Trabalhadores Gráficos. Organizada e articulada, esta Associação promovia eventos e festas em cujos programas havia a encenação de peças teatrais escritas pelos próprios trabalhadores. Em um desses eventos, ocorrido em julho de 1904, uma das peças teatrais foi escrita em italiano e a conferência, que encerrava a festa, proferida por Valentim Diego, foi pronunciada em espanhol. Os jornais operários davam ampla cobertura às conferências pronunciadas na sede da Associação, publicando os resumos. No entanto, a preocupação dos dirigentes abrangia não apenas a questão social, mas também a formação moral e cultural dos associados. A esse respeito, relembra Jacob Penteado de que, por iniciativa desses dirigentes, especialmente de Everardo Dias e Florentino de Carvalho se organizariam, no início da segunda década, "cursos de alfabetização para adultos, escolas de esperanto, biblioteca circulante", além de palestras, seguidas de debates; competições esportivas; concertos corais e festivais dramático-recreativos ${ }^{116}$.

Os gráficos eram tidos neste momento, inícios da primeira década do Novecentos, como "vanguarda e modelo a seguir" na organização das classes trabalhadoras, fato que pode estar na raiz da intensa repressão de que seria objeto a Associação, em represália à intensificação do movimento grevista, a partir de 1906.

No final de 1904 a Associação publicaria o jornal O Trabalhador Gráfico, importante veículo de propaganda entre o operariado em geral e entre os gráficos em particular, por se tratar também de informativo de caráter técnico sobre as artes do seu ofício ${ }^{117}$. "Os artigos de politização [do operariado] e o acompanhamento da situação dos operários gráficos, nas oficinas e nos jornais ocupavam a maioria de seu espaço”, informa Maria Nazareth Ferreira que, para sua pesquisa, dele se utilizou ${ }^{118}$.

O Trabalhador Gráfico constituiu-se outra das publicações que teve a colaboração de Isidoro Diego (irmão de Valentim Diego). O periódico, contudo, não resistiria à crise de 1906, provocada, entre outras coisas, pela perda da greve da Casa Duprat, de repercussão negativa e fatal para alimentar o clima de desconfiança contra os gráficos, tidos como uma espécie de

${ }^{116}$ PENTEADO, J. Op. cit., 1962, p. 154.

${ }^{117}$ EDE 06.12.1913. A Agencia de revistas e periódicos espanhóis, de Antonio Scafuto, na rua XV de novembro, 51, dentre as várias publicações e periódicos à disposição da clientela oferecia o Mundo Gráfico, para assinatura anual ou semestral.

${ }^{118}$ FERREIRA, M. Op. cit., pp. 105 e ss. A autora também esclarece a diferença entre a imprensa operária e a empresarial no tangente ao tratamento da notícia, diagramação, formato do jornal e periodicidade. 
intelectualidade entre os operários. Com a intensa repressão de que seria objeto a Associação, em represália à intensificação do movimento grevista, com a sede fechada e as lideranças encarceradas, o clima de desconfiança e desavença gerado pelos acontecimentos provocaria o seu inevitável desaparecimento - temporariamente, porque ocorreriam inúmeras tentativas de refundá-la em 1908 e em 1912, concretizadas somente em 1919. A militância parece não ter dado trégua também com relação às publicações: neste mesmo ano de 1906 apareceria, sob a batuta de Isidoro Diego, o A Luta Proletária, jornal ao qual se seguiria, como vimos, tantas outras folhas.

A militância consistia atividade que requeria, dos ativistas, certa disponibilidade de tempo inclusive para deslocamentos para outras cidades ou Estados. Por meio do EDE pudemos constatar que Isidoro Diego, paralelamente à militância, mantinha uma atividade comercial, em sociedade. Tratava-se de uma casa importadora, que se apresentou com pequenos anúncios no EDE apenas entre os anos de 1913 e 1914: "Isidoro Diego \& Comp. Importadores de azeites, azeitonas, vinhos, passas e outros produtos espanhóis. Rua da Alfândega, 19”. Em 1914 mudara-se da Rua da Alfândega (pequena travessa da Rua Santa Rosa, ainda hoje existente) para a Avenida Rangel Pestana, 6: "Azeites de Oliva Salat? Só em Isidoro Diego \& Cia", informava, numa abordagem direta ao leitor ${ }^{19}$. Foram os únicos reclames que reunimos a respeito dessa firma, provavelmente constituída entre 1912/3, momento de acirramento da repressão.

Pouco antes de publicar o A Luta Proletária, em 1906, Isidoro Diego editara dois outros jornais: o Jornal Operário de que pouco se sabe, e o A Terra Livre, em 1905, que circulou em São Paulo e no Rio de Janeiro entre 1906 e 1911; para este, Isidoro contou com a participação de Manuel Moscoso, linotipista espanhol e líder itinerante, que desde 1904, com Everardo Dias e Neno Vasco (português), editava O Libertário, também no Rio de Janeiro ${ }^{120}$.

Eram jornais editados com dificuldades, na base da contribuição dos militantes, que os vendiam pessoalmente. Seu público-alvo, lembremos, compunha-se de trabalhadores de baixo poder aquisitivo. Para as despesas de edição e postagem de exemplares pelo correio, especialmente no caso do A Terra Livre, Edgard Rodrigues informa de que eram programadas "Festas Libertárias" que ocorreram em diversos salões da cidade, a partir do ano de $1907^{121}$. Nesses jornais, a publicidade era quase inexistente. Em muitos casos, ao contrário, o jornal

\footnotetext{
${ }^{119}$ EDE 21.08.1913 e EDE 23.05.1914, respectivamente. Trad. da autora.

${ }^{120}$ A respeito do A Terra Livre, ver o trabalho de BARRIGUELLI, José Cláudio. Op. cit.

${ }^{121}$ RODRIGUES, E. O anarquismo... op. cit., pp. 144 e ss.
} 
chegava a recomendar o boicote de certos produtos, cujos fabricantes se achavam em litígio com seus empregados.

Em resumo, com periodicidade variável e sem regularidade na distribuição, muitos desapareciam de circulação ou circulariam com grandes intervalos de tempo, sujeitos sempre às repressões, empastelamentos e apreensões que se davam com violência, destruição do maquinário e prisões, fatores que não impediram o alcance e a intensidade de seu raio de ação: "na tentativa de semear o ideal anarquista, estes pioneiros cruzaram o solo brasileiro de ponta a ponta, implantando uma rede de comunicação que jamais existira no país; era a forma mais eficaz para atingir seus objetivos, diante do contexto que atuavam", pontua Maria Nazareth Ferreira $^{122}$.

Em 1908, em função da viagem para Portugal do principal redator do A Terra Livre, Neno Vasco, Manuel Moscoso o substituiria pelo A Liberdade, editado no Rio de Janeiro a partir de 1908. No ano seguinte, 1909, em protesto à execução do educador Ferrer, Moscoso seria um dos principais organizadores da série de comícios realizados em São Paulo e no Rio de Janeiro $^{123}$. É dele também a iniciativa, anos mais tarde, da publicação do jornal $A$ Voz do Trabalhador, órgão oficial da Confederação Operária Brasileira, responsável pela organização dos sindicatos e das federações operárias estaduais e regionais, em substituição à dissolvida União dos Trabalhadores Gráficos. Em 1912, esse jornal alcançaria a tiragem de 4.000 exemplares.

Os anos de 1912-1914, a propósito, foram dos mais tumultuados do ponto de vista de greves, uma das quais, a promovida exatamente pela Sociedade das Artes Gráficas, duraria 45 dias. A economia do país ingressava em profunda depressão face ao conflito mundial, pela perda dos mercados consumidores de café. Não bastasse isso, pairava a ameaça, recebida de diversas Confederações do Trabalho (da França, Itália e Portugal) de boicote ao café brasileiro, caso os imigrantes expulsos não pudessem retornar ${ }^{124}$. A grita era geral. O EDE já vinha se pronunciando há muito a respeito da "Polícia Inquisitorial", afirmando que "los atropellos, los tormentos y la deportación impuestos a varios compatriotas nuestros por la policia están siendo el único asunto de las conversaciones entre la colónia española de esta Capital y de Santos y pronto será el de la de todo el Brasil". Prosseguia dizendo que "en las calles y en nuestros domicilios particulares vimos continuamente asediados por conacionales",

122 FERREIRA, M. Op. cit., pp. 104 e ss.

${ }^{123}$ Sobre a manifestação literária e as propostas utópico-messiânicas da literatura anarquista produzida na e para a cidade do Rio de Janeiro, ver: FENERICK, José Adriano. O anarquismo literário: uma utopia na contramão da modernização do Rio de Janeiro, 1900-1920. São Paulo: Dissertação de mestrado, FFLCH-USP, 1997.

${ }^{124}$ EDE 06.05.1913. 
concluindo: "la situación creada por la brutal policia es por demás gravísima". Sugeria à polícia 'inquisitorial' que, ao invés de ficar perseguindo e prendendo pobres grevistas, devia vigiar os "ricos locos y borrachos que pretenden significarse haciendo carreras de vehículos por calles y paseos de la gran urbe ${ }^{\# 125}$.

As greves do início de 1913 também recebem, por parte do periódico, farta divulgação: na Fábrica de Tecidos Ypiranga e nas fábricas do Belenzinho, eram mais de 1.500 operários $\operatorname{parados}^{126}$. Agitações populares lideradas por operários, especialmente pelos gráficos, com grandes movimentos de rua, irrompem a partir de 1914. A retomada do crescimento industrial deu-se em parte provocada pelo declínio das importações em consequiência da guerra. Entre 1915 e 1919 surgiram quase 6.000 novas indústrias no país, e, já em 1916, com a diminuição do desemprego, ocorre a reanimação do movimento operário nos anos seguintes: é a fase áurea das lutas operárias na República Velha que receberiam formidável impulso das revoluções russas, culminando com a maior expressão do período, a greve geral de 1917, que paralisou a cidade de São Paulo por mais de um mês.

Foi decisiva, conforme procuramos destacar, a participação política do imigrante nos primeiros anos da República. Atuando em várias frentes, individual ou coletivamente, é lapidar a sua atuação nos momentos iniciais dos movimentos operários: anarquistas, liberais, conservadores, revolucionários, eles aqui aportavam trazendo suas ideologias, intervindo decisivamente nas postulações operárias. As greves reivindicatórias irrompidas no período também a eles podem ser creditadas, como a ocorrida no porto de Santos, em 1889, para cuja negociação foram chamados os cônsules português e espanhol, em claro demonstrativo da presença ostensiva, se não entre os trabalhadores, mas certamente entre os líderes e grevistas, de elementos oriundos desses países ${ }^{127}$.

Componente majoritário na formação da mão-de-obra urbana, cujos quadros, em momento de definição e em diversos segmentos, operários ou não, passou a ocupar, é também dele, que desembarcara trazendo em sua bagagem a experiência da militância, ou, no mínimo, a informação sobre os movimentos ocorridos na Europa, a iniciativa da liderança no processo de conscientização política.

Prova incontestável da sua participação e predominância nesses movimentos, é revelada pelo exame, elaborado por Maran, das principais lideranças do período compreendido entre

\footnotetext{
${ }^{125}$ EDE 29.11.1912.

${ }^{126}$ EDE 08.05.1913.

${ }^{127}$ BEIGUELMAN, Paula. Os companheiros de São Paulo. São Paulo: Ed. Símbolo, 1977, pp. 15-16.
} 
1890 e 1920 em São Paulo, Rio de Janeiro e Santos, três cidades onde sua presença foi marcante. Referindo-se especialmente à participação dos espanhóis nos movimentos, Maran se surpreenderia pelo fato de "aparecerem com um índice muito mais alto de representatividade nos grupos de liderança operária do que sua participação na população imigrante e na força de trabalho daquelas três cidades"128.

\section{A Greve Geral de 1917}

Conforme destacamos anteriormente, a Greve de 1917 representou o clímax, o ápice da expressão das lutas operárias no período da República Velha. A guerra, a especulação, o alto custo de vida, os baixos salários, enfim, a situação precária do trabalhador representaram motes para os movimentos organizados que começam a pipocar. Passeatas, comícios, discursos, estabelecimentos fabris aderindo ao movimento, hesitação dos operários, paredões, pressões, prisões, submissão ao empregador foram os elementos que constituíram a dialética daquele momento. As manifestações, multiplicando-se, fervilhavam pela cidade. Na fase aguda de julho de 1917 trabalhadores chegam a deixar a cidade intransitável, com batalhas, levantamento de barricadas e violência. O movimento toma vulto e, no auge das manifestações, um trabalhador, um jovem anarquista espanhol de 22 anos, o sapateiro José Martinez, que acompanhava uma multidão de grevistas, é morto pelo tiroteio da polícia, então chamada para impedir uma greve de solidariedade que eclodia na Fábrica Mariângela. A polícia tenta frear o movimento, adotando medidas arbitrárias, como o fechamento da Liga Operária da Moóca e da Escola Moderna, de orientação anarquista, prendendo, de forma indiscriminada, pessoas que se encontravam nas ruas da cidade, o que faz acirrar os ânimos.

O enterro de Martinez, "uma das mais impressionantes demonstrações populares até então verificadas em São Paulo [algo] como um oceano humano"129, quando vários oradores pronunciaram inflamados discursos em "português, espanhol e italiano, as três línguas mais faladas entre o operariado paulistano" protestando com veemência contra a prisão dos grevistas e exigindo a reabertura dos dois estabelecimento fechados ${ }^{130}$, pode ser considerado o estopim para a greve geral.

A situação se agrava e diante dos acontecimentos, militantes libertários assumem a coordenação do movimento grevista, cuja idéia inicial, a da formação de um comitê para agrupar as diversas categorias de trabalhadores em greve ganha corpo, o que acaba redundando

${ }^{128}$ MARAN, S. Op. cit., pp. 20-21.

129 ROLNIK, R. Op. cit., p. 173, citando Edgard Leuenroth. Fala-se que 10 mil pessoas teriam acompanhado o féretro.

${ }^{130}$ LOPREATO, C. Op. cit., 2000, pp. 32 e ss. 
na constituição do Comitê de Defesa Proletária (CDP). Experientes militantes, dentre eles os espanhóis Florentino de Carvalho e José Sarmento Marques, destacam-se na coordenação do movimento grevista ${ }^{131}$, organizando grande manifestação popular de repúdio à violência policial na Praça da Sé, o que fez aumentar a mobilização, com os grevistas enfrentando a força pública e saqueando depósitos de farinha de trigo, sob o controle do CDP. E, ainda que se tenda a concordar com Yara Khoury - em As greves de 1917 em São Paulo e o processo de organização proletária - de que tais manifestações operárias não eram “tão homogêneas quanto possam parecer à primeira vista"132, o alcance do movimento é indiscutível. São 70.000 operários em greve! É o movimento das fábricas que vai para as ruas, transformadas em verdadeiros campos de batalha.

Nesse jogo de forças entre a liderança operária e frações da camada dominante, acusamse os militantes anarquistas estrangeiros de perturbadores e de agir de modo comprometedor à segurança nacional. Muitos deles são presos, outros são expulsos do país, dentre os quais alguns espanhóis, enquanto, simultaneamente, jornais, sindicatos, associações, escolas e ligas são fechados; em outras palavras, procurava-se eliminar qualquer foco de disseminação de idéias libertárias.

O embarque dos banidos daria uma crônica à parte: diante da recusa das companhias estrangeiras de navegação em transportá-los, provavelmente pela evidência do ilícito, foram eles finalmente embarcados, em setembro de 1917, sem passaporte e sem constar da lista de passageiros, no Vapor Curvelo, da Cia. Lloyd Brasileiro, que zarpou de Santos com destino a Nova York.

Dentre os embarcados, os seguintes eram espanhóis: Antonio Lopes, tecelão, solteiro, 11 anos de residência no país ${ }^{133}$; José Fernandes, caixeiro-viajante, solteiro, 6 anos de residência; Francisco Peralta, pedreiro, casado, 10 anos de residência e 5 filhos brasileiros; Marcial Megia, sapateiro, solteiro, 6 anos de residência e Francisco Arouca, sapateiro, solteiro,

${ }^{131}$ Cf. idem, ibidem, "Dias de Tensão", pp. 34 e ss.

132 Para uma melhor compreensão da conjuntura paulista de 1917, na qual eclodem as greves operárias, resultantes das precárias condições do trabalhador quanto à segurança no trabalho; instabilidade no emprego; salários insuficientes e incompatíveis com o encarecimento do custo de vida; problemas no abastecimento de gêneros de primeira necessidade; as reações do empresariado; a repressão policial e as deportações, $c f$. KHOURY, Yara. As greves de 1917 em São Paulo e o processo de organização proletária. Dissertação de Mestrado. PUC-SP, 1978; FAUSTO, B. “Conflito social na República oligárquica: a greve de 1917”. In: Estudos Cebrap. São Paulo: v. 10, out./nov./ dez. 1974, pp. 81-101; SILVA, Lígia Maria Osório. Movimento sindical operário na Primeira República. Dissertação de mestrado, Unicamp, 1977; MARCÍLIO, M. L. "La gréve générale dans l'industrie pauliste de 1917”. In : Le mouvement social. Paris : n. 53. Les Éditions Ouvrières, oct.-déc. 1965, pp. 123-129 e LOPREATO, C. Op. cit., 2000 .

${ }^{133}$ A prova de residência no país que equiparava, em tese, os estrangeiros aos brasileiros, garantindo-lhes a permanência, foi objeto de interpretações ambíguas. No caso de Virgilio Hidalgo e Florentino de Carvalho, por exemplo, evocou-se o caráter "internacional" de seu crime, daí os mesmos serem considerados "itinerantes". $C f$. KENEZ, K. Op. cit., 2001, pp.157 e ss. 
7 anos de residência. José Sarmento Marques, chapeleiro, naturalizado brasileiro, 27 anos de residência no país, e pai de 3 filhos brasileiros e Virgílio Hidalgo, sapateiro, haviam embarcado em outro vapor, o Itapuca, onde ficariam confinados mesmo depois da posse de um habeascorpus, sob a alegação da polícia de que desconhecia seu paradeiro ${ }^{134}$. Completando a lista, o mais "perigoso" deles, Florentino de Carvalho, que narra os dolorosos acontecimentos de sua prisão e embarque no Curvelo em "A nossa expulsão. Apontamentos para a história das infâmias burguesas"135. Conforme ele, embarcara com Francisco Arouca e Antonio Lopes "com destino ignorado" no "navio-fantasma", depois de permanecer incomunicável na prisão de Vila Matias, em Santos, para onde fora levado. Chegando ao Recife, onde o navio fizera uma escala, Florentino e seus companheiros conseguiriam escapar, burlando a vigilância. Seriam, contudo, recapturados depois da partida do navio, dando início a um périplo sem precedentes, conforme veremos ${ }^{136}$.

A Greve Geral de 1917, que paralisou a cidade de São Paulo por uma semana, encerrava-se com um acordo pelo qual os operários aceitavam, após inúmeras objeções, um aumento de $20 \%$, sem a dispensa dos grevistas e com a condição de o Governo tomar providências contra a carestia.

\section{Florentino de Carvalho, ou Primitivo Raimundo Soares (ou Suarez)}

Nascido em Oviedo, nas Astúrias, em 1871, Florentino chegara ainda criança ao Brasil, onde estudou em colégio de padres, tendo entrado para a Força Pública da cidade de Santos, em 1898, alcançando o posto de $3^{\circ}$ sargento, de onde pediu baixa para participar do movimento libertário. Empregou-se nas Docas antes de trabalhar como sapateiro e tipógrafo. Nesta cidade, ele imprime orientação nova ao movimento sindicalista e, em 1910, é expulso para Portugal de onde regressa clandestinamente. Dirigiu diversos jornais ${ }^{137}$, uma revista ${ }^{138}$ e deixou alguns livros publicados ${ }^{139}$, quase todos apreendidos. Foi professor na Escola Moderna, no Brás e na Escola Nova, na Moóca ${ }^{140}$.

${ }^{134}$ ALVES, P. "Estratégias de expulsão de estrangeiros". In: Op. cit., 1990, p.161.

${ }^{135}$ In: HARDMAN, F. e PRADO, A. (orgs.) Op. cit., 1985, pp. 60-63.

${ }_{136}$ A esse respeito, $c f$. "Os errantes navegantes". In: LOPREATO, C. Op. cit., 2000, pp. 161 e ss.

${ }^{137}$ Como o Germinal, por exemplo que contou com a ajuda de sua irmã, também militante, Angelina Soares; os A Nova Era; O Libertário; A Rebelião; A Revolta e a Plebe. Cf. RODRIGUES, E. Op. cit., 1969, pp. 266269.

${ }^{138}$ Chamava-se A Obra. In: ALVES, P. Op. cit., 1990

139 Como: Da Escravidão à liberdade, 1927; A guerra civil em São Paulo, 1932. Deixou inédito: A Filosofia do sindicalismo; Os anarquistas e os movimentos políticos e Crise do sindicalismo. Cf. ALVES, P. Passim.

${ }^{140}$ Informações obtidas em: "Florentino de Carvalho é expulso da Argentina". In: RODRIGUES, E. $O p$. cit., 1969, pp. 266-269. 
Na Greve Geral de 1917, como vimos, embarcado pelo Curvelo para a América, ele, contudo, consegue escapar, sendo recapturado na cidade do Recife. Nesta cidade, ele permaneceria detido por 6 meses. Consta que os expulsos, despachados pelo Curvelo para a América, lá não tinham podido descer, uma vez que o país se negou a recebê-los.

Não se tratava, contudo, da primeira deportação a que fora submetido Florentino. Pronunciando-se em 1912, o EDE informaria que os expulsos que viajavam pelo Vapor Orita fizeram tanta "desordem que, chegando ao Rio, foi necessária intervenção policial", perguntando-se do paradeiro de Primitivo Raimundo Suarez e Antonio Filgueira Vieytes, tidos como os agitadores da greve $\mathrm{e}^{141}$.

Desta feita, novamente o EDE se pronunciaria, informando do retorno dos expulsos, chegados ao Rio de Janeiro pelo Vapor Avaré, esclarecendo que, dentre os detidos, estava Florentino de Carvalho, "espanhol naturalizado brasileiro, o líder do grupo de nove detidos", e que, apesar disso, a polícia informara não saber do paradeiro e nem do novo destino deles ${ }^{142}$. Esse longo episódio pode ser responsabilizado pelo estrangulamento da Escola Moderna, então dirigida por ele, e fechada um ano depois.

A família Soares, de Florentino, viveu, conforme dizíamos, alguns anos em Santos, cidade em que ele trabalhara em várias atividades e onde liderara o movimento sindicalista. Em 1914, contudo, a família se muda para São Paulo, fixando-se na Rua Bresser, cuja casa foi transformada em "pousada de anarquistas foragidos, desempregados e de passagem". Esse quase-albergue, acolhia também os que vinham em busca de abrigo e de comida e os que buscavam saber o endereço dos companheiros. Para completar, era também o ponto de encontro das reuniões e das redações de jornais anarquistas. E onde se ministravam aulas de alfabetização $^{143}$.

As irmãs de Florentino, Angelina e Maria Antonia, foram professoras de escolas anarquistas e ativistas. Maria Antonia casou-se com Manuel Campos, também ativista, e expulso duas vezes, uma em 1913 e outra em 1921, a primeira ocorrência relacionando-se à sua militância junto aos estivadores de Santos, onde residira anteriormente ${ }^{144}$. Consta que Maria Antonia seria também a responsável pela venda de livros para os militantes das associações operárias, cujos pedidos deveriam ser encaminhados à Rua Uruguaiana, 108, provavelmente a residência do casal ${ }^{145}$.

${ }^{141}$ EDE 29.08.1912. Trad. da autora.

${ }^{142}$ EDE 26.01.1918. Trad. da autora.Trata da tramitação dos processos de expulsão e do habeas corpus.

${ }^{143}$ CORREIA, F. Op. cit., 1987, pp. 38-63.

${ }^{144}$ Cf. MARAN, S. Op. cit., 1979, p. 21 e RODRIGUES, E. Op. cit., 1972, pp. 73 e ss.

145 PINHEIRO, P. e HALL, M. Op. cit., 1981, pp. 119-120. 


\section{O ocaso do movimento operário}

Em fins de 1919, a inquietação era geral e o país encontrava-se afligido pelas greves. Se em 1917 haviam sido nove os espanhóis expulsos e deportados, agora eles seriam mais. A "maré vermelha", no dizer de Maran, tinha de ser contida a qualquer custo. Mirava-se contra os “indesejáveis”, responsáveis pela onda de revoltas sociais: "os espanhóis, portugueses e italianos que se arrogam o direito de defender a classe trabalhadora no Brasil ficariam melhor em sua própria terra", bradavam setores da imprensa em numerosos artigos, sustentando ter o Executivo "amplos poderes" para expulsar esses "perigosos elementos"146.

Desse modo, mais uma leva de espanhóis seria expulso entre 1919 e 1920, mais exatamente dezesseis em cada um dos $\operatorname{anos}^{147}$.

Kátia Kenez que examinou detidamente o Movimento Operário em 1919, com base na imprensa operária, comenta da dificuldade de se recompor esse período e seus personagens, lamentando haver localizado apenas "notas, por vezes algumas linhas soltas, na sua grande maioria nomes que percorrem uma ou duas edições desaparecendo sem deixar pistas", numa evidência que o destino desses homens, a partir da prisão, era incerto e indefinido ${ }^{148}$.

Há muito vinha o EDE encabeçando uma campanha contra o que denominava "la burla hecha de las leyes", pronunciando-se contra as leis de expulsão então vigentes, cujos preceitos, dizia, não têm sido cumpridos, já que, entre os deportados há muitos que residem no país por mais de 20 anos e outros que têm filhos brasileiros ${ }^{149}$.

Em 1920 os anarcossindicalistas, minando as próprias forças já declinantes do movimento, deflagram diversas greves na Capital de São Paulo, no Rio de Janeiro e em Santos, franqueando ao Governo o ensejo para prisões em massa, deportações de líderes e o fechamento de sindicatos.

\footnotetext{
${ }^{146}$ MARAN, S. Op. cit., 1979, pp. 51 e ss.

${ }^{147}$ Sobre a expulsão de estrangeiros no período de 1907 a 1921, ver também: MARAN, S. Op. cit., Tabela III, p. 43.

${ }_{149}^{148}$ KENEZ, K. Op. cit., 2001, p. 129.
} 


\section{Everardo Dias}

O caso mais notório de ativista e militante espanhol, cuja influência, conforme a pesquisa sinalizou, também se fez notar na criação e na gestão de diversas associações beneficentes, deu-se com Everardo Dias.

Everardo Dias tinha 18 anos quando compareceu pela primeira vez ao CGE, em 1901. Já se declarava tipógrafo e se dizia natural de Pontevedra, na Galícia ${ }^{150}$, como Eiras Garcia. Consta que chegara ao Brasil com apenas 2 anos de idade, portanto, em 1885, e que muito jovem ingressara na Maçonaria ${ }^{151}$. É de Edgard Leuenroth, também militante no período, na Apresentação do livro História das Lutas Sociais no Brasil, de sua autoria, algumas informações sobre ele, como a de ter sido "gráfico e tipógrafo-caixista em $O$ Estado de São Paulo", quando então teria tido contato com "intelectuais nacionais decepcionados, vindos da propaganda republicana e emancipacionista do braço escravo, estudiosos, eruditos e adeptos dos sistemas socialista e anarquista-comunista". E também com "velhos militantes italianos e espanhóis, emigrados de seus países de origem", dos quais alguns haviam experimentado a perseguição policial, outros haviam escapado de confinamentos, de trabalhos forçados e até mesmo da forca, em represália à sua atuação sindical e à vasta biografia de conspirações, atentados e levantes ${ }^{152}$. Everardo foi atuante na greve geral de 1917, sendo a ele atribuído o Manifesto aos Soldados que, tendo alarmado o governo, o faria chegar a um acordo com o Comitê de Greve. Foi, contudo, na greve geral de outubro de 1919 que a figura de Everardo Dias ganharia destaque, tanto assim que teria provocado a sua expulsão do país, tornando-se, a partir desse momento, um alvo sempre na mira da polícia política, tendo sido preso também em 1924 e em 1935.

Esse episódio, o de sua expulsão, em razão de sua estreita relação pessoal com Eiras Garcia, recebeu substantiva cobertura pelo EDE. Nessas questões, Eiras buscava, sem eximirse completamente, pautar-se por um certo comedimento, afinal não desconhecia o quanto essas divergências polarizavam o conjunto da colônia e quanto uma tomada de posição poderia comprometer o bom relacionamento que procurava manter na criação e na gestão das diversas associações, para o que necessitava do esforço conjunto, da soma dos indivíduos.

Acreditamos que tenha sido complexa a manutenção de uma convivência sem sobressaltos com os demais integrantes do staff dessas agremiações, para Eiras Garcia. O fato é que, como empresário, dependia de alguns deles, em sua maioria comerciantes bem postados,

\footnotetext{
${ }^{150}$ LRC 09.09.1901. Residia então à Rua Sayão Lobato, 26.

${ }^{151}$ HARDMAN, F. e PRADO, A. (orgs.) Op. cit., 1985, pp. 126-127.

${ }^{152}$ DIAS, E. Op. cit., 1962, p.7.
} 
alguns dos quais pudemos identificar como seus anunciantes regulares, e que se apresentavam, em geral, com uma postura conservadora, rechaçando qualquer envolvimento com as questões "perigosas". Por outro, à testa das associações, esbarrava com ativistas como Everardo Dias, Manuel Rodrigues, Antonio Dias, com quem mantinha excelente relacionamento, e com os demais, com quem procurava manter um contato civilizado, tanto pessoal quanto profissionalmente. Além disso, havia outras questões, fora do âmbito da colônia, também a serem levadas em conta. Sucede que Eiras Garcia, por insurgir-se contra os maus tratos a que eram submetidos os colonos espanhóis nas fazendas, já havia sido objeto de um desgastante processo judicial - que implicara em sua detenção - impetrado por um órgão da "imprensa paulista, porta-voz da aristocracia cafeeira", contra as manifestações que tinham como veículo o seu jornal diário. Condenado a dois meses de prisão, receberia caloroso apoio da colônia espanhola - "a questão de tal modo exacerbou os ânimos da colônia que justamente rebelada contra o procedimento das autoridades vai convocar uma reunião de todos os espanhóis residentes no Brasil" ${ }^{\text {"153 }}$. No entanto, em que pese as manifestações de solidariedade, o episódio, do ponto de vista da autoridade diplomática, representara um fiasco, prontamente relatado a Madri:

El señor Eiras, que usa em sus escritos palabras de mal tono e injurias sin fundamento se ha visto esta vez llamado ante los tribunales, por un particular. Tanto las autoridades del pais como las españolas que han sido objeto de sus injustos ataques, los dejaban pasar en silencio, por no concederle importancia y valido sin duda de esta impunidad arremetió contra todo el mundo $(. . .)^{154}$

As pressões que passou a sofrer desde então, podem tê-lo feito ponderar. Cioso por manter seu periódico em circulação, e até por permanecer no país, é compreensível que não tenha podido manter uma postura "coerente" durante todo o período examinado, obrigado a recuar estrategicamente por vezes, dependendo da situação.

Desse modo, apesar da evidência da estreita vinculação com membros ativistas do movimento operário, com quem fundou jornais e diversas associações, e com quem dividiu a direção de outras tantas, Eiras Garcia enquanto empresário e diretor do EDE durante o período, revelou-se cauteloso, notadamente quando o assunto envolvia os "perigosos conspiradores", objeto de exíguas menções e por vezes silêncio absoluto do jornal; o mesmo ocorria com as prisões e as deportações, de pouca cobertura pelo EDE, ressalvando-se o caso de Everardo Dias.

153 "Colônia espanhola". Jornal do Brasil, 19.08.1907. In: AMAE. Série Brasil. Correspondencia Embajadas y Legaciones, H-1419. Consta que o Centro Gallego que possuía um grupo de teatro, teria encenado um espetáculo em seu benefício. Cf. GALLEGO, A. Op. cit., 1995, p.44.

${ }^{154}$ AMAE. Série Brasil. Correspondencia Embajadas y Legaciones, H-1419. Correspondência datada de 19.08.1907. 
Assim, se recuava estrategicamente por um lado, por outro, Eiras era incansável. Dirigia-se à colônia, pronunciando-se de maneira incisiva quanto à "nuestra debilidad colectiva - causas del excepticismo", conclamando-a à união e aos interesses coletivos. Falava em "vazio da colônia", produto da "estreita visão das sociedades criadas que, ao invés da união, a tem dividido, alimentando a discórdia" ${ }^{\text {155 }}$. Sua batalha, de certo modo, assemelhava-se à de outros militantes. Inúmeras tentativas de unificar as diversas sociedades espanholas foram tentadas no período, como forma de superação das cisões que marcaram a sua trajetória, o que só se efetivará mais tarde por força de lei, vetando a sua criação por elementos estrangeiros ${ }^{156}$.

De todo modo, a questão agora envolvia Everardo Dias, por quem Eiras nutria profunda consideração. E, desta vez, ele não recuou, colocando à disposição do amigo o periódico que dirigia, e onde aquele já trabalhara. Em novembro de 1919, por exemplo, na cobertura à sua deportação, o periódico informava do pedido de habeas corpus por ele requerido, o qual teria motivado acirrada discussão no Supremo Tribunal de Justiça, no Rio de Janeiro ${ }^{157}$. Na semana seguinte, o periódico publicaria uma carta de Everardo Dias, na qual este narrava os fatos ocorridos em Santos, antes de sua deportação, referindo-se aos maus-tratos que recebera, quando então vivia em uma solitária, sem roupa, doente com febre, sem dormir e nem se alimentar, e da tortura à que fora submetido antes do embarque, quando recebera 25 chicotadas nas $\operatorname{costas}^{158}$.

Em dezembro, o jornal reproduzia uma carta da filha de Everardo, encaminhada ao Presidente da República, Epitácio Pessoa, na qual expunha a situação de seu pai, que não conseguira desembarcar em Cádiz por não portar passaporte "assinado pelo cônsul espanhol no Rio de Janeiro e por ser considerado cidadão brasileiro" 159 . No ano seguinte, no mês de fevereiro, o EDE traria a notícia do "indulto" de que se beneficiara, concedido pelo Governo Federal, informando que ele estaria no Vapor Benevente ancorado no Rio de Janeiro, no qual havia "vários passageiros atacados de enfermidade", razão que motivou a ordem para que fosse ao lazareto. O jornal informava ainda das inúmeras manifestações de apreço que estavam sendo preparadas para recebê-lo na Capital de São Paulo ${ }^{160}$.

${ }^{155}$ EDE 27.02.1913. Trad. da autora.

${ }^{156}$ Decreto do governo brasileiro, de 1938, impedia a brasileiros natos ou naturalizados de participarem de centros e associações estrangeiras, cujas diretorias deveriam compor-se apenas de brasileiros. Além disso, as reuniões e encontros das mesmas só poderiam ocorrer com a presença de um representante legal da Delegacia de Ordem Política e Social, o DOPS. Cf. CORNER, D. Op. cit., p. 63.

${ }^{157}$ EDE 11.11.1919. Nesta mesma edição, nota da acusação sofrida por José Gregório Esteban, secretário da Seção de Catanduva da FE, de divulgar "idéias maximalistas", o que motivara sua prisão e escolta até a Capital de São Paulo.

${ }^{158}$ EDE 18.11.1919.

${ }^{159}$ EDE 06.12.1919. Trad. da autora.

${ }^{160}$ EDE 02.02.1920. 
Everardo também narraria a sua experiência, detalhada por ele no livro de sua autoria Memórias de um exilado - episódios da deportação, editado tão logo chegou à cidade e cuja venda, ao preço de $1 \$ 000$, passou a divulgar em pequenos anúncios pelo EDE, a partir de junho de $1920^{161}$. Nessa época, ele residia à Rua Washington Luis, 1 , local que indicava para o envio dos pedidos. No ano seguinte, 1921, ele publicaria Semeando... Palestras e Conferências, contendo oito das conferências por ele proferidas em diversos Templos de Maçonaria da cidade. No prólogo da obra, uma "explicação" de sua autoria, pela qual esclarecia a pretensão em oferecer uma "explanação de doutrina, expondo ao público o pensar do demoníaco propagandista, do ser estranho e revel, que a Ordem Maçônica, por seus altos poderes, disputou leoninamente às garras potentíssimas da fera - clericalismo - e da fera - despotismo governativo" 162 .

Trata-se de uma coletânea temática, abrangendo os anos de 1908 a 1918. A primeira delas, intitulada "Maçonaria e Clericalismo" foi realizada na Loja União Espanhola, assim como a homenagem a Ferrer, datada de 13 de outubro de 1910, também aí realizada. As demais conferências, reproduzidas na publicação, referem-se a outras Lojas Maçônicas ${ }^{163}$. Mais tarde, início da década de 1960, pouco antes de morrer, Everardo escreveria História das Lutas Sociais no Brasil, cujo distanciamento permitiu-lhe um primoroso exame da questão social e dos imigrantes. Destes, sua opinião era a de que "grande parte não era constituída de lavradores ou operários", mas de "trabalhadores sem especialização e sem ofício determinado", que buscavam a "independência econômica". Essa "descrença" no imigrante típico, partilhada por boa parcela da liderança, que também o identificava como desinteressado por reformas sociais e pela melhoria nas condições de trabalho, ficou consignada em seu texto, no qual admitia tratarse de "massa heterogênea, com tendências puramente utilitaristas de independência econômica, de enriquecimento em negócios, visando voltar logo para o seu torrão natal" ou, eventualmente interessada apenas em "viver por si, sem sujeição a patrão"164.

Essa era uma idéia largamente difundida nos jornais anarquistas, em complemento à outra, a de que esses militantes constituíam um "grupo de abnegados apologistas da revolução mundial, confrontados com uma massa ignorante e individualista, que pensava unicamente em

${ }^{161}$ EDE 02.06.1920.

${ }^{162}$ DIAS, E. "Explicação". In: Semeando, op. cit.,s. n.

${ }^{163} \mathrm{Idem}$, ibidem. As demais Lojas Maçônicas citadas foram a de nome Amizade, onde, em janeiro de 1916 foi realizada a conferência "A Igreja e o Estado" (p. 51); a Ordem e Progresso, com as conferências "Uma comemoração maçônica", realizada a 24 de fevereiro de 1917 (p. 28) e "O que é maçonaria", em agosto de 1918 (p.155); a Loja Independência e Ordem, na qual proferiu "O dia da independência", conferência realizada a 7 de setembro de 1917 (p. 87) e "O XX de setembro sob o ponto de vista maçônico" (s. l. n. d., p. 51).

${ }^{164}$ DIAS, E. Op. cit.,1962, pp. 39 e ss. 
melhorar de vida" ${ }^{, 165}$, interessada apenas no retorno a seu país de origem, muitos dos quais imbuídos de idéias nacionalistas. Decorrentes destas, acrescentavam, produzia-se a intolerância, nutrida pelo preconceito que a maioria alimentava pelo país de acolhida, que se revelaria "apontando como estigma as doenças tropicais, as pragas, os insetos, a insegurança pessoal". Esse estrangeiro, a quem Everardo Dias atribuía um “egoísmo pessoal”, olhava com desprezo os nativos, por ele considerados "tipos inferiores (negros, mulatos, caboclos), vadios, indolentes, dados à embriaguez, mal vestidos, mal-alimentados, sem moral, enfim”. O próprio Everardo Dias, certa feita, se pronunciaria a respeito de alguns anarquistas, aos quais chamava de "viajantes do mundo", mas que, a despeito disso, continuamente "rebaixavam" as coisas brasileiras, havendo um deles em especial, cujo nome não menciona, que teria colocado "um grande número de pessoas fora de nossas fileiras" pelos insultos intoleráveis proferidos contra o Brasil $^{166}$.

Mas seu juízo era de que também os "nacionais" levavam sua parcela de responsabilidade pela derrocada do movimento. Everardo os acusava de serem desinteressados, de não se sensibilizarem com as idéias - "exóticas" -, transportadas de outros países, os quais vivenciavam outro momento histórico, com "fome, miséria, falta de emprego". No Brasil, esclarecia, "ninguém passava fome. Era só entrar no mato e encontrar fruta, caça e pesca à vontade". Havia, ainda, entre brasileiros e estrangeiros um outro conflito latente, provocado pelo ressentimento daqueles, que se julgavam preteridos no mercado de trabalho, por serem considerados cultural e racialmente inferiores ao trabalhador europeu. Daí, concluía Dias, a dificuldade, para esses militantes, em "conseguir unidade de ação", em ambiente tão adverso e hostil.

Em sua cruzada, Everardo procurou despertar os trabalhadores, alertando-os para a crescente exploração a que se viam submetidos, idéias estas registradas em alguns de seus escritos, dos quais “As reivindicações da canalha”, publicado em Contos Anarquistas ${ }^{167}$.

Referindo-se aos "festivais", ele revela que sua realização ocorria no Salão Itália Fausta, mas também em outros locais modestos, de bairro, alguns dos quais eram específicos dos espanhóis, que "tinham ponto de reunião no Brás, em salões apropriados, à Rua do Gasômetro ou Rangel Pestana, pois todos moravam nas Ruas Carneiro Leão, Caetano Pinto, Pires Ramos, Wandenkolk, Coronel Mursa, Maria Domitila"168. Contudo, sua realização

${ }^{165}$ SILVA, Lígia Maria Osório. Op. cit., 1977, pp. 179-180, referindo-se ao trabalho de Michael Hall, baseado em jornais operários.

${ }^{166}$ DIAS, E. Op. cit., 1962, pp. 209-210.

${ }^{167}$ In: HARDMAN, F. e PRADO, A. (orgs.) Op. cit., 1985, p. 116.

${ }^{168}$ DIAS, E. Op. cit.,1962, pp. 39 e ss. 
também podia ocorrer em "pontos pitorescos dos arredores da cidade", onde se realizavam as palestras doutrinárias e de crítica social, cujo baile, programado para encerrar a programação "servia de chamariz à juventude".

A ascensão social, vislumbre de todo imigrante típico, na perspectiva de Everardo Dias, já não significava apenas um vago anseio para muitos dos seus compatriotas - muitos dos quais não tardariam em aderir, conforme pontuamos, ao viver elegante da sociedade paulistana.

Era, a propósito, com esses mesmos conterrâneos que Everardo e outros militantes dividiam a direção e as preocupações que nortearam a criação da maioria das associações pertencentes à colônia. Para alguns desses, as manifestações e greves não passavam de obra de uma minoria de agitadores anarquistas, e, desse modo, sob perspectivas e aspirações tão distintas, não é de se estranhar que a aludida "debilidade coletiva" mencionada por Eiras Garcia, espelhasse esse universo, tendo dividido opiniões, provocado rivalidades e representado ensejo para divergências e querelas entre seus dirigentes, em um microcosmo que espelhava, basicamente, o que motivou o enfraquecimento do movimento operário no Brasil, envolvido por animosidade étnica, não apenas entre brasileiros e estrangeiros, mas destes entre si. Com efeito, os conflitos étnicos, umas das principais limitações do movimento operário brasileiro, fizeram abortar greves e muitas tentativas de organização, e destruíram sindicatos, cuja formação custou anos de trabalho e esforço.

De qualquer modo, pondera Maran, o imigrante comum - aquele que considerava sua estadia no país temporária, até que obtivesse o suficiente para melhorar de vida e retornar à sua terra natal - resistia a participar de um movimento que, pondo em risco esse objetivo pragmático, pudesse levá-lo, no limite, à deportação, em outras palavras, ao retorno à miséria. Além do mais, faltava-lhe experiência, fruto do pouco ou nenhum envolvimento que tivera em sua terra natal com o trabalho organizado ${ }^{169}$.

Compreende-se, por esse raciocínio, o insulto que significava para esse imigrante a naturalização, fator importante para os socialistas que pretendiam transformá-lo em um cidadão, através do voto. Nessa divergência com os princípios do anarquismo - contrário ao nacionalismo e à participação no processo eleitoral - residiu um dos pontos da fragilidade do movimento brasileiro.

Para o anarcossindicalismo brasileiro os laços com a terra natal, ao contrário, eram proveitosos ao sentimento de solidariedade internacional, que procuravam infundir na classe trabalhadora, aspecto em particular de que se valeu a causa dos anarquistas. Contudo, erros

${ }^{169}$ MARAM, S. Op. cit., pp. 161-163. 
táticos como incitar greves em meio a crises econômicas, e quando o desemprego grassava, desgastou o movimento, abrindo brechas para que as elites, valendo-se disso, passassem a conquistar os últimos nichos refratários à repressão. Decisiva para a derrocada do movimento operário, a tese da "conspiração estrangeira" que subverteria o país, assim, passou a ser aceita por distintos setores da sociedade, legitimando a prática de medidas repressivas e estimulando o ressentimento dos trabalhadores nacionais contra os estrangeiros, líderes do movimento sindical. No apogeu do sindicalismo revolucionário, entre os anos de 1917 e 1920, esse apelo "nacionalista", disseminado na opinião pública pelos meios de comunicação e por segmentos interessados, foi fundamental para a campanha anticonspiração então encetada, sobretudo por eliminar as resistências de setores liberais da sociedade, que passam a apoiar as elites e a repressão policial $^{170}$.

Foge ao âmbito dessa exposição a tentativa de explicar o fracasso do anarquismo no Brasil, tema de inúmeras pesquisas publicadas ${ }^{171}$ e resultante, aliás, de uma convergência de forças que gradualmente o debilitaram, algumas das quais procuramos rapidamente enumerar.

Basta destacar para os limites desse trabalho a importância de alguns líderes espanhóis (sobretudo dos gráficos) do movimento, figuras das quais procuramos recuperar alguns fragmentos de atuação e que, enquanto se ocupavam das questões envolvendo a militância e o trabalho de politização, criando associações e agremiações de classe, fundando jornais, semeando idéias por meio de conferências, organizando greves, promovendo, enfim, intensa organização associativa, foram simultaneamente vistos à dianteira de iniciativas que visavam o amparo aos seus conterrâneos indefesos e oprimidos. Desse modo, pela criação de associações beneficentes, buscaram primeiramente o amparo a questões vitais, sobretudo no caso de doenças, porém não relegaram outros aspectos, procurando, por exemplo, lutar bravamente para a manutenção de uma escola. Mas também puderam ser percebidos arriscando-se, como de praxe o fazia Eiras Garcia pelas folhas de seu periódico, pelas quais investia contra a imprensa burguesa dos barões do café, ou diretamente contra estes - manifestação que repetia, quase inconscientemente, o longínquo episódio que motivara a fuga de sua terra natal. No fundo, em qualquer dos casos, prevalecia a busca do mesmo ideal, o de igualdade social. Isso em ambiente de condições inóspitas, sob perseguições, falsos complôs e deportações.

Ainda mais obscura que a marcha desses homens no movimento operário, permanece a participação da imigrante espanhola libertária, a mulher que militou, tal como o homem, e não

\footnotetext{
${ }^{170}$ Passim.

${ }^{171}$ Cf. MARAN, S. Op. cit., 1979, pp. 127-167.
} 
apenas na cidade de São Paulo, seja ministrando aulas nas escolas operárias pelos métodos da Escola Moderna, ou colaborando na imprensa libertária, seja participando de Congressos, como representante do Centro Feminino Jovens Idealistas (caso de Angelina e Maria Antonia Soares).

Sua participação também nas fábricas, onde organizavam as operárias, na conscientização dos seus direitos (como o fazia Maria Alles) ${ }^{172}$, ou participando de grupos de teatro, um dos mais eficientes veículos de divulgação do anarquismo (ao modo de Mercedes Solé, as irmãs Soares e outras), ou seja em que âmbito for que a sua presença tenha se dado, ainda não foi devidamente desvendada ${ }^{173}$. Algumas seriam também expulsas, conforme observamos nos processos de deportação do Ministério da Justiça, disponíveis no Arquivo Nacional $^{174}$ e, não obstante, sua determinação adentrou a terceira década do Novecentos, enfrentando a polícia política de Vargas, fascinante capítulo que merecidamente começa a ser examinado.

O anarquismo, que irradiado a partir das cidades onde havia maior concentração de imigrantes, marcaria fundamentalmente o movimento operário brasileiro do período, se viria ameaçado quando, a partir de 1922, ocorreria a cisão entre os militantes, fato que se refletiria também nas associações operárias. A divergência que provocou a ruptura era de orientação e princípios. Aos militantes do Partido Comunista Brasileiro, o engajamento dos trabalhadores na máquina política do sistema representava ponto crucial, o que rejeitavam frontalmente os anarquistas que, aos poucos, foram sendo alijados das cúpulas sindicais ${ }^{175}$.

Para Edgar Rodrigues que em seus escritos procurou deixar registros de relatos dos antigos militantes operários, a fase áurea do movimento operário ocorreu sob a influência do anarquismo, cuja ideologia traduziria os reais anseios dos oprimidos, potencial que o movimento operário posterior a 1922 perderia, "sucumbindo às nefastas influências do comunismo e do trabalhismo oficial, tornando-se essencialmente um movimento reformista, sem combater a dominação capitalista"176.

172 Essa militante foi mencionada por GAMBI, Esther. "Castanholas Vermelhas. À frente das lutas proletárias em São Paulo, imigrantes espanholas se tornaram alvo da implacável polícia política de Getúlio Vargas”. In: Revista de História. Rio de Janeiro: ano I, n.2, agosto de 2005, p. 49.

${ }^{173}$ Diversas outras mulheres espanholas foram citadas por Francisco Correia, que recorreu a depoimentos de três sobreviventes daquela época. Em seu trabalho Mulheres libertárias: um roteiro, op. cit., p.44, ele faz referência a Maria Angelina Soares, irmã de Florentino de Carvalho; Esmeralda Barrios; Nena Valverde; Cândida Alarcón; Nieves Simon; Maria e Angelina Valverde Dias e Mercedes Solé.

${ }^{174} \mathrm{Cf}$. nota 23.

${ }^{175}$ FERREIRA, M. Op. cit., pp. 145 e ss.

$0{ }^{176}$ MAGNANI, S. Op. cit., 1982, pp. 21 e ss. 


\section{Notas conclusivas}

Rua Lucas. As calçadas estão cimentadas de crianças brincando com tranças de cebola. Por uma porta baixa, em arco, vejo um interior. Pinturas alegres de vinhas na cal da parede; sobre uma mesa, duas moringas frescas, de barro, cobertas por toalhinhas de crochet; quadros; Afonso XIII vestido de rei torce os bigodes, entre um São José amarelo e lilás e uma folhinha heráldica com os quartéis de ouro e goles de Espanha, e a estrela verde e amarela do Brasil ${ }^{1}$.

$\mathrm{Na}$ caracterização do conceito de "imigrante" enquanto tal, há que se fazer duas distinções. Do ponto de vista sociológico, remete ao indivíduo que se deslocou de uma sociedade de origem para uma outra, a receptora, definitiva ou temporariamente. Já o conceito político de estrangeiro, atributo intrínsico a todo imigrante enquanto tal, é condição da qual decorre, em seus pressupostos jurídicos, a sua não-participação na atividade cidadã do país receptor. Para Carlos Zubillaga, que no bojo desses dois parâmetros conceituais buscou examinar a medida da participação política do imigrante espanhol que se deslocou no contexto da imigração massiva para a América Latina, esse momento guarda especificidades, que condicionaram aquela experiência. A princípio, não se deveria, a priori, supor como obrigatória no imigrante a vocação de estrangeiro e nem, por outro lado, condicionar a sua participação política à posse da cidadania e a formalizações do sistema institucional do país de destino. Essa ação política, afirma o autor, supondo o cumprimento de uma agenda que expressasse engajamento, ou seja, o comprometimento desse sujeito com os destinos da coletividade, estaria expressa na aceitação da cidadania do país de acolhida, ou poderia ainda se manifestar por meio de múltiplas articulações sociais - participação em instituições étnicas, entidades sindicais, movimentos culturais, por exemplo - pelas quais o imigrante, sem deixar de ser estrangeiro, tornar-se-ia partícipe da vida política ${ }^{2}$.

Nesse particular, no tocante à especificidade do imigrante espanhol no contexto da Paulicéia, face ao que pudemos assinalar e destacar no decorrer do trabalho, alguns aspectos devem ser pontuados, retomando-se pela tentativa de se pensar aquele espaço que, em momento de profundas transformações, passa a atrair, de modo progressivo, imigrantes provenientes de diferentes países, de horizontes culturais diversos e em condições também diferenciadas, que ali se juntavam aos nativos. Completando esse quadro heterogêneo, vemos

\footnotetext{
${ }^{1}$ ALMEIDA, G. "Um carvão de Goya". In: Op. cit., 1929, p. 62.

2 ZUBILlAGA, Carlos. "Participación política. Bases para su estudio". In: Historia General de la emigración española a Iberoamérica. Madrid: v. 1, Fundación Cedeal, 1992, p. 360.
} 
pulsar em seu interior uma massa de população flutuante e desgarrada, deslocando-se incessantemente à procura de um "lugar", imprimindo à atmosfera da jovem metrópole um aspecto desconcertante de provisoriedade, de descontinuidade e de atemporalidade. Essa dimensão exalada pela cidade, a da transitoriedade, é um traço que espelhará o destino da maioria dos espanhóis que nela aportaram. Eles, em sua grande maioria, haviam partido para um exílio involuntário. O protótipo do emigrante espanhol que chegou ao Brasil resistiu ao êxodo ultramarino o quanto pode. Engajando-se em movimentos locais de mobilidade sazonal, ele desencadeara, no período imediatamente anterior ao das grandes emigrações, uma movimentação em múltiplas direções, fenômeno observado especialmente na população rural andaluza. A ocorrência de uma reordenação provincial, das zonas tipicamente minifundiárias para aquelas onde predominavam os latifúndios, pôde ser atestada pelo considerável coeficiente imigratório registrado, cuja desaceleração coincidirá com o ritmo desferido ao movimento ultramarino ${ }^{3}$.

A muitos daqueles não restava qualquer outra opção, e assim, frente à avalanche que se esvaía pelos portos de Málaga e Gibraltar, o êxodo em massa, muitas vezes clandestino, inescapável diante da penúria, nutria-se da fome e se impregnava da crise de identidade que perpassava o país ${ }^{4}$. Esse indivíduo deixava atrás de si um país destroçado - ou "invertebrado", na expressão de Ortega y Gasset ${ }^{5}$ - econômica e politicamente, cujas forças minavam-se, em razão das guerras coloniais.

Por conseguinte, o ciclo da emigração espanhola, comparado ao das demais correntes européias do período da emigração em massa, especialmente ao da italiana, revelaria, em seu conjunto, um caráter retardatário, atingindo seus índices máximos somente nas duas primeiras décadas do Novecentos - aspecto que, como já pontuamos anteriormente, veio contribuir para intensificar o descompasso entre as reais oportunidades com que se depararam e as expectativas nutridas por essa população, em boa parcela seduzida pelas promessas dos recrutadores por cabeça (ganchos).

Partia-se, no entanto, para resolver uma situação que se imaginava passageira, e

\footnotetext{
${ }^{3}$ A respeito da mobilidade populacional interna, das condicionantes locais e do índice comparativo entre as diversas Províncias andaluzas, no período imediatamente anterior ao fenômeno de massa, $c f$. CÁNOVAS, M. $O p$. cit., 2001, pp. 97 e ss.

${ }^{4}$ A esse respeito, consultar especialmente a obra de Antonio Machado, Baroja e Unamuno, os quais constituíram a geração de escritores e poetas que identificou aquele momento como de "crise de identidade". In: CÁNOVAS, M. Op. cit., 2001, pp. 88 e ss.

5 ORTEGA Y GASSET, José. España invertebrada: bosquejo de algunos pensamientos históricos. Madrid: Calpe, $2^{\mathrm{a}}$ ed., 1922.
} 
retornar. Marchavam para o desconhecido. Alguns sequer sabiam onde desembarcariam. Renúncia, perda, ansiedade, sofrimento e dor faziam parte do repertório que, em doses variadas, acompanhou o êxodo desses desterrados, nos porões insalubres dos navios abarrotados que cruzavam o Atlântico. Muitos não chegavam, ficavam pelo mar, onde eram despejados, quando não resistiam. Nessa aventura e em condições subumanas, desembarcavam em terra estranha e eram despachados, à mercê de contratos que a maioria sequer sabia decifrar, e nem mesmo assinar, para o trato do cafezal, nas bocas de sertão, atividade que desconheciam, como desconhecidos também eram o país, a língua, a vizinhança, os hábitos alimentares e tudo o mais. Realidade crua e inapelável. Rápido concluiriam pelo engodo do compromisso consubstanciado no subsídio da passagem. E o sonho da redenção se transmutava em arrependimento, fortalecendo a idéia do regresso. Muitos adoeciam, outros se acidentavam, tornando-se incapazes para o trabalho, restando, nesse caso, apenas a repatriação. E havia os que precocemente morriam, vitimados pelas más condições sanitárias e pelas epidemias. Nessas condições, era grande o quadro de desintegração familiar, como foram incontáveis os casos de viúvas com filhos, egressos do colonato, solicitando o auxílio do consulado ou dos conterrâneos para a repatriação. Desenganados e movidos pelo mais profundo desalento, outros mais tentavam resistir, fugindo a pé das fazendas, num movimento itinerante e constante que será a marca distintiva do período. Nesse caso, o infortúnio era o motor a acionar novas e desafiadoras tentativas. Marchavam para as cidades, especialmente para a capital de São Paulo, vagando na direção da incerteza. $\mathrm{O}$ impacto da chegada à metrópole que, frenética, despertava, era assustador, provocando receio e estranhamento. Ali, esgueirando-se nos seus desvãos, e concorrendo no saturado mercado de trabalho, passariam a viver promiscuamente, engrossando as sinistras fileiras dos miseráveis e desempregados. "O migrante que chega à cidade ou à terra alheia é um homem mutilado, um ser reduzido ao osso da privação", diria Alfredo Bosi ${ }^{6}$.

O problema de uma maior ou menor capacidade de adaptação às exigências do trabalho urbano, embora crucial para sua sobrevivência, não representava, apesar disso, o único a ser enfrentado por esse imigrante, que tinha o campo como referência. A vida na cidade acarretava profundas alterações no seu modo de vida, implicando, em suma, um "reordenamento de todo o seu estoque simbólico". Uma vez na cidade, urgia "reconstruir uma nova identidade, reconstruir laços de parentesco e vizinhança, acostumar-se aos equipamentos urbanos" ${ }^{\text {"7 }}$. Nessa jornada crucial, muitos sonhos e anseios foram deixados para trás. Irremovível permaneceria, no entanto, o projeto, acalentado pela maioria, e ao qual se apegavam como a um bote salva-vidas,

\footnotetext{
${ }^{6}$ BOSI, Alfredo. Dialética da colonização. São Paulo: Companhia das Letras, 1992.

${ }^{7}$ MAGNANI, J. Op. cit., 1998, pp. 25-26.
} 
do retorno à terra natal, evidenciando a intenção declaradamente transitória da passagem pelo Brasil. Lapidar a esse respeito revelou-se a manifestação de um de nossos depoentes, então com 85 anos: "nas primeiras eleições que tiveram aqui, me aconselharam muito, faziam tudo de graça [referindo-se ao processo de naturalização], mas eu não quis. Eu não! Porque tinha intenção de voltar pra Espanha. E chego lá, não sou mais espanhol, né?! Então, não quero ser brasileiro!", afirmava o Sr. Ildefonso Blasquez Sanchez, que chegara aos 9 anos de idade, em $1905^{8}$. Na maioria dos casos, o do Sr. Ildefonso incluso, o almejado regresso jamais ocorreria, situação que condenava o imigrante a "engendrar uma situação que parec[ia] destiná-lo a uma dupla contradição: não se sab[ia] mais se se trata[va] de um estado provisório que se preferir[ia] prolongar indefinidamente, ou, ao contrário, se se trata[va] de um estado mais duradouro, mas que se gosta[ria] de viver com intenso sentimento de provisoriedade"

A partir dessas premissas, a interrogação que insiste em se colocar é em que medida, nas condições concretas de sua existência, essa idéia fixa que o impregnava, uma quase obsessão, cederia margem a algum outro projeto ou motivação, que não àquele unicamente relacionado à sua sobrevivência? $\mathrm{O}$ que de dignidade restava a esse sujeito desfigurado, a essa massa disforme e discriminada? Algumas atitudes políticas de resistência, acreditamos, e, dentre elas, a manutenção de sua cidadania - ou a recusa em aceitar a cidadania brasileira, i.é., a preferência por manter-se estrangeiro -, o finca-pé inarredável que lhe dava caução à convicção do retorno. A faina diária, a dura labuta e as necessidades que a maioria dos imigrantes enfrentou, só pode ser compreendida por essa via, a da reação, pelo comprometimento com o projeto do retorno. Algumas indicações nesse sentido parecem ter sido suficientemente encaminhadas no texto, em cujo transcurso deixamos entrever mecanismos e táticas esboçadas, longe de expressar atitude apolítica. Notadamente por parte da camada melhor aquinhoada da colônia, mas especialmente pelos expoentes ilustrados (os intelectuais e/ou militantes), tais ações convergiram para o estabelecimento de plataformas, por meio das entidades criadas, visando o amparo à massa dos desfavorecidos. Porém, não se limitaram a esse escopo. Como não considerar com virtualidade política as ações a distância - subscrições para os sobreviventes ou familiares dos combatentes mortos na Guerra do Marrocos, por exemplo caracterizando permanências afetivas na sociedade de origem, que moveram grandemente a colônia no período examinado? E o que dizer da ação política direta de que se ocupavam os militantes? Ou do modus operandi de um Eiras Garcia, que de seu Diário desancava denúncias a fazendeiros, de cujo enfrentamento não desconhecia as inevitáveis conseqüências? Quer seja

\footnotetext{
${ }^{8}$ Fragmento de depoimento. Villa Novaes, 1981. In: CÁNOVAS, M. Op. cit., 2001, p. 22.

${ }^{9}$ SAYAD, A. Op. cit., p. 45.
} 
"fazer política" tendo em vista a sociedade de origem ou a sociedade receptora, esse é um dos aspectos que constitui a chave interpretativa da dicotomia assimilação-marginalização, que infligiu o imigrante, e que não cessou de dividi-lo mais tarde, frente à primeira geração de brasileiros, seus filhos aqui nascidos. Nesse equilíbrio instável, como compreender, em suma, a postura da parcela majoritariamente subalterna dessa população imigrante? E como distingui-la das ações daqueles que, social e intelectualmente falando, dela se distanciavam?

O Brasil, é necessário lembrar, acabava de experimentar a passagem do regime monárquico para o republicano. O projeto político dos republicanos ou de fração deles representada pelos fazendeiros de café do Oeste Paulista - os mesmos responsáveis pela política imigratória -, assentava-se habilmente em uma prática política que forjava um discurso pelo qual a República aparecesse como o regime político do progresso e da civilização, fundamentado no trabalho livre: "só o trabalho livre é fecundo". E mais: "A república, como 'regime do trabalho` tem no ato produtivo a condição para o exercício da cidadania”, afirmaria Quintino Bocaiúva em manifesto, ao ser eleito para exercer as funções de diretor da política do Partido Republicano Brasileiro ${ }^{10}$. Desse modo, à nascente República, apresentou-se o desafio de impor o seu projeto civilizador democrático-liberal, ainda que, para Maria do Carmo Campello de Souza ${ }^{11}$, apenas na forma, posto que se mantinha oligárquico no seu funcionamento efetivo, tendo como sustentáculo o pacto social, centrado na ética do trabalho e no respeito à propriedade.

Nessa perspectiva, o imigrante europeu aparecerá como a opção para o escravo. No entanto, acostumados a séculos de convivência com o trabalho escravo, e com a massa de homens livres pobres, agregada pelo "favor", estes governantes, mesmo sob a República, não dissimulavam a falta de conviç̧ão na adoção dos novos comportamentos decorrentes da instituição do trabalho livre e na ampliação dos direitos civis ${ }^{12}$. Pela proclamação da República, enfim, se adota o sufrágio universal, concedendo o direito de voto aos maiores de 21 anos, embora discriminando e excluindo boa parcela da população, pelas restrições impostas ${ }^{13}$, e pela manipulação das eleições.

${ }^{10}$ SALLES, I. Op. cit., 1995, p. 12 e ss.

${ }^{11}$ SOUZA, M. do Carmo Campello de. "O processo político-partidário na Primeira República". In: MOTA, C. (org.). Brasil em perspectiva. São Paulo: Difel, 1975, pp. 167 e ss.

${ }_{13}^{12}$ Idem, ibidem, p. 52.

${ }^{13}$ Eram excluídos do sufrágio universal os mendigos, analfabetos, os religiosos de ordens monásticas, companhias, congregações ou comunidades de qualquer denominação sujeitos a voto de obediência, regra ou estatuto e as mulheres. $C f$. RIBEIRO, Maria Teresinha Janine. Desejado e temido. Preconceito contra o imigrante italiano em São Paulo na Primeira República. São Paulo: Dissertação de Mestrado, FFLCH-USP, 1985, p. 136. 
Ao trabalhador estrangeiro, institucionalizando uma aparente igualdade, foi imposta a “grande naturalização". Assim denominado, o processo de naturalização automática (artigo 69, parágrafo $4^{\circ}$ da Constituição de 1891), estabelecia que todos que residissem no país antes da data da Proclamação da República (15.11.1889), teriam seis meses para declarar-se em contrário, mantendo a nacionalidade de origem. Também seriam considerados cidadãos brasileiros os estrangeiros que ainda residissem no país nos dois anos subsequientes ao da aplicação do decreto em questão. Parecia clara a idéia do legislador em obter, por inércia ou desconhecimento dos estrangeiros, uma naturalização em massa, tomando o silêncio como presunção da aceitação. Fortalecia-se a representação, que assim se legitimava, em prejuízo da participação política, que se "concedia". De todo modo, as restrições impostas pelas exclusões, acabariam eliminando sistematicamente parcela considerável desse contingente imigratório do exercício dos direitos políticos, consubstanciado pelo voto - nele, em especial o espanhol, por seus elevados índices de analfabetismo.

Desse modo, se oficialmente o estrangeiro alcançava a condição de cidadão num passe de mágica - outorga de que à maioria deles não interessava usufruir - na prática, não se desconhecia que eles, os imigrantes, "estavam sendo transplantados para o país não como

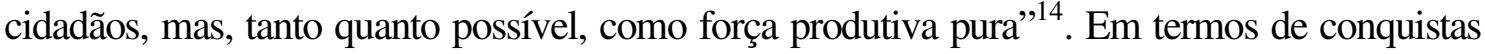
efetivas, garante José Murilo de Carvalho ${ }^{15}$, a Constituição de 1891 pouco representou no tocante aos direitos civis e políticos. A maioria, se soubesse da "concessão" da naturalização por decreto, a ela se teria oposto. Consta que somente $20 \%$ dos estrangeiros a aceitaram, depois da lei ${ }^{16}$ - justamente por implicar a renúncia à sua própria cidadania.

O espanhol que, à época, ainda se constituía um grupo bastante restrito, parece tê-la rechaçado, a considerar as manifestações de repúdio já mencionadas. No entanto, é provável que muitos deles desconhecessem a sua condição, após a aplicação da lei, por desinformação. Essa questão parece ter mobilizado largamente setores da imigração italiana, muitos dos quais se manifestaram favoráveis à naturalização. Nos LRC, em todo o período examinado, teríamos a oportunidade de constatar apenas dois casos de "funcionários públicos", exercício que pressupunha a adoção da cidadania brasileira.

Por outro lado, naquele cenário, a não-aceitação da cidadania brasileira, do ponto de vista de seus direitos civis, tinha o efeito sinistro de acentuar ainda mais a sua exclusão. Mesmo que esse imigrante desconhecesse a pecha de traidor da pátria a ele atribuída, e por menos

${ }^{14}$ FAUSTO, B. Op. cit., 1977, p. 69.

${ }^{15}$ CARVALHO, J. M. Os bestializados. O Rio de Janeiro e a República que não foi. São Paulo: Companhia das Letras, 1987, p. 44.

${ }^{16}$ Idem, ibidem, pp. 81-82. 
informado que fosse, não lhe passaria desapercebida a conspícua ausência da autoridade consular, a quem em tese deveria reclamar os seus direitos de cidadão. E não se tratava apenas de omissão: puro descaso e negligência pautaram a atitude desses funcionários para com os paisanos. A paralisia desses representantes diplomáticos - da maioria deles, no período examinado - só se atenuava quando vislumbravam poder auferir vantagens do cargo. Desse modo, sua função básica parecia restringir-se à administração e ao controle do contingente disponível para alistamento, em clara sintonia com as diretrizes do Estado espanhol, indisfarçável em sua política de encaminhar as correntes migratórias apenas en "los límites del próprio suelo o dirigirla a nuestras posesiones ultramarinas"17.

Assim entendido, esse indivíduo exibia uma dupla segregação. De direito, enquanto imigrante/estrangeiro que era, mas também de fato, em seu país de origem, enquanto emigrante: "Sendo o político monopólio exclusivo do nacional - ele é inclusive sua característica distintiva por excelência -, o imigrante, como não-nacional é dele excluído, e excluído de direito", diria Sayad, para quem "o emigrante que ele também é (e que continua sendo, enquanto for designado e nomeado como imigrante) é excluído de fato, enquanto é um nacional ausente (ausência da nação) do político"18.

Em suma, conforme pontuamos, uma grande parcela do contingente espanhol da cidade não teria auferido condições de votar, mesmo que quisesse, pelo dispositivo altamente excludente, do veto ao analfabeto. E quanto à camada abastada a quem, a princípio, aquele impedimento deveria incidir em menor escala, como reagiu à naturalização por decreto? Indícios parecem sinalizar que também neles, quase em maioria, não se despertara qualquer interesse especial por se naturalizar. Pudemos acompanhar alguns casos que demonstraram como, valendo-se da ascendência social conquistada, expoentes dessa esfera procuravam intensificar as relações com seu país de origem, aonde permaneciam em longas estadias. Esse era um dos sentidos que assumia a provisoriedade. Com o estabelecimento de fortes laços econômicos no país de acolhida, com prósperos negócios e, provavelmente, com a oposição dos filhos aqui nascidos, esses elementos se viam forçados a permanecer, o que não raro aconteceu, e, assim, lentamente, sua ação tendeu à integração no novo espaço social.

De qualquer modo, como bem acentuou Trento, na análise que realizou sobre os italianos, em caso contrário, i.é., partindo-se da hipótese (remota) da aceitação da cidadania, é bastante provável que esbarrassem no "absoluto imobilismo e impermeabilidade da vida política local [...] e [na] ausência de forças e frentes que fossem a expressão das camadas

\footnotetext{
${ }^{17}$ Real Orden de 11.07.1891. Apud: SANCHEZ, B. Op. cit., 1989, p. 445.

${ }^{18}$ SAYAD, A. Op. cit., pp. 269-270.
} 
médias"19. Tal comportamento social, exibido por essa primeira geração de imigrantes, que passou a compor uma camada média emergente, cujo viver procurava inspirar-se na elite nacional, de quem assimilavam hábitos e códigos ditados por modismos europeus, se por um lado favorecia uma relação mais estreita com a sociedade local, refletia-se muitas vezes nas suas relações com os paisanos, a massa de conterrâneos pobre, da qual se distanciavam mais e mais. Em não poucas ocasiões, pudemos presenciar, na retórica de Eiras Garcia, as "convocações" que dirigia a esse grupo próspero, a elite econômica da colônia - que sofregamente ansiava por aderir a um estilo de vida fundamentado em valores, símbolos e comportamentos, que os diferenciassem dos demais grupos sociais, e pelos quais buscava ser reconhecida - exortando-os à necessidade de abraçarem a causa dos menos favorecidos. Nessa cruzada de convencimento, e nesse equilíbrio instável, vozes se uniram, muitas delas ideologicamente dissonantes, como a dos intelectuais e militantes, pelas quais se apelava às raízes comuns, na evocação do espírito de coletividade que "deveria pautar a convivência em terra estrangeira". Invocando um frágil sentimento de coletividade, Eiras lamentava, apropriadamente, a respeito da "nossa debilidade coletiva", cujo maior elemento de coesão deveria ser a imagem da pátria distante, revigorada frente aos demais grupos que coexistiam na cidade, argumento por vezes falacioso, que nem sempre se mostrou suficientemente capaz de amalgamar remotas e fundas divergências que, oportunistas, emergiam e se sobrepunham a quaisquer interesses comuns. As assimetrias, conforme ficou evidenciado, não envolviam apenas disparidades econômicas e de status social. Eram também de caráter ideológico. Ou regionalista. Ou ambos. Episódios que em sua superfície poderiam significar meros desentendimentos, fruto de rivalidades triviais, desancavam para inexplicáveis desfechos, por trás dos quais mal se escondiam arraigadas hostilidades. Assim, sob a palpitante vida comunitária, deflagravam-se tramas mal-costuradas, que se esgarçavam, comprometendo projetos coletivos e dificultando a organização comunitária.

A multiplicação de associações e agremiações que despontavam nesse contexto malgrado a idéia latente de fusão defendida por alguns que, embora imperativa, não conseguia força suficiente para firmar-se - representava a evidência da fragilidade sistêmica, do equilíbrio delicado e da iminência de fragmentação, prevalecendo acima dos interesses comunitários e sob os quais se escondia um maldisfarçado egocentrismo das elites econômicas e intelectuais.

Se assim não fosse, como explicar a tendência às reiteradas cisões, que se refletiam na proliferação de novas associações, surgidas mais por conflitos pessoais e urdidas,

${ }^{19}$ TRENTO, A. Op. cit., 1989, pp. 200 e ss. 
eminentemente para dar lugar a maquinações e conchavos de um determinado grupo, que efetivamente como manifestação espontânea de solidariedade em favor dos menos favorecidos? Que outros sentidos não-declarados estariam expressos nesse pipocar de iniciativas de grupos antagônicos, pairando acima dessas motivações pontuais? Trento, que tão bem investigou esse aspecto com respeito aos italianos, quer ver uma possibilidade no fato de que "a elite econômica e intelectual italiana, participando pouco da vida política e pública do país - por impossibilidade ou por escolha -, descarregava na vida associativa da colônia ambições, frustrações, manias de grandeza e querelas pessoais, 20 .

Excede os propósitos desse trabalho uma discussão que recupere as inúmeras tentativas de análise dos setores médios urbanos, ainda mal documentados na historiografia brasileira. "Classes médias", para alguns, "camadas médias", para outros, o conceito encontrou, durante muito tempo, na dicotomia burguesia/proletariado, calcada na teoria de estrutura de classes, a principal objeção para a sua formulação. Tal aspecto foi em parte superado na percepção de que evocava unicamente a formulação teórica do modo de produção, não se aplicando, contudo, a formas sociais concretas nas quais coexistem diferentes modos de produção ou a formas históricas de transição. Como lembra Paulo Sérgio Pinheiro, "as classes médias [...] se situam numa oposição intermédia em relação à contradição principal capital/trabalho inerente ao modo de produção capitalista" ${ }^{21}$. Em sua abordagem, Carone, num esforço para o entendimento da composição dessa "classe média" na Primeira República, sugere a existência de três níveis: a "alta", a "intermediária" e a "baixa" classe média sem, contudo, precisar o papel político e as práticas concretas equivalentes a cada uma dessas divisões ${ }^{22}$. Dos autores que se debruçaram sobre o tema, pudemos destacar tentativas várias de garantir à categoria uma dimensão conceitual, dificuldade que aflora como consenso dentre os mesmos, pela constituição heterogênea do grupo examinado.

Partindo desse diagnóstico, e com base nos dados obtidos junto à documentação analisada, do imigrante espanhol que galgou patamares variados na escala social, temos de admitir a dificuldade em identificar, para aquela atmosfera de turbilhão da cidade, as inúmeras fórmulas e artifícios que mediaram essa escala ascendente, e o modo como se processou esse percurso assimétrico, largamente ensejado por descontinuidades, limites móveis e fluídos, e em

${ }^{20}$ Idem, ibidem, p. 172.

${ }^{21}$ PINHEIRO, P. Op. cit., 1978, p. 11.

${ }^{22}$ CARONE, E. A República Velha I (instituições e classes sociais, 1889-1930). São Paulo: Difel, 1972, pp. 175 e ss. 
condições subjetivas difíceis de serem fixadas. No período que tratamos, não há como se estabelecer um "modelo", apenas algumas tipologias sugestivas de possibilidades, como a que aventamos para o caso dos negociantes de cereais que, embora numericamente expressivo, apresentou, ainda assim, um padrão irregular. Todavia, não foram os únicos setores prósperos que identificamos. Não cabe aqui uma retrospectiva acerca das diversas modalidades, auferidas e usufruídas no desenho urbano, e suas respectivas especificadades, já devidamente esmiuçadas. Contudo, julgamos conveniente destacar, nesse momento, um aspecto que nos pareceu revelador: o modo com esse indivíduo, representante das nascentes camadas médias, passou a se identificar nos registros consulares. Em outras palavras, a representação que "de si" passou a fazer esse sujeito, fazendo valer o primado do seu (novo e ambicionado) status. Nesse particular, as indicações são densas de significados, especialmente para um estudo das mentalidades, reproduzindo-se em categorias emblemáticas, como capitalista, empresário, industrial, comerciante, negociante e proprietário - além, evidentemente, das demais categorias laborais, digamos, técnicas, surgidas em menor escala, como dentista, engenheiro, professor, escrevente ou fotógrafo. Porém, é com relação aos primeiros, àqueles afortunados cuja prosperidade fora conquistada em seu itinerário de imigrante, que recai a nossa atenção. Como um sujeito nessas condições, tão cioso de sua imagem social, a legitimaria diante da sociedade de adoção?

Analisando os grupos médios da Primeira República, Paulo Sérgio Pinheiro considerou que os mesmos tiveram uma atuação condinzente com as classes dominantes, sem jamais se impor e nem colocar em risco a dominação vigente. As únicas iniciativas de oposição tiveram como cenário a conjugação de interesses com grupos do mesmo bloco, dissidentes nãohegemônicos, interessados em compor com as classes médias, o que não os converteu em "agentes de transformação, mas em colaboradores eficientes das modificações que obrigatoriamente [tinham] de ser levadas a cabo pelas classes dominantes, para manterem intacta a pauta de exploração",23.

Décio Saes analisou a composição de alguns desses setores, por ele denominados "intermediários urbanos", chegando por concluir que os segmentos mais altos do terciário foram ocupados por grupos decadentes compostos por ramos empobrecidos das mesmas famílias aristocráticas que, situadas no nervo do sistema político, controlavam o acesso aos cargos públicos, dispondo aos mesmos o ingresso a altos cargos administrativos, e até mesmo no judiciário. Um aparelho burocrático de Estado nas mãos de prepostos e familiares, seria, por

\footnotetext{
${ }^{23}$ PINHEIRO, P. Op. cit., p. 36.
} 
certo, uma garantia de favorecimentos. Era, contudo, nos cargos menos prestigiados desse funcionalismo que o autor identificaria os brasileiros de origem mais pobre, e também os imigrantes europeus, nos quais identificaria uma performance bastante peculiar, diferenciada da expressa pelo grupo "familiar", justamente pela possibilidade do exercício de uma atitude mais “independente" diante da política oligárquica.

Ainda segundo o autor, interessando-nos particularmente recuperar uma crítica que enceta, esses setores ou camadas - segundo ele, um conjunto de agregados que não deve ser confundido com uma classe social - em decorrência da sua extraordinária heterogeneidade (ocupacional, social e cultural), não teriam logrado conquistar unidade e coesão, em que pese o denominador comum, qual seja, a posição similar na estrutura ocupacional. A utilização da expressão camadas no plural pretende, sem negligenciar a existência desse denominador comum, destacar a sua heterogeneidade dos pontos de vista social, cultural e ideológico e, em decorrência, "uma variedade com possíveis repercussões políticas",24. O grande divisor de águas, para Saes, é o trabalho braçal. O exercício de uma atividade não-manual, quer trabalhando por conta própria, quer vendendo a sua capacidade de trabalho a terceiros, conferiria às pessoas, para Saes, nessa quadra histórica, uma posição comum na hierarquia de prestígio social, ainda que com gradações, ou seja, uma posição intermediária, a meio caminho entre os grandes proprietários e os braçais. Essa posição tende a ser valorizada pelos seus ocupantes em termos de status social, porém, sua vinculação à oligarquia os torna pouco suscetíveis a uma ação política autônoma. Em vista disso, seus diferentes segmentos se mantêm em estado de isolamento, sem unidade, a reboque de grupos sociais mais definidos. Esses elementos, no exercício de diferentes profissões (o que lhes exigia diferentes aptidões ou qualificações, em conseqüência do que se estabeleciam as gradações na valorização social) auferiam também distintos níveis de renda, introduzindo assimetrias no conjunto, tornando ainda mais difícil a sua "unificação", aspecto que redundou em comportamento ambíguo e hesitante. Nesse sentido, há que se acrescentar o fator étnico, como motor de rivalidades na disputa pelas oportunidades, tornando-se, assim, mais um elemento de desunião.

Essa incapacidade de manutenção de um projeto político em defesa de seus interesses, relacionada à evolução mesma da categoria, só se daria "mediante a arrancada do processo de industrialização, que renovaria o terciário urbano", universo no qual gravitavam as oportunidades da camada média. Daí que, conforme pondera Saes, concordando com Hélio Jaguaribe, na "industrialização [residiria] o verdadeiro interesse da classe média ao longo da

\footnotetext{
${ }^{24}$ SAES, Décio. Op. cit., 1973, pp. 19 e ss.
} 
Primeira República",25.

O regime político instaurado pela República, juridicamente liberal-democrático, continuaria oligárquico no seu funcionamento, não intimidando as elites rurais que se valeram das novas instituições para consolidar, sobretudo por meio do federalismo, pelo qual se operou a descentralização republicana, uma maior autonomia regional. Na prática, assim, o que se assistiu, foi a legitimação da dominação política das elites, que passaram a orientar, na esfera local, estadual e nacional, todo o funcionamento do sistema político - regime de um só partido; voto de cabresto; falsificação de atas eleitorais, força armada, etc.

O sistema político da Primeira República permaneceu inacessível à parcela considerável das populações rural e urbana, bloqueio ao qual nem mesmo o empresariado industrial, que acabaria por aderir ao "quartel-general oligárquico, o Partido Republicano Paulista", seria capaz de romper. Afinal, interrroga-se Saes, as camadas médias possuíam condições de "substituí-los" nessa tarefa? O próprio autor fornece pistas que desautorizam qualquer hipótese nesse sentido. Para ele, o que se assistiu, por parte desse segmento incapaz de algum "projeto político que justificasse a sua presença como força política autônoma", foram formas de incorporação precárias que redundariam na submissão aos diversos grupos oligárquicos, situacionistas ou dissidentes, cujo padrão de vida procuravam imitar $^{26}$, fatores que, segundo Zubillaga, se coadjuvaram para transformar o exercício cidadão uma via de inserção secundária dos imigrantes espanhóis na vida política dos países receptores ${ }^{27}$.

Nesse sentido, despojados da possibilidade de participação política e mantidos à margem da vida pública e das instâncias do poder, essa geração de imigrantes, dedicada quase exclusivamente ao projeto de ascensão social pela via do trabalho, passa a compor novos espaços de vida comunitária, delineando e reescrevendo, habilmente, formas opcionais de expressão no conjunto da sociedade.

Por meio das agremiações e das sociedades de ajuda mútua, e em meio à prática da solidariedade étnica, através de pequenas ações descontínuas, forjam um meio de expressão política, driblando, assim, a marginalização a que se viam submetidos. Desse modo, sutilmente delimitados aos seus respectivos espaços, intensificam a sua sociabilidade por meio das associações recreativas, transformando sua vida associativa e cultural, e suas práticas, em formas de atuação segura dentro da própria comunidade, valendo-se de festas, círculos de conferências, concertos musicais, jornais, teatro dramático e amador, e muitos et ceteras,

\footnotetext{
${ }^{25}$ Passim.

${ }^{26}$ Passim.

${ }^{27}$ ZUBILLAGA, C. Op. cit., p. 369.
} 
passando a conformar novos espaços de convívio social. Sociabilidade ascendente, que delineou o surgimento de pequenos empresários remediados e comerciantes mais prósperos, que foram aos poucos compondo um fenômeno social novo na cidade.

Compondo-se, como tal, à margem dos setores hegemônicos - e em que pese o monopólio político efetivamente exercido sobre o aparato das eleições, e sobre a nomeação de cargos na máquina administrativa e no judiciário - o destino dessa população nova de imigrantes, recém-chegada à cidade, escaparia do controle efetivo das elites que, da mesma maneira, nem mesmo conseguiria intervir no processo de surgimento de novos grupos médios na população cosmopolita. Assim, os segmentos médios imigrantes foram, por meio de negócios de porte variado, e de naturezas diversas, se consolidando, tornando exequíivel um projeto pessoal sem vinculação aparente aos favores do clientelismo burocrático. Diante disso, os limites materiais ou simbólicos (o preconceito de que era objeto, por exemplo), impostos ao elemento imigrante parecem não ter sido suficientemente eficientes para impedir a sua ascensão social e, então, ao passo que administravam seus negócios, e multiplicavam espontaneamente formas de convívio comunitário, permaneceriam, em maioria, não votando, e nem participando das atividades políticas.

Numa itinerância que nunca cessava, os trabalhadores entravam em contato assíduo e constante com grupos sociais urbanos extremamente desiguais. Cruzavam-se, conviviam nas ruas, nas habitações coletivas, nos bailes caseiros, no trabalho, nas festas públicas e religiosas, nas pescarias no Tietê, nos concertos musicais dos parques onde, face a face, fazia-se sentir a diferença da fortuna, da classe social, da etnia. Mesclava-se, assim, a um meio urbano que vivia saturado de usos africanos e tradições caipiras, uma esfera de circulação de valores e tradições culturais de origens européias diversificadas, espaço fecundo para a análise desse processo de mudanças. Eram culturas que se amalgamavam no cadinho de sincretismo da cidade, nos espaços de sociabilidade multiculturais, processo desencadeado a partir de múltiplas diferenças sociais, culturais e étnicas. Sociabilidade peculiar à cidade cosmopolita que se moldava na brecha da hegemonia das elites, criando, na urbanização de São Paulo, novos espaços de vida cultural e comunitária.

Há uma estreita e complexa relação entre os espaços de vida comunitária e a identidade cultural que se anseia preservar através deles, pela manutenção de mecanismos capazes de manter viva a memória coletiva do grupo. Pudemos notar, no entanto, nas transformações decorrentes do processo de assimilação e integração ocorridas, um redesenho, matizado pela dinâmica que se instaurou na cidade. 
Entendida como produção histórica, e não como um dado ou herança que se transmite imutável de geração para geração, a cultura é uma construção que se inscreve na história e, mais precisamente, na história das relações dos grupos sociais entre $\mathrm{si}^{28}$. No contexto migratório da cidade de São Paulo na passagem do século XX, o encontro de indivíduos de diversas origens/culturas ensejou um processo permanente de construção, desconstrução e reconstrução cultural. A mudança de contexto cultural do imigrado implica, em decorrência, um complexo processo de negociação quanto a sua existência - envolvendo a própria identidade, seus próprios valores, a identidade do grupo, questões étnico-raciais, etc. ${ }^{29}$ - em que variados graus de assimilação, integração, separação ou marginalização, dependendo do contexto histórico e das particularidades de cada grupo, podem ocorrer.

Resultado de um processo de interação contínua entre três vínculos de integração, o espacial, o temporal e o social, o sentimento de identidade desenvolve-se enquanto tal, por conseguinte, no vínculo com os "outros",30 , não sendo despropositado lembrar em decorrência que, na percepção da existência do outro, pela relação de contraste à própria identidade e à consciência de si, ou seja, pela via da alteridade, é que provavelmente muitos se descobrissem espanhóis - ou galegos, ou asturianos, ou ainda, andaluzes -, depois de emigrar ${ }^{31}$. " $L a$ identidad no es solamente la búsqueda o el reconocimiento de las similitudes que nos aproximan a lo que consideramos nuestro grupo, que nos unifican a 'nosotros', sino que se trata al mismo tiempo de un reconocimiento de las diferencias que nos separan de los 'otros`, de los grupos que concebimos como ajenos" afirma Joaquín Giró ${ }^{32}$, para quem a definição de "nosso" emerge como um processo simultâneo à constatação do "outro".

Nesse aspecto, pensar que os grupos, como o espanhol, que compuseram o imenso mosaico de etnias da paisagem paulistana nesse dado período, possam ser definidos por características culturais inapelavelmente fadadas à dissipação, é um vaticínio equivocado, ao qual os estudiosos da etnicidade, hoje um campo de debates, tentam contrapor. Com uma visão que privilegia a "interação" dos grupos, por terem sido partícipes de experiências compartilháveis - e aí se poderia incluir todo o eloqüente repertório de similaridades dos emigrados do período - em outras palavras, fundamentando-se na "percepção das

\footnotetext{
${ }^{28}$ CUCHE, Denys. A noção de cultura nas ciências sociais. Bauru: Edusc, 1999.

${ }^{29}$ DEBIAGGI, S. Op. cit., 2005, p. 17.

${ }^{30}$ GRINBERG, Leon e GRINBERG, Rebeca. Psicoanálisis de la migración y del exílio. Madrid: Alianza Editorial, 1984, p. 156.

31 MELLO Silvia Leser de. "Pensando o cotidiano em Ciências Sociais: identidade e trabalho". In: Cadernos CERU. São Paulo: n. 05, série 2, 1994, pp.23-31.

${ }^{32}$ GIRÓ, Joaquín. "La vida cotidiana. Planteamiento y datos para su investigación". In: Historia General de la emigración española a Iberoamérica. Madrid: v.1, Cedeal, 1992, p. 397.
} 
semelhanças", o estatuto epistemológico da etnicidade se arroga o postulado segundo o qual se deve evitar o erro de reificar os conceitos e pensar os "grupos étnicos" como entidades sociais possuidoras de certos atributos culturais e organizativos fixos. A identidade não é uma essência. Não é fixa, estável, coerente, unificada e permanente. Tampouco é homogênea, acabada e definitiva. Ela é uma construção, um processo ${ }^{33}$. Assim entendido, o fenômeno da etnicidade seria, em suma, um aspecto das relações sociais que implicaria "interação" e "um campo comum de comunicação" entre os grupos envolvidos, percepção que tem sido relegada, na literatura existente, em que se procura privilegiar as fronteiras e diferenças entre os grupos e não a sua "integração"34. A essa visão estática e "museológica", que encerra a cultura como um acervo de produtos acabados e cristalizados, alheios às mudanças das condições de vida de seus portadores, também se contrapõe Magnani, para quem, "mais relevante que lamentar a perda de uma suposta autenticidade", é tentar analisar as transformações e mudanças na forma como se apresentam, pois a "cultura, mais que uma soma de produtos, é o processo de sua constante recriação, num espaço socialmente determinado"35. Em outras palavras, reconhecer o pertencimento a um determinado grupo étnico, não torna incompatível o reconhecimento das transformações decorrentes do processo de assimilação e integração. Para Jeffrey Lesser que analisou detidamente o grupo emigrado dos não-europeus do período, "uma identidade nacional única ou estática jamais existiu: a própria fluidez do conceito fez que ele se abrisse a pressões vindas tanto de baixo quanto de cima", concorrendo, para o fenômeno, a criação, por parte dos imigrantes e de seus descendentes, de "maneiras sofisticadas e bem-sucedidas de tornarem-se brasileiros", nas areias movediças da nacionalidade e da etnicidade ${ }^{36}$.

Não existe, em síntese, assimilação total de uma cultura pela outra. O que ocorre são "intensas trocas entre territórios-rede, pois, se o movimento migratório retira o sujeito de um determinado espaço, não o desterritorializa por completo", porquanto "permanecem geografias imaginárias, que trazem memórias e emoções de países e cidades invisíveis"37.

Esperamos que o nosso texto, parafraseando Guimarães Rosa, possa valer pelo muito que nele não deveu caber. Esta é também, por certo, uma história inconclusa.

\footnotetext{
${ }^{33}$ SILVA, Tomaz Tadeu da (org.). Identidade e diferença. A perspectiva dos estudos culturais. Petrópolis, RJ: Vozes, 2000, pp. 96 e ss.

${ }^{34}$ BALLINA, Sebastián. "Etnicidad y estratégias identitarias: modalidade de estructuración en un grupo eslavo de Berisso, Argentina". In: Revista del Cesla - Centro de Estudios Latinoamericanos. Varsóvia: n.8, Universidad de Varsóvia, 2006, pp. 63-86.

${ }^{35}$ MAGNANI, J. Op. cit., 1998, p. 26.

${ }^{36}$ LESSER, Jeffrey. A negociação da identidade nacional. Imigrantes, minorias e a luta pela etnicidade no Brasil. Trad. Patrícia Zimbres. São Paulo: Editora Unesp, 2001, pp. 19 e ss.

37 MELO, Walter. Resenha de Cruzando fronteiras: um panorama dos estudos migratórios. Rio de Janeiro: Ed. Revan, 2005, de POVOA NETO, Helion e FERREIRA, Ademir P., a ser publicada na Revista LatinoAmericana de Psicopatologia. Correspondência eletrônica recebida em 13.06.2006.
} 


\section{ÍNDICE DE TABELAS E QUADROS}

\section{Capítulo I}

- Tabela 1. São Paulo (Capital) - Estrutura Ocupacional, 1893, p. 67

- Tabela 2. Estado de São Paulo - Distribuição percentual dos imigrantes espanhóis por Regiões, 1893-1922, por decênios (destaque para as três principais Regiões), p. 80

- Tabela 3. São Paulo (Capital e Interior) - Distribuição percentual por Regiões de origem dos imigrantes espanhóis, 1893-1922, por decênios (destaque para os domicílios não declarados), p. 82

- Tabela 4. São Paulo (Capital) - Distribuição percentual dos imigrantes espanhóis por Regiões, 1893-1922, por decênios (destaque para as três principais Regiões), p. 83

- Tabela 5. São Paulo (Capital e Interior). Jornaleros: principais Regiões de origem, por decênios - \%, p. 85

- Tabela 6. São Paulo (Capital e Interior). Outras ocupaciones: principais Regiões de origem, por decênios - \%, p. 90

- Tabela 7. São Paulo (Capital) - Região da Andaluzia: jornaleros e outras ocupaciones. Percentual por províncias e por decênios, p. 91

- Tabela 8. São Paulo (Capital) - Região da Galícia: jornaleros e outras ocupaciones. Percentual por províncias e por decênios, p. 91

- Tabela 9. São Paulo (Capital) - Região de Castilla-León: jornaleros e outras ocupaciones. Percentual por províncias e por decênios, p. 92

- Tabela 10. Imigrantes espanhóis entrados em São Paulo, 1885-1929. Porcentagem em relação às outras correntes, por qüinquiênio, p. 108

- Quadro 1. São Paulo (Capital) - Ocupaciones declaradas, 1893, p. 70

- Quadro 2. São Paulo (Capital) - Composição da estrutura ocupacional dos imigrantes espanhóis, 1893-1902 (destaque especial para a categoria jornalero), p. 73

- Quadro 3. Ocupaciones suprimidas (1893-1902) e novas ocupaciones declaradas (1903-1912), p. 74

- Quadro 4. Novas ocupaciones, 1913-1922, p. 77

\section{Capitulo III}

- Tabela 11. Parque Industrial Paulista, 1901, p. 228 


\section{Crédito das imagens}

Capa Acervo pessoal

Capítulo I Figura 1, p. 122

Afrodisio Gutierrez, diretor cênico da Sociedade Monte Alegre (sentado, ao centro), c.1918.

Acervo: Fundação Pró-Memória de São Caetano do Sul - Centro de Documentação Histórica

Capítulo II Figura 2, p. 140

Funcionários e família de imigrante espanhol, proprietário de depósito de ferrovelho. São Paulo (SP), década de 1920.

Acervo: Memorial do Imigrante

Figura 3, p. 143

Cristobal M. Rodriguez, na rua Padre Carvalho, em Pinheiros, onde se situava seu ferro-velho. São Paulo (SP), anos 50.

Acervo: Dolores Martin Rodriguez Corner

Figura 4, p. 145

Imigrantes espanhóis na construção civil. São Paulo (SP), s.d.

Acervo: Memorial do Imigrante

Figura 5, p. 155

Móveis executados pela marcenaria e carpintaria de Thomaz Alliegro, participante da primeira exposição municipal industrial de São Paulo. Rua da Consolação, 21 [1916]. In: Picarollo, A. e Finocchi, L. O desenvolvimento industrial de São Paulo, através da primeira exposição municipal. São Paulo: Pocai \& Comp. 1918, p. 265.

Figuras de nos. 6 a 9, p. 192

Vidraria Santa Marina [1916]. In: Picarollo, A. e Finocchi, L. $O$ desenvolvimento industrial de São Paulo, através da primeira exposição municipal. São Paulo: Pocai \& Comp. 1918, pp. 149-152.

Capítulo IV Figura 10, p. 293

Diretoria da Sociedade de Beneficência Espanhola. São Paulo SP), 1919.

Acervo: Memorial do Imigrante

Figura 11, p. 295

Associadas da Sociedade Beneficência Espanhola, aguardando atendimento assistencial e/ou médico. São Paulo (SP), s.d.

Acervo: Memorial do Imigrante 
Figura 12, p. 301

Fachada da primeira sede da Sociedade Espanhola de Socorros Mútuos. Rua Silveira Martins. São Paulo (SP), s.d.

Acervo: Memorial do Imigrante

Figura 13, p. 313

Entrega de diploma oficial da Sociedade Espanhola de Socorros Mútuos a um membro da coletividade pelos relevantes serviços prestados à comunidade espanhola de São Paulo. São Paulo (SP), 1923.

Acervo: Memorial do Imigrante

Figura 14. p. 324

Grupo lírico-dramático da Federação Espanhola. Excursão a Santos, SP, s.d. Acervo: Fundação Arquivo e Memória de Santos (SP) - Fundasantos

Figura 15, p. 339

Grupo de espanhóis na África, 1919.

Acervo: Fundação Pró-Memória de São Caetano do Sul - Centro de Documentação Histórica 


\section{Abreviaturas e Siglas}

AGA Archivo General Administración Pública

AHI Archivo Histórico del AMAE

AMAE Archivo Ministerio Asuntos Exteriores

BE Beneficencia Española

CE Centro Español

CDE Casa de España

CG Centro Gallego

CGE Consulado Geral da Espanha

CR Centro Republicano Español

CRE Cruz Roja Española

CUC Centro Unión Catalán

CUE Centro Unión Española

EDE El Diario Español

FE Federación Española

GDC Grupo Dramático Cervantes

LDE Liga Defensora de los Españoles

LRC Livro de Registro Consular

LTE La Tribuna Española

LVE La voz de España

MRE Ministerio Relaciones Exteriores

MTAS Ministerio de Trabajo y Asuntos Sociales

SAIP Sociedad Artística Isaac Peral

SESM Sociedad Española de Socorros Mutuos 


\section{Acervos consultados}

São Paulo, SP

Arquivo Histórico do Estado de São Paulo

Arquivo Histórico Municipal Washington Luis

Biblioteca da Escola de Comunicações e Artes da USP

Biblioteca da Faculdade de Arquitetura e Urbanismo da USP

Biblioteca da Faculdade de Direito da USP

Biblioteca da Faculdade de Filosofia, Letras e Ciências Humanas da USP

Biblioteca da Faculdade Ibero-Americana

Biblioteca do Instituto de Estudos Brasileiros da USP

Biblioteca Municipal de São Paulo Mário de Andrade

Biblioteca Municipal de São Paulo Presidente Kennedy (S.Amaro)

Biblioteca do Museu Paulista

Biblioteca da Pontifícia Universidade Católica de São Paulo

Centro de Apoio à Pesquisa Histórica da USP

Consulado Geral da Espanha de São Paulo

Instituto Histórico e Geográfico de São Paulo (Hemeroteca Júlio de Mesquita)

Memorial do Imigrante

Campinas, $S P$

Centro de Memória da Unicamp

Santos, SP

Fundação Arquivo e Memória de Santos - Fundasantos (acervo fotográfico)

\section{São Caetano do Sul, SP}

Fundação Pró-Memória de São Caetano do Sul - Centro de Documentação

Histórica

Rio de Janeiro, $R \boldsymbol{J}$

Arquivo Nacional

Biblioteca Nacional

\section{Madrid, Espanha}

Archivo General del Ministerio de Asuntos Exteriores y de Cooperación

Biblioteca Central do Ministerio de Trabajo y Asuntos Sociales

Biblioteca Migraciones, da Secretaria de Estado de Inmigración y Emigración, do MTAS

\section{Alcalá de Henares, Espanha}

Archivo General de la Administración 


\section{Fontes manuscritas}

\section{A. Consulado Geral da Espanha (São Paulo, SP)}

- Libros de Inscripción de súbditos españoles residentes en el Districto Consular (1893-1922)

Livro 1: 13.04 .1893 a 31.03.1911 (3.505 registros)

Livro 2: 01.04.1911 a 09.02.1913 (1.647 registros)

Livro 3: 11.02 .1913 a 31.12.1914 ( 712 registros)

Livro 4: 02.01 .1915 a 27.03.1916 (2.349 registros)

Livro 5: 27.03 .1916 a 07.05 .1917 (2.257 registros)

Livro 6: 08.05 .1917 a 23.07.1918 (2.359 registros)

Livro 7: 24.07 .1918 a 20.10.1919 (2.422 registros)

Livro 8: 20.10 .1919 a 14.08 .1920 (2.392 registros)

Livro 9: 14.08 .1920 a 20.10 .1921 ( 2.374 registros)

Livro 10: 22.10 .1921 a 13.09 .1922 (1.954 registros)

- Libro de Registro de emigrados repatriados

Livro 2: $\quad 03.04 .1909$ a 22.01.1913

\section{B. Arquivo Nacional (Rio de Janeiro)}

- Processos de expulsão - Ministério da Justiça

Série Expulsão IJJ

Período: 1907 a 1930

C. Archivo General Ministerio de Asuntos Exteriores y de Cooperación (Madrid, Espanha).

- Série Brasil

Correspondencia con embajadas y legaciones: H-1418 (1883-1894); H-1419 (18951910); H-1420 (1911-1920); H-1421 (1854-1930); H-1829 (1919-1931); H-1886 (18501930); H-1952 (1912-1915); H-2006 (1895-1928); H-2020 (1920-1931); H-2030 (18561930).

Comercio: Proyectos de tratados bilaterales: TR 410. 014 (1882-1885); 015 (18851911); 016 (1899-1902); 017 (1904-1904); 018 (1911-1911); 019 (1911-1913); 020 (1912-1914); 021 (1916-1919). O expediente 022 (1921-1923), é específico sobre emigração, e contém um detalhado informe sobre a vida dos emigrantes espanhóis no Brasil, com imagens.

- Série São Paulo

Correspondência Consulados: H-2048 (1908-1923); H-2049 (1924-1931)

- Série Santos

Correspondência Consulados: H-2062 (1915-1931).

- Série Política Exterior: H-2331 (1894-1906); H-2332 (1907-1929); H-2761 (anarcossindicalismo).

\section{Archivo General de la Administración Pública (Alcalá de Henares, Espanha)}

- Consulado General de España en São Paulo (1920-1942), 33 unidades

- Centros y Asociaciones españolas (10) 003.005.54/ cajas 1683 a 1692

\section{E. Biblioteca del Ministerio de Trabajo y Asuntos Sociales (Madrid, Espanha)}

- Boletín de la inspeción general de emigración (1909-1934)

- El "Formose”, el "Cap. Norte” y la emigración al Brasil: memoria de un viaje de inspección, por el inspector Luis Fernández Flórez, 1925.

- Información realizada en el Brazil por el inspector de emigración Don Leopoldo D’Ozouville de Bradou y Cruz Alvarez. Barcelona, 1913 
- Lo que el inmigrante debe saber sobre el Brasil, publicado por J. Lucas Imossi \& Sons. Gibraltar, 1926.

- La inspección en los buques "Arlanza", "Sierra Morena”, "Zeelandia” y “Andes”, 1925.

- Los Consulados Españoles (s/d)

- Los emigrados españoles en el Brasil: memoria, por Antonio Luis Fernández Flórez, inspector de emigración, 1925?. Con recortes de prensa, fotos y documentación del viaje.

- Memoria del viaje realizado por el inspector Ángel Gamboa y Navarro, 1912.

\section{Fontes impressas}

\subsection{Periódicos}

- El Diario Español (EDE)

(8 rolos de microfilmes , 4.873 fotogramas)

Datas das edições consultadas:

Ano 1912

Janeiro: 8,30

Fevereiro: 7, 15, 17, 21

Março: 2, 13, 20, 22

Abril: 9, 11, 18

Junho: 10, 12, 15, 18, 26, 27

Julho: 2, 4, 8, 24, 30, 31

Agosto: 1, 24, 28, 29

Setembro: 4, 9,10

Outubro: 22

Novembro: 23,29

Ano 1913

Janeiro: 3, 4, 18, 29, 30

Fevereiro: 1, 3, 11, 12, 17, 25, 26, 27

Março: 6, 13, 14, 18, 19, 26, 27

Abril: 1, 2, 3, 4, 5, 7, 9, 10, 11, 12, 14, 15, 16, 17, 18, 19, 22, 23, 24, 25, 26, 28,29

Maio: 2, 5, 6, 7, 8, 9, 10, 12, 14, 15, 16, 17, 21, 22, 23, 24, 27, 28, 29, 30, 31

Junho: 4, 6, 7, 9, 10,11, 13, 14, 16, 17, 18, 20, 21, 23, 25, 26, 27, 28, 30

Julho: $1,2,3,4,5,7,8,9,10,11,12,21,23,24,28,29,30,31$

Agosto: 1, 2, 4, 5, 6, 7, 8, 9, 11, 12, 13, 14, 16, 19, 20, 21, 22, 23, 25, 26, 27, 28, 29, 30

Setembro: 1, 2, 3, 4, 5, 6, 8, 9, 10, 11, 12, 13, 15, 16, 17, 18, 19, 20, 22, 23, 24, 25, 26, 27, 28, 30

Outubro: 1, 2, 4, 6, 7, 8, 9, 10, 13, 14, 15, 16, 18, 21, 22, 23, 24, 25, 27, 28, 29, 30, 31

Novembro: 4, 5, 6, 7, 8, 10, 11, 12, 13, 14, 17, 18, 19, 20, 21, 22, 24, 25, 26, 27, 28, 29

Dezembro: 1, 2, 3, 4, 5, 6, 9, 10,11, 12, 13, 15, 16, 17, 18, 19, 20, 22, 23, 24, 27, 28, 30, 31

Ano 1914

Janeiro: 2, 5, 7, 8, 9, 10, 12, 13, 14, 15, 16, 17, 18, 20, 21, 22, 23, 24, 26, 27, 28, 29, 30, 31

Fevereiro: 3, 4, 5, 6, 7, 10, 11, 12, 13, 14, 16, 17, 18, 19, 20, 21, 23, 24, 26, 27, 28

Março: 2, 3, 4, 5, 6, 7, 9, 10, 11, 12, 13, 14, 16, 17, 18, 19, 20, 21, 22, 23, 24, 26, 27, 28, 30, 31

Abril: 1, 2, 3, 4, 6, 7, 8, 13, 14, 15, 16, 17, 18, 20, 22, 23, 24, 25, 26, 28, 29, 30

Maio: 2, 5, 6, 7, 8, 9, 11, 14, 15, 16, 17, 18, 19, 20, 23, 25, 26, 28, 29

Junho: 1, 2, 3, 4, 5, 6, 8, 10, 12, 13, 15, 16, 17, 18, 19, 20, 22, 23, 25, 27

Julho: 1, 2, 3, 4, 6, 7, 8, 9, 10, 11, 13, 15, 16, 17, 18, 20, 21, 22, 23, 24, 27, 28, 29, 30, 31

Agosto: 1, 3, 4, 5, 6, 7, 8, 9, 10, 11, 12, 13, 14, 15, 19, 20, 21, 24, 25, 26, 27, 28, 29, 31

Setembro: 1, 2, 4, 5, 9, 10, 11, 14, 15, 16, 17, 18, 19, 21, 22, 23, 24, 25, 26, 28, 29, 30

Outubro: 1, 2, 3, 5, 6, 7, 8, 9, 10, 13, 14, 15, 16, 17, 19, 20, 21, 22, 23, 24, 26, 27, 28, 30,31

Novembro: 3, 4, 5, 6, 7, 9, 10,11, 12, 13, 14, 16, 17, 18, 19, 22, 25, 26, 27, 28

Dezembro: 1, 2, 4, 5, 7, 9, 11, 14, 15, 16, 18, 19, 21, 22, 23, 26, 28, 29, 30, 31

Ano 1915

Janeiro: 4,5 


\section{Ano 1918}

Janeiro: 1, 3, 4, 5, 6, 8, 9, 10, 11, 12, 13, 15, 16, 17, 18, 19, 21, 22, 23, 24, 25, 26, 28, 29, 30, 31

Fevereiro: 1, 2, 4, 5, 6, 7, 8, 9, 11, 14, 15, 16, 18, 19, 20, 21, 22, 23, 25, 26, 27, 28

Março: 1, 2, 4, 5, 6, 7, 8, 9, 11, 12, 13, 14, 15, 16, 18, 19, 20, 21, 22, 23, 25, 26, 27, 28, 30

Abril: 1, 2, 3, 4, 5, 6, 8, 9, 10,11, 12, 13, 15, 16, 17, 18, 19, 20, 22, 23, 24, 25, 26, 27, 29, 30

Maio: 2, 4, 6, 7, 8, 10, 11, 14, 15, 16, 17, 18, 20, 21, 22, 23, 24, 25, 27, 28, 29, 31

Junho: $1,3,4,5,6,7,8,10,12,14,15,17,18,19,20,21,22,25,26,27,28$

Julho: 1, 2, 3, 4, 5, 6, 8, 9, 10, 11, 12, 13, 15, 16, 17, 18, 19, 20, 22, 23, 24, 25, 26, 27, 29, 30

Agosto: 1, 2, 3, 5, 6, 7, 8, 9, 10, 12, 13, 14, 16, 17, 19, 20, 21, 22, 23, 24, 26, 27, 28, 29, 30, 31

Setembro: 2, 3, 4, 5, 6, 9, 10, 11, 12, 13, 14, 16, 17, 18, 19, 20, 21, 23, 24, 25, 26, 30

Outubro: 1, 2, 3, 4, 5, 7, 8, 9, 10, 11, 14, 15, 16, 17, 18, 25, 26, 28, 29, 30

Novembro: 4, 5, 6, 7, 9, 11, 12, 13, 14, 16, 18, 19, 20, 21, 22, 23, 25, 28, 29

Dezembro: 2, 3, 4, 5, 6, 7, 9, 10, 11, 12, 13, 14, 16, 17, 18, 19, 20, 23, 24, 26, 27, 28, 31

Ano 1919

Janeiro: 2, 3, 4, 7, 8, 9, 10, 11, 13, 14, 15, 18, 20, 21, 22, 23, 24, 27, 28, 29, 30, 31

Fevereiro: 1, 3, 4, 5, 6, 7, 8, 10, 11, 12, 13, 14, 15, 17, 18, 19, 21, 23, 26, 27

Março: 1, 3, 5, 6, 7, 8, 10, 11, 12, 13, 14, 15, 17, 18, 20, 21, 22, 24, 25, 27, 28, 29, 31

Abril: 1, 2, 3, 4, 5, 7, 8, 9, 10, 11, 12, 14, 15, 16, 19, 22, 23, 24, 25, 26, 28, 29, 30

Maio: 5, 6, 7, 8, 9, 10, 12, 14, 15, 16, 17, 19, 20, 21, 22, 23, 24, 26, 27, 28, 30, 31

Junho: $2,3,4,5,6,7,9,10,11,12,13,16,17,18,20,21,23,24,25,26,27,28,30$

Julho: 1, 2, 3, 4, 5, 7, 8, 9, 10, 11, 12, 15, 16, 17, 18, 19, 21, 22, 23, 24, 25, 26, 29, 30

Agosto: 1, 2, 4, 5, 6, 7, 8, 9, 11, 12, 13, 14, 16, 18, 20, 21, 22, 23, 25, 26, 27, 28, 29, 30

Setembro: 1, 2, 3, 4, 5, 6, 8, 9, 10, 11, 12, 13, 15, 16, 17, 18, 19, 20, 22, 23, 24, 25, 26, 27, 28, 30

Outubro: 1, 2, 3, 4, 6, 7, 8, 9, 10, 11, 13, 14, 15, 16, 17, 18, 20, 21, 22, 23, 25, 27, 28, 29, 30, 31

Novembro: 3, 5, 6, 7, 8, 10, 11, 12, 13, 14, 17, 18, 19, 20, 21, 23, 24, 25, 26, 27, 28, 29

Dezembro: 1, 2, 3, 4, 5, 6, 9, 10, 11, 12, 13, 15, 16, 17, 18, 19, 20, 22, 24, 26, 27, 29, 30, 31

Ano 1920

Janeiro: 2, 3, 5, 7, 8, 9, 10, 12, 13, 14, 15, 16, 17, 19, 20, 21, 22, 23, 24, 26, 27, 28, 30, 31

Fevereiro: 2, 3, 4, 5, 6, 7, 9, 10, 11, 12, 13, 14, 18, 19, 20, 21, 23, 26, 27, 28

Março: 2, 3, 4, 5, 6, 8, 9, 10, 11, 12, 13, 15, 16, 17, 18, 20, 22, 23, 24, 25, 26, 27, 29, 30, 31

Abril: 3, 5, 6, 7, 8, 9, 10, 13, 14, 15, 16, 17, 19, 20, 22, 23, 24, 26, 27, 28, 29, 30

Maio: 4, 5, 7, 10, 12, 14, 17, 19, 21, 24, 26, 28, 31

Junho: 2, 4, 7, 9, 11, 14, 16, 18, 21, 23, 25, 28, 30

Julho: 2, 3, 7, 9, 12, 14, 16, 19, 21, 23, 26, 28, 30

Agosto: 2, 4, 8, 9, 11, 13, 16, 20, 23, 25, 27, 30

Setembro: 1, 3, 6, 8, 10, 13, 15, 17, 20, 22, 24, 27, 28

Outubro: 1, 4, 6, 8, 11, 13, 15, 18, 20, 22, 27, 29

Novembro: 1, 3, 5, 8, 12, 16, 19, 22, 25, 29

Dezembro: 2, 9, 13, 16, 20, 23, 27

Ano 1921

Janeiro: 4, 7, 8, 10, 11, 12, 13, 14, 15, 17, 18, 19, 20, 21, 22, 24, 27, 28, 29, 31

Fevereiro: 1, 3, 4, 5, 9, 10, 11, 12, 15, 16, 17, 18, 19, 21, 22, 23, 26, 27

Março: 1, 2, 4, 5, 7, 9, 10, 11, 14, 15, 16, 18, 21, 26, 29, 30, 31

Abril: 2, 4, 7, 9, 12, 14, 16, 19, 21, 23, 26, 28, 30

Maio: 3, 5, 7, 10, 12, 14, 17, 21, 24, 26, 28, 31

Junho: 2, 4, 7, 9, 11, 14, 16, 18, 21, 23, 25, 28, 30

Julho: $2,5,8,16,19,23$

Agosto: 3, 5, 9, 12, 16, 17, 18, 19, 20, 21, 23, 24, 25, 26, 27, 28, 30, 31

Setembro: 1, 2, 3, 4, 6, 8, 9, 10, 11, 13, 14, 15, 16, 17, 18, 20, 21, 22, 24, 25, 27, 29, 30

Outubro: 1, 2, 4, 6, 7, 8, 9, 11, 12, 13, 14, 16, 19, 20, 21, 22, 23, 25, 26, 27, 28, 29

Novembro: 4, 5, 6, 8, 9, 10,11, 13, 18, 19, 21, 22, 23, 25, 26, 27, 29

Dezembro: 1, 2, 3, 4, 6, 9, 10, 14, 15, 20, 21, 23, 24, 25

Ano 1922

Janeiro: 4, 5, 6, 8, 10, 11, 12, 13, 14, 15, 16, 18, 19, 20, 21, 22, 24, 25, 27, 28, 31 
Fevereiro: 3, 5, 8, 9, 10, 11, 14, 15, 17, 18, 19, 21, 22, 23, 24, 28

Março: 2, 4, 7, 10, 11, 12, 13, 24, 28, 29, 30, 31

Abril: 1, 2, 5, 6, 7, 8, 9, 11, 13, 16, 18, 19, 20, 21, 23, 26, 27, 28, 29

Maio: 2, 5, 6, 7, 10, 11, 14, 16, 17, 18, 19, 23, 24, 25, 27, 28, 30, 31

Junho: 1, 2, 3, 4, 7, 9, 10, 11, 12, 14, 16, 17, 18, 20, 21, 22, 23, 24, 25, 27, 28, 29

Julho: 1, 5, 6, 7, 8, 9, 11, 12, 14, 18, 19, 20, 21, 22, 25, 26, 27, 28, 29, 30

Agosto: 2, 3, 4, 5, 8, 9, 10, 12, 13, 15, 18, 20, 22, 23, 24, 25, 26, 27, 29, 30, 31

Setembro: 10, 12, 13, 14, 15, 16, 17, 19, 20, 21, 22, 23, 26, 27

Outubro: 4, 5, 6, 7, 8

Novembro: 9, 10, 11, 12, 21, 22, 28

Dezembro: 5, 15, 29.

\section{- El Diario Español}

\section{- La Tribuna Española}

$(1911,1914,1916,1920 \text { e } 1924-\text { nos. avulsos })^{\circ}$

\section{- La Voz de España}

(1904 e $1908-n^{\circ}$ s. avulsos)

$\left(1902,1904\right.$ e $1908-n^{\circ}$ s. avulsos $)$

\subsection{Oficiais}

- Anuário Estatístico de São Paulo (Brazil), 1901. Repartição de Estatística e do Arquivo do Estado de São Paulo. São Paulo: Typografia do Diário Oficial, 1904.

- Anuário Estatístico de São Paulo (Brazil). 1902. Repartição de Estatística e do Arquivo de São Paulo. Typografia do Diário Oficial, 1905.

- Anuário Estatístico de São Paulo (Brazil). 1903. Repartição de Estatística e do Arquivo de São Paulo. Typ. Espíndola, Siqueira \& Comp., 1905.

- Anuário Estatístico de São Paulo (Brazil). 1905, v. II, tomo 2. Estatística Econômica e Moral. Repartição de Estatística e do Arquivo de São Paulo. . Typ. Espíndola, Siqueira \& Comp., 1907.

- Anuário Estatístico de São Paulo (Brazil), 1907, v. II, tomo 2. Estatística Econômica e Moral. São Paulo: Duprat \& Comp., 1910.

- Anuário Estatístico de São Paulo (Brazil), 1908, v. I, tomo 1. Repartição de Estatística e do Arquivo de São Paulo. Typografia do Diário Oficial, 1910.

- Anuário Estatístico de São Paulo (Brazil), 1908, v. II, tomo 2. Estatística Econômica e Moral. Repartição de Estatística e do Arquivo de São Paulo. São Paulo: Typografia do Diário Oficial, 1911.

- Anuário Estatístico de São Paulo (Brazil), 1909, v. I, tomo 1. Movimento da População. Repartição de Estatística e do Arquivo de São Paulo. São Paulo: Casa Vanorden, 1911.

- Anuário Estatístico de São Paulo (Brazil). 1910, v. II, tomo 2. Estatística Econômica e Moral. Repartição de Estatística e do Arquivo de São Paulo. São Paulo: Duprat \& Comp., 1912.

- Anuário Estatístico de São Paulo (Brazil), 1911, v. I, tomo 1. Movimento da População e Estatística Moral. Repartição de Estatística e do Arquivo de São Paulo. São Paulo: Typ. Siqueira, Nagel \& C., 1913.

- Boletim da Diretoria de Terras, Colonização e Imigração, D.C.T.I. São Paulo: Secretaria da Agricultura, Indústria e Comércio, ano I, nº 01, outubro de 1937.

- Boletim do Departamento Estadual do Trabalho. São Paulo: Secretaria de Agricultura, Comércio e Obras Públicas do Estado de São Paulo, 1911-1929.

- Catálogo dos periódicos publicados no Estado de São Paulo. Organizado pelo Dr. Pedro Augusto Carneiro Lessa, para as comemorações e exposição da Imprensa no Brasil. Primeiro Centenário da Imprensa no Brasil, 1808-1908 (2164 títulos).

- Coleção de Leis e Decretos do Estado de São Paulo. Lei 1.045-C, de 27/12/1906 e decreto 1.458, de 10/04/1907, artigo 1. São Paulo: Typografia do Diário Oficial. Tomo XVI, 1906. 
- Dados sobre a história da immigração e da colonização em São Paulo. Enviados pela Seção de Informações do Departamento Estadual do Trabalho à Diretoria do Serviço de Povoamento. São Paulo: Typografia Brasil de Rothschild \& Cia., 1916.

- Decreto $n^{\circ}$ 2400, de 9 de julho de 1913. São Paulo: Typografia do Diário Oficial, 1913.

- A NOSA TERRA. Boletim decenal. Idearium da Hirmandade de fala en Galicia e nas colônias gallegas d’América e Portugal. Vigo, Espanha: Tomo III. Boletines del 123 al 172 (15.07.1920 a 01.11.1922), Nova Galícia Ediciones, s/d.

- "A imigração estrangeira na cidade de São Paulo: os registros da Hospedaria dos Imigrantes", organizado por Rosana Baeninger. São Paulo: $17^{\circ}$ Congresso Internacional de Ciências Históricas. São Paulo: SEADE - Fundação Sistema Estadual de Análise de Dados, 1990.

- Imigrantes estrangeiros entrados no Estado de São Paulo - 1885/1961. Discriminação por qüinqüennios das principais nacionalidades entradas no Estado, em três quartos de século de existência da Hospedaria Visconde de Parnaíba. São Paulo: Hospedaria dos Imigrantes, 1978.

- Recenseamento Geral da República dos Estados Unidos do Brasil em 31.12.1890. Brasil. Diretoria Geral de Estatística. Distrito Federal, RJ: 1891.

- Recenseamento Geral do Brasil, realizado em $1^{o} .09 .1920$ - Vol. IV, $5^{a}$ Parte - População do Brasil, por Estados e Municípios, Segundo o Sexo, a Nacionalidade, a Idade e as Profissões. Brasil. Ministério da Agricultura, Indústria e Comércio. Diretoria Geral de Estatística. Rio de Janeiro: Imprensa Oficial, 1920, pp.170-173.

- A reconstituição da memória estatística da Grande São Paulo. São Paulo: Secretaria dos Negócios Metropolitanos. Emplasa - Empresa Metropolitana de Planejamento da Grande São Paulo S.A., 2 vols., 1983.

- Relatórios da Secretaria da Agricultura, Comércio e Obras Públicas do Estado de São Paulo. São Paulo: Secretaria da Agricultura. Anos 1894 a 1928.

- Sinopse do Recenseamento de 31 de dezembro de 1900. São Paulo: Diretoria de Estatística do Ministério da Indústria, Viação e Obras Públicas da República dos Estados Unidos do Brasil, 1905.

2.3. Memórias, crônicas, relatos de viagem, romances, contos, ensaios, estudos, críticas, novelas, poesias, iconografia e obras literárias

AGUDO, José.

- Gente audaz-scenas da vida paulistana. São Paulo: Emp. Typ. Edt. O Pensamento, 1913.

- Gente rica - scenas da vida paulistana. São Paulo: Emp. Typ. Edt. O Pensamento, 1912.

ALMEIDA, Aluísio de. “São Paulo em 1907”. In: O Estado de São Paulo, de 29.12.1950.

ALMEIDA, Guilherme de. “Cosmópolis". In: O Estado de São Paulo: 10,17, 24 e 31/03; 07 e 21/04; 05 e 19/05/1929 (ou) São Paulo: Cia. Ed. Nacional, 1929.

AMARAL, Amadeu.

- "Memorial de um passageiro de bonde". In: Tradições populares. $2^{\mathrm{a}}$ ed., São Paulo: Hucitec/Secr. da Cultura, Ciência e Tecnologia, 1976; (1 $1^{a}$ ed. 1927).

- Novela e conto. São Paulo: Hucitec/Secretaria da Cultura, Ciência e Tecnologia, 1976; (1 ${ }^{\text {a }}$ ed. 1920).

AMARAL, Edmundo.

- A grande cidade. Rio de Janeiro: José Olympio Editora, 1950.

- Rotulas e mantilhas - evocações do passado paulista. Rio de Janeiro: Civilização Brasileira, 1932.

AMERICANO, Jorge.

- São Paulo naquele tempo (1895/1915). São Paulo: Saraiva, 1957.

- São Paulo nesse tempo (1915-1935). São Paulo: Ed.Melhoramentos, s/d.

ANDRADE, Mário de.

- Amar, Verbo Intransitivo - Idilio. 16 a ed., Belo Horizonte/Rio de Janeiro, Villa Rica Editoras Reunidas, s.d., (1 ${ }^{\mathrm{a} e d .}$, 1927). 
- Os contos de Belazarte. Belo Horizonte/Rio de Janeiro: Vila Rica Editoras Reunidas Limitada,

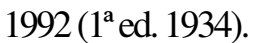

ANDRADE, Oswald de.

- Os condenados. $3^{\text {a }}$ ed., Rio de Janeiro: Civilização Brasileira, 1978 (1ª ed. 1922).

- Um Homem sem profissão: sob as ordens da mamãe. $2^{\mathrm{a}}$ ed., São Paulo: Globo/Secretaria de Estado da Cultura, 1990, (Obras Completas de Oswald de Andrade, v. 1)

- Memórias sentimentais de João Miramar. Rio de Janeiro: José Olympio Editora / Civilização Brasileira / Ed.Três, 1973 (Coleção Literatura Brasileira Contemporânea); (1ªd. 1923).

- Serafim Ponte Grande. Rio de Janeiro: José Olympio Editora / Civilização Brasileira / Ed.Três, 1973 (Coleção Literatura Brasileira Contemporânea); (1 $1^{\text {e ed. } 1929) .}$

- Marco Zero. Rio de Janeiro: Civilização Brasileira, 1978.

ARANHA, Graça. Canaã (romance). Rio de Janeiro: Editora Nova Aguilar, 1976.

AZEVEDO, Aluísio de. O cortiço. São Paulo: Editora Ática, 1995.

AZEVEDO, Militão de. São Paulo em três tempos: álbum comparativo da cidade de São Paulo (1862-1887-1914). São Paulo: Casa Civil/Imprensa Oficial do Estado/ Secretaria da Cultura. Arquivo do Estado, 1982.

BAKHTIN, Mikhail. Questões de literatura e de estética (a teoria do romance). São Paulo: Editora Unesp, 1998.

BARBOSA, Agenor. “Onde São Paulo se diverte”. In: A Capital Paulista (álbum). São Paulo: 1920.

BARRETO, Lima. Bagatelas (romance). São Paulo: Editora Brasiliense, 1956.

BARROS, Maria Paes de. "No tempo de dantes". In: MOURA, Carlos Eugênio Marcondes de. Vida cotidiana em São Paulo no século XIX: memórias, depoimentos, evocações. São Paulo: Ateliê Editorial, Fundação Ed. Unesp, Imprensa Oficial do Estado, Secretaria de Estado da Cultura, 1998, pp. 79-140 (1 ${ }^{a}$ ed. 1946).

BATINI, Tito. Entre o chão e as estrelas. Rio de Janeiro/São Paulo: Editora Civilização Brasileira S/A, 1943.

BLANCO AGUINAGA, Carlos, RODRIGUEZPUÉRTOLAS, Julio e ZAVALA, Íris M. Historia social de la Literatura española (en lengua castellana). Madrid: Editorial Castalia, 1987.

BLASCO IBAÑEZ, V. La bodega (novela). Valencia: Prometeo, 1919.

BINZER, Inna Von. Os meus romanos - alegrias e tristezas de uma educadora alemã no Brasil. $3^{\mathrm{a}} \mathrm{ed}$., Rio de Janeiro: Paze Terra, 1982.

BOLLE, Willi. "A cidade sem nenhum caráter: leitura da Paulicéia desvairada de Mário de Andrade". In: Espaço e Debates. São Paulo: ano IX, n. 27, 1989, pp. 14-27.

BOSI, Ecléa. Memória e sociedade: lembranças de velhos. São Paulo: T.A. Queiróz, 1979.

BRANDÃO, Otávio. Combates e batalhas: memórias. São Paulo: Alfa-Omega, 1978, vol. 1.

BRUNO, Ernani da Silva.

- “Com os imigrantes, o movimento na velha São Paulo". In: Folha de São Paulo. São Paulo: 9/8/1980. Folha llustrada, p. 21.

- História e tradições da cidade de São Paulo. São Paulo: Hucitec, 1991.

- Memória da cidade de São Paulo. Depoimentos de moradores e visitantes, 1553-1958. São

Paulo: Prefeitura do Município de São Paulo/DPH, 1981 (série Registros, $n^{\circ}$ 4).

BUENO, Francisco de Assis Vieira (1816-1908). A cidade de São Paulo: recordações evocadas de memória, notícias históricas. São Paulo: Academia Paulista de Letras, 1976,

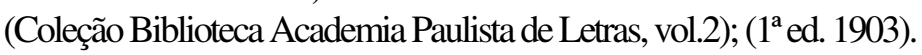

CARVALHO, Afonso José de. "São Paulo Antigo (1882-1886)". In: Revista do Instituto Histórico e Geográfico de São Paulo. São Paulo: Imprensa Oficial do Estado, 1949, pp.47-64.

CERODETTI, João Emílio e CORNEJO, Carlos. Lembranças de São Paulo. O litoral paulista nos cartões postais e álbuns de lembranças. São Paulo: Solaris Ed. Culturais, 2001.

COSTA, Ciro e GOES, Eurico de. Sob a metralha... (Histórico da Revolta em São Paulo, de 5 de julho de 1924). São Paulo: Cia. Gráphico-Editora Monteiro Lobato, 1924.

COUTO, Ruy Ribeiro.

- Cabocla. $5^{\text {a }}$ ed., Rio de Janeiro: Organizações Simões Editora, 1960 (1ª ed. 1931).

- Club das esposas enganadas. Rio de Janeiro: Schmidt Editor, 1933.

- O crime do estudante Baptista (contos). São Paulo: Monteiro Lobato \& Cia. Editores, s/d (1 ${ }^{\mathrm{a}} \mathrm{ed}$. 1922).

- Espirito de São Paulo. Rio de Janeiro: Schmidt Editor, 1932.

- Isaura. Lisboa: Editorial Inquérito Ltda, 1944 (1ª ed. 1933). 
DAVATZ, Thomas. Memórias de um colono no Brasil: 1850. São Paulo: Martins, 1941.

DENIS, Pierre. O Brazil no século XX. Lisboa: Antiga Casa Bertrand, José Bastos \& Cia.Ed., s/d.

DÍAZ, Nidia A. La protesta social en la obra de Rosalía de Castro. Vigo: Editorial Galáxia, 1976.

DINIZ, Firmo de Albuquerque (Junius). Notas de viagem. São Paulo: Governo do Estado, 1978, (Coleção Paulística, v.5), (1ª ed. 1882).

FERRAZ, Breno. Cidades vivas. Monteiro Lobato \& Cia., São Paulo: 1924.

FLOREAL, Sylvio.

- A coragem de Amar. $2^{a}$ ed., São Paulo: Empresa Editora Nova Era, 1925.

- Ronda da meia noite. Vícios, misérias e esplendores da cidade de São Paulo. São Paulo: Paz e Terra, 2003 (escrito originalmente em 1925).

FREITAS, Affonso Antonio de (1868-1930).

- "A imprensa periódica de São Paulo". In: Revista do Instituto Histórico e Geográfico de São Paulo. São Paulo: no 19, 1914, pp. 323-1136.

- A imprensa periódica de São Paulo desde os seus primórdios em 1823 até 1914. São Paulo: Typografia do Diário Oficial, 1915.

- Tradições e reminiscências paulistanas. $3^{a}$ ed. São Paulo: Governo do Estado, 1978 (Coleção Paulística 9); (1ª ed. 1921).

GALVÃO, Patrícia. Parque Industrial. $3^{\text {a }}$ ed. Porto Alegre: Mercado Aberto/S.Paulo: EDUFSCar, 1994; (1 $1^{\mathrm{a} e d}$. 1933).

GATTAI, Zélia. Anarquistas, graças a Deus. 11ª ed., Rio de Janeiro; Record, 1987.

GIL, Bonifácio (recopilación). Cancionero del campo (Antologia). Madrid: Taurus, 1966.

HOLANDA, Chico Buarque de. Ópera do Malandro. São Paulo: Círculo do Livro, 1978, pp. 21 e 23.

ITAGIBA, J. Nogueira. Trechos de vida (Memórias). Rio de Janeiro: Leuzinger S.A., 1934.

JUÓ BANANÉRE. La divina increnca. São Paulo: Irmãos Marrano Editores, 1925.

KOENIGSWALD, Gustavo. São Paulo-Álbum. São Paulo: 1895.

KOSERITZ, Carl Von. Imagens do Brasil. São Paulo: Editora da Universidade de São Paulo, 1972, (Coleção Biblioteca Histórica Brasileira). ( $1^{\mathrm{a}}$ ed. 1885).

KOSSOY, B. Dicionário Histórico-Fotográfico Brasileiro. Fotógrafos e oficios da fotografia no Brasil (1833-1910). São Paulo: Instituto Moreira Salles, 2002.

LEÃO, A. Carneiro. São Paulo em 1920. Rio de Janeiro: Annuário Americano, 1920.

LEITE, Aureliano. Dias de pavor - Figuras e cenas da Revolta de São Paulo. São Paulo: Cia. GráficoEditora Monteiro Lobato, 1924.

LORCA, Federico Garcia. Obras completas. Tomo II, Madrid: Aguillar, 1954.

MACHADO, Antonio de Alcântara.

- Brás, Bexiga e Barra Funda. São Paulo: Imprensa Oficial do Estado/Arquivo do Estado, 1982 (ed. fac-similar); (1 $1^{\text {ed. }}$ 1927).

- Cavaquinho \& Saxofone. Rio: Livraria José Olympio Ed., 1940.

- Laranja da China. São Paulo: Imprensa Oficial do Estado/Arquivo do Estado, 1988 (ed. facsimilar); (1 $1^{\mathrm{e}} \mathrm{ed}$. 1928).

- Pathé Baby. São Paulo: Imprensa Oficial do Estado/Arquivo do Estado, 1982 (ed. fac-similar); (1 $1^{\mathrm{a}}$ ed. 1926).

- Novelas paulistanas - Contos avulsos/Mana Maria/Inéditos em livro. Belo Horizonte: Itatiaia/ São Paulo: EDUSP, 1988, pp. 250-293.

- "Estética suburbana”. In: Revista do Arquivo Municipal de São Paulo. São Paulo: v. XII, 1935, pp.39-44.

- "Lira paulistana". In: Revista do Arquivo Municipal de São Paulo. São Paulo: v. XVII, 1930, pp.189-220.

MACHADO, Antonio.

- Poesias completas. Madrid: Espasa-Calpe, 1955.

- Los complementarios. Madrid: Cátedra Letras Hispánicas, 1987.

MACHADO, Antonio e outros. Siete poetas españoles. Madrid: Taurus, 1966.

MACHADO DE ASSIS. Quincas Borba. Rio de Janeiro: Civilização Brasileira, 1975.

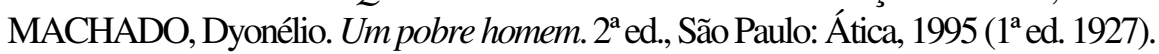

MARQUES, Cícero.

• De pastora a rainha (memórias). São Paulo: Ed. Rádio Panamericana, 1944. 
- Tempos passados.... São Paulo: Moema Editora, 1942.

MARQUES, Gabriel. Ruas e tradições de São Paulo. Uma história em cada rua. São Paulo: Cons. Estadual de Cultura, s/d (1ª edição 1957).

MARTIN, Jules e PESTANA, Nestor. São Paulo antigo e São Paulo moderno. São Paulo: Vanhorden, 1905.

MARTINS, Antonio Egídio (1863-1922).

- São Paulo Antigo: 1554-1910. Ed. org. por Fernando Góes. São Paulo, Cons. Estadual de Cultura, 1973 (ou) Rio de Janeiro: Livraria Francisco Alves, 1911, vol. I (ou) São Paulo: Typ. do Diário Oficial, 1912, vol.II.

- Jornais e jornalistas. In: Revista do Instituto Histórico e Geográfico de São Paulo. São Paulo: vol. XVII, 1912, pp. 107/8.

MARX, Geraldina. Os humildes. São Paulo: Publisher Brasil, 1996.

MAWE, John. Viagens ao interior do Brasil. Belo Horizonte: Ed. Itatiaia; São Paulo: EDUSP, 1978.

MILANO, Miguel. Os fantasmas da São Paulo antiga: estudo histórico-literário de São Paulo. São Paulo: Saraiva, 1939.

MOURA, Paulo Cursino de. São Paulo de outr'ora (evocações da metrópole - Pysicologia das ruas). $3^{\mathrm{a}}$ ed., São Paulo: Livraria Martins S/A, 1954 (ou) São Paulo: Itatiaia/Edusp, 1980; (1ª ed. 1932).

NAY, Aldo. Os três sargentos (São Paulo: Typografia Garraux, 1931).

PENTEADO, Jacob.

- Belenzinho, 1910 (Retrato de uma época). São Paulo: Martins, 1962.

- Memórias de um postalista. São Paulo: Martins, 1963.

PEREDA, José M. de.

-De tal palo, tal astilla. Buenos Aires: Espasa-Calpe Argentina, 1944 (escrito em 1879).

- Don Gonzalo González de la Gonzalera. Madrid: Espasa-Calpe, $5^{a}$ ed., 1965.

- Pedro Sánchez. Madrid: Espasa-Calpe, 1958.

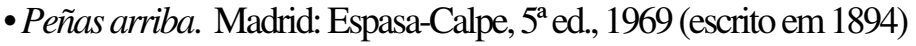

- El sabor de la tirrueca. Buenos Aires: Espasa-Calpe, 1951 (escrito em 1881)

- Sotileza. Madrid: Espasa-Calpe, $4^{\mathrm{a}}$ ed., 1969 (escrito em 1884).

PERRELLA, Nicola. Entre as tórbas de São Caetano. São Paulo: Ed. Alarico, 1961.

PINTO, Alfredo Moreira (1847-1903). A cidade de São Paulo em 1900. $2^{\mathrm{a}}$ ed., fac-símile. São Paulo: Governo do Estado, 1979 (Coleção Paulística, 14); (1ª ed. 1900).

POMPÉIA, Raul. "O Ateneu”. In: Obras. Rio de Janeiro: v.2, Civilização Brasileira, Oficina Literária Afrânio Coutinho, Fename, 1981 (escrito em 1888).

PORCHAT, Milciades de Luné. Do que precisa São Paulo - Um punhado de idéias sobre São Paulo. São Paulo: Casa Duprat, 1920.

PRADO, Antonio de Almeida. Crônica de outrora. São Paulo: Brasiliense, 1963.

PRADO, Ian de Almeida.

- Circo de Cavalinhos (crônica paulistana de 1929). São Paulo: 1931.

- "Iconografia Paulista". In: Revista do Arquivo Municipal. São Paulo: vol. XL, p. 178.

- "São Paulo Antigo e sua Arquitetura”. In: Ilustração Brasileira. São Paulo: set.1929.

RAFFARD, Henrique. Alguns dias na paulicéia. São Paulo: Biblioteca Academia Paulista de Letras, vol. 4, 1977 (Coleção Academia Paulista de Letras); (1 $1^{\mathrm{a}}$ ed.1890).

REALE, Ebe. Brás, Pinheiros, Jardins, três bairros, três mundos. São Paulo: Pioneira/Edusp, 1982.

REFRANERO ESPAÑOL (ditos populares). Páginas internet

- http://www.totana.com/cgi-bin/el-arcon-refranero.asp

- http://www.gestialba.com/public/utilidadescast07.htm

- http://personal.telefonica.terra.es/web/dechemo/chorradas/refranero.htm

- http://www.geocities.com/Vienna/Choir/7652/wolf/profanas.htm

RIZZO, Paulo Lício. Pedro Maneta. Biografia romanceada. Rio de Janeiro: Imprensa Nacional, 1942.

ROCHA, Francisco Franco da. Hospício e Colônias de Juqueri. São Paulo: 1912.

RODRIGUES, Jorge Martins. São Paulo de onteme de hoje. São Paulo: Dept de Cultura, 1938.

ROSA, João Guimarães. Sagarana. Rio de Janeiro: 39ª ed., Ed. Nova Fronteira, 1993.

SAHAGÚN, C. Siete poetas españoles. Madrid: Taurus, $3^{\mathrm{a}}$ ed., 1966.

SAINT-HILAIRE, Auguste de. Viagem à Província de São Paulo e Resumo das viagens ao

Brasil, Província Cisplatina e Missões do Paraguai. São Paulo: $2^{\mathrm{a}}$ ed., Livraria Martins Editora, 1945. 
SAMPAIO, Theodoro.

- "Os costumes de São Paulo nos princípios do século XIX". In: Almanaque Popular Brasileiro. Porto Alegre: 1908, p.77

- "São Paulo no século XX”. In: Revista do Instituto Histórico e Geográfico de São Paulo. São Paulo: vol. 6, 1900-1901, p.159.

SANT'ANA, Nuto.

- Rua Aimorés. São Paulo: Tipografia Rossolillo, 1958.

- São Paulo Histórico (Aspectos, Lendas e Costumes). São Paulo: Departamento de Cultura, 1934$1944,4 \mathrm{v}$.

- Documentário histórico. São Paulo: Departamento de Cultura, 1951, 4 v.

- Metrópole. São Paulo: Departamento de Cultura, 1953.

SANTOS, Rubens Pereira dos. "São Paulo operária sob a ótica de três cronistas da cidade: Mário de Andrade, Alcântara Machado e João Antônio". In: Revista da Biblioteca Mário de Andrade. São Paulo: Prefeitura do Município de São Paulo, v. 57, jan./dez. 1999, pp. 31-40.

SCHMIDT, Afonso.

- São Paulo de meus amores. São Paulo: Paz e Terra, 2003 (1ª ed. em 1954).

- Mirita e o ladrão. São Paulo: Clube do Livro, 1960.

SESSO JUNIOR, Geraldo. Retalhos da velha São Paulo. São Paulo: Gráfica Municipal de São Paulo, 1983.

SILVA, Ivan. “O linguajar paulistano”. In: Planalto. São Paulo: n 4, 1941, pp. 4-20.

SOUZA, Everardo Vallim.

- “A Paulicéia há 60 anos”. In: Revista do Arquivo Municipal. São Paulo: CXI, 1946, pp. $53-65$.

- "Reminiscências acadêmicas 1887-1891”. In: Revista do Arquivo Municipal. São Paulo: XCIII, pp. 111-127.

TÁCITO, Hilário (pseudônimo de José Maria de Toledo Malta). Madame Pommery. São Paulo: Academia Paulista de Letras, 1977; (Coleção da Biblioteca da Academia de Letras, vol. 6); Campinas, SP: Editora da Unicamp; Rio de Janeiro: Fundação Casa de Rui Barbosa, 1997 (1ª ed. 1920).

TAUNAY, Afonso d Escragnole. Velho São Paulo. Vol. II. São Paulo: Ed. Melhoramentos, vol. II, 1954.

VAIRO, Orlando. Os vícios elegantes` particularmente em São Paulo. São Paulo: Cia. Gráphica Editora Monteiro Lobato, 1925.

VALERA, Juan.

- A poesia do Brasil. Edição bilingüe. Estudo introdutório e tradução de Maria de la Concepción Piñero Valverde. Madrid: La Factoria de Ediciones; Brasilia: Consejeria de Educación y Ciencia de la Embajada de España, D.L., 1996 (publicação original: Madrid, 1855)

- Juanita La Larga. Madrid: Clásicos Castalia, 1992.

VAMPRÉ, João. "Fatos e festas na tradição". In: Revista do Instituto Histórico e Geográfico de São Paulo. São Paulo, v. XIII, 1908, pp.285-310.

VITOR, Manuel. São Paulo de antigamente - História pitoresca de suas ruas. São Paulo: Grafistyl Ed. Gráfica, 1976.

\section{Fontes orais}

- Depoimento de Márcia Dieguez, residente em Santos e funcionária da Biblioteca do Centro Español daquela cidade, a 17.03.2003. 


\section{Bibliografia}

ABREU, Luis Alberto de. Borandá. Auto do Migrante. São Paulo: Editora EME, 2004.

AB’S SABER, Aziz Nacib. “A terra paulista”. In: Boletim Paulista de Geografia. São Paulo: n.23, 1956, pp. 5-38.

AGUIAR, Cláudio. Os espanhóis no Brasil: contribuição ao estudo da emigração espanhola no Brasil. Rio de Janeiro: Tempo Brasileiro 1991.

ALBAN, Maria del Rosário. A imigração galega na Bahia. Salvador: Universidade Federal da Bahia, 1983.

ALBORNOZ, Suzana. O que é trabalho? São Paulo: Editora Brasiliense, 1992.

ALMEIDA, Vicente U. e MENDES SOBR ${ }^{\circ}$, Octávio T. Migração rural-urbana. São Paulo: Secretaria da Agricultura, (1948).

ALVES, Paulo.

- Anarquismo, movimento operário e o Estado. Suas relações no contexto capitalista da Primeira República (1906-1922). Dissertação de Mestrado. FFLCH-USP, 1981.

- A verdade da repressão. Práticas penais e outras estratégias na ordem republicana (1890-1921). Tese de doutoramento. FFLCH-USP, 1990.

ALVIM, Zuleika.

- Brava gente! São Paulo: Brasiliense, 1986.

- "A participação política da mulher no início da industrialização em São Paulo". In: Revista de História, São Paulo: n. 114, jan.jun. 1983, pp. 61-84.

AMARAL, Araci Abreu. A hispanidade em São Paulo: da casa rural à Capela de Santo Antônio. São Paulo, Nobel, Ed. da Universidade São Paulo, 1981.

ANDRIGHETTI, Yná. Mulher e trabalho. A operária têxtil paulistana. São Paulo: Dissertação de Mestrado, FFLCHUSP, 1987.

ANDERSEN, Benedict. Nação e consciência nacional. São Paulo: Ática, 1989.

ANTONACCI, M. Antonieta.

- "Trabalho, cultura e educação: Escola Nova e Cinema Educativo nos anos 1920/30". In: Revista Projeto História. São Paulo: n. 10, 1993, pp. 147-178.

- "Atravesando el Atlántico: españolas en São Paulo". In: Historia, Antropologia y Fuentes Orales. Barcelona: n.

28, Universitat de Barcelona, 2002, pp. 3-31.

- "Atravessando o Atlântico: Memórias de imigrantes espanholas no fazer-se de São Paulo". In: Trajetos, São Paulo: vol. 1 n. 2., 2002.

ANTONACCI, M. Antonieta e MACIEL, Laura Antunes.

- "Espanhóis em São Paulo: modos de vida e experiências de associação". In: Revista Projeto História, PUC-SP. São Paulo: n. 12, 1995, pp. 173-192.

- "Revisitando a imigração: cultura cotidiana e experiências de espanhóis em São Paulo: 1890-1930". In: Margem. São Paulo: n. 6, 1997, pp.61-76.

APROBATO $\mathrm{F}^{\mathrm{D}}$, Nelson. Sons da metrópole: entre ritmos, ruídos, harmonias e dissonâncias. As novas camadas sonoras da cidade de São Paulo (final século XIX-início do XX). Dissertação de mestrado. FFLCH-USP, 2001.

AQUINO, Maria Aparecida de. Caminhos Cruzados. Imprensa e Estado autoritário no Brasil (1964-80). Tese de doutoramento. São Paulo: FFLCH-USP, 1994.

ARANTES, Antonio A. Paisagens paulistanas. Transformações do espaço público. Campinas, SP: Editora da Unicamp; São Paulo: Imprensa Oficial, 2000.

ARAÚJO, Maria Mafalda Baldoino de. Cotidiano e imaginário. Um olhar historiográfico.Teresina: EDUFPI/Instituto Dom Barreto, 1997.

ARAÚJO, Oscar Egídio de.

- Latinos e não latinos no município de São Paulo (mimeo, s/d).

- “A alimentação da classe obreira de São Paulo". In: Revista do Arquivo Municipal. São Paulo: v. 69, 1940, pp. 91-116. 
ARAÚJOFo , José R. de.

- Santos, o porto do café. Rio de Janeiro: Fundação IBGE/Instituto Brasileiro De Geografia, 1969.

- “A população paulistana”. In: AZEVEDO, Aroldo de. A cidade de São Paulo. vol. II - A evolução urbana. São Paulo: Cia. Editora Nacional, 1958, pp. 167-211.

ARAUUJO, José Renato de Campos. Imigração e futebol: o caso Palestra Itália. Campinas: Dissertação de mestrado, IFCH-UNICAMP, 1996.

ARENDT, Hanna. A condição humana. Rio de Janeiro: Forense/Universitária, 1989, p. 12.

ASCENCIO, Yolanda. "Imigrantes espanhóis que lutaram e venceram em São Caetano: Família Pereira Otero". In: Revista Raízes. São Caetano do Sul: ano IX, n. 17, jul. 1998, pp. 44-45.

AUDERA, V. La población y la inmigración en Hispanoamérica. Madrid: Hispánica, 1954.

AUGÉ, Marc. Não-lugares. Introdução a uma antropologia da supermodernidade. Campinas, SP: Papirus, 1994.

AUGUSTO, Maria Helena Oliva. “Tempo e indivíduo: o sentido da morte”. In: História em debate - Problemas, temas e perspectivas. Anais do XVI Simpósio da Associação Nacional dos professores de História. Rio de Janeiro, 22 a 26 de julho de 1991. São Paulo: 1991.

AZANHA, José Mário Pires. "O estudo do cotidiano: alguns pontos a considerar". In: Cadernos CERU. São Paulo: n. 05, série 2, 1994, pp. 32-35.

AZCONA, José Manuel. "La participación vasca en la empresa migratoria americana". In: VIVES, Pedro, VEGA, Pepa \& OYAMBURU, Jesús. Historia General de la Emigración Española a Iberoamérica. Madrid: v. 2, Cedeal, 1992, pp. 469-499.

AZEVEDO, Aroldo de. Subúrbios orientais de São Paulo. Tese de concurso à cadeira de Geografia do Brasil (XXV") daFFLCH-USP, 1945.

AZEVEDO, Aroldo de (org.). A cidade de São Paulo. Estudos de geografia urbana. São Paulo: v. III. Cia. Editora Nacional/AGB, Seção Regional, 1954.

AZEVEDO, Célia Maria Marinho de. Onda negra, medo branco. O negro no imaginário das elites - século XIX. Rio de Janeiro: Paz e Terra, 1990.

AZEVEDO, Sálvio de Almeida. "Imigração e colonização no Estado de São Paulo". In: Revista do Arquivo Municipal. São Paulo: v. 75, 1941, pp. 105-136.

BACELAR, Jeferson Afonso.

- Negros e espanhóis. Identidade e Ideologia étnica em Salvador. Salvador: UFBA, 1983.

- Galegos no paraíso racial. Salvador: Ianamá/CEAO/CED, 1994.

BAHAMONDE, Angel. 'Los dos lados de la migración transoceánica”. In: Historia General de la emigración española a Iberoamérica. Madrid: v. 1, Fundación Cedeal, 1992, p. 93-134.

BAHAMONDE, A. \& MARTINEZ, Jesus. Historia de España, siglo XIX. Madrid: Ediciones Cátedra, 1994.

BALLINA, Sebastián. "Etnicidad y estratégias identitarias: modalidade de estructuración en un grupo eslavo de Berisso, Argentina". In: Revista del Cesla - Centro de Estudios Latinoamericanos. Varsóvia: n.8, Universidad de Varsóvia, 2006, pp. 63-86.

BANDEIRA JR., Antonio Francisco. A indústria no Estado de São Paulo. São Paulo: Typ. do Diário Oficial, 1901.

BARBOSA, Maria do Carmo Bicudo. Tudo como dantes na casa de Abrantes. As práticas da produção de espaço na cidade de São Paulo. São Paulo: Tese de Doutoramento, FAU-USP, 1987.

BARRAGAN, Antonio; GONZALES, Manuel y SEVILLA, Eduardo. "Las revueltas campesinas andaluzas (18201939)". In: Cuadernos Historia 16. Madrid: Melsa, 1985.

BARREIRO, José Carlos. O cotidiano e o discurso dos viajantes. Criminalidade, ideologia e luta social no Brasil do século XIX. São Paulo: Tese de Doutoramento, FFLCH-USP, 1988.

BARROS, Gilberto Leite de. A cidade e o planalto, processo de dominância da cidade de São Paulo. São Paulo: Martins, 1967 (2 vols).

BARROS, Myriam Moraes Lins de. "Memória e família". In: Estudos Históricos. Rio de Janeiro: v. 2, n. 3, Vértice, 1989.

BAUDRILLARD, Jean. "Significação da publicidade". In: Teoria da Cultura de massa.Rio de Janeiro, Paz e Terra, 1978.

BAUTISTA VILAR, Juan. "Las emigraciones murcianas a Iberoamerica". In: Historia General de la emigración española a Iberoamérica. Madrid: v. 2, Fundación Cedeal, 1992, p. 371-408.

BEGUIN, François. "As maquinarias inglesas do conforto". In: Espaço e Debates. São Paulo: ano XI, no 34, 1991, pp. 39-54. 
BEIGUELMAN, Paula.

- "O movimento operário ante a grande lavoura no período imigrantista". In: PRADO, Antonio Arnoni. Libertários no Brasil-memória, lutas, cultura. São Paulo: Brasiliense, 1987, pp.98-108.

- Os companheiros de São Paulo. São Paulo, Ed. Símbolo, 1977.

- A crise do escravismo e a grande imigração. São Paulo: Brasiliense, 1982.

BELLOTTO, Manoel Lelo.

- “A emigração espanhola no Brasil. Estado do fluxo migratório para o Estado de São Paulo (1931-1936)”. In: Estudios Interdisciplinarios de América Latina y el Caribe. Vol. 3, nº 2, jul./dic.1992, pp. 1-15.

- "A imigração espanhola para o Brasil: a vertente canária. Um estudo prévio". Separata do IV Colóquio de História canário-americana. Gran Canária: T.II, 1984, pp. 707-740.

BERNAL, Antonio M. 'La emigración de Andalucía". In: SANCHEZ ALBORNOZ, N (comp.) Españoles hacia América. La emigración en masa, 1880-1930. Madrid: Alianza Editorial, 1988, pp.143-165.

BERRY, John W. “Migração, Aculturação e Adaptação”. In: DeBIAGGI, Sylvia Dantas e PAIVA, Geraldo José (org.) Psicologia, efimigração e cultura. São Paulo: Casa do Psicólogo Livraria e Editora, 2004, pp. 29-45.

BERTOLLI FILHO, Cláudio. A gripe espanhola em São Paulo, 1918: epidemia e sociedade. São Paulo: Paz e Terra, 2003.

BLAY, Eva.

- "Dormitórios e vilas operárias: o trabalhador no espaço urbano brasileiro". In: VALADARES, Lícia do Prado. Habitação em questão. $2^{\mathrm{a}}$ edição, Rio de Janeiro: Zahar, 1981, p. 143.

- Eu tenho onde morar - vilas operárias na cidade de São Paulo. São Paulo: Nobel, 1985.

- A luta pelo espaço: textos de sociologia urbana. Petrópolis: Vozes, 1979.

BONDUKI, Nabil Georges. “Origem do problema da habitação popular em São Paulo - primeiros estudos”. In: Espaço e Debates. São Paulo: Cortez Editora, ano 2, n. 05, 1982, pp. 81-111.

BOSI, Alfredo. Dialética da colonização. São Paulo: Companhia das Letras, 1992.

BORGES, Maria Urquiza. Negociantes da cidade de São Paulo, 1875-1880. São Paulo: Dissertação de mestrado. FFLCH-USP, 1979.

BORGES, V.P. “A imprensa como fonte de pesquisa histórica: a experiência de uma década na PUC-SP”. In: Cadernos Intercom. São Paulo: ano 2, n. 6, out. 1983, pp. $42-46$.

BOTELLA, D. Cristóbal. El problema de la emigración. Madrid: Tipografía de los huérfanos, 1888.

BRAGA, Célia M. Leal. Os espanhóis em Salvador. Análise sociológica das possibilidades de assimilação de um grupo de imigrantes. Salvador: FFCH-UFBA, 1972.

BRANDÃO, Roberto de Oliveira. "O trabalho na poesia de Jorge de Lima". In: Revista da Biblioteca Mário de Andrade. São Paulo: v. 57, Prefeitura do Município de São Paulo, jan. /dez. 1999, pp.73-85.

BREFE, Ana Cláudia. A cidade inventada. A paulicéia inventada nos relatos memorialistas. Campinas: Dissertação de mestrado, IFCH-UNICAMP, 1993.

BRENAN, Gerald. El laberinto español: antecedentes sociales y políticos de la guerra civil. Madrid: Ed. Ruedo Ibérico, 1962.

BRESCIANI, Maria Stella Martins. "Metrópoles: as faces do monstro urbano (as cidades no século XIX)". In: Revista Brasileira de História. São Paulo: v. 5, n. 8/9, set.84/abr.85, pp. 35-68.

CAGIAO, Pilar. "Cinco siglos de emigración gallega a América". In: Historia General de la emigración española a Iberoamérica. Madrid: v. 2. Fundación Cedeal, 1992, p. 293-316.

CAMARGO, Ana Maria de Almeida. A imprensa periódica como objeto de instrumento de trabalho: Catálogo da Hemeroteca Júlio de Mesquita do Instituto Histórico e Geográfico de São Paulo. São Paulo: Tese de Doutoramento, FFLCH-USP, 1975.

CAMARGO, Dayse de. O teatro do medo: a encenação de um pesadelo nas imagens do periódico anarquista A Plebe (1917-1951). São Paulo: Dissertação de mestrado, PUC-SP, 1998.

CAMARGO, Luis. "Imagens do trabalho na poesia brasileira do século XX". In: Revista da Biblioteca Mário de Andrade. São Paulo: v. 57, Prefeitura do Município de São Paulo, jan.dez. 1999, pp.87-103.

CAMARGO, José Francisco de. "Crescimento da população no estado de São Paulo e seus aspectos econômicos. Ensaio sobre as relações entre a demografia e a economia". In: Boletim $n^{o}$ 153. Economia política e história das doutrinas econômicas $n^{o}$ 1. São Paulo: FFLCH-USP, 1952.

CANO, Wilson. Raízes da concentração industrial em São Paulo. São Paulo: Difel, 1977.

CÁNOVAS, Marília D.K.

- Hambre de tierra. Imigrantes espanhóis na cafeicultura paulista, 1880-1930. São Paulo: Lazuli Editora, 2005. 
- "Espanhóis na cafeicultura paulista, 1880-1930: protagonistas ou coadjuvantes". In: Revista História Hoje Revista Eletrônica de História, Associação Nacional dos Professores Universitários de História, vol. 2, no 6, ano 2005, pp. 1-16 (www.anpuh.uepg.br).

- "A grande emigração européia para o Brasil e o imigrante espanhol no cenário da cafeicultura paulista: aspectos de uma (in) visibilidade". In: Saeculum Revista de História. João Pessoa, PB: ano 10, n.11. Publicação do Departamento de História da UFPB, Programa de Pós-Graduação, ago-dez 2004, pp. 115-135.

- "Os espanhóis de Villa Novaes e suas narrativas". In: Travessia: Revista do Migrante. São Paulo: Gráfica e Editoria Peres Ltda., Ano XVII, no 49, maio-agosto/2004, pp. 31/39.

- “Aspectos da imigração espanhola e da trajetória do imigrante na cafeicultura paulista, 1880-1930”. In: VV.AA. Bagagem imaginária: estudos antropologicos, históricos e sociológicos sobre imigração, integração cultural e inclusão social. Recife: Companhia Editora de Pernambuco, 2003, pp. 54-64.

- "Aspectos de la emigración española a Brasil, y de la trayectoria del inmigrante en la cafecultura paulista, 1880-1930". In: Revista Cambios y Continuidades. Entre Ríos, Argentina: Instituto de Historia de la Universidad Autónoma de Entre Ríos, 2003. V. III, pp.12-20.

- "Aspectos de la emigración española a Brasil y de la trayectoria del inmigrante en la cafecultura paulista, 18801930”. In: ESPINA BARRIO, Angel (org.) Antropología en Castilla y León e Iberoamérica, V. Emigración e Integración Cultural. Instituto de investigaciones Antropológicas de Castilla y León. Salamanca: Ediciones Universidad de Salamanca, 2002, pp. 339-351.

- A emigração espanhola e a trajetória do imigrante na cafeicultura paulista: o caso de Villa Novaes, 1880-1930. Dissertação de mestrado. FFLCH-USP, 2001.

CARDOSO, Fernando Henrique. "Condições sociais da industrialização de São Paulo". In: Revista Brasiliense. São Paulo: n. 28, Brasiliense, mar/abr.1960, pp. 31-58.

CARELLI, Mário. Carcamanos e comendadores - Os italianos de São Paulo: da realidade à ficção (1919-1930). São Paulo: Ática, 1985.

CARLOS, Ana Fani Alessandri

- Os caminhos da reflexão sobre a cidade e o urbano. São Paulo: Edusp, 1994

- Espaço e indústria. São Paulo: Editora Contexto, 1989.

-A (re)produção do espaço urbano. São Paulo: Edusp, 1994.

CARMO, Maurício Martins do. Paulicéia scugliambada, paulicéia desvairada. Juó Bananére e a imagem do italiano na literatura brasileira. Niterói, RJ: Editora da Universidade Federal Fluminense, 1998.

CARNEIRO, J. Fernando. Imigração e colonização no Brasil. Rio de Janeiro: Publicação avulsa $n^{\circ}$ 2, Faculdade Nacional de Filosofia, Universidade do Brasil, 1950.

CAROLLO BLANCO, Maria de la Asunción. Paisagem da alma: a experiência de emigrar. São Paulo: Dissertação de Mestrado. Psicologia Social, PUC-SP, 1996.

CARONE, Edgard.

- Movimento operário no Brasil (1877-1944). São Paulo: Difel, 1979.

- A primeira república, 1889-1930. Texto e contexto. São Paulo: Difel, 1973.

- A República Velha I (instituições e classes sociais, 1889-1930). São Paulo: Difel, 1972.

- A República Velha. Evolução política. São Paulo: Difel, 1971.

CARPINTÉRO, Marisa Varanda Teixeira. "Imagens do conforto: a casa operária nas primeiras décadas do séc. XX em São Paulo". In: BRESCIANI, Stella (org.) Imagens da cidade, séculos XIX e XX. São Paulo: ANPUHS.Paulo/Marco Zero/Fapesp, 1993, pp. 123-146.

CARREIRO OUBINHA. José. Influencias célticas en el psiquismo gallego. Conferencia pronunciada en homenaje a los fundadores del Centro Cultural Recreativo Español, el 12 de octubre de 1962, cuando se conmemoraba el cincuentenario de su fundación s/l. (mimeo).

CARVALHO, M. Brant de e NETO, J.P. Cotidiano: conhecimento e crítica. São Paulo: Cortez, 1996.

CARVALHO, Vânia Carneiro de. "Do indivíduo ao tipo. As imagens da (des) igualdade nos álbuns fotográficos da cidade de São Paulo na década de 1950”. São Paulo: Dissertação de mestrado FFLCH-USP, 1995.

CARVALHO, Waldemar Teixeira de. "Habitações operárias". In: A familia e a questão social. São Paulo: Edição Grupo de Ação Social, 1942, p. 287.

CASTRO, Américo. Los españoles: como llegaron a serlo. Madrid: Taurus Ediciones, 1965.

CATÁLOGO BIBLIOGRÁFICO: Transformações urbanas e mercado de trabalho em São Paulo, 1870-1954. Coordenação de Maria Ruth Amaral de Sampaio. São Paulo: FAU-USP, 1994.

CECCHI, C. "O fluxo migratório e o problema do retorno”. In: Sociologia. São Paulo: v. 22, ano 3, 1960, pp. $262-277$. 
CENNI, Franco. Italianos no Brasil. São Paulo: $2^{\mathrm{a}}$ edição fac-similar comemorativa do centenário da imigração italiana no Brasil, 1875-1975, Martins, Edusp, 1975.

CERQUEIRA Fo, Gisálio. A influência das idéias socialistas no pensamento político brasileiro, 1890-1922. São Paulo: Loyola, 1978.

CERTEAU, Michel de.

- A invenção do cotidiano: 1. Artes de fazer. Petrópolis, RJ: Vozes, 1994.

- "Teoria e método no estudo das práticas cotidianas". In: SZMRECSANYI. Maria Irene. Cotidiano, cultura popular e planejamento urbano. São Paulo: Anais do encontro-FAUUSP, 1985.

CHACON, Vamireh. História das idéias socialistas no Brasil. Rio de Janeiro: Civ. Brasileira, 1967.

CHALHOUB, Sidney. Trabalho, lar e botequim. O cotidiano dos trabalhadores no Rio de Janeiro na belle époque. São Paulo: Brasiliense, 1986.

CHALMERS, Vera Maria. "A prole de Caim (um estudo do folhetim na imprensa anarquista)". In: PRADO, Antonio Arnoni. Libertários no Brasil-memória, lutas, cultura. São Paulo: Brasiliense, 1987, pp. 288-306.

CHARTIER, Roger.

- Escribir las prácticas. Buenos Aires: Ediciones Manantial SRL, 1996.

- “O mundo como representação”. In: Estudos Avançados. São Paulo: v. 11, nº 5, 1991, pp. 173-191.

- Cultura escrita, literatura e História: conversas de Roger Chartier com Carlos Aguirre Anaya, Jesús Anaya Rosique, Daniel Goldin e Antonio Saborit. Porto Alegre: Artmed Editora, 2001.

CHIAPPINI, Ligia e AGUIAR, Flávio Wolf de (org). Literatura e História na América Latina: Seminário Internacional, 9 a 13 de setembro de 1991. São Paulo: Edusp, 1993.

CONSOLMAGNO, Marina. Fanfulla: perfil de um jornal de colonia (1893-1915). São Paulo: Dissertação de mestrado. FFLCH-USP, 1993.

CORNER, Dolores Martin Rodriguez. A gastronomia como fator identitário. Lembranças e silêncios dos imigrantes espanhóis na cidade de São Paulo (1946-1965). São Paulo: Dissertação de Mestrado, PUC-SP, 2005.

CORREIA, Francisco. "Mulheres libertárias: um roteiro". In: PRADO, Antonio Arnoni. Libertários no Brasil memória, lutas, cultura. São Paulo: Brasiliense, 1987, pp.38-63.

COSTA, Angela Marques da e SCHWARCS, Lilia Moritz. 1890-1914: no tempo das certezas. São Paulo: Cia. das Letras, 2000.

COSTA, Caio Túlio. O que é anarquismo? São Paulo: Brasiliense, 1980.

COSTA, Emília Viotti da. Da monarquia à república. Momentos decisivos. São Paulo: Editora Brasiliense, 1985.

CRUZ, Heloisa de Faria.

• “A cidade do reclame: propaganda e periodismo em São Paulo" - 1890-1915. In: Revista Projeto História. São Paulo: n. 13, PUC-SP, jun.1996, pp. 81-92.

- "Mercado e polícia - São Paulo, 1890/1915". In: Revista Brasileira de História. São Paulo: v. 7, n. 14, mar./ago.1987, pp. 115-130.

- Na cidade, sobre a cidade. Cultura letrada, periodismo e vida urbana. São Paulo, 1890/1915. São Paulo: Tese de doutoramento, FFLCH-USP, 1994.

- Trabalhadores em serviços: dominação e resistência (São Paulo, 1900/1920). São Paulo: Marco Zero, 1991.

CUADERNOS HISTORIA 16. La Semana Trágica. Madri: TEMI, 1985.

CUADRAT, Xavier; ULMAN, J.C. y VALERO, Alberto. "La semana trágica". In: Cuadernos 16. Madrid: Melsa, 1985.

CUBERO, Jaime. "Arquivos militantes". In: Encontro de Arquivos de São Paulo. Arquivo de História Contemporânea. S.Carlos: UFSC, julho/1987, mimeo.

CUNHA, Manuela Carneiro da. Antropologia do Brasil. Mito, história, etnicidade. São Paulo: Editora Brasiliense, 1987.

D’ÁVILA, Rosemeire Pereira. Lembranças da imigração: cenas e cenários dos imigrantes espanhóis em Bauru 18921930. Bauru: Editora da Universidade do Sagrado Coração, 2004.

DEAECTO, Marisa Midori. Comércio e vida urbana na cidade de São Paulo (1889-1930). São Paulo: Editora Senac São Paulo, 2002.

DEAN, Warren. A industrialização de São Paulo (1880-1945). São Paulo: Difel, 1971.

DeBIAGGI, Sylvia Dantas. "Migração e implicações psicológicas. Vivências reais para o indivíduo e o grupo". In: Travessia. Revista do Migrante. São Paulo: ano XVIII, n.53, set/dez. 2005, pp. 16-20.

DeBIAGGI, Sylvia Dantas e PAIVA, Geraldo José (org.) Psicologia, efimigração e cultura. São Paulo: Casa do Psicólogo Livraria e Editora, 2004.

DECCA, Edgar S. O nascimento das fábricas. São Paulo: Brasiliense, 1982. 
DECCA, Maria Auxiliadora Guzzo de. Cotidiano de trabalhadores na República. São Paulo, 1889-1940. São Paulo: Brasiliense, 1990 (Coleção Tudo é História).

DEL ROYO, José Luiz (org.) Trabalhadores no Brasil: imigração e industrialização. Tradução de Ivan E. Rocha. São Paulo: Ícone, 1990.

DEMARTINI, Zeila de Brito Fabri. “A procura da escrita e da leitura na Primeira República: recolocando questões”. In: Cadernos Ceru. São Paulo: série 2, n.9, 1998.

DEVOTO, Fernando.

- "En torno a la historiografía reciente sobre las migraciones españolas e italianas a Latinoamerica". In: Revista Estudios Migratorios Latinoamericanos. Buenos Aires: v.8, n. 25, 1993, pp. 441-474.

- "Las migraciones españolas a la Argentina desde la perspectiva de los partes consulares (1910). Um ejercício de tipologia regional'. In: Revista Estudios Migratórios Latinoamericanos. Buenos Aires: v.11, n. 34, 1996, pp.479488.

DIAS, Eduardo. Um imigrante e a Revolução. Memórias de um militante operário, 1934-51. São Paulo: Brasiliense, 1983.

DIAS, Everardo.

- História das lutas sociais no Brasil. São Paulo: Ed. Edaglit, 1962.

- "Bastilhas modernas: 1924-26". In: HARDMAN, Francisco Foot e PRADO, Antonio Arnoni (orgs.) Contos anarquistas. Antologia da prosa libertária no Brasil (1901-1935). São Paulo: Brasiliense, 1985.

- "Memórias de um exilado: episódio de uma deportação" (1920).

- Semeando... Palestras e Conferências. Rio de Janeiro: Oficina Gráfica da Escola Profissional Maçônica José Bonifácio, 1921.

DIAS, Maria Odila Silva.

- Cotidiano e poder em São Paulo no século XIX. São Paulo, Brasiliense, 1984.

- "Hermenêutica do quotidiano na historiografia contemporânea". In: Projeto História. Revista do Programa de Estudos Pós-Graduados em História e do Departamento de História da PUC-SP. Trabalhos de Memória. São Paulo: n. 17, EDUC, nov. 1998, pp. 223-258.

- "Teoria e método dos estudos feministas: perspectiva histórica e hermenêutica do cotidiano". In: Uma questão de gênero. Rio de Janeiro: Fundação Carlos Chagas, 1992.

DICCIONARIO DE HISTORIA DE ESPAÑA. Tomo II, I-Z y Apendices. Madrid: Revista de Occidente, 1952.

DICCIONARIO DE LA LENGUA ESPAÑOLA. Madrid: Editorial Espasa Calpe, S.A., 2000.

DICCIONARIO ESENCIAL SANTILLANA DE LENGUA ESPAÑOLA. Ed. Santillana.Barcelona, 1996.

DICCIONARIO PANHISPÁNICO DE DUDAS. Madrid: Real Academia de España, Santillana Ediciones Generales, 2005.

DIEGUES JR., Manuel.

- Imigração, urbanização e industrialização. Estudos sobre alguns aspectos da contribuição cultural do imigrante no Brasil. Rio de Janeiro: Centro Brasileiro Pesquisas Educacionais, 1964.

- Etnias e culturas no Brasil. Coleção Cadernos de Cultura. Rio de Janeiro: Documentação Ministério Educação e Cultura, 1952.

- Estudos de relações de cultura no Brasil. Rio de Janeiro: Documentação Ministério Educação e Cultura, 1953.

DONATO, Hernâni. Filhos do Destino: história do café e do imigrante em S. Paulo: $3^{\mathrm{a}}$ ed., S. Paulo: Clube do Livro, 1980.

DORO, Norma Marinovic. A imigração iugoslava no Brasil. São Paulo: Tese de doutoramento, FFLCH-USP, 1987.

DULLES. J. W. Foster. Anarquistas e comunistas no Brasil (1900-1935). Rio de Janeiro: Nova Fronteira, 1977.

DUMAZEDIER, Joffre. Lazer e cultura popular. São Paulo: Perspectiva, 1976.

EIRAS ROEL, Antonio y REY CASTELAO, Ofelia. Los gallegos y América. Madrid: Editorial Mapfre, 1992.

EISENBERG, Peter. Homens esquecidos - escravos e trabalhadores livres no Brasil século XIX e XX. Campinas: Ed. da Unicamp, 1989.

ELAZARI, Judith Mader. Lazer e vida urbana em São Paulo, 1850-1910. São Paulo: Dissertação de Mestrado. FFLCH-USP, 1979.

ELIAS, Norbert. Sobre o Tempo. Rio de Janeiro: Zahar, 1998.

ESCRIBANO, Antonio Izquierdo. Españoles en América Latina. Madrid: v. I, Centro Publicaciones Min. Trabajo y Seguridad Social, 1992.

ESPIG, Márcia Janete. "O uso da fonte jornalística no trabalho historiográfico: o caso do Contestado". In: Estudos Iberoamericanos. Porto Alegre: v. 24, n. 2, dez. 1998, pp. $269-289$. 
EUFRÁSIO, Mário A. Estrutura urbana e ecologia humana: a escola sociologica de Chicago (1915-1940). São Paulo: Curso de Pós-Graduação em Sociologia da USP, Editora 34, 1999.

FAUSTO, Boris.

- "Os anarquistas e as minhas lembranças". In: PRADO, Antonio Arnoni. Libertários no Brasil-memória, lutas, cultura. São Paulo: Brasiliense, 1987, pp.17-28.

- “Conflito social na República oligárquica: a greve de 1917”. In: Estudos Cebrap. São Paulo: v. 10, out./nov./ dez. 1974, pp. 79-109.

- "Controle social e criminalidade em São Paulo: um apanhado geral (1890-1924)". In: PINHEIRO, Paulo Sérgio (org.) Crime, violência e poder. São Paulo: Brasiliense, 1983, pp. 195-210.

- Crime e cotidiano. A criminalidade em São Paulo (1880-1924). São Paulo: Brasiliense, 1984.

- Historiografia da imigração para São Paulo. São Paulo: Sumaré/FAPESP/Instituto de Estudos Econômicos, Sociais e Políticos de São Paulo, 1991 (Série Imigração).

- "Imigração: cortes e continuidades". In: NOVAIS, Fernando Antonio (coord.) História da Vida Privada no Brasil. Contrastes da intimidade contemporânea. São Paulo: v.4, Companhia das Letras, 1998, pp. 13-61.

- Trabalho urbano e conflito social, 1880-1920. São Paulo: Difel, 1977.

- “Um balanço da historiografia para o Estado de São Paulo". In: Revista Estúdios Migratórios Latinoamericanos. Buenos Aires: v.8, n. 25, 1993, pp.415-440.

FENERICK, José Adriano. O anarquismo literário: uma utopia na contramão da modernização do Rio de Janeiro, 1900-1920. São Paulo: Dissertação de mestrado, FFLCH-USP, 1997.

FERES, Cristina de Lourdes Pellegrino. Herdeiros da Fundação. "Lavoro" e "famiglia" em São Caetano. São Paulo: Hucitec; S. Caetano do Sul: Prefeitura de S. Caetano do Sul, 1998.

FERNANDES, Elóy y PINILLA, Vicente. "La emigración aragonesa a Iberoamérica". In: VIVES, VEGA \& OYAMBURU. Historia General de la emigración española a lberoamérica. Madrid: v. II, CEDEAL, 1992, pp. 25-50.

FERREIRA, Maria Nazareth. A imprensa operária no Brasil (1880-1920). Petrópolis: Vozes, 1978.

FERREIRA, Tolstoi de Paula. "Subsídios para a História da Assistência Social em São Paulo". In: Revista do Arquivo Municipal. São Paulo: v. LXVII, p.5.

FIORENTINO, Teresina Aparecida del. A produção e o consumo da prosa de ficção em São Paulo (1900-1922). São Paulo: Dissertação de mestrado, FFLCH-USP, 1976.

FLORENCIO, Rafael Nuñez. Con la salsa de su hambre: los extranjeros ante la mesa hispana. Madrid: Alianza, 2004.

FONSECA, Guido.

- Crimes, criminosos e a criminalidade em São Paulo (1870-1950). São Paulo: Ed. Resenha Tributária, 1988.

- História da prostituição em São Paulo. São Paulo: Resenha Tributária, 1982.

FONTANA, Josep. "Cambio económico y actitudes políticas en la España del siglo XIX”. In: TUÑON DE LARA, M. (org). Historia de España. Barcelona: Tomo VII, Ed. Labor, 1983.

FORACCHI, Marialice M. "A valorização do trabalho na ascensão social dos imigrantes". In: Revista do Museu Paulista. São Paulo: v. XV, 1963, pp. 310-319.

FOUCAULT, Michel. "Por uma genealogia do poder". In: Microfisica do poder. Rio de Janeiro: Ed. Graal, 1979.

FRANCO, Maria Sylvia de Carvalho.

- Homens livres na ordem escravocrata. São Paulo: IEB, 1969.

- "Sobre o conceito de tradição". Comunicação apresentada à XXIII Reunião da Sociedade Brasileira para o progresso de ciência. Curitiba, PR, 04-10.07.1971. In: Cadernos CERU. São Paulo: n. 5, 1972, pp. 9-37 (volume especial).

FREITAS, Maria Teresa de. "A História na Literatura: princípios de abordagem”. In: Revista de História. São Paulo: n. 117 (nova série), USP, 1984, pp.171-176.

FREITAS, Sonia Maria de. Falam os imigrantes: armênios, chineses, espanhóis, húngaros, italianos de Monte San Giacomo e Sanza, lituanos, okinawanos, poloneses, russos, ucranianos. São Paulo: Tese de doutoramento, FFLCH-USP, 2001.

FRUTUOSO, Maria Suzel Gil. A emigração portuguesa e sua influência no Brasil. O caso de Santos, 1850 a 1950. São Paulo: Dissertação mestrado, FFLCH-USP, 1989.

FURTADO, Celso. Formação econômica do Brasil. São Paulo: Cia. Editora Nacional, 1971.

GADAMER, Hans-Georg. Verdade e método. Petrópolis: Vozes, 1997.

GALLEGO, Avelina Martinez.

- Os espanhóis em São Paulo: presença e invisibilidade. São Paulo: Dissertação de mestrado. PUC-SP, 1993.

- "Espanhóis". In: Cadernos de migração. São Paulo: 5. CEM-Centro Estudos Migratórios, 1995. 
GALVÃO, Maria Rita. Crônica do cinema paulistano. São Paulo: Ática, 1975.

GAMA, Lúcia Helena. "Produção cultural na metrópole". In: Revista da Biblioteca Mário de Andrade. São Paulo: v. 57. Prefeitura do Município de São Paulo, jan./dez. 1999, pp.13-24.

GAMBI, Esther.

- "La inmigración española en Brasil a través de sus asociaciones". In: Revista Brasil Espanha. São Paulo: ano I, 2006, pp. 10-11. Disponível em: www.camara-brasilespanha.com.

- "Castanholas Vermelhas. À frente das lutas proletárias em São Paulo, imigrantes espanholas se tornaram alvo da implacável polícia política de Getúlio Vargas”. In: Revista de História. Rio de Janeiro: ano I, n.2, agosto de 2005, pp. 47-51.

GARCIA FERNANDEZ, Jesus. La emigración exterior de España. Barcelona: Ariel, 1965.

GARCIA-GUILLÉN, Mario.

- Máquinas para o progresso (romance). São Paulo: Editora do Escritor, 1975.

- "Permanente presencia española en Brasil: La gran emigración a Brasil 1824-1914)". In: MARCONDES, Neide e BELLOTTO, Manoel (orgs.). Turbulência cultural em cenários de transição. O século XIX iberoamericano. São Paulo: Edusp, 2005, pp. 149-163.

-Viemos por nuestras águas. Espanhóis no Brasil. São Paulo: Editora Senac São Paulo, 2005 (Série Imigrantes).

GARCIA LÓPEZ, J. Ramón. Las remesas de los emigrantes españoles en América. Siglos XIX e XX. Astúrias: Ediciones Jucar, 1992.

GARCIA-SANZ MARCOTEGUI, Angel. "La emigración navarra a América a traves de la publicística, 1877-1915". In: Historia General de la emigración española a Iberoamérica. Madrid: v. 2, Cedeal, 1992, pp. 409-442.

GATTAZ, André Castanheira. Braços da Resistência. Uma história oral da imigração espanhola. São Paulo: Xamã, 1996.

GIL, Antonio Carlos. Migração e atitudes perante o trabalho. Memória apresentada para obtenção do grau de mestre em Ciências. São Paulo: Fundação Escola de Sociologia e Política de São Paulo, 1978.

GITAHY, Malú. "Porto de Santos, 1888-1908”. In: PRADO, Antonio Arnoni. Libertários no Brasil - memória, lutas , GIRÓ, Joaquin. cultura. São Paulo: Brasiliense, 1987, pp.64-81.

- "Los estudios de emigración en La Rioja. Estado de la cuestión". In: Historia General de la emigración española a Iberoamérica. Madrid: v.2, Cedeal, 1992, pp. 317-344.

- "La vida cotidiana. Planteamiento y datos para su investigación". In: Historia General de la emigración española a Iberoamérica. Madrid: v.1, Cedeal, 1992, pp. 389-407.

GLEZER, Raquel.

- "Instrumentos de pesquisa para a História de São Paulo". In: Revista de História. São Paulo: n.139, $2^{\circ}$ semestre 1998, pp. 127-135.

- "Visões de São Paulo". In: BRESCIANI, Stella (org.). Imagens da cidade, séculos XIX e XX. São Paulo: ANPUH-S.Paulo/Marco Zero/Fapesp, 1993, pp.163-175.

GODOY, Oscar de. "Imigração e criminalidade". In: Revista Arquivo Municipal. São Paulo: v. LXVII, ano VI, 1940, pp.149-163.

GOLDSTEIN, Norma Seltzer. "Ecos da atividade humana na poesia penumbrista brasileira". In: Revista da Biblioteca Mário de Andrade. São Paulo: v. 57, Prefeitura do Município de São Paulo, jan./dez. 1999, pp. 67-72.

GOMES, Angela Maria de Castro.

- Burguesia e trabalho: política e legislação social no Brasil, 1917-1937. Rio de Janeiro: Campus 1979.

- "A República não oligárquica e o liberalismo dos empresários". In: SILVA, Sérgio e SZMRECSÁNYI, Tamás (org.) História Econômica da Primeira República. Coletânia de textos apresentados no I Congresso Brasileiro de História Econômica. São Paulo: Campus da USP, setembro de 1993, Editora Hucitec/Fapesp, 1996.

GOMES, Angela de C. e FERREIRA, Marieta de Moraes.

- "Primeira República: um balanço historiográfico". In: Estudos Históricos. Rio de Janeiro: v. 2, n. 4, 1989, pp.244-280.

GOMES, Paulo Emílio Salles. Humberto Mauro, Cataguases, Cinearte. São Paulo: Editora Perspectiva/EDUSP, 1974. GONZÁLEZMARTÍNEZ, EldaE.

- "O Brasil como país de destino para os migrantes espanhóis". In: FAUSTO, B. (comp). Fazer a América. A emigração em massa para a América Latina. São Paulo: Edusp, 1999, pp. 239-271.

- Café e inmigración: los españoles en São Paulo, 1880-1930. Madrid: CEDEAL, 1990a.

- "Españoles en Brasil: características generales de un fenómeno emigratorio". In: Ciência e Cultura. Revista da SBPC. São Paulo: v. 42, n. 5/6, jun.1990b, pp. 341-346. 
- "Identidad y representación coletiva de um grupo inmigrante: los españoles en São Paulo, 1850-1970". In: Reflexiones en torno a 500 años de historia do Brasil. Madrid: Ed. Catriel, 2001.

- "La estructura ocupacional de los gallegos en la ciudad de San Pablo (Brasil), 1893-1903". In: Revista da Comisión Galega do Quinto Centenario, La Coruña: n. 05, 1992, pp.57-68.

- "Los inmigrantes invisibles: condiciones de vida e identidad de los españoles en São Paulo, en la Segunda mitad del siglo XX". In: Estudios Interdisciplinarios de América Latina y el Caribe. Inst. Historia y Cultura de América Latina. Escuela de Historia. Universidad Tel Aviv. Israel: v. II, n. 1, ene.jjun.2000, pp.1-17.

- "Los pequeños propietarios en los Núcleos Coloniales del Estado de São Paulo - un intento frustrado de participación española". In: Ciencia, pensamiento y cultura. Madrid: n. 536-537, Arbor, 1990c, pp. 127-142.

- "Presencia española en San Pablo: notas sobre la emigración andaluza". In: Ciência e Cultura. São Paulo: v. 42, n. 10/12, 1990d, pp.780-785.

- "São Paulo, metrópolis económica. El aporte de los inmigrantes". In: PESSET, José Luis (coord.) Ciencia, vida y espacio en Iberoamerica. Madrid: CSIC, 1989.

GONZÁLEZ, Elda \& MARQUES, Rosario. "Andalucía y América: las alternativas de una comunidad migrante". In: VIVES, Pedro, VEGA, Pepa \& OYAMBURU, Jesús. Historia General de la Emigración Española a Iberoamerica. Madrid: v.2, Cedeal, 1992a, pp. 3-24.

GORZ, André. Metamorfoses do trabalho. Crítica da razão econômica. Tradução de Ana Montoia. São Paulo: Annablume, 2003.

GOTTDIENER, Mark. A produção social do espaço urbano. São Paulo: EDUSP, 1977.

GRACIA, Jordi. "Algunos memorialistas españoles". In: Cuadernos Hispanoamericanos. Madrid: n. 584, Gráficas Varona, fev/1999.

GRAHAM, Douglas. "Migração estrangeira e a questão da oferta de mão-de-obra no crescimento econômico brasileiro, 1880-1930”. In: Estudos Econômicos, IPE-USP. São Paulo: v.3, n.1, 1973, pp. 7-64.

GRINBERG, Leon e GRINBERG, Rebeca. Psicoanálisis de la migración y del exalio. Madrid: Alianza Editorial, 1984.

GUIMARÃES, Lúcia Maria Paschoal. Espanhóis no Rio de Janeiro (1880-1914). Contribuição à historiografia da imigração. Rio de Janeiro: Tese de concurso a livre docência-IFCH/UERJ, 1988.

HAHNER, June E. Pobreza e política. Os pobres urbanos no Brasil - 1870/1920. Brasília: Edunb, 1993.

HALL, Michel.

• “Italianos em São Paulo". In: Anais do Museu Paulista. São Paulo: tomo 29, 1979, pp.201-215.

- The origins of mass immigration in Brazil, 1871-1914. PHD Th., Columbia University, 1969.

HALL, Stuart. A identidade cultural na pós-modernidade. Rio de Janeiro: DP\&A, 2003.

HARDMAN, Francisco Foot.

- 'Lyra da Lapa: acorde imperfeito menor”. In: PRADO, Antonio Arnoni. Libertários no Brasil-memória, lutas , cultura. São Paulo: Brasiliense, 1987, pp. 150-161.

- Nem pátria, nem patrão. Vida operária e cultura anarquista no Brasil. São Paulo: Brasiliense, 1983.

- "Trabalho urbano e vida operária". In: MENDES JR., Antonio et alii. Brasil História. Texto e consulta. Republica Velha. São Paulo: v.3, Brasiliense, 1979.

- Trem fantasma: a modernidade na selva. São Paulo: Cia. das Letras, 1988; Unicamp, 1991.

HARDMAN, Francisco Foot e PRADO, Antonio Arnoni (org.). Contos anarquistas. Antologia da prosa libertária no Brasil (1901-1935). São Paulo: Brasiliense, 1985.

HELLER, Agnes.

- O cotidiano e a História. $4^{\text {a }}$ ed., São Paulo: Paz e Terra, 1992.

- Sociología de la vida cotidiana. $4^{a}$ ed., Barcelona: Ed. Península, 1994.

- La revolución de la vida cotidiana. Barcelona: Ed. Península, 1982.

HERNÁNDEZ BORGE, Julio. "La mujer en la legislación emigratoria española". In: Revista Estudios Migratorios latinoamericanos. B. Aires: ano 13, n. 39, CEMLA, 1992, pp. 275-289.

HERNANDEZ GARCIA, Julio. "Panorama de la emigración a iberoamérica de las Islas Canarias, siglos XVI-XX". In: Historia General de la emigración española a Iberoamérica. Madrid: v.2, Cedeal, 1992, pp. 115-146.

HOBSBAWM, Eric.

- A era dos extremos. O breve século XX, 1914-1991. São Paulo: Companhia das Letras, 1995.

- Rebeldes Primitivos. Estudo sobre as formas arcaicas de movimentos sociais nos séculos XIX e XX. Rio de Janeiro: Zahar, 1970.

- Revolucionários - Ensaios Contemporâneos. Tradução de João Carlos Garcia e Adelângela Saggioro Garcia. Rio de Janeiro: Paze Terra, 1985.

- Os trabalhadores: estudo sobre a história do operariado. Rio de Janeiro: Paze Terra, 1982. 
HOLLOWAY, Thomas H.

- "Condições do mercado de trabalho e organização de trabalho nas plantações na economia cafeeira de S. Paulo, 1885-1915: uma análise preliminar”. In: Estudos Econômicos. São Paulo: v.2, n.6, 1972, pp. 145-180.

- Imigrantes para o café: café e sociedade em São Paulo -1886/1934. São Paulo: Paz e Terra, 1984.

HOMEM, Maria Cecília Naclério. O palacete paulistano e outras formas urbanas de morar da elite cafeeira. São Paulo: Martins Fontes, 1996.

HOYOS SAINZ, Luis de. La densidad de población y el acrecentamiento en España. Madrid: I. Juan S. Elcano, 1952.

HUCK, Hermes Marcelo. A influência do imigrante no processo político brasileiro: o movimento operário e sindical (mimeo, s/d).

HUTCHINSON, Bertram. "Mobilidade de estrutura e de intercâmbio na assimilação de imigrantes no Brasil". In: Educação e Ciências Sociais. Rio de Janeiro: Ano 4, v.5, n.11, CBPE, Centro Brasileiro de Pesquisas Educacionais, 1959, pp. 7-22.

HUTTER, Lucy M.

- Imigração italiana em São Paulo, 1880-1889: os primeiros contatos do imigrante com o Brasil. São Paulo: IEB/USP, 1972.

- Imigração italiana em São Paulo de 1902 a 1914 - O processo imigratório. São Paulo: IEB/USP, 1986.

- "Metodologia da história social da imigração". In: Anais da V Reunião da Sociedade Brasileira de Pesquisa Histórica (SBPH). São Paulo: 1986.

• "Saúde e Imigração (1902-1914): dados históricos". In: Ciência e Cultura. São Paulo: v. 31, n. 6, jun.1979, pp. $621-631$.

IANNI, Constantino.

- "Capitalismo, escravidão e trabalho livre". In: FERNANDES, Florestan (org.). Comunidade e sociedade no Brasil. $2^{a}$ ed., São Paulo: Ed. Nacional, 1975.

- Homens sem paz. Os conflitos e os bastidores da emigração italiana. São Paulo: Civilização Brasileira, 1972.

IANNI, Otávio. "Fatores humanos da industrialização no Brasil'. In: Revista Brasiliense. S. Paulo: v. 30, 1960, pp. 50-66.

IKEDA, Alberto Tsuyoshi. Música na cidade em tempo de transformação - São Paulo, 1900-1930. São Paulo: Dissertação de mestrado, ECA-USP, 1988.

IOKOI, Zilda Márcia Gricoli. "Cotidiano e cotidianeidade. Novos paradigmas no ensino da História". In: História \& Utopias. Textos apresentados no XVII Simpósio Nacional de História. São Paulo: ANPUH, 1996, pp.467-479.

IZQUIERDO ESCRIBANO, Antonio. Españoles en América Latina I. Madrid: Centro de Publicaciones, Ministerio de Trabajo y Seguridad Social, 1992.

JOLL, James. Anarquistas e anarquismo. Trad. de Manuel Dias Duarte. Lisboa: D. Quixote, 1977.

JORDÃONETO, A.

- "Barreiras no controle da mobilidade ocupacional do imigrante espanhol". In: Sociologia. São Paulo: v.24, n.2, jun. 1962, pp. 117-179.

- "O imigrante espanhol em São Paulo: principais conclusões de uma pesquisa”. In: Sociologia. São Paulo: v.26, n..2, jun. 1964, pp. 243-252.

JORDÃO NETO, Antonio e BOSCO, S. Helena. O imigrante espanhol em São Paulo. São Paulo: Secretaria Promoção Social, 1953.

KENEZ, Kátia Cristina. Movimento operário em 1919 - Repressão e controle social. São Paulo: Dissertação de mestrado. FFLCH-USP, 2001.

KHOURY, Yara. As greves de 1917 em São Paulo e o processo de organização proletária. São Paulo: Dissertação de mestrado. PUC-SP, 1978.

KLEIN, Herbert.

- A emigração espanhola no Brasil. São Paulo: IDESP/FAPESP, 1994 (Série Imigração).

- "A integração social e econômica dos imigrantes espanhóis no Brasil". In: Estudos Econômicos. São Paulo: v.19, n.3, 1989.

- La inmigración española en Brasil (siglos XIX e XX). Astúrias, Espanha: Mercantil Astúrias, 1996.

- "Los inmigrantes españoles en Brasil". In: Revista Estudios Migratorios latinoamericanos. Buenos Aires: v.10, n.29, CEMLA, 1995, pp. 77-111.

KLINTOWITZ, Jacob. A arte do comércio. São Paulo, 1900-1930. São Paulo: Senac, 1988.

KOGURUMA, Paulo. "A saracura: ritmos sociais e temporalidades da metrópole do café (1890-1920)". In: Revista Brasileira de História. São Paulo: v.19, n.38, 1999, pp. 1-12.

KOSELLECK, Reinhart. Futuro pasado. Para una semántica de los tiempos históricos. Barcelona: Paidós, 1993.

KOSIK, Karel. Dialética do concreto. Rio de Janeiro: Paz e Terra, 1969. 
KOSSOY, Boris. DICIONÁRIO HISTÓRICO-FOTOGRÁFICO BRASILEIRO. Fotógrafos e ofícios da fotografia no Brasil (1833-1910). São Paulo: Instituto Moreira Salles, 2002.

KOWARICK, Lúcio. Trabalho e vadiagem. A origem do trabalho livre no Brasil. São Paulo: Brasiliense, 1987.

KOWARICK, Lúcio e ANT Clara. "Cem anos de promiscuidade: o cortiço na cidade de São Paulo". In: Novos Estudos Cebrap. São Paulo: v.1, n. 1, abr/1982,p. 59.

KRUCHIN, Samuel. "Modernismo e cidade: o sentido do urbano nas três primeiras décadas". In: Espaço e debate. Revista de Estudos Regionais e Urbanos. São Paulo: ano VI, v. 3, n.19, 1986, pp. 43-63.

KUJAWSKI, Gilberto de Mello. “Brasil y lo español”. In: Revista Cuenta y razón. Madrid: 8, 1982, pp. 69-81.

LAMPARELLI, Celso. "Três conceitos essenciais no estudo do cotidiano". In: SZMRECSANYI. Maria Irene. Cotidiano, cultura popular e planejamento urbano. São Paulo: Anais do encontro-FAUUSP, 1985, pp.77-80.

LANGENBUCH, Jurgen Richard. Estruturação da grande São Paulo. Estudo de geografia urbana. Rio de Janeiro: IBGE, 1971.

LANNA, Ana Lúcia Duarte. "Santos - transformações urbanas e mercado de trabalho livre, 1870-1914". In: SILVA, Sérgio e SZMRECSÁNYI, Tamás. História econômica da Primeira República. São Paulo: Hucitec, 1996, pp. 297-319.

LEFEVRE, Eugênio. A administração do Estado de São Paulo na República Velha. São Paulo: Ed. Cupolo, 1937.

LEFEBVRE, Henri.

- La vida cotidiana en el mundo moderno. Madrid: Alianza Editorial S., 1972.

- "Espacio y política". In: El derecho a la ciudad II. Barcelona: Ed. Península, 1976, pp. $23-62$.

LE GOFF, J. "Documento/monumento". In: Memória-história. Tradução de Suzana Ferreira Borges. Lisboa: Imprensa Nacional/Casa da Moeda, 1984. p.102 (Enciclopédia Einaudi, 1).

LEITE, Miriam Moreira. Retratos de familia. Leitura da fotografia histórica. São Paulo: Editora da Universidade de São Paulo, 1993 (Texto \& Arte, vol. 9).

LEME, Marisa Saenz. Aspectos da evolução urbana de São Paulo na Primeira República. São Paulo: Tese de doutoramento, FFLCH-USP, 1984.

LEMUS, Encarnación. "Extremeños hacia América: la emigración la edad moderna". In: VIVES, VEGA, OYAMBURU. Historia General de la emigración española a Iberoamérica. Madrid: v.2, CEDEAL, 1992, p. 292.

LEPETIT, Bernard. "É possível uma hermenêtica urbana?" e "O presente da História”. In: Por uma nova História urbana. São Paulo: Edusp, 2001.

LESSER, Jeffrey. A negociação da identidade nacional. Imigrantes, minorias e a luta pela etnicidade no Brasil. Trad. Patrícia Zimbres. São Paulo: Editora Unesp, 2001.

LEUENROTH, Edgard. Anarquismo, roteiro da libertação social. Rio de Janeiro: Mundo Livre, 1963.

LEVY, Maria Stella Ferreira. "O papel da imigração internacional na evolução da população brasileira (1872 a 1972)". In: Revista de Saúde Pública, 8 (supl.). São Paulo: 1974, pp.49-90.

LIMA, Heitor Ferreira.

- Evolução industrial de São Paulo e outros estudos. São Paulo: Martins, 1954.

- História do pensamento econômico no Brasil. São Paulo: Editora Nacional, 1978.

- História político-econômica e industrial do Brasil. São Paulo: Editora.Nacional, 1970.

LIMA, Lana Lage da Gama. "Fronteiras da História". In: História: Fronteiras. São Paulo: Humanitas/FFLCHUSP/ANPUH, 1999, pp. 17-40.

LIMA, Luiz Costa. “Documento e ficção". In: Sociedade e discurso ficcional. Rio de Janeiro: 1986, pp. 187-242.

LIMA, Mariângela Alves de e VARGAS, Maria Thereza. "Teatro operário em São Paulo". In: PRADO, Antonio Arnoni. Libertários no Brasil - memória, lutas, cultura. São Paulo: Brasiliense, 1987, pp.162-250.

LIMA, Solange Ferraz de. São Paulo na virada do século: as imagens da razão urbana. A cidade nos álbuns fotográficos de 1887-1919. São Paulo: Dissertação de mestrado, FFLCH- USP, 1995.

LLORDEN MIÑAMBRES, Moises.

- "O asociacionismo dos emigrantes españois en America (1840-1930). Unha explicación historica do feito". In: Estudios Migratorios. Santiago de Compostela: n.2, dec.1996, Conselho de Cultura Galega, pp.39-84.

- "La acción mutuo-social de las sociedades españolas de emigrantes: una explicación historica del hecho". In: Revista Estudios Migratorios latinoamericanos. Buenos Aires: ano 7, n. 28, CEMLA, 1994, pp. 597-615.

.Posicionamientos del estado y de la opinión pública ante la emigración española ultramarina a lo largo del siglo XIX"'. In: Revista Estudios Migratorios latinoamericanos. Buenos Aires: ano 7, n. 21, CEMLA, 1992, pp. $275-$ 289. 
LOBO, T. de Souza. São Paulo na federação: problemas sociais, questões raciais, política imigrantista, estudos econômicos. São Paulo: s.e.p., 1924.

LOPES, Juarez Brandão. Desenvolvimento e mudança social. Formação da sociedade urbano-industrial no Brasil. São Paulo: Editora Nacional, 1968.

LOPREATO, Christina Roquette. O espírito da revolta. A greve geral anarquista de 1917. São Paulo: Annablume, 2000.

LOTITO, Márcia Padilha. A cidade como espetáculo - publicidade e vida urbana na São Paulo dos anos 20. São Paulo: Dissertação de mestrado, FFLCH-USP, 1977.

LOVE, Joseph. A locomotiva. São Paulo na federação brasileira, 1889-1937. Rio de Janeiro: Paze Terra, 1982.

LOWENTHAL, David. "Como conhecemos o passado?'. In: Projeto História. PUC-SP. Trabalhos de Memória. São Paulo: n. 17, EDUC, nov. 1998, pp. 63-201.

LOWRIE, Samuel Harman.

- "Origens da população da cidade de São Paulo e diferenciação das classes sociais". In: Revista do Arquivo Municipal. São Paulo: XLIII, jan./1938, pp. 195-212.

- Imigração e crescimento da população no Estado de São Paulo. São Paulo: Ed. da Escola Livre de Sociologia e Política, 1938.

LOZINSKY, Saádio. Memórias da imigração. Rio de Janeiro: Ed. Garamond, 1997.

LUCA, Tânia R. de. O sonho do futuro assegurado (o mutualismo em São Paulo). São Paulo: Contexto; Brasillia: DF: CNPQ, 1990 (Série República).

LUCENA, Célia Toledo. Bairro do Bexiga, a sobrevivência cultural. São Paulo: Brasiliense, 1984.

LUCKÁCS, Georg. Ontologia do ser social. São Paulo: Ciências Humanas, 1979.

LUZ, Nícia Vilela. A luta pela industrialização do Brasil: 1808 a 1930. S. Paulo: Alfa-Omega, 1975.

MAFFEI, Eduardo. A greve. São Paulo: Paz e Terra, 1978.

MAGALDI, Sábato e VARGAS, Maria Thereza. Cem anos de teatro em São Paulo, 1875/1974. São Paulo: Editora Senac São Paulo, 2000.

MAGNANI, José Guilherme Cantor. Festa no pedaço. Cultura popular e lazer na cidade. São Paulo: Unesp/Hucitec, 1998.

MAGNANI, Silvia Ingrid Lang. O movimento anarquista em São Paulo (1906-1917). São Paulo: Brasiliense, 1982.

MAIA, Francisco Prestes. Estudo de um plano de avenidas para a cidade de São Paulo. São Paulo: Cia. Melhoramentos, 1930.

MALUF, Marina. Ruídos da memória. São Paulo: Siciliano, 1995.

MAMIGONIAN, Armen. "O processo de industrialização em São Paulo". In: Boletim Paulista de Geografia. São Paulo: n. 50, 1976, pp. 83-101.

MARAN, Sheldon Leslie. Anarquistas, imigrantes e o movimento operário brasileiro, 1890-1920. Tradução de José Eduardo Moretzsohn. Rio de Janeiro: Paze Terra, 1979.

MARCÍLIO, Maria Luiza.

- A cidade de São Paulo, Povoamento e população, 1750-1850. São Paulo: Pioneira, Editora da Universidade de São Paulo, 1973.

- Crescimento demográfico e evolução agrária paulista, 1700-1836. São Paulo: Hucitec, Edusp, 2000.

- História da escola. Em São Paulo e no Brasil. São Paulo: IMESP/Instituto Braudel, 2005.

- "Industrialisation et mouvement ouvrier à Sao-Paulo au début du XX siècle". In : Le mouvement social. Paris :

n. 53. Les Éditions Ouvrières, oct.-déc. 1965, pp. 112-129.

MARCONDES, J.V.Freitas. São Paulo: espírito, povo, instituições (comp). São Paulo: Pioneira, 1968.

MARCONDES, Neide e BELLOTTO, Manoel (orgs.). Turbulência cultural em cenários de transição. O século XIX ibero-americano. São Paulo: Edusp, 2005.

MARINS, Paulo César Garcez. "Habitação e vizinhança: limites da privacidade no surgimento das metrópoles brasileiras". In: NOVAES, Fernando. História da vida privada. São Paulo: vol. 3 - República: da belle époque à era do rádio. Cia. das Letras, 1992, pp. 49 a 130.

MARQUES, Antonio José. "Escola libertária em São Caetano”. In: Revista Raízes, São Caetano do Sul: ano IV, n. 7, jul./1992, pp. 35-39.

MARTIN, André Roberto. $O$ bairro do Brás e a deterioração urbana. São Paulo: Dissertação de mestrado em Geografia Urbana. São Paulo: FFLCH-USP, 1984.

MARTÍN, María Del Pilar Sacristán. Produção escrita em língua portuguesa e castelhana: realização de imigrantes estabelecidos em São Paulo, 1960/70. São Paulo: Dissertação de mestrado, FFLCH-USP, 1985. 
MARTINEZ, Jesus e CASAUS, Marta. "Planteamento general del contexto socio-económico: España e Iberoamerica". In: Historia General de la emigración española a Iberoamérica. Madrid: v. 2, Cedeal, 1992, pp. $151-176$

MARTINS, Ana Luiza.

- “A invenção e/ou eleição dos símbolos urbanos: História e memória da cidade paulista”. In: BRESCIANI, Stella (org.) Imagens da cidade, séculos XIX e XX. ANPUH-São Paulo: Marco Zero/Fapesp, 1993, pp.177-190.

- Gabinetes de leitura da Província de São Paulo - a pluralidade de um espaço esquecido, 1847-1890. São Paulo: Dissertação de Mestrado. FFLCH-USP, 1990.

MARTINS, José de Souza.

- O cativeiro da terra. São Paulo: Livraria Editora Ciências Humanas, 1979.

- Conde Matarazzo. O empresário e a empresa. São Paulo: Hucitec, 1976.

- "Del esclavo al asalariado en las haciendas de café, 1880-1914. La génesis del trabajador volante". In: SANCHEZ-ALBORNÓZ, N. (comp.) Población y mano de obra en América Latina. Madrid: Alianza Edit., 1985, pp. 229-257.

-(Des)figurações. A vida cotidiana no imaginário onírico da metrópole. São Paulo: Hucitec, 1996.

- "A imigração espanhola para o Brasil e a formação da força de trabalho na economia cafeeira: 1880-1930". In: Revista de História. São Paulo: n.121, 1989, pp.5-26.

- A imigração e a crise do Brasil agrário. São Paulo: Pioneira, 1973.

- "O senso comum e a vida cotidiana". In: Tempo social. Revista Sociologia USP. São Paulo: 10 (1): 1-8, maio 1998, pp.1-8.

- Subúrbio. Vida cotidiana e História no subúrbio da cidade de São Paulo: São Caetano, do fim do Império ao fim da República Velha. São Paulo: Hucitec; São Caetano, SP: Prefeitura de São Caetano do Sul, 1992.

MARTINS, Silvia Helena Zanirato.

- Artífices do ócio: mendigos e vadios em São Paulo (1932-1942). Assis: Tese de Doutoramento. Faculdade de Ciências e Letras - UNESP Júlio de Mesquita Filho, 1996.

MATOS, Maria Izilda Santos de.

- Cotidiano e Cultura. História, cidade e trabalho. Bauru: EDUSC, 2002.

- "Na trama do cotidiano". In: Cadernos CERU. São Paulo: n.5, série 2, 1994, pp. 13-31.

- "Na trama urbana: do público, do privado e do íntimo". In: Projeto História. São Paulo: n. 13, PUC-SP, 1996, pp. 129-149.

MATOS, Odilon Nogueira.

- Café e ferrovias. A evolução ferroviária de São Paulo e o desenvolvimento da cultura cafeeira. São Paulo: Edições Arquivo do Estado, 1981.

- “A cidade de São Paulo no século XIX”. In: Revista de História. São Paulo: 21/22, 1955.

- "São Paulo no século XIX”. In: AZEVEDO, Aroldo de. A cidade de São Paulo. Estudos de geografia urbana. São Paulo: vol. II - A evolução urbana. Cia. Editora Nacional, 1958, pp. $49-66$.

MATTOS, Dirceu Lino de. "O Parque Industrial Paulistano". In: AZEVEDO, Aroldo de. A cidade de São Paulo. Estudos de geografia urbana. São Paulo: v. III. Aspectos da Metrópole Paulista. Cia. Editora Nacional/AGB, Seção Regional, 1954, pp. 5-98.

MEDICI, Ademir. Migração e urbanização. A presença de São Caetano na região do ABC. São Paulo/São Caetano: Editora Hucitec-Prefeitura de São Caetano do Sul, 1993.

MELLO Silvia Leser de. "Pensando o cotidiano em Ciências Sociais: identidade e trabalho". In: Cadernos CERU. São Paulo: n. 05, série 2, 1994, pp.23-31.

MELLO, João Manuel Cardoso de. O Capitalismo tardio. Contribuição à revisão crítica da formação e do

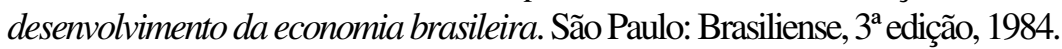

MELLO, Zélia Maria Cardoso de. São Paulo, 1845-1895: metamorfoses da riqueza. Contribuição ao Estudo da passagem da economia mercantil-escravista à economia exportadora capitalista. São Paulo: Tese de doutoramento, FEA-USP, 1981.

MENDONÇA, Carlos V.C. e ALVES, Gabriela Santos. "Os desafios teóricos da História e a Literatura”. In: Revista História Hoje. Revista eletrônica de História, ANPUH, v.1, n.02, dez./2003. Disponível em: www.anpuh.uepg.br

MENDOZA, Eduardo. A cidade dos prodígios. São Paulo: Cia. das Letras, 1987.

MERCHÁN, M. Antologia de poetas españoles de la emigración paulista, 1950-1995. São Paulo: Gráficos Chesterman, s.d.

MERRICK, Thomas W. e GRAHAM, Douglas. População e desenvolvimento econômico no Brasil. Rio de Janeiro: Zahar Editores, 1981. 
MERTZIG, Lia R. As dificuldades de adaptação do imigrante no Estado de São Paulo: repatriação e reemigração, 1889-1920. São Paulo: Dissertação de Mestrado, FFLCH-USP, 1977.

MESQUITA, Alfredo. Notas para a história do teatro em São Paulo. São Paulo: 1951.

MEYER, Marlyse. Folhetim: uma história. São Paulo: Cia. das Letras, 1996.

MILLIET, Sérgio. Roteiro do café e outros ensaios. São Paulo: Bipa Editora, 1946.

MOLINA NAVARRO, Manuel González de. "Siete problemas en la interpretación tradicional sobre el movimiento campesino andaluz”. In: Historia y fuente oral. Barcelona: Universitat de Barcelona, n.8, 1992.

MONBEIG, Pierre.

- Aspectos geográficos do crescimento da cidade de São Paulo. Separata do Boletim Paulista de Geografia. São Paulo: n. 16, mar./1954, pp. 3-29.

- Novos estudos de geografia humana brasileira. São Paulo: Difel, 1957.

- “La croissance de la Ville de São Paulo". In: Revue de Geographic Alpine. Grenoble: s/n., v. XLI, 1953, pp.5997.

MORAES, José Geraldo Vinci de. Metrópole em sinfonia - história, cultura e música popular em São Paulo nos anos 30. São Paulo: Tese de doutorado FFLCH-USP, 1997.

MORAES FILHO, Mello. Festas e tradições populares do Brasil. Belo Horizonte: Ed. Itatiaia/São Paulo: v. 55, EDUSP, 1979 (Coleção Reconquista do Brasil).

MORALES SARO, Maria Cruz.

- "Las fundaciones de los indianos en Asturias". In: SÁNCHEZ ALBORNOZ, N. (org). Españoles hacia América. La emigración en masa, 1880-1930. Madrid: Alianza América, 1988.

- “La emigración asturiana a América”. In: VIVES, VEGA, OYAMBURU. Historia General de la emigración española a Iberoamérica, Madrid: v. 2, CEDEAL, 1992, pp. 51-86.

MÖRNER, Magnus. Aventureros y proletarios. Los emigrantes en Hispanoamérica. Madrid: Ed. Mapfre, 1992.

MORSE, Richard M. De comunidade a metrópole. Biografia de São Paulo. Tradução de Maria Aparecida M. Kerbeg. São Paulo: Comissão do IV Centenário, 1954.

MOURA, Carlos Eugênio Marcondes de (org.). Vida cotidiana em São Paulo no século XIX: memórias, depoimentos, evocações. São Paulo: Ateliê Editorial, Fundação Editora Unesp, Imprensa Oficial do Estado, Secretaria de Estado da Cultura, 1998.

MOURA, Esmeralda Blanco Bolsonaro de.

- Mulheres e menores no trabalho industrial: os fatores sexo e idade na dinâmica do capital. Petrópolis: Vozes, 1982.

- O acidente de trabalho em São Paulo (1890-1919). São Paulo: Tese de Doutoramento. FFLCH-USP, 1984.

- "Além da indústria têxtil: o trabalho feminino em atividades masculinas". In: Revista Brasileira de História. São Paulo: v. 9, n.18, ago./set.1989, pp. 83-98.

- “O processo de imigração em São Paulo, nas primeiras décadas republicanas: questões em aberto". In: CEDHAL-Série Cursos e eventos. São Paulo: n.8, 1996.

- "Trabalhadoras no lar: reflexões sobre o trabalho domiciliar em São Paulo nos primeiros anos da República”. In: Diálogos. U.E.M., Maringá, PR: v.4, 2000, p. 161-181.

MOYA, José C. “Aspectos macroestructurales y microsociales de la emigración española a la Argentina, 1850-1930”. In: Galícia y América: el papel de la emigración. Madrid: Orense, 1990.

MUELLER, Helena Isabel. Flores aos rebeldes que falharam. Giovani Rossi e a utopia anarquista: Colônia Cecília. São Paulo: Tese de doutoramento, FFLCH-USP, 1989.

MUNAKATA, Kazumi. A Legislação trabalhista no Brasil. $2^{a}$ edição. São Paulo: Brasiliense, 1984 (Coleção Tudo é História).

MUNHÓS, Wilson Toledo.

- Contratos, salários e paternalismo. O trabalho forçado em São Paulo na segunda metade do século XIX. São Paulo: Tese de doutoramento, FFLCH-USP, 1997.

- Da circulação trágica ao mito da irradiação liberal: negros e imigrantes em Santos na década de 1880. São Paulo: Mestrado, PUC-SP, 1992.

MUNHOZ, Sidney J. Cidade ao avesso - desordem e progresso em São Paulo no limiar do século XX. São Paulo: Tese de doutoramento, FFLCH-USP, 1997.

NADAL, Jorge.

- "Historia de la población española (apéndice)". In: REINHARD,M. \& ARMENGAUD, A. Historia de la población mundial. Barcelona: Ediciones Ariel, 1961.

• “La población española (siglos XVI-XX)”. In: Historia de la población mundial. Barcelona: Ed. Ariel, 1973. 
NARANJO OROVIO, Consuelo.

- "Hacer la América: un sueño continuado". In: Ciencia, pensamiento y cultura. Madrid: n. 536-537, CSIC, agoset.1990.

- "Análisis cuantitativo". In: Historia General de la emigración española a Iberoamérica. Madrid: v.1, CEDEAL, 1992, pp. 177-201.

NASCIMENTO, José Leonardo do.

- "Trabalho e prestígio social: os espanhóis em São Paulo". In: SILVA, Sérgio e SZMRECSÁNYI, Tamás. História econômica da Primeira República. São Paulo: Hucitec, 2002, pp. 381-387.

- "Os imigrantes espanhóis na literatura brasileira". In: Perspectivas Revista de Ciências Sociais. São Paulo: v. 17-18, Editora Unesp, 1994/5, pp. 241-248.

NEGRI, Barjas. "A interiorização da indústria paulista (1920-1980)". In: A interiorização do desenvolvimento econômico no Estado de São Paulo (1920-1980). São Paulo: SEADE, 1988, p. 59-113.

NETO, Antonio e SANTA HELENA, Bosco. O imigrante espanhol em São Paulo. São Paulo: Departamento de Imigração e Colonização, 1963.

NIETHAMMER, Lutz. “Conjunturas de identidade coletiva”. In: Projeto História. PUC-SP: São Paulo: nº 15, EDUC, abr.1997, pp.119-144.

NETTO, José Paulo e CARVALHO, Maria do Carmo Brandt de. Cotidiano: conhecimento e crítica. São Paulo: Cortez, 1996.

NOBRE, Freitas. História da imprensa em São Paulo. São Paulo: Leia, 1950.

NOGUEIRA, Arlinda. "Como São Paulo hospedava seus imigrantes no início da República". In: Revista do Instituto de Estudos Brasileiros. São Paulo: $\mathrm{n}^{\circ}$ 23, 1981, pp. $27-49$.

NOGUEIRA, Oracy. Desenvolvimento de São Paulo: imigração estrangeira e nacional e índices demográficos, demógrafos-sanitários e educacionais. São Paulo: CIBPU, 1964.

NOZOE, Nelson Hideiki. São Paulo: economia cafeeira e urbanização. Estudo da estrutura tributária e das atividades econômicas na capital paulista (1889-1933). São Paulo: PNPE - Programa Nacional de Pesquisa EconômicaUSP, 1984.

NUÑEZ SEIXAS, Xose M. "Las remesas invisibles. Algunas notas sobre la influencia socio-política de la emigración transoceánica en Galicia (1890-1930)". In: Revista Estudios Migratorios latinoamericanos. Buenos Aires: ano 9, n. 27, CEMLA,1994, pp. 301-346.

OCTÁVIO, Laura Oliveira Rodrigo. Elos de uma corrente - seguidos de novos elos. $2^{\mathrm{a}}$ ed., Rio de Janeiro: Civilização Brasileira, 1994.

OITICICA, José. A ação direta (meio século de pregação libertária). Rio de Janeiro: Germinal, 1970.

OLIVEIRA, Ana Luiza Martins Camargo de. Revistas, em revista...- Imprensa e práticas culturais em tempos de República, 1890-1922. São Paulo: Tese de doutorado, FFLCH-USP, 1997.

OLIVEIRA, Maria Luiza Ferreira de. Relações sociais e experiências de urbanização. São Paulo, 1870-1900. São Paulo: Tese de doutorado, FFLCH-USP, 2003.

OLIVEIRA, Sérgio Coelho de. Os espanhóis. Sorocaba: TCM, 2002.

OLIVEIRA, Roberto Cardoso de. Identidade, etnia e estrutura social. São Paulo: Livraria Pioneira Editora, 1976.

ORTEGA Y GASSET, José. España invertebrada: bosquejo de algunos pensamientos históricos. Madrid: Calpe, $2^{\mathrm{a}} \mathrm{ed}$., 1922.

OTERO, Hernán. "Asociacionismo, trabajo e identidade étnica (a propósito de un libro reciente)". In: Revista Estudios Migratorios latinoamericanos. Buenos Aires: 8, 1993, pp. 475-484.

PACHECO, Renato José Costa. "O imigrante na literatura brasileira de ficção". In: Sociologia, v.18, n.3, agosto 1956, pp. 201-232.

PALAZÓNFERRANDO, S. Los españoles en América Latina, 1850-1990. Madrid: CEDEAL, 1995.

PAOLI, Maria Célia. 'São Paulo operária e suas imagens (1900-1940)". In: Espaço e debates. São Paulo: n. 33, 1991, pp. 27-41.

PASCAL, Maria Aparecida Macedo. “A pedagogia libertária: um resgate histórico". In: I Congresso Internacional de Pedagogia Social. Ano I, 2006. Disponível em: http://www.proceedings.scielo.br/scielo.

PASQUA, Suzana Podkolinski. São Paulo, a eterna utopia de uma cidade equivalente: o caso do Brás (1890-1920). São Paulo: CEDHAL,1997, pp.15-33. (Série Pós - Graduação).

PAZ-ANDRADE, Valentin. A galeguidade na obra de Guimarães Rosa. Traduzido por Paulo Rónai. São Paulo: Difel, 1983.

PÉCORA, Alcir. 'Documentação histórica e literatura (a propósito das Cartas Chilenas)". In: Revista USP. São Paulo: n. 40, dez./1998-fev./1999, pp. 150-157. 
PEIRÓ ARROYO, Antonio. Jornaleros y mancebos. Identidad, organización y conflicto en los trabajadores del Antiguo Régimen. Barcelona: Crítica, 2002.

PEREIRA, Luiz Carlos Bresser.

- Empresários e administradores no Brasil. São Paulo: Brasiliense, 1974.

- "Origens do empresariado paulista". In: Revista de Administração de Empresas. Rio de Janeiro: v.13, n.1, jan.mar.1973, pp. $57-66$.

PERES, Elena Pájaro. A inexistência da terra firme. A imigração galega em São Paulo (1946-1964). São Paulo: Edusp/Fapesp/Imprensa Oficial do Estado, 2003.

PESAVENTO, Sandra Jatahy. "Fronteiras da ficção: diálogos da História com a literatura". In: História: Fronteiras. Florianópolis: v. II, Simpósio Nacional da Associação Nacional de História, jul./1999, pp.819-831.

PIETROFORTE, Antonio Vicente Seraphim. "A cidade da mulher do povo". In: Revista da Biblioteca Mário de Andrade. São Paulo: v. 57, Prefeitura do Município de São Paulo, jan.dez. 1999, pp.47-64.

PETRONE, Maria Theresa S. "Imigração". In: HOLANDA, Sérgio B. História Geral da Civilização Brasileira. O Brasil Republicano. São Paulo: $2^{\circ}$ vol., Tomo III, Difel, 1978, pp. 95-133.

PETRONE, Pasquale.

• “A cidade de São Paulo no século XX”. In: Revista de História. São Paulo: n.21/22, jan.jun.1955, pp. 89-170.

- "O homem paulista". In: Boletim Paulista de Geografia. São Paulo: n. 23, 1956, pp. 39-77.

- "As indústrias paulistanas e os fatores de sua expansão". In: Boletim Paulista de Geografia. São Paulo: n.14, 1953, pp. 26-37.

PHINNEY, Jean S. "Formação da identidade de grupo e mudança entre migrantes e seus filhos". In: DeBIAGGI, Sylvia Dantas e PAIVA, Geraldo José (org.) Psicologia, efimigração e cultura. São Paulo: Casa do Psicólogo Livraria e Editora, 2004, pp. 47-62.

PIÑERO VALVERDE, Concha. Juan Valera y Brasil. Un encuentro pionero. Madrid: Quiásyeditorial, 1995.

PINHEIRO Paulo Sérgio.

- "Classes médias urbanas: formação, natureza, intervenção na vida política". In: FAUSTO, Bóris (org.) O Brasil Republicano. (Sociedade e Instituições). Rio de Janeiro/ São Paulo: Tomo III, $2^{\circ}$ volume , Difel, 1978, pp. 7-37.

- Política e trabalho no Brasil. Rio de Janeiro: Paze Terra, 1977.

- "O proletariado industrial na Primeira República". In: FAUSTO, Bóris (org.) O Brasil Republicano. (Sociedade e Instituições). Rio de Janeiro/ São Paulo: Tomo III, $2^{\circ}$ volume Difel, 1978, pp. 135-178.

PINHEIRO, Paulo Sérgio e HALL, Michael.

- A classe operária no Brasil (1889-1930). Documentos. O movimento operário. São Paulo: v.1, Alfa Omega, 1979.

- A classe operária no Brasil (1889-1930). Documentos. Condições de vida e de trabalho, relações com os empresários e o Estado. São Paulo: v. II, Brasiliense; Campinas: Funcamp, 1981.

- "Imigração e movimento operário no Brasil: uma interpretação". In: DEL ROIO, José Luis (org.). Trabalhadores no Brasil: imigração e industrialização. São Paulo: Ícone/Edusp, 1990, pp. $43-57$.

PINOTTI, José Luis. "Valencianos en Iberoamérica. Identidad y integración". In: VIVES, VEGA, OYAMBURU. Historia General de la emigración española a lberoamérica. Madrid: v. 2., CEDEAL, 1992, pp.443-453.

PINTO, Alfredo Augusto. História da viação pública de São Paulo. São Paulo: v.2, Governo do Estado, 1977 (Coleção Paulística).

PINTO, Júlio Pimentel. "Os muitos tempos da História". In: Projeto História. PUC-SP. Trabalhos de Memória. São Paulo: n. 17, EDUC, nov. 1998, pp.203-212.

PINTO, Maria Ignez Machado Borges.

- "A Cena Muda: Maquinismo e Lazer na Metrópole Cafeeira, 1910-1930”. Edição Especial da Revista de História n.5 - Fontes Alternativas para a História (Anais do X Simpósio História). Vitória: Universidade Federal do Espírito Santo, Centro de Estudos Gerais, Departamento de História, 1997, pp. 17-22.

- Cotidiano e sobrevivência: a vida do trabalhador pobre na cidade de São Paulo, 1890-1914. São Paulo: Tese de doutoramento, FFLCH-USP, 1984; São Paulo: Edusp, 1994 (Coleção Campi, 18).

- "Cultura de massas e papéis femininos na construção de ícones da modernidade na Paulicéia dos anos 20". In: Revista de História. São Paulo: n. 139, $2^{\circ}$ semestre 1998, pp. 63-73.

- "Flashes do cotidiano: modernidade postiça e provincianismo na urbes da belle époque, S.Paulo nos anos 20". In: História: Fronteiras. XX Simpósio Nacional da ANPUH. São Paulo: Humanitas/FFLCH-USP, 1999, pp.883-897.

PONS, Marcial. España Contemporánea, 1808-1986-Aproximación Bibliográfica. Madrid: M.P.Librero, 1985. 
POSADA, Adolpho. "Política da emigração". In: Boletim do Dept Estadual do Trabalho. São Paulo: n.8 e 9, ano II, Typ. Brasil de Rothschild \& Cia., $3^{\circ}$ e $4^{\circ}$ trim. 1913-14, pp. 389-390.

POVOA NETO, Helion e FERREIRA, Ademir P. Cruzando fronteiras: um panorama dos estudos migratórios. Rio de Janeiro: Ed. Revan, 2005.

PRADO JR. Caio. História econômica do Brasil.17ª ed., São Paulo: Brasiliense, 1974.

PRADO, Maria Ligia e CAPELATO, Maria Helena. O Bravo Matutino. Imprensa e Ideologia: o jornal O Estado de São Paulo. São Paulo: Alfa-Ômega, 1980.

PRADO, Paulo da Silva (1869-1943). Paulística: história de São Paulo. São Paulo: Cia. Gráfico-Editora Monteiro Lobato, 1925.

QUEIROZ, Ior. “O Teatro de Ópera”. In: Revista XI de Agosto. São Paulo: 1943.

RAGO, Margareth.

- "Nos bastidores da imigração”. In: Revista Brasileira de História. São Paulo: v. 9, n.18, ago./set.1989, pp. 145180.

- Os prazeres da noite (prostituição e códigos de sociabilidade feminina em São Paulo, 1890-1930). Rio de Janeiro: Paz e Terra, 1991.

- "Prazer e perdição: a representação da cidade nos anos vinte". In: Revista Brasileira de História. São Paulo: v. 7, n. 13, set/1986-fev./1987.

RAMA, Carlos M. Historia del movimiento obrero y social latinoamericano contemporáneo. Barcelona: Editorial Laia, 1976.

RAMOS, Adriana e SOUZA, Mônica de. Cotidiano e História em São Caetano do Sul. São Paulo/São Caetano do Sul: Editora Hucitec-Prefeitura de São Caetano do Sul, 1992.

RAMOS, Ricardo. Do reclame à comunicação. Pequena história da propaganda no Brasil. São Paulo: Atual Editora, 1985.

RANCIÉRE, Jacques. A noite dos proletários: arquivos do sonho operário. São Paulo: Cia. das Letras, 1988.

RANGEL PESTANA, Paulo.

- A expansão econômica do Estado de São Paulo num século (1822-1922). São Paulo: Secretaria da Agricultura, Com. e Obras Públicas do Estado de São Paulo, 1923.

- A riqueza paulista. São Paulo: 1920.

RANGEL, Wellman Galvão de França. "Algumas contribuições espanholas ao folclore paulista". In: Revista do Arquivo Municipal de São Paulo. São Paulo: v. CXLIV, ano XVIII, nov./dez.1951, pp.395-446.

RATTNER, Henrique. Industrialização e concentração econômica em São Paulo. Rio de Janeiro: Fundação Getúlio Vargas, Instituto de Documentação, 1972.

REINHARD, M. \& ARMENGAUD, A. Historia de la población mundial. Barcelona: Ed. Ariel, 1961.

REIS F ${ }^{\circ}$, Nestor Goulart.

- “Habitação popular no Brasil: 1880-1920”. In: Cadernos de Pesquisa do LAP. São Paulo: n.2, set/out.1994, p.15.

- São Paulo e outras cidades. Produção social e degradação dos espaços urbanos. São Paulo: Hucitec, 1994, p. 89 (Coleção Estudos Urbanos. Série Arte e Vida Urbana).

RENAULT, Delso. A vida brasileira no final do século XIX - visão sócio-cultural e política, 1890-1901. Rio de Janeiro: José Olympio Ed., 1987.

REVISTA EXAME, 02.05.1984.

RIBEIRO, Gladys Sabina. Mata galegos: os portugueses e os conflitos de trabalho na República Velha. São Paulo: Brasiliense, 1990 (Coleção Tudo é História, 120).

RIBEIRO, Maria Alice Rosa.

- Condições de trabalho na indústria têxtil paulista (1870-1930). São Paulo: Hucitec/Unicamp, 1988.

- História sem fim ... Inventário da saúde pública - São Paulo, 1880-1930. São Paulo: Editora Unesp, 1993.

- "O mercado de trabalho na cidade de São Paulo nos anos vinte". In: SILVA, Sérgio e SZMRECSÁNYI, Tamás. História econômica da Primeira República. São Paulo: Hucitec, 1996, pp. 341-368.

RIBEIRO, Maria Therezinha Janine. Desejado e temido. Preconceito contra o imigrante italiano em São Paulo na primeira república. São Paulo: Dissertação de mestrado, FFLCH-USP, 1985.

RIBEIRO, Suzana Barretto. Italianos do Brás. Imagens e memórias, 1920-1930. São Paulo: Brasiliense, 1994.

RICOEUR, Paul

- Tempo e narrativa. Campinas, SP: Tomo I. Papirus, 1994; Campinas, SP: Tomo III. Papirus, 1997.

- O conflito das interpretações. Ensaios de hermenêutica. Tradução de M. Sá Correia. Portugal: Rés-Editora, s.d. 
RIEZNIK, Pablo. Las formas del trabajo y la Historia. Una introducción al estudio de la economía políica. Buenos Aires: Biblos, 2003.

RIVAS, Pierre. "Homem novo e novo mundo". In: Encontro entre literaturas. França-Brasil-Portugal. São Paulo: Hucitec, 1995.

ROCHA, Frances. "Algumas notas sobre a polêmica entre novos e velhos temas da História". In: Revista Projeto História. PUC-SP. São Paulo: n. 4, EDUC, jun. 1985, pp. 15-19.

RODRIGUES, Edgar.

- Alvorada Operária. Os congressos operários no Brasil. Rio de Janeiro: Mundo livre, 1979.

- O anarquismo, na escola, no teatro, na poesia. Rio de Janeiro: Edições Achiamé Ltda., s/d.

- Os anarquistas: trabalhadores italianos no Brasil. São Paulo: Global, 1984.

- Nacionalismo e cultura social, 1913-1922. Rio de Janeiro: Laemmert, 1972.

- Nova aurora libertária (1945-1948). Rio de Janeiro: Achiamé, 1992.

- Novos Rumos (historia do movimento operário e das lutas sociais no Brasil, 1922-1946). Rio de Janeiro: Mundo Livre, s/d.

- Quem tem medo do anarquismo? Rio do Janeiro: Achiamé, 1992.

- Socialismo e sindicalismo no Brasil, 1675-1913. Rio de Janeiro: Laemmert, 1969.

- Trabalho e conflito-pesquisa histórica, 1906-1935. S/d e s/l.

RODRIGUES, Leôncio Martins.

- Industrialização e atitudes operárias (estudo de um grupo de trabalhadores). São Paulo: Brasiliense, 1970.

- Trabalhadores, sindicatos e industrialização. São Paulo: Brasiliense, 1974.

ROLNIK, Raquel.

- Cada um no seu lugar (São Paulo, início da industrialização: Geografia do poder). São Paulo: Dissertação de mestrado. Faculdade de Arquitetura e Urbanismo-USP, 1985.

- "São Paulo na virada do século: o espaço é político". In: Espaço e debate. Revista de Estudos Regionais e Urbanos. São Paulo: v. 4, n.17, 1986, pp. 44-53.

- "São Paulo na virada do século: territórios e poder". In: Cadernos de História de São Paulo 2, A cidade e a Rua. São Paulo: Museu Paulista da USP, jan./dez. 1993, pp. 39-44.

ROMERO, Mariza. Do bom cidadão: as normas médicas em São Paulo (1889-1930). São Paulo: Dissertação de mestrado, FFLCH-USP, 1995.

ROSSI, Mirian Silva. Organização do campo artístico paulistano, 1890-1920. São Paulo: Dissertação de mestrado, FFLCH-USP, 2001.

SAES, Décio.

- "O civilismo das camadas médias urbanas na Primeira República Brasileira (1889-1930)". In: Cadernos do Instituto de Filosofia e Ciências Humanas. Campinas: n.1, Universidade Estadual de Campinas, 1973.

- Classe média e sistema político no Brasil. São Paulo: T.A.Queiróz, Editor, 1984.

SAEZ, Flavio Azevedo Marques de. As ferrovias de São Paulo, 1870-1940. São Paulo: Hucitec/Instituto Nacional do Livro/MEC, 1981.

SALGADO, Plínio. O estrangeiro. $8^{\mathrm{a}}$ ed., Rio de Janeiro: J.Olympio, 1972.

SALIBA, Elias Thomé.

- "A dimensão cômica do dilema brasileiro: testemunhos da Bélle Époque (1890-1914)". In: Revista Cultura Vozes. s.l., n.1, jan./fev.1993, pp. 46-53.

- "A dimensão cômica da vida privada na República". In: NOVAIS, Fernando (coord). História da vida privada no Brasil. República: da belle époque à era do rádio. São Paulo: vol. 3, Cia. das Letras, 1992, pp. 49 a 130.

SALLES, Iraci Galvão.

- Trabalho, progresso e a sociedade civilizada (o Partido Republicano Paulista e a política de mão-de-obra, 1870-1889). São Paulo: Dissertação de mestrado, FFLCH-USP, 1980.

- República: a civilização dos excluídos (representações do "trabalhador nacional", 1870-1919). São Paulo: Tese de doutoramento, FFLCH-USP, 1995.

SAMARA, Eni de Mesquita. "Mercado de trabalho, gênero e família no Brasil (1836-1996)". In: Revista da Biblioteca Mário de Andrade. São Paulo: v. 57, Prefeitura do Município de São Paulo, jan./dez. 1999, pp.55-64.

SAMPAIO, Maria Ruth Amaral de (coord.). Catálogo bibliográfico: transformações urbanas e mercado de trabalho em São Paulo, 1870-1954. São Paulo: FAU/USP, 1994.

SANCHEZ ALONSO, Blanca.

- “La emigración española, 1882-1930”. In: Revista de História Econômica: Madrid: v. 7. n.1, Centro de Estudios Constitucionales, 1990, pp. 133-170. 
- "La emigración española a la Argentina”. In: Españoles hacia América. La emigración en masa, 1880-1930. Madrid: Alianza Editorial, 1988, pp. 205-234.

- "La visión contemporánea de la inmigración española". In: Revista de Estúdios Migratórios Latinoamericanos. Buenos Aires: $\mathrm{n}^{\circ} 13,1989, \mathrm{p} .445$.

SANCHEZ-ALBORNÓZ, Nicolás.

- "Las etapas de la migración española a América Latina". In: Ciencia, pensamiento y cultura. Madrid: $\mathrm{n}$. 536/7,1990, pp.15-24.

- España hace un siglo. Madrid: Alianza Editorial, 1968.

- Población y mano de obra en América Latina. Madrid: Alianza Editorial, 1985.

- "Medio siglo de emigración masiva de España hacia América". In: SANCHEZ-ALBORNÓZ, Nicolás (org.). Españoles hacia América - La emigración en masa, 1880-1930. Madrid: Alianza Edit., 1988, pp. 13-32.

SANT'ANNA, Denise Bernuzzi de. 'Propaganda e História: antigos problemas, novas questões". In: Revista Projeto História. PUC-SP. São Paulo: n. 14, EDUC, fev./97, pp. 89-112.

SANTOS, Carlos José Ferreira dos. Nem tudo era italiano. São Paulo e pobreza, 1890-1915. São Paulo: Annablume, 1998.

SANTOS, Ricardo Evaristo dos. "La evolución cuantitativa del proceso migratorio español a lberoamérica (18901950), con especial referencia a Brasil". In: Revista de Economia y Sociologia del Trabajo. Madrid: 19-20, 1993.

SAYAD, Abdelmalek. A imigração ou os paradoxos da alteridade. São Paulo: Edusp, 1998.

SCANTIMBURGO, João de. Os paulistas: evolução social, política econômica do povo paulista. São Paulo: Governo do Estado, 1983.

SCHREINER, Davi Félix. Cotidiano, trabalho e poder. A formação da cultura do trabalho no Extremo Oeste do Paraná. Curitiba, PR: Editora Toledo-EdT, 1997.

SCLIAR, Moacyr. "Sonho em movimento: a imagem do imigrante na literatura brasileira". Revista USP. São Paulo: n.36, Coord. Comunicação Social/USP, dez.1997 a fev. 1998, pp. 136-139.

SEGAWA, Hugo Massaki. Alguns aspectos da arquitetura e do urbanismo em São Paulo na passagem do século. Trabalho de graduação interdisciplinar, FAU-USP, 1979.

SEOANE, Maria Cruz. Historia del periodismo en España, II. El siglo XIX. Madrid: Alianza, 1983.

SEVCENKO, Nicolau

- "O cosmopolitismo pacifista da belle époque - uma utopia liberal". In: Revista de História. São Paulo: n. 114, jan.jun. 1983, pp. 85-93.

- Euclides da Cunha e Lima Barreto: a literatura como missão, 1900-1920 (estudo comparativo de história sócio-cultural). São Paulo: Tese de doutoramento FFLCH-USP, 1981 (ou) Literatura como missão. Tensões sociais e criação cultural na Primeira República. São Paulo: Brasiliense, 1985.

- Orfeu extático na metrópole. São Paulo, sociedade e cultura nos frementes anos 20. São Paulo: Tese de livredocência, FFLCH-USP, 1991 ou São Paulo: Cia. das Letras, 1992.

- "Periferia no centro". In: Catálogo da Exposição Brasmitte - Intervenções urbanas. São Paulo: Grupo de Intervenção Urbana, 1997, pp. 60-69.

- "Introdução: o prelúdio republicano, astúcias da ordem e ilusões do progresso". In: NOVAES, F. (org.). História da vida privada no Brasil, São Paulo: v.3, Cia. das Letras, 1998, pp. 7-48.

- "República: da belle époque à era do rádio". In: NOVAES, F. (org.).História da Vida Privada no Brasil. São Paulo: v.3, Cia das Letras, 1998.

SEYFERTH, Giralda. Imigração e cultura no Brasil. Brasília: Ed. da Universidade de Brasília, 1990.

SILBERSTEIN, Carina Frid de. "A imigração espanhola na Argentina (1880-1930)”. In: FAUSTO, B. (comp). Fazer a América. A emigração em massa para a América Latina. São Paulo: Edusp, 1999, pp.93-126.

SILVA, Lafayette. História do teatro brasileiro. Rio de Janeiro: Serviço Gráfico do Ministério da Educação e Saúde, 1938.

SILVA, Lígia Maria Osório. Movimento sindical operário na Primeira República. Campinas: Dissertação de mestrado, Unicamp, 1977.

SILVA, Maria Manuela Ramos de Souza. Horror a farda ou A saga dos imigrantes portugueses no Gazeta Lusitana. São Paulo: Tese de doutoramento FFLCH-USP, 1991.

SILVA, Marcos Antonio da. "A cidade e seus patrimônios (textos, imagens e sons)". In: Revista Projeto História, PUCSP. São Paulo: n. 13, EDUC, jun. 1996, pp. 71-79.

SILVA, Maria Aparecida de Moraes. "Contribuições metodológicas para a análise das migrações". In: DEMARTINI, Z. e TRUZZI, O. (orgs.). Estudos Migratórios. Perspectivas Metodológicas. São Carlos: EdUFSCar, 2005. 
SILVA, Regina Helena Alves da. A invenção da metrópole. São Paulo: Tese de doutoramento, FFLCH-USP, 1997.

SILVA, Sérgio. Expansão cafeeira e origens da indústria no Brasil. São Paulo: Alfa Omega, 1976.

SILVA, Sérgio e SZMRECSÁNYI, Tamás (org). História Econômica da Primeira República. $2^{\mathrm{a}}$ edição revista, São Paulo: Hucitec/Ass. Brasileira de Pesquisadores em História Econômica/Edusp/Imprensa Oficial, 2002.

SILVA, Tomaz Tadeu da (org.). Identidade e diferença. A perspectiva dos estudos culturais. Petrópolis, RJ: Vozes, 2000.

SILVA, Zélia Lopes da. "A greve dos tecelões em São Paulo: 1920". In: Anais do IV Congresso Regional de História de São Paulo. Araraquara: UNESP, 1980.

SILVEIRA, Miroel. A contribuição italiana ao teatro brasileiro (1895-1964). São Paulo: Brasília: Quíron, Instituto Nacional do Livro, 1976.

SIMÃO, Aziz. Sindicato e Estado. Suas relações na formação do proletariado de São Paulo. São Paulo: Dominus, 1966.

SIMONSEN, Roberto. Evolução Industrial do Brasil e outros estudos. São Paulo: Brasiliana/Nacional/Edusp, 1973.

SINGER, Paul. Economia política da urbanização. São Paulo: Editora Brasiliense, 1975.

SINGER, P. e MADEIRA, F.R. Estrutura do emprego e trabalho feminino no Brasil: 1920-1970. São Paulo: n.13, Cadernos CEBRAP, 1973.

SODRÉ, Nelson Werneck.

- Formação histórica do Brasil. $3^{\mathrm{a}}$ ed., São Paulo: Brasiliense, 1963

- História da imprensa no Brasil. Rio de Janeiro: Civilização Brasileira, 1966.

- "História da industrialização em São Paulo". In: O observador econômico e financeiro. São Paulo: v.12, n.141, out.1947, p. 46.

SOLDEVILLA, Consuelo. "Cantabria: cién años de emigración a América, 1860-1960". In: VIVES, P., VEGA, P. \& OYAMBURU, J. Historia General de la emigración española a Iberoamérica. Madrid: v.II, CEDEAL, 1992, pp.147-172.

SOUZA, Ismara Izepe de. República Espanhola: um modelo a ser evitado. Coleção Inventário DEOPS. São Paulo: Arquivo do Estado/Imprensa Oficial, 2001.

SOUZA, Luiz Antonio Francisco. "Política, classe trabalhadora e delinquiência na Primeira República: um debate a ser refeito". In: Revista Plural. São Paulo: v.1, $1^{\circ}$ semestre 1994, pp.17-35.

SOUZA, Maria Adélia Aparecida de. "Metropolização e o estudo do cotidiano". In: SZMRECSANYI, Maria Irene (org.). Cotidiano, cultura popular e planejamento urbano. São Paulo: Anais do encontro-FAUUSP, 1985, pp. 115-117.

SOUZA, M. do Carmo Campello de. "O processo político-partidário na Primeira República". In: MOTA, C. (org.). Brasil em perspectiva. São Paulo: Difel, 1975.

SOUZA, Newton Stadler de. O anarquismo da Colônia Cecília. Rio de Janeiro: Civ. Brasileira, 1970.

SPINDEL, Cheywa R. Homens e máquinas na transição de uma economia cafeeira. São Paulo: Paze Terra, 1979.

SUZIGAN, Wilson e SZMRECSÁNYI, Tamás (org.). "Os investimentos estrangeiros no início da industrialização do Brasil'. In: História Econômica da Primeira República. Hucitec/Fapesp, 1996, pp. 261-283.

SZMRECSANYI, Maria Irene de Q. F. (org.) "O cotidiano como foco de estudos da realidade urbana". In: Cotidiano, cultura popular e planejamento urbano. São Paulo: Anais do encontro-FAU-USP, 1985, pp. 99-102.

TABANERA, Núria. "Aportaciones castellano-manchegas a la emigración española a Iberoamérica". In: Historia General de la emigración española a Iberoamérica. Madrid: v.2, Cedeal, 1992, pp. 173-204.

TANNURI, Luiz Antonio. $O$ encilhamento. São Paulo: Hucitec; Campinas, SP: Fundação de Desenvolvimento da Unicamp, 1981.

THOMPSON, Edward P.

- Costumes em comum. Estudos sobre a cultura popular tradicional.São Paulo: Companhia das Letras, 1998.

- A formação da classe Operária Inglesa. A Árvore da liberdade. Rio de Janeiro: v. I, Paz e Terra, 1997; A maldição de Adão. Rio de Janeiro: v. II, Paz e Terra, 1988 e A força dos trabalhadores. Rio de Janeiro: v. III, Paze Terra, 1989.

- “La sociedad inglesa del siglo XVIII: lucha de clases sin clases?”. In: Tradición, revuelta y conciencia de clase. Barcelona: Crítica, 1979.

- A miséria da teoria ou um planetário de erros: uma crítica ao pensamento de Althusser. Tradução de Waltensir Dutra. Rio de Janeiro: Zahar, 1981 (Biblioteca de Ciências Sociais, Sociologia).

- A voz do passado: História Oral. Rio de Janeiro: Paz e Terra, 1992.

- "Tiempo, disciplina del trabajo y capitalismo industrial". In: Tradición y conciencia de clase. Barcelona: Ed. Critica, 1979, pp. 257-8.

TOLEDO, Benedito Lima de. São Paulo: três cidades em um século. São Paulo: Duas Cidades, 1981. 
TORRES, Maria Celeste Teixeira Mendes. O Bairro do Brás. São Paulo: Prefeitura Municipal de S.Paulo, s.d.

TÓRTIMA, Pedro. Polícia e justiça de mãos dadas: a conferência judiciária policial de 1917 (uma contribuição para o enfrentamento da questão operária pelas classes dominantes e pelo Estado. Rio de Janeiro, 1900-1925). Niterói: Dissertação de Mestrado em História, Instituto de Ciências Humanas e Filosofia. Centro de Estudos Gerais. UFF, 1988.

TRAGTENBERG, Maurício. "Francisco Ferrer e a pedagogia libertária”. In: Educação e sociedade, Campinas: v.1, n.1. CEDES, 1978, pp.17-49.

TRENTO, Angelo.

- Do outro lado do Atlântico. Um século de imigração italiana no Brasil. Tradução de Mariarosária Fabris (cap. 2 a 5) e Luiz Eduardo de L.Brandão (cap. 1, 6 e 7). São Paulo: Nobel/Inst. Italiano di Cultura di San Paolo: Inst.Cultural Ítalo Brasileiro, 1988.

- "Miséria e esperanças: a emigração italiana para o Brasil: 1887-1902". In: DEL ROIO, José Luis (org.). Trabalhadores no Brasil: imigração e industrialização. São Paulo: Ícone/Edusp, 1990, pp. 15-42.

TRUZZI, Oswaldo.

- "Inmigrantes y oportunidades em el comercio de São Paulo. El caso de los sírios y libaneses". In: Revista Estudios Migratorios Latinoamericanos. Buenos Aires: ano 10, n. 29, CEMLA, 1995, pp. 129-147.

- De mascates a doutores: sírios e libaneses em S. Paulo. São Paulo: Ed. Sumaré, 1991.

TRUZZI, Oswaldo e MONSMA, Karl. "Cotidiano e violência. Crimes e identidades étnicas entre imigrantes italianos no meio rural paulista”. In: Travessia. Revista do Migrante. São Paulo: ano XV, n. 47, CEM - Centro de Estudos Migratórios, set./dez.2003, pp.38-45.

TUÑON DE LARA, Manuel (org.). Historia de España. Barcelona: Tomo VII. Ed. Labor, 1983.

TURMO, Isabel González. "Movimientos migratórios y culturas del trabajo en las cocinas populares. El caso de Andaluzia". In: ARANDA, Antonio Garrido (comp). Cultura alimentaria de España y América. Huesca: La Val de Onsera, 1995, pp. 321-344.

VAINFAS, Ronaldo. "História da vida privada: dilemas, paradigmas, escalas". In: Anais do Museu Paulista. São Paulo: v. 4, jan./dez. 1996, pp.9-58.

VANGELISTA, Chiara. Os braços da lavoura. Imigrantes e "caipiras" na formação do mercado de trabalho paulista (1850-1930). São Paulo: Editora Hucitec-Istituto Italiano di Cultura-Instituto Cultural Ítalo-Brasileiro, 1991.

VATTIMO, Gianni. O fim da modernidade: niilismo e hermenêutica na cultura pós-moderna. São Paulo: Martins Fontes, 1996.

VÁZQUEZ CHAMORRO, Germán. "El nuevo mundo y Madrid: historia de una relación". In: Historia General de la emigración española a Iberoamérica. Madrid: v. 2, Cedeal, 1992, pp. 345-370.

VAZQUEZ GONZALEZ, Alejandro.

- "Las dimensiones microsociales de la emigración gallega a América: la función de las redes sociales informales". In: Estudios migratorios latinoamericanos. Buenos Aires: Ano 7, n. 22, 1993, pp.497-533.

- "De la vela al vapor. La modernización de los buques en la emigración gallega a América, 1835-1939". In: Revista Estudios Migratorios latinoamericanos. Buenos Aires: CEMLA, ano 9, nº 28, 1994, pp. 569-595.

VAZQUEZ GONZALEZ, Alejandro y ESTRADA, Baldomero. "Causas de la emigración y tipología de los emigrantes". In: Historia General de la emigración española a Iberoamérica. Madrid: v. 1, Cedeal, 1992, pp. 201-240.

VENEZIANO, Neyde. O teatro de revista no Brasil. Campinas: Pontes/Editora da Universidade Estadual de Campinas, 1991.

VERSIANI, Flávio Rabelo. "Escravos, homens livres e imigrantes: notas sobre a oferta de trabalho para a indústria no período até 1920". In: SILVA, Sérgio e SZMRECSÂNYI, Tamás. História econômica da Primeira República. São Paulo: Hucitec, 1996, pp. 189-213.

VERSIANI, Flávio Rabelo e BARROS, José Roberto Mendonça de. Formação econômica do Brasil: a experiência da industrialização. São Paulo: Saraiva, 1977.

VILAR, Pierre. Hidalgos, amotinados y guerrilleros. Pueblo y poderes en la historia de España. Barcelona: Editorial Crítica, 1982.

VIÑAS Y MEY, Carmelo. Estudios de Historia Social de España. Madrid: Consejo Superior de Investigaciones Científicas, 1952.

VIVES, J. Vicens (org.). Historia de España y America. Social y Económica. 2a ed., Barcelona: v. V, Editoral VicensVives, 1971. 
VIVES, Pedro A., VEGA, Pepa y OYAMBURU, Jesus (coord.). Historia general de la emigración española a Iberoamérica. Madrid: v. I e II, Min. Trabajo y Seguridad Social. Dirección General de Migraciones. Quinto Centenário, CEDEAL, 1992.

WEFFORT, Francisco C. Sindicato e política. São Paulo: Tese Livre docência. FFLCH-USP, 1973.

WILHEIM, Jorge. São Paulo, metrópole 65. São Paulo: Difel, 1965.

WISSENBACH, M.Cristina Cortez. "Da escravidão à liberdade: dimensões de uma privacidade possível'. In: NOVAIS, Fernando (coord). História da vida privada no Brasil. República: da belle époque à era do rádio. São Paulo: v. 3, Cia. das Letras, 1992, pp. 49-130.

XAVIER, Sônia Maria Franco. "Imigração espanhola remonta ao início da colonização do Brasil". In: Revista Raízes. São Caetano: ano X, n. 19, jul.1999, pp. 23-30.

XAVIER, Sônia Maria Franco e PATRÃO, Jayme. "A presença espanhola em São Caetano do Sul”. In: Revista Raízes. São Caetano: ano IV, n. 8, dez 1992, pp. 13-21.

XIDIEH, Oswaldo Elias. Narrativas Pias Populares. São Paulo: Instituto de Estudos Brasileiros, 1967.

ZUBILLAGA, Carlos. "Participación política. Bases para su estudio". In: Historia General de la emigración española a Iberoamérica. Madrid: v. 1, Fundación Cedeal, 1992, pp. 359-387. 
Anexo

CGE - Índice de sobrenomes (apellidos) São Paulo (Capital), 1893-1922

\begin{tabular}{|c|c|c|c|c|c|}
\hline Abad & Alarcon & Aloner & Ararida & Asensio & Baltazar \\
\hline Aballe & Alarza & Alonso & Araújo & Aserrador & Banes \\
\hline Abarca & Alastra & Alsola & Aravid & Asina & Bañesa \\
\hline Abarrategui & Alazaga & Altamirano & Arca & Aspeitia & Bañils \\
\hline Abejón & Alba & Alvarado & Arcas & Astraín & Baños \\
\hline Abela & Albadalejo & Alvaredo & Arcáz & Asunción & Banuls \\
\hline Abeleira & Albaladejo & Alvares & Arce & Atanes & Banus \\
\hline Abelend & Albanez & Alvarez & Archilla & Atanez & Baptista \\
\hline Abella & Albás & Alves & Archotegui & Atienza & Baquero \\
\hline Abellaneda & Albava & Amador & Arcos & Auguitia & Barahona \\
\hline Abensa & Alberdi & Amat & Ardany & Auraty & Barahorra \\
\hline Abisna & Albert & Amelivia & Ardiaca & Auri & Barainco \\
\hline Abolafio & Albisna & Amengual & Areas & Autas & Barajo \\
\hline Abreu & Alboitis & Ametlla & Areascua & Avalez & Barazal \\
\hline Acebo & Alcade & Amo & Arellano & Avejón & Barba \\
\hline Acedo & Alcaide & Amorena & Ares & Avellano & Barbas \\
\hline Acevedo & Alcalá & Anastasi & Arguelles & Avellar & Barberan \\
\hline Achotegui & Alcalde & Anaya & Arguello & Avello & Barbero \\
\hline Acosta & Alcaraz & Andrade & Arias & Avena & Barca \\
\hline Acostre & Alcayde & Andrades & Aricas & Avenza & Barcela \\
\hline Acuña & Alcazar & Andrea & Arillo & Ávila & Barcelona \\
\hline Adaid & Alcibar & Andreo & Arin & Avilez & Barcojo \\
\hline Adalvira & Alcoba & Andrés & Ariza & Avilla & Barea \\
\hline Adan & Alcobas & Andujar & Arjon & Avillez & Baredero \\
\hline Adorna & Alcobaz & Angel & Arjona & Ayala & Bargo \\
\hline Adrian & Alcorta & Anglas & Armengol & Ayestaran & Bargorri \\
\hline Afonso & Aldama & Angoitia & Armesto & Azcona & Barja \\
\hline Agradana & Aldana & Ângulo & Armeugal & Azevedo & Barnó \\
\hline Agrasio & Aldecoa & Anirall & Arnadas & Azuar & Barquero \\
\hline Aguado & Aledo & Añon & Arnol & Azurza & Barquilla \\
\hline Agudo & Alejandro & Anta & Arraes & Bacas & Barra \\
\hline Aguero & Alejo & Antelo & Arraniz & Baccochini & Barrado \\
\hline Aguila & Alfajeme & Antequera & Arrebole & Badia & Barral \\
\hline Aguilar & Alfonsín & Antonio & Arrevalo & Baelo & Barrancos \\
\hline Aguilera & Alfonso & Antuña & Arrevola & Baena & Barranquero \\
\hline Aguillar & Algarín & Antunes & Arribas & Baesa & Barredo \\
\hline Aguillera & Alias & Aparicio & Arrospide & Bagettiluzzi & Barreira \\
\hline Aguirra & Alijostes & Apellaniz & Arroy & Baigorri & Barreiro \\
\hline Aguirre & Allende & Aquilino & Arroyo & Baix & Barrequeros \\
\hline Aia & Alloga & Ara & Arruebarrena & Baizan & Barrera \\
\hline Aires & Almada & Aracena & Artacho & Bal & Barrero \\
\hline Aisa & Almagro & Aragón & Artanez & Balado & Barriento \\
\hline Ajellanes & Almansa & Aragunde & Artero & Baliño & Barrionuevo \\
\hline Alabarga & Almarzan & Aramburo & Artigas & Balladares & Barrios \\
\hline Alaman & Almasqué & Araña & Artuño & Ballester & Barros \\
\hline Alamino & Almazán & Arana & Arual & Ballestero & Barroso \\
\hline Alamo & Almeida & Aranda & Arza & Balsally & Bartolomé \\
\hline Alancon & Almendral & Aranjo & Asencio & Balsalobre & Barues \\
\hline Alarcón & Almendro & Aranor & Asenjo & Balsells & Bascojo \\
\hline
\end{tabular}




\begin{tabular}{|c|c|c|c|c|c|}
\hline Basi & Bermuda & $\mathrm{Boz}$ & Camino & Carrasco & Cazas \\
\hline Basilez & Bermudes & Brabo & Camnpos & Carrascosa & Cazorla \\
\hline Basilia & Bermudez & Bravo & Campano & Carreira & Ceballos \\
\hline Basoco & Bermudo & Braz & Campelo & Carrelles & Cebolla \\
\hline Basos & Bernaben & Brazale & Campo & Carreño & Cebrian \\
\hline Bastena & Bernal & Brime & Campos & Carrera & Cecilia \\
\hline Basterra & Bernardo & Brione & Campoy & Carreras & Cehez \\
\hline Bastias & Bernés & Brocal & Camus & Carrero & Celestino \\
\hline Bastida & Bernils & Brotons & Caña & Carreta & Celma \\
\hline Bastos & Beroiz & Bry & Cañada & Carretero & Celoso \\
\hline Bautista & Berondo & Buceta & Cañadas & Carreterps & Cendol \\
\hline Bayan & Berrnejo & Buckoss & Canañeros & Carrilles & Cendón \\
\hline Bayón & Berrois & Budelón & Cañas & Carrillo & Ceneto \\
\hline $\mathrm{Baz}$ & Berrueso & Buenaventura & Canavilles & Carrión & Centaro \\
\hline Baza & Bertoles & Bueno & Cancela & Carro & Centerro \\
\hline Bazán & Bestard & Bugallo & Candil & Carrocera & Cepeda \\
\hline Bazo & Bestué & Buil & Caneba & Carvajal & Cerdán \\
\hline Bea & Bichino & Builon & Canedo & Casado & Cerdeiro \\
\hline Becerra & Bid & Burgallo & Canel & Casajuana & Cereto \\
\hline Becia & Bidegain & Burgos & Cañestro & Casal & Cerezo \\
\hline Bedolla & Biel & Burillo & Cañete & Casalls & Cerillo \\
\hline Beiro & Bielma & Bustamante & Cañisares & Casañas & Cernadas \\
\hline Bejarón & Bilirbina & Bustegui & Cañizares & Casañes & Cerral \\
\hline Belasquez & Blanca & Bustos & Cano & Casanova & Cerroz \\
\hline Belber & Blanch & Caballero & Canocoba & Casarejas & Cervantes \\
\hline Belfort & Blanco & Caballier & Canos & Casas & Cervera \\
\hline Belido & Blanes & Cabanas & Canovas & Casasola & Cesar \\
\hline Belinchon & Blanez & Cabañas & Cansino & Cascales & Céspedes \\
\hline Bellido & Blas & Cabanez & Cantalejo & Cascalez & Chacón \\
\hline Bello & Blaschi & Cabello & Cantón & Cascarro & Chamocho \\
\hline Belmonte & Blasco & Cabezas & Cantos & Caseo & Chans \\
\hline Beltran & Blasi & Cabo & Canudas & Casio & Chao \\
\hline Belver & Blat & Cabrera & $\mathrm{Cao}$ & Casorla & Chasco \\
\hline Benavente & Blaya & Cabrerizo & Caparróz & Cassina & Chaus \\
\hline Bendito & Blazquez & Cáceres & Capel & Casta & Chaves \\
\hline Benega & Blesa & Cadaird & Cara & Castaño & Chavez \\
\hline Beneroso & Bocero & Cadavid & Caramés & Castellano & Chazco \\
\hline Bengoechea & Bohe & Cadaviol & Caravaca & Castellanos & Checa \\
\hline Benigno & Boix & Cal & Carbaleda & Castellir & Chibras \\
\hline Benites & Boja & Calcera & Carballal & Castellón & Chinchilla \\
\hline Benitez & Bole & Calderón & Carballeda & Castelo & Chinelvilla \\
\hline Benito & Boloix & Calero & Carballo & Castilla & Choso \\
\hline Benoliel & Bonego & Callado & Carbonell & Castillo & Ciballas \\
\hline Beral & Bonet & Calle & Cardado & Castillon & Cid \\
\hline Berbel & Bonilla & Calme & Cardenete & Castro & Cifuentes \\
\hline Berdayes & Bonllosa & Calp & Cardona & Catalá & Cindad \\
\hline Berdion & Bonsán & Calvo & Cardoso & Catalan & Ciniza \\
\hline Berdugo & Bonzada & Camacho & Careso & Catena & Cintas \\
\hline Berenguel & Bonzas & Camañes & Carin & Cato & Ciudad \\
\hline Berenguer & Boquizo & Camaño & Carmasana & Catropho & Ciurana \\
\hline Berenguez & Bordas & Camara & Carmona & $\mathrm{Cau}$ & Clark \\
\hline Berges & Borrego & Cambranero & Carmosana & Caurel & Claro \\
\hline Bericat & Botana & Camero & Carnedas & Causino & Claros \\
\hline Berlanda & Botejara & Camerón & Carnero & Cautela & Clemente \\
\hline Berlanga & Botella & Camilo & Carnerón & Cavabaco & Cobo \\
\hline Bermejo & Botellas & Camiña & Carracedo & Cavas & Cobos \\
\hline Bermendez & Bouzán & Camiñas & Carrano & Cazado & Coca \\
\hline
\end{tabular}




\begin{tabular}{|c|c|c|c|c|c|}
\hline Cocin & Cruzado & Doña & Esteban & Fines & Games \\
\hline Colazos & Cuadrado & Donaire & Estepa & Floren & Gamorra \\
\hline Collada & Cuadrenx & Donato & Estevan & Flores & Ganga \\
\hline Collado & Cuadro & Donnay & Estevanes & Florido & Ganijo \\
\hline Collados & Cubells & Dualde & Esteve & Folgoso & Ganimo \\
\hline Collazo & Cubero & Duclós & Esteves & Folgueral & Garabatos \\
\hline Collazos & Cubi & Dueñas & Estevez & Fondon & Garayarza \\
\hline Colmenero & Cubiles & Duenas & Estremera & Fons & Garaza \\
\hline Colominas & Cuellar & Duque & Estremesa & Fonseca & Garbero \\
\hline Colón & Cuenca & Durán & Estuvo & Font & Garcia \\
\hline Comaña & Cuerva & Duró & Eusébio & Fonta & Garde \\
\hline Conde & Cuesta & Echegoen & Expósito & Forn & Gardón \\
\hline Conejero & Cueto & Echenique & Fabra & Fornes & Garica \\
\hline Conejeros & Cueva & Echevarria & Fabrega & Fornos & Garnica \\
\hline Conesa & Cuevas & Edo & Fabregas & Fortejada & Garralda \\
\hline Coneza & Cuidad & Egea & Fabregat & Fortes & Garramiola \\
\hline Conrado & Curado & Egido & Faguas & Fos & Garreta \\
\hline Constantin & Curiel & Egina & Falcón & Founit & Garrido \\
\hline Constanzo & Curta & Eguia & Famadas & Fraga & Garro \\
\hline Consuegra & Curto & Eiras & Fandino & Fraile & Garrucho \\
\hline Contal & Custa & Elias & Fandón & Francia & Garruma \\
\hline Contreras & Custodio & Elicegni & Faneiro & Franco & Garzón \\
\hline Corbella & Cutelo & Elvira & Fariña & Francoli & Gasch \\
\hline Corcho & Dalamo & Embi & Farinas & Franqueira & Gascón \\
\hline Corcoba & Dallavalle & Encinas & Fariñas & Frenesi & Gaspar \\
\hline Cordeiro & Dalman & Enrique & Farré & Frias & Gaudos \\
\hline Cordero & Darac & Enriques & Farson & Fuente & Gavilán \\
\hline Cordo & Dartelli & Equiles & Fausto & Fuentes & Gavira \\
\hline Córdoba & David & Erce & Fedeño & Fuerte & Gaza \\
\hline Cordón & D'Avila & Eredia & Federico & Funcia & Gazcón \\
\hline Corlato & De la Cruz & Escalauto & Feijó & Fustel & Gazquez \\
\hline Corpos & De la Torre & Escobar & Feito & Fuster & Gea \\
\hline Corral & De Ó & Escol & Feliberto & Gabaldá & Gelabert \\
\hline Corrales & De Rio & Escomer & Felipe & Gabarrón & Genes \\
\hline Correa & Del Camino & Escribano & Felix & Gabela & Genover \\
\hline Correcher & Delgado & Escudero & Fenollar & Gacio & Ger \\
\hline Cortada & Destefanis & España & Fenoy & Gago & Gerón \\
\hline Cortés & Devas & Esparre & Fermoselle & Gajate & Gervilla \\
\hline Cortez & Devesa & Espejo & Fernande & Gala & Gierpe \\
\hline Cortizo & Dias & Esperto & Fernandes & Galán & Gijón \\
\hline Cosagaya & Diaz & Espi & Fernandez & Galdeano & Gil \\
\hline Cosar & Dieguez & Espigare & Ferrando & Galeano & Gimenes \\
\hline Cosio & Diez & Espigares & Ferraz & Galera & Gimenez \\
\hline Costa & Dios & Espin & Ferré & Galiano & Gimeno \\
\hline Costamagna & Diz & Espina & Ferreira & Galindo & Giner \\
\hline Costas & Dobán & Espiña & Ferreiro & Gallando & Gines \\
\hline Cota & Docal & Espíndola & Ferrer & Gallardo & Giraldez \\
\hline Cote & Docampo & Espinel & Ferrero & Gallego & Girban \\
\hline Cotiella & Dodero & Espinosa & Ferres & Gallegos & Girón \\
\hline Coto & Dolado & Espinoza & Ferrez & Galves & Godinez \\
\hline Cous & Domench & Esposito & Ferro & Galvez & Godoy \\
\hline Crespo & Domene & Espósito & Ferrón & Gama & Gogorza \\
\hline Criado & Domenech & Espózito & Ferroy & Gamallo & Golfetti \\
\hline Criscuolo & Domingos & Espumy & Fierro & Gamana & Gomala \\
\hline Cristo & Domingue & Esquerro & Figueredo & Gamarra & Gomara \\
\hline Critelli & Domingues & Esquioga & Figueroa & Gambín & Gomarra \\
\hline Cruz & Dominguez & Esquivel & Fineo & Gamero & Gomes \\
\hline
\end{tabular}




\begin{tabular}{|c|c|c|c|c|c|}
\hline Gomez & Gusavell & Isern & Laro & Loredo & Manlubir \\
\hline Gonçalves & Gutierre & Ituño & Larret & Loreiro & Manrubia \\
\hline Gongora & Gutierrez & Iturbe & Larrido & Lorente & Mansano \\
\hline Goñi & Guvinchaga & Izquierdo & Larrubia & Lorenzo & Manso \\
\hline Gonzaga & Guzman & Jabar & Laso & Lorete & Mantas \\
\hline Gonzale & Habales & Jaenada & Latorre & Lornas & Manuel \\
\hline Gonzalez & Hara & Jaime & Lavini & Losada & Manzanero \\
\hline Gonzalo & Haro & Jaimes & Layima & Losano & Manzano \\
\hline Gordillo & Hellin & Janerjin & Lázaro & Lostal & Mara \\
\hline Gordo & Heras & Jara & Lazo & Loureiro & Marca \\
\hline Gordon & Herce & Jary & Leal & Lousao & Marcelo \\
\hline Gorgal & Heredero & Jato & Lecheren & Lozada & Marcerino \\
\hline Gorgosa & Heredia & Jauregui & Leciñena & Lozano & Marchante \\
\hline Gorjón & Hermida & Javilan & Ledeño & Lubirachs & Marchena \\
\hline Gorrochategui & Hernaes & Jerez & Leijo & Lucas & Marcillo \\
\hline Gorzanejo & Hernandez & Jeronimo & Leiva & Luengo & Marcos \\
\hline Gosende & Hernando & Jimenez & Leñan & Luengos & Marés \\
\hline Gostia & Herrera & Jimeno & León & Luezada & Mariano \\
\hline Grabalos & Herreria & Jodar & Leonato & Lugo & Marin \\
\hline Gracia & Herrero & Jontova & Lerva & Luis & Marino \\
\hline Graciano & Hidalgo & Jordá & Lestido & Luiz & Mariño \\
\hline Grana & Hierro & Jordan & Leyaspe & Luján & Mariscal \\
\hline Graña & Higuera & Jorge & Leyoa & Luna & Marjenet \\
\hline Granada & Hinnarejos & Jose & Liberato & Lupiañes & Marmol \\
\hline Granado & Hinojosa & Jover & Lifante & Luppicich & Maro \\
\hline Granados & Holgado & Juan & Lillo & Luque & Maroñas \\
\hline Grande & Horcas & Juares & Lima & Mabarola & Marongero \\
\hline Grané & Hornos & Juarez & Limeres & Machado & Marote \\
\hline Grañe & Hortal & Juliá & Linares & Machuca & Maroto \\
\hline Graner & Hoyas & Julian & Lindes & Macia & Marques \\
\hline Granero & Huerta & Jurado & Linero & Macias & Marquez \\
\hline Granja & Huertal & Justo & Lino & Maciel & Marra \\
\hline Gravalos & Huertas & Juzua & Liria & Macua & Marreco \\
\hline Grazia & Hueso & La Heras & Lison & Madnell & Marrull \\
\hline Grillo & Huezo & La Mata & Llabres & Madrazo & Marset \\
\hline Groba & Hulo & La Rubia & Llaces & Madri & Marti \\
\hline Grobas & Hurtado & La Torre & Llamas & Maduell & Martim \\
\hline Guarnido & Iañez & Labrador & Llano & Maese & Martin \\
\hline Guedea & Ibañez & Labreras & Llerín & Maestro & Martín \\
\hline Guel & Ibarra & Labresa & Llobregat & Maestu & Martina \\
\hline Guermo & Iglesia & Lago & Llorca & Magallanes & Martinex \\
\hline Guero & Iglesias & Laguna & Lloreda & Maillo & Martinez \\
\hline Guerol & Iglésias & Laita & Lloredo & Mairena & Martins \\
\hline Guerra & Ijust & Laja & Llorente & Málaga & Marto \\
\hline Guerrero & Iladó & Lajal & Llorenz & Maldonado & Martos \\
\hline Guevara & Ilario & Lajara & Lloret & Mallor & Martrore \\
\hline Guia & Ilazer & Laje & Lobato & Malmagro & Marure \\
\hline Guill & Ildefonso & Lama & Lodijian & Malmuerca & Mas \\
\hline Guillén & Illañez & Lamba & Loma & Malvar & Masa \\
\hline Guimarra & Inesa & Lamelas & Lomas & Mañasco & Maserino \\
\hline Guirado & Iñesta & Landrei & Lomba & Mancebo & Masip \\
\hline Guirao & Inestrosa & Lanik & Lombardo & Mancha & Mata \\
\hline Guirola & Infiesta & Lanza & Lopes & Manchón & Maté \\
\hline Gumarra & Iñiguez & Lapeira & Lopez & Mancilla & Matellán \\
\hline Gundin & Instegneras & Lara & Lorca & Mandianes & Mateo \\
\hline Gure & Insua & Lardon & Lorden & Manez & Mateos \\
\hline Gurruchaga & Insuela & Lareo & Lorea & Mangano & Matias \\
\hline
\end{tabular}




\begin{tabular}{|c|c|c|c|c|c|}
\hline Matilla & Mestres & Montey & Nachez & Oliveiver & Pallardo \\
\hline Matos & Meza & Montez & Nalda & Oliver & Palma \\
\hline Matute & Mezquiriz & Montezino & Nandarez & Oliveros & Palmares \\
\hline Mauleon & Mielas & Montiel & Narvaes & Ollé & Palmero \\
\hline Maya & Miguel & Montilla & Natera & Oller & Palomares \\
\hline Maynar & Migueles & Montolar & Navajas & Ollers & Palomeros \\
\hline Mayor & Miguez & Montoro & Naval & Olmedo & Palomino \\
\hline Mayorga & Mijez & Montoya & Navarrete & Olmo & Palomo \\
\hline Maza & Milan & Montserrat & Navarro & Olmos & Palop \\
\hline Mazaneto & Millán & Mora & Navas & Onandia & Pan \\
\hline Mazo & Miñarro & Moraes & Navaz & Oncina & Pandiño \\
\hline Meca & Miñas & Moral & Navero & Onieva & Pando \\
\hline Meceguiner & Mingo & Morales & Navio & Oñon & Panilla \\
\hline Medialdea & Mingorance & Moralles & Negrete & Ontañon & Pano \\
\hline Medina & Minguella & Morán & Negro & Ontineroz & Parada \\
\hline Medinilla & Minteginaya & Morante & Neiva & Ordonés & Paradela \\
\hline Meinos & Mira & Morata & Nery & Ordoñes & Paradero \\
\hline Mejas & Miranda & Morato & Nicanor & Ordoñez & Pardal \\
\hline Mejias & Miras & Moreda & Nicolas & Orellana & Pardo \\
\hline Melcan & Miraz & Moreno & Nieto & Orellano & Paredero \\
\hline Melchor & Mirelas & Morente & Nievas & Orén & Paredes \\
\hline Melendez & Miró & Morgado & Nieves & Orenga & Pareja \\
\hline Melero & Mirón & Morilla & Niño & Orero & Parejo \\
\hline Melgar & Misa & Morillas & Nogueira & Orio & Parera \\
\hline Melgarejo & Mochón & Morña & Noguer & Oriola & Parra \\
\hline Melian & Mogica & Mornelo & Noguera & Orneta & Parrilla \\
\hline Meliran & Mojica & Mornón & Nogueral & Oropesa & Parte \\
\hline Mellado & Moldes & Morote & Nogues & Orreguela & Pascoal \\
\hline Mellina & Moledo & Morrientes & Nolazco & Ortega & Pascua \\
\hline Mellinas & Molina & Morrillas & Norez & Ortigosa & Pascual \\
\hline Melo & Molinera & Morrodán & Nouche & Ortis & Pasenal \\
\hline Melquizo & Moña & Morsoletto & Novas & Ortiz & Pasios \\
\hline Mena & Monconill & Morte & Novo & Ortuño & Pasos \\
\hline Mendano & Mondejar & Morton & Novoa & Oseda & Pastor \\
\hline Mendes & Mondo & Mostaza & Noya & Oses & Patan \\
\hline Mendez & Mondragon & Mota & Nuevo & Osório & Patiño \\
\hline Mendia & Moneda & Motila & Nunes & Osuma & Paudes \\
\hline Mendiente & Monedero & Moto & Nuñes & Otanes & $\mathrm{Paz}$ \\
\hline Mendignen & Monfil & Moura & Nuñez & Otero & Pazo \\
\hline Mendíola & Monfor & Moure & Nurubela & Ovalle & Pazos \\
\hline Mendo & Monfort & Moya & Obelleira & Oviedo & Pedraza \\
\hline Mendoza & Monge & Moyano & Obensa & Pablos & Pedreira \\
\hline Menendez & Monjon & Moztarra & Ocaña & Pabrón & Pedrosa \\
\hline Menez & Monné & Muellas & Ocio & Pacheco & Pedroza \\
\hline Menis & Moñoz & Muiña & Odriola & Padial & Peinado \\
\hline Menjón & Monre & Mulet & Oja & Padilla & Pelegrín \\
\hline Mepia & Monserrat & Muliterno & Ojea & Padró & Peleteiro \\
\hline Mera & Monso & Munir & Ojeda & Padrón & Pelfort \\
\hline Merelles & Montalbán & Muños & Oladó & Paez & Peña \\
\hline Merelo & Montalvo & Muñoz & Olaje & Paino & Pena \\
\hline Meride & Montañer & Murcayo & Olbad & Palacio & Peñalves \\
\hline Merino & Monte & Murcia & Olea & Palacios & Peñalvez \\
\hline Merlo & Monteagudo & Mures & Olegário & Palanco & Pensado \\
\hline Mesa & Montenegro & Murga & Oliart & Palazón & Peñuela \\
\hline Mesas & Montero & Muriano & Oliovares & Palima & Peral \\
\hline Mesequer & Montes & Murillo & Olivares & Pallaes & Perales \\
\hline Mesquida & Montesinos & Murroy & Oliveira & Pallarde & Peralta \\
\hline
\end{tabular}




\begin{tabular}{|c|c|c|c|c|c|}
\hline Percelas & Pouza & Ramion & Rivero & Ruesca & Sangar \\
\hline Perdiz & Poveda & Ramirez & Robina & Ruete & Sanjuan \\
\hline Perea & Povedano & Ramiro & Robledo & Rufino & Sanober \\
\hline Pereda & Pozadas & Ramón & Robles & Rufo & Sanpedro \\
\hline Peregrina & Pozo & Ramos & Roca & Rui & Sanpol \\
\hline Pereira & Pozos & Rando & Rocamoza & Ruiz & Sanse \\
\hline Peres & Pracias & Rangel & Roceira & Rumbo & Santacren \\
\hline Perez & Prada & Ranis & Rocha & Rumi & Santaella \\
\hline Peris & Prades & Raposeiras & Roda & Ruperes & Santaeulalia \\
\hline Pernias & Prado & Real & Rodenas & Rus & Santalla \\
\hline Pero & Prados & Reaos & Ródenas & Rute & Santamaria \\
\hline Personal & Prat & Rebollo & Rodolfo & Ruvira & Santamariña \\
\hline Perujo & Prates & Recco & Rodra & Ruzafa & Santano \\
\hline Peyre & Prego & Reche & Rodriguez & Saba & Santasmana \\
\hline Pezo & Presa & Recober & Roger & Sabariz & Santiago \\
\hline Pico & Prieto & Redondo & Roig & Sabio & Santillana \\
\hline Picón & Primareya & Refusta & Roján & Saenz & Santo \\
\hline Piegay & Prina & Regas & Rojas & Saez & Santos \\
\hline Pilares & Prini & Regidor & Rojo & Sagardoy & Santoyo \\
\hline Piña & Prior & Regos & Roldán & Sal & $\operatorname{Sanz}$ \\
\hline Pinaso & Puartoles & Regueiro & Román & Sala & Saqui \\
\hline Pinazo & Puente & Reguero & Romay & Salado & Sardá \\
\hline Pineda & Pueras & Reina & Romeo & Salamero & Sardo \\
\hline Piñero & Puerta & Reinés & Romera & Salas & Sarroche \\
\hline Pingenier & Puertas & Reinoso & Romeral & Salazar & Saruemed \\
\hline Pinilla & Puerto & Reis & Romero & Salce & Sauce \\
\hline Pino & Puertolas & Rejuillo & Romo & Salceda & Saura \\
\hline Piñol & Puga & Rendo & Ronan & Salcedo & Savalls \\
\hline Pintado & Puig & Rengel & Ronchel & Saldaña & Sayar \\
\hline Pinteño & Pujana & Renia & Rondel & Saler & Sayergo \\
\hline Pinto & Pujo & Repiro & Ronoquillo & Sales & Seara \\
\hline Pires & Pullero & Requeira & Ronquillo & Salgado & Sebane \\
\hline Pistoni & Push & Requena & Ropero & Salgueiro & Sebastien \\
\hline Pladevall & Quadrado & Requeña & Ros & Salguero & Segana \\
\hline Plaza & Queija & Rertoy & Rosa & Salido & Segerév \\
\hline Podadera & Queiróz & Revuelta & Rosales & Salinas & Segovia \\
\hline Poderoso & Quel & Rey & Rosende & Salinero & Segura \\
\hline Polan & Quendós & Reyes & Roset & Salles & Segurado \\
\hline Polido & Quero & Reynes & Rosique & Salmerón & Seijo \\
\hline Polo & Quesada & Reza & Rosiqui & Salón & Seisdedos \\
\hline Pomar & Quevedo & Ribantos & Rosset & Salorido & Sejudo \\
\hline Pombas & Quijada & Ribas & Rouchel & Salsona & Sellera \\
\hline Pomero & Quijeiro & Ribeira & Rourich & Salvador & Selva \\
\hline Ponce & Quindós & Ribera & Rovira & Samaniego & Sempere \\
\hline Pons & Quindox & Ribero & Royán & Sambrano & Sendín \\
\hline Pont & Quiñon & Ribes & Rua & Sampere & Sendón \\
\hline Pontes & Quiñones & Ribo & Ruano & Sampol & Senín \\
\hline Ponz & Quintana & Rico & Rubert & San & Seoane \\
\hline Porcel & Quinteiro & Riego & Rubi & Sanahuja & Sequeiros \\
\hline Porras & Quirante & Riguero & Rubia & Sanapio & Serane \\
\hline Porta & Quirantes & Rincón & Rubiales & Sance & Serena \\
\hline Portas & Quiroga & Rinoso & Rubio & Sancha & Serezo \\
\hline Portella & Quirós & Rio & Rubirales & Sanchez & Serna \\
\hline Portero & Rabinat & Rios & Rubiro & Sanchez-Barrios & Serón \\
\hline Portillo & Racero & Riós & Rubis & Sandrez & Serra \\
\hline Portola & Rafi & Rivas & Rueda & Sandro & Serrallach \\
\hline Postigo & Rami & Rivera & Ruedo & Sanduvete & Serrano \\
\hline
\end{tabular}




\begin{tabular}{|c|c|c|c|c|c|}
\hline Serrenes & Taberna & Toribio & Ubiña & Vedia & Villegas \\
\hline Setó & Tabernas & Torices & Uceda & Vega & Villodres \\
\hline Sevilla & Tabernero & Torné & Uchon & Veiga & Villoria \\
\hline Siana & Taboada & Tornieles & Ugarte & Veja & Villoslada \\
\hline Sierra & Taborda & Tornillero & Ureña & Vela & Viniegra \\
\hline Sierro & Tabrienca & Toro & Urós & Velardo & Viñolas \\
\hline Sillero & Tabuenca & Toronjo & Urquidi & Velasco & Virado \\
\hline Silva & Taez & Torras & Urquiza & Velasquez & Virgili \\
\hline Silveira & Tagua & Torre & Uruzul & Velazco & Virto \\
\hline Silver & Tairne & Torrecilla & Utrera & Velazdo & Viruel \\
\hline Simón & Tamerón & Torrecillas & Uzada & Velazo & Vitelo \\
\hline Simón & Tamoyo & Torregosa & Uzeda & Velazquez & Viudez \\
\hline Sindín & Tañes & Torregroso & Vaca & Velderrama & Vivancas \\
\hline Siorra & Tapia & Torrejón & Vacas & Velez & Vivancos \\
\hline Siquier & Tapis & Torrell & Vad & Ventura & Vivero \\
\hline Soalleiro & Tardido & Torrente & Vadillo & Vera & Vivo \\
\hline Sobran & Tarifa & Torrenz & Vaez & Verdegay & Wehland \\
\hline Sobrino & Tarrago & Torres & Val & Verdeguez & Wiquel \\
\hline Soidán & Tarrano & Torrez & Valadez & Verdugo & Xaobet \\
\hline Sol & Tarraque & Torroglosa & Valdez & Vergara & Yague \\
\hline Sola & Tato & Torrón & Valdivia & Vergel & Yañes \\
\hline Solana & Tebar & Tortell & Valdivierso & Verges & Yañez \\
\hline Solani & Tegedor & Tortosa & Valeije & Vericat & Ybarbuén \\
\hline Solano & Teijo & Touriño & Valencia & Viales & Yelmo \\
\hline Solé & Tello & Tovar & Valenzuela & Vicario & Ylleca \\
\hline Sole & Telmo & Toves & Valera & Vicente & Zabal \\
\hline Soledad & Tena & Tranqueira & Valerioba & Viciedo & Zabar \\
\hline Soler & Tenado & Trapero & Valero & Vicioso & Zafrico \\
\hline Solis & Teodoro & Trasiena & Valez & Vidal & Zague \\
\hline Solo & Tercero & Travé & Valiente & Vidaud & Zalacain \\
\hline Sopedra & Terna & Travesedo & Valladares & Vieira & Zaldivar \\
\hline Sopo & Terneiro & Trevicat & Valle & Viguel & Zaldivia \\
\hline Sorbes & Terra & Triarte & Valleja & Vila & Zambrana \\
\hline Soria & Terrón & Tribarren & Vallejo & Vilán & Zamora \\
\hline Soriano & Teruel & Tricando & Valles & Vilanova & Zapata \\
\hline Soro & Tesitore & Trigo & Vallina & Vilar & Zapater \\
\hline Sotelo & Tetilla & Triguero & Vallo & Vilches & Zapico \\
\hline Soteras & Timón & Trincado & Valls & Vilchez & Zaragoza \\
\hline Soto & Tinco & Tristán & Vallujera & Villa & Zarat \\
\hline Souto & Tirador & Troitiño & Valmoradillo & Villadangos & Zarate \\
\hline Souza & Todar & Troncoso & Valverde & Villafranca & Zarzavilla \\
\hline Suarez & Togores & Troyano & Vaquero & Villagrasa & Zena \\
\hline Subira & Toledano & Truella & Var & Villagraza & Zeron \\
\hline Subiraches & Toledo & Trujillano & Varela & Villalba & Zinco \\
\hline Sueiro & Tomáz & Trujillo & Varella & Villamil & Zordillo \\
\hline Suejo & Tombo & Tudela & Vargas & Villanisar & Zorrilla \\
\hline Suel & Tomé & Tuñon & Vasquez & Villanueva & Zubia \\
\hline Suntelodibera & Tonda & Tutor & Vaudez & Villar & Zubiour \\
\hline Suriñach & Tone & Ubach & Vaz & Villares & Zurado \\
\hline Taballero & Tonsaler & Ubeda & Vazquez & Villasegura & Zurano \\
\hline
\end{tabular}

